UNIVERSIDADE DE SÃO PAULO

ESCOLA DE COMUNICAÇÕES E ARTE

JUREMA LUZIA DE FREITAS SAMPAIO

O que se ensina e o que se aprende nas

Licenciaturas em Artes Visuais a Distância? 


\author{
UNIVERSIDADE DE SÃO PAULO \\ ESCOLA DE COMUNICAÇÕES E ARTE
}

JUREMA LUZIA DE FREITAS SAMPAIO

\title{
O que se ensina e o que se aprende nas \\ Licenciaturas em Artes Visuais a Distância?
}

Tese apresentada à Escola de Comunicação e Artes da Universidade de São Paulo como exigência parcial para obtenção do título de doutor em Artes Visuais.

Área de Concentração: Teoria, Ensino e Aprendizagem da Arte; Linha de Pesquisa: Fundamentos do Ensino e Aprendizagem da Arte.

Orientadoras: Profa. Dra. Ana Mae Tavares Bastos Barbosa (Brasil); Profa. Dra. Maria de Las Mercedes Reitano (Argentina). 
Autorizo a reprodução e divulgação total ou parcial deste trabalho, por qualquer meio convencional ou eletrônico, para fins de estudo e pesquisa, desde que citada a fonte.

Sampaio, Jurema L. F.

o que se ensina e que se aprende nas Licenciaturas em Artes Visuais a Distancia? / Jurema L. F, Sampaio, .- Sao Paulo: J. Sampaio, 2014.

289 p.: 11 .

Tese (Doutorado) - Programa de Pôs-Graduaçà en Artę Visuals - Escola de Comunicaçes e Artes / Universidade de Sao Paulo.

Orientadora: Ana Mae Tavares Bastos Barbosa

Coorientador: Maria de Las Mercedes Reitano (Argentina)

Bibliografia

1. Educaça a Distáncia 2. Fornaçăo de Profesaores 3. Artes Visuals 4. Transdisoiplinaridade 5. Tecnologia e Educaçao I. Barbosa, Ana Mae Tavares Bastos II. Titulo. 
TERMO DE APROVAÇÃO

Nome: SAMPAIO, Jurema Luzia de Freitas.

Título: $O$ que se ensina e o que se aprende nas licenciaturas em Artes Visuais a distância?

Tese apresentada à Escola de Comunicação e Artes da Universidade de São Paulo como exigência parcial para obtenção do título de doutor em Artes Visuais.

Aprovado em: 31 de março de 2014.

Banca Examinadora

Prof $^{\mathrm{a}}$. Dr ${ }^{\mathrm{a}}$. Ana Mae Tavares Bastos Barbosa (Orientadora) - ECA USP Prof $^{a}$. Dr ${ }^{a}$. Dália Rosenthal - ECA USP

Prof $^{a}$. Dr ${ }^{a}$. Prof ${ }^{a}$. Dr ${ }^{\mathrm{a}}$. Maria Cristina da Rosa Fonseca da Silva - UDESC Prof $^{a}$. Dr ${ }^{a}$. Maria Christina de Souza Lima Rizzi - ECA USP Prof $^{a}$. Dr ${ }^{a}$. Maria Emília Sardelich - UFPB - CE

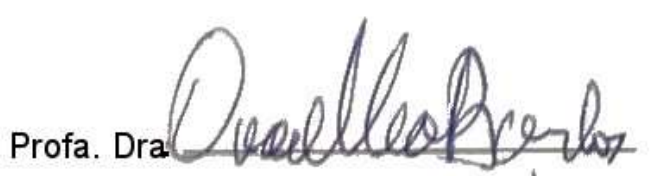

Julgamento

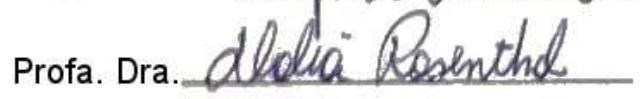
Julgamento eproredo

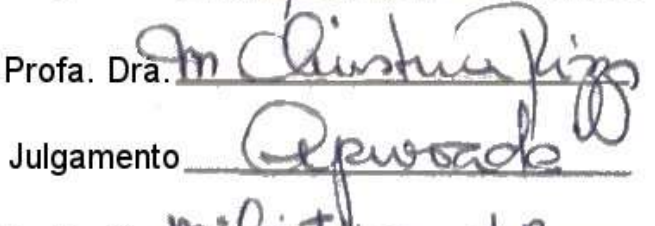
Profa. Dra.m:Chistine drem Julgamento of mewede. Profa. Dra. Mavia bruba fandele Julgamento A poinde

Instituição Assinatura

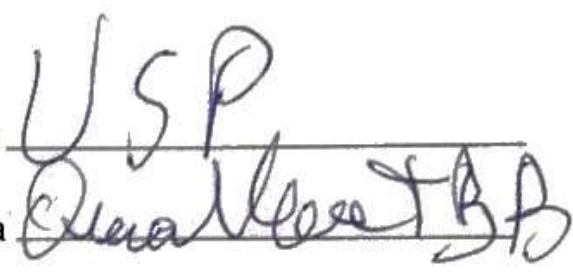
Instituição USP Assinatura

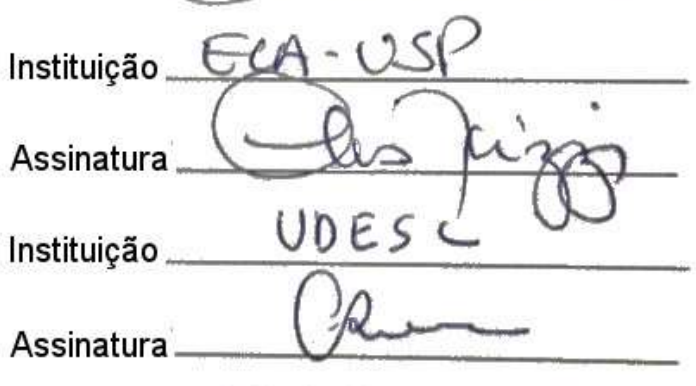

Instituição $U F P B \cdot C E$ Assinatura

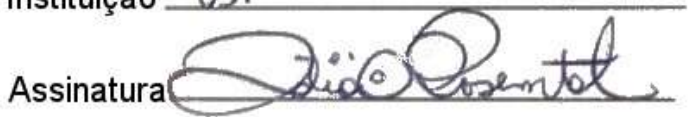

arlos

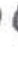

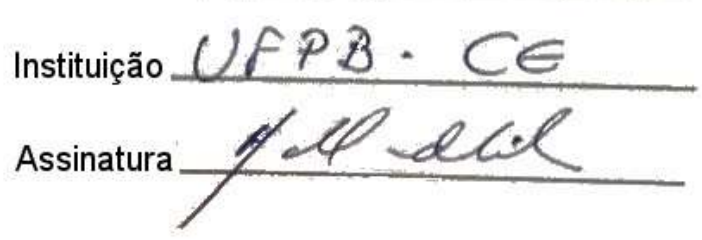




\section{EPÍGRAFES}

Não há como ter somente uma única epígrafe para o trabalho todo, com uma pessoa como eu: passional, às vezes bem radical, disciplinada, com opinião própria e sempre exigente, mas, múltipla, em essência. Assim, algumas citações, frases e pensamentos "guiam" os meus pensamentos, escolhas e decisões de vida. Pessoais e profissionais. "Guiam meus passos", eu diria, se eu fosse poeta.

"Aqueles que se entregam à prática sem ciência são como o navegador que embarca em um navio sem leme nem bússola. Sempre a prática deve fundamentar-se em boa teoria. Antes de fazer de um caso uma regra geral, experimente-o duas ou três vezes e verifique se as experiências produzem os mesmos efeitos".

Leonardo da Vinci

"Chegará o dia que o volume da instrução recebida por correspondência será maior do que o transmitido nas aulas de nossas escolas; em que o número de estudantes por correspondência ultrapassará o dos presenciais". William Harper, 1886.

"A função da arte não é a de passar por portas abertas, mas a de abrir portas fechadas". Ernst Fischer, 1959

"Para mim a arte não tem nem passado nem futuro. Se uma obra de arte não pode viver no presente, ela não merece que a contemplemos". Pablo Picasso

"Quem pensa por si mesmo é livre. E, ser livre, é coisa muito séria". Renato Russo 


\section{DEDICATÓRIA}

Dedico este trabalho aos meus filhos, Hannah Marina e João Fernando, que são, com certeza, as minhas melhores produções;

À minha mãe, Elcy de Freitas Sampaio, com quem contei todo o tempo, com todo apoio, inclusive financeiro, durante esse longo processo;

Ao meu pai, que não está aqui fisicamente, mas que nunca deixou de me apoiar em minhas escolhas, mesmo nas "erradas";

À toda a família, que sempre é meu porto seguro. Nominalmente: Meu irmão João Luiz de Freitas Sampaio, sua esposa e minha cunhada Cláudia Sampaio, seu enteado Léo e minha sobrinha Julia Sampaio. Minha irmã de alma, Giselle Moreira Sampaio, mãe dos meus sobrinhos Amanda Moreia Sampaio e Maurício Moreira Sampaio, viúva do meu irmão José Luiz;

Por fim, especialmente, dedico essa conquista pessoal ao meu irmão José Luiz de Freitas Sampaio, falecido em 06 de agosto de 2010. Ele foi o maior incentivador de eu tentar a seleção de doutorado e a primeira pessoa a quem contei que havia passado, quando me disse: "Parabéns, doutora!".

Ele estaria orgulhoso de mim agora, tenho certeza. 


\section{AGRADECIMENTOS}

"As pessoas entram na nossa vida por acaso. Mas não é por acaso que elas permanecem".

Pablo Picasso.

À orientadora e, principalmente, amiga, Profa. Dra. Ana Mae Tavares Bastos Barbosa, pela presença constante. Ela entrou na minha vida ainda na minha graduação, dando sustentação teórica aos sonhos, ideias e ideais de uma jovem estudante. Permanece até hoje, como amiga e orientadora de verdade: de caminhos e escolhas que, sim, são pessoais, mas que, apoiadas, tornam os caminhos mais seguros. Obrigada!

À Mercedes Reitano, co-orientadora, em La Plata, Argentina, pelo carinho, acolhida, liberdade, confiança e apoio ao trabalho.

À Profa. Dra. Maria Emília Sardelich. Minha eterna "chefa". Ela foi, sim, minha superiora num dado momento da nossa vida profissional, mas o "cargo" de "chefa" foi "conquistado" por seu bom senso, sua clareza de ideias, seu caráter e, principalmente, sua ética. Excepcional. Obrigada!

À professora, colega e, principalmente amiga Prof ${ }^{a}$. Dra. Maria Christina de Souza Lima Rizzi. Sempre pude contar com sua opinião sincera, apoio e "luz". Sempre me acompanha nessa jornada. Sempre amiga. Obrigada!

À Profa. Dra. Dália Rosenthal. A quem eu sempre admirei pelo o trabalho. Inicialmente "de longe". Depois, como sua aluna, eu pude constatar a grandeza de sua generosidade em compartilhar suas escolhas, caminhos e descobertas.

Á Profa. Dra. Sumaya Mattar, que me "obrigou" a revisitar, reler e rever 'coisas' que, trinta anos depois da graduação, ganharam novos significados, sob novas perspectivas, que foram muito importantes no processo da pesquisa. 
Aos professores da pós-graduação da ECA USP; todos os funcionários, sempre atenciosos e solícitos; e a todos os colegas de pós-graduação. Um beijo especial para José Minerini Neto e Carlos Weiner. Somos um time e tanto, meninos. Valeu!

Um beijo especial para Isabela Frade, Maria Cristina Rosa, Federico Buján e Victor Kun. Todos são professores doutores, sim, mas, aqui, faço agradecimentos aos MEUS AMIGOS, com quem compartilhei dúvidas, ideias, sonhos e momentos, mais que especiais, no período de residência em Buenos Aires, Argentina.

Ao Eduardo Henrique de Assumpção Pereira, por ser quem é, pelo seu papel na minha vida e por me fazer acreditar em mim mesma.

À CAPES pelo apoio financeiro durante o período de Bolsa Sanduíche na Argentina.

E a todos que, nesses anos de trabalho cruzaram meu caminho e contribuíram, alguns sem nem mesmo saber o quanto, para as reflexões agora presentes nessas páginas e a todas as pessoas que, de alguma forma, contribuíram com este trabalho, respondendo a pesquisa, lendo, comentando, discutindo, dando dicas etc. etc. etc.

Obrigada! 


\section{RESUMO}

Esta pesquisa de doutorado em Artes Visuais começou no ano de 2010, na Escola de Comunicação e Artes da Universidade de São Paulo - ECA/USP, intitulada "O que se ensina e o que se aprende nas Licenciaturas em Artes Visuais a distância?', sob orientação da Profa. Dra. Ana Mae Tavares Bastos Barbosa, e tem como objetivo principal o de realizar síntese analítica e crítica de currículos de formação de profissionais de Ensino de Artes Visuais nos cursos de Licenciatura em Artes Visuais oferecidos na modalidade de Educação a Distância. Trata, principalmente, do mapeamento de uma área ainda iniciante em termos de pesquisa: a verificação da qualidade da formação de professores de arte visuais feita na modalidade de Ensino chamada de Educação a Distância - EaD. Como o tema é inédito na área de Ensino de arte, os três capítulos, mais as considerações finais percorrem um caminho pavimentado de muito mais perguntas do que certezas, buscando dar voz aos atores desses processos educativos, em especial aos alunos dos cursos dessas licenciaturas. Composta de referencial teórico inter e multidisciplinar, mais a pesquisa de campo, com entrevistas, busca traçar as bases para a construção de uma Epistemologia do Ensino de Artes Visuais por Educação a Distância, se colocando como uma abertura ao diálogo e à reflexão, necessários, em especial no cenário contemporâneo aonde, a cada dia mais, a Educação a Distância vem ganhando significativa expressão numérica, com a convicção de que $\mathrm{EaD}$ não pode ser entendida somente, como uma sucessão, ou substituição da Educação presencial, pois, sua função é, além de aumentar o acesso ao conhecimento, a de realizar-se como uma prática significativa e consequente em relação aos princípios dos projetos pedagógico contemporâneos.

Palavras-chave: Educação a Distância, Formação de Professores de Artes Visuais, Epistemologia da Educação a Distância em Artes Visuais. 


\section{ABSTRACT}

This doctoral research in Visual Arts began in 2010 in the School of Communication and Arts of University of São Paulo - ECA / USP, entitled "O que se ensina e o que se aprende nas Licenciaturas em Artes Visuais a distância?" under supervision of Prof $^{a}$. Dr ${ }^{a}$. Ana Mae Tavares Bastos Barbosa, and aims to perform the analytical and critical synthesis of the training curricula of professional education in Visual Arts Bachelor of Visual Arts offered in the form of distance education. Comes mainly from the mapping of a fledgling area research terms checking the quality of teacher education in visual art made teaching method called Distance Education (e-Learning). As the topic is unprecedented in the field of art education, the three chapters, plus the final considerations go a path paved with more questions than answers, seeking to give voice to these actors educational processes, in particular the students of undergraduate courses such. Composed of inter and multidisciplinary theoretical framework, more field research with interviews, seeks to trace the foundations for building an epistemology of teaching Arts, posing as an opening to dialogue and reflection necessary, especially in the contemporary scenario where, every day more, distance education has been gaining significant numeric expression, with the belief that distance education cannot be understood only as a succession or replacement of classroom education, because its function is, in addition to increasing access to knowledge, to be held as a significant and consistent practice on the principles of contemporary pedagogical projects.

Keywords: Distance Education, Teacher Training for Visual Arts, Epistemology of Distance Education in Visual Arts. 


\section{LISTA DE FIGURAS}

Figura 1 - Pesquisa no Google com o termo "EaD em arte". .......................... 21

Figura 2 - Cartaz de divulgação. .............................................................. 25

Figura 3 - Página inicial do curso ......................................................... 26

Figura 4 - Mapa das universidades brasileiras ............................................. 44

Figura 5 - Percentual das Unidades Educacionais Argentinas........................ 68

Figura 6 - Alunos em Instituições de Ensino - Argentina................................ 68

Figura 7 - Nível de alfabetização do povo argentino. ...................................... 69

Figura 8 - Mapa interativo da Educação na Argentina. .................................. 69

Figura 9 - Modalidades da Educação na Argentina....................................... 70

Figura 10 - Mapa das universidades argentinas........................................... 73

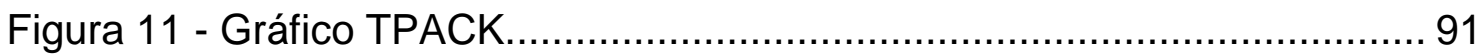

Figura 12 - Percentual de professores formado por EaD............................ 121

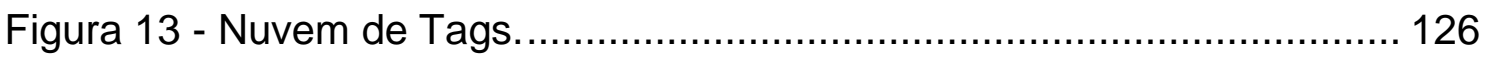

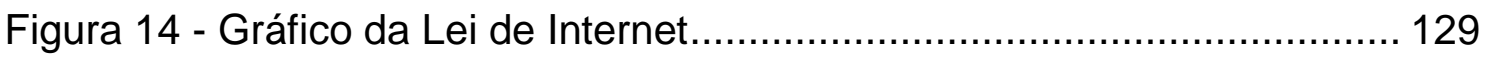

Figura 15 - Desconhecimento das possibilidades tecnológicas. .................... 151

Figura 16 - Trabalhos sobre EaD em Artes Visuaisentre 1999 e 2013 .......... 163

Figura 17 - Sistemas educacionais eletrônicos segundo Piconez.................. 178

Figura 18 - Escaneamento da Estátua de David........................................ 180

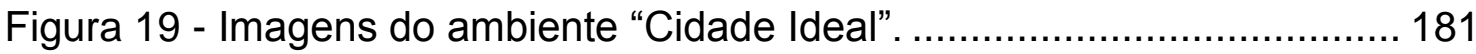

Figura 20 - Distribuição dos cursos por tipo de instituição. ............................ 185

Figura 21 - Imagem do LMS/AVA da IES Claretiano.................................... 193

Figura 22 - Imagem do LMS/AVA da IES UGF .......................................... 194

Figura 23 - Imagem do LMS/AVA da IES UCS ......................................... 194

Figura 24 - Imagem do LMS/AVA da IES UECE (Antigo) ............................. 195

Figura 25 - Imagem do LMS/AVA da IES UECE (Novo) …........................... 195

Figura 26 - Imagem do LMS/AVA da IES UFAM ......................................... 196

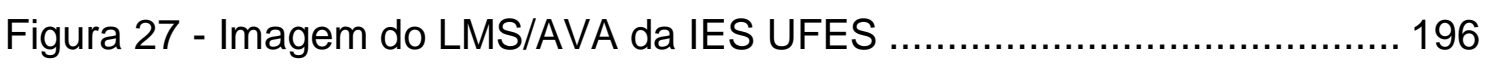

Figura 28 - Imagem do LMS/AVA da IES UFG …..................................... 197

Figura 29 - Imagem do LMS/AVA da IES UFMA ........................................ 197

Figura 30 - Imagem do LMS/AVA da IES UFRGS ..................................... 198

Figura 31 - Imagem do LMS/AVA da IES UFRPE .................................... 198

Figura 32 - Imagem do LMS/AVA da IES UNAR ....................................... 199

Figura 33 - Imagem do LMS/AVA da IES UNB - Pro-Licenciatura ................ 199

Figura 34 - Imagem do LMS/AVA da IES UNB - UAB …............................ 200

Figura 35 - Imagem do LMS/AVA da IES UNIASSELVI.............................. 200

Figura 36 - Imagem do LMS/AVA da IES UNICENTRO ............................... 201 
Figura 37 - Imagem do LMS/AVA da IES UNIMES ................................ 201

Figura 38 - Imagem do LMS/AVA da IES UNIMONTES ............................ 202

Figura 39 - Imagem do LMS/AVA da IES UNITAU.................................. 202

Figura 40 - Imagem do LMS/AVA da IES UNIVASF ................................ 203

Figura 41- Imagem do LMS/AVA da IES UNOPAR ................................... 203

Figura 42 - AulaNet ................................................................ 204

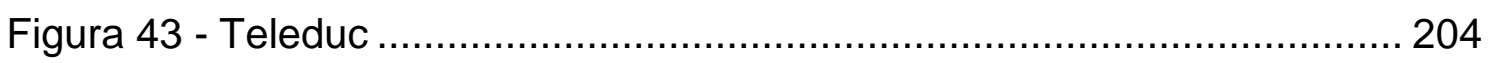

Figura 44 - Learning Space .................................................................. 204

Figura 45 - Top Class .................................................................... 205

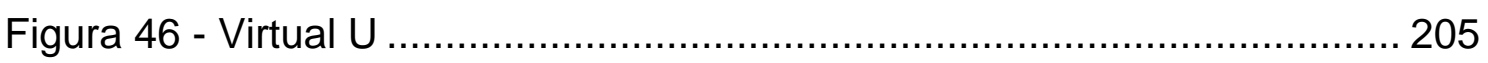

Figura 47 - Universite ...................................................................... 205

Figura 48 - QuadroNegro (Blackboard) ........................................... 205

Figura 49 - Licenciatura em Artes Visuais de acordo com o tipo................... 213

Figura 50 - Estrutura do questionário da pesquisa de campo. ......................226

Figura 51 - Texto da mensagem/convite para responder ao questionário ..... 227

Figura 52 - Experiência com Educação a Distância ..................................... 229

Figura 53 - Alunos em EaD, primeira experiência ....................................... 229

Figura 54 - Primeira experiência com EaD como professor/tutor.................. 230

Figura 55 - Recursos usados por conteudistas ........................................ 232

Figura 56 - Formato/recursos dos conteúdos do cursos. ........................... 232

Figura 57 - Cursos de Licenciatura em Artes Visuais por EaD...................... 233

Figura 58 - Predominância de texto em relação aos demais recursos ........... 237

Figura 59 - Alunos EaD - Licenciatura em Artes Visuais........................... 237

Figura 60 - Alunos que cursa Ensino superior pela primeira vez. ................. 238

Figura 61 - Estado civil ................................................................. 238

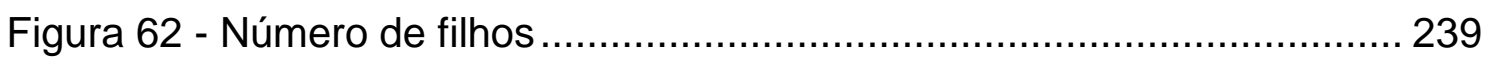

Figura 63 - Principal responsável financeiro pela família ........................... 239

Figura 64 - Percentual de colaboração da renda familiar ............................. 239

Figura 65 - Datas de formatura e percentuais de formados ......................... 240

Figura 66 - Sobre voltar a fazer cursos por EaD ..................................... 242

Figura 67 - Conclusão do curso e vida profissional ................................... 243

Figura 68 - Formados que exerce atividade profissional na área.................. 243

Figura 69 - Motivos por estar atuando fora da área de formação................... 244

Figura 70 - Tempo entre a formatura e início em atividade profissional ........ 244

Figura 71 - Frequência de encontros presenciais ...................................... 245

Figura 72 - Atividades em encontros presenciais ..................................... 246

Figura 73 - Duração dos cursos ..................................................... 249

Figura 74 - Previsão de conclusão do curso ........................................ 250 
Figura 75 - Percentual de alunos em primeira graduação............................. 250

Figura 76 - Frequência de encontros presenciais ......................................... 251

Figura 77 - O que acontece nos encontros presenciais .............................. 252

Figura 78 - Conclusão do curso e vida profissional ...................................... 255

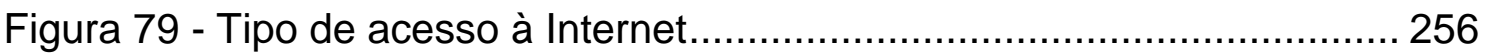

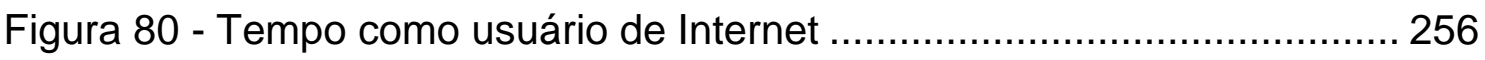

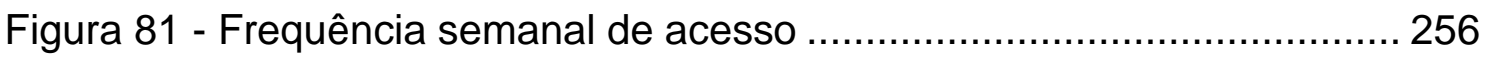

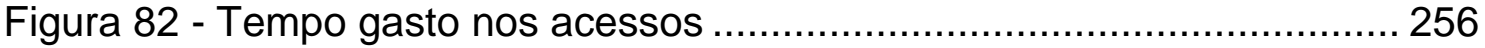

Figura 83 - Principal motivo de acesso à Internet ....................................... 257

Figura 84 - Uso de navegadores web .................................................. 257

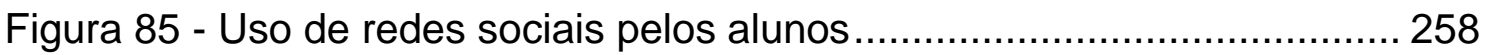

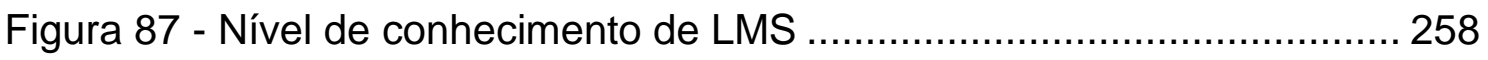

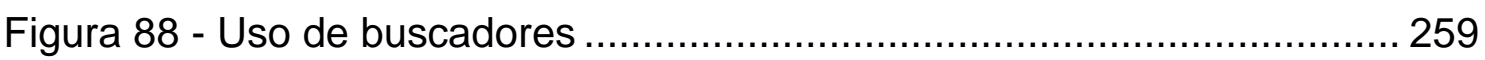

Figura 86 - Uso de comunicadores em rede ............................................... 260 


\section{LISTA DE TABELAS}

Tabela 1 - Matrículas em instituições de Ensino públicas 33

Tabela 2 - Cursos de Graduação segundo a Modalidade de Ensino............... 42

Tabela 3 - Número e Percentual de Cursos de Graduação.............................. 43

Tabela 4 - Instituições de Ensino Superior Brasileiras - Artes Visuais ............. 45

Tabela 5 - Instituições de Ensino Superior na Argentina - Arte ....................... 74

Tabela 6 - Gráfico TPACK em Artes Visuais.................................................... 94

Tabela 7 - Primeiras definições de EaD ...................................................... 99

Tabela 8 - Mais definições de EaD........................................................... 100

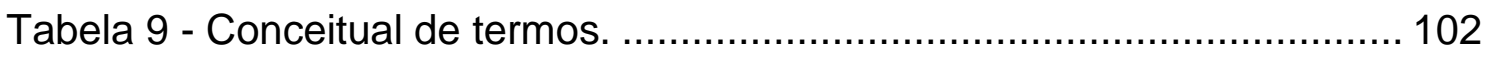

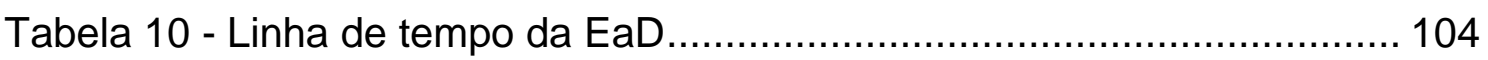

Tabela 11 - Linha de tempo da EaD no Brasil............................................ 108

Tabela 12 - Decretos relacionados à regulamentação da EaD no Brasil. ...... 112

Tabela 13 - Portarias relacionadas à regulamentação da EaD no Brasil. ...... 113

Tabela 14 - Resoluções relacionadas à regulamentação da EaD no Brasil... 115

Tabela 15 - Instituições que fazem Educação a Distância na Argentina........ 118

Tabela 16 - Escolas pedagógicas ......................................................... 122

Tabela 17 - As gerações de Ensino a Distância............................................ 123

Tabela 18 - Três gerações da Pedagogia EaD. …………………............... 124

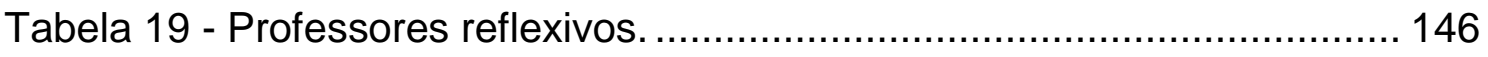

Tabela 20 - Linha do tempo das licenciaturas em Artes Visuais no Brasil ..... 152

Tabela 21 - Trabalhos de pesquisa sobre o Tema EaD em Artes Visuais. .... 164

Tabela 22 - Instituições credenciadas pelo MEC para em Artes Visuais. ...... 183

Tabela 23 - Detalhamento das Instituições credenciadas............................ 186

Tabela 24 - LMS/AVA classificados quanto às suas especificidades .............. 204

Tabela 25 - Instituições com oferta de licenciaturas em artes por EaD.......... 206

Tabela 26 - Orientação de produção de conteúdo de disciplina..................... 207

Tabela 27 - Tradução de Strong e Harmon .................................................... 208

Tabela 28 - Questões comuns a todos os Modelos de Cursos. ..................... 209

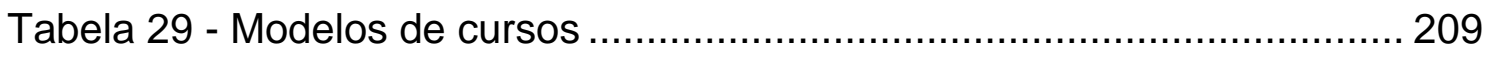

Tabela 30 - Acesso aos dados da proposta............................................. 212

Tabela 31 - Síntese dos programas - Artes Visuais por EaD ......................... 215 


\section{SUMÁRIO}

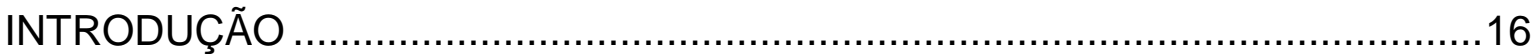

CAPÍTULO I - ENSINO DE ARTE E FORMAÇÃO DOCENTE ............................28

1.1 Como são formados os professores de Arte no Brasil? ...................................32

1.1.1 A Educação Superior no Brasil .............................................................40

$1.2 \mathrm{E}$ como são formados os professores de arte na Argentina? .........................66

1.2.1 Educação Superior na Argentina ..........................................................71

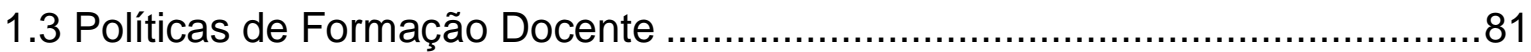

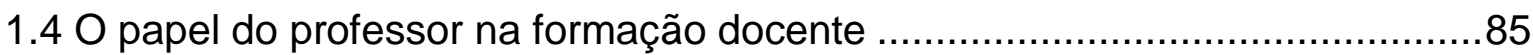

1.4.1 Proposição Metodológica: TPACK ……………….................................90

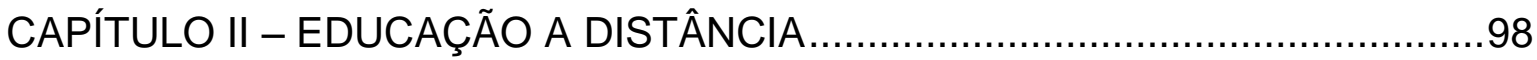

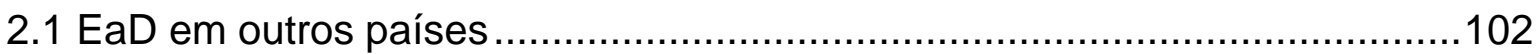

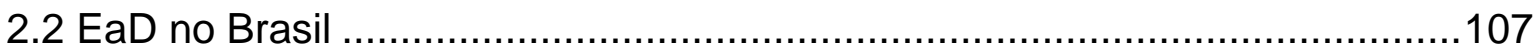

2.2.1 Legislação que regulamenta a EaD no Brasil.........................................111

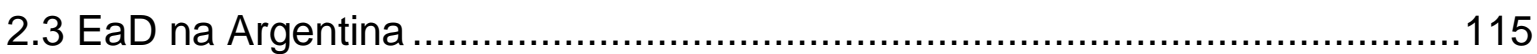

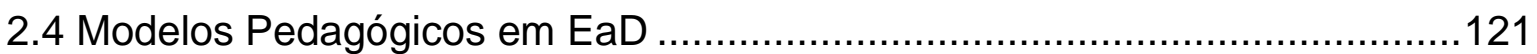

CAPÍTULO III - EDUCAÇÃO A DISTÂNCIA EM ARTES VISUAIS ...................128

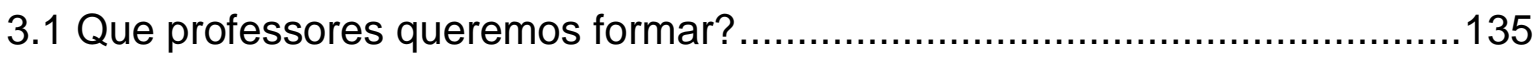

3.2 As primeiras experiências de EaD em Artes Visuais....................................150

3.2.1 A Universidade Aberta do Brasil - UAB ....................................................154

3.3 Trabalhos sobre o tema EaD em Artes Visuais / licenciaturas .......................161

3.4 Recursos e ferramentas para EaD em Artes Visuais ..................................173

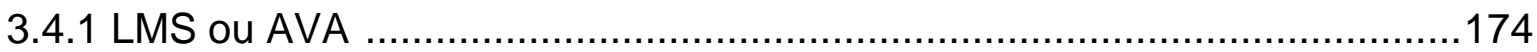

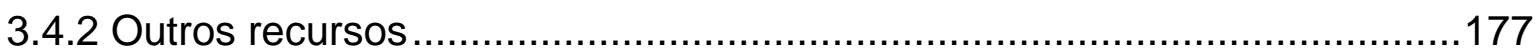

3.5 Instituições credenciadas para EaD em Artes Visuais .................................183

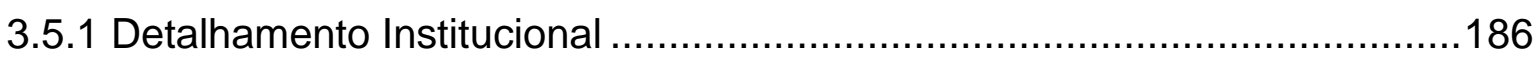

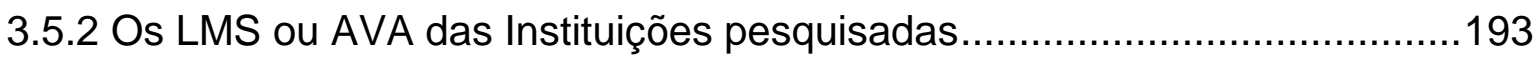

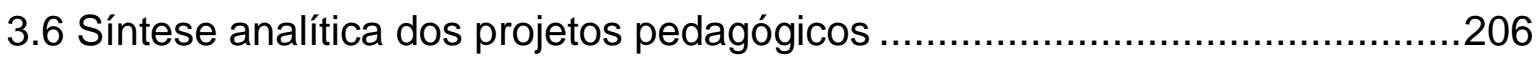

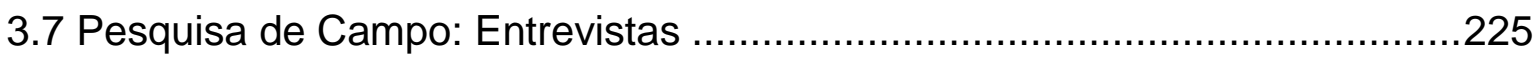

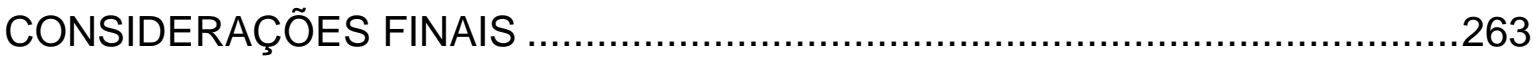

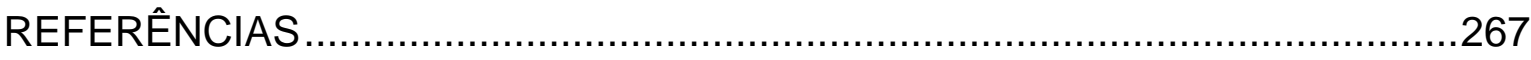

ANEXOS 


\title{
INTRODUÇÃO
}

\begin{abstract}
"A função da arte não é a de passar por portas abertas, mas a de abrir portas fechadas."
\end{abstract}

Ernst Fischer, 1959

Desde 1971, pela Lei 5692, a disciplina Educação Artística torna-se parte dos currículos escolares. Ana Mae Barbosa (BARBOSA, 1989, S/N), ao afirmar que "[...] isto não foi uma conquista de arte-educadores brasileiros, mas uma criação ideológica de educadores norte-americanos que, sob um acordo oficial (Acordo MEC-USAID), reformulou a Educação Brasileira, estabelecendo em 1971 os objetivos e o currículo configurado na Lei Federal №. 5.692 denominada "Diretrizes e Bases da Educação"', ou seja, mais do que uma simples questão de reserva de mercado para os arte-educadores, uma política educacional específica foi posta em prática desde os anos 70, com a concepção de Ensino de arte pensada como parte da formação educacional de nossos alunos. Ainda Ana Mae (Idem) nos fala que já no ano de 1988:

[...] a Constituição da Nova República menciona cinco vezes as artes no que se refere a proteção de obras, liberdade de expressão e identidade nacional. Na Seção sobre Educação, Art. 26, parágrafo II, a Constituição determina:

O Ensino tomará lugar sobre os seguintes princípios [...]. II - liberdade para aprender, ensinar, pesquisar e disseminar pensamento, arte e conhecimento (Idem, ibidem).

Com essa visão como base, mesmo que, ao longo do tempo, tenham ocorrido mudanças nas concepções de Ensino de arte, ora tecnicista, ora sensibilizante e, ainda, como agente transdisciplinar, a Nova LDB, Lei №. 9.394, de 20 de dezembro de 1996, vem consolidar a justificativa da existência do Ensino de arte na escola. Em seu Art. § 2o diz que:

O Ensino da Arte constituirá componente curricular obrigatório, nos diversos níveis da Educação básica, de forma a promover o desenvolvimento cultural dos alunos.

Ou seja, Arte é área de conhecimento que corrobora na formação dos indivíduos. Essa visão, ratificada em 1997 pelos Parâmetros Curriculares Nacionais que, apesar de apresentarem alguns problemas na sua estrutura, apontam para uma 
necessária formação consistente, nas respectivas linguagens da arte, para exercício do magistério em arte.

A teoria de Paulo Freire, assentada numa visão humanista e antropológica, concebe o homem como o sujeito pensante, que pode atuar de forma transformadora na sociedade na qual está inserido. Para Freire (1970, p. 91-94), a dialogicidade é a essência da Educação como prática da liberdade. "Sem o diálogo não há comunicação" (FREIRE, 1987, p. 83) e sem comunicação não há Educação. Freire (1982) defende também a importância da interação na Educação (MATTAR, 2012, p. 27).

Tema ainda atual, apesar dos 20 anos passados entre o relatório de Ana Mae Barbosa (1989) e os dias de hoje, a formação dos professores de arte é, ainda, fonte de pesquisas e debates entre os arte/educadores, no sentido de mais e melhor atender às expectativas de realizar uma formação de qualidade para as futuras gerações.

Nesse cenário surgem as propostas de formação profissional e acadêmica por meio da Educação à Distância - EaD. Melhor seria dizer ressurgem, já que a modalidade de aprendizagem à distância não é nova, o que pode ser considerado como novidade é a introdução das tecnologias digitais de comunicação como ferramenta. O uso dessa modalidade é grandemente estimulado com o desenvolvimento de popularização das Tecnologias Digitais de Informação e Comunicação, as TIC, no fim dos anos de 1990.

O decreto lei №. 2.494, de 10 de fevereiro de 1998 (BRASIL, 1998, p. 1), que regulamentou ${ }^{1}$ a Educação à Distância (EaD) no Brasil, diz que:

Art. 1ํㅡㄹ Educação a Distância é uma forma de Ensino que possibilita a autoaprendizagem, com a mediação de recursos didáticos sistematicamente organizados, apresentados em diferentes suportes de informação, utilizados isoladamente ou combinados, e veiculados pelos diversos meios de comunicação.

\footnotetext{
${ }^{1}$ Revogado pelo Decreto2.561, também de 1998 que, por sua vez também já foi revogado pelo Decreto №. 5.622, de 19 de dezembro de 2005.
} 
Ou seja, a Educação à Distância, ou EaD, seria um nome genérico para definir a Educação feita sem a presença física de um professor para orientar a aprendizagem (MEC, 2001, p. 1). Mas isto não quer dizer auto aprendizado, ou a eliminação da figura do professor (SAMPAIO \& DOMINGUES, 2012).

Segundo o relatório do Coordenação Central de Educação a Distância da Pontifícia Universidade Católica do Rio de Janeiro - CEAD/PUC - Rio (2001, p. 2), numa versão parcialmente adaptada do material "Distance Education at a Glance" da Universidade de Ohio, encontramos a seguinte proposição:

Existem diversas definições e diferentes denominações para Educação a Distância, que são usadas popularmente. Entre estas definições e denominações podemos citar: Aprendizagem a Distância (AD) 'Sistema dirigido ou um processo para conectar os aprendizes aos recursos remotos. $A D$ pode ser um meio preliminar ou suplementar de aprendizagem' e Educação a Distância (EaD) Educação realizada através de mídia eletrônica, utilizando satélite, vídeo, áudio-gráfico, computador, multimídia etc.

É interessante notar que o termo EaD quase sempre se refere a situações de Ensino-aprendizagem nas quais o(s) professor(es) e o(s) aprendiz(es) estão geograficamente separados e, consequentemente, se valem de meios eletrônicos e de materiais impressos para a distribuição de conteúdos educacionais.

Nos dias atuais, para além dos questionamentos e discussões sobre a validade, ou não, dos processos de formação por EaD, caracteristicamente encontradas nas pesquisas dos anos 2000 é necessário considerar o fato de que programas de Educação e formação foram criados e implementados nas diversas áreas do conhecimento e essa tendência, apontada por diversas pesquisas da área educacional, consolidada nos anos 2000, atingiu, também, as artes e a formação de professores de arte.

Os cursos de licenciatura que, em meados dos anos 1990, já sofreram revisões e modificações em suas estruturas para incluir a necessária formação de seus alunos para a manipulação dessas tecnologias se vêem, então, diante da necessidade de discutir possibilidades de formação, agora não mais somente relativas ao uso dessas tecnologias, porém identificando-as como suporte e meio para esta formação. Não se trata mais de ensinar a "mexer no computador" e 
habilitar ao trânsito pela tecnologia, mas, sim, ensinar usando essas tecnologias como mediadores dessa relação de Ensino-aprendizagem.

Uma das metas do Ensino de arte é "o desenvolvimento da disposição de apreciar obras de arte", em que dois fatores têm grande influência nessa busca: " $A$ disposição de apreciar a excelência nas artes em função da experiência maior que a arte é capaz de proporcionar" (SMITH, 2001, p. 99) e que cursos de arte "consistentes" incluem o fazer artístico e as elaborações "sensível-cognitivas" em suas propostas e essas elaborações são construídas, principalmente pela apreciação artística (FUSARI e FERRAZ, 1993, p. 70) e, para o Ensino de arte, o uso de imagens como recurso pedagógico é corrente e mesmo considerado necessário pela maioria dos professores (SAMPAIO-RALHA, 2003).

Conhecer arte, segundo Ana Mae Barbosa implica um conhecimento que se organiza "inter-relacionando o fazer artístico, a apreciação da arte e a história da arte" (2010, p. 33). Ressaltando que nenhuma das três áreas, sozinha, representa - que Ana Mae Barbosa (Idem) chama de "Epistemologia" da arte como pressuposto e como meio". O que também não são, quando tratamos de Educação a Distância para a formação de professores de Artes Visuais.

As tecnologias digitais de comunicação e informação são, assim, um recurso importante, permitindo explorações para o Ensino de Artes Visuais, rompendo a com bidimensionalidade e ativando os canais sensoriais de interação (SAMPAIORALHA, 2003). Mas, como os processos de Ensino-aprendizagem em arte se comportam no espaço virtual? Como têm sido propostas as práticas artísticas? E a apreciação, como é feita/estudada/medida? Como são pensados, planejados e estruturados estes cursos para atender a formação de professores? E os recursos da web 2.0, essencialmente interativos e com base em colaboração em rede, como estão sendo trabalhados? Esses e outros questionamentos iniciais, que deram origem à este projeto de pesquisa, resumidos na questão: Os recursos das

\footnotetext{
${ }^{2}$ Epistemologia, do grego episteme, conhecimento, e logos, razão, explicação. Estudo da natureza do conhecimento e justificativa. Mais especificamente, estudo de a) características definidoras, b) de suas condições substantivas, c) dos limites do conhecimento e da justificação. As últimas três categorias são representadas pelas controvérsias filosóficas tradicionais acerca das análises do conhecimento e a justificação (por exemplo, racionalismo versus empirismo) e a visibilidade de uma postura cética diante do conhecimento e da justificação (AUDI, 2004, p. 293).
} 
tecnologias digitais de comunicação e informação estão efetivamente sendo utilizados em suas potencialidades ou estão sendo subestimados, à luz de interesses, quais sejam, que não os de formação? A pergunta, recorrente, que, inclusive, na área de Ensino de Arte inspira o nome desta pesquisa é: Como está sendo feita essa formação?

Importante notar que Maria Cristina Rosa, em 2010, já apontava que...

[...] até o presente momento não temos uma avaliação concreta sobre o impacto da formação de professores de artes na Educação a Distância (2010, p. 261).

Urge, portanto, a necessidade de reflexão objetiva quanto aos métodos e metodologias usados para essas práticas, no sentido de compreender como os processos de Ensino-aprendizagem da arte transitam e comportam-se frente ao uso dessas tecnologias como mediadores desses mesmos processos. É imperativa uma reflexão criteriosa acerca dessa formação.

Algumas críticas à $\mathrm{EaD}$ referem-se à EaD como fatalmente negativa por promover o autodidatismo. Um olhar cuidadoso percebe que essas críticas se dirigem, em especial aos processos que, mesmo recebendo o nome de $\mathrm{EaD}$, não vão além de produção e distribuição de material didático sem que, no entanto, haja uma mediação consistente do processo Ensino aprendizagem.

A principal e mais significativa diferença entre autodidatismo e EaD é que, no primeiro caso, são os próprios alunos os selecionadores dos materiais e caminhos de sua aprendizagem, enquanto, na EaD, o professor é o mediador dessas escolhas, orientando o percurso.

Processos significativos em EaD buscam promover a autonomia da aprendizagem, o que é muito diferente de auto aprendizado.

Por aprendizagem autônoma entende-se um processo de Ensino e aprendizagem centrado no aprendente, cujas experiências são aproveitadas como recurso, e no qual o professor deve assumir-se como recurso do aprendente, considerado como um ser autônomo, gestor de seu processo de aprendizagem, capaz de autodirigir e autorregular este processo. Este modelo de aprendizagem é apropriado a adultos com 
maturidade e motivação necessárias à autoaprendizagem e possuindo um mínimo de habilidades de estudo (TRINDADE, 1992; CARMO, 1997, p. 300; KNOWLES, 1990 apud BELLONI, p. 40).

Muito se fala, também, sobre a "diferença" entre EaD e Educação presencial. Tentar comparar ambos é, no mínimo, inócuo. Que são diferentes é o óbvio, não seria necessário nem comentar a esse respeito, mas, comparar as diferenças é improdutivo (entendendo 'produtividade' como resultado na relação entre investimento de tempo e resultados alcançados), pois cada uma das modalidades tem suas características e, em si, vantagens e desvantagens, sendo, ambas, opções de trabalho educacional, e não concorrentes.

No percurso de estudos também defendo que é preciso haver um perfil claro para ser aluno em EaD. Mas não um perfil "inato", ou seja, o perfil pode ser construído, entendendo-se as especificidades da modalidade.

Muitas propagandas de cursos por EaD parecem equivocadas ao destacar que EaD é para "quem não tem tempo". Basta uma busca simples do termo "EaD em arte" no Google, por exemplo, para verificar.

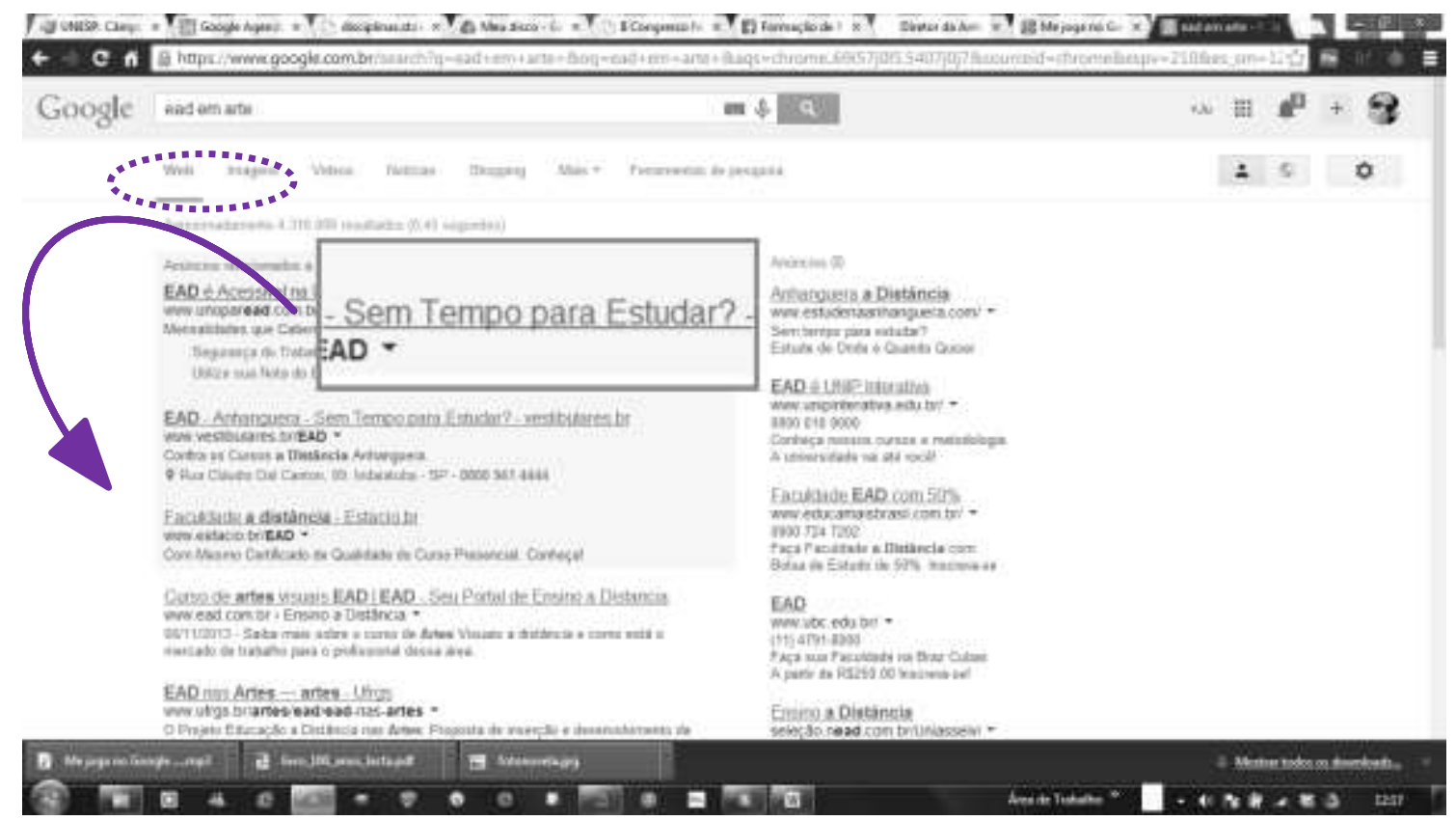

Figura 1 - Pesquisa no Google com o termo "EaD em arte".

A modalidade é para todos que saibam gerenciar seu tempo e otimizar o aproveitamento dele, de modo que possa se organizar para dedicar tempo 
adequado às atividades sem estar restrito, ou "preso", aos horários convencionais de aulas.

EaD não é 'mais fácil' que Educação presencial, nem mais difícil. Participar de processos por EaD é diferente de participar de processos educacionais presenciais. Não haver presença física de um professor em determinados contextos não significa não haver professor. Não haver sincronicidade de tempo para as seções educacionais (aulas), não significa que não haja necessidade de dedicação e tempo destinado à práticas educativas. Em EaD alunos e professores têm, ou podem ter, outros e diferentes papéis. Assim, tentar reproduzir ambientes presenciais por sistemas digitais, tem se mostrado infrutífero e, principalmente, revela concepções no mínimo antigas do processo Ensino aprendizagem.

Ambientes digitais são diferentes de salas de aula e livros, e requerem, assim, posturas e propostas diferentes frente aos seus recursos. Livros servem para ser lidos, ou seja, o acesso ao conteúdo de um livro se faz pela leitura. Processos multimídia não requerem somente a leitura para serem usufruídos. A multimídia "estende o âmbito da comunicação eletrônica para todo o domínio da vida: de casa a trabalho, de escolas a hospitais, de entretenimento a viagens" (CASTELLS, 1999, p. 392). Embora a facilidade de 'trânsito' de conteúdos e textos digitalizados seja verdadeira em ambientes digitais, a função desses ambientes se mostra diferente de uma sala de aulas convencional. Usar sistemas digitais como "repositório" de textos é um dos possíveis usos, não o único, ou o objetivo de existência desses sistemas, e seria como acreditar que uma biblioteca é o mesmo que uma sala de aula, o que não é verdade.

Para verificar a validade dessas proposições, os procedimentos metodológicos usados nesta pesquisa, procuraram construir um diálogo investigativo entre as atuais proposições de formação em Artes Visuais e seus referencias teóricos, e os referenciais ideológicos que sustentam as práticas na modalidade EaD em Artes Visuais. Assim, inicialmente, foi necessário realizar um levantamento do número de cursos de Licenciatura em Artes Visuais, na modalidade à distância, existentes no país (pesquisa quantitativa), bem como ter acesso aos seus projetos pedagógicos, para buscar compreender seus aspectos de 
representatividade quantitativa no universo da formação de professores de arte e suas propostas de formação à luz das teorias da área (referencial histórico com base nas atuais proposições metodológicas para o Ensino de arte e os critérios de avaliação de eficiência e eficácia dessas propostas). Considero, porém, que a maioria dessas teorias ainda representam uma abordagem behaviorista de Educação, concordando com Mattar, quando diz que o modelo vigente de EaD no Brasil [...] reforça um modelo de EaD conteudista, industrial e instrucional [...] embora esse não seja o único modelo possível de se fazer Educação a Distância (2012, p. xix) pois, como diz ainda Mattar

\begin{abstract}
Enquanto o fordismo está associado ao behaviorismo, o neofordismo e o pós-fordismo estariam associados ao construtivismo - e diversas teorias dele derivadas. $\mathrm{O}$ fordismo em $\mathrm{EaD}$ é um sistema formalizado de produção monitorado, mantido e controlado como em uma fábrica; já os modelos posteriores estariam associados à ideia de uma administração descentralizada, democrática e participativa. [...] (MATTAR, 2012, grifo nosso).
\end{abstract}

Em seguida, esses dados foram analisados como forma de constituição de um banco de dados que retrate uma "radiografia" dessas propostas e da situação contemporânea do Ensino de arte por EaD. A ideia foi de que pudessem servir de base para a análise de formação entre as propostas por EaD.

Os pontos analisados nos projetos pedagógicos, estudados nesta investigação foram predominantemente: (a) argumentação de sustentação de opção pela modalidade de Ensino (EaD); (b) bases teóricas que sustentam essas propostas, procurando identificar os autores e teorias que sustentem as argumentações pela opção de oferta de cursos nesta modalidade (EaD); (c) levantamento qualitativo dos critérios de avaliação e auto avaliação de projetos e propostas, em resumo, a excelência em Ensino de arte (SMITH, 2001) e, por fim, (d) levantamento dos perfis de egresso esperados por estas propostas de formação.

Também, em paralelo a este estudo, foi feito o levantamento e mapeamento da legislação referente aos temas (Ensino de arte e Educação à distância), que dá base legal às propostas de formação, buscando verificar a adequação aos referenciais curriculares de formação em Artes Visuais (pesquisa quantitativa com análise qualitativa, de acordo com referencial teórico que embasa a presente 
proposta de pesquisa). Em seguida foram analisados os cursos de licenciatura oferecidos pelas instituições públicas e particulares de Ensino superior.

Ao longo da pesquisa, a participação como pesquisadora do Observatório de Formação de Professores de Arte na América Latina CAPES/MINCyT proporcionou a oportunidade de estagiar na Argentina, na Universidad de La Plata, para conhecer e refletir sobre a formação docente de arte nesse país e ampliar as possibilidades de troca de informação. O Projeto do Observatório de Formação de Professores de Arte na América Latina CAPES/MINCyT envolve as Universidades Brasileiras de São Paulo - USP, do Estado de Santa Catarina UDESC e do Estado do Rio de Janeiro - UERJ, e, na Argentina, a Universidad de La Plata e o Instituto Universitario Nacional del Arte - IUNA. O Observatório é uma iniciativa que visa proporcionar troca de experiências em formação docente entre os dois países envolvidos. A Universidad Nacional de La Plata é uma universidade localizada na cidade de La Plata, Provincia de Buenos Aires. Foi fundada no ano 1897. É o principal centro universitário da província.

O estágio sanduíche na Universidad de La Plata, Argentina, de duração de três meses, entre outubro de 2013 e janeiro de 2014 proporcionou o desenvolvimento de uma ampliação do estudo, em especial na relação com formação de professores de arte por EaD na Argentina, e gerou uma reflexão acerca das possíveis interações com o Brasil. O convite da direção do Observatório para apresentar as linhas gerais desta pesquisa no Colóquio Internacional Pensamiento emergente en la formación docente en artes, organizado pela Profa. Dra. Isabela Frade (UERJ-Brasil) e Prof. Dr. Federico Buján (IUNA-Argentina), permitiu, pelos diálogos proporcionados durante o evento, o aclaramento de questões significativas para a formação de professores de arte, tanto de forma presencial, como por EaD, encaminhando o encerramento deste trabalho.

As reflexões e, em especial, as percepções acerca das semelhantes necessidades educacionais entre os dois países levaram ao desenvolvimento de um interesse pelas políticas educacionais na América Latina, o que, mesmo sem ser o tema central desta pesquisa, cruza-se com as questões trabalhadas aqui, em especial em relação aos aspectos de perfil de egresso esperado e critérios de 
qualidade em formação de docente em artes, independente do modo como esse professor seja formado, seja presencialmente ou por EaD. Todos esses aspectos são reflexos do que é esperado como resultado de políticas públicas de Educação e formação de professores, adotadas por ambos os países.

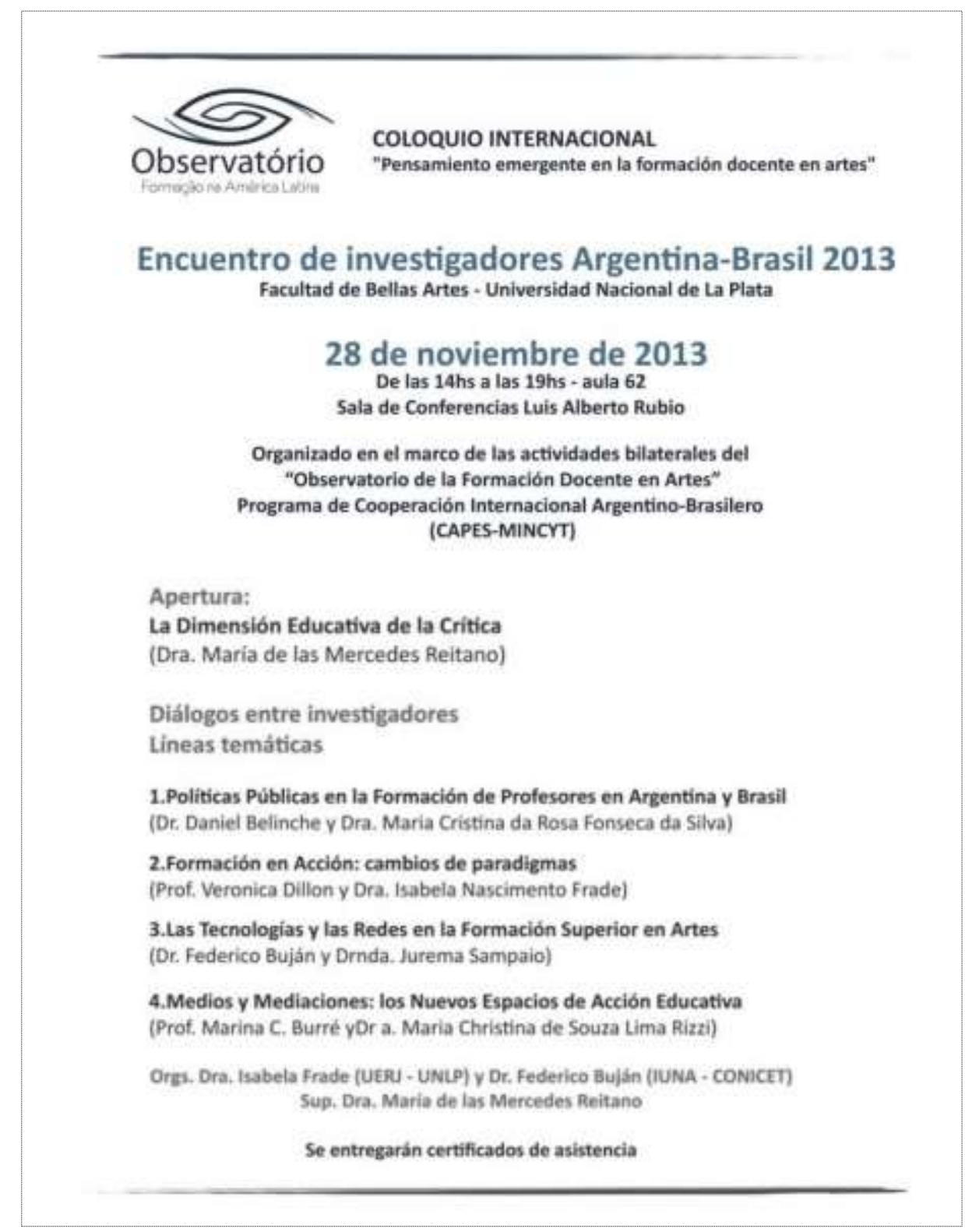

Figura 2 - Cartaz de divulgação do colóquio Internacional "Encuentro de investigadores Argentina-Brasil 2013"3.

\footnotetext{
${ }^{3}$ Evento multipresencial, centralizado na Universidad de La Plata, Argentina, contando com salas de debates na Universidade Estadual de Santa Catarina - UDESC; Universidade de São Paulo USP e Universidade do Estado do Rio de Janeiro - UERJ, as três no Brasil.
} 
Também foi desenvolvido e implementado por EaD, um curso destinado à professores de arte em exercício, disponível no ambiente EaD da UDESC (http://www.moodle.udesc.br/), onde as proposições defendidas por esta pesquisa são aplicadas no Design Instrucional proposto.

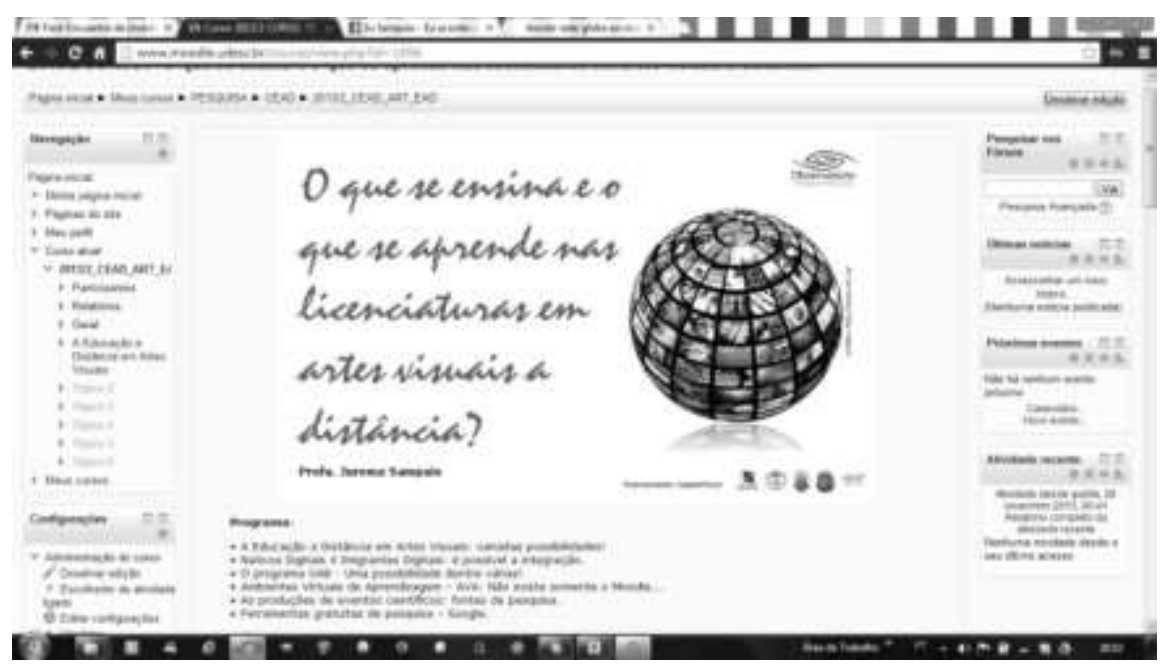

Figura 3 - Página inicial do curso

Por fim, esta tese, etapa final de todo o processo da pesquisa, busca, ao longo de seus capítulos e em suas considerações finais, organizar e refletir sobre as hipóteses e informações levantadas junto ao referencial teórico das áreas de Ensino de Arte e Educação a Distância, numa expectativa de firmar a necessidade urgente de serem traçadas as bases do que se venha a se configurar como uma Epistemologia da Educação a Distância em Artes Visuais. Não como fim em si mesmo, mas como marco inicial dos possíveis encaminhamentos e desdobramentos das múltiplas questões que decorrem da hipótese central que dá título a esta proposta: "O que se ensina e o que se aprende nas licenciaturas em Artes Visuais a distância?", buscando, ainda, conhecer o universo dos profissionais envolvidos em EaD em Artes Visuais.

As questões que guiaram as reflexões foram, dentre outras:

- Quais as expectativas das Instituições de Ensino Superior para a oferta de licenciaturas em Artes Visuais nessa modalidade? 
- Como atendem às necessidades já constatadas na formação de professores de arte, como as práticas de atelier e demais temas técnicos?

- Quais os motivos, expectativas e perfil dos alunos que buscam essa forma de aprendizagem/formação?

- Como é medida, atualmente, ou ao menos está prevista a avaliação da qualidade da formação profissional dos licenciados formados por este método de Ensino?

- Quais seriam os possíveis e/ou desejáveis critérios de qualidade a serem estabelecidos para avaliação da eficiência e eficácia da formação do professor de arte com uso das tecnologias digitais de comunicação e informação? 


\title{
CAPÍTULO I - ENSINO DE ARTE E FORMAÇÃO DOCENTE
}

\author{
"Para mim a arte não tem nem passado nem \\ futuro. Se uma obra de arte não pode viver no \\ presente, ela não merece que a \\ contemplemos."
}

\section{Pablo Picasso}

No Brasil, pela Lei n. 9.394, de dezembro de 1996, de Diretrizes e Bases da Educação Nacional - LDB, Arte é componente curricular obrigatório. Em 1971 a arte já havia sido incluída no currículo escolar, com o título de Educação Artística pela Lei de Diretrizes e Bases da Educação Nacional, mas era considerada "atividade educativa” e não disciplina. Só em 1996 o Ensino de Arte é considerado área de conhecimento com características próprias, que o diferencia da produção em arte.

A LDB se refere às artes nos artigos $3^{\circ}, 24^{\circ}, 26^{\circ}, 32^{\circ}$ e $36^{\circ} . O$ art. $2^{\circ}$ diz que "o Ensino da Arte constituirá componente curricular obrigatório, nos diversos níveis da Educação básica, de forma a promover o desenvolvimento cultural dos alunos" (BRASIL(1), 1999). O art. 26 determina que o Ensino das Artes constituirá componente curricular obrigatório nos diversos níveis de Educação básica para "promover o desenvolvimento cultural dos alunos" deixando de ser considerada uma "atividade educativa" conforme era referida na lei anterior, de 1971. O art. $36^{\circ}$ destaca, ainda, a importância da compreensão do sentido da arte pelos alunos (BRASIL(1), 1999).

A concepção contemporânea de que ensinar arte é, em abordagem bem ampla ${ }^{4}$, a de proporcionar a vivência de experiências de representação artística que "conformam novos sentidos, significados e experiências às parcelas de mundo que possam ser a ela associadas", como diz Frederico de Morais (2002).

Com base no art. 9 , inc. IV da LDB, que determina como uma das obrigações do governo federal é

\footnotetext{
${ }^{4}$ Esta introdução de trabalho não tem a intenção de discutir conceituar ou mesmo teorizar sobre as diversas abordagens da função do Ensino da arte, mas sim parte dessa abordagem, do Ensino de arte como fator de otimização da cognição dos indivíduos pelo desenvolvimento da capacidade crítica e da "conformação de novos sentidos de mundo", como ressalta Frederico Morais.
} 
[...] estabelecer, em colaboração com os Estados, Distrito Federal e os Municípios, competências e diretrizes para a Educação infantil, o Ensino fundamental e o Ensino médio que nortearão os currículos e os seus conteúdos mínimos, de modo a assegurar a formação básica comum (BRASIL, 1999).

Para atender à demanda de formação em Ensino básico, são necessários professores formados licenciados nesses componentes curriculares para ministrar as aulas necessárias à formação dos alunos. Para isso, são necessários cursos de licenciatura nas diversas áreas do conhecimento, contempladas pela LDB para formar esses professores.

Pelo Decreto de 1931, "o licenciado seria o professor dos cursos de Ensino secundário" (CASTRO, 1974, p. 630) e os documentos e decretos, entre os anos de 1930 a 1961 trazem concepções e modificações dos conceitos, diplomas e estruturas das licenciaturas. Em 1934, por exemplo, a Universidade de São Paulo conferia a "licença cultural" para os alunos que cursassem os três anos de qualquer seção e subseção da Faculdade de Filosofia, Ciências e Letras, mas esse diploma não conferia a licença para o magistério, pois essa exigia também formação pedagógica complementar.

Com a Lei de Diretrizes e Bases da Educação Nacional, de 1961

[...] licenciatura e bacharelado passam a ser graus que podem ser obtidos paralelamente, a partir de disciplinas comuns [...] e a partir do movimento de reforma geral do Ensino iniciado pela Lei 5.540/68, e sobre tudo pela Lei 5.692/71 foram estruturadas algumas áreas de licenciatura (CASTRO, 1974).

Quanto à formação de docentes em arte Araújo (2009) nos esclarece que:

A formação superior de professores no Brasil é muito recente se comparada a outros países da América Latina. Tem seu marco na década de 1930, durante o Governo provisório de Getúlio Vargas, com a "Reforma Francisco Campos" [...]. Foi na década de 1970 que se criou as condições reais para a institucionalização da pesquisa, mas em função do alto controle político do regime militar vigente, as áreas foram priorizadas de acordo com os planos nacionais de desenvolvimento [...] O primeiro registro de dissertação de Mestrado sobre Ensino de Artes plásticas defendida no Brasil foi de Margarida Góes de Araújo Pinho, em 1983, intitulado "Ensino de Artes plásticas nos ginásios estaduais vocacionais: 1961-1969", orientado pelo prof. Walter Zanini (ECA/USP). Depois, em 1988, Maria Lúcia Toralles Pereira, defende, na ECA, a dissertação 'Arte na pré-escola e desenvolvimento psicomotor: relato de 
uma experiência', sob a orientação da Profa. Ana Mae Tavares Barbosa, esta, a responsável pela fundação da primeira linha de pesquisa em Arte-Educação, no Brasil (ARAúJO, 2009).

Para Sampaio (1991) "a criação da universidade no Brasil foi antes um processo de sobreposição de modelos do que de substituição". Nessa perspectiva de formação, os profissionais, a licenciatura mostra caráter polivalente

[...] composta de disciplinas comuns às artes (Fundamentos da expressão e comunicação humanas; Estética e História da Arte; Folclore brasileiro; Formas de expressão e comunicação artística), além das disciplinas pedagógicas (Psicologia da Educação; Didática; Estrutura e funcionamento do Ensino; Prática de Ensino e estágio supervisionado) que deveriam corresponder a $1 / 8$ das 1.500 horas fixadas. Esta formação genérica, que poderíamos assim chamar, dava ao professor a licença para atuar de $5^{\text {a }}$ a $8^{\text {a }}$ série. Para atuar no $2^{0}$ grau, seria necessário cursar a licenciatura plena: complementação de mais 1.000 horas de uma habilitação específica a ser escolhida entre artes plásticas, cênicas, música ou desenho (ARAÚJO, 2009).

E é com o crescimento e expansão das pesquisas sobre Ensino de Arte que se transformam as concepções acerca do Ensino de Arte no Brasil. Porém, é muito importante ressaltar, o reconhecimento que Gatti \& Barretto (2009) fazem ao destacar a participação efetiva e significativa dos professores de arte na busca por novos modelos de ensinar e aprender arte.

As licenciaturas curtas e polivalentes foram ter o seu fim na década de 1980, a partir de intensas discussões das sociedades científicas, entre elas a SBPC (Sociedade Brasileira para o Progresso da Ciência) que, preocupadas com as licenciaturas nas áreas de física, química, matemática e biologia, iniciaram uma grande discussão e pressionaram - MEC a rever esta situação. Nas Artes, o estado de São Paulo já contava com um grande número de professores licenciados, o que favoreceu encontros da área com expressiva participação e o início da organização política da classe em associações. Estas, articuladas nacionalmente na FAEB (Federação dos Arte-Educadores do Brasil), desenvolveram ações políticas em defesa do Ensino de Artes e de sua valorização (GATTI \& BARRETTO, 2009 apud GATTI, 2010, p. 13601361).

A reforma legislativa de 1968 reflete essas "novas" concepções, mesmo que ainda carregada de uma visão tecnicista, culmina na consolidação da área de arte como disciplina, publicada na resolução específica, a de №. 23/73, que, juntamente com a Lei 5.692/71, fixavam as normas para o funcionamento dos cursos (ARAÚJO, 2009). 
Desde 1971, pela Lei №. 5.692, a disciplina Educação Artística torna-se parte dos currículos escolares e, segundo Biasoli (1999)

[...] tem como finalidade incorporar à Educação escolar as atividades artísticas para enfatizar o processo expressivo e criativo dos alunos. Entretanto, em virtude do contexto do momento de sua implantação, a Educação artística passa a fazer parte de um currículo que valoriza a tecnicidade e a profissionalização em detrimento das culturas humanística e científica, priorizadas anteriormente. E, assim, a Educação artística passa a existir com uma fundamentação humanística dentro de uma lei tecnicista (BIASOLI, 1999, p. 86).

Ana Mae Barbosa (1989) nos fala sobre essa inclusão, lembrando que

[...] isto não foi uma conquista de arte/educadores brasileiros, mas uma criação ideológica de educadores norte-americanos que, sob um acordo oficial (Acordo MEC-USAID), reformulou a Educação Brasileira, estabelecendo em 1971 os objetivos e o currículo configurado na Lei Federal №. 5.692 denominada "Diretrizes e Bases da Educação" (BARBOSA, 1989).

Ou seja, mais do que uma simples questão de 'reserva de mercado' para os arte/educadores, uma política educacional específica, tecnicista (BIASOLI, 1999, P. 86), com base na ideologia norte-americana (BARBOSA, 1989) foi posta em prática, desde os anos de 1970, com a concepção de Ensino de Arte pensada como parte da formação educacional de nossos alunos. Ainda Ana Mae (Idem) nos fala que já em 1988

[...] a Constituição da Nova República menciona cinco vezes as artes no que se refere a proteção de obras, liberdade de expressão e identidade nacional. Na Seção sobre Educação, Art. 206, parágrafo II, a Constituição determina:

O Ensino tomará lugar sobre os seguintes princípios [...]. II - liberdade para aprender, ensinar, pesquisar e disseminar pensamento, arte e conhecimento (Idem, ibidem).

Neste mesmo texto Ana Mae (1989) questiona a qualidade do Ensino de Arte nas escolas, afirmando que "chegamos a 1989 tendo arte-educadores com uma atuação bastante ativa e consciente, mas com uma formação fraca e superficial no que diz respeito ao conhecimento de arte-Educação e de arte", ou seja, "o que" e "como" a arte é ensinada nas escolas pode ser considerado reflexo direto da formação dos professores de arte. 
Com essa visão como base e considerando que, ao longo do tempo, tenham ocorrido mudanças nas concepções de Ensino de Arte, ora tecnicista, ora sensibilizante e, ainda, como agente transdisciplinar (SAMPAIO, 2010; 2012), em 1996 a LDB vem consolidar a justificativa da existência do Ensino de Arte na escola como agente de promoção do "desenvolvimento cultural dos alunos" (BRASIL(1), 1999).

Sabemos que a arte na escola não tem como objetivo formar artistas, assim como a matemática não tem como objetivo formar matemáticos, embora artistas, matemáticos e escritores devam ser igualmente benvindos numa sociedade desenvolvida (BARBOSA, 2001, p. 32).

Assim, visão de arte como área de conhecimento que corrobora na formação dos indivíduos, é ratificada em 1997 pelos Parâmetros Curriculares Nacionais - PCN que, apesar de apresentarem alguns problemas na sua estrutura, apontam para uma necessária formação consistente, nas respectivas linguagens da arte, para exercício do magistério em arte.

É essa formação que se torna, então, ponto central das preocupações deste trabalho, em especial, as que ocorrem por meio de Ensino a Distância, mediado por redes de comunicação, como a Internet, e tecnologias digitais de comunicação e informação, pois

As questões que se colocam à formação de professores de Arte hoje, propondo novos caminhos frente aos novos conhecimentos da arte, da filosofia e da ciência, não geram respostas prontas para reprodução. Geram profundo questionamento sobre a lógica dos cursos de formação, já que é neles que aprendemos a prática do enciclopedismo, da didática bancária, do Ensino proposicional, do mover-se pela força reativa (estudar para passar na prova) (SANTOS, 2005, p. 182-203).

\subsection{Como são formados os professores de Arte no Brasil?}

Os números da Educação brasileira são monumentais. Segundo os dados do levantamento preliminar oficial do governo brasileiro, pelo censo da Educação de 2012, no país são 39.712 .698 alunos matriculados nas unidades educacionais públicas brasileiras, da creche ao Ensino médio, regular e Educação de Jovens e Adultos - EJA. No Ensino superior, em 2012 o INEP (2012) registrou mais de 160 
mil matrículas na área de Humanidades e artes, que correspondem a 2,3\% do total de matrículas no Ensino Superior em 2012.

Tabela 1 - Número de matrículas em instituições de Ensino públicas, da creche ao Ensino médio, em 2012.

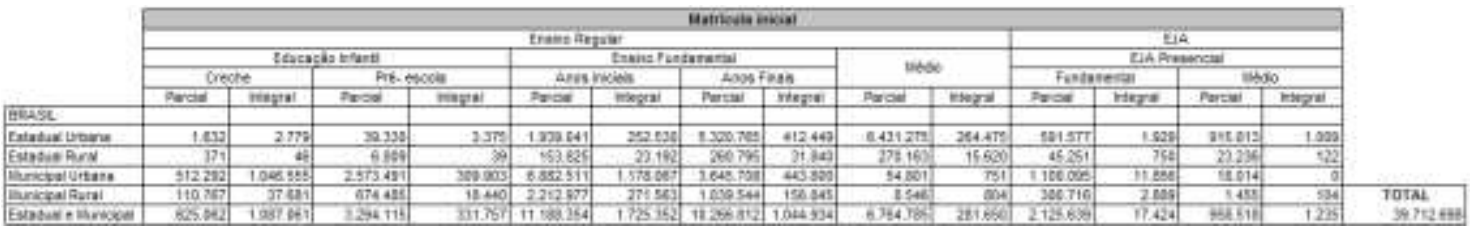

Fonte: Adaptado de MEC/INEP.

Mesmo com essa magnitude de números, a organização da Educação no Brasil apresenta uma estrutura que centralizada no Ministério da Educação - MEC, com suas secretarias e programas.

Parte da história da Educação brasileira nos é contada por Castro (2007, p. 0609)

[...] no século XIX a construção de uma política de unificação nacional e de estruturação do modelo político Estado-Nação, tendo as instituições escolares se constituído em um dos principais fatores de integração política, de coesão social, de transmissão dos valores dos grupos dirigentes e, portanto, de legitimação da nova ordem (HOBSBAWN, 1979). [...] O processo de formação do Estado nacional foi marcado por intensos conflitos, notadamente os que opunham o poder político central e os provinciais.

Nas novas nações que se formavam, as marcas do período colonial mostraram-se mais fortes no Brasil: a persistência do sistema latifundiário agroexportador e da escravidão bloquearam a modernização econômica, bem como a constituição de um modelo político mais participativo e o enraizamento do princípio de cidadania, indispensáveis à difusão da escolarização de massa. Assim, as diversas medidas tomadas para generalizar o Ensino primário ao longo do século XIX caíram no vazio, inclusive o Regulamento de 17 de fevereiro de 1854, que, pela primeira vez, estabeleceu o Ensino obrigatório no país. Apesar de o Estado monárquico brasileiro ter-se caracterizado pelo unitarismo ressalvado breve período que se seguiu à edição do Ato Adicional de 1834 -, a Educação equivalente aos níveis primário e secundário permaneceu a cargo das províncias, que pouco realizavam, enquanto o governo central apenas mantinha as poucas escolas da Corte.

O advento da República não alterou esse quadro de omissão governamental, em razão da permanência da estrutura econômica e do modelo político excludente. Ademais, apesar do surgimento de diversas correntes de pensamento autoritárias, que ansiavam por um Estado forte e promotor da modernização do país, inclusive quanto ao acesso à Educação, prevaleceram entre as elites dirigentes, até 1930, ideias liberais e positivistas, que rejeitavam ou reduziam ao máximo as responsabilidades sociais do Estado, inclusive seu envolvimento na Educação popular. 
Enquanto esta era deixada a cargo dos poderes locais, que pouco faziam, as elites foram contempladas, logo após a independência, com a criação, pelo governo central, das primeiras faculdades. As instituições universitárias, contudo, começaram a ser criadas praticamente após o primeiro terço do século XX.

O modelo institucional herdado do século XIX começou a soçobrar a partir da terceira e quarta décadas do século XX: o crescimento da participação de novos atores no cenário político (classe média urbana e operariado), a crise econômica mundial - que afetou fortemente a economia agroexportadora -, bem como a difusão, em todo o mundo ocidental, de ideais favoráveis à criação de Estados fortemente interventores no domínio econômico e social, deram origem à reorganização institucional no País.

Oscilando entre a ditadura e a democracia liberal, esse novo modelo institucional caracterizou-se pela presença de um Estado que liderava esforços em favor da industrialização, ao mesmo tempo em que tentava intermediar os conflitos de classe de uma sociedade ainda acentuadamente marcada pelas desigualdades sociais e regionais. Nesse contexto, a Educação passou a ser preocupação marcante das ações do poder público, ainda que com reflexos mais claros no campo das formalidades do que no da efetiva ampliação de oportunidades de acesso escolar. Assim, todas as Constituições, a partir da de 1934, conferiram destaque à Educação e estabeleceram o princípio da obrigatoriedade do Ensino elementar. No entanto, com a oferta desse nível escolar a cargo dos estados e dos municípios, apenas muito lentamente as taxas de matrícula cresceram, com avanços sempre mais difíceis nas regiões menos desenvolvidas do norte do país, especialmente nas áreas rurais.

O governo federal concentrou seus esforços na criação de uma rede de instituições de Educação superior e de escolas técnicas de nível médio, processo muito influenciado por interesses políticos. Até recentemente, a função supletiva e redistributiva do governo central manteve-se praticamente limitada à manutenção dessa rede. Em grande parte por conta de um tributo específico (o salário-Educação, instituído em 1964), foram desenvolvidos alguns programas federais suplementares de apoio aos estudantes do Ensino obrigatório (de alimentação, de transporte e de saúde), apenas recentemente racionalizados e ampliados.

A Lei de Diretrizes e Bases da Educação Nacional de 1961, cuja longa tramitação foi perturbada por discussões arcaicas (Ensino religioso versus Ensino laico, principalmente), continha, apesar de suas preocupações formais, normas promissoras, logo anuladas pelo autoritarismo pós-1964.

O regime então instalado manteve a responsabilidade da oferta da Educação obrigatória nas mãos de estados e municípios enquanto desencadeava uma reforma economicista de profissionalização compulsória no Ensino secundário (1971), cujo retumbante fracasso logo obrigou à sua revisão (1982). [...] No campo educacional, os anos de redemocratização iniciados em 1985 foram marcados por valiosos ganhos representados pela retomada dos ideais de cidadania e gestão democrática. Contudo, a estagnação econômica e a crise fiscal do Estado lançaram a Educação pública em um mar de greves, com efeitos mais deletérios na Educação básica, cuja decadência já vinha afastando a classe média pelo menos desde os anos setenta.

As normas educacionais contidas na Constituição Federal (CF) de 1988 e na nova LDB, de 1996, trouxeram novas esperanças, embora contivessem muitos princípios programáticos, de reduzida ou demorada efetividade, especialmente em um país repleto de desigualdades e com baixas taxas de crescimento econômico. Nesse panorama, a criação, em 1996, do Fundo de Manutenção e de Desenvolvimento do Ensino Fundamental e de Valorização do Magistério (FUNDEF) trouxe novo 
alento ao Ensino obrigatório, mediante a promoção de maior equidade nos gastos públicos de estados e de municípios e um maior, embora insuficiente, envolvimento do governo federal nesse nível escolar. Os avanços representados pelo Fundef inspiraram a recente criação do Fundo de Manutenção e Desenvolvimento da Educação Básica e de Valorização dos Profissionais da Educação (FUNDEB), no qual a participação da União deve ser mais efetiva. Já na Educação superior, apesar da existência de setores de ponta, predomina o conservadorismo e o receio de mudanças, refletidos, inclusive, na dita proposta de reforma universitária apresentada em 2006 pelo Poder Executivo e em discussão no Congresso Nacional (CASTRO, 2007, p. 06-09).

O mesmo autor, em trabalho anterior, nos esclarece, ainda, que a Lei de Diretrizes e Bases da Educação - LDB brasileira resultou de uma iniciativa parlamentar e, segundo Castro (2007, p.117-130)

\begin{abstract}
as discussões ocorreram, quase sem nenhuma coordenação, durante a tramitação no Legislativo, o que resultou, juntamente com a lentidão do processo, em acordos frágeis e comprometedores nos vários projetos de substitutivo apresentados nas comissões. Apenas após o Poder Executivo ter-se interessado pela aprovação da matéria - nos Governos Itamar Franco e Fernando Henrique, embora com perspectivas diferentes - é que o processo pôde ser concluído, embora sob suspeição de segmentos da sociedade, que questionaram o rompimento de acordos e a ingerência do Poder Executivo, particularmente na tramitação do projeto no Senado (CASTRO, 2007, p.117-130).
\end{abstract}

Em seu Art. 62ำ a atual LDB determina que a formação dos profissionais da Educação Básica seja feita em nível superior em cursos de Licenciatura.

Nos dias de hoje a formação dos professores de arte é, ainda, grande fonte de pesquisas na área de Educação para, em teoria, mais e melhor realizar uma formação de qualidade. Gatti (2010, p. 02) afirma que "a formação de professores, em geral, é tema constante de pesquisas, e que isso é ótimo, pois se configura como um leque de oportunidades, de esclarecimentos e de proposição de caminhos", mas, no que concerne à esfera das artes, Jorge Coli nos lembra de que, além das questões do Ensino e da Educação "são tantas as flutuações no tempo dos vários juízos sobre as artes [...] que não sabemos a que nos ater" (COLI, 1977, p. 21).

Dessa forma, a formação de professores de arte sofre influências diretas tanto dos aspectos da própria ideia de formação, pelo aspecto educacional, quanto das questões relativas às artes, como área de conhecimento. José Afonso Medeiros 
(2010), em retrospectiva sobre o Ensino de Arte no Brasil, nos apresenta um pequeno histórico da formação em arte.

No Ensino formal de artes, aparentemente tudo começou com a criação da Escola Real de Ciências, Artes e Ofícios, fundada por D. João VI em 1816, mas efetivamente instalada por D. Pedro I dez anos depois, agora denominada de Academia Imperial de Belas Artes. Depois, já como Escola Nacional de Belas Artes (desde 1890), passou a integrar a Universidade do Rio de Janeiro em 1931 e, a partir de 1965, simplesmente Escola de Belas Artes da UFRJ.

Essa ascendência "nobre" do Ensino formal da arte no Brasil (com 184 anos completados em 2010) é pura aparência, visto que a Arte, já em sua certidão de batismo que é o Decreto de 1816, é acessória e supérflua, o que fez com que a tradição do Ensino institucionalizado da arte no Brasil fosse tecida em meio a conflitos e preconceitos ainda hoje impregnados em todo o sistema educacional brasileiro, da pré-escola à pós-graduação. Além do mais, a formação superior de profissionais das artes não encontrou ressonância efetiva no sistema geral da Educação brasileira por mais de um século.

Quase 150 anos se passaram para que o Ensino das Artes se tornasse efetivamente obrigatório nos níveis primário e secundário das escolas brasileiras (através da Lei 5692/71), justamente no período mais obscuro e funesto da história recente do país, quando os militares detinham o poder e sufocavam toda e qualquer tentativa de participação democrática ou de organização da sociedade civil. Aliás, muitos dos atos governamentais importantes para a implantação do Ensino da Arte no Brasil se deram em momentos sombrios, francamente ditatoriais ou populistas.

[...] A constituição das universidades federais em todo o território nacional, a partir da agregação de escolas e faculdades isoladas ou da federalização de algumas já existentes, é um fenômeno das décadas de 1950 e 1960 do século passado. Portanto, o início da democratização do acesso ao Ensino superior no Brasil tem, somente, pouco mais de 50 anos e, apesar dos avanços recentes, ainda existem assimetrias na distribuição de oferta.

[...] Os cursos universitários de artes no Brasil só começaram a ser efetivamente disseminados pelo país - e mesmo assim, de maneira acanhada - a partir da década de 1960. Um novo impulso seria dado a partir da obrigatoriedade do Ensino da Educação artística (Lei 5692/71) nas escolas de todo o país. Por força dessa reforma no Ensino básico brasileiro, licenciaturas em Educação Artística (com habilitações em Artes Plásticas, Música, Artes Cênicas e Desenho) foram criadas em quase todo o território nacional, no mais das vezes, sem infraestrutura mínima e com professores que, em sua maioria, não tinham Educação formal adequada na área de artes, exceto nos grandes centros. Raros eram os professores com pós-graduação em artes (inexistente no país até 1974).

[...] A década de 1980, a par do processo de redemocratização do país, foi um momento privilegiado de organização e reflexão dos arteeducadores brasileiros. Foi nessa década que se intensificaram os debates em torno da formação de professores de arte, questionando-se a formação polivalente e a licenciatura curta, por exemplo. Em 1986, surgiram a Federação de Arte-Educadores do Brasil (FAEB), que reuniu as associações estaduais então nascentes, e a Associação Nacional de Pesquisadores em Artes Plásticas (ANPAP). Também foi em 1986 que começaram as articulações para que a área de Artes tivesse um assento no Conselho do CNPq. Esse movimento de organização dos pesquisadores e professores de artes teve continuidade na década 
seguinte, com a criação da Associação Brasileira de Educação Musical (ABEM) em 1991 e da Associação Brasileira de Pesquisa e PósGraduação em Artes Cênicas (ABRACE) em 1998.

Mas o auge das articulações e organização democrática em torno do Ensino da Arte no Brasil se deu em 1996. Depois de dez anos em que se discutiu amplamente uma nova lei de diretrizes e bases da Educação nacional e que redundou num projeto que era uma costura mal feita de vários lobbies mais ou menos inconfessáveis, Darcy Ribeiro apresentou um projeto substitutivo que, finalmente, entrou na pauta de discussões do Congresso Nacional e que desembocou na Lei 9394/96 (MEDEIROS, 2010).

No mesmo estudo Medeiros ainda informa que:

O país tem atualmente 607 cursos superiores credenciados na área de artes (dados de 2010 do e-Mec ${ }^{5}$ ), dos quais se presume que cerca de $1 / 3$ (pouco mais de 200) são licenciaturas. Para efeito de credenciamento e avaliação, o Ministério da Educação considera cada habilitação/especialidade como um curso. Desses 607 cursos/habilitações, 189 são de Música, 185 de Artes Visuais, 97 de Artes, 43 de Cinema e Audiovisual, 34 de Artes Cênicas, 33 de Teatro e 26 de Dança. Portanto, só com esses números, podemos perceber que na área em que atuamos, as discrepâncias são mais visíveis e gritantes. Se Música e Artes Visuais adquiriram capilaridade, Cinema, Teatro e Dança ainda estão muito aquém da quantidade e da distribuição desejável em todo o país (MEDEIROS, 2010).

Detalhando as ações e iniciativas governamentais para a expansão do Ensino em artes, como

a criação (em 2008) dos Institutos Federais de Educação, Ciência e Tecnologia (a partir dos CEFET) em todos os estados da nação [...]", mesmo ressaltando que "anda é parca a oferta de cursos superiores de artes nesses institutos, pois só os institutos do Ceará (Artes Cênicas, Artes Visuais e Dança), do Maranhão (Artes Visuais), do Paraná (Artes Visuais) e do Tocantins (Artes Cênicas) oferecem cursos na área (Idem, 2010),

e anunciando o Plano Nacional de Professores (PARFOR ${ }^{6}$ ) coordenado pela CAPES.

\footnotetext{
${ }^{5}$ O e-MEC é um sistema eletrônico de acompanhamento dos processos que regulam a Educação superior no Brasil. Todos os pedidos de credenciamento e recredenciamento de instituições de Educação superior e de autorização, renovação e reconhecimento de cursos, além dos processos de aditamento, que são modificações de processos, serão feitos pelo e-MEC. Fonte: MEC. Disponível em: <https://emec.mec.gov.br/ies/>. Acesso em 20 jan.2014.

${ }^{6}$ O PARFOR prevê, em parceria com as secretarias estaduais de Educação e instituições de Ensino superior, a oferta de licenciaturas para professores da Educação básica que ainda não a cursaram ou que atuam em disciplinas diversas de sua formação. Segundo dados da Plataforma Paulo Freire (http://freire.mec.gov.br/ssd/index), foram mais de 8.000 cursos de licenciaturas oferecidos em 2011 (entre implantados e novos).
} 
O Plano Nacional de Formação de Professores da Educação Básica PARFOR visa induzir e fomentar a oferta emergencial de vagas em cursos de Educação superior, gratuitos e de qualidade, nas modalidades presencial e a distância, para professores em exercício na rede pública de Educação básica, a fim de que estes profissionais possam obter a formação exigida pela Lei de Diretrizes e Bases da Educação Nacional LDB e contribuir para a melhoria da qualidade da Educação básica (BRASIL, 2014).

Esses cursos, como também os do programa Pro-Licenciatura, estão fora do escopo desta pesquisa.

Em levantamento que fiz de 2003, junto com Anna Rita Araújo, encontramos que

\begin{abstract}
Nas bases contemporâneas de formação e prática da arte-Educação, vemos que a criatividade, a sensibilidade, a percepção do mundo e a reflexão são capacidades que norteiam os caminhos e as abordagens metodológicas da maioria dos programas, fazendo do Ensino e aprendizado em artes um estudo do cotidiano sob a ótica da arte e da visão que cada um faz desta.

A Arte/Educação, nesta concepção, passa a ter um caráter social de agente de transformação do processo de Ensino assumindo uma visão includente da arte e sua dinâmica como naturalmente transdisciplinar (SAMPAIO-RALHA \& ARAÚJO, 2003, p. 01).
\end{abstract}

Como já anunciado na introdução deste trabalho, esse é o cenário em que se dá o ressurgimento das propostas de formação profissional docente e acadêmica por EaD e o fato 'novo' desse processo de retomada, é a efetiva participação das Tecnologias Digitais de Comunicação e Informação como ferramentas para a modalidade, que foi fortemente estimulada com a popularização dessas tecnologias, no fim dos anos 1990. Porém, vamos falar da história da Formação Docente por EaD e, em especial, a História da Universidade Aberta do Brasil, maior programa de formação inicial docente do Brasil, no terceiro capítulo.

Ao nos referirmos à formação docente, é importante diferenciar Formação inicial e formação continuada. As diferenças são claras, até mesmo pelo nome, mas ao nos referirmos à formação inicial, legalmente, a compreensão é de que esta é a que é feita nas licenciaturas em nível superior, em uma das quatro linguagens artísticas: Artes Visuais, música, dança e teatro, ou cênicas.

A regulamentação dessa formação é feita com as orientações das Diretrizes Curriculares Nacionais do Curso de Graduação em Artes Visuais, Bacharelado e 
Licenciatura, resolução № 1, de 16 de Janeiro de 2009. Pelas diretrizes, o perfil profissional desejado do egresso das licenciaturas em Artes Visuais é o de "um profissional reflexivo, criativo, que apresente considerável conhecimento sobre a realidade artístico-cultural, sobre a arte em diferentes tempos, espaços e proposições e que aponte um viés multicultural-critico" (SILVA, 2010, p. 10).

Ana Luísa Rushel Nunes (2012), em pesquisa sobre as diretrizes para a formação inicial de professores em cursos de licenciatura em nível superior e o Ensino das Artes Visuais, lembra que

Para atender ao perfil e a identidade do ser professor desde a formação inicial a formação continuada de professores também se faz necessário a formação dos formadores, elencando uma possível práxis na formação do professor como professor e pesquisador. Uma forma de avançar na formação inicial e continuada para a docência na escola básica seguindo planejamentos que se configuram numa proposta que pode ser construída de forma colaborativa, tendo em vista as necessidades concretas dos acadêmicos(as) e que possibilite a flexibilização ao longo da formação, considerando as variáveis que podem surgir nesse processo (NUNES, 2012).

Em relação à formação inicial, a pesquisa de Nunes (2012), tendo em vista o momento atual das Políticas Educacionais e suas implicações na Formação Inicial de Professores de Artes Visuais para atuarem na Educação Básica, traz considerações importantes, e aponta, como resultado da pesquisa de verificação de implementação das Diretrizes para a Formação Inicial de Professores em Cursos de Licenciatura em nível superior e o Ensino das Artes Visuais, as necessidades a serem atendidas.

- Estabelecer Grupo de discussão nos Cursos de Licenciatura, neste caso, nos Cursos de Licenciatura em Artes Visuais, no sentido de discutir as Políticas Públicas e o perfil do profissional que este Curso quer formar.

- Organizar conforme discussão acima a construção do Projeto Político Pedagógico de Formação de Professores de Artes Visuais de Instituições Federais, Estaduais e Particulares de Ensino Superior, considerando cada uma a suas especificidades em termos de contextos culturais e regionais, o corpo docente e a sua estrutura física ou de ambiência e seu entorno para um Curso de Formação de Professores e pesquisadores.

- Configurar redesenhando propostas concretas e viáveis, cujas responsabilidades de todo o corpo docente sejam compartilhadas para as transformações curriculares, que deveriam ser implementadas a partir das Diretrizes Curriculares Nacionais do Curso de Graduação em Artes Visuais, bacharelado e licenciatura. PARECER CNE/CES №: 280/2007. APROVADO em: 6/12/2007 e em atendimento a RESOLUÇÃO № 1, DE 16 DE JANEIRO DE 2009. 
- Buscar um espaço e tempo interno nos cursos de formação de formadores de professores de Artes Visuais para estabelecer ações e grupos de estudos, tendo em vista a formação inicial e continuada do corpo docente.

- Buscar uma parceria dos Cursos, estes articulados de forma institucional interna nas IES com outras Instituições escolares da Educação Básica, pensando os processos colaborativos tanto na implementação como no acompanhamento das práticas e Estágios Curriculares Supervisionados sem dissociar conhecimento específico em Artes Visuais e a Formação de novas narrativas Pedagógicas no Ensino. - Constituir parceria buscando um programa específico para a Formação Continuada de Professores de Artes Visuais que atuam em escolas e que por certo, atuarão nos espaços educacionais escolares como tutores e/ou supervisores dos Estágios Supervisionados através de convênios realizados pela Instituição de Ensino Superior em parceria com as Instituições da Educação Básica, cujo campo estará aberto aos alunos dos Cursos de Licenciatura para atuarem com a iniciação a docência buscando uma formação profissional de Ensino de Artes Visuais (NUNES, 2012, p. 11).

A formação continuada se refere aos cursos de extensão e pós-graduação, nos diversos níveis. No Brasil, são "39 cursos de pós-graduação na área de artes, entre estes 19 cursos são de doutorado" (SILVA, FRADE, RIZZI E BUJÁN, 2012, p. 02), mas nem todos têm linhas de pesquisa em Ensino de Arte. Segundo Ana Mae Barbosa (2014), orientadora desta pesquisa, só há um curso de mestrado específico em Arte/Educação, na UFPB, como linha de pesquisa.

\subsubsection{A Educação Superior no Brasil}

Das 2.416 instituições de Educação superior do Brasil, apenas 8\% são Universidades e detêm mais de 54\% dos alunos, são, portanto, grandes instituições. Por outro lado, as Faculdades têm uma participação superior a 84\%, mas atendem pouco menos de $29 \%$ dos alunos. O total de 30.420 cursos de graduação é declarado ao Censo 2011 (INEP, 2012), sendo 29.376 (96,6\%) na modalidade presencial e 1.044 (3,4\%) na modalidade a distância. Porém, Stallivier (2006) nos lembra de que

A Educação superior no Brasil não pode ser discutida sem que se tenha presente o cenário e o contexto em que ela surge, ou seja, deve-se ter presente o tempo e o espaço em que ela está inserida, analisando desde o momento de seu surgimento até a realidade atual da Educação, tanto no panorama local, regional como mundial. [...] O Brasil está localizado na América Latina, um Continente visto por muitos como de exacerbada pobreza. [...] O grande desafio para os países latino-americanos consiste em oferecer aprendizagem, investigação e oportunidades de trabalho para seus indivíduos, de forma equitativa e equilibrada, a fim de 
assegurar conhecimentos avançados que oportunizem 0 desenvolvimento de suas economias, uma vez que esses mesmos países estão se convertendo em protagonistas do mercado global. [...] A primeira universidade brasileira, Universidade do Rio de Janeiro, foi fundada em 1920, no Rio de Janeiro, e definitivamente marcou os rumos da Educação superior no Brasil, sinalizando para o estabelecimento de uma nova era. [...] O Brasil é hoje a décima maior economia do mundo, possuindo dimensões de proporções continentais, ou seja, sua extensão territorial equivale a 8,5 milhões de quilômetros quadrados, e sua população ultrapassa o número de 183 milhões de habitantes, que cresce numa taxa anual de $1,31 \%$. Nessa realidade, estão inseridas as instituições de Ensino Superior, que compõem um sistema complexo, diversificado, em constante mudança e expansão e que está prestes a aprovar um novo documento que rege a sua própria reforma universitária. Para que se possa analisar o sistema de Ensino Superior brasileiro, tem-se que entender as divisões e classificações que the são atribuídas (STALLIVIER, 2006, p. 01-05).

E, ainda, como destaca Castro (2007), ela está intimamente relacionada às questões históricas e políticas.

Na Educação superior, os aspectos modernizantes da reforma de 1968, como a consolidação da pós-graduação acadêmica, com a adoção do formato institucional da research university (ingenuamente estabelecido como modelo estabelecido para toda a Educação superior), não ocultavam a preocupação de conter a insatisfação dos estudantes, em especial mediante o favorecimento de uma significativa ampliação da oferta de vagas, principalmente na rede privada (inclusive com crédito subsidiado para os alunos), fenômeno que deu origem a um Ensino massificado e de baixa qualidade (CASTRO, 2007, p. 08).

Na modalidade presencial, a categoria de instituições privadas é responsável pela oferta de $68,1 \%$ dos cursos de graduação, e as categorias federal, estadual em municipal são responsáveis por 18,2\%, 11,1\% e 2,6\%, respectivamente, dos cursos ofertados. A modalidade a distância distribui de forma mais equilibrada essa oferta: "as IES privadas abrigam $55,5 \%$ dos cursos de graduação e as IES públicas, complementarmente, 44,5\%. Na modalidade a distância, as IES federais são responsáveis por $32,0 \%$ dos cursos de graduação e as IES estaduais e municipais respondem, respectivamente, por 10,6\% e 1,9\% dos cursos" (INEP, 2013, p. 42).

O Ministério de Educação do Brasil define, para efeito fins de geração de estatísticas, que as instituições de Ensino Superior estão classificadas como Públicas (federais, estaduais e municipais) e Privadas (comunitárias, confessionais, filantrópicas e particulares). A definição "está seguramente 
relacionada com as formas de financiamento com que cada um dos modelos procura sobreviver no cenário da Educação superior" (STALLIVIER, 2006, p. 06).

Se o Ministério da Educação utiliza as categorias público-privado com seus derivados para diferenciar e classificar o sistema de Ensino Superior no Brasil, é, então, fundamental ter a compreensão do que isso significa no que diz respeito à forma de manutenção financeira e administrativa de cada um deles.

Basicamente o sistema de Ensino Superior público é mantido pelo poder público, em nível federal, estadual ou municipal.

As instituições públicas federais colocadas nessa categoria utilizam recursos públicos para a sua manutenção, ou seja, o governo federal é o seu principal mantenedor, já que nelas o Ensino é gratuito e somente cerca de $3,5 \%$ do orçamento global é constituído por recursos diretamente por elas arrecadados.

As instituições estaduais, por sua vez, têm no governo estadual o seu principal financiador, sendo que o Ensino também é gratuito. No Brasil, nem todos os estados possuem instituições dessa natureza. Essa modalidade de instituição de caráter estadual está mais concentrada na região sudeste do Brasil, onde estão as grandes universidades que apresentam programas de Ensino e pesquisa avaliados como sendo os de melhor qualidade do país [...].Já as instituições municipais, que são de número bastante inferior se comparado aos outros dois tipos de instituições que recebem recursos do governo, contam com o apoio financeiro do governo municipal. Estatisticamente, têm-se apenas 62 instituições dessa natureza no Brasil, distribuídas entre universidades, centros universitários, faculdades ou centros educacionais tecnológicos. O que distingue o sistema de instituições confessionais, comunitárias e filantrópicas são as isenções fiscais que usufruem, por se caracterizarem como instituições sem fins lucrativos. Isso significa que os resultados positivos de suas atividades devem ser reinvestidos nelas mesmas, não podendo haver distribuição de lucros (STALLIVIER, 2006, p. 06-07).

Tabela 2 - Número de Cursos de Graduação, por Categoria Administrativa, segundo a Modalidade de Ensino. Brasil, 2011.

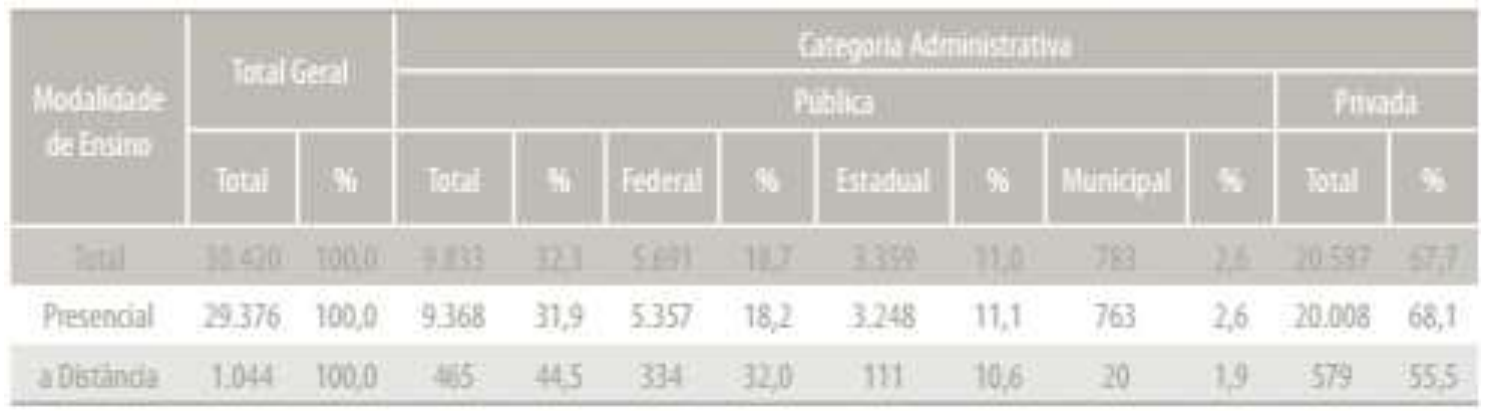

Fonte: MEC/INEP

Dos 30.420 cursos de graduação, "17.031 (ou 56,0\%) são bacharelados, 7.911 (ou 26,0\%) são licenciaturas e 5.478 (ou 18,0\%) são cursos tecnológicos" (Idem, p. 43) e $80,7 \%$ deles "ofertam condições de acessibilidade às pessoas com 
deficiência" (Idem Ibidem, p. 44). Desse total de 7.911 são cursos de licenciaturas.

Tabela 3 - Número e Percentual de Cursos de Graduação (Presencial e a Distância) por Grau Acadêmico - Brasil, 2011.

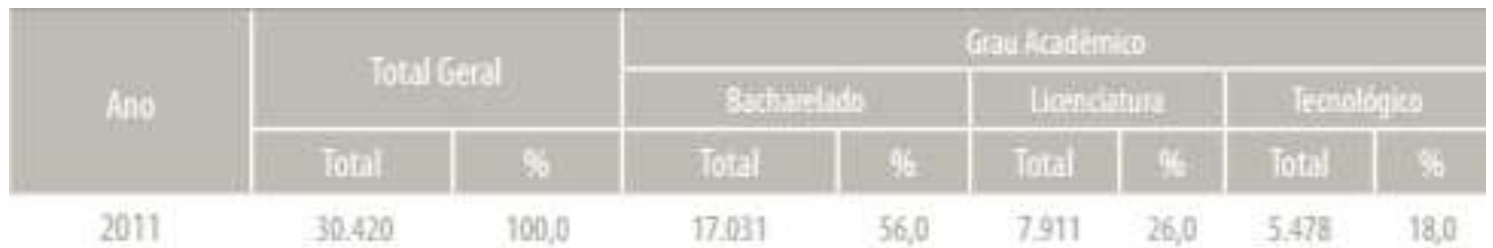

Fonte: Adaptado de MEC/INEP.

Observando o crescimento relativo dos cursos de formação de professores, entre 2001 e 2006, pode-se notar que a oferta de cursos de Pedagogia, destinados à formação de professores polivalentes, praticamente dobrou (94\%). As demais licenciaturas tiveram um aumento menor nessa oferta, de 52\%. As universidades respondem por $63 \%$ desses cursos e, quanto ao número de matriculados, a maior parte está nas instituições privadas: 64\% das matrículas em Pedagogia e 54\% das matrículas nas demais licenciaturas (GATTI, 2010, p. 1361).

No período 2011-2012, as matrículas cresceram 4,6\% nos cursos de bacharelado, 0,8\% nos cursos de licenciatura e $8,5 \%$ nos cursos tecnológicos. Os cursos de bacharelado têm uma participação de $67,1 \%$ nas matrículas, enquanto os cursos de licenciatura e tecnológicos participam com 19,5\% e 13,5\%, respectivamente (INEP, 2013).

\subsubsection{Mapa das Universidades}

O Ministério da Educação - MEC disponibiliza aos interessados um sistema de mapa interativo, navegável, para localização geográfica de Instituições de Educação Superior e Cursos Cadastrados no Brasil, o e-Mec, já apresentado. 


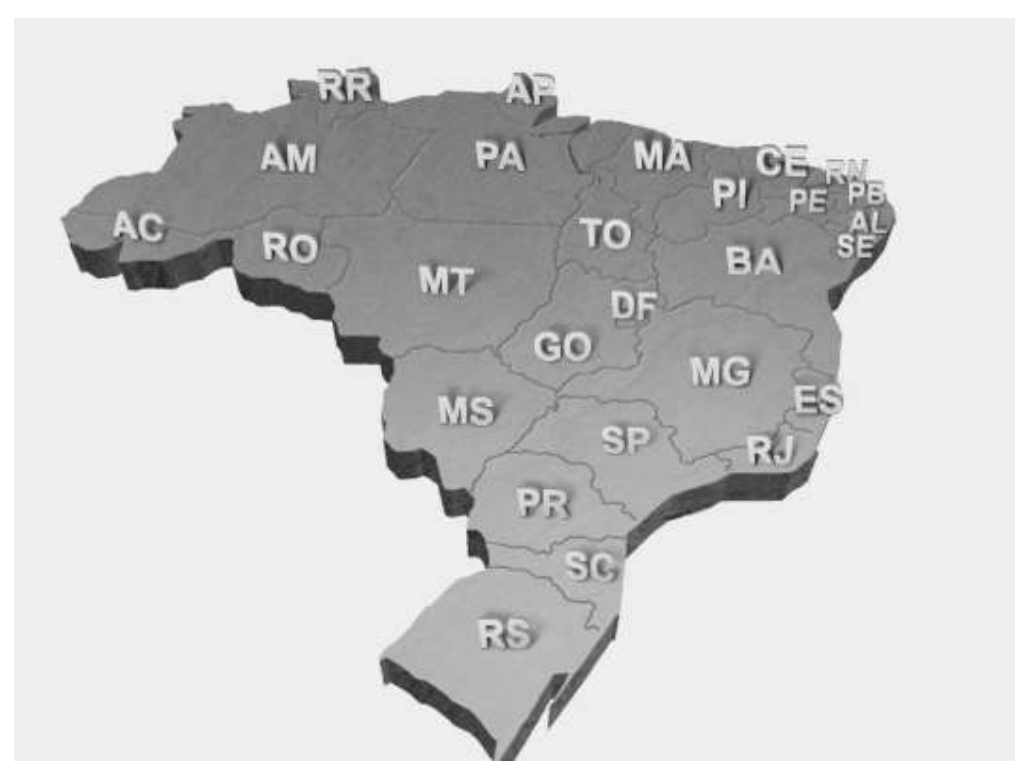

Figura 4 - Mapa das universidades brasileiras

As instituições de Ensino que contam com cursos de formação em arte visuais ${ }^{7}$ podem ser vistas na tabela a seguir. No Brasil, há cursos em Artes Visuais de bacharelado e licenciatura. A licenciatura é o curso que 'licencia' o profissional para a prática docente em Ensino fundamental e médio, ou seja, a formação inicial de professores de arte.

Contamos, em janeiro de $2014^{8}$, com 161 licenciaturas em Artes Visuais $^{9}, 71$ bacharelados, 37 licenciaturas que se cruzam com Artes Visuais (licenciatura em artes plásticas, licenciatura em Educação artística e licenciatura em arte) e um curso. As licenciaturas se dividem em 167 presenciais, e 19 das licenciaturas são à distância. Esses dados podem não estar atualizados, pois os retirei do site do eMEC. Um exemplo é o Centro Universitário Metodista Bennett, que fechou a licenciatura que ainda consta no site até a finalização desta pesquisa.

\footnotetext{
${ }^{7}$ Interesse desta pesquisa.

${ }^{8}$ Esse número é atualizado em 2014, pois, dos dados de 2010, da pesquisa de Afonso Medeiros, já citada, com 185 de Artes Visuais, passamos para 2014 a contar com 254 cursos de Artes Visuais.

${ }^{9}$ Interesse desta pesquisa.
} 
Tabela 4 - Instituições de Ensino Superior Brasileiras, que oferecem cursos em Artes Visuais

\begin{tabular}{|c|c|c|c|c|c|c|c|c|}
\hline Instituição (IES) & Sigla & Grau & Modalidade & endereço & estado & telefone & $\underline{\text { URL }}$ & Administração \\
\hline $\begin{array}{l}\text { Faculdade da } \\
\text { Amazônia } \\
\text { Ocidental }\end{array}$ & FAAO & $\begin{array}{l}\text { Licenciatura em } \\
\text { Artes Visuais }\end{array}$ & Presencial & $\begin{array}{l}\text { Estrada Dias Martins, 894. Jardim } \\
\text { Primavera, Rio Branco/AC. }\end{array}$ & $A C$ & $\begin{array}{l}\text { (68) } 2106-8235 \\
/ 2106-8200\end{array}$ & http://www.faao.com.br/ & $\begin{array}{l}\text { Privada com fins } \\
\text { lucrativos }\end{array}$ \\
\hline $\begin{array}{l}\text { Universidade } \\
\text { Estadual de } \\
\text { Alagoas }\end{array}$ & UNEAL & $\begin{array}{l}\text { Licenciatura } \\
\text { Intercultural } \\
\text { Indígena em } \\
\text { línguas, artes e } \\
\text { literatura }\end{array}$ & Presencial & $\begin{array}{l}\text { Rua Governador Luiz Cavalcante, } \\
\text { S/N. Arapiraca/AL. }\end{array}$ & $\mathrm{AL}$ & $(82) 3521-3019$ & http://www.uneal.edu.br/ & Pública Estadual \\
\hline $\begin{array}{l}\text { Universidade } \\
\text { Federal do } \\
\text { Amazonas }\end{array}$ & UFAM & $\begin{array}{l}\text { Licenciatura em } \\
\text { Artes Visuais }\end{array}$ & Presencial & $\begin{array}{l}\text { Av. Rodrigo Otávio, 6200. Coroado II, } \\
\text { Manaus/AM. }\end{array}$ & AM & (92) 3305-4513 & http://www.ufam.edu.br/ & Pública Federal \\
\hline $\begin{array}{l}\text { Universidade } \\
\text { Federal do } \\
\text { Amazonas }\end{array}$ & UFAM & $\begin{array}{l}\text { Licenciatura em } \\
\text { Artes Visuais }\end{array}$ & Presencial & $\begin{array}{l}\text { Rua Paraíba } 2186 \text { Campus } \\
\text { Universitário, Parintins/AM. }\end{array}$ & AM & (92) 3305-4513 & $\underline{\text { http://www.ufam.edu.br/ }}$ & Pública Federal \\
\hline $\begin{array}{l}\text { Universidade } \\
\text { Federal do } \\
\text { Amazonas }\end{array}$ & UFAM & $\begin{array}{l}\text { Licenciatura em } \\
\text { Artes Visuais }\end{array}$ & $\begin{array}{c}\text { A } \\
\text { Distância }\end{array}$ & $\begin{array}{l}\text { Av. Rodrigo Otávio, } 6200 \text {. Coroado II, } \\
\text { Manaus/AM. }\end{array}$ & AM & (92) 3305-4513 & http://www.ufam.edu.br/ & Pública Federal \\
\hline $\begin{array}{l}\text { Faculdade de } \\
\text { Macapá }\end{array}$ & FAMA & $\begin{array}{l}\text { Licenciatura em } \\
\text { Artes Visuais }\end{array}$ & Presencial & $\begin{array}{l}\text { Rodovia Duque de Caxias, KM } 05 . \\
\text { Cabralzinho, Macapá/AP. }\end{array}$ & AP & (96) 2101-0400 & $\begin{array}{l}\text { http://www.faculdaded } \\
\text { emacapa.com.br/ }\end{array}$ & $\begin{array}{l}\text { Privada com fins } \\
\text { lucrativos }\end{array}$ \\
\hline $\begin{array}{l}\text { Universidade } \\
\text { Federal do Amapá }\end{array}$ & UNIFAP & $\begin{array}{l}\text { Licenciatura em } \\
\text { Artes Visuais }\end{array}$ & Presencial & $\begin{array}{l}\text { Rodovia Juscelino Kubitschek, S/N. } \\
\text { Macapá/AP. }\end{array}$ & AP & (96) 3312-1705 & http://www.unifap.br & Pública Federal \\
\hline $\begin{array}{l}\text { Universidade } \\
\text { Federal do Amapá }\end{array}$ & UNIFAP & $\begin{array}{l}\text { Licenciatura em } \\
\text { Artes Visuais }\end{array}$ & Presencial & $\begin{array}{l}\text { Rua Joaquim Caetano da Silva S/N. } \\
\text { Oiapoque/AP. }\end{array}$ & AP & (96) 3312-1705 & http://www.unifap.br & Pública Federal \\
\hline $\begin{array}{l}\text { Universidade } \\
\text { Católica do } \\
\text { Salvador }\end{array}$ & UCSAL & $\begin{array}{l}\text { Licenciatura em } \\
\text { Artes Visuais }\end{array}$ & Presencial & Praça Ana Nery, S/N. Salvador/BA. & $\mathrm{BA}$ & (71) 3324-7530 & http://www.ucsal.br/ & $\begin{array}{l}\text { Privada sem fins } \\
\text { lucrativos }\end{array}$ \\
\hline $\begin{array}{l}\text { Universidade do } \\
\text { Estado da Bahia }\end{array}$ & UNEB & $\begin{array}{l}\text { Licenciatura em } \\
\text { Artes Visuais }\end{array}$ & Presencial & $\begin{array}{l}\text { Rodovia Alagoinhas, BR } 110 \text { - Km } 03 \\
\text { S/N. Alagoinhas/BA. }\end{array}$ & BA & $\begin{array}{c}\text { (71) } 3117-2354 \\
\text { / } 3117-2734\end{array}$ & http://www.uneb.br/ & Pública Estadual \\
\hline $\begin{array}{l}\text { Universidade do } \\
\text { Estado da Bahia }\end{array}$ & UNEB & $\begin{array}{l}\text { Licenciatura em } \\
\text { Artes Visuais }\end{array}$ & Presencial & $\begin{array}{l}\text { Rodovia Alagoinhas, BR } 110 \text { - Km } 03 \\
\text { S/N. Alagoinhas/BA. }\end{array}$ & $\mathrm{BA}$ & $\begin{array}{l}\text { (71) } 3117-2354 \\
\text { / } 3117-2734\end{array}$ & http://www.uneb.br/ & Pública Estadual \\
\hline $\begin{array}{l}\text { Universidade do } \\
\text { Estado da Bahia }\end{array}$ & UNEB & $\begin{array}{l}\text { Licenciatura em } \\
\text { Artes Visuais }\end{array}$ & Presencial & $\begin{array}{l}\text { Loteamento Flamengo, BR } 242-\mathrm{Km} \\
04 \mathrm{~S} / \mathrm{No} \text {. Barreiras/BA. }\end{array}$ & $\mathrm{BA}$ & $\begin{array}{c}\text { (71) } 3117-2354 \\
\text { / } 3117-2734\end{array}$ & http://www.uneb.br/ & Pública Estadual \\
\hline $\begin{array}{l}\text { Universidade do } \\
\text { Estado da Bahia }\end{array}$ & UNEB & $\begin{array}{l}\text { Licenciatura em } \\
\text { Artes Visuais }\end{array}$ & Presencial & $\begin{array}{l}\text { Loteamento Flamengo, BR } 242 \text { - Km } \\
04 \text { S/No. Barreiras/BA. }\end{array}$ & BA & $\begin{array}{l}\text { (71) } 3117-2354 \\
\text { / } 3117-2734\end{array}$ & http://www.uneb.br/ & Pública Estadual \\
\hline $\begin{array}{l}\text { Universidade do } \\
\text { Estado da Bahia }\end{array}$ & UNEB & $\begin{array}{l}\text { Licenciatura em } \\
\text { Artes Visuais }\end{array}$ & Presencial & Rua Cel. Magno 533. Barreiras/BA. & $\mathrm{BA}$ & $\begin{array}{c}\text { (71) } 3117-2354 \\
\text { / 3117-2734 }\end{array}$ & http://www.uneb.br/ & Pública Estadual \\
\hline $\begin{array}{l}\text { Universidade do } \\
\text { Estado da Bahia }\end{array}$ & UNEB & $\begin{array}{l}\text { Licenciatura em } \\
\text { Artes Visuais }\end{array}$ & Presencial & Rua Cel. Magno 533. Barreiras/BA. & $\mathrm{BA}$ & $\begin{array}{c}\text { (71) } 3117-2354 \\
\text { / } 3117-2734\end{array}$ & http://www.uneb.br/ & Pública Estadual \\
\hline
\end{tabular}




\begin{tabular}{|c|c|c|c|c|c|c|c|c|}
\hline $\begin{array}{l}\text { Universidade do } \\
\text { Estado da Bahia }\end{array}$ & UNEB & $\begin{array}{l}\text { Licenciatura em } \\
\text { Artes Visuais }\end{array}$ & Presencial & $\begin{array}{l}\text { Avenida David Jonas Fadini } 300 . \\
\text { Eunápolis/BA. }\end{array}$ & $\mathrm{BA}$ & $\begin{array}{c}(71) \text { 3117-2354 } \\
\text { / } 3117-2734\end{array}$ & http://www.uneb.br/ & Pública Estadual \\
\hline $\begin{array}{l}\text { Universidade do } \\
\text { Estado da Bahia }\end{array}$ & UNEB & $\begin{array}{l}\text { Licenciatura em } \\
\text { Artes Visuais }\end{array}$ & Presencial & $\begin{array}{l}\text { Avenida David Jonas Fadini } 300 . \\
\text { Eunápolis/BA. }\end{array}$ & $\mathrm{BA}$ & $\begin{array}{c}\text { (71) } 3117-2354 \\
\text { / } 3117-2734\end{array}$ & http://www.uneb.br/ & Pública Estadual \\
\hline $\begin{array}{l}\text { Universidade do } \\
\text { Estado da Bahia }\end{array}$ & UNEB & $\begin{array}{l}\text { Licenciatura em } \\
\text { Artes Visuais }\end{array}$ & Presencial & $\begin{array}{l}\text { Av. Universitária Vanessa Cardoso } \\
\text { S/N. Guanambi/BA. }\end{array}$ & $\mathrm{BA}$ & $\begin{array}{c}\text { (71) } 3117-2354 \\
\text { / 3117-2734 }\end{array}$ & http://www.uneb.br/ & Pública Estadual \\
\hline $\begin{array}{l}\text { Universidade do } \\
\text { Estado da Bahia }\end{array}$ & UNEB & $\begin{array}{l}\text { Licenciatura em } \\
\text { Artes Visuais }\end{array}$ & Presencial & $\begin{array}{l}\text { Av. Universitária Vanessa Cardoso } \\
\text { S/N. Guanambi/BA. }\end{array}$ & $\mathrm{BA}$ & $\begin{array}{c}\text { (71) } 3117-2354 \\
\text { / } 3117-2734\end{array}$ & http://www.uneb.br/ & Pública Estadual \\
\hline $\begin{array}{l}\text { Universidade do } \\
\text { Estado da Bahia }\end{array}$ & UNEB & $\begin{array}{l}\text { Licenciatura em } \\
\text { Artes Visuais }\end{array}$ & Presencial & Av. Getúlio Vargas 769. Ipiaú/BA. & $\mathrm{BA}$ & $\begin{array}{c}\text { (71) } 3117-2354 \\
\text { / } 3117-2734\end{array}$ & http://www.uneb.br/ & Pública Estadual \\
\hline $\begin{array}{l}\text { Universidade do } \\
\text { Estado da Bahia }\end{array}$ & UNEB & $\begin{array}{l}\text { Licenciatura em } \\
\text { Artes Visuais }\end{array}$ & Presencial & Av. Getúlio Vargas 769. Ipiaú/BA. & $\mathrm{BA}$ & $\begin{array}{c}\text { (71) } 3117-2354 \\
\text { / } 3117-2734\end{array}$ & http://www.uneb.br/ & Pública Estadual \\
\hline $\begin{array}{l}\text { Universidade do } \\
\text { Estado da Bahia }\end{array}$ & UNEB & $\begin{array}{l}\text { Licenciatura em } \\
\text { Artes Visuais }\end{array}$ & Presencial & Rua Tiradentes 54. Irecê/BA. & $\mathrm{BA}$ & $\begin{array}{c}\text { (71) } 3117-2354 \\
\text { / } 3117-2734\end{array}$ & http://www.uneb.br/ & Pública Estadual \\
\hline $\begin{array}{l}\text { Universidade do } \\
\text { Estado da Bahia }\end{array}$ & UNEB & $\begin{array}{l}\text { Licenciatura em } \\
\text { Artes Visuais }\end{array}$ & Presencial & Rua Tiradentes 54. Irecê/BA. & $\mathrm{BA}$ & $\begin{array}{c}\text { (71) } 3117-2354 \\
\text { / } 3117-2734\end{array}$ & http://www.uneb.br/ & Pública Estadual \\
\hline $\begin{array}{l}\text { Universidade do } \\
\text { Estado da Bahia }\end{array}$ & UNEB & $\begin{array}{l}\text { Licenciatura em } \\
\text { Artes Visuais }\end{array}$ & Presencial & Rua Tiradentes 54. Irecê/BA. & $\mathrm{BA}$ & $\begin{array}{c}\text { (71) } 3117-2354 \\
\text { / 3117-2734 }\end{array}$ & http://www.uneb.br/ & Pública Estadual \\
\hline $\begin{array}{l}\text { Universidade do } \\
\text { Estado da Bahia }\end{array}$ & UNEB & $\begin{array}{l}\text { Licenciatura em } \\
\text { Artes Visuais }\end{array}$ & Presencial & Rua Tiradentes 54. Irecê/BA. & $\mathrm{BA}$ & $\begin{array}{c}\text { (71) } 3117-2354 \\
\text { / } 3117-2734\end{array}$ & http://www.uneb.br/ & Pública Estadual \\
\hline $\begin{array}{l}\text { Universidade do } \\
\text { Estado da Bahia }\end{array}$ & UNEB & $\begin{array}{l}\text { Licenciatura em } \\
\text { Artes Visuais }\end{array}$ & Presencial & Rua Tiradentes 54. Irecê/BA. & $\mathrm{BA}$ & $\begin{array}{c}\text { (71) } 3117-2354 \\
\text { / } 3117-2734\end{array}$ & http://www.uneb.br/ & Pública Estadual \\
\hline $\begin{array}{l}\text { Universidade do } \\
\text { Estado da Bahia }\end{array}$ & UNEB & $\begin{array}{l}\text { Licenciatura em } \\
\text { Artes Visuais }\end{array}$ & Presencial & Rua Tiradentes 54. Irecê/BA. & $\mathrm{BA}$ & $\begin{array}{l}\text { (71) } 3117-2354 \\
\text { / 3117-2734 }\end{array}$ & http://www.uneb.br/ & Pública Estadual \\
\hline $\begin{array}{l}\text { Universidade do } \\
\text { Estado da Bahia }\end{array}$ & UNEB & $\begin{array}{l}\text { Licenciatura em } \\
\text { Artes Visuais }\end{array}$ & Presencial & $\begin{array}{l}\text { Rua Edgard Chastinet, S/N. } \\
\text { Juazeiro/BA. }\end{array}$ & $\mathrm{BA}$ & $\begin{array}{c}\text { (71) } 3117-2354 \\
\text { / } 3117-2734\end{array}$ & http://www.uneb.br/ & Pública Estadual \\
\hline $\begin{array}{l}\text { Universidade } \\
\text { Federal do Oeste } \\
\text { da Bahia }\end{array}$ & UFOB & $\begin{array}{l}\text { Bacharelado em } \\
\text { Artes Visuais }\end{array}$ & Presencial & $\begin{array}{l}\text { Rua Professor José Seabra, S/N. } \\
\text { Barreiras/BA. }\end{array}$ & $\mathrm{BA}$ & (77) 3614-3500 & http://www.ufob.edu.br & Pública Federal \\
\hline $\begin{array}{l}\text { Universidade } \\
\text { Federal do } \\
\text { Recôncavo da } \\
\text { Bahia }\end{array}$ & UFRB & $\begin{array}{l}\text { Bacharelado em } \\
\text { Artes Visuais }\end{array}$ & Presencial & $\begin{array}{l}\text { Rua Maestro Irineu Sacramento } 11 . \\
\text { Quarteirão Leite Alves, Cachoeira/BA. }\end{array}$ & $\mathrm{BA}$ & (75) $3621-2350$ & $\begin{array}{l}\text { http://www.ufrb.edu.br/ } \\
\text { portal/ }\end{array}$ & Pública Federal \\
\hline $\begin{array}{l}\text { Universidade } \\
\text { Federal do Sul da } \\
\text { Bahia }\end{array}$ & $\begin{array}{l}\text { UFESBA } \\
\text { (UFSB) }\end{array}$ & $\begin{array}{l}\text { Bacharelado } \\
\text { Interdisciplinar } \\
\text { em Artes }\end{array}$ & Presencial & $\begin{array}{l}\text { Rodovia Ilhéus-Vitória da Conquista, } \\
\text { BR-415, km 39. Ferradas, Itabuna/BA. }\end{array}$ & $\mathrm{BA}$ & (71) 8726-4003 & http://www.ufsba.ufba.br/ & Pública Federal \\
\hline $\begin{array}{l}\text { Universidade } \\
\text { Salgado de } \\
\text { Oliveira }\end{array}$ & $\begin{array}{l}\text { UNIVER } \\
\text { SO }\end{array}$ & $\begin{array}{l}\text { Licenciatura - } \\
\text { Educação } \\
\text { Artística }\end{array}$ & Presencial & $\begin{array}{l}\text { Avenida Antônio Carlos Magalhães, } \\
\text { 2728. Salvador/BA }\end{array}$ & $\mathrm{BA}$ & (21) 2620-1069 & $\frac{\text { http://www.universo.ed }}{\underline{\text { u.br/portal/salvador/ }}}$ & $\begin{array}{l}\text { Privada sem fins } \\
\text { lucrativos }\end{array}$ \\
\hline
\end{tabular}




\begin{tabular}{|c|c|c|c|c|c|c|c|c|}
\hline $\begin{array}{l}\text { Instituto Federal } \\
\text { de Ciência e } \\
\text { Tecnologia do } \\
\text { Ceará }\end{array}$ & IFCE & $\begin{array}{l}\text { Licenciatura em } \\
\text { Artes Plásticas }\end{array}$ & Presencial & $\begin{array}{l}\text { Avenida Treze de Maio, } 2081 . \\
\text { Benfica, Fortaleza/CE. }\end{array}$ & CE & (85) 3307-3666 & http://www.ifce.edu.br/ & Pública Federal \\
\hline $\begin{array}{l}\text { Instituto Federal } \\
\text { de Ciência e } \\
\text { Tecnologia do } \\
\text { Ceará }\end{array}$ & IFCE & $\begin{array}{l}\text { Licenciatura em } \\
\text { Artes Visuais }\end{array}$ & Presencial & $\begin{array}{l}\text { Avenida Treze de Maio, } 2081 . \\
\text { Benfica, Fortaleza/CE. }\end{array}$ & CE & (85) 3307-3666 & http://www.ifce.edu.br/ & Pública Federal \\
\hline $\begin{array}{l}\text { Universidade de } \\
\text { Fortaleza }\end{array}$ & UNIFOR & $\begin{array}{l}\text { Bacharelado em } \\
\text { Artes Visuais }\end{array}$ & Presencial & $\begin{array}{l}\text { Avenida Washington Soares, } 1321 . \\
\text { Fortaleza/CE. }\end{array}$ & CE & (85) 3477-3400 & http://www.unifor.br/ & $\begin{array}{l}\text { Privada sem fins } \\
\text { lucrativos }\end{array}$ \\
\hline $\begin{array}{l}\text { Universidade } \\
\text { Estadual do Ceará }\end{array}$ & UECE & $\begin{array}{l}\text { Licenciatura em } \\
\text { Artes Visuais }\end{array}$ & $\begin{array}{c}\text { A } \\
\text { Distância }\end{array}$ & $\begin{array}{l}\text { Av. Paranjana, 1700. Serrinha, } \\
\text { Fortaleza/CE. }\end{array}$ & CE & (85) 3101-9610 & http://www.uece.br & Pública Estadual \\
\hline $\begin{array}{l}\text { Universidade } \\
\text { Regional do Cariri }\end{array}$ & URCA & $\begin{array}{l}\text { Licenciatura em } \\
\text { Artes Visuais }\end{array}$ & Presencial & $\begin{array}{l}\text { Av. Coronel Antonio Luiz, } 1161 . \\
\text { Crato/CE. }\end{array}$ & CE & (88) 3102-1213 & http://www.urca.br/ & Pública Estadual \\
\hline $\begin{array}{l}\text { Faculdade de } \\
\text { Artes Dulcina de } \\
\text { Moraes }\end{array}$ & FADM & $\begin{array}{l}\text { Licenciatura - } \\
\text { Educação } \\
\text { Artística }\end{array}$ & Presencial & $\begin{array}{l}\text { Sds Bl C Edifício FBT, Asa Sul. } \\
\text { Brasília/DF. }\end{array}$ & DF & (61) 3323-8475 & http://facinor.br/ & $\begin{array}{l}\text { Privada sem fins } \\
\text { lucrativos }\end{array}$ \\
\hline $\begin{array}{l}\text { Faculdade de } \\
\text { Artes Dulcina de } \\
\text { Moraes }\end{array}$ & FADM & $\begin{array}{l}\text { Licenciatura em } \\
\text { Artes Visuais }\end{array}$ & Presencial & $\begin{array}{l}\text { Sds BI C Edifício FBT, Asa Sul. } \\
\text { Brasília/DF. }\end{array}$ & DF & (61) $3323-8475$ & http://facinor.br/ & $\begin{array}{l}\text { Privada sem fins } \\
\text { lucrativos }\end{array}$ \\
\hline $\begin{array}{l}\text { Faculdade Mauá } \\
\text { de Brasília }\end{array}$ & MAUADF & $\begin{array}{l}\text { Bacharelado em } \\
\text { Artes Visuais }\end{array}$ & Presencial & $\begin{array}{l}\text { Colônia Agrícola Vicente Pires, } 54 \text {. } \\
\text { Região Administrativa III Taguatinga, } \\
\text { Brasília/DF. }\end{array}$ & DF & (61) $3397-5251$ & $\begin{array}{l}\text { http://www.mauadf.co } \\
\underline{\text { m.br/ }}\end{array}$ & $\begin{array}{l}\text { Privada com fins } \\
\text { lucrativos }\end{array}$ \\
\hline $\begin{array}{l}\text { Faculdade Santa } \\
\text { Terezinha }\end{array}$ & FAST & $\begin{array}{l}\text { Licenciatura em } \\
\text { Artes Visuais }\end{array}$ & Presencial & $\begin{array}{l}\text { QI } 20 \text { Lotes Ímpares de } 01 \text { a } 25 . \\
\text { Taguatinga, Brasília/DF. }\end{array}$ & DF & (61) 3475-2244 & $\begin{array}{l}\text { http://www.anhanguer } \\
\text { a.com/home/ }\end{array}$ & $\begin{array}{l}\text { Privada com fins } \\
\text { lucrativos }\end{array}$ \\
\hline $\begin{array}{l}\text { Universidade de } \\
\text { Brasília }\end{array}$ & UNB & $\begin{array}{l}\text { Bacharelado em } \\
\text { Artes Plásticas }\end{array}$ & Presencial & $\begin{array}{l}\text { Campus Universitário Darcy Ribeiro, } \\
\text { S/N. Asa Norte, Brasília/DF. }\end{array}$ & DF & $\begin{array}{l}\text { (61) } 3307-1750 \\
/ 3307-2600\end{array}$ & http://www.unb.br/ & Pública Federal \\
\hline $\begin{array}{l}\text { Universidade de } \\
\text { Brasília }\end{array}$ & UNB & $\begin{array}{l}\text { Licenciatura em } \\
\text { Artes Plásticas }\end{array}$ & Presencial & $\begin{array}{l}\text { Campus Universitário Darcy Ribeiro, } \\
\text { S/N. Asa Norte, Brasília/DF. }\end{array}$ & DF & $\begin{array}{l}\text { (61) } 3307-1750 \\
/ 3307-2600\end{array}$ & http://www.unb.br/ & Pública Federal \\
\hline $\begin{array}{l}\text { Universidade de } \\
\text { Brasília }\end{array}$ & UNB & $\begin{array}{l}\text { Licenciatura em } \\
\text { Artes Visuais }\end{array}$ & $\begin{array}{c}\text { A } \\
\text { Distância }\end{array}$ & $\begin{array}{l}\text { Campus Universitário Darcy Ribeiro, } \\
\text { S/N. Asa Norte, Brasília/DF. }\end{array}$ & DF & $\begin{array}{l}\text { (61) } 3307-1750 \\
/ 3307-2600\end{array}$ & http://www.unb.br/ & Pública Federal \\
\hline $\begin{array}{l}\text { Universidade } \\
\text { Federal do } \\
\text { Espírito Santo }\end{array}$ & UFES & $\begin{array}{l}\text { Bacharelado em } \\
\text { Artes Plásticas }\end{array}$ & Presencial & $\begin{array}{l}\text { Av. Fernando Ferrari, } 514, \\
\text { Goiabeiras, } 514 \text {. Goiabeiras, } \\
\text { Vitória/ES. }\end{array}$ & ES & (27) 40092200 & http://www.ufes.br/ & Pública Estadual \\
\hline $\begin{array}{l}\text { Universidade } \\
\text { Federal do } \\
\text { Espírito Santo }\end{array}$ & UFES & $\begin{array}{l}\text { Licenciatura em } \\
\text { Artes Visuais }\end{array}$ & Presencial & $\begin{array}{l}\text { Av. Fernando Ferrari, 514, } \\
\text { Goiabeiras, 514. Goiabeiras, } \\
\text { Vitória/ES. }\end{array}$ & ES & (27) 40092200 & http://www.ufes.br/ & Pública Estadual \\
\hline $\begin{array}{l}\text { Universidade } \\
\text { Federal do } \\
\text { Espírito Santo }\end{array}$ & UFES & $\begin{array}{l}\text { Licenciatura em } \\
\text { Artes Visuais }\end{array}$ & $\begin{array}{c}\text { A } \\
\text { Distância }\end{array}$ & $\begin{array}{l}\text { Av. Fernando Ferrari, } 514, \\
\text { Goiabeiras, 514. Goiabeiras, } \\
\text { Vitória/ES. }\end{array}$ & ES & (27) 40092200 & http://www.ufes.br/ & Pública Estadual \\
\hline Faculdade & $\begin{array}{l}\text { CATOLICA } \\
\text { DE }\end{array}$ & Licenciatura em & Presencial & Rua B-10, Qd. 10, Its. 13, 14, 15 e 16, & GO & (62) $3328-8900$ & http://www.catolicadea & $\begin{array}{l}\text { Privada sem fins } \\
\text { lucrativos }\end{array}$ \\
\hline
\end{tabular}




\begin{tabular}{|c|c|c|c|c|c|c|c|c|}
\hline $\begin{array}{l}\text { Católica de } \\
\text { Anápolis }\end{array}$ & ANAPOLIS & Ensino de Artes & & 580. Cidade Jardim, Anápolis/GO. & & & $\underline{\text { napolis.edu.br/ }}$ & \\
\hline $\begin{array}{l}\text { Universidade } \\
\text { Federal de Goiás }\end{array}$ & UFG & $\begin{array}{l}\text { Bacharelado em } \\
\text { Artes Visuais }\end{array}$ & Presencial & $\begin{array}{l}\text { Rodovia Goiânia Nierópolis, km 12, } \\
\text { Goiânia/GO. }\end{array}$ & GO & (62) 35211063 & http://www.ufg.br/ & Pública Federal \\
\hline $\begin{array}{l}\text { Universidade } \\
\text { Federal de Goiás }\end{array}$ & UFG & $\begin{array}{l}\text { Bacharelado em } \\
\text { Artes Visuais / } \\
\text { Artes Plásticas }\end{array}$ & Presencial & $\begin{array}{l}\text { Rodovia Goiânia Nierópolis, km 12, } \\
\text { Goiânia/GO. }\end{array}$ & GO & (62) 35211063 & http://www.ufg.br/ & Pública Federal \\
\hline $\begin{array}{l}\text { Universidade } \\
\text { Federal de Goiás }\end{array}$ & UFG & $\begin{array}{l}\text { Bacharelado em } \\
\text { Artes Visuais / } \\
\text { Design Gráfico }\end{array}$ & Presencial & $\begin{array}{l}\text { Rodovia Goiânia Nierópolis, km 12, } \\
\text { Goiânia/GO. }\end{array}$ & GO & (62) 35211063 & http://www.ufg.br/ & Pública Federal \\
\hline $\begin{array}{l}\text { Universidade } \\
\text { Federal de Goiás }\end{array}$ & UFG & $\begin{array}{l}\text { Licenciatura em } \\
\text { Artes Visuais }\end{array}$ & Presencial & $\begin{array}{l}\text { Rodovia Goiânia Nierópolis, km 12, } \\
\text { Goiânia/GO. }\end{array}$ & GO & (62) 35211063 & http://www.ufg.br/ & Pública Federal \\
\hline $\begin{array}{l}\text { Universidade } \\
\text { Federal de Goiás }\end{array}$ & UFG & $\begin{array}{l}\text { Licenciatura em } \\
\text { Artes Visuais }\end{array}$ & $\begin{array}{c}\text { A } \\
\text { Distância }\end{array}$ & $\begin{array}{l}\text { Rodovia Goiânia Nierópolis, km 12, } \\
\text { Goiânia/GO. }\end{array}$ & GO & (62) 35211063 & http://www.ufg.br/ & Pública Federal \\
\hline $\begin{array}{l}\text { Universidade } \\
\text { Federal de Goiás }\end{array}$ & UFG & $\begin{array}{l}\text { Licenciatura em } \\
\text { Artes Visuais }\end{array}$ & $\begin{array}{c}\text { A } \\
\text { Distância }\end{array}$ & $\begin{array}{l}\text { Rodovia Goiânia Nierópolis, km 12, } \\
\text { Goiânia/GO. }\end{array}$ & GO & (62) 35211063 & http://www.ufg.br/ & Pública Federal \\
\hline $\begin{array}{l}\text { Universidade } \\
\text { Federal de Goiás }\end{array}$ & UFG & $\begin{array}{l}\text { Licenciatura em } \\
\text { Artes Visuais }\end{array}$ & $\begin{array}{c}\text { A } \\
\text { Distância }\end{array}$ & $\begin{array}{l}\text { Rodovia Goiânia Nierópolis, km 12, } \\
\text { Goiânia/GO. }\end{array}$ & GO & (62) 35211063 & http://www.ufg.br/ & Pública Federal \\
\hline $\begin{array}{l}\text { Universidade } \\
\text { Salgado de } \\
\text { Oliveira }\end{array}$ & $\begin{array}{l}\text { UNIVER } \\
\text { SO }\end{array}$ & $\begin{array}{l}\text { Bacharelado - } \\
\text { Educação } \\
\text { Artística }\end{array}$ & Presencial & $\begin{array}{l}\text { Av. Cora Coralina, Qd. F-25 Lote } 40 . \\
\text { Goiânia/GO. }\end{array}$ & GO & (21) 2620-1069 & $\frac{\text { http://www.universo.ed }}{\text { u.br/portal/goiania/ }}$ & $\begin{array}{l}\text { Privada sem fins } \\
\text { lucrativos }\end{array}$ \\
\hline $\begin{array}{l}\text { Instituto Federal } \\
\text { de Ciência e } \\
\text { Tecnologia do } \\
\text { Maranhão }\end{array}$ & IFMA & $\begin{array}{l}\text { Licenciatura em } \\
\text { Artes Visuais }\end{array}$ & Presencial & $\begin{array}{l}\text { Avenida Getúlio Vargas, 4. Monte } \\
\text { Castelo, São Luís/MA. }\end{array}$ & MA & $\begin{array}{l}\text { (98) } 3218-9001 / \\
32189033\end{array}$ & http://www.ifma.edu.br & Pública Federal \\
\hline $\begin{array}{l}\text { Universidade } \\
\text { Federal do } \\
\text { Maranhão }\end{array}$ & UFMA & $\begin{array}{l}\text { Licenciatura em } \\
\text { Artes Visuais }\end{array}$ & Presencial & $\begin{array}{l}\text { Avenida dos Portugueses, S/N. } \\
\text { Bacanga, São Luís/MA. }\end{array}$ & MA & $\begin{array}{l}\text { (98) 3301-8004 } \\
/ 3301-8005\end{array}$ & http://portais.ufma.br/ & Pública Federal \\
\hline $\begin{array}{l}\text { Universidade } \\
\text { Federal do } \\
\text { Maranhão }\end{array}$ & UFMA & $\begin{array}{l}\text { Licenciatura em } \\
\text { Artes Visuais }\end{array}$ & $\begin{array}{c}\text { A } \\
\text { Distância }\end{array}$ & $\begin{array}{l}\text { Avenida dos Portugueses, S/N. } \\
\text { Bacanga, São Luís/MA. }\end{array}$ & MA & $\begin{array}{l}\text { (98) 3301-8004 } \\
\text { / 3301-8005 }\end{array}$ & http://portais.ufma.br/ & Pública Federal \\
\hline $\begin{array}{l}\text { Universidade } \\
\text { Salgado de } \\
\text { Oliveira }\end{array}$ & UNIVERSO & $\begin{array}{l}\text { Bacharelado - } \\
\text { Educação } \\
\text { Artística }\end{array}$ & Presencial & Rua Paru, 784. Belo Horizonte/BH. & MG & (21) 2620-1069 & $\begin{array}{l}\text { http://www.universo.ed } \\
\text { u.br/portal/belo- } \\
\text { horizonte/ }\end{array}$ & $\begin{array}{l}\text { Privada sem fins } \\
\text { lucrativos }\end{array}$ \\
\hline $\begin{array}{l}\text { Centro de Ensino } \\
\text { Superior de } \\
\text { Uberaba }\end{array}$ & CESUBE & $\begin{array}{l}\text { Licenciatura em } \\
\text { Artes Visuais }\end{array}$ & Presencial & $\begin{array}{l}\text { Avenida Randolfo Borges Junior, } \\
\text { 1250. Uberaba/MG. }\end{array}$ & MG & (34) $3331-5555$ & http://www.cesube.edu.br & $\begin{array}{l}\text { Privada sem fins } \\
\text { lucrativos }\end{array}$ \\
\hline $\begin{array}{l}\text { Centro de Ensino } \\
\text { Superior de } \\
\text { Uberaba }\end{array}$ & CESUBE & $\begin{array}{l}\text { Licenciatura em } \\
\text { Artes Visuais }\end{array}$ & Presencial & $\begin{array}{l}\text { Avenida Randolfo Borges Junior, } \\
\text { 1250. Uberaba/MG. }\end{array}$ & MG & (34) $3331-5555$ & http://www.cesube.edu.br & $\begin{array}{l}\text { Privada sem fins } \\
\text { lucrativos }\end{array}$ \\
\hline $\begin{array}{l}\text { Universidade do } \\
\text { Estado de Minas } \\
\text { Gerais }\end{array}$ & UEMG & $\begin{array}{l}\text { Bacharelado em } \\
\text { Artes Plásticas }\end{array}$ & Presencial & $\begin{array}{l}\text { Rodovia Prefeito Américo Renê } \\
\text { Gianetti, } 3701 \text {. Serra Verde, Belo } \\
\text { Horizonte/MG. }\end{array}$ & MG & (31) 3916-0471 & http://www.uemg.br/ & Pública Estadual \\
\hline
\end{tabular}




\begin{tabular}{|c|c|c|c|c|c|c|c|c|}
\hline $\begin{array}{l}\text { Universidade do } \\
\text { Estado de Minas } \\
\text { Gerais }\end{array}$ & UEMG & $\begin{array}{l}\text { Licenciatura em } \\
\text { Artes Educação } \\
\text { Artística }\end{array}$ & Presencial & $\begin{array}{l}\text { Rodovia Prefeito Américo Renê } \\
\text { Gianetti, } 3701 \text {. Serra Verde, Belo } \\
\text { Horizonte/MG. }\end{array}$ & $M G$ & (31) 3916-0471 & http://www.uemg.br/ & Pública Estadual \\
\hline $\begin{array}{l}\text { Universidade do } \\
\text { Estado de Minas } \\
\text { Gerais }\end{array}$ & UEMG & $\begin{array}{l}\text { Licenciatura em } \\
\text { Artes Visuais }\end{array}$ & Presencial & $\begin{array}{l}\text { Rodovia Prefeito Américo Renê } \\
\text { Gianetti, } 3701 \text {. Serra Verde, Belo } \\
\text { Horizonte/MG. }\end{array}$ & $M G$ & (31) 3916-0471 & http://www.uemg.br/ & Pública Estadual \\
\hline $\begin{array}{l}\text { Universidade } \\
\text { Estadual de } \\
\text { Montes Claros }\end{array}$ & UNIMONTES & $\begin{array}{l}\text { Licenciatura em } \\
\text { Artes Visuais }\end{array}$ & Presencial & $\begin{array}{l}\text { Campus Universitário Prof. Darcy } \\
\text { Ribeiro, S/N. Montes Claros/MG. }\end{array}$ & $M G$ & (38) 3229-8000 & http://www.unimontes.br & Pública Estadual \\
\hline $\begin{array}{l}\text { Universidade } \\
\text { Estadual de } \\
\text { Montes Claros }\end{array}$ & UNIMONTES & $\begin{array}{l}\text { Licenciatura em } \\
\text { Artes Visuais }\end{array}$ & $\begin{array}{c}\text { A } \\
\text { Distância }\end{array}$ & $\begin{array}{l}\text { Campus Universitário Prof. Darcy } \\
\text { Ribeiro, S/N. Montes Claros/MG. }\end{array}$ & MG & (38) 3229-8000 & http://www.unimontes.br & Pública Estadual \\
\hline $\begin{array}{l}\text { Universidade } \\
\text { Federal de Juiz de } \\
\text { Fora }\end{array}$ & UFJF & $\begin{array}{l}\text { Bacharelado em } \\
\text { Artes Visuais }\end{array}$ & Presencial & $\begin{array}{l}\text { Campus Universitário, Martelos, Juiz } \\
\text { de Fora/MG. }\end{array}$ & MG & $\begin{array}{l}\text { (32) 2102-3905 } \\
/ 2102-3903\end{array}$ & http://www.ufjf.br/ & Pública Federal \\
\hline $\begin{array}{l}\text { Universidade } \\
\text { Federal de Juiz de } \\
\text { Fora }\end{array}$ & UFJF & $\begin{array}{l}\text { Bacharelado } \\
\text { Interdisciplinar } \\
\text { em Artes e } \\
\text { Design }\end{array}$ & Presencial & $\begin{array}{l}\text { Campus Universitário, Martelos, Juiz } \\
\text { de Fora/MG. }\end{array}$ & $M G$ & $\begin{array}{l}\text { (32) } 2102-3905 \\
\text { / } 2102-3903\end{array}$ & http://www.ufjf.br/ & Pública Federal \\
\hline $\begin{array}{l}\text { Universidade } \\
\text { Federal de Juiz de } \\
\text { Fora }\end{array}$ & UFJF & $\begin{array}{l}\text { Licenciatura em } \\
\text { Artes Visuais }\end{array}$ & Presencial & $\begin{array}{l}\text { Campus Universitário, Martelos, Juiz } \\
\text { de Fora/MG. }\end{array}$ & MG & $\begin{array}{l}\text { (32) 2102-3905 } \\
/ 2102-3903\end{array}$ & http://www.ufjf.br/ & Pública Federal \\
\hline $\begin{array}{l}\text { Universidade } \\
\text { Federal de Minas } \\
\text { Gerais }\end{array}$ & UFMG & $\begin{array}{l}\text { Bacharelado em } \\
\text { Artes Visuais }\end{array}$ & Presencial & $\begin{array}{l}\text { Avenida Antonio Carlos, } 6627 \text {. } \\
\text { Pampulha, Belo Horizonte/MG. }\end{array}$ & $M G$ & (31) 3409-4124 & http://www.ufmg.br & Pública Federal \\
\hline $\begin{array}{l}\text { Universidade } \\
\text { Federal de Minas } \\
\text { Gerais }\end{array}$ & UFMG & $\begin{array}{l}\text { Bacharelado em } \\
\text { Cinema de } \\
\text { Animação e } \\
\text { Artes Digitais }\end{array}$ & Presencial & $\begin{array}{l}\text { Avenida Antonio Carlos, } 6627 \text {. } \\
\text { Pampulha, Belo Horizonte/MG. }\end{array}$ & $M G$ & (31) 3409-4124 & http://www.ufmg.br & Pública Federal \\
\hline $\begin{array}{l}\text { Universidade } \\
\text { Federal de Minas } \\
\text { Gerais }\end{array}$ & UFMG & $\begin{array}{l}\text { Licenciatura em } \\
\text { Artes Visuais }\end{array}$ & Presencial & $\begin{array}{l}\text { Avenida Antonio Carlos, } 6627 . \\
\text { Pampulha, Belo Horizonte/MG. }\end{array}$ & MG & (31) 3409-4124 & http://www.ufmg.br & Pública Federal \\
\hline $\begin{array}{l}\text { Universidade } \\
\text { Federal de São } \\
\text { João Del Rei }\end{array}$ & UFSJ & $\begin{array}{l}\text { Bacharelado em } \\
\text { Artes Aplicadas }\end{array}$ & Presencial & $\begin{array}{l}\text { Praça Dom Helvécio, 77. Dom Bosco, } \\
\text { São João Del Rei/MG. }\end{array}$ & $M G$ & $\begin{array}{c}(32) 3379 \\
2340 /(32) 3379 \\
2344\end{array}$ & http://www.ufsj.edu.br/ & Pública Federal \\
\hline $\begin{array}{l}\text { Universidade } \\
\text { Federal de } \\
\text { Uberlândia }\end{array}$ & UFU & $\begin{array}{l}\text { Bacharelado em } \\
\text { Artes Visuais }\end{array}$ & Presencial & $\begin{array}{l}\text { Avenida João Naves de Ávila, } 2121 . \\
\text { Santa Mônica, Uberlândia/MG. }\end{array}$ & $\mathrm{MG}$ & (34)3239-4411 & http://www.ufu.br/ & Pública Federal \\
\hline $\begin{array}{l}\text { Universidade } \\
\text { Federal de } \\
\text { Uberlândia }\end{array}$ & UFU & $\begin{array}{l}\text { Licenciatura em } \\
\text { Artes Visuais }\end{array}$ & Presencial & $\begin{array}{l}\text { Avenida João Naves de Ávila, } 2121 . \\
\text { Santa Mônica, Uberlândia/MG. }\end{array}$ & MG & (34)3239-4411 & http://www.ufu.br/ & Pública Federal \\
\hline
\end{tabular}




\begin{tabular}{|c|c|c|c|c|c|c|c|c|}
\hline $\begin{array}{l}\text { Universidade } \\
\text { Salgado de } \\
\text { Oliveira }\end{array}$ & UNIVERSO & $\begin{array}{l}\text { Bacharelado - } \\
\text { Educação } \\
\text { Artística }\end{array}$ & Presencial & $\begin{array}{l}\text { Avenida dos Andradas, 731. Juiz de } \\
\text { Fora/MG. }\end{array}$ & $M G$ & (21) 2620-1069 & $\frac{\text { http://www.universo.ed }}{\text { u.br/portal/juiz-de-fora/ }}$ & $\begin{array}{l}\text { Privada sem fins } \\
\text { lucrativos }\end{array}$ \\
\hline $\begin{array}{l}\text { Centro } \\
\text { universitário da } \\
\text { Grande Dourados }\end{array}$ & UNIGRAN & $\begin{array}{l}\text { Licenciatura em } \\
\text { Artes Visuais }\end{array}$ & Presencial & $\begin{array}{l}\text { Rua Balbina de Matos, } 2121 . \\
\text { Dourados/MS. }\end{array}$ & MS & (67) $3411-4141$ & http://www.unigran.br/ & $\begin{array}{l}\text { Privada sem fins } \\
\text { lucrativos }\end{array}$ \\
\hline $\begin{array}{l}\text { Faculdades } \\
\text { Magsul }\end{array}$ & FAMAG & $\begin{array}{l}\text { Licenciatura em } \\
\text { Artes Visuais }\end{array}$ & Presencial & $\begin{array}{l}\text { Avenida Presidente Vargas, Ponta } \\
\text { Porã/MS. }\end{array}$ & MS & (67) 3437-3804 & $\frac{\text { http://www.magsul- }}{\text { ms.com.br/ }}$ & $\begin{array}{l}\text { Privada sem fins } \\
\text { lucrativos }\end{array}$ \\
\hline $\begin{array}{l}\text { Instituto de } \\
\text { Ensino Superior } \\
\text { Funlec }\end{array}$ & IESF & $\begin{array}{l}\text { Licenciatura em } \\
\text { Artes Visuais }\end{array}$ & Presencial & $\begin{array}{l}\text { Rua Cel. Cacildo Arantes, } 322 . \\
\text { Cachoeira II, Campo Grande/MS. }\end{array}$ & MS & (67) $3901-2871$ & $\begin{array}{l}\text { http://www.iesf.funlec. } \\
\underline{\text { com.br/ }}\end{array}$ & $\begin{array}{l}\text { Privada sem fins } \\
\text { lucrativos }\end{array}$ \\
\hline $\begin{array}{l}\text { Universidade } \\
\text { Federal de Mato } \\
\text { Grosso do Sul }\end{array}$ & UFMS & $\begin{array}{l}\text { Bacharelado em } \\
\text { Artes Visuais }\end{array}$ & Presencial & $\begin{array}{l}\text { Av. Costa e Silva, S/N. Cidade } \\
\text { Universitária, campo Grande, MS. }\end{array}$ & MS & $\begin{array}{c}\text { (67) } 3345-7010 \\
/ 3345-701\end{array}$ & http://www-nt.ufms.br/ & Pública Federal \\
\hline $\begin{array}{l}\text { Universidade } \\
\text { Federal de Mato } \\
\text { Grosso do Sul }\end{array}$ & UFMS & $\begin{array}{l}\text { Licenciatura em } \\
\text { Artes Visuais }\end{array}$ & Presencial & $\begin{array}{l}\text { Av. Costa e Silva, S/N. Cidade } \\
\text { Universitária, campo Grande, MS. }\end{array}$ & MS & $\begin{array}{c}\text { (67) } 3345-7010 \\
\text { / 3345-701 }\end{array}$ & http://www-nt.ufms.br/ & Pública Federal \\
\hline $\begin{array}{l}\text { Universidade de } \\
\text { Cuiabá }\end{array}$ & $\begin{array}{c}\text { UNIIC/ } \\
\text { PITÁGORAS }\end{array}$ & Tecnológico & Presencial & $\begin{array}{l}\text { Avenida Beira Rio, 3100. Jardim } \\
\text { Europa, Cuiabá/MT. }\end{array}$ & MT & (65) 3615-1000 & $\begin{array}{l}\text { http://www.unic.br/Pag } \\
\text { inas/home.aspx }\end{array}$ & $\begin{array}{l}\text { Privada com fins } \\
\text { lucrativos }\end{array}$ \\
\hline $\begin{array}{l}\text { Escola Superior } \\
\text { Madre Celeste }\end{array}$ & ESMAC & $\begin{array}{l}\text { Bacharelado em } \\
\text { Artes Visuais }\end{array}$ & Presencial & $\begin{array}{l}\text { Estrada da Providência, 10. Coqueiro, } \\
\text { Ananindeua/PA. }\end{array}$ & PA & (91) 3273-1558 & http://www.esmac.com & $\begin{array}{l}\text { Privada com fins } \\
\text { lucrativos }\end{array}$ \\
\hline $\begin{array}{l}\text { Escola Superior } \\
\text { Madre Celeste }\end{array}$ & ESMAC & $\begin{array}{l}\text { Licenciatura em } \\
\text { Artes Visuais }\end{array}$ & Presencial & $\begin{array}{l}\text { Estrada da Providência, 10. Coqueiro, } \\
\text { Ananindeua/PA. }\end{array}$ & PA & (91) 3273-1558 & $\begin{array}{l}\text { http://www.esmac.com } \\
. \mathrm{br} /\end{array}$ & $\begin{array}{l}\text { Privada com fins } \\
\text { lucrativos }\end{array}$ \\
\hline $\begin{array}{l}\text { Universidade da } \\
\text { Amazônia }\end{array}$ & UNAMA & $\begin{array}{l}\text { Bacharelado em } \\
\text { Artes Visuais }\end{array}$ & Presencial & $\begin{array}{l}\text { Avenida Alcindo Cacela, } 287 . \\
\text { Umarizal, Belém/PA. }\end{array}$ & PA & (91) 4009-3000 & http://www.unama.br/ & $\begin{array}{l}\text { Privada com fins } \\
\text { lucrativos }\end{array}$ \\
\hline $\begin{array}{l}\text { Universidade da } \\
\text { Amazônia }\end{array}$ & UNAMA & $\begin{array}{l}\text { Licenciatura em } \\
\text { Artes Visuais }\end{array}$ & Presencial & $\begin{array}{l}\text { Avenida Alcindo Cacela, } 287 . \\
\text { Umarizal, Belém/PA. }\end{array}$ & PA & (91) 4009-3000 & http://www.unama.br/ & $\begin{array}{l}\text { Privada com fins } \\
\text { lucrativos }\end{array}$ \\
\hline $\begin{array}{l}\text { Universidade } \\
\text { Federal do Pará }\end{array}$ & UFPA & $\begin{array}{l}\text { Bacharelado em } \\
\text { Artes Visuais }\end{array}$ & Presencial & $\begin{array}{l}\text { Rua Augusto Correa, 01. Guamá, } \\
\text { Belém/PA. }\end{array}$ & PA & (91)3201-7112 & $\begin{array}{l}\text { http://www.portal.ufpa. } \\
\underline{\mathrm{br} /}\end{array}$ & Pública Federal \\
\hline $\begin{array}{l}\text { Universidade } \\
\text { Federal do Sul e } \\
\text { Sudeste do Pará }\end{array}$ & $\begin{array}{l}\text { UNIFES } \\
\text { SPA }\end{array}$ & $\begin{array}{l}\text { Licenciatura em } \\
\text { Artes Visuais }\end{array}$ & Presencial & $\begin{array}{l}\text { Folha 31, Quadra 7, Lote Especial } \\
\text { S/N. Nova marabá, Marabá/PA. }\end{array}$ & PA & (91) 3201-8511 & $\frac{\text { http://www.ceps.ufpa.b }}{\frac{\text { r/daves/UNIFESSPA/ }}{\text { UNIFESSPA.htm }}}$ & Pública Federal \\
\hline $\begin{array}{l}\text { Universidade } \\
\text { Federal do Pará }\end{array}$ & UFPA & $\begin{array}{l}\text { Licenciatura em } \\
\text { Artes Visuais }\end{array}$ & Presencial & $\begin{array}{l}\text { Rua Augusto Correa, 01. Guamá, } \\
\text { Belém/PA. }\end{array}$ & PA & (91)3201-7112 & $\frac{\text { http://www.portal.ufpa. }}{\text { br/ }}$ & Pública Federal \\
\hline $\begin{array}{l}\text { Universidade } \\
\text { Federal da } \\
\text { Paraíba }\end{array}$ & UFPB & $\begin{array}{l}\text { Bacharelado em } \\
\text { Artes Visuais }\end{array}$ & Presencial & $\begin{array}{l}\text { Cidade Universitária, s/a. Castelo } \\
\text { Branco, João Pessoa/PB. }\end{array}$ & PB & (83) 3216-7150 & http://www.ufpb.br/ & Pública Federal \\
\hline $\begin{array}{l}\text { Universidade } \\
\text { Federal da } \\
\text { Paraíba }\end{array}$ & UFPB & $\begin{array}{l}\text { Licenciatura em } \\
\text { Artes Visuais }\end{array}$ & Presencial & $\begin{array}{l}\text { Cidade Universitária, s/a. Castelo } \\
\text { Branco, João Pessoa/PB. }\end{array}$ & PB & (83) 3216-7150 & http://www.ufpb.br/ & Pública Federal \\
\hline
\end{tabular}




\begin{tabular}{|c|c|c|c|c|c|c|c|c|}
\hline $\begin{array}{l}\text { Faculdades } \\
\text { Integradas Barros } \\
\text { Melo }\end{array}$ & FIBAM & $\begin{array}{l}\text { Bacharelado em } \\
\text { Artes Visuais }\end{array}$ & Presencial & $\begin{array}{l}\text { Avenida Transamazônica, } 405 . \\
\text { Jardim Brasil II, Olinda/PE. }\end{array}$ & PE & (81) 21289797 & $\begin{array}{l}\text { http://www.barrosmelo } \\
\text {.edu.br/ }\end{array}$ & $\begin{array}{l}\text { Privada com fins } \\
\text { lucrativos }\end{array}$ \\
\hline $\begin{array}{l}\text { Faculdades } \\
\text { Integradas Barros } \\
\text { Melo }\end{array}$ & FIBAM & $\begin{array}{l}\text { Bacharelado em } \\
\text { Artes Visuais }\end{array}$ & Presencial & $\begin{array}{l}\text { Avenida Transamazônica, } 405 . \\
\text { Jardim Brasil II, Olinda/PE. }\end{array}$ & PE & (81) 21289797 & $\begin{array}{l}\text { http://www.barrosmelo } \\
\text {.edu.br/ }\end{array}$ & $\begin{array}{l}\text { Privada com fins } \\
\text { lucrativos }\end{array}$ \\
\hline $\begin{array}{l}\text { Faculdades } \\
\text { Integradas Barros } \\
\text { Melo }\end{array}$ & FIBAM & $\begin{array}{l}\text { Bacharelado em } \\
\text { Artes Visuais }\end{array}$ & Presencial & $\begin{array}{l}\text { Avenida Transamazônica, } 405 . \\
\text { Jardim Brasil II, Olinda/PE. }\end{array}$ & PE & (81) 21289797 & $\begin{array}{l}\text { http://www.barrosmelo } \\
\text { edu.br/ }\end{array}$ & $\begin{array}{l}\text { Privada com fins } \\
\text { lucrativos }\end{array}$ \\
\hline $\begin{array}{l}\text { Universidade } \\
\text { Federal de Pelotas }\end{array}$ & UFPEL & $\begin{array}{l}\text { Bacharelado em } \\
\text { Artes Visuais }\end{array}$ & Presencial & $\begin{array}{l}\text { Rua Gomes Carneiro, 01. Centro, } \\
\text { Pelotas/RS. }\end{array}$ & $\mathrm{PE}$ & (53) 3921-1027 & http://portal.ufpel.edu.br/ & Pública Federal \\
\hline $\begin{array}{l}\text { Universidade } \\
\text { Federal de Pelotas }\end{array}$ & UFPEL & $\begin{array}{l}\text { Licenciatura em } \\
\text { Artes Visuais }\end{array}$ & Presencial & $\begin{array}{l}\text { Rua Gomes Carneiro, 01. Centro, } \\
\text { Pelotas/RS. }\end{array}$ & PE & (53) 3921-1027 & http://portal.ufpel.edu.br/ & Pública Federal \\
\hline $\begin{array}{l}\text { Universidade } \\
\text { Federal de } \\
\text { Pernambuco }\end{array}$ & UFPE & $\begin{array}{l}\text { Bacharelado em } \\
\text { Artes Visuais }\end{array}$ & Presencial & $\begin{array}{l}\text { Av. Prof. Moraes Rego, 1235. Cidade } \\
\text { Universitária, Recife/PE. }\end{array}$ & $P E$ & (81) 2126-8001 & http://www.ufpe.br/ufpenoval & Pública Federal \\
\hline $\begin{array}{l}\text { Universidade } \\
\text { Federal do Vale } \\
\text { do São Francisco }\end{array}$ & UNIVASF & $\begin{array}{l}\text { Bacharelado em } \\
\text { Artes Visuais }\end{array}$ & Presencial & $\begin{array}{l}\text { Avenida José de Sá Maniçoba, S/N. } \\
\text { Petrolina/PE. }\end{array}$ & PE & (87) $2101-6830$ & http://www.univasf.edu.br & Pública Federal \\
\hline $\begin{array}{l}\text { Universidade } \\
\text { Federal do Vale } \\
\text { do São Francisco }\end{array}$ & UNIVASF & $\begin{array}{l}\text { Licenciatura em } \\
\text { Artes Visuais }\end{array}$ & Presencial & $\begin{array}{l}\text { Avenida José de Sá Maniçoba, S/N. } \\
\text { Petrolina/PE. }\end{array}$ & PE & (87) 2101-6830 & http://www.univasf.edu.br & Pública Federal \\
\hline $\begin{array}{l}\text { Universidade } \\
\text { Salgado de } \\
\text { Oliveira }\end{array}$ & UNIVERSO & $\begin{array}{l}\text { Bacharelado - } \\
\text { Educação } \\
\text { Artística }\end{array}$ & Presencial & $\begin{array}{l}\text { Av. Marechal Mascarenhas de } \\
\text { Moraes, 2159. Recife/PE. }\end{array}$ & $P E$ & (21) 2620-1069 & $\begin{array}{l}\text { http://www.universo.edu. } \\
\text { br/portal/recife/ }\end{array}$ & $\begin{array}{l}\text { Privada sem fins } \\
\text { lucrativos }\end{array}$ \\
\hline $\begin{array}{l}\text { Universidade } \\
\text { Federal Rural de } \\
\text { Pernambuco }\end{array}$ & UFRPE & $\begin{array}{l}\text { Licenciatura em } \\
\text { Artes Visuais } \\
\text { Digitais }\end{array}$ & $\begin{array}{c}\text { A } \\
\text { Distância }\end{array}$ & $\begin{array}{l}\text { Rua Dom Manoel de Medeiros, S/N. } \\
\text { Dois Irmãos, Recife/PE. }\end{array}$ & PE. & (81) $3320-6001$ & http://www.ufrpe.br/ & Pública Federal \\
\hline $\begin{array}{l}\text { Instituto de } \\
\text { Ciências Jurídicas } \\
\text { e Sociais } \\
\text { Professor Camillo } \\
\text { Filho }\end{array}$ & ICF & $\begin{array}{l}\text { Bacharelado em } \\
\text { Artes Visuais }\end{array}$ & Presencial & $\begin{array}{l}\text { Rua Napoleão Lima, 1175. Jóquei } \\
\text { Clube, Teresina/PI. }\end{array}$ & $\mathrm{PI}$ & $\begin{array}{l}\text { (86) } 31228800 / \\
31228816\end{array}$ & http://www.icf.edu.br/novol & $\begin{array}{l}\text { Privada com fins } \\
\text { lucrativos }\end{array}$ \\
\hline $\begin{array}{l}\text { Universidade } \\
\text { Federal do Piauí }\end{array}$ & UFPI & $\begin{array}{l}\text { Licenciatura em } \\
\text { Artes Visuais }\end{array}$ & Presencial & $\begin{array}{l}\text { Avenida Coronel Messias Melo, } 1109 . \\
\text { Praça Nilo Castro, Batalha, PI. }\end{array}$ & $\mathrm{PI}$ & $\begin{array}{c}\text { (86) 3215-5620 } \\
\text { / 3215-5621/ } \\
3215-1104\end{array}$ & http://www.ufpi.br & Pública Federal \\
\hline $\begin{array}{l}\text { Universidade } \\
\text { Federal do Piauí }\end{array}$ & UFPI & $\begin{array}{l}\text { Licenciatura em } \\
\text { Artes Visuais }\end{array}$ & Presencial & BR 343 km 3,5 S/N, Floriano/PI. & $\mathrm{PI}$ & $\begin{array}{c}\text { (86) } 3215-5620 \\
/ 3215-5621 / \\
3215-1104\end{array}$ & http://www.ufpi.br & Pública Federal \\
\hline
\end{tabular}




\begin{tabular}{|c|c|c|c|c|c|c|c|c|}
\hline $\begin{array}{l}\text { Universidade } \\
\text { Federal do Piauí }\end{array}$ & UFPI & $\begin{array}{l}\text { Licenciatura em } \\
\text { Artes Visuais }\end{array}$ & Presencial & Rua Cícero Duarte, 905. Picos/PI. & $\mathrm{PI}$ & $\begin{array}{c}\text { (86) } 3215-5620 \\
/ 3215-5621 / \\
3215-1104\end{array}$ & http://www.ufpi.br & Pública Federal \\
\hline $\begin{array}{l}\text { Universidade } \\
\text { Federal do Piauí }\end{array}$ & UFPI & $\begin{array}{l}\text { Licenciatura em } \\
\text { Artes Visuais }\end{array}$ & Presencial & $\begin{array}{l}\text { Campus Universitário Ministro } \\
\text { Petrônio Portela, sg 07. Ininga, } \\
\text { Teresina/PI. }\end{array}$ & PI & $\begin{array}{c}(86) 3215-5620 \\
/ 3215-5621 / \\
3215-1104\end{array}$ & http://www.ufpi.br & Pública Federal \\
\hline $\begin{array}{l}\text { Centro } \\
\text { Universitário de } \\
\text { Maringá }\end{array}$ & UNICESUMAR & $\begin{array}{l}\text { Bacharelado em } \\
\text { Artes Visuais }\end{array}$ & Presencial & $\begin{array}{l}\text { Avenida Guedner, 1610. Jardim } \\
\text { Aclimação, Maringá/PR. }\end{array}$ & PR & $\begin{array}{l}\text { (44) } 3027-6385 \\
\text { - RAMAL } 1109\end{array}$ & $\begin{array}{l}\text { http://www.unicesumar } \\
\text { edu.br/ }\end{array}$ & $\begin{array}{l}\text { Privada com fins } \\
\text { lucrativos }\end{array}$ \\
\hline $\begin{array}{l}\text { Centro } \\
\text { Universitário de } \\
\text { Maringá }\end{array}$ & UNIICESUMAR & $\begin{array}{l}\text { Licenciatura em } \\
\text { Artes Visuais }\end{array}$ & Presencial & $\begin{array}{l}\text { Avenida Guedner, 1610. Jardim } \\
\text { Aclimação, Maringá/PR. }\end{array}$ & PR & $\begin{array}{l}\text { (44) } 3027-6385 \\
\text { - RAMAL } 1109\end{array}$ & $\begin{array}{l}\text { http://www.unicesumar } \\
. \text { edu.br/ }\end{array}$ & $\begin{array}{l}\text { Privada com fins } \\
\text { lucrativos }\end{array}$ \\
\hline $\begin{array}{l}\text { Escola de Música } \\
\text { e Belas Artes do } \\
\text { Paraná }\end{array}$ & EMBAP & $\begin{array}{l}\text { Licenciatura em } \\
\text { Artes Visuais }\end{array}$ & Presencial & $\begin{array}{l}\text { Rua Emiliano Perneta, 179. Centro, } \\
\text { Curitiba/PR. }\end{array}$ & PR & (41) 3026-0029 & $\begin{array}{l}\text { http://www.embap.pr.g } \\
\underline{\text { ov.br/ }}\end{array}$ & Pública Estadual \\
\hline $\begin{array}{l}\text { Faculdade de } \\
\text { Ciências } \\
\text { Aplicadas de } \\
\text { Cascavel }\end{array}$ & FACIAP & $\begin{array}{l}\text { Licenciatura em } \\
\text { Artes Visuais }\end{array}$ & Presencial & $\begin{array}{l}\text { Avenida Brasil, } 7210 \text {. Centro, } \\
\text { Cascavel/PR. }\end{array}$ & PR & (45) $3219-4411$ & $\begin{array}{l}\text { http://www.anhanguer } \\
\text { a.com/home/ }\end{array}$ & $\begin{array}{l}\text { Privada com fins } \\
\text { lucrativos }\end{array}$ \\
\hline $\begin{array}{l}\text { Faculdade de } \\
\text { Ampére }\end{array}$ & FAMPER & $\begin{array}{l}\text { Licenciatura em } \\
\text { Artes }\end{array}$ & Presencial & Rua dos Andradas, 144. Ampére/PR. & PR & (46) 3547-3031 & $\underline{\text { http://www.famper.com.br }}$ & $\begin{array}{l}\text { Privada com fins } \\
\text { lucrativos }\end{array}$ \\
\hline $\begin{array}{l}\text { Faculdade de } \\
\text { Artes do Paraná }\end{array}$ & FAP & $\begin{array}{l}\text { Licenciatura em } \\
\text { Artes Visuais }\end{array}$ & Presencial & $\begin{array}{l}\text { Rua dos Funcionários, 1357. Bairro } \\
\text { Cabral, Curitiba/PR. }\end{array}$ & PR & (41) $3250-7300$ & http://www.fap.pr.gov.br/ & Pública Estadual \\
\hline $\begin{array}{l}\text { Faculdade de } \\
\text { Ciências e } \\
\text { Tecnologia }\end{array}$ & FACITEC & $\begin{array}{l}\text { Licenciatura em } \\
\text { Artes Visuais }\end{array}$ & Presencial & $\begin{array}{l}\text { Avenida Presidente Kennedy, } 2300 . \\
\text { Palotina/PR. }\end{array}$ & PR & $\begin{array}{l}\text { (44) } 36499002 \\
\text { e } 3649-9024\end{array}$ & http://www.uespar.edu.br/ & $\begin{array}{l}\text { Privada com fins } \\
\text { lucrativos }\end{array}$ \\
\hline $\begin{array}{l}\text { Faculdade de } \\
\text { Ciências Sociais } \\
\text { Aplicadas de } \\
\text { Cascavel }\end{array}$ & FCSAC & $\begin{array}{l}\text { Licenciatura em } \\
\text { Artes }\end{array}$ & Presencial & $\begin{array}{l}\text { Avenida Tito Muffato, } 2317 . \\
\text { Cascavel/PR. }\end{array}$ & PR & (45) 3036-3636 & http://www.univel.br/ & $\begin{array}{l}\text { Privada sem fins } \\
\text { lucrativos }\end{array}$ \\
\hline $\begin{array}{l}\text { Faculdade } \\
\text { Intermunicipal do } \\
\text { Noroeste do } \\
\text { Paraná }\end{array}$ & FACINOR & $\begin{array}{l}\text { Licenciatura em } \\
\text { Artes Visuais }\end{array}$ & Presencial & $\begin{array}{l}\text { Rua Mato Grosso, 240. Alto da Glória, } \\
\text { Loanda/PR. }\end{array}$ & PR & (44) 3425-1037 & $\underline{\text { http://facinor.br/ }}$ & $\begin{array}{l}\text { Privada sem fins } \\
\text { lucrativos }\end{array}$ \\
\hline $\begin{array}{l}\text { Faculdade } \\
\text { Intermunicipal do } \\
\text { Noroeste do } \\
\text { Paraná }\end{array}$ & FACINOR & $\begin{array}{l}\text { Licenciatura em } \\
\text { Artes Visuais }\end{array}$ & Presencial & $\begin{array}{l}\text { Rua Mato Grosso, 240. Alto da Glória, } \\
\text { Loanda/PR. }\end{array}$ & PR & (44) $3425-1037$ & http://facinor.br/ & $\begin{array}{l}\text { Privada sem fins } \\
\text { lucrativos }\end{array}$ \\
\hline $\begin{array}{l}\text { Faculdade Sul } \\
\text { Brasil }\end{array}$ & FASUL & $\begin{array}{l}\text { Licenciatura em } \\
\text { Artes Visuais }\end{array}$ & Presencial & $\begin{array}{l}\text { Avenida Ministro Cirne Lima, } 2565 . \\
\text { Jardim Coopagro, Toledo/PR. }\end{array}$ & PR & (45) $3277-4000$ & http://www.fasul.edu.br & $\begin{array}{l}\text { Privada com fins } \\
\text { lucrativos }\end{array}$ \\
\hline
\end{tabular}




\begin{tabular}{|c|c|c|c|c|c|c|c|c|}
\hline $\begin{array}{l}\text { Faculdade } \\
\text { Unilagos }\end{array}$ & UNILAGOS & $\begin{array}{l}\text { Bacharelado em } \\
\text { Artes Visuais }\end{array}$ & Presencial & $\begin{array}{l}\text { Rua Saldanha Marinho, S/N. } \\
\text { Mangueirinha/PR. }\end{array}$ & PR & (46) 3243-1371 & http://www.unilagos.com.br/' & $\begin{array}{l}\text { Privada sem fins } \\
\text { lucrativos }\end{array}$ \\
\hline $\begin{array}{l}\text { Faculdade } \\
\text { Vizinhança Vale } \\
\text { do Iguaçu }\end{array}$ & VIZIVALI & $\begin{array}{l}\text { Licenciatura em } \\
\text { Artes Visuais }\end{array}$ & Presencial & $\begin{array}{l}\text { Rua Pedro Álvares Cabral, 905. São } \\
\text { Francisco de Assis, Dois Vizinhos/PR. }\end{array}$ & PR & $(46) 3536-4438$ & http://www.vizivali.edu.br/ & Pública Municipal \\
\hline $\begin{array}{l}\text { Instituto Federal } \\
\text { de Ciência e } \\
\text { Tecnologia do } \\
\text { Paraná }\end{array}$ & IFPR & $\begin{array}{l}\text { Licenciatura em } \\
\text { Artes Visuais }\end{array}$ & Presencial & $\begin{array}{l}\text { Rua João Negrão, 1285. Rebouças, } \\
\text { Curitiba/PR. }\end{array}$ & PR & (41) 3595-7610 & http://www.ifpr.edu.br/ & Pública Federal \\
\hline $\begin{array}{l}\text { Universidade } \\
\text { Estadual de } \\
\text { Londrina }\end{array}$ & UEL & $\begin{array}{l}\text { Licenciatura em } \\
\text { Artes Educação } \\
\text { Artística }\end{array}$ & Presencial & $\begin{array}{l}\text { Rodovia Celso Garcia Cid/Pr 445. Km } \\
\text { 380. Londrina/PR. }\end{array}$ & PR & (43) 33714311 & http://www.uel.br/portal/ & Pública Estadual \\
\hline $\begin{array}{l}\text { Universidade } \\
\text { Estadual de } \\
\text { Londrina }\end{array}$ & UEL & $\begin{array}{l}\text { Licenciatura em } \\
\text { Artes Visuais }\end{array}$ & Presencial & $\begin{array}{l}\text { Rodovia Celso Garcia Cid/Pr 445. Km } \\
\text { 380. Londrina/PR. }\end{array}$ & PR & (43) 33714311 & http://www.uel.br/portal/ & Pública Estadual \\
\hline $\begin{array}{l}\text { Universidade } \\
\text { Estadual de } \\
\text { Maringá }\end{array}$ & UEM & $\begin{array}{l}\text { Licenciatura em } \\
\text { Artes Visuais }\end{array}$ & Presencial & Avenida Colombo, 5790. Maringá/PR. & PR & $\begin{array}{l}\text { (44) } 3011-4240 \\
\text { / } 3011-4426\end{array}$ & http://www.uem.br/ & Pública Estadual \\
\hline $\begin{array}{l}\text { Universidade } \\
\text { Estadual de Ponta } \\
\text { Grossa }\end{array}$ & UEPG & $\begin{array}{l}\text { Licenciatura em } \\
\text { Artes Visuais }\end{array}$ & Presencial & $\begin{array}{l}\text { Av. Carlos Cavalcanti, } 4748 . \\
\text { Uvaranas, Ponta Grossa/PR. }\end{array}$ & PR & $\begin{array}{l}\text { (42) 3220-3000 } \\
\text { / 3220-3300 }\end{array}$ & http://portal.uepg.br/ & Pública Estadual \\
\hline $\begin{array}{l}\text { Universidade } \\
\text { Federal do Paraná }\end{array}$ & UFPR & $\begin{array}{l}\text { Bacharelado em } \\
\text { Artes Visuais }\end{array}$ & Presencial & $\begin{array}{l}\text { Rua XV de Novembro, 1299. Centro, } \\
\text { Curitiba/PR. }\end{array}$ & PR & $(41) 3360-5001$ & $\begin{array}{l}\text { http://www.ufpr.br/port } \\
\text { alufpr/ }\end{array}$ & Pública Federal \\
\hline $\begin{array}{l}\text { Universidade } \\
\text { Federal do Paraná }\end{array}$ & UFPR & $\begin{array}{l}\text { Licenciatura em } \\
\text { Artes }\end{array}$ & Presencial & Rua Jaguariaíva, 512. Matinhos/PR. & PR & $(41) 3360-5001$ & $\begin{array}{l}\text { http://www.ufpr.br/port } \\
\text { alufpr/ }\end{array}$ & Pública Federal \\
\hline $\begin{array}{l}\text { Universidade } \\
\text { Federal do Paraná }\end{array}$ & UFPR & $\begin{array}{l}\text { Licenciatura em } \\
\text { Artes Visuais }\end{array}$ & Presencial & $\begin{array}{l}\text { Rua XV de Novembro, 1299. Centro, } \\
\text { Curitiba/PR. }\end{array}$ & PR & $(41) 3360-5001$ & $\begin{array}{l}\text { http://www.ufpr.br/port } \\
\text { alufpr/ }\end{array}$ & Pública Federal \\
\hline $\begin{array}{l}\text { Universidade } \\
\text { Norte do Paraná }\end{array}$ & UNOPAR & $\begin{array}{l}\text { Bacharelado em } \\
\text { Artes Visuais }\end{array}$ & Presencial & Avenida Paris, 675. Londrina/PR. & PR & $\begin{array}{c}(43) 3371-7700 / \\
3371-7824\end{array}$ & http://www.unopar.br/ & $\begin{array}{l}\text { Privada com fins } \\
\text { lucrativos }\end{array}$ \\
\hline $\begin{array}{l}\text { Universidade } \\
\text { Norte do Paraná }\end{array}$ & UNOPAR & $\begin{array}{l}\text { Licenciatura em } \\
\text { Artes Visuais }\end{array}$ & $\begin{array}{c}\text { A } \\
\text { Distância }\end{array}$ & Avenida Paris, 675. Londrina/PR. & PR & $\begin{array}{c}(43) 3371-7700 / \\
3371-7824\end{array}$ & http://www.unopar.br/ & $\begin{array}{l}\text { Privada com fins } \\
\text { lucrativos }\end{array}$ \\
\hline $\begin{array}{l}\text { Universidade } \\
\text { Tuiutí do Paraná }\end{array}$ & UTP & $\begin{array}{l}\text { Bacharelado em } \\
\text { Artes Visuais }\end{array}$ & Presencial & $\begin{array}{l}\text { Rua Cícero Jaime Bley, S/N. Hangar } \\
\text { 40. Bacacheri, Curitiba/PR. }\end{array}$ & PR & (41) 33317700 & http://www.utp.br/ & $\begin{array}{l}\text { Privada com fins } \\
\text { lucrativos }\end{array}$ \\
\hline $\begin{array}{l}\text { Universidade } \\
\text { Tuiutí do Paraná }\end{array}$ & UTP & $\begin{array}{l}\text { Licenciatura em } \\
\text { Artes Visuais }\end{array}$ & Presencial & $\begin{array}{l}\text { Rua Cícero Jaime Bley, S/N. Hangar } \\
\text { 40. Bacacheri, Curitiba/PR. }\end{array}$ & PR & (41) 33317700 & http://www.utp.br/ & $\begin{array}{l}\text { Privada com fins } \\
\text { lucrativos }\end{array}$ \\
\hline $\begin{array}{l}\text { Centro } \\
\text { Universitário de } \\
\text { Barra Mansa }\end{array}$ & UBM & $\begin{array}{l}\text { Licenciatura em } \\
\text { Artes Visuais }\end{array}$ & Presencial & $\begin{array}{l}\text { Rua Vereador Pinho de Carvalho, } \\
\text { 267. Barra Mansa/RJ. }\end{array}$ & RJ & $\begin{array}{l}\text { (24) } 3325-0216 \\
\text { / 3325-0280 }\end{array}$ & http://web.ubm.br/page/ & $\begin{array}{l}\text { Privada sem fins } \\
\text { lucrativos }\end{array}$ \\
\hline
\end{tabular}




\begin{tabular}{|c|c|c|c|c|c|c|c|c|}
\hline $\begin{array}{l}\text { Centro } \\
\text { Universitário } \\
\text { Fluminense }\end{array}$ & UNIFLU & $\begin{array}{l}\text { Licenciatura em } \\
\text { Artes Visuais }\end{array}$ & Presencial & $\begin{array}{l}\text { Rua Tenente Coronel Cardoso, } 349 . \\
\text { Campos dos Goytacazes/RJ. }\end{array}$ & RJ & (22) 2101-3350 & http://www.uniflu.edu.br/ & $\begin{array}{l}\text { Privada sem fins } \\
\text { lucrativos }\end{array}$ \\
\hline $\begin{array}{l}\text { Centro } \\
\text { Universitário } \\
\text { Metodista Bennett }\end{array}$ & BENNETT & $\begin{array}{l}\text { Licenciatura em } \\
\text { Artes Visuais }\end{array}$ & Presencial & $\begin{array}{l}\text { Rua Marquês de Abrantes, } 55 . \\
\text { Flamengo. Rio de Janeiro/RJ. }\end{array}$ & RJ & (21) 35091000 & http://www.bennett.br/ & $\begin{array}{l}\text { Privada sem fins } \\
\text { lucrativos }\end{array}$ \\
\hline $\begin{array}{l}\text { Conservatório de } \\
\text { Música de Niterói }\end{array}$ & CMN & $\begin{array}{l}\text { Licenciatura - } \\
\text { Educação } \\
\text { Artística }\end{array}$ & Presencial & Rua São Pedro, 96. Niterói/RJ. & RJ & $\begin{array}{l}\text { (21) } 2719-2330 \\
\text { e } 2717-3545\end{array}$ & $\frac{\text { http://www.conservator }}{\text { iocmn.com.br/ }}$ & $\begin{array}{l}\text { Privada sem fins } \\
\text { lucrativos }\end{array}$ \\
\hline $\begin{array}{l}\text { Escola Superior } \\
\text { de Ensino Helena } \\
\text { Antipoff }\end{array}$ & ESEHA & $\begin{array}{l}\text { Bacharelado em } \\
\text { Artes Visuais }\end{array}$ & Presencial & $\begin{array}{l}\text { Estrada Caetano Monteiro, } 857 . \\
\text { Pendotiba, Niterói/RJ. }\end{array}$ & RJ & (21) 2199-4435 & $\begin{array}{l}\text { http://www.pestalozzi. } \\
\text { org.br }\end{array}$ & $\begin{array}{l}\text { Privada sem fins } \\
\text { lucrativos }\end{array}$ \\
\hline $\begin{array}{l}\text { Escola Superior } \\
\text { de Ensino Helena } \\
\text { Antipoff }\end{array}$ & ESEHA & $\begin{array}{l}\text { Bacharelado em } \\
\text { Artes Visuais }\end{array}$ & Presencial & $\begin{array}{l}\text { Estrada Caetano Monteiro, } 857 . \\
\text { Pendotiba, Niterói/RJ. }\end{array}$ & RJ & (21) 2199-4435 & $\begin{array}{l}\text { http://www.pestalozzi. } \\
\text { org.br }\end{array}$ & $\begin{array}{l}\text { Privada sem fins } \\
\text { lucrativos }\end{array}$ \\
\hline $\begin{array}{l}\text { Faculdades } \\
\text { SENAI-CETIQT }\end{array}$ & $\begin{array}{l}\text { SENAI- } \\
\text { CETIQT }\end{array}$ & $\begin{array}{l}\text { Bacharelado em } \\
\text { Artes com } \\
\text { habilitação em } \\
\text { indumentária }\end{array}$ & Presencial & $\begin{array}{l}\text { Rua Doutor Manoel Cotrim, } 195 . \\
\text { Riachuelo, Rio de Janeiro/RJ. }\end{array}$ & RJ & (21)2582-1025 & http://www.cetiqt.senai & $\begin{array}{l}\text { Privada sem fins } \\
\text { lucrativos }\end{array}$ \\
\hline $\begin{array}{l}\text { Faculdades } \\
\text { SENAI-CETIQT }\end{array}$ & $\begin{array}{l}\text { SENAI- } \\
\text { CETIQT }\end{array}$ & $\begin{array}{l}\text { Bacharelado em } \\
\text { Artes Visuais }\end{array}$ & Presencial & $\begin{array}{l}\text { Rua Doutor Manoel Cotrim, } 195 . \\
\text { Riachuelo, Rio de Janeiro/RJ. }\end{array}$ & RJ & (21)2582-1025 & http://www.cetiqt.senai & $\begin{array}{l}\text { Privada sem fins } \\
\text { lucrativos }\end{array}$ \\
\hline $\begin{array}{l}\text { Universidade } \\
\text { Cândido Mendes }\end{array}$ & UCAM & $\begin{array}{l}\text { Bacharelado em } \\
\text { Artes Visuais }\end{array}$ & Presencial & $\begin{array}{l}\text { Rua da Assembleia, 10. Centro, Rio } \\
\text { de Janeiro/RJ. }\end{array}$ & RJ & (21) $3221-9550$ & http://www.ucam.edu.br & $\begin{array}{l}\text { Privada sem fins } \\
\text { lucrativos }\end{array}$ \\
\hline $\begin{array}{l}\text { Universidade do } \\
\text { Estado do Rio de } \\
\text { Janeiro }\end{array}$ & UERJ & $\begin{array}{l}\text { Bacharelado em } \\
\text { Artes Visuais }\end{array}$ & Presencial & $\begin{array}{l}\text { Rua São Francisco Xavier, } 524 . \\
\text { Maracanã, Rio de Janeiro/RJ. }\end{array}$ & RJ & (21) 2334-0652 & http://www.uerj.br/ & Pública Estadual \\
\hline $\begin{array}{l}\text { Universidade do } \\
\text { Estado do Rio de } \\
\text { Janeiro }\end{array}$ & UERJ & $\begin{array}{l}\text { Licenciatura em } \\
\text { Artes Visuais }\end{array}$ & Presencial & $\begin{array}{l}\text { Rua São Francisco Xavier, } 524 . \\
\text { Maracanã, Rio de Janeiro/RJ. }\end{array}$ & RJ & (21) 2334-0652 & http://www.uerj.br/ & Pública Estadual \\
\hline $\begin{array}{l}\text { Universidade do } \\
\text { Grande Rio } \\
\text { Professor José de } \\
\text { Sousa Herdy }\end{array}$ & UNIGRANRIO & $\begin{array}{l}\text { Licenciatura em } \\
\text { Artes Visuais }\end{array}$ & Presencial & $\begin{array}{l}\text { Rua Professor José de Souza Herdy, } \\
\text { 1160. Duque de Caxias/RJ. }\end{array}$ & RJ & (21) $2672-7813$ & http://www.unigranrio.br/ & $\begin{array}{l}\text { Privada sem fins } \\
\text { lucrativos }\end{array}$ \\
\hline $\begin{array}{l}\text { Universidade } \\
\text { Federal do Rio de } \\
\text { Janeiro }\end{array}$ & UFRJ & $\begin{array}{l}\text { Bacharelado em } \\
\text { Artes Visuais - } \\
\text { Escultura }\end{array}$ & Presencial & $\begin{array}{l}\text { Avenida Brigadeiro Trompowsky, S/N. } \\
\text { Cidade Universitária, Ilha do Fundão, } \\
\text { Rio de Janeiro/RJ. }\end{array}$ & RJ & (21) 2598-9603 & http://www.ufrj.br/ & Pública Federal \\
\hline $\begin{array}{l}\text { Universidade } \\
\text { Federal do Rio de } \\
\text { Janeiro }\end{array}$ & UFRJ & $\begin{array}{l}\text { Licenciatura - } \\
\text { Educação } \\
\text { Artística - } \\
\text { Desenho }\end{array}$ & Presencial & $\begin{array}{l}\text { Avenida Brigadeiro Trompowsky, S/N. } \\
\text { llha do Fundão, Rio de Janeiro/RJ. }\end{array}$ & RJ & (21) 2598-9603 & http://www.ufri.br/ & Pública Federal \\
\hline
\end{tabular}




\begin{tabular}{|c|c|c|c|c|c|c|c|c|}
\hline $\begin{array}{l}\text { Universidade } \\
\text { Federal do Rio de } \\
\text { Janeiro }\end{array}$ & UFRJ & $\begin{array}{l}\text { Licenciatura em } \\
\text { Educação } \\
\text { Artística - } \\
\text { Desenho }\end{array}$ & Presencial & $\begin{array}{l}\text { Avenida Brigadeiro Trompowsky, S/N. } \\
\text { Cidade Universitária, Ilha do Fundão, } \\
\text { Rio de Janeiro/RJ. }\end{array}$ & RJ & (21) 2598-9603 & http://www.ufri.br/ & Pública Federal \\
\hline $\begin{array}{l}\text { Universidade } \\
\text { Federal do Rio de } \\
\text { Janeiro }\end{array}$ & UFRJ & $\begin{array}{c}\text { Licenciatura em } \\
\text { Educação } \\
\text { Artística - } \\
\text { Habilitação em } \\
\text { Artes Plásticas }\end{array}$ & Presencial & $\begin{array}{l}\text { Avenida Brigadeiro Trompowsky, S/N. } \\
\text { Cidade Universitária, Ilha do Fundão, } \\
\text { Rio de Janeiro/RJ. }\end{array}$ & RJ & (21) 2598-9603 & http://www.ufri.br/ & Pública Federal \\
\hline $\begin{array}{l}\text { Universidade } \\
\text { Federal } \\
\text { Fluminense }\end{array}$ & UFF & $\begin{array}{l}\text { Licenciatura em } \\
\text { Artes }\end{array}$ & Presencial & $\begin{array}{l}\text { Rua Miguel de Frias, 09. Icaraí, } \\
\text { Niterói/RJ. }\end{array}$ & RJ & (21) 2629-5205 & $\underline{\text { http://www.uff.br }}$ & Pública Estadual \\
\hline $\begin{array}{l}\text { Universidade } \\
\text { Federal Rural do } \\
\text { Rio de Janeiro }\end{array}$ & UFRRJ & $\begin{array}{l}\text { Licenciatura em } \\
\text { Belas Artes }\end{array}$ & Presencial & $\begin{array}{l}\text { Rodovia BR } 465 \text { - Km 07, } \\
\text { Seropédica/RJ }\end{array}$ & RJ & (21) 2682-1090 & http://www.ufrri.br/portal & Pública Federal \\
\hline $\begin{array}{l}\text { Universidade } \\
\text { Salgado de } \\
\text { Oliveira }\end{array}$ & UNIVERSO & $\begin{array}{l}\text { Bacharelado - } \\
\text { Educação } \\
\text { Artística }\end{array}$ & Presencial & $\begin{array}{l}\text { Rua Marechal Deodoro, S/N. } \\
\text { Niterói/RJ. }\end{array}$ & RJ & (21) 2620-1069 & $\frac{\text { http://www.universo.ed }}{\text { u.br/portal/niteroi/ }}$ & $\begin{array}{l}\text { Privada sem fins } \\
\text { lucrativos }\end{array}$ \\
\hline $\begin{array}{l}\text { Universidade } \\
\text { Salgado de } \\
\text { Oliveira }\end{array}$ & UNIVERSO & $\begin{array}{l}\text { Licenciatura - } \\
\text { Educação } \\
\text { Artística }\end{array}$ & Presencial & Rua Lambari, 10. São Gonçalo/RJ & RJ & (21) 2620-1069 & $\begin{array}{l}\text { http://www.universo.ed } \\
\text { u.br/portal/sao- } \\
\text { goncalo/ }\end{array}$ & $\begin{array}{l}\text { Privada sem fins } \\
\text { lucrativos }\end{array}$ \\
\hline $\begin{array}{l}\text { Universidade } \\
\text { Salgado de } \\
\text { Oliveira }\end{array}$ & UNIVERSO & $\begin{array}{l}\text { Licenciatura - } \\
\text { Educação } \\
\text { Artística }\end{array}$ & Presencial & $\begin{array}{l}\text { Av. Osvaldo Cardoso de Melo, } \\
\text { 856/904. Campos dos } \\
\text { Goytacazes/RJ. }\end{array}$ & RJ & (21) 2620-1069 & $\begin{array}{l}\text { http://www.universo.ed } \\
\text { u.br/portal/campos/ }\end{array}$ & $\begin{array}{l}\text { Privada sem fins } \\
\text { lucrativos }\end{array}$ \\
\hline $\begin{array}{l}\text { Universidade } \\
\text { Salgado de } \\
\text { Oliveira }\end{array}$ & UNIVERSO & $\begin{array}{l}\text { Licenciatura - } \\
\text { Educação } \\
\text { Artística }\end{array}$ & Presencial & $\begin{array}{l}\text { Rua Marechal Deodoro, S/N. } \\
\text { Niterói/RJ. }\end{array}$ & RJ & (21) 2620-1069 & $\frac{\text { http://www.universo.ed }}{\text { u.br/portal/niteroi/ }}$ & $\begin{array}{l}\text { Privada sem fins } \\
\text { lucrativos }\end{array}$ \\
\hline $\begin{array}{l}\text { Universidade } \\
\text { Federal do Rio } \\
\text { Grande do Norte }\end{array}$ & FURG & $\begin{array}{l}\text { Bacharelado em } \\
\text { Artes Visuais }\end{array}$ & Presencial & $\begin{array}{l}\text { Av. Itália, KM - 8, Carreiros, Rio } \\
\text { Grande/RN. }\end{array}$ & $\mathrm{RN}$ & (53) 32336730 & http://www.furg.br/ & Pública Federal \\
\hline $\begin{array}{l}\text { Universidade } \\
\text { Federal do Rio } \\
\text { Grande do Norte }\end{array}$ & FURG & $\begin{array}{l}\text { Licenciatura em } \\
\text { Artes Visuais }\end{array}$ & Presencial & $\begin{array}{l}\text { Av. Itália, KM - 8, Carreiros, Rio } \\
\text { Grande/RN. }\end{array}$ & $\mathrm{RN}$ & (53) 32336730 & http://www.furg.br/ & Pública Federal \\
\hline $\begin{array}{l}\text { Universidade } \\
\text { Federal do Rio } \\
\text { Grande do Norte }\end{array}$ & UFRN & $\begin{array}{l}\text { Licenciatura em } \\
\text { Artes Visuais }\end{array}$ & Presencial & $\begin{array}{l}\text { Avenida Senador Salgado Filho, } \\
\text { 3000. Campus Universitário, Lagoa } \\
\text { Nova, Natal/RN. }\end{array}$ & $\mathrm{RN}$ & (84) $3342-2317$ & $\frac{\mathrm{http}: / / \text { www.sistemas.uf }}{\underline{\mathrm{rn} . \mathrm{br} /}}$ & Pública Federal \\
\hline $\begin{array}{l}\text { Faculdade } \\
\text { Metropolitana }\end{array}$ & UNNESA & $\begin{array}{l}\text { Bacharelado em } \\
\text { Artes Visuais }\end{array}$ & Presencial & Rua Araras, 241. Porto Velho/RO. & $\mathrm{RO}$ & (69) 3217-8961 & $\begin{array}{l}\text { http://www.metropolita } \\
\underline{\text { na-ro.com.br/ }}\end{array}$ & $\begin{array}{l}\text { Privada com fins } \\
\text { lucrativos }\end{array}$ \\
\hline $\begin{array}{l}\text { Universidade } \\
\text { Federal de } \\
\text { Rondônia }\end{array}$ & UNIR & $\begin{array}{l}\text { Licenciatura em } \\
\text { Artes Visuais }\end{array}$ & Presencial & BR 364, Km 9,5. Porto Velho/RO. & RO & $\begin{array}{l}\text { (69) } 2182-2019 \\
/ 2182-2018\end{array}$ & http://www.unir.br/ & Pública Federal \\
\hline
\end{tabular}




\begin{tabular}{|c|c|c|c|c|c|c|c|c|}
\hline $\begin{array}{l}\text { Universidade } \\
\text { Federal de } \\
\text { Roraima }\end{array}$ & UFRR & $\begin{array}{l}\text { Licenciatura em } \\
\text { Artes Visuais }\end{array}$ & Presencial & $\begin{array}{l}\text { Avenida Capitão Ene Garce, } 2413 . \\
\text { Aeroporto, Boa Vista/RR. }\end{array}$ & $\mathrm{RR}$ & $\begin{array}{l}\text { (95) } 3621-3100 \\
/ 3621-3102\end{array}$ & http://ufrr.br/ & Pública Federal \\
\hline $\begin{array}{l}\text { Universidade } \\
\text { Federal de } \\
\text { Roraima }\end{array}$ & UFRR & $\begin{array}{c}\text { Licenciatura } \\
\text { Intercultural } \\
\text { Comunicação e } \\
\text { Artes }\end{array}$ & Presencial & $\begin{array}{l}\text { Avenida Capitão Ene Garce, } 2413 . \\
\text { Aeroporto, Boa Vista/RR. }\end{array}$ & RR & $\begin{array}{l}\text { (95) } 3621-3100 \\
/ 3621-3102\end{array}$ & http://ufrr.br/ & Pública Federal \\
\hline $\begin{array}{l}\text { Universidade de } \\
\text { Caxias do Sul }\end{array}$ & UCS & $\begin{array}{l}\text { Bacharelado em } \\
\text { Artes Visuais }\end{array}$ & Presencial & $\begin{array}{l}\text { Rua Francisco Getúlio Vargas, } 1130 . \\
\text { Petrópolis, Caxias do Sul, RS. }\end{array}$ & RS & (54) $3218-2143$ & http://www.ucs.br/ & $\begin{array}{l}\text { Privada sem fins } \\
\text { lucrativos }\end{array}$ \\
\hline $\begin{array}{l}\text { Universidade de } \\
\text { Caxias do Sul }\end{array}$ & UCS & $\begin{array}{l}\text { Licenciatura em } \\
\text { Artes Visuais }\end{array}$ & Presencial & $\begin{array}{l}\text { Rua Francisco Getúlio Vargas, } 1130 . \\
\text { Petrópolis, Caxias do Sul, RS. }\end{array}$ & RS & (54) $3218-2143$ & http://www.ucs.br/ & $\begin{array}{l}\text { Privada sem fins } \\
\text { lucrativos }\end{array}$ \\
\hline $\begin{array}{l}\text { Universidade de } \\
\text { Caxias do Sul }\end{array}$ & UCS & $\begin{array}{l}\text { Licenciatura em } \\
\text { Artes Visuais }\end{array}$ & $\begin{array}{c}\text { A } \\
\text { Distância }\end{array}$ & $\begin{array}{l}\text { Rua Francisco Getúlio Vargas, } 1130 . \\
\text { Petrópolis, Caxias do Sul, RS. }\end{array}$ & RS & (54) $3218-2143$ & http://www.ucs.br/ & $\begin{array}{l}\text { Privada sem fins } \\
\text { lucrativos }\end{array}$ \\
\hline $\begin{array}{l}\text { Universidade de } \\
\text { Passo Fundo }\end{array}$ & UPF & $\begin{array}{l}\text { Bacharelado em } \\
\text { Artes Visuais }\end{array}$ & Presencial & $\begin{array}{l}\text { BR } 285-\text { Km 171. São José, Passo } \\
\text { Fundo/RS. }\end{array}$ & RS & (54) $3316-8113$ & http://www.upf.br/ & $\begin{array}{l}\text { Privada sem fins } \\
\text { lucrativos }\end{array}$ \\
\hline $\begin{array}{l}\text { Universidade de } \\
\text { Passo Fundo }\end{array}$ & UPF & $\begin{array}{l}\text { Licenciatura em } \\
\text { Artes Visuais }\end{array}$ & Presencial & $\begin{array}{l}\text { BR } 285 \text { - Km 171. São José, Passo } \\
\text { Fundo/RS. }\end{array}$ & RS & (54) 3316-8113 & http://www.upf.br/ & $\begin{array}{l}\text { Privada sem fins } \\
\text { lucrativos }\end{array}$ \\
\hline $\begin{array}{l}\text { Universidade } \\
\text { Estadual do Rio } \\
\text { Grande do Sul }\end{array}$ & UERGS & $\begin{array}{l}\text { Licenciatura em } \\
\text { Artes Visuais }\end{array}$ & Presencial & $\begin{array}{l}\text { Rua Sete de Setembro, 1156. Porto } \\
\text { Alegre/RS. }\end{array}$ & RS & (51) 3288-9000 & http://www.uergs.edu.br/ & Pública Estadual \\
\hline $\begin{array}{l}\text { Universidade } \\
\text { Federal de Santa } \\
\text { Maria }\end{array}$ & UFSM & $\begin{array}{l}\text { Bacharelado em } \\
\text { Artes Visuais }\end{array}$ & Presencial & $\begin{array}{l}\text { Cidade Universitária Prof. José } \\
\text { Mariano da Rocha Filho, Avenida } \\
\text { Roraima, 1000. Camobi, Santa } \\
\text { Maria/RS. }\end{array}$ & RS & (55) $3220-8000$ & http://www.ufsm.br/ & Pública Federal \\
\hline $\begin{array}{l}\text { Universidade } \\
\text { Federal de Santa } \\
\text { Maria }\end{array}$ & UFSM & $\begin{array}{l}\text { Licenciatura em } \\
\text { Artes Visuais }\end{array}$ & Presencial & $\begin{array}{l}\text { Cidade Universitária Prof. José } \\
\text { Mariano da Rocha Filho, Avenida } \\
\text { Roraima, 1000. Camobi, Santa } \\
\text { Maria/RS. }\end{array}$ & RS & (55) 3220-8000 & http://www.ufsm.br/ & Pública Federal \\
\hline $\begin{array}{l}\text { Universidade } \\
\text { Federal do Rio } \\
\text { Grande do Sul }\end{array}$ & UFRGS & $\begin{array}{l}\text { Bacharelado em } \\
\text { Artes Visuais }\end{array}$ & Presencial & $\begin{array}{l}\text { Avenida Paulo Gama, } 110 . \\
\text { Farroupilha, Porto Alegre/RS. }\end{array}$ & RS & (51) 3308-3600 & $\underline{\text { http://www.ufrgs.br/ufr }}$ & Pública Federal \\
\hline $\begin{array}{l}\text { Universidade } \\
\text { Federal do Rio } \\
\text { Grande do Sul }\end{array}$ & UFRGS & $\begin{array}{l}\text { Licenciatura em } \\
\text { Artes Visuais }\end{array}$ & Presencial & $\begin{array}{l}\text { Avenida Paulo Gama, } 110 . \\
\text { Farroupilha, Porto Alegre/RS. }\end{array}$ & RS & (51) $3308-3600$ & $\begin{array}{l}\text { http://www.ufrgs.br/ufr } \\
\text { gs/inicial }\end{array}$ & Pública Federal \\
\hline $\begin{array}{l}\text { Universidade } \\
\text { Federal do Rio }\end{array}$ & UFRGS & $\begin{array}{l}\text { Licenciatura em } \\
\text { Artes Visuais }\end{array}$ & $\begin{array}{c}\text { A } \\
\text { Distância }\end{array}$ & $\begin{array}{l}\text { Avenida Paulo Gama, } 110 . \\
\text { Farroupilha, Porto Alegre/RS. }\end{array}$ & RS & (51) 3308-3600 & $\begin{array}{l}\text { http://www.ufrgs.br/ufr } \\
\text { gs/inicial }\end{array}$ & Pública Federal \\
\hline
\end{tabular}




\begin{tabular}{|c|c|c|c|c|c|c|c|c|}
\hline Grande do Sul & & & & & & & & \\
\hline $\begin{array}{l}\text { Universidade } \\
\text { FEEVALE }\end{array}$ & FEEVALE & $\begin{array}{l}\text { Bacharelado em } \\
\text { Artes Visuais }\end{array}$ & Presencial & $\begin{array}{l}\text { Rua 239, } 2755 \text {. Vila Nova, Novo } \\
\text { Hamburgo/RS. }\end{array}$ & RS & (51)3586-9240 & $\underline{\text { http://www.feevale.br/ }}$ & $\begin{array}{l}\text { Privada sem fins } \\
\text { lucrativos }\end{array}$ \\
\hline $\begin{array}{l}\text { Universidade } \\
\text { FEEVALE }\end{array}$ & FEEVALE & $\begin{array}{l}\text { Licenciatura em } \\
\text { Artes Visuais }\end{array}$ & Presencial & $\begin{array}{l}\text { Rua 239, } 2755 \text {. Vila Nova, Novo } \\
\text { Hamburgo/RS. }\end{array}$ & RS & (51)3586-9240 & $\underline{\text { http://www.feevale.br/ }}$ & $\begin{array}{l}\text { Privada sem fins } \\
\text { lucrativos }\end{array}$ \\
\hline $\begin{array}{l}\text { Universidade } \\
\text { FEEVALE }\end{array}$ & FEEVALE & $\begin{array}{l}\text { Licenciatura em } \\
\text { Artes Visuais }\end{array}$ & Presencial & $\begin{array}{l}\text { Rua } 239,2755 \text {. Vila Nova, Novo } \\
\text { Hamburgo/RS. }\end{array}$ & RS & (51)3586-9240 & http://www.feevale.br/ & $\begin{array}{l}\text { Privada sem fins } \\
\text { lucrativos }\end{array}$ \\
\hline $\begin{array}{l}\text { Universidade } \\
\text { Luterana do Brasil }\end{array}$ & ULBRA & $\begin{array}{l}\text { Licenciatura em } \\
\text { Artes Visuais }\end{array}$ & Presencial & $\begin{array}{l}\text { Avenida Farroupilha, 8001. São José, } \\
\text { Canoas/RS. }\end{array}$ & RS & (51) 3477-4000 & http://www.ulbra.br/ & $\begin{array}{l}\text { Privada sem fins } \\
\text { lucrativos }\end{array}$ \\
\hline $\begin{array}{l}\text { Universidade } \\
\text { Regional de } \\
\text { Campanha }\end{array}$ & URCAMP & $\begin{array}{l}\text { Licenciatura em } \\
\text { Artes Visuais }\end{array}$ & Presencial & $\begin{array}{l}\text { Avenida Tupy Silveira, } 2099 . \\
\text { Bagé/RS. }\end{array}$ & RS & $\begin{array}{l}\text { (53) } 3242-8244 \\
\text { Ramal:222 }\end{array}$ & http://www.urcamp.tche.br & $\begin{array}{l}\text { Privada sem fins } \\
\text { lucrativos }\end{array}$ \\
\hline $\begin{array}{l}\text { Universidade } \\
\text { Regional do } \\
\text { Noroeste do } \\
\text { Estado do rio } \\
\text { Grande do Sul }\end{array}$ & UNIJUI & $\begin{array}{l}\text { Bacharelado em } \\
\text { Artes Visuais }\end{array}$ & Presencial & Rua do Comércio, 3000. ljuí/RS. & RS & $\begin{array}{l}\text { (55) } 33320200 \\
\text { Ramal:321 }\end{array}$ & http://www.unijui.edu.br/ & $\begin{array}{l}\text { Privada sem fins } \\
\text { lucrativos }\end{array}$ \\
\hline $\begin{array}{l}\text { Universidade } \\
\text { Regional do } \\
\text { Noroeste do } \\
\text { Estado do rio } \\
\text { Grande do Sul }\end{array}$ & UNIJUI & $\begin{array}{l}\text { Licenciatura em } \\
\text { Artes Visuais }\end{array}$ & Presencial & Rua do Comércio, 3000. ljuí/RS. & RS & $\begin{array}{l}\text { (55) } 33320200 \\
\text { Ramal:321 }\end{array}$ & http://www.unijui.edu.br/ & $\begin{array}{l}\text { Privada sem fins } \\
\text { lucrativos }\end{array}$ \\
\hline $\begin{array}{l}\text { Centro } \\
\text { Universitário } \\
\text { Leonardo Da Vinci }\end{array}$ & UNIASSELVI & $\begin{array}{l}\text { Licenciatura em } \\
\text { Artes Visuais }\end{array}$ & $\begin{array}{c}\text { A } \\
\text { Distância }\end{array}$ & $\begin{array}{l}\text { Rodovia BR-470. Benedito, } \\
\text { Indaial/SC. }\end{array}$ & $\mathrm{SC}$ & (47) 3281-9000 & $\begin{array}{l}\text { http://www.grupouniassel } \\
\text { vi.com.br/ }\end{array}$ & $\begin{array}{l}\text { Privada com fins } \\
\text { lucrativos }\end{array}$ \\
\hline $\begin{array}{l}\text { Centro } \\
\text { universitário para } \\
\text { o } \\
\text { Desenvolvimento } \\
\text { do Alto Vale do } \\
\text { Itajaí }\end{array}$ & UNIDAVI & $\begin{array}{l}\text { Licenciatura em } \\
\text { Artes Visuais }\end{array}$ & Presencial & $\begin{array}{l}\text { Rua Dr. Guilherme Gemballa, 13. Rio } \\
\text { do Sul/SC. }\end{array}$ & SC & (47) $3531-6000$ & http://www.unidavi.edu.br/ & Fundação Privada \\
\hline $\begin{array}{l}\text { Fundação } \\
\text { Universidade do } \\
\text { Sul de Santa } \\
\text { Catarina }\end{array}$ & UNISUL & $\begin{array}{l}\text { Licenciatura em } \\
\text { Artes Visuais }\end{array}$ & Presencial & $\begin{array}{l}\text { Av. José Acácio Moreira, 787. Dehon, } \\
\text { Tubarão/SC. }\end{array}$ & SC & (48) 3621-3000 & http://www.unisul.br/ & Fundação Privada \\
\hline $\begin{array}{l}\text { Fundação } \\
\text { Universidade do } \\
\text { Sul de Santa } \\
\text { Catarina }\end{array}$ & UNISUL & $\begin{array}{l}\text { Licenciatura em } \\
\text { Artes Visuais }\end{array}$ & Presencial & $\begin{array}{l}\text { Rodovia Jorge Lacerda, } 3201 . \\
\text { Araranguá/SC. }\end{array}$ & SC & (48) 3621-3000 & http://www.unisul.br/ & Fundação Privada \\
\hline $\begin{array}{l}\text { Universidade Alto } \\
\text { Vale do Rio do }\end{array}$ & UNIARP & $\begin{array}{l}\text { Bacharelado em } \\
\text { Artes Visuais }\end{array}$ & Presencial & $\begin{array}{l}\text { Avenida Carlos Maister, S/N. } \\
\text { Fraiburgo/SC. }\end{array}$ & SC & (49) $3561-6200$ & $\begin{array}{l}\text { http://www.uniarp.edu. } \\
\underline{\text { br/home/ }}\end{array}$ & Fundação Privada \\
\hline
\end{tabular}




\begin{tabular}{|c|c|c|c|c|c|c|c|c|}
\hline Peixe & & & & & & & & \\
\hline $\begin{array}{l}\text { Universidade Alto } \\
\text { Vale do Rio do } \\
\text { Peixe }\end{array}$ & UNIARP & $\begin{array}{l}\text { Licenciatura em } \\
\text { Artes Visuais }\end{array}$ & Presencial & $\begin{array}{l}\text { Rua Victor Baptista Adami, } 800 \text {. } \\
\text { caçador/SC. }\end{array}$ & SC & (49) 3561-6200 & $\frac{\text { http://www.uniarp.edu. }}{\underline{\text { br/home/ }}}$ & Fundação Privada \\
\hline $\begin{array}{l}\text { Universidade } \\
\text { Comunitária da } \\
\text { região de } \\
\text { Chapecó }\end{array}$ & UNOCHAPECO & $\begin{array}{l}\text { Bacharelado em } \\
\text { Artes Visuais }\end{array}$ & Presencial & $\begin{array}{l}\text { Avenida Senador Atílio Fontana, } 591 . \\
\text { Chapecó/SC. }\end{array}$ & SC & (49) 3321-8233 & $\begin{array}{l}\text { http://www.unochapec } \\
\underline{\text { o.edu.br/ }}\end{array}$ & Fundação Privada \\
\hline $\begin{array}{l}\text { Universidade } \\
\text { Comunitária da } \\
\text { região de } \\
\text { Chapecó }\end{array}$ & UNOCHAPECO & $\begin{array}{l}\text { Licenciatura em } \\
\text { Artes Visuais }\end{array}$ & Presencial & $\begin{array}{l}\text { Avenida Senador Atílio Fontana, } 591 . \\
\text { Chapecó/SC. }\end{array}$ & SC & (49) 3321-8233 & $\begin{array}{l}\text { http://www.unochapec } \\
\text { o.edu.br/ }\end{array}$ & Fundação Privada \\
\hline $\begin{array}{l}\text { Universidade da } \\
\text { Região de } \\
\text { Joinville }\end{array}$ & UNIVILLE & $\begin{array}{l}\text { Licenciatura em } \\
\text { Artes Visuais }\end{array}$ & Presencial & $\begin{array}{l}\text { Rua Paulo Malschitzki, } 10 . \\
\text { Joinville/SC. }\end{array}$ & SC & (47) 3461-9000 & $\begin{array}{l}\text { http://www.univille.edu } \\
\underline{\text { br/ }}\end{array}$ & Fundação Privada \\
\hline $\begin{array}{l}\text { Universidade da } \\
\text { Região de } \\
\text { Joinville }\end{array}$ & UNIVILLE & $\begin{array}{l}\text { Licenciatura em } \\
\text { Artes Visuais }\end{array}$ & Presencial & $\begin{array}{l}\text { Rua dos Imigrantes } 500 \text { Caixa Postal } \\
251 \text {, Jaraguá do Sul, SC. }\end{array}$ & SC & (47) 3461-9000 & $\frac{\mathrm{http}: / / \text { www.univille.edu }}{\underline{\mathrm{br} /}}$ & Fundação Privada \\
\hline $\begin{array}{l}\text { Universidade do } \\
\text { Contestado }\end{array}$ & UNC & $\begin{array}{l}\text { Licenciatura em } \\
\text { Artes Visuais }\end{array}$ & Presencial & $\begin{array}{l}\text { Rua Joaquim Nabuco, 314. Porto } \\
\text { União/SC. }\end{array}$ & SC & (47) 3641-5500 & http://www.unc.br/ & Fundação Privada. \\
\hline $\begin{array}{l}\text { Universidade do } \\
\text { Contestado }\end{array}$ & UNC & $\begin{array}{l}\text { Licenciatura em } \\
\text { Artes Visuais }\end{array}$ & Presencial & $\begin{array}{l}\text { Rua Roberto Ehlke } 86 . \\
\text { Canoinhas/SC. }\end{array}$ & SC & (47) $3641-5500$ & http://www.unc.br/ & Fundação Privada. \\
\hline $\begin{array}{l}\text { Universidade do } \\
\text { Contestado }\end{array}$ & UNC & $\begin{array}{l}\text { Licenciatura em } \\
\text { Artes Visuais }\end{array}$ & Presencial & $\begin{array}{l}\text { Av. Leoberto Leal } 1904 . \\
\text { Curitibanos/SC. }\end{array}$ & SC & (47) 3641-5500 & http://www.unc.br/ & Fundação Privada. \\
\hline $\begin{array}{l}\text { Universidade do } \\
\text { Estado de Santa } \\
\text { Catarina }\end{array}$ & UDESC & $\begin{array}{l}\text { Bacharelado em } \\
\text { Artes Visuais }\end{array}$ & Presencial & $\begin{array}{l}\text { Avenida Madre Benvenuta, } 2007 . \\
\text { Itacurubi, Florianópolis/SC. }\end{array}$ & SC & (48)3321-8017 & http://www.udesc.br/ & Pública Estadual \\
\hline $\begin{array}{l}\text { Universidade do } \\
\text { Estado de Santa } \\
\text { Catarina }\end{array}$ & UDESC & $\begin{array}{l}\text { Licenciatura em } \\
\text { Artes Visuais }\end{array}$ & Presencial & $\begin{array}{l}\text { Avenida Madre Benvenuta, } 2007 . \\
\text { Itacurubi, Florianópolis/SC. }\end{array}$ & SC & (48)3321-8017 & http://www.udesc.br/ & Pública Estadual \\
\hline $\begin{array}{l}\text { Universidade do } \\
\text { Extremo Sul } \\
\text { Catarinense }\end{array}$ & UNESC & $\begin{array}{l}\text { Bacharelado em } \\
\text { Artes Visuais }\end{array}$ & Presencial & $\begin{array}{l}\text { Avenida Universitária, } 1105 . \\
\text { Criciúma/SC. }\end{array}$ & SC & (48) 3431-2720 & $\begin{array}{l}\text { http://www.unesc.net/p } \\
\text { ortal/ }\end{array}$ & $\begin{array}{l}\text { Privada sem fins } \\
\text { lucrativos }\end{array}$ \\
\hline $\begin{array}{l}\text { Universidade do } \\
\text { Extremo Sul } \\
\text { Catarinense }\end{array}$ & UNESC & $\begin{array}{l}\text { Licenciatura em } \\
\text { Artes Visuais }\end{array}$ & Presencial & $\begin{array}{l}\text { Avenida Universitária, } 1105 . \\
\text { Criciúma/SC. }\end{array}$ & SC & (48) $3431-2720$ & $\begin{array}{l}\text { http://www.unesc.net/p } \\
\text { ortal/ }\end{array}$ & $\begin{array}{l}\text { Privada sem fins } \\
\text { lucrativos }\end{array}$ \\
\hline $\begin{array}{l}\text { Universidade do } \\
\text { Oeste de Santa } \\
\text { Catarina }\end{array}$ & UNOESC & $\begin{array}{l}\text { Licenciatura em } \\
\text { Artes Visuais }\end{array}$ & Presencial & $\begin{array}{l}\text { Rua Getúlio Vargas, } 2125 . \\
\text { Joaçaba/SC. }\end{array}$ & SC & (49) 3551-2098 & $\begin{array}{l}\text { http://www.unoesc.edu } \\
\underline{\text { br/ }}\end{array}$ & Fundação Privada \\
\hline $\begin{array}{l}\text { Universidade do } \\
\text { Oeste de Santa } \\
\text { Catarina }\end{array}$ & UNOESC & $\begin{array}{l}\text { Licenciatura em } \\
\text { Artes Visuais }\end{array}$ & Presencial & $\begin{array}{l}\text { Acesso a Cidade Alta, } 5330 . \\
\text { Capinzal/SC. }\end{array}$ & SC & (49) $3551-2098$ & $\begin{array}{l}\text { http://www.unoesc.edu } \\
\underline{\text { br/ }}\end{array}$ & Fundação Privada \\
\hline
\end{tabular}




\begin{tabular}{|c|c|c|c|c|c|c|c|c|}
\hline $\begin{array}{l}\text { Universidade do } \\
\text { Oeste de Santa } \\
\text { Catarina }\end{array}$ & UNOESC & $\begin{array}{l}\text { Licenciatura em } \\
\text { Artes Visuais }\end{array}$ & Presencial & $\begin{array}{l}\text { Rua Oiapoque, 211. São Miguel do } \\
\text { Oeste. }\end{array}$ & SC & (49) $3551-2098$ & $\underline{\text { http::/www.unoesc.edu.br/ }}$ & Fundação Privada \\
\hline $\begin{array}{l}\text { Universidade do } \\
\text { Oeste de Santa } \\
\text { Catarina }\end{array}$ & UNOESC & $\begin{array}{l}\text { Licenciatura em } \\
\text { Artes Visuais }\end{array}$ & Presencial & Rua Paese, 198. CP. 187. Videira/SC. & SC & (49) $3551-2098$ & http://www.unoesc.edu.br/ & Fundação Privada \\
\hline $\begin{array}{l}\text { Universidade do } \\
\text { Oeste de Santa } \\
\text { Catarina }\end{array}$ & UNOESTE & $\begin{array}{l}\text { Licenciatura em } \\
\text { Artes Visuais }\end{array}$ & Presencial & $\begin{array}{l}\text { Rua Dirceu Giordani, } 696 . \\
\text { Xanxerê/SC. }\end{array}$ & SC & (49) $3551-2098$ & $\underline{\text { http: }: / \text { www.unoesc.edu.br/ }}$ & Fundação Privada \\
\hline $\begin{array}{l}\text { Universidade do } \\
\text { vale do Itajaí }\end{array}$ & UNIVALI & $\begin{array}{l}\text { Licenciatura em } \\
\text { Artes Visuais }\end{array}$ & Presencial & Rua Uruguai, 458. Itajaí, SC. & SC & (47) $3341-7575$ & http://www.univali.br/ & $\begin{array}{l}\text { Privada sem fins } \\
\text { lucrativos }\end{array}$ \\
\hline $\begin{array}{l}\text { Universidade } \\
\text { Regional de } \\
\text { Blumenau }\end{array}$ & FURB & $\begin{array}{l}\text { Bacharelado em } \\
\text { Artes }\end{array}$ & Presencial & $\begin{array}{l}\text { Rua Antônio da Veiga, } 140 . \\
\text { Blumenau/SC. }\end{array}$ & SC & $\begin{array}{c}(47) 3321.0381 / \\
3321.0377\end{array}$ & $\frac{\text { http://www.furb.br/web }}{\text { 110/portugues }}$ & $\begin{array}{l}\text { Fundação } \\
\text { Municipal }\end{array}$ \\
\hline $\begin{array}{l}\text { Universidade } \\
\text { Regional de } \\
\text { Blumenau }\end{array}$ & FURB & $\begin{array}{l}\text { Licenciatura em } \\
\text { Artes }\end{array}$ & Presencial & $\begin{array}{l}\text { Rua Antônio da Veiga, } 140 . \\
\text { Blumenau/SC. }\end{array}$ & SC & $\begin{array}{c}(47) 3321.0381 / \\
3321.0377\end{array}$ & $\frac{\text { http://www.furb.br/web }}{\text { /10/portugues }}$ & $\begin{array}{l}\text { Fundação } \\
\text { Municipal }\end{array}$ \\
\hline $\begin{array}{l}\text { Universidade } \\
\text { Regional de } \\
\text { Blumenau }\end{array}$ & FURB & $\begin{array}{l}\text { Licenciatura em } \\
\text { Artes Visuais }\end{array}$ & Presencial & $\begin{array}{l}\text { Rua Antônio da Veiga, } 140 . \\
\text { Blumenau/SC. }\end{array}$ & SC & $\begin{array}{c}(47) 3321.0381 / \\
3321.0377\end{array}$ & $\frac{\text { http://www.furb.br/web }}{\underline{10 / \text { portugues }}}$ & $\begin{array}{l}\text { Fundação } \\
\text { Municipal }\end{array}$ \\
\hline $\begin{array}{l}\text { Universidade } \\
\text { Regional de } \\
\text { Blumenau }\end{array}$ & FURB & $\begin{array}{l}\text { Licenciatura em } \\
\text { Artes Visuais }\end{array}$ & Presencial & Rua Dorval Luz, 123. Brusque/SC. & SC & $\begin{array}{c}(47) 3321.0381 / \\
3321.0377\end{array}$ & $\frac{\text { http://www.furb.br/web }}{\text { /10/portugues }}$ & $\begin{array}{l}\text { Fundação } \\
\text { Municipal }\end{array}$ \\
\hline $\begin{array}{l}\text { Universidade } \\
\text { Federal de } \\
\text { Sergipe }\end{array}$ & UFS & $\begin{array}{l}\text { Licenciatura em } \\
\text { Artes Visuais }\end{array}$ & Presencial & $\begin{array}{l}\text { Avenida Marechal Rondon, S/N. } \\
\text { Jardim Rosa Elze, São Cristóvão/SE. }\end{array}$ & SE & (79) 2105-6408 & http://www.ufs.br/ & Pública Federal \\
\hline $\begin{array}{l}\text { Ação Educacional } \\
\text { Claretiana }\end{array}$ & CEUCLAR & $\begin{array}{l}\text { Licenciatura em } \\
\text { Artes }\end{array}$ & Presencial & Rua Dom Bosco, 466. Batatais/SP. & SP & (16) 3660-1666 & http://claretiano.edu.br/ & $\begin{array}{l}\text { Privada sem fins } \\
\text { lucrativos }\end{array}$ \\
\hline $\begin{array}{l}\text { Ação Educacional } \\
\text { Claretiana }\end{array}$ & CEUCLAR & $\begin{array}{l}\text { Licenciatura em } \\
\text { Artes }\end{array}$ & $\begin{array}{c}\text { A } \\
\text { Distância }\end{array}$ & Rua Dom Bosco, 466. Batatais/SP. & SP & (16) 3660-1666 & http://claretiano.edu.br/ & $\begin{array}{l}\text { Privada sem fins } \\
\text { lucrativos }\end{array}$ \\
\hline $\begin{array}{l}\text { Associação Santa } \\
\text { Marcelina }\end{array}$ & FASM & $\begin{array}{l}\text { Licenciatura - } \\
\text { Educação } \\
\text { Artística }\end{array}$ & Presencial & $\begin{array}{l}\text { Rua Doutor Emílio Ribas, } 89 . \\
\text { Perdizes, São Paulo/SP. }\end{array}$ & SP & (11) 3824-5800 & http://www.fasm.edu.br & $\begin{array}{l}\text { Privada sem fins } \\
\text { lucrativos }\end{array}$ \\
\hline $\begin{array}{l}\text { Centro } \\
\text { Universitário } \\
\text { Belas Artes }\end{array}$ & FEBASP & $\begin{array}{l}\text { Bacharelado em } \\
\text { Artes Visuais, } \\
\text { Pintura, Gravura } \\
\text { e Escultura }\end{array}$ & Presencial & $\begin{array}{l}\text { Rua Dr. Álvaro Alvim, 76. São } \\
\text { Paulo/SP. }\end{array}$ & SP & (11) 5576-5703 & http://www.belasartes.br & $\begin{array}{l}\text { Privada sem fins } \\
\text { lucrativos }\end{array}$ \\
\hline $\begin{array}{l}\text { Centro } \\
\text { Universitário das } \\
\text { Faculdades } \\
\text { metropolitanas } \\
\text { Unidas }\end{array}$ & FMU & $\begin{array}{l}\text { Licenciatura em } \\
\text { Artes Visuais }\end{array}$ & Presencial & $\begin{array}{l}\text { Rua Taguá, 150. Liberdade, São } \\
\text { Paulo/SP. }\end{array}$ & SP & (11) 3346-6221 & http://www.portal.fmu.br/ & $\begin{array}{l}\text { Privada sem fins } \\
\text { lucrativos }\end{array}$ \\
\hline
\end{tabular}




\begin{tabular}{|c|c|c|c|c|c|c|c|c|}
\hline $\begin{array}{l}\text { Centro } \\
\text { Universitário de } \\
\text { Araras }\end{array}$ & UNAR & $\begin{array}{l}\text { Licenciatura em } \\
\text { Artes Visuais }\end{array}$ & Presencial & $\begin{array}{l}\text { Avenida Ernani Lacerda de Oliveira, } \\
\text { 100. Parque Santa Cândida, } \\
\text { Araras/SP. }\end{array}$ & SP & (19) 3321-8000 & http://www.unar.edu.br & $\begin{array}{l}\text { Privada sem fins } \\
\text { lucrativos }\end{array}$ \\
\hline $\begin{array}{l}\text { Centro } \\
\text { Universitário de } \\
\text { Araras }\end{array}$ & UNAR & $\begin{array}{l}\text { Licenciatura em } \\
\text { Artes Visuais }\end{array}$ & $\begin{array}{c}\text { A } \\
\text { Distância }\end{array}$ & $\begin{array}{l}\text { Avenida Ernani Lacerda de Oliveira, } \\
\text { 100. Parque Santa Cândida, } \\
\text { Araras/SP. }\end{array}$ & SP & (19) 3321-8000 & $\underline{\text { http://www.unar.edu.br }}$ & $\begin{array}{l}\text { Privada sem fins } \\
\text { lucrativos }\end{array}$ \\
\hline $\begin{array}{l}\text { Centro } \\
\text { Universitário de } \\
\text { Jales }\end{array}$ & UNIJALES & $\begin{array}{l}\text { Licenciatura - } \\
\text { Educação } \\
\text { Artística }\end{array}$ & Presencial & $\begin{array}{l}\text { Avenida Francisco Jalles, } 1851 \text {. } \\
\text { Jales/SP. }\end{array}$ & SP & (17) 36221620 & $\frac{\text { http://www.unijales.ed }}{\underline{\text { u.br/unijales/ }}}$ & $\begin{array}{l}\text { Privada sem fins } \\
\text { lucrativos }\end{array}$ \\
\hline $\begin{array}{l}\text { Centro } \\
\text { Universitário de } \\
\text { Jales }\end{array}$ & UNIJALES & $\begin{array}{l}\text { Licenciatura em } \\
\text { Artes Visuais }\end{array}$ & Presencial & $\begin{array}{l}\text { Avenida Francisco Jalles, } 1851 \text {. } \\
\text { Jales/SP. }\end{array}$ & $\mathrm{SP}$ & (17) 36221620 & $\frac{\text { http://www.unijales.ed }}{\underline{\text { u.br/unijales/ }}}$ & $\begin{array}{l}\text { Privada sem fins } \\
\text { lucrativos }\end{array}$ \\
\hline $\begin{array}{l}\text { Centro } \\
\text { Universitário de } \\
\text { Rio Preto }\end{array}$ & UNIRP & $\begin{array}{l}\text { Licenciatura em } \\
\text { Artes Visuais }\end{array}$ & Presencial & $\begin{array}{l}\text { Rua Yvette Gabriel Atique, 45. São } \\
\text { José do Rio Preto/SP. }\end{array}$ & SP & (17) $3211-3000$ & http://www.unirp.edu.br/ & $\begin{array}{l}\text { Privada com fins } \\
\text { lucrativos }\end{array}$ \\
\hline $\begin{array}{l}\text { Centro } \\
\text { Universitário } \\
\text { Estácio Radial de } \\
\text { São Paulo }\end{array}$ & $\begin{array}{l}\text { ESTACIO } \\
\text { UNIRADIAL }\end{array}$ & $\begin{array}{l}\text { Licenciatura em } \\
\text { Artes Visuais }\end{array}$ & Presencial & $\begin{array}{l}\text { Rua Promotor Gabriel Netuzzi Perez, } \\
\text { 108. Santo Amaro, São Paulo/SP. }\end{array}$ & SP & $\begin{array}{c}(11) 3139-3314 \\
/ 3139-3311\end{array}$ & http://cursos.estacio.br/ & $\begin{array}{l}\text { Privada com fins } \\
\text { lucrativos }\end{array}$ \\
\hline $\begin{array}{l}\text { Centro } \\
\text { Universitário } \\
\text { Estácio Radial de } \\
\text { São Paulo }\end{array}$ & $\begin{array}{l}\text { ESTACIO } \\
\text { UNIRADIAL }\end{array}$ & $\begin{array}{l}\text { Licenciatura em } \\
\text { Artes Visuais }\end{array}$ & Presencial & $\begin{array}{l}\text { Rua Promotor Gabriel Netuzzi Perez, } \\
\text { 108. Santo Amaro, São Paulo/SP. }\end{array}$ & SP & $\begin{array}{l}\text { (11) } 3139-3314 \\
\text { / } 3139-3311\end{array}$ & http://cursos.estacio.br/ & $\begin{array}{l}\text { Privada com fins } \\
\text { lucrativos }\end{array}$ \\
\hline $\begin{array}{l}\text { Centro } \\
\text { universitário Ítalo- } \\
\text { Brasileiro }\end{array}$ & UNIIITALO & $\begin{array}{l}\text { Licenciatura em } \\
\text { Artes Visuais }\end{array}$ & Presencial & $\begin{array}{l}\text { Avenida João Dias, 2046. Santo } \\
\text { Amaro, São Paulo/SP. }\end{array}$ & $\mathrm{SP}$ & (11) 5645-0073 & http://www.italo.br/ & $\begin{array}{l}\text { Privada sem fins } \\
\text { lucrativos }\end{array}$ \\
\hline $\begin{array}{l}\text { Centro } \\
\text { Universitário } \\
\text { Metropolitano de } \\
\text { São Paulo }\end{array}$ & UNIMESP & $\begin{array}{l}\text { Bacharelado - } \\
\text { Educação } \\
\text { Artística }\end{array}$ & Presencial & $\begin{array}{l}\text { Rua Doutor Solon Fernandes, } 155 . \\
\text { Guarulhos/SP. }\end{array}$ & SP & $\begin{array}{l}\text { (11) 3544-0333 } \\
\text { Ramal: } 202\end{array}$ & $\underline{\text { http://unimespfig.com.br/ }}$ & $\begin{array}{l}\text { Privada sem fins } \\
\text { lucrativos }\end{array}$ \\
\hline $\begin{array}{l}\text { Centro } \\
\text { Universitário } \\
\text { Metropolitano de } \\
\text { São Paulo }\end{array}$ & UNIMESP & $\begin{array}{l}\text { Licenciatura - } \\
\text { Educação } \\
\text { Artística }\end{array}$ & Presencial & $\begin{array}{l}\text { Rua Doutor Solon Fernandes, } 155 . \\
\text { Guarulhos/SP. }\end{array}$ & $\mathrm{SP}$ & $\begin{array}{l}\text { (11) 3544-0333 } \\
\text { Ramal: } 202\end{array}$ & http://unimespfig.com.br/ & $\begin{array}{l}\text { Privada sem fins } \\
\text { lucrativos }\end{array}$ \\
\hline $\begin{array}{l}\text { Centro } \\
\text { Universitário } \\
\text { Moura Lacerda }\end{array}$ & CUML & $\begin{array}{l}\text { Licenciatura em } \\
\text { Artes }\end{array}$ & Presencial & $\begin{array}{l}\text { Rua Padre Euclides, 995. Ribeirão } \\
\text { Preto/SP. }\end{array}$ & SP & (16) 2101-1011 & $\begin{array}{l}\text { http://www.mouralacer } \\
\underline{\text { da.edu.br/ }}\end{array}$ & Pública Municipal \\
\hline $\begin{array}{l}\text { Centro } \\
\text { Universitário } \\
\text { Nossa Senhora do } \\
\text { Patrocínio }\end{array}$ & CEUNSP & $\begin{array}{l}\text { Licenciatura - } \\
\text { Educação } \\
\text { Artística }\end{array}$ & Presencial & $\begin{array}{l}\text { Praça Antônio Vieira Tavares, } 73 . \\
\text { Salto/SP. }\end{array}$ & SP & (11) 4013-9900 & http://www.ceunsp.edu.br & $\begin{array}{l}\text { Privada com fins } \\
\text { lucrativos }\end{array}$ \\
\hline $\begin{array}{l}\text { Centro } \\
\text { Universitário }\end{array}$ & CEUNSP & $\begin{array}{l}\text { Licenciatura em } \\
\text { Artes Visuais }\end{array}$ & Presencial & $\begin{array}{l}\text { Praça Antônio Vieira Tavares, } 73 . \\
\text { Salto/SP. }\end{array}$ & SP & (11) 4013-9900 & http://www.ceunsp.edu.br & $\begin{array}{l}\text { Privada com fins } \\
\text { lucrativos }\end{array}$ \\
\hline
\end{tabular}




\begin{tabular}{|c|c|c|c|c|c|c|c|c|}
\hline $\begin{array}{l}\text { Nossa Senhora do } \\
\text { Patrocínio }\end{array}$ & & & & & & & & \\
\hline $\begin{array}{l}\text { Faculdade } \\
\text { Anhanguera de } \\
\text { Educação, } \\
\text { Ciências e } \\
\text { Tecnologia de } \\
\text { Sorocaba }\end{array}$ & FAECTS & $\begin{array}{l}\text { Licenciatura em } \\
\text { Artes Visuais }\end{array}$ & Presencial & $\begin{array}{l}\text { Rua Professor Arthur Fonseca, } 633 . \\
\text { Jardim Panorama, Sorocaba/SP. }\end{array}$ & SP & $\begin{array}{l}\text { (11) } 4501-9706 \\
/ 9775\end{array}$ & $\begin{array}{l}\text { http://www.anhanguer } \\
\text { a.com/home/ }\end{array}$ & $\begin{array}{l}\text { Privada com fins } \\
\text { lucrativos }\end{array}$ \\
\hline $\begin{array}{l}\text { Faculdade } \\
\text { Anhanguera de } \\
\text { Taboão da Serra }\end{array}$ & FATS & $\begin{array}{l}\text { Licenciatura em } \\
\text { Artes Visuais }\end{array}$ & Presencial & $\begin{array}{l}\text { Rodovia Regis Bittencourt, } 199 . \\
\text { Taboão da Serra/SP. }\end{array}$ & SP & (11) 4097-6050 & $\begin{array}{l}\text { http://www.anhanguer } \\
\underline{\text { a.com/home/ }}\end{array}$ & $\begin{array}{l}\text { Privada com fins } \\
\text { lucrativos }\end{array}$ \\
\hline Faculdade Atibaia & FAAT & $\begin{array}{l}\text { Licenciatura em } \\
\text { Artes Visuais }\end{array}$ & Presencial & $\begin{array}{l}\text { Estrada Municipal Juca Sanches, } \\
\text { 1050. Jardim Brogotá, Atibaia/SP. }\end{array}$ & SP & (11) 4414-4140 & $\frac{\text { http://www.faat.com.br }}{\text { /site/index.asp }}$ & $\begin{array}{l}\text { Privada com fins } \\
\text { lucrativos }\end{array}$ \\
\hline Faculdade Birigui & $\mathrm{FABI}$ & $\begin{array}{l}\text { Licenciatura em } \\
\text { Artes Visuais }\end{array}$ & Presencial & $\begin{array}{l}\text { Rua João Escanhuela, 133. Jardim } \\
\text { Capuano. Birigui/SP. }\end{array}$ & SP & (18) 3643-3880 & http://uniesp.edu.br/ & $\begin{array}{l}\text { Privada sem fins } \\
\text { lucrativos }\end{array}$ \\
\hline $\begin{array}{l}\text { Faculdade de } \\
\text { Administração e } \\
\text { Artes de Limeira }\end{array}$ & FAAL & $\begin{array}{l}\text { Licenciatura em } \\
\text { Artes Visuais }\end{array}$ & Presencial & $\begin{array}{l}\text { Avenida Carlos Kuntz Busch, } 800 . \\
\text { Limeira/SP. }\end{array}$ & SP & (19) 3444-3240 & http://www.faal.com.br/ & $\begin{array}{l}\text { Privada com fins } \\
\text { lucrativos }\end{array}$ \\
\hline $\begin{array}{l}\text { Faculdade de } \\
\text { Artes Plásticas da } \\
\text { Fundação } \\
\text { Armando Álvares } \\
\text { Penteado }\end{array}$ & FAAP & $\begin{array}{l}\text { Bacharelado - } \\
\text { Educação } \\
\text { Artística }\end{array}$ & Presencial & $\begin{array}{l}\text { Rua Alagoas, 903. Higienópolis, São } \\
\text { Paulo/SP. }\end{array}$ & SP & (11) $3662-7312$ & http://www.faap.br/ & Fundação Privada \\
\hline $\begin{array}{l}\text { Faculdade de } \\
\text { Artes Plásticas da } \\
\text { Fundação } \\
\text { Armando Álvares } \\
\text { Penteado }\end{array}$ & FAAP & $\begin{array}{l}\text { Licenciatura - } \\
\text { Educação } \\
\text { Artística }\end{array}$ & Presencial & $\begin{array}{l}\text { Rua Alagoas, 903. Higienópolis, São } \\
\text { Paulo/SP. }\end{array}$ & SP & (11) $3662-7312$ & http://www.faap.br/ & Fundação Privada \\
\hline $\begin{array}{l}\text { Faculdade de } \\
\text { Ciências e Letras } \\
\text { de Bragança } \\
\text { Paulista }\end{array}$ & FESB & $\begin{array}{l}\text { Licenciatura - } \\
\text { Educação } \\
\text { Artística }\end{array}$ & Presencial & $\begin{array}{l}\text { Avenida Francisco Samuel Lucche } \\
\text { Filho, } 770 \text {. Bragança Paulista/SP. }\end{array}$ & SP & (11) 4035-7800 & http://www.fesb.br/ & Pública Municipal \\
\hline $\begin{array}{l}\text { Faculdade de } \\
\text { Filosofia, Ciências } \\
\text { e Letras de São } \\
\text { José do Rio Pardo }\end{array}$ & FFCL & $\begin{array}{l}\text { Licenciatura em } \\
\text { Artes }\end{array}$ & Presencial & $\begin{array}{l}\text { Avenida Deputado Eduardo Vicente } \\
\text { Nasser, 1020. São José do Rio } \\
\text { Pardo/SP. }\end{array}$ & SP & (19) 3608-4704 & $\begin{array}{l}\text { http://www.feucriopard } \\
\text { o.edu.br/capa.html }\end{array}$ & Pública Municipal \\
\hline $\begin{array}{l}\text { Faculdade de } \\
\text { Filosofia, Ciências } \\
\text { e Letras de Tatuí }\end{array}$ & FAFICILE & $\begin{array}{l}\text { Licenciatura - } \\
\text { Educação } \\
\text { Artística }\end{array}$ & Presencial & Rua Oracy Gomes, 665. Tatuí/SP, & SP & (15) 3251-1573 & $\frac{\text { http://www.assetta.co }}{\text { m.br/html/faficile.htm }}$ & $\begin{array}{l}\text { Privada sem fins } \\
\text { lucrativos }\end{array}$ \\
\hline $\begin{array}{l}\text { Faculdade de } \\
\text { Presidente } \\
\text { Epitácio }\end{array}$ & FAPE & $\begin{array}{l}\text { Licenciatura em } \\
\text { Artes Visuais }\end{array}$ & Presencial & $\begin{array}{l}\text { Rua Pernambuco, 17-05. Presidente } \\
\text { Epitácio/SP. }\end{array}$ & SP & (18) 3281-9600 & http://www.uniesp.edu.br/ & $\begin{array}{l}\text { Privada sem fins } \\
\text { lucrativos }\end{array}$ \\
\hline
\end{tabular}




\begin{tabular}{|c|c|c|c|c|c|c|c|c|}
\hline $\begin{array}{l}\text { Faculdade de } \\
\text { Presidente } \\
\text { Epitácio }\end{array}$ & FAPE & $\begin{array}{l}\text { Licenciatura em } \\
\text { Artes Visuais }\end{array}$ & Presencial & $\begin{array}{l}\text { Rua Pernambuco, 17-05. Presidente } \\
\text { Epitácio/SP. }\end{array}$ & SP & (18) 3281-9600 & http://www.uniesp.edu.br/ & $\begin{array}{l}\text { Privada sem fins } \\
\text { lucrativos }\end{array}$ \\
\hline $\begin{array}{l}\text { Faculdade de } \\
\text { Ribeirão Preto }\end{array}$ & AFARP & $\begin{array}{l}\text { Licenciatura em } \\
\text { Artes Visuais }\end{array}$ & Presencial & $\begin{array}{l}\text { Rua Saldanha Marinho, 915. Ribeirão } \\
\text { Preto/SP. }\end{array}$ & SP & (16) $3977-8000$ & $\begin{array}{l}\text { http://www.uniesp.edu. } \\
\text { br/ribeiraopreto }\end{array}$ & $\begin{array}{l}\text { Privada com fins } \\
\text { lucrativos }\end{array}$ \\
\hline $\begin{array}{l}\text { Faculdade Estácio } \\
\text { Cotia }\end{array}$ & $\begin{array}{l}\text { ESTACIO } \\
\text { FAAC }\end{array}$ & $\begin{array}{l}\text { Licenciatura em } \\
\text { Artes Visuais }\end{array}$ & Presencial & $\begin{array}{l}\text { Rua Howard Archibaldi Acheson } \\
\text { Júnior, 393. Cotia/SP. }\end{array}$ & SP & $\begin{array}{l}\text { (1) } 3931-3314 / \\
96569-9131\end{array}$ & http://cursos.estacio.br & $\begin{array}{l}\text { Privada com fins } \\
\text { lucrativos }\end{array}$ \\
\hline $\begin{array}{l}\text { Faculdade } \\
\text { Mozarteum de São } \\
\text { Paulo }\end{array}$ & FAMOSP & $\begin{array}{l}\text { Licenciatura - } \\
\text { Educação } \\
\text { Artística }\end{array}$ & Presencial & $\begin{array}{l}\text { Rua Nova dos Portugueses, 365. São } \\
\text { Paulo/SP. }\end{array}$ & SP & (11) 2236-0788 & http://www.mozarteum.br & $\begin{array}{l}\text { Privada sem fins } \\
\text { lucrativos }\end{array}$ \\
\hline $\begin{array}{l}\text { Faculdade } \\
\text { Paulista de Artes }\end{array}$ & FPA & $\begin{array}{l}\text { Licenciatura em } \\
\text { Artes Visuais }\end{array}$ & Presencial & $\begin{array}{l}\text { Av. Brigadeiro Luís Antônio, } 1224 . \\
\text { Bela Vista, São Paulo/SP. }\end{array}$ & SP & (11) 32874455 & http://fpa.art.br/web/ & $\begin{array}{l}\text { Privada sem fins } \\
\text { lucrativos }\end{array}$ \\
\hline $\begin{array}{l}\text { Faculdade Santa } \\
\text { Cecília }\end{array}$ & FASC & $\begin{array}{l}\text { Licenciatura - } \\
\text { Educação } \\
\text { Artística }\end{array}$ & Presencial & $\begin{array}{l}\text { Praça Barão do Rio Branco, } 59 . \\
\text { Pindamonhangaba/SP. }\end{array}$ & SP & (41) 2105-4071 & http://fascpindasp.com.br/ & $\begin{array}{l}\text { Privada sem fins } \\
\text { lucrativos }\end{array}$ \\
\hline $\begin{array}{l}\text { Faculdades } \\
\text { Estácio Euro-Pan- } \\
\text { americana de } \\
\text { Humanidades e } \\
\text { Tecnologias }\end{array}$ & $\begin{array}{l}\text { ESTACIO } \\
\text { EUROPAN }\end{array}$ & $\begin{array}{l}\text { Licenciatura - } \\
\text { Educação } \\
\text { Artística }\end{array}$ & Presencial & $\begin{array}{l}\text { Rua Howard Archibald Acheson } \\
\text { Junior, 393. Jardim da Glória - Granja } \\
\text { Viana, Cotia/SP. }\end{array}$ & SP & $\begin{array}{l}(11) 5212-6107 \\
/ 5212-6112 / \\
6569-9131\end{array}$ & http://portal.estacio.br/ & $\begin{array}{l}\text { Privada com fins } \\
\text { lucrativos }\end{array}$ \\
\hline $\begin{array}{l}\text { Faculdades } \\
\text { Integradas de } \\
\text { Ourinhos }\end{array}$ & $\mathrm{FIO}$ & $\begin{array}{l}\text { Licenciatura em } \\
\text { Artes Visuais }\end{array}$ & Presencial & $\begin{array}{l}\text { BR } 153, \mathrm{Km} 339+420 \text { m. Água do } \\
\text { Cateto, Ourinhos/SP. }\end{array}$ & SP & (14) 33026400 & http://www.fio.edu.br/ & $\begin{array}{l}\text { Privada sem fins } \\
\text { lucrativos }\end{array}$ \\
\hline $\begin{array}{l}\text { Faculdades } \\
\text { Integradas } \\
\text { Regionais de } \\
\text { Avaré }\end{array}$ & FIRA & $\begin{array}{l}\text { Licenciatura em } \\
\text { Artes }\end{array}$ & Presencial & $\begin{array}{l}\text { Praça Prefeito Romeu Bretas, } 163 . \\
\text { Avaré/SP. }\end{array}$ & SP & (14) $3711-1828$ & http://www.frea.edu.br/ & Pública Municipal \\
\hline $\begin{array}{l}\text { Faculdades } \\
\text { Integradas Teresa } \\
\text { D'Ávila }\end{array}$ & FATEA & $\begin{array}{l}\text { Licenciatura - } \\
\text { Educação } \\
\text { Artística }\end{array}$ & Presencial & $\begin{array}{l}\text { Avenida Doutor Peixoto de Castro, } \\
\text { 539. Lorena/SP. }\end{array}$ & SP & $\begin{array}{l}\text { (12) } 2124-2816 \\
\text { / } 2124-2803 / \\
2124-2870\end{array}$ & http://fatea.br/fatea/ & $\begin{array}{l}\text { Privada sem fins } \\
\text { lucrativos }\end{array}$ \\
\hline $\begin{array}{l}\text { Fundação Vale- } \\
\text { paraibana de } \\
\text { Ensino }\end{array}$ & UNIVAP & $\begin{array}{l}\text { Licenciatura em } \\
\text { Artes Visuais }\end{array}$ & Presencial & $\begin{array}{l}\text { Av. Shishima Hifumi, № 2911, Bairro } \\
\text { Urbanova, São José dos Campos/SP. }\end{array}$ & SP & (12) 3947-1036 & http://www.univap.br/ & $\begin{array}{l}\text { Privada sem fins } \\
\text { lucrativos }\end{array}$ \\
\hline $\begin{array}{l}\text { Instituto } \\
\text { Adventista de } \\
\text { Ensino }\end{array}$ & UNASP & $\begin{array}{l}\text { Licenciatura - } \\
\text { Educação } \\
\text { Artística }\end{array}$ & Presencial & $\begin{array}{l}\text { Estrada Municipal Pastor Walter } \\
\text { Borges, S/N. Fazenda Lagoa Bonita, } \\
\text { Engenheiro Coelho/SP. }\end{array}$ & SP & (19) 3858-5300 & http://www.unasp.edu.br/ & $\begin{array}{l}\text { Privada sem fins } \\
\text { lucrativos }\end{array}$ \\
\hline $\begin{array}{l}\text { Instituto Coração } \\
\text { de Jesus }\end{array}$ & FAINC & $\begin{array}{l}\text { Licenciatura - } \\
\text { Educação } \\
\text { Artística }\end{array}$ & Presencial & $\begin{array}{l}\text { Rua Siqueira Campos, 483. Santo } \\
\text { André/SP. }\end{array}$ & SP & (11) 4433-7477 & http://www.fainc.com.br/ & $\begin{array}{l}\text { Privada sem fins } \\
\text { lucrativos }\end{array}$ \\
\hline
\end{tabular}




\begin{tabular}{|c|c|c|c|c|c|c|c|c|}
\hline $\begin{array}{l}\text { Pan-americana } \\
\text { Faculdade de Arte } \\
\text { e Design }\end{array}$ & PANAMERICANA & $\begin{array}{l}\text { Bacharelado em } \\
\text { artes }\end{array}$ & Presencial & $\begin{array}{l}\text { Avenida Angélica, 1900. Higienópolis, } \\
\text { São Paulo/SP. }\end{array}$ & SP & (11) 3661-8511 & $\begin{array}{l}\text { http://www.escola- } \\
\text { panamericana.com.br/ } \\
\text { escola/? }\end{array}$ & $\begin{array}{l}\text { Privada com fins } \\
\text { lucrativos }\end{array}$ \\
\hline $\begin{array}{l}\text { Pontifícia } \\
\text { Universidade } \\
\text { Católica de } \\
\text { Campinas }\end{array}$ & $\begin{array}{c}\text { PUC- } \\
\text { CAMPINAS }\end{array}$ & $\begin{array}{l}\text { Bacharelado em } \\
\text { Artes Visuais }\end{array}$ & Presencial & $\begin{array}{l}\text { Rodovia Dom Pedro I, km } 136 . \\
\text { Campinas/SP. }\end{array}$ & SP & (19)3343-7000 & $\begin{array}{l}\text { http://www.puc- } \\
\underline{\text { campinas.edu.br/ }}\end{array}$ & $\begin{array}{l}\text { Privada sem fins } \\
\text { lucrativos }\end{array}$ \\
\hline $\begin{array}{l}\text { Pontifícia } \\
\text { Universidade } \\
\text { Católica de } \\
\text { Campinas }\end{array}$ & $\begin{array}{c}\text { PUC- } \\
\text { CAMPINAS }\end{array}$ & $\begin{array}{l}\text { Licenciatura em } \\
\text { Artes Visuais }\end{array}$ & Presencial & $\begin{array}{l}\text { Rodovia Dom Pedro I, km } 136 . \\
\text { Campinas/SP. }\end{array}$ & SP & (19)3343-7000 & $\begin{array}{l}\text { http://www.puc- } \\
\underline{\text { campinas.edu.br/ }}\end{array}$ & $\begin{array}{l}\text { Privada sem fins } \\
\text { lucrativos }\end{array}$ \\
\hline $\begin{array}{l}\text { União das Escolas } \\
\text { do Grupo FAIMI } \\
\text { de Educação }\end{array}$ & FAIMI & $\begin{array}{l}\text { Licenciatura em } \\
\text { Artes Visuais }\end{array}$ & Presencial & $\begin{array}{l}\text { Avenida Luís Fernando Moreira, } \\
\text { 1005. Mirassol/SP. }\end{array}$ & $\mathrm{SP}$ & (17) $3243-7150$ & http://www.faimi.edu.br & $\begin{array}{l}\text { Privada com fins } \\
\text { lucrativos }\end{array}$ \\
\hline $\begin{array}{l}\text { Universidade } \\
\text { Camilo Castelo } \\
\text { Branco }\end{array}$ & UNICASTELO & $\begin{array}{l}\text { Licenciatura em } \\
\text { Artes Visuais }\end{array}$ & Presencial & $\begin{array}{l}\text { Rua Carolina Fonseca, } 584 . \\
\text { Itaquera/SP. }\end{array}$ & SP & (11) 2070-0012 & $\underline{\text { http://www.unicastelo.br/ }}$ & $\begin{array}{l}\text { Privada sem fins } \\
\text { lucrativos }\end{array}$ \\
\hline $\begin{array}{l}\text { Universidade } \\
\text { Cidade de São } \\
\text { Paulo }\end{array}$ & UNICID & $\begin{array}{l}\text { Licenciatura em } \\
\text { Artes Visuais }\end{array}$ & Presencial & $\begin{array}{l}\text { Rua Cesário Galeno, 432. Tatuapé, } \\
\text { São Paulo/SP. }\end{array}$ & SP & (11) 2178-1200 & http://www.unicid.edu.br/ & $\begin{array}{l}\text { Privada com fins } \\
\text { lucrativos }\end{array}$ \\
\hline $\begin{array}{l}\text { Universidade } \\
\text { Cruzeiro do Sul }\end{array}$ & UNICSUL & $\begin{array}{l}\text { Licenciatura em } \\
\text { Artes Visuais }\end{array}$ & Presencial & $\begin{array}{l}\text { Avenida Doutor Ussiel Cirilo, 225. São } \\
\text { Miguel, São Paulo/SP. }\end{array}$ & SP & (11) 2037-5708 & $\frac{\text { http://www.cruzeirodos }}{\text { ul.edu.br/ }}$ & $\begin{array}{l}\text { Privada com fins } \\
\text { lucrativos }\end{array}$ \\
\hline $\begin{array}{l}\text { Universidade } \\
\text { Cruzeiro do Sul }\end{array}$ & UNICSUL & $\begin{array}{l}\text { Licenciatura em } \\
\text { Artes Visuais }\end{array}$ & Presencial & $\begin{array}{l}\text { Av. Regente Feijó } 1.295 \text { Jardim } \\
\text { Anália Franco }\end{array}$ & SP & (11) 2037-5708 & $\frac{\text { http://www.cruzeirodos }}{\text { ul.edu.br/ }}$ & $\begin{array}{l}\text { Privada com fins } \\
\text { lucrativos }\end{array}$ \\
\hline $\begin{array}{l}\text { Universidade de } \\
\text { Franca }\end{array}$ & UNIFRAN & $\begin{array}{l}\text { Licenciatura em } \\
\text { Artes Visuais }\end{array}$ & Presencial & $\begin{array}{l}\text { Avenida Doutor Armando Sales } \\
\text { Oliveira, 201. Franca/SP. }\end{array}$ & SP & (16) 3711-8888 & $\frac{\text { http://www.unifran.edu }}{\text { br/site/home/ }}$ & $\begin{array}{l}\text { Privada com fins } \\
\text { lucrativos }\end{array}$ \\
\hline $\begin{array}{l}\text { Universidade de } \\
\text { Guarulhos }\end{array}$ & UNG & $\begin{array}{l}\text { Licenciatura em } \\
\text { Artes Visuais }\end{array}$ & Presencial & $\begin{array}{l}\text { Praça Tereza Cristina, } 88 . \\
\text { Guarulhos/SP. }\end{array}$ & $\mathrm{SP}$ & (11) 2409-9222 & http://www.ung.br/ & $\begin{array}{l}\text { Privada sem fins } \\
\text { lucrativos }\end{array}$ \\
\hline $\begin{array}{l}\text { Universidade de } \\
\text { Mogi das Cruzes }\end{array}$ & UMC & $\begin{array}{l}\text { Licenciatura em } \\
\text { Artes Visuais }\end{array}$ & Presencial & $\begin{array}{l}\text { Avenida Doutor Cândido Xavier de } \\
\text { Almeida Souza, 200. Centro Cívico, } \\
\text { Mogi das Cruzes/SP. }\end{array}$ & SP & (11) 4798-7048 & http://www.umc.br/ & $\begin{array}{l}\text { Privada com fins } \\
\text { lucrativos }\end{array}$ \\
\hline $\begin{array}{l}\text { Universidade de } \\
\text { São Paulo }\end{array}$ & USP & $\begin{array}{l}\text { Bacharelado - } \\
\text { Artes Visuais } \\
\text { com habilitação } \\
\text { em escultura }\end{array}$ & Presencial & $\begin{array}{l}\text { Rua da Reitoria, 109. Cidade } \\
\text { Universitária, São Paulo/SP. }\end{array}$ & SP & & http://www.eca.usp.br/ & Pública Estadual \\
\hline $\begin{array}{l}\text { Universidade de } \\
\text { São Paulo }\end{array}$ & USP & $\begin{array}{l}\text { Bacharelado - } \\
\text { Artes Visuais } \\
\text { com habilitação } \\
\text { em gravura }\end{array}$ & Presencial & $\begin{array}{l}\text { Rua da Reitoria, 109. Cidade } \\
\text { Universitária, São Paulo/SP. }\end{array}$ & SP & (11) 3091-3500 & http://www.eca.usp.br/ & Pública Estadual \\
\hline
\end{tabular}




\begin{tabular}{|c|c|c|c|c|c|c|c|c|}
\hline $\begin{array}{l}\text { Universidade de } \\
\text { São Paulo }\end{array}$ & USP & $\begin{array}{c}\text { Bacharelado - } \\
\text { Artes Visuais } \\
\text { com habilitação } \\
\text { em multimídia e } \\
\text { intermídia }\end{array}$ & Presencial & $\begin{array}{l}\text { Rua da Reitoria, 109. Cidade } \\
\text { Universitária, São Paulo/SP. }\end{array}$ & SP & (11) 3091-3500 & http://www.eca.usp.br/ & Pública Estadual \\
\hline $\begin{array}{l}\text { Universidade de } \\
\text { São Paulo }\end{array}$ & USP & $\begin{array}{l}\text { Bacharelado - } \\
\text { Artes Visuais } \\
\text { com habilitação } \\
\text { em pintura }\end{array}$ & Presencial & $\begin{array}{l}\text { Rua da Reitoria, 109. Cidade } \\
\text { Universitária, São Paulo/SP. }\end{array}$ & SP & (11) 3091-3500 & http://www.eca.usp.br/ & Pública Estadual \\
\hline $\begin{array}{l}\text { Universidade de } \\
\text { São Paulo }\end{array}$ & UTP & $\begin{array}{l}\text { Licenciatura - } \\
\text { Educação } \\
\text { Artística com } \\
\text { habilitação em } \\
\text { Artes Plásticas }\end{array}$ & Presencial & $\begin{array}{l}\text { Rua da Reitoria, 109. Cidade } \\
\text { Universitária, São Paulo/SP. }\end{array}$ & SP & (11) $3091-3500$ & $\underline{\text { http://www.eca.usp.br/ }}$ & Pública Estadual \\
\hline $\begin{array}{l}\text { Universidade de } \\
\text { Sorocaba }\end{array}$ & UNISO & $\begin{array}{l}\text { Licenciatura em } \\
\text { Artes Visuais }\end{array}$ & Presencial & Rodovia Raposo Tavares, Km 92,5. & SP & (15) 2101-7000 & $\frac{\text { http://www.uniso.br/cs/ }}{\text { vestibular-2014-v2/ }}$ & $\begin{array}{l}\text { Privada sem fins } \\
\text { lucrativos }\end{array}$ \\
\hline $\begin{array}{l}\text { Universidade de } \\
\text { Taubaté }\end{array}$ & UNITAU & $\begin{array}{l}\text { Licenciatura em } \\
\text { Artes Visuais }\end{array}$ & $\begin{array}{c}\text { A } \\
\text { Distância }\end{array}$ & $\begin{array}{l}\text { Rua Quatro de Março, } 432 . \\
\text { Taubaté/SP. }\end{array}$ & SP & (12) 3624-4193 & http://www.unitau.br/ & $\begin{array}{l}\text { Autarquia } \\
\text { Municipal }\end{array}$ \\
\hline $\begin{array}{l}\text { Universidade } \\
\text { Estadual de } \\
\text { Campinas }\end{array}$ & UNICAMP & $\begin{array}{l}\text { Bacharelado em } \\
\text { Artes Visuais }\end{array}$ & Presencial & $\begin{array}{l}\text { Cidade Universitária "Zeferino Vaz", } \\
\text { Barão Geraldo, Campinas/SP. }\end{array}$ & SP & (19) 3521-4722 & http://iar.unicamp.br/ & Pública Estadual \\
\hline $\begin{array}{l}\text { Universidade } \\
\text { Estadual de } \\
\text { Campinas }\end{array}$ & UNICAMP & $\begin{array}{l}\text { Licenciatura em } \\
\text { Artes Visuais }\end{array}$ & Presencial & $\begin{array}{l}\text { Cidade Universitária "Zeferino Vaz", } \\
\text { Barão Geraldo, Campinas/SP. }\end{array}$ & SP & (19) 3521-4722 & http://iar.unicamp.br/ & Pública Estadual \\
\hline $\begin{array}{l}\text { Universidade } \\
\text { Estadual Paulista } \\
\text { Júlio de Mesquita } \\
\text { Filho }\end{array}$ & UNESP & $\begin{array}{l}\text { Bacharelado em } \\
\text { Artes Visuais }\end{array}$ & Presencial & $\begin{array}{l}\text { Rua Dr. Bento Teobaldo Ferraz, } 271 . \\
\text { Barra Funda, São Paulo/SP. }\end{array}$ & SP & (11) 3393-8615 & http://www.ia.unesp.br/ & Pública Estadual \\
\hline $\begin{array}{l}\text { Universidade } \\
\text { Estadual Paulista } \\
\text { Júlio de Mesquita } \\
\text { Filho }\end{array}$ & UNESP & $\begin{array}{l}\text { Licenciatura em } \\
\text { Artes Visuais }\end{array}$ & Presencial & $\begin{array}{l}\text { Rua Dr. Bento Teobaldo Ferraz, } 271 . \\
\text { Barra Funda, São Paulo/SP. }\end{array}$ & SP & (11) 3393-8615 & http://www.ia.unesp.br/ & Pública Estadual \\
\hline $\begin{array}{l}\text { Universidade } \\
\text { Estadual Paulista } \\
\text { Júlio de Mesquita } \\
\text { Filho }\end{array}$ & UNESP & $\begin{array}{l}\text { Licenciatura em } \\
\text { Artes Visuais }\end{array}$ & Presencial & $\begin{array}{l}\text { Av. Eng. } . \text {. Luiz Edmundo Carrijo } \\
\text { Coube, S/N. Bauru/SP. }\end{array}$ & SP & (14) 3103-6000 & https://www.faac.unesp.br/ & Pública Estadual \\
\hline $\begin{array}{l}\text { Universidade } \\
\text { Estadual Paulista } \\
\text { Júlio de Mesquita } \\
\text { Filho }\end{array}$ & UNESP & $\begin{array}{c}\text { Licenciatura em } \\
\text { Educação } \\
\text { Artística }\end{array}$ & Presencial & $\begin{array}{l}\text { Av. Eng. } . \text {. Luiz Edmundo Carrijo } \\
\text { Coube, S/N. Bauru/SP. }\end{array}$ & SP & (14) $3103-6000$ & https://www.faac.unesp.br/ & Pública Estadual \\
\hline
\end{tabular}




\begin{tabular}{|c|c|c|c|c|c|c|c|c|}
\hline $\begin{array}{l}\text { Universidade } \\
\text { Metropolitana de } \\
\text { Santos }\end{array}$ & UNIMES & $\begin{array}{l}\text { Licenciatura em } \\
\text { Artes }\end{array}$ & $\begin{array}{c}\text { A } \\
\text { Distância }\end{array}$ & $\begin{array}{l}\text { Avenida Conselheiro Nébias, } 536 \text {. } \\
\text { Santos/SP. }\end{array}$ & SP & $\begin{array}{l}\text { (13) } 32283400 \\
\text { ramal } 3425\end{array}$ & http://www.unimes.br/ & $\begin{array}{l}\text { Privada sem fins } \\
\text { lucrativos }\end{array}$ \\
\hline $\begin{array}{l}\text { Universidade } \\
\text { Sagrado Coração }\end{array}$ & USC & $\begin{array}{l}\text { Licenciatura - } \\
\text { Educação } \\
\text { Artística }\end{array}$ & Presencial & Rua Irmã Arminda, 10-50. Bauru/SP. & SP & $\begin{array}{l}\text { (14) } 2107-7380 \\
\text { / } 2107-7003\end{array}$ & http://www.usc.br/ & $\begin{array}{l}\text { Privada sem fins } \\
\text { lucrativos }\end{array}$ \\
\hline $\begin{array}{l}\text { Universidade } \\
\text { Santa Cecília }\end{array}$ & UNISANTA & $\begin{array}{l}\text { Licenciatura em } \\
\text { Artes Visuais }\end{array}$ & Presencial & $\begin{array}{l}\text { Rua Oswaldo Cruz, 266. Boqueirão, } \\
\text { Santos/SP. }\end{array}$ & SP & (13) 32027100 & http://www.unisanta.br/ & $\begin{array}{l}\text { Privada sem fins } \\
\text { lucrativos }\end{array}$ \\
\hline $\begin{array}{l}\text { Universidade São } \\
\text { Judas Tadeu }\end{array}$ & USJT & $\begin{array}{l}\text { Bacharelado em } \\
\text { Artes Visuais }\end{array}$ & Presencial & $\begin{array}{l}\text { Rua Taquari, 546. Mooca, São } \\
\text { Paulo/SP. }\end{array}$ & SP & (11) 2799-1931 & http://www.usjt.br/ & $\begin{array}{l}\text { Privada com fins } \\
\text { lucrativos }\end{array}$ \\
\hline $\begin{array}{l}\text { Universidade São } \\
\text { Judas Tadeu }\end{array}$ & USJT & $\begin{array}{l}\text { Licenciatura em } \\
\text { Artes Visuais }\end{array}$ & Presencial & $\begin{array}{l}\text { Rua Taquari, 546. Mooca, São } \\
\text { Paulo/SP. }\end{array}$ & SP & (11) 2799-1931 & http://www.usjt.br/ & $\begin{array}{l}\text { Privada com fins } \\
\text { lucrativos }\end{array}$ \\
\hline $\begin{array}{l}\text { Universidade } \\
\text { Federal do } \\
\text { Tocantins }\end{array}$ & UFT & $\begin{array}{l}\text { Licenciatura em } \\
\text { Artes }\end{array}$ & Presencial & Avenida NS, 15. Palmas/TO. & TO & (63)3232-8109 & http://www.uft.edu.br/ & Pública Federal \\
\hline
\end{tabular}




\title{
1.2 E como são formados os professores de arte na Argentina?
}

A organização da Educação na Argentina apresenta uma estrutura bem semelhante ao que conhecemos no Brasil: Inicial, primária, secundária e superior.

\begin{abstract}
Cabe destacar, inicialmente, uma característica substancial: o sistema de Educação superior se encontra dividido em dois subsistemas, o sistema superior não universitário (terciário) e o sistema superior universitário (Universidades Públicas e Privadas). A formação de professores de artes na Argentina foi se desenvolvendo histórica e tradicionalmente dentro do sistema superior não universitário, em casas de estudos tais como Conservatórios e Escolas Superiores de Artes (Nacionais, Provinciais e Municipais). Paulatinamente, o Ensino das Artes e, dentro dele, a formação de professores de artes, foi ingressando ao nível superior universitário, integrando-se nas Universidades Nacionais (UUNN). No entanto, e conjuntamente com o ingresso paulatino ao sistema superior universitário, parte da formação de professores de artes se realiza ainda hoje dentro do sistema superior não universitário (público e privado). A diferença de base encontra mecanismos diferenciados de regulação, avaliação e credenciamento dos cursos de formação, intervindo em cada caso organismos (Nacionais e/o Regionais) com graus diferenciados de ingerência. Por sua parte, as Universidades Nacionais, além das regulações existentes, concentradas em documentos normativos e levadas a efeito por diversos organismos, tem um alto grau de autonomia para sua organização e gestão.

Este ingresso paulatino do Ensino das Artes nas universidades foi implicando complexos processos de transformação nas culturas institucionais, incidindo nos modos de organização dos cursos de formação e também na configuração de novos perfis tanto dos professores em formação como dos formadores de formadores. No entanto, em muitos casos, as culturas institucionais do nível terciário ainda sobrevivem em algumas instituições que se incorporaram tardiamente ao nível universitário e em muitos docentes cujos trânsitos de formação e desempenho profissional foram desenvolvidos principalmente no nível terciário não universitário. Esta complexa organização do sistema educativo superior na Argentina dá lugar a um panorama de grande diversidade que se torna ainda mais complexo se temos em conta as diferenças regionais $\mathrm{e}$ as diversas culturas institucionais de cada instituição educacional (SILVA, FRADE, RIZZI E BUJÁN, 2012, p. 08).
\end{abstract}

\section{Há legislação específica (Ley Nacional de Educación $N^{\circ} 26.206 / 06$ ) e os documentos oficiais informam que a}

Educación Inicial constituye el primero de los cuatro niveles que conforman el sistema educativo argentino. Constituye una unidad pedagógica y comprende a los/as niños/as desde los cuarenta y cinco días hasta los cinco años de edad inclusive, siendo obligatorio el último año. [...] Educación Primaria es obligatoria para todo/a niño/a a partir de los 6 años. Su finalidad consiste en proporcionar una formación integral, básica y común; garantizando el acceso a un conjunto de saberes comunes y ofreciendo las condiciones necesarias para el desarrollo integral de la infancia en todas sus dimensiones. [...] La Ley de Educación Nacional (LEN) $\mathrm{N}^{\circ}$ 26.206, la Ley de Financiamiento 
Educativo y la Ley de Educación Técnico Profesional representan el marco normativo actual de la educación media en Argentina. Respecto de la estructura del nivel, este marco legal implementa una escuela secundaria obligatoria por primera vez en la historia, de una duración de 5 o de 6 años. En el primer caso, la escuela primaria es de 7 años y la edad teórica de comienzo de la secundaria es de 13 años mientras que en el segundo es de 6 años y el nivel medio comienza a los 12 años de edad. Cada provincia del país implementa estos modelos según sus objetivos y la adecuación a las necesidades de su población escolar. [...] La Educación Superior tiene por finalidad proporcionar formación científica, profesional, humanística y técnica, promoviendo la generación y desarrollo del conocimiento a través de la investigación. Según lo establece la Ley Nacional de Educación, la Educación Superior comprende a los Institutos de Educación Superior (de Formación Docente y de Educación Técnico Profesional) y a las Universidades e Institutos universitarios (MINISTÉRIO DE EDUCACIÓN DE ARGENTINA, 2013).

Castro (2007, p. 23-24) esclarece que

No que diz respeito às modalidades de Ensino, há muitas semelhanças entre as disposições da lei argentina e as da LDB. A Educação técnicoprofissional argentina, que é regida por lei específica, tem característica mais restrita do que a Educação profissional brasileira, uma vez que aquela se vincula necessariamente à Educação secundária ou superior, enquanto a LDB admite essa articulação, mas, também, o desenvolvimento de diferentes estratégias de Educação continuada, em instituições especializadas ou no ambiente de trabalho (art. 40) (CASTRO, 2007, p. 23-24).

Segundo o levantamento oficial do governo argentino, de 2010 (ARGENTINA(11), 2013), são 59.460 unidades educacionais, divididas por níveis em 19.600 de Ensino inicial; 23.010 de Ensino primário; 14.460 de Ensino secundário e 2.390 de Ensino superior.

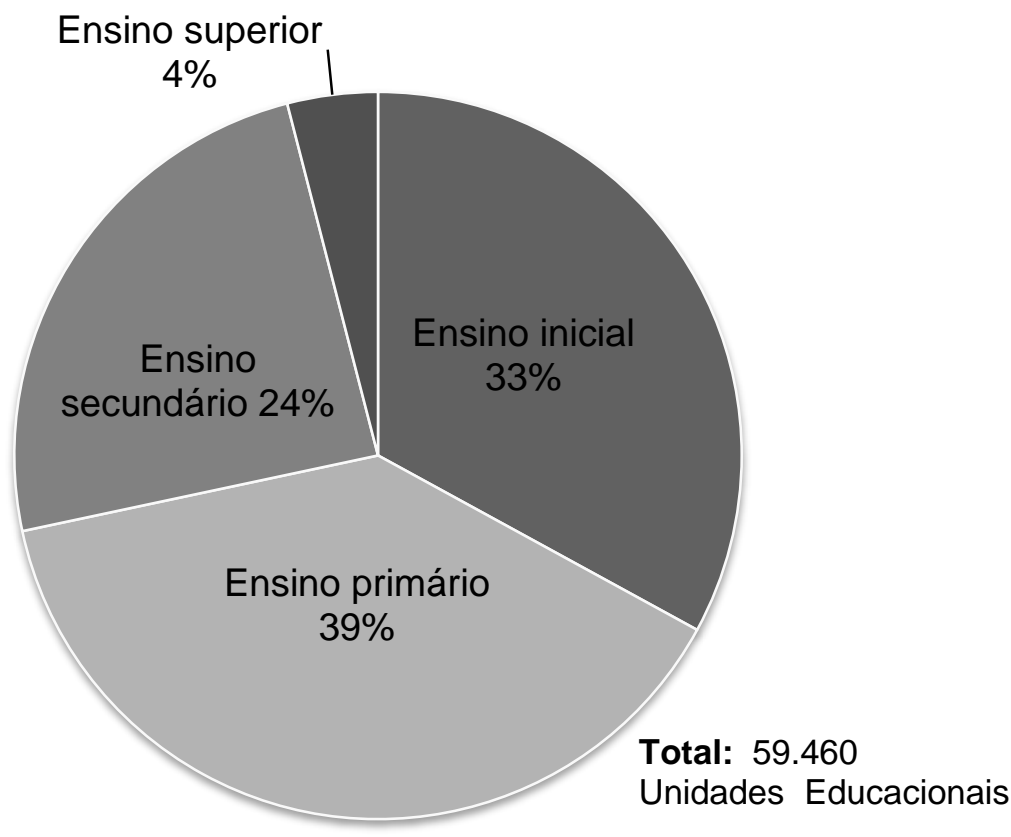


Figura 5 - Percentual das Unidades Educacionais Argentinas.

Os estabelecimentos atendem a 1.553 .418 de alunos no Ensino inicial; 4.637.463 no Ensino primário; 2.276.041 no Ensino secundário básico; 1.403 .587 no Ensino básico orientado e 691.007 no Ensino superior, num total de 10.561 .516 alunos atendidos pelo Ensino formal.

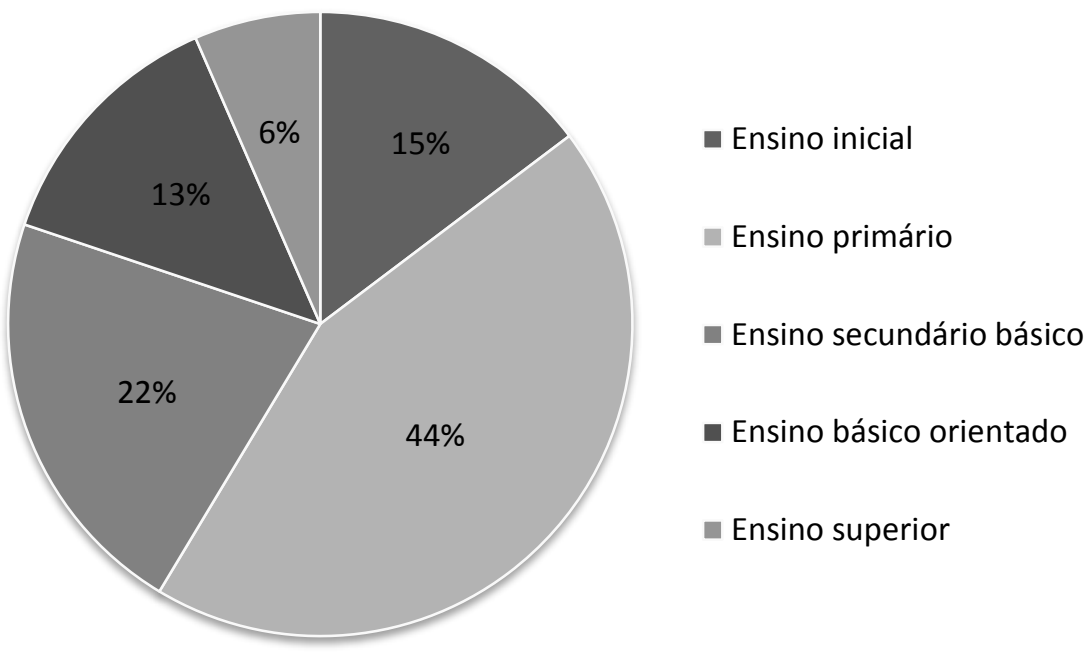

Figura 6 - Alunos em Instituições de Ensino - Argentina.

A Educação primária e secundária são obrigatórias (a partir dos cinco anos até à conclusão do Ensino secundário, o que dura, aproximadamente, nove anos) e o país tem um índice de alfabetização de 97\%, um dos melhores do mundo, sendo que três em cada oito adultos acima de 20 anos completaram os estudos da escola secundária ou superior. 


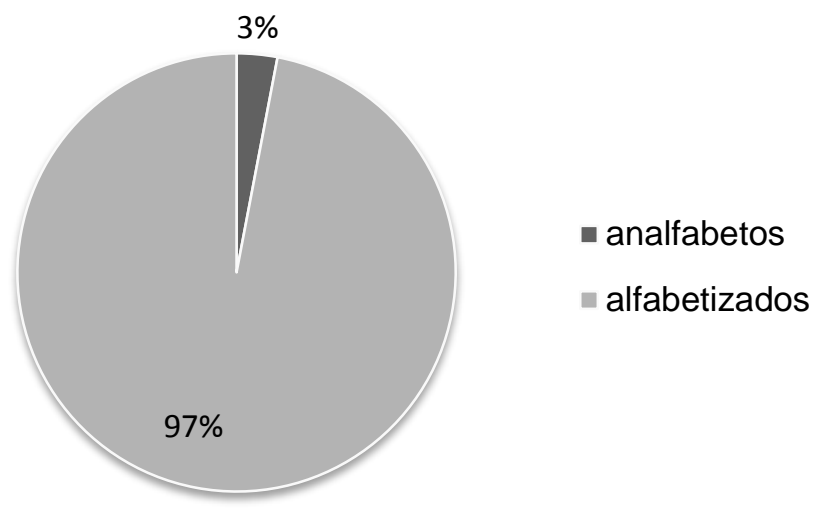

Figura 7 - Nível de alfabetização do povo argentino.

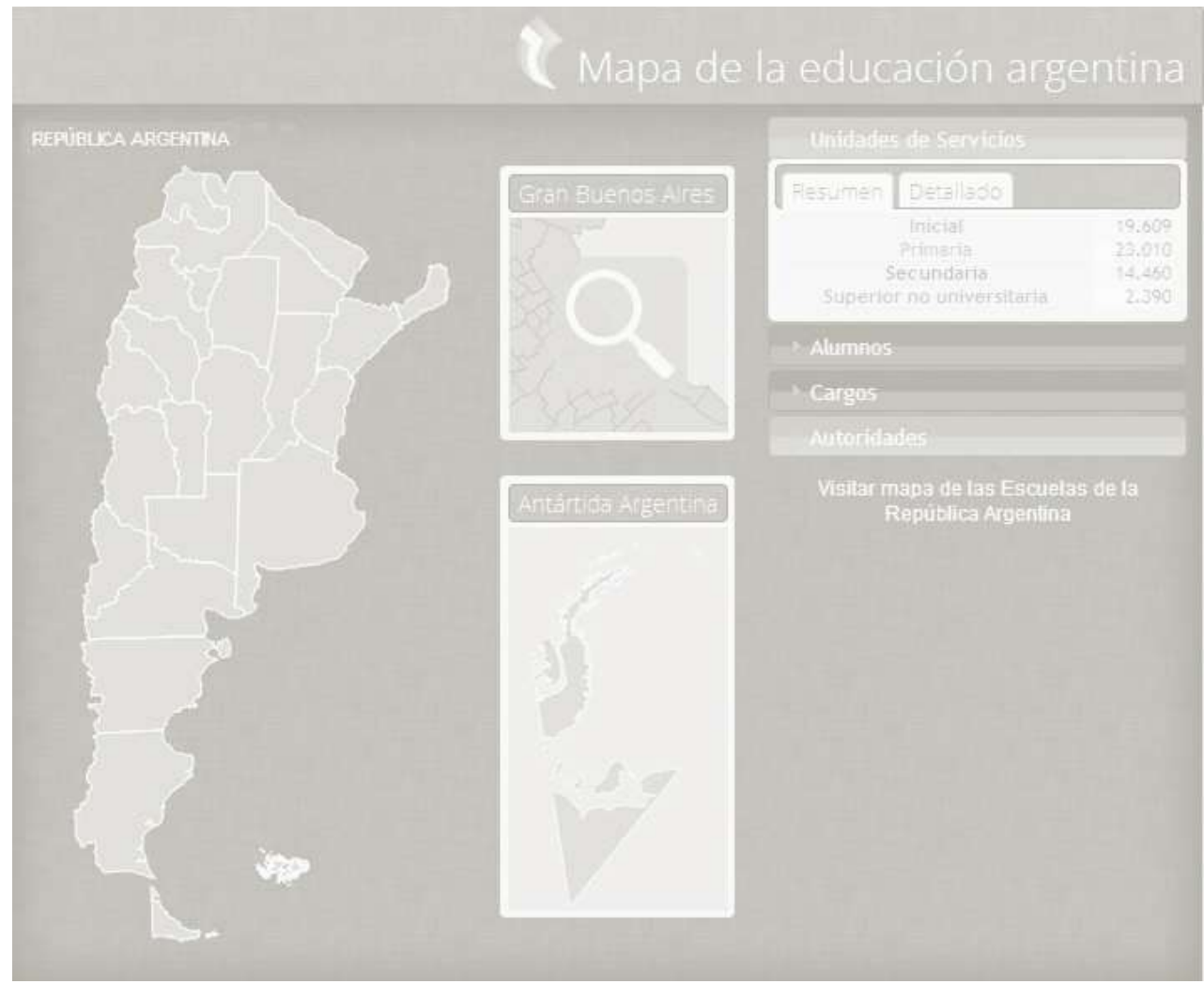

Figura 8 - Mapa interativo da Educação na Argentina (inicial). Nele podem ser encontradas diversas informações sobre a Educação na Argentina. A fonte dessas informações é o Relevamiento Anual 2010. DiNIECE. Ministerio de Educación. Cartografia: Programa Nacional Mapa Educativo 2012.

A fim de garantir a igualdade de direitos à Educação e cumprir os requisitos legais, técnicas pedagógicas e diferentes níveis (Educação infantil, Ensino fundamental, Ensino médio e Ensino superior), o sistema educacional argentino tem oito (8) modalidades de Ensino: Educación Técnico Profesional; Educación Artística; Educación Especial; Educación Permanente de Jóvenes y Adultos; 
Educación Rural; Educación Intercultural Bilíngue; Educación en Contextos de Privación de Libertad e Educación Domiciliaria y hospitalaria.

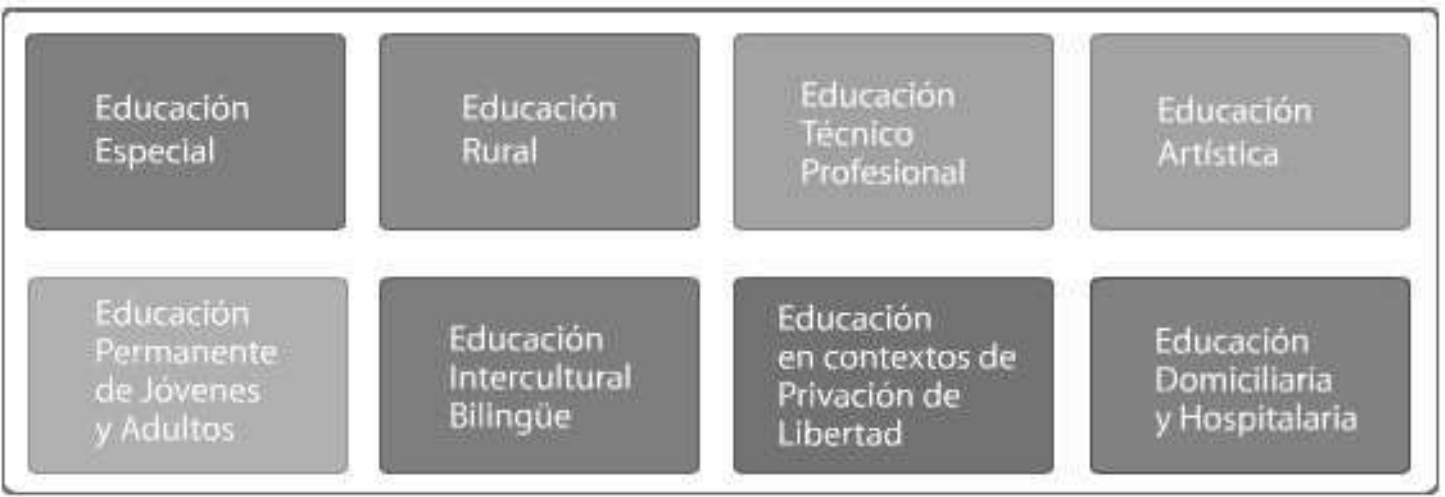

Figura 9 - Modalidades da Educação na Argentina ${ }^{10}$.

A que mais nos interessa conhecer, neste trabalho, é a Educación Artística. Os três eixos da Educación Artística são: Educación Artística General en la Educación Común y Obligatoria, a Educación Artística como una disciplina específica e o eixo "Arte, Educación y Cultura". Diferente do Brasil, o Ensino de Arte é contemplado com uma das modalidades. "Na legislação brasileira, a Educação artística não constitui modalidade de Ensino, mas componente curricular, na forma ou não de disciplina (CASTRO, 2007, p. 23-24)". E, em relação à Educação básica obrigatória a modalidade está presente nos três níveis educativos (ARGENTINA(5), 2013).

\begin{abstract}
La Educación Artística constituye un espacio curricular imprescindible en la educación obligatoria y común de nuestro país. De acuerdo con la Ley de Educación Nacional №. 26.206, el objetivo de esta modalidad consiste en que todos/as los/as alumnos/as -durante el transcurso de su escolaridad obligatoria- tengan la oportunidad de desarrollar su sensibilidad y su capacidad creativa en, al menos, dos (2) disciplinas artísticas.
\end{abstract}

Interessante notar que a articulação entre os níveis e as modalidades se dá de modo flexível, porém busca garantir o atendimento de todos de modo a proporcionar uma Educação ampla e, principalmente, "democrática ${ }^{11 "}$.

\footnotetext{
${ }^{10}$ Disponível em: <http://www.mapaeducativo.edu.ar/Atlas/Modalidades> Acesso em: 15 nov.2014.

${ }^{11}$ Completando 30 anos da queda da ditadura na Argentina em 2013, a democracia é uma preocupação constante e presente em diversos níveis da sociedade. Nos discursos e nas práticas fica implícita a preocupação, como uma espécie de 'ranço' pós-ditadura, mas, principalmente, como objetivo nacional. A saber: La Noche de los bastones largos - que significou um duro golpe para a universidade pública - e La Noche de los lápices - um golpe na participação estudantil
} 


\title{
1.2.1 Educação Superior na Argentina
}

La Educación Superior tiene por finalidad proporcionar formación científica, profesional, humanística y técnica, promoviendo la generación y desarrollo del conocimiento a través de la investigación. Históricamente, la formación de técnicos especializados y profesionales estaba restringida a grupos minoritarios mientras que actualmente el ingreso a este nivel de formación es irrestricto, siendo muchos los ciudadanos argentinos que alcanzan títulos superiores (ARGENTINA(6), 2013).

Segundo $\circ$ Art. $5^{\circ}$. da Lei de Educação Superior Argentina (Ley de Educación Superior $N^{\circ}$ 24.521) esta modalidade educacional se constitui por instituições de formação docente, humanística, social, técnico-profissional ou artística e por instituições de Educação universitária (universidades e institutos universitários). Esta área é dependente da Dirección Nacional de Gestión Curricular y Formación Docente que se ocupa de tudo relacionado à formação nas áreas humanísticas e social.

\begin{abstract}
La enseñanza superior universitaria está a cargo de las Universidades nacionales (financiadas por el Estado nacional), las provinciales y privadas reconocidas por el Estado nacional. Los Institutos Universitarios, públicos o privados, son aquellos que han articulado su propuesta de enseñanza en un área específica en forma conjunta con alguna Universidad (ARGENTINA(7), 2013).
\end{abstract}

As universidades e institutos universitários oferecem os títulos de graduação (licenciaturas, bacharelados etc.) e de pós-graduação (especializações, mestrados e doutoramentos). Oferecem também cursos de pré-graduação, como títulos intermédios ou cursos de curta duração. O Ensino superior na Argentina inclui também institutos não universitários que oferecem cursos curtos (técnicos) e conferem títulos de pré-graduação ('pregrado,12).

\footnotetext{
secundária - ilustram claramente a situação. $O$ retorno da democracia permitiu mudanças e transformações que ainda hoje continuam em processo de implementação e evolução.

12 'Pré-grado' são os estudos de graduação antes da graduação propriamente dita. Equivalem aos cursos tecnológicos no Brasil. São necessários para ter acesso a estudos de pós-graduação. A graduação, ou 'grado' é quando há a opção de carreira a seguir, o que forma o aluno para o exercício de uma profissão específica, comercial ou particular, de natureza tecnológica ou científica ou na área das humanidades, artes e filosofia. São formados por um programa multidisciplinar, também conhecido como estudos de artes liberais, que incluem estudos gerais em ciências, artes e humanidades. De acordo a graduação pretendida podem apresentar ênfase em algumas disciplinas dentro desses campos.
} 
A principal diferença entre universidades e institutos universitários é que os últimos oferecerem cursos numa única área de conhecimento, enquanto as universidades se dividem em faculdades, onde são oferecidos cursos de variadas áreas de conhecimento. Os institutos de Educação superior compreendem os Institutos de Formação Docente ${ }^{13}$ e os Institutos de Educação Técnico Profissional ${ }^{14}$ e respondem ao Instituto Nacional de Formación Docente (INFD) que é uma área do Ministerio de Educación de la Nación, que tem a função de coordenar e dirigir as políticas de formação docente na Argentina (ARGENTINA(10), 2013). O INFD mantém a RED Infod (http://red.infd.edu.ar/), Red Nacional Virtual de Institutos Superiores de Formación Docente, que conecta todos os 792 ISFD do país.

O portal da RED Infod mantém 35.219 salas de aula virtuais em apoio às atividades institucionais. Há polos da RED Infod em Buenos Aires, Catamarca, Córdoba, Corrientes, Chaco, Chubut, Entre Ríos, Formosa, Jujuy, La Pampa, La Rioja, Mendoza, Misiones, Neuquén, Río Negro, Salta, San Juan, San Luis, Santa Cruz, Santa Fe, Santiago del Estero, Tucumán e Tierra del Fuego (ARGENTINA(9), 2013).

\subsubsection{Mapa das Universidades}

O Ministério de Educación de Argentina disponibiliza aos interessados um mapa interativo, navegável, para localização geográfica de suas unidades de Educação, em seus diversos níveis. Diferente do e-Mec, direcionado somente à localização das Instituições de Educação Superior e Cursos Cadastrados,

\footnotetext{
${ }^{13}$ Institutos de Formación Docente: asumen la formación docente inicial para los niveles inicial, primario y secundario; la formación docente continua, el apoyo pedagógico a las escuelas y la investigación. Está regulada a través del Instituto Nacional de Formación Docente (INFD) que, en forma conjunta con las Direcciones de Educación Superior de cada jurisdicción, realiza la planificación de títulos, postítulos, el diseño de los planes de estudio y la gestión y asignación de recursos para la formación docente. Disponível em: $<$ http://www.mapaeducativo.edu.ar/Atlas/Institutos-Educacion-Superior $>$. Acesso em: 25 de nov. 2013.

14 Institutos de Educación Técnico Profesional: responsables de la formación de técnicos superiores en áreas ocupacionales específicas y de la formación profesional. Disponível em: $<$ http://www.mapaeducativo.edu.ar/Atlas/Institutos-Educacion-Superior $>$. Acesso em: 25 de nov. 2013.
} 
Esse mapa navegável (interativo) permite localizar Universidades e Institutos Universitários em todo o território e ter acesso aos seus dados institucionais. A versão que aqui é apresentada representa os dados de 2009 e se refere a 106 Instituições Universitárias (48 de gestão estatal e 56 de gestão privada, uma estrangeiras e uma internacional) com um total de 1.650 .150 estudantes de 'pregrado y grado' (ARGENTINA(7), 2013).

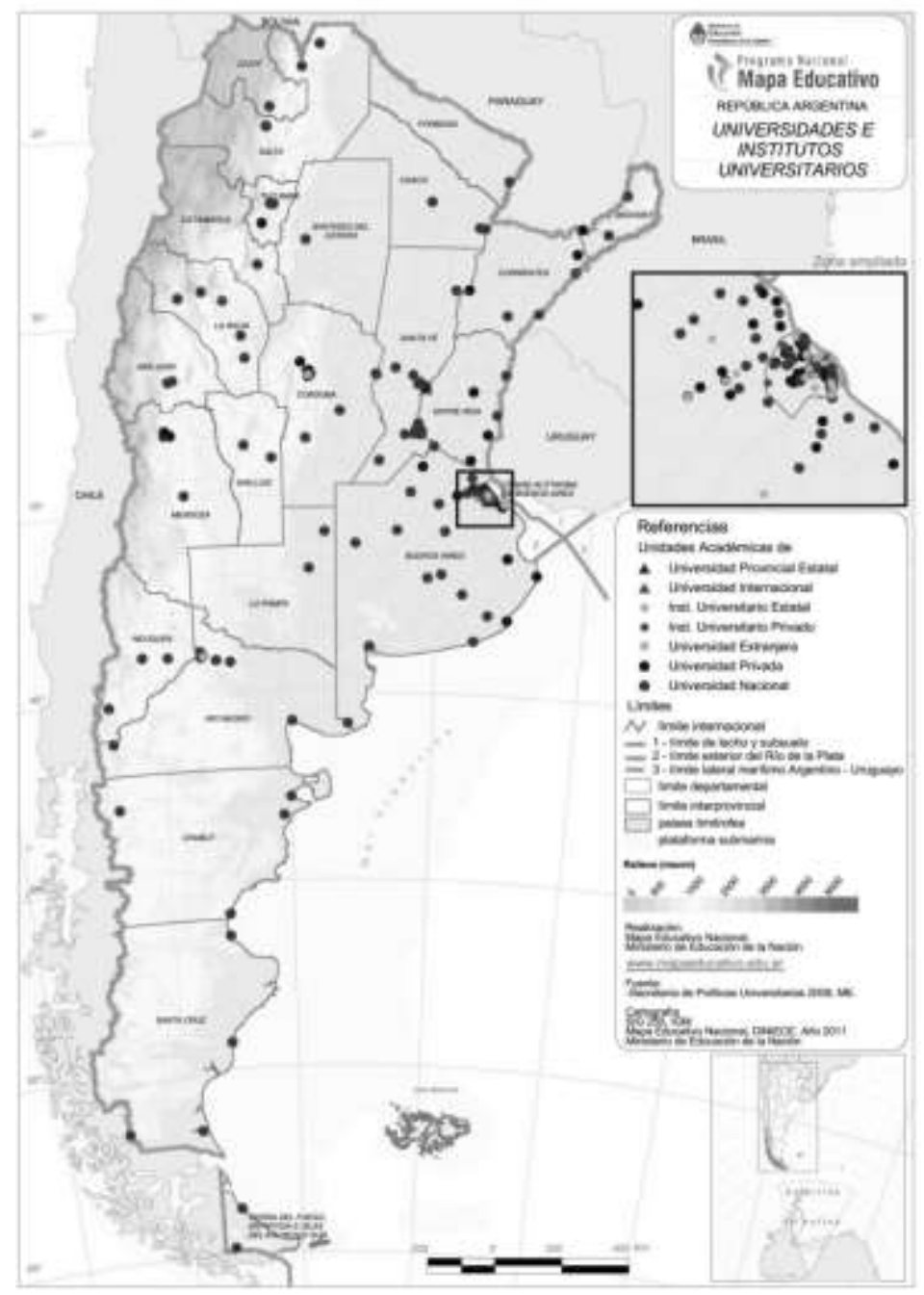

Figura 10 - Mapa das universidades argentinas ${ }^{15}$.

As instituições de Ensino que contam com cursos de formação em arte podem ser vistas na tabela a seguir. Na Argentina, há cursos de Professorado e Licenciatura. A licenciatura é o curso que 'licencia' o profissional para a prática numa carreira. É o equivalente ao Bacharelado no Brasil. O professorado é equivalente às nossas licenciaturas, ou seja, formação de professores.

15 Disponível em: <http://www.mapaeducativo.edu.ar/Atlas/Universidades-e-Institutos>. Acesso em: 15 nov.2013. 
Tabela 5 - Instituições de Ensino Superior na Argentina que oferecem cursos em Arte

\begin{tabular}{|c|c|c|c|c|c|c|}
\hline Universidade & Faculdade & Título conferido & Grau & endereço & Telefone & URL \\
\hline $\begin{array}{l}\text { Instituto Universitário } \\
\text { Escola Superior de } \\
\text { Economia e } \\
\text { Administração de } \\
\text { Empresas }\end{array}$ & Sede Central & $\begin{array}{l}\text { Bacharel em Curadoria e Gestão de } \\
\text { Arte }\end{array}$ & Graduação & $\begin{array}{l}\text { Uriarte } 2472 \text { - Capital } \\
\text { Federal }\end{array}$ & $\begin{array}{l}(11) \\
47727243\end{array}$ & http://www.esEaDe.edu.ar \\
\hline \multirow{18}{*}{$\begin{array}{l}\text { Instituto Universitário } \\
\text { Nacional de Arte }\end{array}$} & \multirow{2}{*}{$\begin{array}{l}\text { Área Transdepartamental } \\
\text { de Artes Multimídia }\end{array}$} & Bacharel em Artes Multimídia & Graduação & \multirow{2}{*}{$\begin{array}{l}\text { Yatay } 843 \text { - Capital } \\
\text { Federal }\end{array}$} & \multirow{2}{*}{$\begin{array}{l}(11) \\
48628209\end{array}$} & \multirow[t]{2}{*}{ http://www.multimedia.iuna.edu.ar } \\
\hline & & Técnico em Artes Multimídia & Técnico & & & \\
\hline & \multirow{2}{*}{$\begin{array}{l}\text { Área Transdepartamental } \\
\text { de Crítica de Arte }\end{array}$} & Bacharel em Crítica de Artes & Graduação & \multirow{2}{*}{$\begin{array}{l}\text { Bartolomé Mitre } 1869 \\
\text { - Capital Federal }\end{array}$} & \multirow{2}{*}{$\begin{array}{l}(11) \\
43717160\end{array}$} & \multirow[t]{2}{*}{ http://www.criticadeartes.iuna.edu.ar } \\
\hline & & Bacharel em Curadoria em Artes & Graduação & & & \\
\hline & \multirow{8}{*}{$\begin{array}{l}\text { Carreiras de Formação } \\
\text { Docente }\end{array}$} & Professor de Artes em Artes Visuais & Graduação & \multirow{8}{*}{$\begin{array}{l}\text { Bolívar } 1674 \text { - Capital } \\
\text { Federal }\end{array}$} & \multirow{8}{*}{$\begin{array}{l}(11) \\
43621699\end{array}$} & \multirow[t]{8}{*}{ http://www.iuna.edu.ar/ } \\
\hline & & $\begin{array}{l}\text { Professor de Artes em Artes Visuais } \\
\text { com Orientação em Artes do Fogo }\end{array}$ & Graduação & & & \\
\hline & & Professor de Artes em Dança & Graduação & & & \\
\hline & & $\begin{array}{l}\text { Professor de Artes em Dança - Danças } \\
\text { Folclóricas e Tango }\end{array}$ & Graduação & & & \\
\hline & & $\begin{array}{l}\text { Professor de Artes em Dança - Énfase } \\
\text { em Expressão Corporal }\end{array}$ & Graduação & & & \\
\hline & & $\begin{array}{l}\text { Professor de Artes em Folclore - } \\
\text { Ênfase Instrumentos Criollos }\end{array}$ & Graduação & & & \\
\hline & & Professor de Artes em Música & Graduação & & & \\
\hline & & Professor de Artes em Teatro & Graduação & & & \\
\hline & $\begin{array}{l}\text { Departamento de Artes } \\
\text { Audiovisuais }\end{array}$ & Bacharel em Artes Audiovisuais & Graduação & $\begin{array}{l}\text { Rocamora } 4141 \text { - } \\
\text { Capital Federal }\end{array}$ & $\begin{array}{l}(11) \\
48644141\end{array}$ & http://www.audiovisuales.iuna.edu.ar \\
\hline & \multirow{5}{*}{$\begin{array}{l}\text { Departamento de Artes } \\
\text { Musicais e Sonoras } \\
\text { Carlos Lopez Buchardo }\end{array}$} & Bacharel em Artes Musicais - Canto & Graduação & \multirow{5}{*}{$\begin{array}{l}\text { Avenida Cordoba } \\
2445 \text { - Capital } \\
\text { Federal }\end{array}$} & \multirow{5}{*}{$\begin{array}{l}(11) \\
49610161\end{array}$} & \multirow[t]{5}{*}{ http://www.artesmusicales.org } \\
\hline & & $\begin{array}{l}\text { Bacharel em Artes Musicais - } \\
\text { Composição }\end{array}$ & Graduação & & & \\
\hline & & $\begin{array}{l}\text { Bacharel em Artes Musicais - } \\
\text { Composição com Meios } \\
\text { Eletroacústicos }\end{array}$ & Graduação & & & \\
\hline & & $\begin{array}{l}\text { Bacharel em Artes Musicais - Direção } \\
\text { de Coral }\end{array}$ & Graduação & & & \\
\hline & & $\begin{array}{l}\text { Bacharel em Artes Musicais - Direção } \\
\text { de Orquestra }\end{array}$ & Graduação & & & \\
\hline
\end{tabular}




\begin{tabular}{|c|c|c|c|c|c|c|}
\hline & & $\begin{array}{l}\text { Bacharel em Artes Musicais - } \\
\text { Instrumento }\end{array}$ & Graduação & & & \\
\hline & \multirow{6}{*}{$\begin{array}{l}\text { Departamento de Artes } \\
\text { Visuais Prilidiano } \\
\text { Pueyrredón }\end{array}$} & Bacharel em Artes Visuais - Desenho & Graduação & \multirow{6}{*}{$\begin{array}{l}\text { Bartolomé Mitre } 1869 \\
\text { - Capital Federal }\end{array}$} & \multirow{6}{*}{$\begin{array}{l}(11) \\
29563440\end{array}$} & \multirow[t]{6}{*}{ http://visuales.iuna.edu.ar } \\
\hline & & $\begin{array}{l}\text { Bacharel em Artes Visuais - } \\
\text { Digitalização de Imagens }\end{array}$ & Graduação & & & \\
\hline & & $\begin{array}{l}\text { Bacharel em Artes Visuais - Gravura e } \\
\text { Arte Impressa }\end{array}$ & Graduação & & & \\
\hline & & $\begin{array}{l}\text { Bacharel em Artes Visuais - Artes do } \\
\text { Fogo }\end{array}$ & Graduação & & & \\
\hline & & Bacharel em Artes Visuais - Escultura & Graduação & & & \\
\hline & & Bacharel em Artes Visuais - Pintura & Graduação & & & \\
\hline $\begin{array}{l}\text { Universidade Argentina } \\
\text { John F. Kemnedy }\end{array}$ & $\begin{array}{l}\text { Escola de Artes e } \\
\text { Ciências do Teatro }\end{array}$ & $\begin{array}{l}\text { Bacharel em Artes e Ciências do } \\
\text { Teatro }\end{array}$ & Graduação & $\begin{array}{l}\text { Bartolomé Mitre } 1411 \\
\text { - Capital Federal }\end{array}$ & $\begin{array}{l}(0800) \\
2225366\end{array}$ & http://www.kemnedy.edu.ar/ \\
\hline \multirow[t]{2}{*}{$\begin{array}{l}\text { Universidade } \\
\text { Autónoma de Entre } \\
\text { Rios }\end{array}$} & \multirow[t]{2}{*}{$\begin{array}{l}\text { Faculdade de } \\
\text { Humanidades, Arte e } \\
\text { Ciências Sociais }\end{array}$} & Bacharel em Artes Visuais & Graduação & \multirow[t]{2}{*}{$\begin{array}{l}\text { Urquiza e Corrientes } \\
\text { - Paraná - Entre Rios }\end{array}$} & \multirow[t]{2}{*}{$\begin{array}{l}(343) \\
4312322\end{array}$} & \multirow[t]{2}{*}{ http://www.fhaycs-uader.edu.ar/ } \\
\hline & & Professor em Artes Visuais & Graduação & & & \\
\hline \multirow[t]{3}{*}{$\begin{array}{l}\text { Universidade Católica } \\
\text { de Salta }\end{array}$} & $\begin{array}{l}\text { Escola de Educação e } \\
\text { Aperfeiçoamento } \\
\text { Docente }\end{array}$ & $\begin{array}{l}\text { Bacharel em Artes Plásticas - Ciclo de } \\
\text { Licenciatura }\end{array}$ & $\begin{array}{l}\text { Ciclo de } \\
\text { Licenciatura }\end{array}$ & $\begin{array}{l}\text { Campo Castañares } \\
\text { S/N - Salta }\end{array}$ & $\begin{array}{l}(387) \\
4268557\end{array}$ & http://www.ucasal.net \\
\hline & \multirow{2}{*}{$\begin{array}{l}\text { Escola Universitária de } \\
\text { Música }\end{array}$} & Bacharel em Artes Musicais & Graduação & \multirow{2}{*}{$\begin{array}{l}\text { Campo Castañares } \\
\text { S/N - Salta }\end{array}$} & \multirow{2}{*}{$\begin{array}{l}(387) \\
4268585\end{array}$} & \multirow[t]{2}{*}{ http://www.ucasal.net } \\
\hline & & $\begin{array}{l}\text { Técnico Universitário em Artes } \\
\text { Musicais }\end{array}$ & Técnico & & & \\
\hline $\begin{array}{l}\text { Universidade Católica } \\
\text { de Santa Fe }\end{array}$ & $\begin{array}{l}\text { Faculdade de } \\
\text { Humanidades }\end{array}$ & $\begin{array}{l}\text { Bacharel em Arte e Design Multimídia - } \\
\text { Ciclo de Licenciatura }\end{array}$ & $\begin{array}{l}\text { Ciclo de } \\
\text { Licenciatura }\end{array}$ & $\begin{array}{l}\text { Eschagüe } 7151 \text { - } \\
\text { Santa Fé }\end{array}$ & $\begin{array}{l}(342) \\
4603030\end{array}$ & http://www.ucsf.edu.ar/ \\
\hline \multirow{5}{*}{$\begin{array}{l}\text { Universidade de } \\
\text { Buenos Aires }\end{array}$} & \multirow{5}{*}{$\begin{array}{l}\text { Faculdade de Filosofia e } \\
\text { Letras }\end{array}$} & Bacharel em Artes (Artes Combinadas) & Graduação & \multirow{5}{*}{$\begin{array}{l}\text { Puán } 480 \text { - Capital } \\
\text { Federal }\end{array}$} & \multirow{5}{*}{$\begin{array}{l}(11) \\
45083619\end{array}$} & \multirow[t]{5}{*}{ http://www.filo.uba.ar } \\
\hline & & Bacharel em Artes (Artes Plásticas) & Graduação & & & \\
\hline & & Bacharel em Artes (Música) & Graduação & & & \\
\hline & & $\begin{array}{l}\text { Professor de Ensino médio e superior } \\
\text { em Artes (Artes Combinadas) }\end{array}$ & Graduação & & & \\
\hline & & $\begin{array}{l}\text { Professor de Ensino médio e superior } \\
\text { em Artes (Artes Plásticas) }\end{array}$ & Graduação & & & \\
\hline
\end{tabular}




\begin{tabular}{|c|c|c|c|c|c|c|}
\hline & & $\begin{array}{l}\text { Professor de Ensino médio e superior } \\
\text { em Artes (Música) }\end{array}$ & Graduação & & & \\
\hline \multirow[t]{3}{*}{ Universidade de Cine } & \multirow[t]{3}{*}{$\begin{array}{l}\text { Faculdade de Ciências } \\
\text { da Comunicação }\end{array}$} & $\begin{array}{l}\text { Comunicador Visual, orientação Artes } \\
\text { Visuais }\end{array}$ & $\begin{array}{l}\text { Pré- } \\
\text { Graduação }\end{array}$ & \multirow[t]{3}{*}{$\begin{array}{l}\text { Pasaje J M Giuffra } \\
330 \text { - Capital Federal }\end{array}$} & \multirow[t]{3}{*}{$\begin{array}{l}(11) \\
43001413\end{array}$} & \multirow[t]{3}{*}{ http://www.ucine.edu.ar } \\
\hline & & $\begin{array}{l}\text { Bacharel em Comunicação Visual, } \\
\text { ênfase em Artes Visuais }\end{array}$ & Graduação & & & \\
\hline & & $\begin{array}{l}\text { Professor em Comunicação Visual, } \\
\text { orientação Artes Visuais }\end{array}$ & Graduação & & & \\
\hline \multirow[t]{3}{*}{$\begin{array}{l}\text { Universidade de Museu } \\
\text { Social Argentino }\end{array}$} & \multirow[t]{3}{*}{ Faculdade de Artes } & Bacharel em Artes Visuais & Graduação & \multirow[t]{4}{*}{$\begin{array}{l}\text { Sarmiento } 1565 \text { - } \\
\text { Capital Federal }\end{array}$} & \multirow[t]{3}{*}{$\begin{array}{l}(11) \\
55307692\end{array}$} & \multirow[t]{3}{*}{ http://www.umsa.edu.ar } \\
\hline & & $\begin{array}{l}\text { Bacharel em Curadoria e História das } \\
\text { Artes }\end{array}$ & Graduação & & & \\
\hline & & $\begin{array}{l}\text { Bacharel em Perito e Avaliação de } \\
\text { Obras de Arte }\end{array}$ & Graduação & & & \\
\hline \multirow[t]{6}{*}{$\begin{array}{l}\text { Universidade de } \\
\text { Salvador }\end{array}$} & $\begin{array}{l}\text { Complexo Educativo } \\
\text { Nuestra Señora del Pilar }\end{array}$ & \multirow[t]{2}{*}{ Bacharel em Artes do Teatro } & Graduação & & $\begin{array}{l}(2322) \\
431260\end{array}$ & http://www.salvador.edu.ar \\
\hline & $\begin{array}{l}\text { Escola de Arte e } \\
\text { Arquitetura }\end{array}$ & & Graduação & $\begin{array}{l}\text { Junin } 1113 \text { - Capital } \\
\text { Federal }\end{array}$ & $\begin{array}{l}(11) \\
48234800\end{array}$ & http://www.salvador.edu.ar \\
\hline & Escola de Design & Bacharel em Arte e Design Digital & Graduação & $\begin{array}{l}\text { Marcelo T. de Alvear } \\
\text { 1335/7 - Capital } \\
\text { Federal }\end{array}$ & $\begin{array}{l}(11) \\
48111279\end{array}$ & http://www.usal.edu.ar \\
\hline & \multirow[t]{2}{*}{$\begin{array}{l}\text { Faculdade de Historia, } \\
\text { Geografia e Turismo }\end{array}$} & $\begin{array}{l}\text { Bacharel Superior em História das } \\
\text { Artes }\end{array}$ & Técnico & \multirow[t]{2}{*}{$\begin{array}{l}\text { Viamonte } 2213 \text { - } \\
\text { Capital Federal }\end{array}$} & $\begin{array}{l}(11) \\
49520591\end{array}$ & \multirow[t]{3}{*}{ http://www.salvador.edu.ar } \\
\hline & & $\begin{array}{l}\text { Bacharel em Gestão e História das } \\
\text { Artes }\end{array}$ & Graduação & & $\begin{array}{l}(11) \\
49520591\end{array}$ & \\
\hline & $\begin{array}{l}\text { Faculdade de Psicologia } \\
\text { e Psicopedagogia }\end{array}$ & Bacharel em Arte Dramático & Graduação & $\begin{array}{l}\text { Marcelo T. de Alvear } \\
1314 \text { - Capital } \\
\text { Federal }\end{array}$ & $\begin{array}{l}(11) \\
48133404\end{array}$ & \\
\hline \multirow[t]{3}{*}{ Universidade de Morón } & \multirow{3}{*}{$\begin{array}{l}\text { Faculdade de } \\
\text { Arquitetura, Design, Arte } \\
\text { e Urbanismo }\end{array}$} & Intérprete de Artes Dramáticas & $\begin{array}{l}\text { Pré- } \\
\text { Graduação }\end{array}$ & \multirow[t]{3}{*}{$\begin{array}{l}\text { Cabildo } 134 \text { - Moron - } \\
\text { Buenos Aires }\end{array}$} & \multirow[t]{3}{*}{$\begin{array}{l}(11) \\
56272000\end{array}$} & \multirow[t]{3}{*}{ http://www.unimoron.edu.ar } \\
\hline & & Bacharel em Artes Dramáticas & Graduação & & & \\
\hline & & Bacharel em Artes Visuais & Graduação & & & \\
\hline
\end{tabular}




\begin{tabular}{|c|c|c|c|c|c|c|}
\hline \multirow[t]{2}{*}{ Palermo } & Sociais & & & \multirow[t]{2}{*}{ Capital Federal } & \multirow[t]{2}{*}{51994500} & \\
\hline & $\begin{array}{l}\text { Faculdade de Design e } \\
\text { Comunicação }\end{array}$ & Bacharel em Direção de Arte & Graduação & & & \\
\hline \multirow{2}{*}{$\begin{array}{l}\text { Universidade } \\
\text { Maimônides }\end{array}$} & \multirow{2}{*}{$\begin{array}{l}\text { Faculdade de } \\
\text { Humanidades, Ciências } \\
\text { Sociais e Empresariais }\end{array}$} & Bacharel em Artes Musicais & Graduação & \multirow{2}{*}{$\begin{array}{l}\text { Hidalgo } 775 \text { - Capital } \\
\text { Federal }\end{array}$} & \multirow{2}{*}{$\begin{array}{l}(11) \\
49051100\end{array}$} & \multirow[t]{2}{*}{ http://www.maimonides.edu } \\
\hline & & $\begin{array}{l}\text { Professor em Arte com ênfase em } \\
\text { Linguagem Musical }\end{array}$ & Graduação & & & \\
\hline $\begin{array}{l}\text { Universidade Nacional } \\
\text { de Avellaneda }\end{array}$ & $\begin{array}{l}\text { Departamento de Cultura } \\
\text { e Arte }\end{array}$ & Bacharel em Artes Audiovisuais & Graduação & $\begin{array}{l}\text { Espanha } 350 \text { - } \\
\text { Avellaneda - Buenos } \\
\text { Aires }\end{array}$ & $\begin{array}{l}(11) \\
42229640\end{array}$ & http://www.undav.edu.ar \\
\hline \multirow{4}{*}{$\begin{array}{l}\text { Universidade Nacional } \\
\text { de Córdoba }\end{array}$} & \multirow[t]{4}{*}{ Faculdade de Artes } & Bacharel em Artes Visuais & Graduação & \multirow{4}{*}{$\begin{array}{l}\text { Pabellón México, } \\
\text { Cidade Universitária - } \\
\text { Córdoba }\end{array}$} & \multirow{4}{*}{$\begin{array}{l}(351) \\
4334195\end{array}$} & \multirow[t]{4}{*}{ http://www.artes.unc.edu.ar } \\
\hline & & $\begin{array}{l}\text { Professor Superior de Educação em } \\
\text { Artes Plásticas: Escultura }\end{array}$ & Graduação & & & \\
\hline & & $\begin{array}{l}\text { Professor Superior de Educação em } \\
\text { Artes Plásticas: Gravura }\end{array}$ & Graduação & & & \\
\hline & & $\begin{array}{l}\text { Professor Superior de Educação em } \\
\text { Artes Plásticas: Pintura }\end{array}$ & Graduação & & & \\
\hline \multirow{5}{*}{$\begin{array}{l}\text { Universidade Nacional } \\
\text { de Cuyo }\end{array}$} & \multirow{5}{*}{$\begin{array}{l}\text { Faculdade de Artes e } \\
\text { Design }\end{array}$} & Bacharel em Arte Dramático & Graduação & \multirow{5}{*}{$\begin{array}{l}\text { Centro Univ. - Parque } \\
\text { Gral. San Martín - } \\
\text { Mendoza }\end{array}$} & \multirow{5}{*}{$\begin{array}{l}(261) \\
4494004\end{array}$} & \multirow[t]{5}{*}{ http://www.fad.uncu.edu.ar } \\
\hline & & Bacharel em Artes Plásticas & Graduação & & & \\
\hline & & $\begin{array}{l}\text { Bacharel em História das Artes } \\
\text { Plásticas }\end{array}$ & Graduação & & & \\
\hline & & $\begin{array}{l}\text { Professor de Graduação Universitário } \\
\text { de Historia de Arte }\end{array}$ & Graduação & & & \\
\hline & & $\begin{array}{l}\text { Professor de Graduação Universitário } \\
\text { em Artes Visuais }\end{array}$ & Graduação & & & \\
\hline \multirow{2}{*}{$\begin{array}{l}\text { Universidad Nacional } \\
\text { de General San Martín }\end{array}$} & Artes & Bacharel em Artes Cênicas & Graduação & \multirow{2}{*}{$\begin{array}{l}25 \text { de Maio e Francia } \\
\text { - Barrio Gral. San } \\
\text { Martin - Buenos Aires }\end{array}$} & \multirow{2}{*}{$\begin{array}{l}(11) \\
40061500\end{array}$} & \multirow[t]{2}{*}{ http://www.unsam.edu.ar } \\
\hline & $\begin{array}{l}\text { Escola de Humanidades } \\
\text { - Centro }\end{array}$ & $\begin{array}{l}\text { Bacharel em Ensino das Artes } \\
\text { Audiovisuais - Ciclo de Licenciatura }\end{array}$ & $\begin{array}{l}\text { Ciclo de } \\
\text { Licenciatura }\end{array}$ & & & \\
\hline $\begin{array}{l}\text { Universidade Nacional } \\
\text { de Lanús }\end{array}$ & $\begin{array}{l}\text { Departamento de } \\
\text { Humanidades e Artes }\end{array}$ & $\begin{array}{l}\text { Bacharel em Ensino das Artes } \\
\text { Combinadas - Ciclo de Licenciatura }\end{array}$ & $\begin{array}{l}\text { Ciclo de } \\
\text { Licenciatura }\end{array}$ & $\begin{array}{l}29 \text { de Setembro } 3901 \\
\text { - Remédios de } \\
\text { Escalada - Buenos } \\
\text { Aires }\end{array}$ & $\begin{array}{l}(11) \\
55336000\end{array}$ & http://www.unla.edu.ar \\
\hline \multirow[t]{3}{*}{$\begin{array}{l}\text { Universidad Nacional } \\
\text { de La Plata }\end{array}$} & \multirow[t]{3}{*}{$\begin{array}{l}\text { Faculdade de Belas } \\
\text { Artes }\end{array}$} & $\begin{array}{l}\text { Bacharel em Artes Audiovisuais - } \\
\text { Orientação em Direção Fotográfica }\end{array}$ & Graduação & \multirow[t]{3}{*}{$\begin{array}{l}7 \text { e } 60 \text { - La Plata - } \\
\text { Buenos Aires }\end{array}$} & \multirow[t]{3}{*}{$\begin{array}{l}(221) \\
4235754\end{array}$} & \multirow[t]{3}{*}{ http://www.fba.unlp.edu.ar } \\
\hline & & $\begin{array}{l}\text { Bacharel em Artes Audiovisuais - } \\
\text { Orientação em Roteiro }\end{array}$ & Graduação & & & \\
\hline & & $\begin{array}{l}\text { Bacharel em Artes Audiovisuais - } \\
\text { Orientação em Realização / Produção }\end{array}$ & Graduação & & & \\
\hline
\end{tabular}




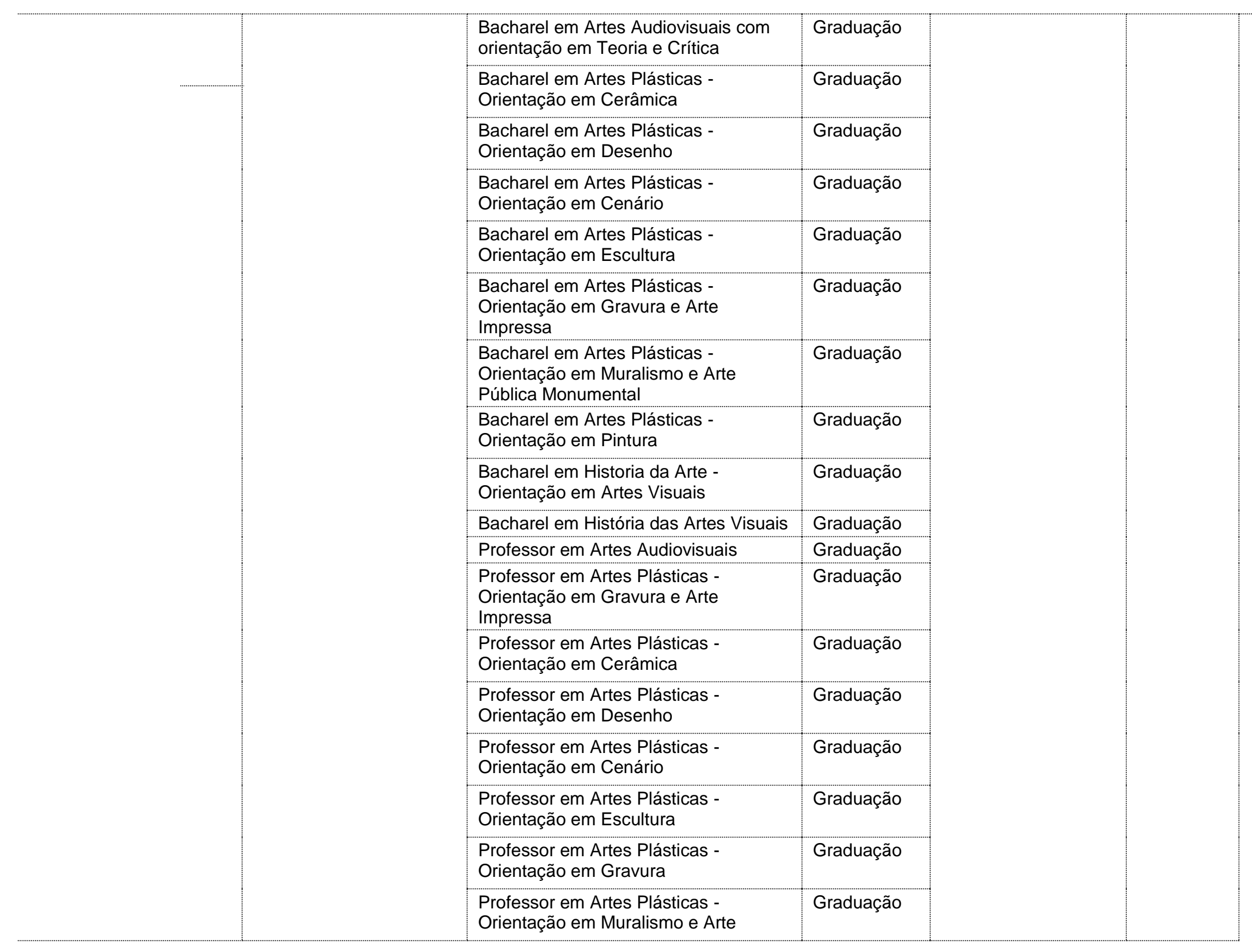




\begin{tabular}{|c|c|c|c|c|c|c|}
\hline & & Pública Monumental & & & & \\
\hline & & Professor em Artes Plásticas - Pintura & Graduação & & & \\
\hline & & $\begin{array}{l}\text { Professor em Historia da Arte - Artes } \\
\text { Visuais }\end{array}$ & Graduação & & & \\
\hline \multirow{3}{*}{$\begin{array}{l}\text { Universidad Nacional } \\
\text { de La Rioja }\end{array}$} & \multirow[t]{3}{*}{ Sede La Rioja } & Bacharel em Arte - Cenário & Graduação & \multirow{3}{*}{$\begin{array}{l}\text { Av. Luis M. de la } \\
\text { Fuente S/N - La Rioja } \\
\text { - La Rioja }\end{array}$} & \multirow{3}{*}{$\begin{array}{l}(3822) \\
457000\end{array}$} & \multirow[t]{3}{*}{$\underline{\text { http://www.unlar.edu.ar }}$} \\
\hline & & Bacharel em Artes Plásticas & Graduação & & & \\
\hline & & Professor em Artes Plásticas & Graduação & & & \\
\hline $\begin{array}{l}\text { Universidade Nacional } \\
\text { de Nordeste }\end{array}$ & $\begin{array}{l}\text { Faculdade de Artes, } \\
\text { Design e Ciências da } \\
\text { Cultura }\end{array}$ & Bacharel em Artes Combinadas & Graduação & $\begin{array}{l}\text { Juan B. Justo } 354 \text { - } \\
\text { Corrientes }\end{array}$ & $\begin{array}{l}(3722) \\
445527\end{array}$ & http://www.artes.unne.edu.ar/ \\
\hline \multirow{4}{*}{$\begin{array}{l}\text { Universidade Nacional } \\
\text { de Misiones }\end{array}$} & \multirow[t]{2}{*}{ Faculdade de Artes } & Bacharel em Artes Plásticas & Graduação & \multirow{4}{*}{$\begin{array}{l}\text { Carhué } 832 \text { - } \\
\text { Posadas - Misiones }\end{array}$} & \multirow{4}{*}{$\begin{array}{l}(3755) \\
401150\end{array}$} & \multirow[t]{2}{*}{ http://www.artes.unam.edu.ar/ } \\
\hline & & Professor em Artes Plásticas & Graduação & & & \\
\hline & \multirow{2}{*}{$\begin{array}{l}\text { Faculdade de Arte e } \\
\text { Design }\end{array}$} & Bacharel em Artes Plásticas & Graduação & & & \multirow[t]{2}{*}{ http://www.unam.edu.ar/ } \\
\hline & & Professor em Artes Plásticas & Graduação & & & \\
\hline \multirow[t]{2}{*}{$\begin{array}{l}\text { Universidade Nacional } \\
\text { de Rio Negro }\end{array}$} & $\begin{array}{l}\text { Unidade Académica Alto } \\
\text { Valle }\end{array}$ & Bacharel em Artes Visuais & Graduação & $\begin{array}{l}\text { Villa Regina - Rio } \\
\text { Negro }\end{array}$ & $\begin{array}{l}(2920) \\
428970\end{array}$ & \multirow[t]{2}{*}{ http://www.unrn.edu.ar } \\
\hline & $\begin{array}{l}\text { Unidade Académica } \\
\text { Sede Andina }\end{array}$ & Bacharel em Arte Dramático & Graduação & $\begin{array}{l}\text { Villegas } 147 \text { - San } \\
\text { Carlos De Bariloche - } \\
\text { Rio Negro }\end{array}$ & $\begin{array}{l}(2944) \\
431988\end{array}$ & \\
\hline \multirow{3}{*}{$\begin{array}{l}\text { Universidade Nacional } \\
\text { de Rosário }\end{array}$} & \multirow{3}{*}{$\begin{array}{l}\text { Faculdade de } \\
\text { Humanidades e Artes }\end{array}$} & Auxiliar de Oficina em Belas Artes & Técnico & \multirow{3}{*}{$\begin{array}{l}\text { Entre Rios } 758 \text { - } \\
\text { Rosário - Santa Fé }\end{array}$} & \multirow{3}{*}{$\begin{array}{l}(341) \\
4802673\end{array}$} & \multirow[t]{3}{*}{ http://www.fhumyar.unr.edu.ar } \\
\hline & & Bacharel em Belas Artes & Graduação & & & \\
\hline & & Professor em Belas Artes & Graduação & & & \\
\hline \multirow{2}{*}{$\begin{array}{l}\text { Universidad Nacional } \\
\text { de San Juan }\end{array}$} & \multirow{2}{*}{$\begin{array}{l}\text { Faculdade de Filosofia, } \\
\text { Humanidades e Artes }\end{array}$} & Bacharel em Artes Visuais & Graduação & \multirow{2}{*}{$\begin{array}{l}\text { Av. José I. de la Roza } \\
\text { (Oeste) } 230 \text { - San } \\
\text { Juan }\end{array}$} & \multirow{2}{*}{$\begin{array}{l}(264) \\
4214586\end{array}$} & \multirow[t]{2}{*}{ http://www.unsj.edu.ar/ } \\
\hline & & Professor de Artes Visuais & Graduação & & & \\
\hline \multirow[t]{4}{*}{$\begin{array}{l}\text { Universidade Nacional } \\
\text { de Três de Fevereiro }\end{array}$} & \multirow[t]{4}{*}{ Secretaria Acadêmica } & Interprete em Artes de Circo & $\begin{array}{l}\text { Pré- } \\
\text { Graduação }\end{array}$ & \multirow{4}{*}{$\begin{array}{l}\text { Valemtín Gómez } \\
4828 / 38 \text { - } 3 \text { De } \\
\text { Febrero - Buenos } \\
\text { Aires }\end{array}$} & \multirow[t]{4}{*}{$\begin{array}{l}(11) \\
45755012\end{array}$} & \multirow[t]{4}{*}{ http://www.untref.edu.ar/ } \\
\hline & & Bacharel em Artes Electrónicas & Graduação & & & \\
\hline & & $\begin{array}{l}\text { Bacharel em Gestão de Arte e da } \\
\text { Cultura }\end{array}$ & Graduação & & & \\
\hline & & $\begin{array}{l}\text { Técnico em Gestão de Arte e da } \\
\text { Cultura }\end{array}$ & Técnico & & & \\
\hline \multirow{2}{*}{$\begin{array}{l}\text { Universidade Nacional } \\
\text { de Tucumán }\end{array}$} & \multirow[t]{2}{*}{ Faculdade de Artes } & Bacharel em Artes Plásticas & Graduação & \multirow{2}{*}{$\begin{array}{l}\text { Bolívar } 700 \text { - San } \\
\text { Miguel De Tucumán - } \\
\text { Tucumán }\end{array}$} & \multirow{2}{*}{$\begin{array}{l}(381) \\
4244394\end{array}$} & \multirow[t]{2}{*}{$\underline{\text { http://www.unt.edu.ar/fartes }}$} \\
\hline & & $\begin{array}{l}\text { Bacharel em Artes Plásticas } \\
\text { (Especialidade: Escultura) }\end{array}$ & Graduação & & & \\
\hline
\end{tabular}




\begin{tabular}{|c|c|c|c|c|c|}
\hline & $\begin{array}{l}\text { Bacharel em Artes Plásticas } \\
\text { (Especialidade: Gravura) }\end{array}$ & Graduação & & & \\
\hline & $\begin{array}{l}\text { Bacharel em Artes Plásticas } \\
\text { (Especialidade: Pintura) }\end{array}$ & Graduação & & & \\
\hline $\begin{array}{l}\text { Instituto Universitário } \\
\text { Multidisciplinar de } \\
\text { Aguilares (Artes) }\end{array}$ & Bacharel em Artes Plásticas & Graduação & $\begin{array}{l}\text { General Savio S/N - } \\
\text { Aguilares - Tucumán }\end{array}$ & $\begin{array}{l}(381) \\
4244394\end{array}$ & http://www.herrera.unt.edu.ar/facet \\
\hline
\end{tabular}




\title{
1.3 Políticas de Formação Docente
}

A Educação é uma garantia constitucional no Brasil e as políticas públicas devem ser direcionadas para que esse direito constitucional seja garantido a todos. Mas o que são políticas públicas? Políticas públicas são um

\begin{abstract}
campo do conhecimento que busca ao mesmo tempo, colocar o "governo em ação" e/ou analisar essa ação (variável independente) e, quando necessário, propor mudanças no rumo ou curso dessas ações (variável dependente). A formulação de políticas públicas constitui-se no estágio em que governos democráticos traduzem seus propósitos e plataformas eleitorais em programas e ações, que produzirão resultados e mudanças no mundo real. (SOUZA 2003, 2006, p.69).
\end{abstract}

A autora nos esclarece que a essência do conceito de Políticas Públicas é que elas existem para melhorias das condições de vida das pessoas. Políticas públicas de Educação são, então, as ações concretas dos governos que promovam, de fato, melhorias na Educação.

Art. 6o. Da Constituição Federal de 1988, diz que "são direitos sociais a Educação, a saúde, a alimentação, o trabalho, a moradia, o lazer, a segurança, a previdência social, a proteção à maternidade e à infância, a assistência aos desamparados, na forma desta Constituição" (BRASIL(12), 2012. Redação dada pela Emenda Constitucional № 64, de 2010).

No Brasil, as reformas para a formação do professor, iniciadas na década de 1990, não estão isoladas do contexto internacional e se originam nas Conferências Mundiais da Educação realizadas em Jontiem (1990) e Dakar (2000), entre outras indicações expressas em documentos expedidos pelos organismos internacionais como o Banco Mundial (BM), a Organização das Nações Unidas para a Educação, Ciência e Cultura (UNESCO), a Organização de Cooperação e Desenvolvimento Econômico (OCDE) e a Comissão Econômica para América Latina (CEPAL) (SARDELICH, p. 65).

Assim, em 30 de Janeiro de 2009, o então presidente da república, assinou decreto $^{16}$ que institui a Política Nacional de Formação de Professores no Brasil, que foi publicado no Diário Oficial da União nesse mesmo dia, e cuja finalidade foi

\footnotetext{
${ }^{16}$ Decreto n. 6.755, de 29 de janeiro de 2009, publicado no Diário Oficial da União em 30 de janeiro de 2009.
} 
a de "organizar a formação inicial e continuada dos profissionais do magistério para a Educação básica, em regime de colaboração entre a União, os estados, o Distrito Federal e os municípios" (BRASIL(13), 2009).

\begin{abstract}
Para melhor compreender as atuais discussões a respeito da formação de professores e as recentes políticas regulamentadoras dessa atividade, é importante lembrar o contexto mais amplo em que a LDB foi aprovada. $\mathrm{Na}$ época, particularmente na América Latina, respirava-se uma atmosfera hegemônica de políticas neoliberais, de interesse do capital financeiro, impostas por intermédio de agencias como Banco Mundial e Fundo Monetário Internacional (FMI), que procuravam promover a reforma do estado, minimizando seu papel, e favorecer o predomínio de regras do mercado em todos os setores da sociedade, incluindo as atividades educacionais (PEREIRA, 1999, p. 110-111).
\end{abstract}

Com o objetivo de alterar essa realidade, o MEC, tendo como suporte o Plano Nacional de Educação - PNE, vem realizando um sistema de formação de professores da rede pública visando

a) sólida formação teórica nos conteúdos específicos a serem ensinados na Educação Básica, bem como nos conteúdos especificamente pedagógicos;

b) ampla formação cultural;

c) atividade docente como foco formativo;

d) contato com a realidade escolar desde o início até o final do curso, integrando a teoria à prática pedagógica;

e) pesquisa como princípio formativo;

f) domínio das novas tecnologias de comunicação e da informação e capacidade para integrá-las à prática do magistério;

g) análise dos temas atuais da sociedade, da cultura e da economia;

h) inclusão das questões relativas à Educação dos alunos com necessidades especiais e das questões de gênero e de etnia nos programas de formação;

i) trabalho coletivo interdisciplinar;

j) vivência, durante o curso, de formas de gestão democrática do Ensino;

k) desenvolvimento do compromisso social e político do magistério; e

l) conhecimento e aplicação das diretrizes curriculares nacionais dos níveis e modalidades da Educação básica (BRASIL(14), 2001).

O Plano Nacional e Educação 2001-2010, de acordo com Didonet (2005), entra na história da Educação brasileira com seis qualificações que o distinguem de todos os outros já elaborados:

1) é o primeiro plano submetido à aprovação do Congresso Nacional; portanto, tem força de lei;

2) cumpre um mandato constitucional (art. 214 da Constituição Federal de 1988) e uma determinação da Lei de Diretrizes e Bases da Educação Nacional (LDB, art. 87, $1^{\circ}$ ); 
3) fixa diretrizes, objetivos e metas para um período de 10 anos, o que garante continuidade da política educacional e coerência nas prioridades durante uma década;

4) contempla todos os níveis e modalidades de Educação e os âmbitos da produção de aprendizagens, da gestão e do financiamento e da avaliação;

5) envolve o Poder Legislativo no acompanhamento de sua execução; e

6) chama a sociedade para acompanhar e controlar a sua execução (DIDONET, 2005).

Em relação à EaD o PNE estabeleceu objetivos e metas importantes a serem implementados ao longo de dez anos como, por exemplo,

ampliar, gradualmente, a oferta de formação a distância em nível superior para todas as áreas, incentivando a participação das universidades e das demais instituições de Educação superior credenciadas" e "equipar, em dez anos, todas as escolas de nível médio e todas as escolas de Ensino fundamental com mais de cem alunos, com computadores e conexões internet que possibilitem a instalação de uma Rede Nacional de Informática na Educação e desenvolver programas educativos apropriados, especialmente a produção de softwares educativos de qualidade (PNE, 2001).

\section{Diversas pesquisas mostram que o déficit de professores formados no Brasil é} imenso, havendo grande necessidade de investimentos nessa área para atender as necessidades e, assim,

O pressuposto de que Investir na formação do professor e na sua atualização pode ser um fator determinante na melhoria da qualidade da Educação, tem incentivado o governo brasileiro a investir nessa área com maior intensidade nos últimos anos. Milhares de docentes atuam na rede pública sem atender a exigência de formação prevista na Lei de Diretrizes e Bases da Educação Nacional de 1996 (MELO \& LUZ, 2005, p. 40).

\section{Maria Emília Sardelich (2012, p. 63) corrobora essas ideias ao destacar que}

Desde finais do século $X X$, tanto no cenário internacional, como no brasileiro, a discussão em torno da formação dos professores se configura como o desafio mais urgente dos sistemas de Ensino. $\mathrm{Na}$ análise de Pérez-Gomez (2010), as Universidades e centros de formação de professores encontram-se, ainda, muito distantes do que se supõe, da formação de docentes competentes para a tarefa que demanda a Educação do século XXI. No Brasil, as reformas para a formação do professor, iniciadas na década de 1990, não estão isoladas do contexto internacional. Essas reformas vêm se materializando por meio de atos normativos: Leis, Decretos, Resoluções, Pareceres (SARDELICH, 2012, p. 63).

Ou seja, para bem além da ideia de uma "bondade" ou "generosidade" de governo e governantes, a formação de professores é uma necessidade para atendimento 
de expectativas políticas de um governo em sintonia com políticas internacionais às quais o Brasil adere e atende, em intencionalidade, por questões diversas, não só educacionais.

\begin{abstract}
A Educação brasileira passou por uma profunda transformação entre 2002 e 2010. A universalização dos primeiros anos do Ensino fundamental foi consolidada. Criou-se a Rede Federal de Educação Profissional e Tecnológica ofertando Ensino médio para milhares de jovens. O governo federal apresentou a firme disposição de expandir as redes municipais de Educação infantil. $O$ atendimento especial e a Educação de jovens e adultos foram impulsionados por ações concretas em particular de apoio do governo federal (PICONEZ, 2014).
\end{abstract}

A Lei № 11.502, de julho de 2007, atribui à Coordenação de Aperfeiçoamento de Pessoal de Nível Superior (CAPES) a responsabilidade pela formação de professores da Educação básica - uma prioridade do Ministério da Educação. O objetivo é assegurar a qualidade da formação dos professores que atuarão ou que já estejam em exercício nas escolas públicas, além de integrar a Educação básica e superior visando à qualidade do Ensino público. A Política Nacional de Formação de Professores tem como objetivo expandir a oferta e melhorar a qualidade nos cursos de formação dos docentes (BRASIL(1), 2012). Nesse sentido, os convênios entre IES (Instituições de Ensino Superior) em parceria com o Programa UAB (Universidade Aberta do Brasil), têm apontado caminhos para a busca de uma Educação pública de qualidade e em afinidade com a permanente necessidade de expansão da Educação no Brasil. Nesse cenário, a EaD apresenta-se como uma modalidade importante no desenvolvimento e qualificação da Educação superior brasileira, podendo ser considerada como uma das alternativas para se atender às diferentes necessidades de formação superior, sendo que em alguns casos, constitui, senão a única, a mais rápida forma de satisfação dessas necessidades. Porém, concordo com Sardelich (2012, p. 79) quando afirma que "o problema da formação de professores para a Educação Básica é estrutural e não emergencial e as medidas emergências tomadas em programas de formação especial e privatização aprofundam 'sua desprofissionalização pela flexibilização e aligeiramento da formação" (FREITAS, 2007, p. 1207, apud SARDELICH, 2012, p. 79), ou, como diz Maria Cristina Rosa, a proletarização da atuação docente (SILVA, 2010). 


\title{
1.40 papel do professor na formação docente com uso de Tecnologias Digitais de Comunicação e Informação
}

As tecnologias digitais de comunicação e informação fazem parte da vida contemporânea em muitos aspectos. Na Educação não é diferente. Ivanildo Amaro de Araújo (2010, p. 01) diz que

\begin{abstract}
No contexto das velozes alterações tecnológicas no qual nos encontramos neste século XXI, algumas exigências se impõem e atingem diretamente mudanças na formação de professores. No espaço da universidade, essa formação deve se sustentar numa sólida formação teórica articulada com as capacidades de intervir de modo crítico na realidade cotidiana dos espaços formativos. A escola é um desses espaços. É fundamental que receios, medos, temores das tecnologias da informação e da comunicação possam ser dirimidos no sentido de tornar o professor um profissional capaz de avançar na construção dos conhecimentos de forma criativa, crítica e autônoma (ARAÚJO, 2010, p. 01).
\end{abstract}

Márcio Roberto de Lima e Murilo Cruz Leal (2010, p. 01) afirmam que "o uso do computador na Educação tem sido majoritariamente associado à perspectiva da pedagogia da transmissão" questionando se "o que vem sendo praticado na modalidade de Educação on-line difere do que, tradicionalmente, é efetivado na sala presencial". A questão da transmissão de conhecimentos não é nova. Paulo Freire já a questionava quando afirmava que

ensinar não é a simples transmissão do conhecimento em torno do objeto ou do conteúdo. Transmissão que se faz muito mais através da pura descrição do conceito do objeto a ser mecanicamente memorizado pelos alunos (FREIRE, 1982, p. 42).

Porém Silva (2008, p. 69) constata a replicação do modelo transmissivo na EaD/Educação on-line, afirmando que

em grande parte dos cursos via Internet prevalece o modelo comunicacional centrado na transmissão de informações. Os ambientes "virtuais" de aprendizagem continuam estáticos, ainda centrados na distribuição de dados desprovidos de mecanismos de interatividade, de criação colaborativa e de aprendizagem construída. Muito já se questionou a prática pedagógica baseada na transmissão para memorização e repetição, mas pouco se fez para modificá-la efetivamente (SILVA, 2008, p. 69). 
Assim, equacionar a escolha e uso das particularidades e potencialidades das Tecnologias Digitais de Comunicação e Informação na aprendizagem e na construção de instrumentos e estratégias de acompanhamento e avaliação adequadas aos novos contextos é tarefa que se mostra particular e nada simples, ou que possa somente ser atendida com produção teórica sobre o tema, mas requer, também, análise e amadurecimento das experiências concretas deste modelo.

Demo ((1), 1998) já nos mostrou que:

\begin{abstract}
Se queremos realmente oferecer oportunidades de aprendizagem, com possível certificação e relação mais clara entre estudar e continuar empregado ou reencontrar novo trabalho, é mister trabalhar em outra direção, já que programações abertas são apenas insumo informativo; ainda que se possa elaborar material de excelente qualidade, não passa de "material didático" [...] e, ainda, o processo de aprendizagem não se coaduna com eventos muito rápidos, ainda que envolventes, porque o desafio reconstrutivo exige pesquisa e elaboração própria (DEMO (1), 1998).
\end{abstract}

Para Fernando Almeida (2001, apud ALMEIDA, 2003) "participar de um ambiente digital se aproxima do estar junto virtual' (PRADO e VALENTE, 2002). Atuar nesses ambientes significa

expressar pensamentos, tomar decisões, dialogar, trocar informações e experiências e produzir conhecimento. As interações por meio dos recursos disponíveis no ambiente propiciam as trocas individuais e a constituição de grupos colaborativos que interagem, discutem problemáticas e temas de interesses comuns, pesquisam e criam produtos ao mesmo tempo em que se desenvolvem (ALMEIDA, 2003).

Desse modo, os ambientes digitais de aprendizagem podem possibilitar a formação de redes de aprendizagem colaborativa (peers), que são formadas pela união dos participantes em comunidades virtuais de prática (SAMPAIO-RALHA, 2007), incorporando as suas várias formas de interação no processo de Ensinoaprendizagem e que empregam as Computer Mediated Communications (CMC) para aprender em conjunto, por meio da interação, comunicação multidimensional e produção colaborativa (BARANAUSKAS, ROCHA, MARTINS E D'ABREU, 1999). 
Sims (1997), ao apresentar as propostas e exemplos de uma série de conceitos que podem ser utilizados na avaliação de material multimídia para Educação nos diz que é possível perceber os diversos tipos e possibilidades de interatividade.

Interatividade de objetos: botões, pessoas, coisas, que, quando clicados, oferecem algum tipo de resposta audiovisual;

Interatividade linear: a possibilidade de o usuário mudar (para frente ou para trás) páginas digitais ou outras sequências no material instrucional; Interatividade de suporte: de simples mensagens de ajuda a complexos tutoriais;

Interatividade de atualização: envolve um diálogo entre o aprendiz e o conteúdo gerado pelo computador, em que as respostas do aprendiz a problemas são levadas em consideração pelo programa de produzir atualizações ou feedbacks individualizados;

Interatividade de construção: extensão da anterior, em que o aprendiz é solicitado a manipular objetos para atingir objetivos específicos;

Interatividade refletida: em lugar de simples mensagens de "certo" e "errado", respostas de outras pessoas (incluindo textos, especialistas e outros usuários) são mostradas para que o aprendiz possa refletir sobre a precisão e correção da sua;

Interatividade de simulação: ligada à interatividade de construção, em que o usuário pode escolher parâmetros para simular um objeto ou situação, funcionando como um controlador ou operador, em suas seleções individuais determinam a sequência do material;

Interatividade de hiperlinks: em que o usuário pode navegar por uma diversidade de informações, através de links sugeridos;

Interatividade contextual não imersiva: reúne os níveis anteriores em um ambiente virtual bastante rico, que imita o mundo real e no qual o aprendiz tem um papel ativo;

Interatividade virtual imersiva: características dos mundos virtuais (SIMS 1997, apud MATTAR, 2012, p. 28-30).

E também a variação dos graus de interatividade...

Grau zero: livros, rádio e televisão, que permitem leituras lineares, com opção apenas de interatividade de acesso, ou não lineares;

Linear: mídias que permitem avanços e retrocessos no percurso do conteúdo;

Arborescente: menus;

Linguística: acessos por palavras-chave, formulários etc.;

Criação: o usuário pode compor mensagens;

Comendo contínuo: usuário pode modificar os objetos (KRETS, apud SILVA, 2006, p. 86-87).

Isso envolve, ainda segundo Sims (2006, p. 5), uma redefinição dos modelos correntes de design instrucional e desenvolvimento, centrando o foco no aprendiz.

Em geral, enxergamos os papéis associados com design centrados em conteúdo ou instituições - designers instrucionais, administradores de projetos, artistas gráficos e especialistas em redes. Mas onde estão os 
designers para aprendizado ou os arquitetos da interação? Onde estão os especialistas em ambientes colaborativos? Operamos num contexto colaborativo centrado no aprendiz, mas nossos modelos de design são ainda baseados em paradigmas presenciais e centrados no professor. Se desejamos o potencial e os benefícios plenos que um ambiente online permite, precisamos repensar as filosofias e as práticas que trazemos para o ambiente de design (SIMS, 2006 apud MATTAR, 2012, p. 31).

O impacto social do uso dos ambientes digitais interativos de aprendizagem, onde cada pessoa busca as informações que lhe são mais pertinentes, internaliza e se apropria delas, transformando essas informações em uma nova representação, é percebido quando, ao mesmo tempo em que isso transforma a pessoa, na retroalimentação a volta da ação ao grupo transforma o indivíduo e transforma o grupo.

O entendimento efetivo dessa abordagem descortina as possíveis práticas de professores e alunos nesse processo. O que muda na relação do professor com o processo do ensinar e do aprender? "Ensinar" e "aprender", nos ambientes digitais interativos de aprendizagem, têm uma amplitude bastante diferente. Não se afirma que melhores ou piores, mas, justamente, diferentes. Essa diferença pode ser assimilada na elaboração de propostas que venham a se desenrolar nesse suporte. É necessário e urgente compreender como as interações virtuais ajudam a atingir os objetivos de aprendizagem de um curso.

A atuação em Educação à distância on-line, com suporte de tecnologias digitais e interativas, pelo uso efetivo de peering ${ }^{17}$ para o Ensino/aprendizagem necessita da preparação de profissionais capazes de desenvolver e utilizar as possibilidades dos recursos tecnológicos em sintonia com as necessidades educacionais. E como poderiam ser preparados esses profissionais?

No Capítulos 2 trato com mais detalhamento os Modelos Pedagógicos usados na EaD, por hora é importante frisar que para atuar na "nova" formação é necessário

\footnotetext{
17 O termo "peering" foi criado pelo professor de Yale, Yochai Benkler, num artigo do Yale Law Journal, V. 12, 2002-2003 e é usado como síntese do conceito de colaboração de massa de forma intercambiável. Na sua forma mais pura, é uma maneira de produzir bens e serviços que depende totalmente de comunidades auto-organizadas e igualitárias de indivíduos que se unem voluntariamente para produzir um resultado compartilhado (TAPSCOT, 2006).
} 
integrar conhecimentos intra, inter e transdisciplinares de Educação, design, comunicação, programação e desenvolvimento de ambientes. E esse trabalho geralmente tende a ter melhores resultados quando desenvolvido em equipe, pois, por sua complexidade, necessita da convivência harmônica e colaborativa de competências de criação, desenvolvimento e uso de tecnologias digitais, habilidades específicas, ainda difíceis de serem encontradas em uma pessoa individualmente.

João Mattar nos alerta para o fato que

Cursos a distância expositivos e sem interação podem ser batizados [...], de $\mathrm{EBaD}^{18}$. Entretanto, [...], interação em EaD não é sinônimo apenas de interação professor/aluno. Há diversos tipos de interação (por exemplo, aluno/aluno) e interatividade, assim como diversas tecnologias podem ser utilizadas, que não envolvem necessariamente custos elevados. Cada mídia tem características interativas próprias e custos específicos, o que deve ser levado em consideração no planejamento da interação em cursos de EaD. Pode-se então pensar em algo como uma multiinteração, no sentido de que várias podem ser as interações simultâneas em um curso de EaD. Interatividade (no sentido mais restrito ou reativo) e interação (no sentido mais amplo e social) podem ser combinadas com sucesso em EaD (MATTAR, 2012, p. 49-50).

É certo acreditar que, dentro desse cenário, o papel do professor sofre alterações. Quais são elas?

De disseminador do conhecimento, ou transmissor, o professor passa a ter, necessariamente, a atuação de mediador e orientador, de agente do processo, capaz de fornecer informação e proporcionar a reflexão para o favorecimento de formação, dos alunos, de conceitos. Os alunos, que "aprendem", tendem, por sua vez, a abandonar a atitude passiva de receptores de informação e tornam-se agentes ativos de sua aprendizagem, investigando, estabelecendo conexões entra as informações recebidas, buscando desenvolver as próprias competências em resolução de problemas e, ainda, interagir em grupo com este fim. $O$ aluno assume para si a responsabilidade sobre sua aprendizagem e o professor tornase "parceiro" dessa "jornada", aquele que ajuda, provoca e incentiva, mas que

\footnotetext{
${ }^{18}$ Educação Bancária a Distância, conceito criado por João Mattar (2012) em referência às teorias de Paulo Freire como ponto de análise de projetos de EaD.
} 
pode deixar ao aluno o prazer da descoberta (ALMEIDA, 2003). O processo passa a ser realmente colaborativo (peering) e

[...] o peering continuará ganhando importância porque as condições essenciais para seu desenvolvimento existem e estão crescendo. Isso inclui acesso à capacidade computacional e a aplicativos, transparência, globalização, democratização do conhecimento e das competências, e crescente complexidade dos sistemas (TAPSCOT, 2006).

\subsubsection{Proposição Metodológica: TPACK - Conhecimento Tecnológico Pedagógico do Conteúdo}

Chamada de Conteúdo de Conhecimento Tecnológico e Pedagógico, ou TPACK (de, em Inglês, Pedagogical Content Knowledge) (SHULMAN, 1986) ${ }^{19}$, é uma proposta de metodologia de trabalho com tecnologia e Educação que tentar capturar algumas das qualidades essenciais de conhecimento, exigidas do professor atual, para integrar a tecnologia no seu Ensino, referindo-se à natureza complexa e multifacetada do conhecimento do necessário à função docente.

No centro do gráfico TPACK está a complexa relação de três formas principais de conhecimento: Conteúdo (CC), Pedagogia (CP), e Tecnologia (CT). O quadro TPACK é construído sobre a ideia de Pedagogical Content Knowledge.

19 SHULMAN, L.S. Those who understand: Knowledge growth in teaching. Educational Researcher, 15(4). 1986. 


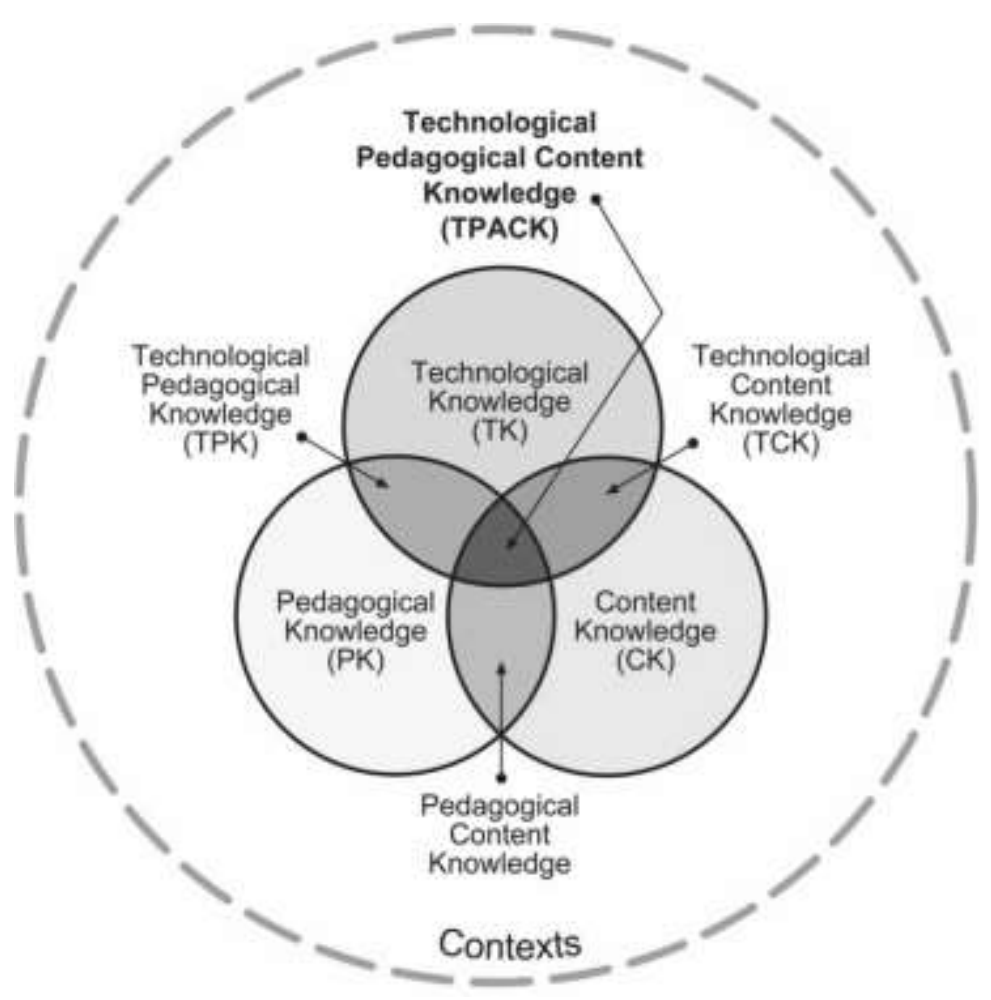

Figura 11 - Gráfico TPACK <http://www.tpack.org>.

A abordagem TPACK não é uma ideia nova. Uma série de estudiosos vem argumentando que o conhecimento sobre a tecnologia não pode ser tratado como livre de contexto, e que um bom Ensino com uso da tecnologia requer uma compreensão de como essa tecnologia se relaciona com a pedagogia e com o conteúdo disciplinar. O quadro TPACK está ganhando popularidade entre os pesquisadores e estudiosos. Na literatura de pesquisa (que remonta a 1998) a TPACK vai além de ver as três áreas (Tecnologia, Pedagogia e Conteúdos de disciplinas) isoladamente. Propõe-se a trabalhar os novos tipos de conhecimento que estão na interseção das áreas, que consiste no que é chamado de Conteúdo de Conhecimento Tecnológico e Pedagógico. Ou seja, a TPACK é uma abordagem essencialmente transdisciplinar, compreendendo a construção do conhecimento por meio da tecnologia como um processo dinâmico e vivo.

As considerações iniciais da Carta da Transdisciplinaridade são esclarecedoras em si mesmas, e não cabe, neste trabalho, reproduzir tão somente os itens e artigos da carta, porém, esclarecer as bases do pensamento transdisciplinar é imprescindível para dar encaminhamento às reflexões aqui desenvolvidas. 
O conceito de transdisciplinaridade vem sendo construído ao longo dos anos, a partir de 1970, e em diversos encontros - França (1970), quando pela primeira vez o termo "transdisciplinaridade" é cunhado por Piaget; Veneza (1986), quando foi redigida a "Declaração de Veneza", com o intuito de incorporar o diálogo entre ciências exatas, humanas, artes e tradição; Paris (1991), onde surge a proposta da atitude transdisciplinar; Portugal (1994), onde foi escrita a "Carta da Transdisciplinaridade", dimensionando seus parâmetros, bem como seus princípios: múltiplos níveis de realidade, diferentes lógicas e complexidade; Suíça (1997), onde se debateu a evolução transdisciplinar na universidade e foi criada a Cátedra UNESCO para a difusão destes princípios; e Vila Velha (2005), com o objetivo de criar um espaço de discussão no que tange a pesquisa, reflexão, ação e atitude transdisciplinar (EGREJA, MACHADO \& SILVA, 2009, p. 03).

Embora não se tenha, ainda, um consenso científico para o significado de transdisciplinaridade (SANTOS, 2010), a "Carta da Transdisciplinaridade" (MORRIN, NICOLESKU \& LIMA DE FREITAS, 1994, art. $7^{\circ}$ ) afirma que

[...] a Transdisciplinaridade não constitui nem uma nova religião, nem uma nova filosofia, nem uma nova metafísica, nem uma ciência das ciências" e também "não se constitui num cientismo neopositivista, nem numa ideologia, nem numa nova linguagem e não deve ser um mero hibridismo, uma importação de metáforas (SANTOS, 2010, p. 02).

Por vezes a tentativa de importar-se um método de uma disciplina para outra sugere uma abordagem interdisciplinar, que é vista equivocadamente por alguns como transdisciplinar. Um entendimento particular e possivelmente equivocado, mas certamente raso da transdisciplinaridade, seria o de tentar transformar sua essência em método, pois a transdisciplinaridade não é uma metodologia, mas sim uma visão de mundo, uma postura em relação ao mundo e, por consequência, às práticas educacionais. E essa...

[...] visão transdisciplinar está resolutamente aberta na medida em que ela ultrapassa o domínio das ciências exatas por seu diálogo e sua reconciliação não somente com as ciências humanas, mas também com a arte, a literatura, a poesia e a experiência espiritual (MORRIN, NICOLESKU \& LIMA DE FREITAS, 1994, art. 5ํ).

...ultrapassa, ou melhor, "transpassa" a métodos e metodologias convencionais, regidos por regras duras e inflexíveis e, ainda, restritivas e segmentadoras do conhecimento em disciplinas estanques e... 
a ética transdisciplinar recusa toda a atitude que rejeita o diálogo e a discussão, de qualquer origem - de ordem ideológica, científica, religiosa, económica, política, filosófica. O saber partilhado deve conduzir a uma compreensão partilhada, fundada sobre 0 respeito absoluto das alteridades unidas por uma vida comum numa única e mesma Terra (MORRIN, NICOLESKU \& LIMA DE FREITAS, 1994, art. 7º).

A visão transdisciplinar vai além dos métodos. Santos (2010, p. 2) afirma que a necessidade, cada dia mais viva nos campos dos conhecimentos, de...

[...] cruzar as fronteiras de sua própria disciplina e estabelecer uma ponte que permita estudar fenômenos que se situam fora e além do âmbito das disciplinas existentes", "a Transdisciplinaridade não é uma nova disciplina" (NICOLESCU, 1994), e "não diz respeito nem ao método (nem, portanto, à transferência do método), nem à justaposição de conhecimentos que fazem parte de uma disciplina já existente" [Idem]. É antes "uma atitude rigorosa em relação a tudo o que se encontra no espaço que não pertence a nenhuma disciplina (Idem, ibidem).

É possível perceber que, ao aplicar a proposição TPACK à área de conhecimentos de arte, emerge a similaridade às propostas transdisciplinares.

Se detalharmos os itens do gráfico em uma tabela, veremos que

A fluência tecnológica requer um processo de aprendizado ao longo da vida, no qual indivíduos continuamente aplicam o que eles sabem para adaptarem-se às mudanças e adquirir mais conhecimento para serem mais efetivos na aplicação da tecnologia da informação no seu trabalho e em suas vidas pessoais (National Research Council, 1999, apud ROCHA, 2006, p. 05)

O exercício de construção do papel do professor na formação docente com uso de Tecnologias Digitais de Comunicação e Informação é o que responde à questão: Quais conhecimentos um professor de arte pode ter/buscar/saber em cada um dos âmbitos apresentados no TPACK?

Desmembrando os elementos do gráfico TPACK, teríamos uma organização assim: 
Tabela 6 - Desmembramento do gráfico TPACK em Artes Visuais.

\begin{tabular}{|c|c|c|c|c|c|}
\hline \multicolumn{6}{|c|}{ TPACK } \\
\hline $\begin{array}{l}\text { Technological } \\
\text { Pedagogical } \\
\text { Knowledge (TPK) }\end{array}$ & $\begin{array}{l}\text { Pedagogical Content } \\
\text { Knowledge (PCK) }\end{array}$ & $\begin{array}{l}\text { Technological Content } \\
\text { Knowledge (TCK) }\end{array}$ & $\begin{array}{l}\text { Content Knowledge } \\
\text { (CK) }\end{array}$ & $\begin{array}{l}\text { Technology Knowledge } \\
\text { (TK) }\end{array}$ & Pedagogical Knowledge (PK) \\
\hline $\begin{array}{l}\text { Fluência em recursos } \\
\text { e atividades } \\
\text { educacionais em } \\
\text { geral. }\end{array}$ & $\begin{array}{l}\text { Conhecer teorias de } \\
\text { aprendizagem }{ }^{20} \mathrm{e} \\
\text { estratégias de Ensino } \\
\text { em geral, e específicas } \\
\text { de arte. }\end{array}$ & $\begin{array}{l}\text { Estar atualizado em relação } \\
\text { aos softwares, app, objetos de } \\
\text { aprendizagem e demais } \\
\text { recursos tecnológicos }{ }^{21} \\
\text { desenvolvidos para a área de } \\
\text { conhecimento. }\end{array}$ & $\begin{array}{l}\text { Conhecer a fundo os } \\
\text { conteúdos de sua } \\
\text { área de } \\
\text { conhecimento, no } \\
\text { caso, artes. }\end{array}$ & $\begin{array}{l}\text { Saber operar tecnologias } \\
\text { padrão, em Educação, como } \\
\text { quadro, giz etc., e também as } \\
\text { mais recentes }{ }^{22} \text {, bem como } \\
\text { conhecer o vocabulário } \\
\text { tecnológico como "wilfer"23. }\end{array}$ & $\begin{array}{l}\text { Ter conhecimento pedagógico em relação } \\
\text { às teorias de desenvolvimento de } \\
\text { aprendizagem, nos diversos modelos, } \\
\text { bem como conhecimentos de sua } \\
\text { aplicabilidade em aula. }\end{array}$ \\
\hline
\end{tabular}

20 Denominam-se teorias da aprendizagem, em Psicologia e em Educação, aos diversos modelos que visam explicar o processo de aprendizagem pelos indivíduos. Embora desde a Grécia antiga se hajam formulado diversas teorias sobre a aprendizagem, as de maior destaque na Educação contemporânea são a de Jean Piaget e a de Lev Vygotsky (WIKIPEDIA, 2012).

${ }^{21}$ Os recursos tecnológicos são ferramentas complementares às atividades de Ensino usuais e que, devido à sua flexibilidade e abrangência, favorece a constituição de redes de conhecimento (CUNHA, BRAZ, DUTRA \& CHAMON, 2012).

${ }^{22}$ Nessa perspectiva, compreender as potencialidades inerentes a cada tecnologia e suas contribuições ao processo de Ensino e de aprendizagem poderá trazer avanços substanciais à mudança da escola, a qual se relaciona com um processo de conscientização e de transformação que vai além do domínio de tecnologias e traz subjacente uma visão de mundo, de homem, de ciência e de Educação (TORNAGHI; PRADO; ALMEIDA, 2005, p. 47).

${ }^{23}$ É a pessoa perdida na Internet que fica navegando sem rumo e sem saber o que fazer (HERMANN, 2007, citando o artigo " $A$ study of 2,400 people carried out by YouGov found more than a quarter of internet users wilf - a rough acronym of What Was I Looking For? - for two days every month", o que, numa tradução livre, seria algo como "um estudo com 2.400 pessoas mostra que mais de um quarto dos usuários da internet wilf (Que seria um acrônimo da expressão 'What Was I Looking For', ou 'O que eu estou procurando?'). 
A Abordagem Triangular ${ }^{24}$, de Ana Mae Barbosa (1996), revista recentemente em livro organizado pela própria, junto com Fernanda Cunha (BARBOSA \& CUNHA, 2010), é reafirmada como uma visão (com seus três fundamentos: Fazer, ler e contextualizar a arte), e não uma metodologia. Pensada como um modo de orientar o caminho do professor de arte e não de ser uma receita a ser seguida. Numa relação possível com os princípios transdisciplinares a Abordagem Triangular pode ser vista como paralela à visão transdisciplinar, também apoiada em três elementos (os 'níveis de realidade', a lógica do 'terceiro incluído' e a 'complexidade').

A Educação transdisciplinar revaloriza o papel da intuição, do imaginário, da sensibilidade e do corpo na transmissão dos conhecimentos (SANTOS, 2010, P. 3). $O$ Art. $11^{\circ}$ da Carta da Transdisciplinaridade diz que:

Uma Educação autêntica não pode privilegiar a abstração no conhecimento. Ela deve ensinar a contextualizar, concretizar e globalizar. A Educação transdisciplinar reavalia o papel da intuição, do imaginário, da sensibilidade e do corpo na transmissão do conhecimento (MORRIN, NICOLESKU \& LIMA DE FREITAS, 2010, art. 11ㅇ).

Os autores da Carta da transdisciplinaridade (1994) afirmam que "a transdisciplinaridade não busca o domínio de várias disciplinas, mas a abertura de todas elas àquilo que as atravessa e as ultrapassa". Segundo Mariotti (2005), realidade é aquilo que se percebe objetiva e subjetivamente, é o que se observa, o que se sente e o que se pensa em relação ao que se observa. Assim, a realidade vivenciada por meio das ferramentas e do ciberespaço também é o que se percebe objetiva e subjetivamente neste espaço não material, desterritorializado, mas não desprovido de significados e de potenciais experiências a serem vivenciadas. Pedro Nunes Filho (2003) diz que:

\footnotetext{
${ }^{24}$ Ana Mae Barbosa é a autora da proposição denominada Abordagem Triangular, que pode ser conhecida no livro que a apresentou: BARBOSA, A.M.T.B. A imagem no Ensino da arte. São Paulo: Perspectiva, 1996. Série Estudos, $2^{\underline{a}}$ Ed. Reimpressão e, revisitada, 20 anos depois, em outro livro, da mesma autora, em coautoria com e CUNHA, F.P. (Org.) Abordagem Triangular no Ensino das Artes Visuais e Culturas Visuais. São Paulo: Cortez, 2010. A proposição é peça central de diversos trabalhos na área de Ensino de arte.
} 
Os sistemas hipermídia ${ }^{25}$ apresentam características dinâmicas em termos de construção significante, disseminação de conhecimentos e produção de sentidos que Diferem dos processos midiáticos que precedem os suportes digitais.

e, para Nicholas Negroponte (1995):

A hipermídia é um desenvolvimento do hipertexto, designando a narrativa com alto grau de interconexão, a informação vinculada [...] Pense na hipermídia como uma coletânea de mensagens elásticas que podem ser esticadas ou encolhidas de acordo com as ações do leitor. As ideias podem ser abertas ou analisadas com múltiplos níveis de detalhamento (NEGROPONTE, 1995).

As propostas de EaD em Artes Visuais para formação de professores até agora conhecidas reproduzem os currículos e formações presenciais de modo virtualizado, apoiadas em suportes digitais, como veremos a seguir, nas análises dos programas e, em grande maioria, subutilizando as potencialidades dos "múltiplos níveis de detalhamento" de Negroponte (1995). Isto é, ao que parece, em grande parte, por falta de embasamento teórico epistemológico nessa modalidade.

Salas de aula são reproduzidas em Ambientes Virtuais de Aprendizagem - AVA, com conteúdos, tarefas e exigências niveladoras de atividades, infelizmente muitas vezes síncronas, assim como na Educação presencial, desconsiderando as principais "vantagens" da EaD, procurando (segundo declaram) "superar" o que chamam de "deficiências", que os estudiosos chamam tão somente de características, desconsiderando mesmo o "lugar" virtual e suas particularidades. Como ressalta Kátia Alonso (2008, p. 755)

O resultado do Ensino com uso mais intenso, por exemplo, de tecnologia eletrônica tem redundado em sistemas de baixíssima interação, que replicam grosseira e indefinidamente uma matriz de aula como as denominadas, mais recentemente, de tele aulas (ALONSO, 2008, p. 755).

\footnotetext{
${ }^{25} \mathrm{O}$ termo hipermídia é aqui entendido como deslocamento do conceito de hipertexto formulado nos anos 60 por Theodor Nelson que já se reportava ao texto eletrônico como escrita ramificada que sugere ao usuário/leitor percursos previamente predefinidos, permitindo abertura do texto e, consequentemente, possibilitando a circularidade por parte do sujeito usuário no tocante às estruturas significantes digitais.
} 
Buscar uma única e certa metodologia para EaD em Artes Visuais não parece ser o caminho mais adequado. A ideia de criar "receitas" de "como fazer", mantendo a mesma visão "tradicional" de Educação, trocando o suporte (de material para digital) e mantendo a mentalidade linear, num espaço essencialmente não-linear, configurado rizomaticamente, em rede, me parece sem sentido.

Dentre os desafios a serem assumidos nos cursos de formação de professores está o de transpor a cômoda e rotineira prática instrucionista, em busca de outras formas de atuação pedagógica que estimulem a criatividade e valorizem o espírito empreendedor, na busca de superação da transmissão de um conhecimento em forma de conteúdo pronto e elaborado (EGREJA, MACHADO \& SILVA, 2009, p. 08).

Algumas propostas interessantes de formação de professores de arte, como a A/R/Tografia, de Rita Irwin, que entende a atuação do professor como um ser multifacetado que é, ao mesmo tempo artista-pesquisador-professor (artistresearcher-teacher/) (IRWIN, 2008) e a de Fábio Rodrigues (2010), que vê a Didática das Artes Visuais, concebida como

[...] não dizer ao futuro professor como ensinar, mas mediar seu caminho para ele conhecer, aprender e compreender as pedagogias contemporâneas e seus modos educativos" para o que chama de "(re)conceituação dos currículos [...] que começa pela aceitação do professor como pesquisador e que, a partir dessa perspectiva se (re)contextualiza tendo nos pressupostos da pesquisa qualitativa suas principais ferramentas" (RODRIGUES, 2010)...

...também trazem perspectivas que dialogam com essas ideias. 


\section{CAPÍTULO II - EDUCAÇÃO A DISTÂNCIA}

\begin{abstract}
"Chegará o dia que o volume da instrução recebida por correspondência será maior do que o transmitido nas aulas de nossas escolas; em que 0 número de estudantes por correspondência ultrapassará 0 dos presenciais."
\end{abstract}

William Harper, 1886.

Muitas pesquisas e diversos livros já foram escritos sobre a conceituação de Educação a distancia. Em pesquisa anterior, para a dissertação de mestrado, eu mesma desenvolvi um histórico que caracterizava a EaD da seguinte forma:

Particularmente, creio que uma das melhores definições de EaD já feitas foi a de lan Mugridge (1993, p. 313) que diz que é "uma forma de Educação onde, normalmente, há a separação entre professor e aluno e onde são usados meios - escritos e impressos, telefone, conferências por computador ou teleconferência - para criar uma ponte que supra essa distância física ${ }^{26 ",}$, sem esquecer de que, como lembra Eduardo Chaves (2001. p. 6), "há uma conexão conceitual entre Educação e aprendizagem: não há Educação sem que ocorra aprendizagem" e, por mais variantes conceituais que se tenha nos diversos documentos e estudos já feitos sobre a temática, pode-se centrar a definição de EaD em alguns pontos gerais, onde a Educação à Distância é caracterizada pela separação do professor e aluno no espaço e/ou tempo (PERRATON, 1998, p. 34-45); com controle do aprendizado realizado mais intensamente pelo aluno do que pelo instrutor distante (JONASSEN, 1992, apud SÁ, 2000, p. 33) e pela comunicação entre alunos e professores, que é mediada por documentos impressos ou alguma forma de tecnologia (KEEGAN, 1996, p. 25). E é importante ainda destacar que, nesta forma de Educação, o aluno pode organizar seu próprio aprendizado e estudar segundo o seu próprio ritmo (CIRIGLIANO, 1983, p. 175) e que deste modo, aqueles que trabalham e não têm horário compatível com os rígidos horários escolares; aqueles que têm dificuldades físicas de locomoção e aqueles que querem criar seu próprio programa de estudo poderão encontrar, na Educação à distância uma saída eficiente para suas demandas (TODOROV, 1994, p. 5-6), mas o que podemos perceber, no entanto, é que todos os pesquisadores parecem quase unânimes em afirmar que a $\mathrm{EaD}$ é uma forma particular de Educação, com características próprias.

Entendendo a ideia de estudo com separação de professor e aluno, seja ela espacial ou temporal, vários nomes são usados para se referir a essa forma de aprendizagem. No Reino Unido é chamado de estudo em casa (home study), nos Estados Unidos; estudos externos (external studies), na Austrália; Ensino à distância, na Open University do Reino Unido e também, télé-enseignement, em francês; Fernstudium/Fernunterricht, em alemão; educación a distância, em espanhol; e TelEducação, em português (SAMPAIO-RALHA, 2003)

26 "A form of education in which there is normally a separation between teacher and learner and thus one in which other means the printed and written word, the telephone, computer conferencing or teleconferencing, for example - are used to bridge the physical gap." Tradução livre da autora. 
Junto com a pesquisadora Juliana Arantes Domingues (SAMPAIO \& DOMINGUES, 2012) lembro que, "no Brasil, Ivônio Barros Nunes (1999, p. 1) é um dos pesquisadores que há mais tempo vem investigando sobre as possibilidades da EaD". Seu trabalho chamado "Noções de Educação à Distância" (1999, p. 01-30), sintetiza algumas pesquisas internacionais, notando que

a Educação a Distância é um recurso de incalculável importância como modo apropriado para atender a grandes contingentes de alunos de forma mais efetiva que outras modalidades e sem riscos de reduzir a qualidade dos serviços oferecidos em decorrência da ampliação da clientela atendida (NUNES, 1999, p. 01).

É dele a compilação de definições, usada na maioria das pesquisas que tratam do tema EaD colhidas ao longo de seu trabalho.

Tabela 7 - Primeiras definições de EaD feitas por pesquisadores ao longo da história ${ }^{27}$.

\begin{tabular}{l|l}
\hline \multicolumn{1}{c}{ AUTOR } & \multicolumn{1}{c}{ DEFINIÇÃO } \\
\hline Holmberg (1994) & $\begin{array}{l}\text { "o termo Educação a Distância esconde várias formas de estudo, nos } \\
\text { diversos níveis sob contínua e imediata supervisão de tutores" } \\
\text { "um método racional de partilhar conhecimento, habilidades e atitudes, } \\
\text { Otto Peters (1998) } \\
\text { organizacionais [...] é uma modalidade de Ensino decorrente da era } \\
\text { industrial” }\end{array}$ \\
\hline $\begin{array}{l}\text { Michael G. Moore } \\
\text { (1989) }\end{array}$ & $\begin{array}{l}\text { "Ensino a Distância pode ser definido como a família de métodos } \\
\text { instrucionais onde as ações dos professores são executadas à parte } \\
\text { da ação dos alunos". }\end{array}$ \\
\hline
\end{tabular}

No entanto, também é essencial conhecer as definições de Desmond Keegan (1996), Lorenzo Aretio (1996), Jaime Sarramona (1975), Dereck Rowntree (1976), José Luís Garcia Llamas (1999) e Walter Perry e Greville Rumble (1987), pois complementam a visão que temos hoje dessa modalidade educacional.

Importante ainda considerar que

A Educação a Distância é compreendida como uma abordagem que transcende os limites da dimensão espacial, temporal, cultural e curricular, pois é concebida como sistema aberto, flexível, com práticas individuais e coletivas, mas principalmente, que respeita o ritmo de trabalho de cada um. Dessa forma, apresenta-se intimamente associada aos princípios e características da transdisciplinaridade (EGREJA, MACHADO \& SILVA, 2009, p. 02).

\footnotetext{
${ }^{27}$ Segundo Ivônio Barros Nunes (1999, apud SAMPAIO \& DOMINGUES, 2012, p. 96).
} 
No quadro abaixo podem ser vistas as principais definições feitas por esses pesquisadores em suas pesquisas, em ordem cronológica, da mais antiga, para a mais recente, organizadas por Juliana Arantes e por mim (SAMPAIO \& DOMINGUES, 2012, p. 97).

Tabela 8 - Mais definições de EaD feitas por pesquisadores ao longo da história ${ }^{28}$.

\begin{tabular}{|c|c|}
\hline AUTOR & DEFINIÇÃO \\
\hline $\begin{array}{l}\text { Jaime Sarramona } \\
\text { (1975) }\end{array}$ & $\begin{array}{l}\text { "metodologia de Ensino em que as tarefas docentes acontecem em } \\
\text { um contexto distinto das discentes, de modo que estas são, em } \\
\text { relação às primeiras, diferentes no tempo, no espaço ou em ambas } \\
\text { as dimensões ao mesmo tempo" }\end{array}$ \\
\hline Dereck Rowntree (1976) & $\begin{array}{l}\text { "sistema de Ensino em que o aluno realiza a maior parte de sua } \\
\text { aprendizagem por meio de materiais didáticos previamente } \\
\text { preparados, com um escasso contato direto com os professores" }\end{array}$ \\
\hline Greville Rumble (1987) & $\begin{array}{l}\text { "a característica da Educação a Distância é o estabelecimento de } \\
\text { uma comunicação de dupla via, na medida em que o professor e o } \\
\text { aluno não se encontram juntos na mesma sala, pode ser chamada } \\
\text { de: estudo aberto, Educação não tradicional, estudo moderno, } \\
\text { extensão, estudo por contrato, estudo experimental" }\end{array}$ \\
\hline $\begin{array}{l}\text { Desmond Keegan } \\
\text { (1996) }\end{array}$ & "um conjunto de estratégias educativas" \\
\hline Lorenzo Aretio (1996) & $\begin{array}{l}\text { "é um sistema tecnológico de comunicação bidirecional, que pode } \\
\text { ser de massa e que substitui a interação pessoal entre professor e } \\
\text { aluno na sala de aula como meio preferencial do Ensino, pela ação } \\
\text { sistemática e conjunta de diversos recursos didáticos e pelo apoio de } \\
\text { uma organização e tutoria que propiciam a aprendizagem autônoma } \\
\text { dos estudantes" }\end{array}$ \\
\hline $\begin{array}{l}\text { José Luís Garcia } \\
\text { Llamas (1999) }\end{array}$ & $\begin{array}{l}\text { "uma estratégia educativa baseada na aplicação da tecnologia à } \\
\text { aprendizagem, sem limitação do lugar, tempo, ocupação ou idade } \\
\text { dos alunos. Implica novos papéis para os alunos e para os } \\
\text { professores, novas atitudes e novos enfoques metodológicos" }\end{array}$ \\
\hline
\end{tabular}

Todas essas variantes conceituais, embora sejam esclarecedoras para pesquisadores, acabam por fazer com que muitos professores ainda não saibam efetivamente o que seja EaD (SAMPAIO \& DOMINGUES, 2012).

Vários, inclusive, acham que é uma 'novidade'29 e, segundo Gatti (1993), uma das reações mais comuns dos educadores às inovações, é "o ceticismo crônico provocado pela descrença frente a programas mal implementados e interrompidos a cada novo governo, aliado a uma resistência natural às mudanças e inovações".

${ }^{28}$ Por (SAMPAIO \& DOMINGUES, 2012, p. 97).

${ }^{29}$ Os resultados da pesquisa de campo mostram que a maioria, ao se referir à EaD sempre faz alusão a computadores, internet e tecnologias digitais de comunicação, esquecendo-se mesmo das tecnologias tradicionais, como TV e Rádio, precursoras em uso educacional, para EaD. É fato que as novas tecnologias vêm propiciando às universidades, em todo o mundo, a expansão do Ensino ou Educação à distância e os termos Ensino à distância e Educação à distância, segundo Sherry (1999), têm sido empregados como sinônimos na literatura da área. 
Adotamos no Brasil um modelo invertido, em relação à visão de Peters, de Ensino pós-moderno a distância. [...] $O$ fordismo e o design instrucional tradicional não nos servem mais, e uma base para teorias que deem conta dos novos desafios pode ser encontrada no construtivismo [...]. O instrucionismo nos afasta do pensamento crítico, com sua proposta engessada de seguir modelos de sistemas de Ensino, protegendo-nos de enfrentar a complexidade do mundo em que temos que agir, que é problemático, ambíguo e em constante mutação (MATTAR, 2012, p. 06-07).

Isso explica, em parte, a dificuldade de muitos professores em se relacionar com desenvoltura com as tecnologias digitais de comunicação e informação mesmo como usuários, menos ainda para EaD, chegando, alguns, a fazerem juízo de valor antes de conhecerem, de fato, suas reais possibilidades, reafirmando a viabilização da proposta TPACK nos dias atuais.

Educação on-line é uma das possibilidades de Educação à distância, realizada via internet, cuja comunicação ocorre de forma síncrona ou assíncrona e que usa os recursos da rede para distribuir as informações fazendo uso da interação proporcionada por essa mídia para concretizar a interação entre as pessoas. Assim a comunicação, essencial para qualquer processo educativo, pode acontecer de acordo com modalidades distintas.

Comunicação um a um, ou dito de outra forma, comunicação entre uma e outra pessoa, como é o caso da comunicação via e-mail, que pode ter uma mensagem enviada para muitas pessoas desde que exista uma lista específica para tal fim, mas sua concepção é a mesma da correspondência tradicional, portanto, existe uma pessoa que remete a informação e outra que a recebe;

Comunicação de um para muitos, ou seja, de uma pessoa para muitas pessoas, como ocorre no uso de fóruns de discussão, nos quais existe um mediador e todos que têm acesso ao fórum, enxergam as intervenções e fazem suas intervenções;

Comunicação de muitas pessoas para muitas pessoas, ou comunicação estelar, que pode ocorrer na construção colaborativa de um site ou na criação de um grupo virtual, como é o caso das comunidades

${ }^{30}$ Fordismo é o termo usado para referenciar o sistema de produção industrial baseado na fabricação em larga escala, na especialização do trabalho e na linha de montagem. Sua denominação mais adequada é taylorismo-fordismo, já que foi criado em 1913 pelo industrial norte-americano Henry Ford (1863-1947) com base nas ideias do engenheiro norte-americano Frederick W. Taylor (1856-1915). O modelo foi inicialmente utilizado na indústria automobilística e trouxe redução de tempo e de custo em relação ao sistema anterior, que era quase artesanal. No Brasil, foi adotado por grandes empresas na década de 1940. Mas desde os anos 1920 o país já abrigava outra iniciativa de Ford: seringais nas cidades de Fordlândia e Belterra, no Pará, que tinham como objetivo produzir matéria-prima para a fabricação de pneus (FERREIRA, 2012). 
colaborativas em que todos participam da criação e desenvolvimento da própria comunidade e respectivas produções (ALMEIDA, 2003).

Dentro dessa perspectiva a Educação On-Line, Educação à distância e eLearning são alternativas possíveis para a formação de professores e requerem políticas educacionais e públicas direcionadas para o efetivo desenvolvimento dessa formação. Esses termos, usuais, não são sinônimos, embora sejam congruentes entre si e...

[...] a consideração da oferta de EaD como uma atividade do setor terciário, de serviços, e não como uma atividade industrial, permitiria incorporar melhor uma lógica de atendimento mais individualizado aos interesses da clientela, numa perspectiva de oferta de serviços diversificados que 0 estudante pode organizar segundo suas necessidades e expectativas (TRINDADE, 1998 apud BELLONI, 1999, p. 20).

O Quadro conceitual dos termos de referência às modalidades (SAMPAIORALHA, 2003) esclarece as principais características de cada termo.

Tabela 9 - Conceitual de termos ${ }^{31}$.

\begin{tabular}{ll}
\hline \multicolumn{1}{c}{ TERMO } & \multicolumn{1}{c}{ DEFINIÇÃO } \\
\hline EaD & $\begin{array}{l}\text { Educação à Distância. Distance Education. Cenário educacional em que } \\
\text { instrutor e alunos estão separados pelo tempo, posição, ou ambos os fatores. }\end{array}$ \\
\hline e-Learning & $\begin{array}{l}\text { Inclui uma ampla gama de aplicações e processos, tais como aprendizagem } \\
\text { baseada na Internet, no computador, aulas virtuais, colaboração digital. Inclui a } \\
\text { entrega de conteúdos através da Internet, extranet, intranet, (LAN/WAN), áudio } \\
\text { e vídeo, transmissão via satélite, televisão interativa e CD-ROM. }\end{array}$ \\
\hline $\begin{array}{l}\text { Refere-se a quando dois computadores estão conectados através de modems. } \\
\text { On-Line } \\
\text { Por exemplo, um BBS é um sistema on-line. Seria o mesmo que dizer "ao } \\
\text { vivo". O estado em que um computador está conectado a outro computador ou } \\
\text { servidor através de uma rede. }\end{array}$ \\
\hline
\end{tabular}

\subsection{EaD em outros países}

A EaD não é novidade, nem surgiu simplesmente "no vácuo" como diz Keegan (1996, p. 11 apud NUNES, 1999, p. 02), mas sim tem uma longa história de experiências contando com alguns sucessos e fracassos. Sua origem pode ser localizada nas experiências de Educação por correspondência iniciadas no final do século XVIII e com largo desenvolvimento a partir de meados do século XIX (NUNES, 1999, p. 02).

\footnotetext{
${ }^{31}$ Fonte SAMPAIO-RALHA, 2003. Glossário. Anexo de dissertação de mestrado.
} 
Para alguns pesquisadores o início da $\mathrm{EaD}$ foi marcado quando a "Gazeta de Boston", em 20 de março de 1728, publicou o anúncio da oferta de um curso de taquigrafia por correspondência (LOBO NETO, 1995). Mas, a criação, em 1856, por Charles Toussaint e Gustav Langenscheidt, da Escola de Línguas por Correspondência, em Berlim, Alemanha é, segundo a maioria dos pesquisadores da área, o mais antigo registro que se tem notícias sobre a EaD (SARAIVA, 1996). Registros apontam que já em 1891, Thomas Foster, iniciou, na Pennsylvania, EUA, o International Correspondence Institute e outra experiência em EaD bastante antiga foi a criação da Divisão de Ensino por correspondência no Departamento de Extensão da Universidade de Chicago, em 1892, sendo criado em 1898 o Instituto Hermod, na Suécia.

Com o passar dos anos, a EaD foi se consolidando e se expandindo, conforme o prognóstico de William Harper feito em 1886, já citado na epígrafe deste capítulo.

Com o aperfeiçoamento e evolução dos trabalhos e serviços dos correios, a agilização dos meios de transporte e com os surgimento dos mídia de massa (Primeiro o rádio e, posteriormente, a televisão) iniciou-se uma fase de expansão pelo mundo da EaD, ou da TelEducação (tele - do grego - distância), como alguns autores, como Dias Bordenave (1987) e Pedro Demo ((2), 1998), preferem se referir a essa modalidade.

São esses meios de comunicação que vem, na década de 1960, trazer dinamismo à EaD, mesmo que ainda dentro de um modelo chamado de "fordista" (MATTAR, 2012), ou seja, Educação industrial. É a British Open University que se torna marco de transição do modelo fordista a uma Educação mais flexível, ao ser fundada no ano de 1969.

Segundo Saraiva (1996) somente nos anos de 1970 iniciam-se as discussões sobre "técnicas e estratégias" para EaD. Essas discussões acrescentam aspectos interessantes às práticas, trazendo um aumento significativo da utilização de 
inovações tecnológicas de comunicação que foram se desenvolvendo e sendo socializadas massivamente a partir da década de 1990.

A partir da segunda metade da década de 1990

"um novo sistema de comunicação eletrônica começou a ser formado a partir da fusão da mídia de massa personalizada globalizada com a comunicação mediada por computadores" [...] "caracterizado pela integração de diferentes veículos de comunicação e seu potencial interativo" (CASTELLS, 1999, p. 387).

Este trabalho de pesquisa não tem pretensões históricas e, por este motivo, tomo como base o quadro abaixo, desenvolvido inicialmente pelo Núcleo de Educação Aberta e à distância da Universidade Federal de Ouro Preto (UFOP, 2001, p. 01), complementado com informações de pesquisa ${ }^{32}$, como base para ilustrar, em linhas gerais, a evolução da $\mathrm{EaD}$, numa compreensão ampla de sua existência como possibilidade de formação, e não como substituição dos modelos convencionais, presenciais.

Tabela 10 - Linha de tempo da EaD

\begin{tabular}{c:l}
\hline Ano & \multicolumn{1}{c}{ Evento } \\
\hline 1728 & $\begin{array}{l}\text { A Gazeta de Boston, em sua edição de } 20 \text { de março, oferece num anúncio: "material } \\
\text { para Ensino e tutoria por correspondência". }\end{array}$ \\
\hline 1833 & $\begin{array}{l}\text { número } 30 \text { do periódico sueco Lunds Weckoblad comunica a mudança de } \\
\text { endereço, durante o mês de agosto, para as remessas postais dos que estudam } \\
\text { "Composição" por correspondência. }\end{array}$ \\
\hdashline 1840 & $\begin{array}{l}\text { Um sistema de taquigrafia a base de fichas e intercâmbio postal com os alunos e } \\
\text { criado pelo inglês lsaac Pitman. }\end{array}$ \\
\hdashline 1843 & $\begin{array}{l}\text { Funda-se a Phonographic Correspondence Society, que se encarrega de corrigir as } \\
\text { fichas com os exercícios de taquigrafia anteriormente aludidos. }\end{array}$ \\
\hdashline 1856 & $\begin{array}{l}\text { Em Berlim, a Sociedade de Línguas Modernas patrocina os professores Charles } \\
\text { Toussain e Gustav Laugenschied para ensinar francês por correspondência. }\end{array}$ \\
\hdashline 1858 & $\begin{array}{l}\text { A Universidade de Londres passa a conceder certificados a alunos externos que } \\
\text { recebem Ensino por correspondência. }\end{array}$ \\
\hdashline 1873 & Surge, em Boston, EUA, a Sociedade para a Promoção do Estudo em Casa. \\
\hdashline 1977 & Na França vários organismos privados oferecem cursos por correspondência de \\
& cultura geral, artes, línguas e preparação para concursos.
\end{tabular}

${ }^{32}$ Desenvolvido pelo Núcleo de Educação aberta e à distância da Universidade Federal de Ouro Preto (UFOP, 2001, P. 1) Complementado com informações encontradas nas apresentações $<$ http://www.slideshare.net/guest7c79d19/leitura-basica-historia-EaD-presentation-824484> $>\quad$ e $<$ http://www.slideshare.net/guestc8aba15/a-histria-da-EaD-no-mundo> 


\begin{tabular}{|c|c|}
\hline 1880 & O Skerry's College oferece cursos preparatórios para concursos públicos. \\
\hline 1883 & $\begin{array}{l}\text { Começa a funcionar, em Ithaca, no Estado de Nova Iorque, EUA, a Universidade por } \\
\text { Correspondência. }\end{array}$ \\
\hline 1884 & Foulkes Lynch Correspondence Tuition Service ministrou cursos de Contabilidade. \\
\hline 1891 & $\begin{array}{l}\text { Por iniciativa do reitor da Universidade de Chicago, W. Raineu Harper é criado um } \\
\text { Departamento de Ensino por Correspondência. } \\
\text { Na Universidade de Wisconsin, os professores do Colégio de Agricultura mantém } \\
\text { correspondência com alunos que não podem abandonar seu trabalho para voltar às } \\
\text { aulas no campus. Nos Estados Unidos são criadas as Escolas Internacionais por } \\
\text { Correspondência. }\end{array}$ \\
\hline 1894 & $\begin{array}{l}\text { O Rutinsches Fernelehrinstitut de Berlim organiza cursos por correspondência } \\
\text { obtenção do Abitur (aceitação de matrícula na Universidade). }\end{array}$ \\
\hline 1903 & $\begin{array}{l}\text { Julio Cervera Baviera abre, em Valência, Espanha, a Escola Livre de Engenheiros. } \\
\text { As Escolas Calvert de Baltimore, EUA, criam um Departamento de Formação em } \\
\text { Casa, para acolher crianças de escolas primárias que estudam sob a orientação dos } \\
\text { pais. }\end{array}$ \\
\hline 1910 & $\begin{array}{l}\text { Professores rurais do curso primário começam a receber material de Educação } \\
\text { secundária pelo correio, em Vitória, Austrália. }\end{array}$ \\
\hline 1910 & $\begin{array}{l}\text { A Universidade de Queensland, na Austrália, inicia programas de Ensino por } \\
\text { correspondência. }\end{array}$ \\
\hline 1911 & $\begin{array}{l}\text { Ainda na Austrália, com a intenção de minorar os problemas das enormes distâncias, } \\
\text { a Universidade de Queensland começa a experiência para solucionar a dificuldade. }\end{array}$ \\
\hline 1914 & $\begin{array}{l}\text { Na Noruega, funda-se a Norst Correspndanseskole e, na Alemanha, a Fernschule } \\
\text { Jena. }\end{array}$ \\
\hline 1920 & Na antiga URSS, implanta-se, também, este sistema por correspondência. \\
\hline 1921 & Mormons de Salt Lake City criam a primeira rádio universitária. \\
\hline 1922 & $\begin{array}{l}\text { A New Zeland Correspondence School começa suas atividades com a intenção } \\
\text { inicial de atender a crianças isoladas ou com dificuldade de } 105 \text { requentar as aulas } \\
\text { convencionais. A partir de } 1928 \text {, atende também a alunos do Ensino secundário. }\end{array}$ \\
\hline 1924 & $\begin{array}{l}\text { Fritz Reinhardt cria a Escola Alemã por correspondência de Negócios (Bytwer e } \\
\text { Diehl, 1989). }\end{array}$ \\
\hline 1926 & Criada a primeira rádio universitária de Luxemburgo. \\
\hline 1927 & Criada a Rádio Pariz PTT. \\
\hline 1938 & $\begin{array}{l}\text { No Canadá, na cidade de Victória, realiza-se a Primeira Conferência Internacional } \\
\text { sobre a Educação por Correspondência. }\end{array}$ \\
\hline 1939 & $\begin{array}{l}\text { Nasce o Centro Nacional de Ensino a Distância na França (CNED), que, em } \\
\text { princípio, atende, por correspondência, a crianças refugiadas de guerra. É um centro } \\
\text { público, subordinado ao Ministério da Educação Nacional. }\end{array}$ \\
\hline 1940 & $\begin{array}{l}\text { Na década de } 1940 \text {, diversos países do centro e do leste europeu iniciam esta } \\
\text { modalidade de estudos. Já por esses anos os avanços técnicos possibilitam outras } \\
\text { perspectivas que as de Ensino meramente por correspondência. }\end{array}$ \\
\hline 1946 & $\begin{array}{l}\text { A Universidade de Sudafrica (UNISA) começa a ensinar também por } \\
\text { correspondência. }\end{array}$ \\
\hline 1947 & $\begin{array}{l}\text { Através da Rádio Sorbonne, transmitem-se aulas de quase todas as matérias } \\
\text { literárias da Faculdade de Letras e Ciências Humanas de Paris. }\end{array}$ \\
\hline 1950 & $1950 \mathrm{a}$ \\
\hline
\end{tabular}


oferecer a Educação a Distância, visando o aperfeiçoamento de professores, através do National Teachers Distance Education Upgranding Course Development Centre.

1950 A República Popular da China mantém projetos de Educação a Distância desde a década de 1950. Um ano depois foi instituído o Departamento de Educação por correspondência da universidade do Povo. Entre 1955 e 60 foram organizados cursos por rádio (Beijing e Tiajing), seguida pelas primeiras televisões universitárias (Beijing, Tiajing, Xangai, Sheiang, Harbing) que foi um importante meio de EaD até a Revolução Cultural, ficando desativada até a década de 80. Na atualidade funciona o Sistema Chinês de Universidade pela Televisão (Dianda) que possui um grande número de alunos já formados e um grande número de inscritos. Estudos mostram que em torno de $77 \%$ da população que se graduou nesta modalidade conseguiram seu espaço no mercado de trabalho, mais especificamente em sua área de atuação.

1951 A Universidade de Sudafrica, atualmente única Universidade a Distância na África, dedica-se exclusivamente a desenvolver cursos a distância.

1960 Funda-se o Beijing Television College, na China, que encerra suas atividades durante a Revolução Cultural, o que acontece também ao restante da Educação póssecundária.

1962 Índia, projeto piloto de Educação a Distância Universitário iniciado em Delhi em 1962, tendo como fase experimental até 1970 envolvendo ainda as universidades de Punjabi, Patiala, Meerut e Mysone, o projeto logo entrou numa segunda fase de rápida expansão que até a década de 80 abrangeu várias outras universidades particulares e ainda cursos de pós-graduação.

1962 Inicia-se, na Espanha, uma experiência de Bacharelado Radiofônico.

A Universidade de Dehli cria um Departamento de Estudos por Correspondência, como experiência para atender aos alunos que, de outro modo, não podem receber Ensino universitário.

1963 Surge na Espanha o Centro Nacional de Ensino Médio por Rádio e Televisão, que substitui o Bacharelado Radiofônico, criado no ano anterior.

Inicia-se, na França, um Ensino universitário, por radio, em cinco faculdades de Letras (Paris, Bordeaux, Lille, Nancy e Strasbourg) e na Faculdade de Direito de Paris, para os alunos do curso básico.

Duas instituições neozelandesas se unem (Victoria University of Wellington e Massey Agricultural College) e formam a Massey University Centre for University Extramural Studies da Nova Zelândia.

1968 O Centro Nacional de Ensino Médio por Rádio e Televisão da Espanha se transforma no Instituto Nacional de Ensino Médio a Distância (INEMAD).

1969 Cria-se a British Open University, instituição verdadeiramente pioneira e única do que hoje se entende como Educação superior à distância. Inicia seus cursos em 1971. A partir desta data, a expansão da modalidade tem sido inusitada.

1971 Open Learning Institute (Charles Sturt University), Austrália.

1972 Curtin University of Technology (Perth), Austrália.

1972 Cria-se em Madri, Espanha, a Universidad Nacional de Educación a Distancia (UNED), primeira instituição de Ensino superior a suceder a Open University, em nível mundial.

1973 Athabasca University foi criada com ideia de um campus organizado com uma rede de telecomunicações. Tendo como base um eficiente sistema de tutoria e de interação através do telefone, constituindo em 1976 um modelo próprio, evoluindo-se e desenvolvendo-se a partir de então, tendo como paradigma a sociedade da informação.

1974 Criada a Universidade Aberta de Israel, que oferece, em hebreu, cerca de quatrocentos cursos em domínios variados. 


\begin{tabular}{|c|c|}
\hline 1975 & Victorian Tafe off-Campus Network, Austrália. \\
\hline 1975 & $\begin{array}{l}\text { Criada a Fernuniversitatt, na Alemanha, dedicada exclusivamente ao Ensino } \\
\text { universitário. }\end{array}$ \\
\hline 1979 & $\begin{array}{l}\text { Indonésia. Centre for Educational Communication Tecnology foi criada pelo } \\
\text { ministério da Cultura e da Educação, abrangendo o Ensino secundário. Cinco anos } \\
\text { mais tarde, estes mesmos ministérios intermediaram junto ao governo nacional que } \\
\text { instituiu a Universitas Terbuka (The Open University of Indonésia) atuando nas áreas } \\
\text { de Educação, economia, administração, matemática, estatística, administração } \\
\text { pública, entre outros. }\end{array}$ \\
\hline 1979 & $\begin{array}{l}\text { Criado o Instituto Português de Ensino a Distância, cujo objetivo era lecionar cursos } \\
\text { superiores para população distante das instituições de Ensino presencial e qualificar } \\
\text { o professorado. }\end{array}$ \\
\hline 1979 & $\begin{array}{l}\text { O início da EaD em Cuba com a Faculdade de Ensino Dirigido da Universidade de } \\
\text { Havana. Contando com o apoio de mais } 15 \text { instituições em todo o país, seu } \\
\text { programa curricular é o mesmo oferecido no presencial. }\end{array}$ \\
\hline 1982 & $\begin{array}{l}\text { Foi instituída a primeira universidade a distância da Índia, a Andhra Pradesh Open } \\
\text { University. Nos anos seguintes mais instituições com a mesma metodologia de } \\
\text { Ensino foram criadas e, em } 1990 \text { já era superior a } 35 \text { o número de universidades } \\
\text { ofertando a Educação a Distância. }\end{array}$ \\
\hline 1885 & $\begin{array}{l}\text { Bangladesh Em } 1985 \text { a EaD foi implementada como pós-graduação em Educação } \\
\text { como parte de um programa do governo de capacitação de professores, pelo } \\
\text { National Institute of Educational Media and Technology (NIEMT) que no início da } \\
\text { década de } 90 \text { passou a ser mantido pelo Instituto de Educação a Distância de } \\
\text { Bangladesh com três mil alunos. }\end{array}$ \\
\hline 1988 & $\begin{array}{l}\text { O Instituto Português de Ensino a Distância da origem a Universidade Aberta de } \\
\text { Portugal. }\end{array}$ \\
\hline 1992 & É criada a Universidade Aberta do Brasil \\
\hline
\end{tabular}

\subsection{EaD no Brasil}

E no Brasil, como se desenvolveu a EaD? Na pesquisa de mestrado já referenciada, relato um pequeno histórico, como contextualização:

No Brasil, a fundação do Instituto Rádio Monitor, em 1939 e depois do Instituto Universal Brasileiro, em 1941, são as primeiras experiências de sucesso. O Instituto Universal Brasileiro vem, desde então, formando centenas de alunos em seus cursos profissionalizantes. Mais de 3.800.000 pessoas já estudaram a distância no IUB. Baseado em uma metodologia simples: Organização e envio de material ao aluno que tenha dificuldades de acesso aos cursos presenciais, faz com que este possa estudar em sua conveniência de horários e prestar exames de aprovação para a obtenção do certificado. Atualmente conta com cerca de 200 mil alunos matriculados.

Nunes (1999) nos revela que "as experiências brasileiras, governamentais, não governamentais e privadas, são muitas $e$ representaram, nas últimas décadas, a mobilização de grandes contingentes de técnicos e recursos financeiros nada desprezíveis". Das experiências brasileiras, uma das que têm maior destaque é 0 
"Movimento de Educação de Base (MEB)", cuja preocupação básica era alfabetizar e apoiar os primeiros passos da Educação de milhares de jovens e adultos através das "escolas radiofônicas", principalmente nas regiões Norte e Nordeste do Brasil' (SAMPAIO-RALHA, 2003).

O quadro abaixo, desenvolvido também tendo como base o que foi inicialmente feito pelo Núcleo de Educação Aberta e à Distância da Universidade Federal de Ouro Preto, complementado com informações desta pesquisa, podemos acompanhar a evolução da EaD no Brasil nas suas diversas formas e modalidades, até o surgimento da UAB em 1992, principal programa de EaD no Brasil, na atualidade.

A partir do ano 2000 ocorre uma "interiorização do Ensino superior no país" (VIANNEY, TORRES e SILVA, 2003), nesse movimento, encontram-se as iniciativa relacionadas ao uso da EaD como ferramenta de atendimento das propostas do PNE de capacitação de professores e é nesse cenário que surgem as bases da UAB.

Os principais objetivos da UAB, então, se consolidam nas ideias de "formação de professores que não possuem graduação; aos funcionários de estatais interessados em obter um diploma de formação superior; e a aumentar o acesso ao Ensino superior em todo o país" (BRASIL, 2005). E, para que isso ocorre, prevê parcerias das universidades.

[...] Em meio à miríade de políticas educacionais patrocinadas pelo governo brasileiro, as quais se coadunam no objetivo de que seja arrefecida nossa defasagem universitária em relação a outros países, o programa Universidade Aberta do Brasil se diferencia não só pelos consórcios estabelecidos entre os três níveis governamentais, mas principalmente por se caracterizar como um programa de formação universitária na modalidade de Educação a Distância (EaD) (ZUIN, 2006).

Tabela 11 - Linha de tempo da EaD no Brasil ${ }^{33}$,

\begin{tabular}{c|l}
\hline Ano & Evento \\
\hline 1923 & Fundação da Rádio Sociedade do Rio de Janeiro. \\
\hline 1936 & Doação da Radio Sociedade do Rio de Janeiro ao Ministério da Educação e Saúde. \\
\hline
\end{tabular}

${ }^{33}$ Desenvolvida pelo Núcleo de Educação aberta e à distância da Universidade Federal de Ouro Preto (UFOP, 2001, p. 02) (até 1992, complementado pela autora com os últimos 20 anos). 


\begin{tabular}{|c|c|}
\hline 1937 & Criação do Serviço de Radiodifusão Educativa do Ministério da Educação. \\
\hline 1959 & Início das escolas radiofônicas em Natal (RN). \\
\hline 1960 & $\begin{array}{l}\text { Início da ação sistematizada do Governo Federal em EAD; contrato entre o MEC e a } \\
\text { CNBB: expansão do sistema de escolas radiofônicas aos estados nordestinos, que } \\
\text { faz surgir o MEB - Movimento de Educação de Base -, sistema de Ensino a } \\
\text { Distância não-formal. }\end{array}$ \\
\hline 1965 & $\begin{array}{l}\text { Início dos trabalhos da Comissão para Estudos e Planejamento da Radiodifusão } \\
\text { Educativa. }\end{array}$ \\
\hline $\begin{array}{l}1966 \mathrm{a} \\
1974\end{array}$ & $\begin{array}{l}\text { Instalação de oito emissoras de televisão educativa: TV Universitária de } \\
\text { Pernambuco, TV Educativa do Rio de Janeiro, TV Cultura de São Paulo, TV } \\
\text { Educativa do Amazonas, TV Educativa do Maranhão, TV Universitária do Rio } \\
\text { Grande do Norte, TV Educativa do Espírito Santo e TV Educativa do Rio Grande do } \\
\text { Sul. }\end{array}$ \\
\hline 1967 & $\begin{array}{l}\text { Criada a Fundação Padre Anchieta, mantida pelo Estado de São Paulo com o } \\
\text { objetivo de promover atividades educativas e culturais através do rádio e da } \\
\text { televisão (iniciou suas transmissões em 1969); constituída a Feplam (Fundação } \\
\text { Educacional Padre Landell de Moura), instituição privada sem fins lucrativos, que } \\
\text { promove a Educação de adultos através de tele-Educação por multimeios. }\end{array}$ \\
\hline 1969 & $\begin{array}{l}\text { TVE Maranhão/CEMA - Centro Educativo do Maranhão: programas educativos para } \\
\text { a } 5^{\mathrm{a}} \text { série, inicialmente em circuito fechado e a partir de } 1970 \text { em circuito aberto, } \\
\text { também para a } 6^{\text {a }} \text { série. }\end{array}$ \\
\hline 1970 & $\begin{array}{l}\text { Portaria } 408 \text { - emissoras comerciais de rádio e televisão: obrigatoriedade da } \\
\text { transmissão gratuita de cinco horas semanais de } 30 \text { minutos diários, de segunda a } \\
\text { sexta-feira, ou com } 75 \text { minutos aos sábados e domingos. É iniciada em cadeia } \\
\text { nacional a serie de cursos do Projeto Minerva, irradiando os cursos de Capacitação } \\
\text { Ginasial e Madureza Ginasial, produzidos pela Feplam e pela Fundação Padre } \\
\text { Anchieta. }\end{array}$ \\
\hline 1970 & $\begin{array}{l}\text { Projeto Minerva - Produção de programas e textos pela Fundação Padre Landel e } \\
\text { Fundação Padre Anchieta. ( (http://www.slideshare.net/ClayreMontes/histria-da- } \\
\text { educao-a-distncia-no-mundo-e-no-brasil) }\end{array}$ \\
\hline 1971 & $\begin{array}{l}\text { Nasce a ABT - inicialmente como Associação Brasileira de Tele-Educação, que já } \\
\text { organizava desde } 1969 \text { os Seminários Brasileiros de Tele-Educação atualmente } \\
\text { denominados Seminários Brasileiros de Tecnologia Educacional. Foi pioneira em } \\
\text { cursos a distância, capacitando os professores através de correspondência. }\end{array}$ \\
\hline 1972 & $\begin{array}{l}\text { Criação do Prontel - Programa Nacional de Tele-Educação - que fortaleceu o Sinred } \\
\text { - Sistema Nacional de Radiodifusão Educativa. }\end{array}$ \\
\hline 1973 & $\begin{array}{l}\text { Projeto Minerva passa a produzir o Curso Supletivo de } 1^{\circ} \text { Grau, Il fase, envolvendo o } \\
\text { MEC, Prontel, Cenafor e secretarias de Educação. }\end{array}$ \\
\hline 1973-74 & $\begin{array}{l}\text { Projeto SACI conclusão dos estudos para o Curso Supletivo "João da Silva", sob o } \\
\text { formato de telenovela, para o Ensino das quatro primeiras séries do Io grau; o curso } \\
\text { introduziu uma inovação pioneira no mundo, um projeto - piloto de tele - didática da } \\
\text { TVE, que conquistou o prêmio especial do Júri Internacional do Prêmio Japão. }\end{array}$ \\
\hline 1974 & $\begin{array}{l}\text { TVE Ceará começa a gerar tele aulas; o Ceteb - Centro de Ensino Técnico de } \\
\text { Brasília - inicia o planejamento de cursos em convênio com a Petrobrás para } \\
\text { capacitação dos empregados desta empresa e do projeto Logus II, em convênio com } \\
\text { o MEC, para habilitar professores leigos sem afastá-los do exercício docente. }\end{array}$ \\
\hline 1978 & $\begin{array}{l}\text { Lançado o Telecurso de } 2^{\circ} \text {. Grau, pela Fundação Padre Anchieta (TV Cultura/SP) e } \\
\text { Fundação Roberto Marinho, com programas televisivos apoiados por fascículos } \\
\text { impressos, para preparar o telealuno para os exames supletivos. }\end{array}$ \\
\hline 1979 & Criação da FCBTVE - Fundação Centro Brasileiro de Televisão Educativa/MEC; \\
\hline
\end{tabular}


dando continuidade ao Curso "João da Silva", surge o Projeto Conquista, também como telenovela, para as últimas séries do primeiro grau; começa a utilização dos programas de alfabetização por TV - (MOBRAL), em recepção organizada, controlada ou livre, abrangendo todas as capitais dos estados do Brasil.

1979 a É implantado, em caráter experimental, o Posgrad - pós-graduação Tutorial a 1983 Distância - pela Capes - Coordenação de Aperfeiçoamento do Pessoal de Ensino Superior - do MEC, administrado pela ABT - Associação Brasileira de Tecnologia Educacional - com o objetivo de capacitar docentes universitários do interior do país.

Anos Entre as décadas de 1970 e 1980, fundações privadas e organizações não1980 governamentais iniciaram a oferta de cursos supletivos a distância, no modelo de telEducação, com aulas via satélite complementadas por kits de materiais impressos, demarcando a chegada da segunda geração de EaD no país.

1981 FCBTVE trocou sua sigla para FUNTEVE: Coordenação das atividades da TV Educativa do Rio de Janeiro, da Rádio MEC-Rio, da Rádio MEC-Brasília, do Centro de Cinema Educativo e do Centro de Informática Educativa.

1983 / Criação da TV Educativa do Mato Grosso do Sul. Início do "Projeto Ipê", da

1984 Secretaria da Educação do Estado de São Paulo e da Fundação Padre Anchieta, com cursos pura atualização e aperfeiçoamento do magistério de $1^{\circ}$ e $2^{\circ}$ Graus, utilizando-se de multimeios.

1988 "Verso e Reverso - Educando o Educador": curso por correspondência para capacitação de professores de Educação Básica de Jovens e Adultos/ MEC Fundação Nacional para Educação de Jovens e Adultos (EDUCAR), com apoio de programas televisivos através da Rede Manchete.

1991 O "Projeto Ipê" passa a enfatizar os conteúdos curriculares.

A Fundação Roquete Pinto, a Secretaria Nacional de Educação Básica e secretarias estaduais de Educação implantam o Programa de Atualização de Docentes, abrangendo as quatro séries iniciais do Ensino fundamental e alunos dos cursos de formação de professores. Na segunda fase, o projeto ganha o título de "Um salto para o futuro".

1992 O Núcleo de Educação a Distância do Instituto de Educação da UFMT (Universidade Federal do Mato Grosso), em parceria com a Unemat (Universidade do Estado do Mato Grosso) e a Secretaria de Estado de Educação e com apoio da Tele-Universite du Quebec (Canada), criam o projeto de Licenciatura Plena em Educação Básica: 1a a 4ํㅗㄹ séries do $1^{\circ}$ grau, utilizando o EAD. 0 curso é iniciado em 1995.

Criada a Universidade Aberta do Brasil.

Duas tendências educacionais se firmaram no Brasil, no contexto da Educação a Distancia, segundo Barros (2003, p. 52): "[...] a universalização das oportunidades e a preparação para o universo do trabalho". Atualmente a Educação a Distância no país, vem se desenvolvendo por iniciativa das universidades, que têm demonstrando o interesse por promover pesquisas e desenvolver programas de $\mathrm{EaD}$, com significativa participação do governo federal pela implantação da Universidade Aberta do Brasil, UAB, em 2006.

Existem diversas publicações que tratam do histórico de EaD no Brasil. Como sugestão, apresenta-se o Guia Brasileiro da Educação a Distância e o livro 
EaD.br: Experiências inovadoras em Educação a Distância no Brasil - reflexões atuais em tempo real, organizado pela jornalista Carmem Maia.

\subsubsection{Legislação que regulamenta a EaD no Brasil}

A Educação a Distância (EaD) é normatizada no Brasil pela Lei de Diretrizes e Bases da Educação Nacional (Lei №. 9.394, de 20 de dezembro de 1996). Nela, o Art. 80 incentiva a EaD em todos os níveis e modalidades de Ensino no Brasil); pelo Decreto №. 2.494, de 10 de fevereiro de 1998 (publicado no D.O.U. de 11/2/98, revogado pelo Decreto №. 5.622); Decreto №. 2.561, de 27 de abril de 1998 (publicado no D.O.U. de 28/4/98, revogado pelo Decreto №. 5.622) e pela Portaria Ministerial №. 301, de 07 de abril de 1998 (publicada no D.O.U. de 9/4/98, revogada pela Portaria №. 4.361).

O Art. $80^{\circ}$ da LDB (Lei 9.394/96) foi a primeira referência sobre EaD na legislação brasileira atual e a criação da Secretaria Especial de Educação à Distância (SEED) pelo MEC (Extinta pelo decreto de reestruturação №. 7.480, de 16 de maio de 2011, transferindo seus programas e ações vinculados a Secretaria de Educação Continuada, Alfabetização, Diversidade e Inclusão - SECADI), foram indicadores deste reconhecimento e expansão.

A EaD constitui-se em um importante e eficaz instrumento de democratização do acesso à Educação, em uma opção de qualidade, para atender uma população considerável e, muitas vezes, desassistida historicamente, e que busca uma habilitação em nível superior.

A Educação a Distância no Brasil vem passando por transformações significativas nos últimos anos, gerando assim novas demandas para os gestores com relação ao planejamento, ao desenvolvimento, ao acompanhamento e à avaliação das atividades relacionadas a essa modalidade educacional.

Alterações na legislação, na organização dos órgãos de regulação, e o aprimoramento constante das tecnologias digitais são apenas alguns dos fatores que tornam a abordagem de assuntos relacionados à gestão de EAD um grande desafio. Somam-se a isso as diferentes visões que educadores e especialistas de diferentes áreas têm sobre o tema (NOVATEC, 2014). 


\subsubsection{Decretos}

Tabela 12 - Decretos em vigor relacionados à regulamentação da EaD no Brasil.

\begin{tabular}{|c|c|c|}
\hline DECRETO & DATA & CONTEÚDO \\
\hline Decreto №. 1.237 & 1994 & $\begin{array}{l}\text { Instituiu, no âmbito da administração federal, } \\
\text { o Sistema Nacional de Educação à Distância } \\
\text { (SINEAD) sob a coordenação do MEC. Esse } \\
\text { Decreto é pouco mencionado na bibliografia } \\
\text { sobre EaD no Brasil, porém o mesmo trouxe } \\
\text { o conceito de educação aberta que não foi } \\
\text { retomado nos decretos posteriores. }\end{array}$ \\
\hline Decreto №. 5.773 & 09 de maio de 2006 & $\begin{array}{l}\text { Dispõe sobre o exercício das funções de } \\
\text { regulação, supervisão e avaliação de } \\
\text { instituições de Educação superior e cursos } \\
\text { superiores de graduação e sequenciais no } \\
\text { sistema federal de Ensino. }\end{array}$ \\
\hline Decreto №. 5.622 & 19 de dezembro de 2005 & $\begin{array}{l}\text { Regulamenta o art. } 80 \text { da Lei №. } 9.394 \text {, de } \\
20 \text { de dezembro de } 1996 \text { (LDB) e foi alterada } \\
\text { parcialmente pelo Decreto №. } 6.303 \text {. }\end{array}$ \\
\hline Decreto №. 5.800 & 08 de junho de 2006 & $\begin{array}{l}\text { Instituição do Sistema Universidade Aberta } \\
\text { do Brasil - UAB. }\end{array}$ \\
\hline Decreto №. 6.303 & 12 de dezembro de 2007 & $\begin{array}{l}\text { Altera dispositivos dos Decretos, №. } 5.622 \text {, } \\
\text { de } 19 \text { de dezembro de } 2005 \text {, que estabelece } \\
\text { as diretrizes e bases da Educação nacional, } \\
\text { e №. } 5.773 \text {, de } 09 \text { de maio de } 2006 \text {, que } \\
\text { dispõe sobre o exercício das funções de } \\
\text { regulação, supervisão e avaliação de } \\
\text { instituições de Educação superior e cursos } \\
\text { superiores de graduação e sequenciais no } \\
\text { sistema federal de Ensino. }\end{array}$ \\
\hline
\end{tabular}




\subsubsection{Portarias}

Tabela 13 - Portarias relacionadas à regulamentação da EaD no Brasil.

\begin{tabular}{|c|c|c|}
\hline PORTARIA & DATA & CONTEÚDO \\
\hline $\begin{array}{l}\text { Portaria } \\
\text { Ministerial №. } \\
2.253\end{array}$ & 18 de outubro de 2001 & $\begin{array}{l}\text { Regulamenta as aulas semipresenciais nos } \\
\text { curso reconhecidos das IES - (Foi revogado } \\
\text { pela Portaria №. } 4.059 \text { ). }\end{array}$ \\
\hline $\begin{array}{l}\text { Portaria } \\
\text { Ministerial №. } \\
4.059\end{array}$ & 10 de dezembro de & $\begin{array}{l}\text { Regulamenta as aulas semipresenciais nos } \\
\text { curso reconhecidos das IES. }\end{array}$ \\
\hline $\begin{array}{l}\text { Portaria } \\
\text { Ministerial №. } \\
4.361\end{array}$ & 29 de dezembro de 2004 & Credenciamento de IES para oferecer EaD. \\
\hline $\begin{array}{l}\text { Portaria } \\
\text { Normativa №. } 2 \\
\text { (revogada) }\end{array}$ & 10 de janeiro de 2007 & $\begin{array}{l}\text { Dispõe sobre os procedimentos de regulação } \\
\text { e avaliação da Educação superior na } \\
\text { modalidade a distância. }\end{array}$ \\
\hline Portaria №. 40 & 12 de dezembro de 2007 & $\begin{array}{l}\text { Institui o e-Mec, sistema eletrônico de fluxo } \\
\text { de trabalho e gerenciamento de informações } \\
\text { relativas aos processos de regulação da } \\
\text { Educação superior no sistema federal de } \\
\text { Educação. }\end{array}$ \\
\hline $\begin{array}{l}\text { Portaria Conjunta } \\
\text { №. } 01 \\
\text { (CAPES/CNPq) }\end{array}$ & 12 de dezembro de 2007 & $\begin{array}{l}\text { Dispõe sobre bolsistas da CAPES e do } \\
\text { CNPq. }\end{array}$ \\
\hline Portaria №. 10 & 02 de julho de 2009 & $\begin{array}{l}\text { Fixa critérios para dispensa de avaliação } \\
\text { in loco e dá outras providências. }\end{array}$ \\
\hline $\begin{array}{l}\text { Portaria №. } 40 \\
\text { (MEC) }\end{array}$ & 21 de janeiro de 2010 & $\begin{array}{l}\text { Implanta polos de apoio presencial nos } \\
\text { municípios do Estado de Minas Gerais, } \\
\text { referente às ações do Plano de Ações } \\
\text { Articuladas (PAR), com a finalidade de } \\
\text { compor o conjunto de polos do Sistema } \\
\text { Universidade Aberta do Brasil bem como } \\
\text { aprovar as Instituições de Ensino Superior } \\
\text { públicas, para oferta de cursos em polos do } \\
\text { Sistema UAB. }\end{array}$ \\
\hline $\begin{array}{l}\text { Portarias №. } 370 \mathrm{e} \\
371 \text { (MEC) }\end{array}$ & 29 de março de 2010 & $\begin{array}{l}\text { Implanta polos de apoio presencial em } \\
\text { quatro municípios do estado do Rio Grande } \\
\text { do Norte (Apodi, Parelhas, São Gonçalo e } \\
\text { Touros) e em quatorze municípios do estado } \\
\text { do Piauí (Altos, Anísio de Abreu, Barras, } \\
\text { Cocal, Itainópolis, Itaueira, Luís Correia, } \\
\text { Paes Landim, Palmeirais, Paulistana, } \\
\text { Regeneração, Santa Cruz do Piauí, São } \\
\text { Raimundo Nonato e Teresina), referente às } \\
\text { ações do Plano de Ações Articuladas (PAR), } \\
\text { com a finalidade de compor o conjunto de } \\
\text { polos do Sistema Universidade Aberta do } \\
\text { Brasil. }\end{array}$ \\
\hline
\end{tabular}

${ }^{34}$ DOU, no. . 238, seção 1, p. 34, de 13/12/2004. 


\begin{tabular}{|c|c|c|}
\hline $\begin{array}{l}\text { Portaria №. } 75 \\
\text { (CAPES/MEC) }\end{array}$ & 14 de abril de 2010 & $\begin{array}{l}\text { Cria o Grupo Assessor do Sistema } \\
\text { Universidade Aberta do Brasil (UAB). As } \\
\text { atribuições do grupo são apoiar a Capes na } \\
\text { formulação das diretrizes estratégicas de } \\
\text { desenvolvimento do Sistema UAB, e: } \\
\text { - apoiar os processos de acompanhamento e } \\
\text { avaliação de cursos e polos de apoio } \\
\text { presencial do Sistema UAB; } \\
\text { - apoiar na formulação de diretrizes para a } \\
\text { elaboração de editais que visem a } \\
\text { consolidação e o desenvolvimento do } \\
\text { Sistema da UAB; } \\
\text { - auxiliar na formulação de políticas e ações } \\
\text { de desenvolvimento do Sistema UAB; } \\
\text { - apoiar na formulação do Plano de Ação } \\
\text { anual para o Sistema UAB. }\end{array}$ \\
\hline $\begin{array}{l}\text { Portaria №. } 77 \\
\text { (CAPES) }\end{array}$ & 14 de abril de 2010 & $\begin{array}{l}\text { Institui o Banco de Consultores para } \\
\text { Acompanhamento e Avaliação do Sistema } \\
\text { Universidade Aberta do Brasil, com o } \\
\text { objetivo de auxiliar a diretoria de Educação a } \\
\text { Distância da Capes nos processos de: } \\
\text { - avaliação e acompanhamento dos polos de } \\
\text { apoio presencial do Sistema UAB e os } \\
\text { oriundos de Programas e Ações do } \\
\text { Ministério da Educação que estão sob a } \\
\text { gestão da diretoria de Educação a Distância; } \\
\text { - avaliação e acompanhamento dos cursos } \\
\text { ofertados na modalidade a distancia pelas } \\
\text { Instituições Públicas de Ensino Superior, no } \\
\text { âmbito do Sistema UAB; } \\
\text { - elaboração e julgamento do objeto de } \\
\text { editais no âmbito de suas atividades e } \\
\text { competências. }\end{array}$ \\
\hline $\begin{array}{l}\text { Portaria №. } 78 \\
\text { (CAPES) }\end{array}$ & 14 de abril de 2010 & $\begin{array}{l}\text { Institui os fóruns }{ }^{35} \text { de área do Sistema } \\
\text { Universidade Aberta do Brasil - UAB, } \\
\text { constituído das seguintes áreas: Matemática, } \\
\text { Física, Biologia, Química, Letras, Pedagogia, } \\
\text { Filosofia, História, Geografia, Artes, } \\
\text { Informática, Teatro, Música, Educação } \\
\text { Física, Sociologia, Administração, } \\
\text { Especializações. }\end{array}$ \\
\hline $\begin{array}{l}\text { Portaria №. } 79 \\
\text { (CAPES) }\end{array}$ & 14 de abril de 2010 & $\begin{array}{l}\text { Institui o Fórum Nacional de Coordenadores } \\
\text { e Coordenadores Adjuntos do Sistema } \\
\text { Universidade Aberta do Brasil - UAB } \\
\text { composto pelos Coordenadores UAB das }\end{array}$ \\
\hline
\end{tabular}

${ }^{35}$ Compete aos fóruns apoiar a diretoria de Educação a Distância da Capes na formulação de parâmetros e diretrizes para o desenvolvimento de ações relacionadas à implantação, oferta, acompanhamento e avaliação dos cursos ofertados no âmbito do Sistema UAB, bem como dos cursos integrados no âmbito do Programa de Ações Articuladas - PAR e dos cursos ofertados pelo Pró-Licenciatura, visando seu aperfeiçoamento e garantia de qualidade (BRASIL, 2010).

${ }^{36}$ Compete aos Fóruns Nacional e Regionais de Coordenadores do Sistema UAB apoiar a diretoria de Educação a Distância na formulação de diretrizes, na definição de parâmetros e critérios técnicos e pedagógicos que norteiem as ações do Sistema UAB relacionados à infraestrutura de polos, oferta de cursos em polos de apoio presencial, seleção e capacitação de tutores, dentre outros (BRASIL, 2010). 


\begin{tabular}{l|l|l}
\hline & \multicolumn{1}{|l|}{$\begin{array}{l}\text { Instituições Públicas de Ensino Superior } \\
\text { (IES) integrantes Sistema Universidade } \\
\text { Aberta do Brasil (UAB) e institui os Fóruns } \\
\text { Regionais de Coordenadores do Sistema } \\
\text { UAB, composto pelos coordenadores de polo } \\
\text { de apoio presencial da região e pelos } \\
\text { Coordenadores e Coordenadores Adjuntos } \\
\text { das IES integrantes do Sistema UAB e que } \\
\text { ofertam cursos na região. }\end{array}$} \\
\hline $\begin{array}{l}\text { Portaria №.1.369 } \\
\text { (MEC) }\end{array}$ & 07 de dezembro de 2010 \\
& $\begin{array}{l}\text { Credencia as Instituições Públicas de } \\
\text { Educação Superior, vinculadas ao Sistema } \\
\text { Universidade Aberta do Brasil, para a oferta } \\
\text { de cursos superiores na modalidade a } \\
\text { distância, pelo prazo de 5 (cinco) anos; e } \\
\text { credencia os polos de apoio presencial para } \\
\text { a modalidade de Educação a Distância. }\end{array}$ \\
\hline
\end{tabular}

\subsubsection{Resoluções}

Tabela 14 - Resoluções relacionadas à regulamentação da EaD no Brasil.

\begin{tabular}{|c|c|c|}
\hline RESOLUÇÃO & DATA & CONTEÚDO \\
\hline $\begin{array}{l}\text { Resolução } \\
\text { FNDE/CD №. } 44\end{array}$ & 29 de dezembro de 2006 & $\begin{array}{l}\text { Estabelece orientações e diretrizes para a } \\
\text { concessão de bolsas de estudo e de } \\
\text { pesquisa a participantes dos cursos e } \\
\text { programas de formação superior, no âmbito } \\
\text { do Sistema Universidade Aberta do Brasil. }\end{array}$ \\
\hline $\begin{array}{l}\text { Resolução } \\
\text { CD/FNDE №. } 24\end{array}$ & 04 de junho de 2008 & $\begin{array}{l}\text { Estabelece orientações e diretrizes para o } \\
\text { apoio financeiro às instituições de Ensino } \\
\text { participantes do Sistema Universidade } \\
\text { Aberta do Brasil, vinculado a CAPES e à } \\
\text { Secretaria de Educação a Distância do } \\
\text { Ministério da Educação, nos exercícios de } \\
\text { 2008/2009. }\end{array}$ \\
\hline $\begin{array}{l}\text { Resolução } \\
\text { CD/FNDE №. } 26\end{array}$ & 05 de junho de 2009 & $\begin{array}{l}\text { Estabelece orientações e diretrizes para o } \\
\text { pagamento de bolsas de estudo e de } \\
\text { pesquisa aos participantes da preparação e } \\
\text { execução dos cursos dos programas de } \\
\text { formação superior, inicial e continuada no } \\
\text { âmbito do Sistema Universidade Aberta do } \\
\text { Brasil (UAB), vinculado à Coordenação de } \\
\text { Aperfeiçoamento de Pessoal de Nível } \\
\text { Superior (Capes), a serem pagas pelo FNDE } \\
\text { a partir do exercício de } 2009 \text {. }\end{array}$ \\
\hline $\begin{array}{l}\text { Resolução } \\
\text { MEC/FNDE №. } 49\end{array}$ & 10 de setembro de 2009 & $\begin{array}{l}\text { Dispõe sobre orientações e diretrizes para o } \\
\text { apoio financeiro às instituições de Ensino } \\
\text { participantes do Sistema Universidade } \\
\text { Aberta do Brasil. }\end{array}$ \\
\hline
\end{tabular}

\subsection{EaD na Argentina}


Na América Latina a Argentina (FACUNDO, 2004, p. 05), junto com o México, é pioneira na Educação a Distância virtual (ALFARO, 2007, p. 111).

La oferta del sistema de educación abierta y a distancia de la Universidad Nacional de Mar del Plata se genera a partir del año 1985. Aparece en el espíritu de la normativa que da cuenta de la creación un fuerte compromiso con la región, a partir de la creación de los CREAP (4) y con un principio rector que estaba asociado a la democratización de la educación de nivel superior, por tanto, democratización del conocimiento. En este sentido, los centros regionales actuaron como elemento clave y configurador del sistema. Este esquema que comienza en 1988 con un curso de "Educador Abierto", logra en 1997 lo que Burton Clark denomina el proceso auto expansivo (5) con una múltiple oferta que va desde cursos sobre Apicultura hasta Introducción a la Informática, pasando por Ciencias Naturales, Bioética y Comercio Exterior. En este esquema de expansión aparece la segunda etapa del sistema que está asociada al surgimiento de una oferta no esencialmente dirigida a cursos o seminarios, sino a carreras: surgen de esta manera, los ciclos superiores de licenciatura -servicio social- o las tecnicaturas: administración pública (1998), gestión cultural (2000), laboratorio (2000) o los ciclos iniciales de carrera: abogacía (1999). Estas dos etapas del sistema recuperan un interjuego muy interesante entre la Universidad y la comunidad a través de una importante oferta académica. A partir de 2001 el sistema se reestructura de acuerdo con la OCS 527/01 que asigna la oferta académica en su vinculación con las Unidades Académicas y terceros. Ésta comprende principalmente cursos de extensión y posgrado y carreras de pre, grado y posgrado. Éste es el comienzo de la tercera etapa del sistema que procura, más allá de las restricciones presupuestarias, incorporar la infraestructura material y técnica así como la actualización de sus recursos humanos para alinearse, junto a otras universidades nacionales y extranjeras, en los umbrales de la virtualidad (UNMdP, 2013).

Porém, na Argentina a Educação a Distância não é considerada somente uma 'modalidade', mas sim um 'serviço', e é oferecida, também, pelo governo especialmente, aos níveis iniciais, como forma de atendimento à formação básica dos filhos de argentinos que estejam residindo temporariamente fora do país (Educación General Básica - EGB ${ }^{37}$ ), pelo programa do Servicio de Educación a Distancia' (ARGENTINA(12), 2013). Desde 2003 a Comisión Federal de Registro y Evaluación Permanente de las Ofertas de Educación a Distancia avalia e gere os processo de EaD para essa demanda.

Em nível médio a iniciativa do Proyecto de Educación Adultos 2000 do governo da cidade de Buenos Aires, lançado em 1998 oferecendo formação secundária paras as pessoas que não haviam completado, sem a obrigatoriedade de assistirem aulas: "Adultos 2000 es un programa de educación a distancia y permite

\footnotetext{
${ }^{37}$ Tem nove anos de duração.
} 
completar el bachillerato sin obligación de asistir a clases, pero contando con el apoyo necesario para poder estudiar" (BUENOS AIRES, 1998).

Em nível superior, diversas opções são oferecidas, porém não há registros de Licenciaturas em Artes Visuais nessa modalidade de Ensino. Apenas na Universidade de Quilmes há um curso de artes que, com parte do programa, é cursado a distância. Porém essa modalidade é chamada de "bimodal", pois tem instâncias que devem ser cursadas presencialmente, na sede da Universidad Nacional de Quilmes: Roque Saenz Peña 352, Bernal, Buenos Aires. Há, ainda, dois bacharelados em Artes Visuais, um na Universidade Nacional del Nordeste UNNE Virtual, e outro na Universidade Nacional do Litoral - UNL Virtual. 
Tabela 15 - Instituições que fazem Educação a Distância na Argentina

Federais:

CURSOS DE ARTES

VISUAIS

\begin{tabular}{|c|c|c|c|}
\hline Instituição & Distância & Presencial & Endereço Internet \\
\hline $\begin{array}{l}\text { Universidad de } \\
\text { Buenos Aires }\end{array}$ & não & não & http://www.uba.ar/academicos/uba21/ \\
\hline $\begin{array}{l}\text { Universidad Nacional } \\
\text { de Rio Cuarto }\end{array}$ & não & não & http://www.eco.unrc.edu.ar/distancia/index.asp \\
\hline $\begin{array}{l}\text { Universidad Nacional } \\
\text { de Rosario }\end{array}$ & não & $\operatorname{sim}^{38}$ & http://www.campusvirtualunr.edu.ar/ \\
\hline $\begin{array}{l}\text { Universidad Virtual de } \\
\text { Quilmes }\end{array}$ & $\operatorname{sim}^{39}$ & $\operatorname{sim}$ & http://www.virtual.unq.edu.ar/ \\
\hline $\begin{array}{l}\text { Universidad Nacional } \\
\text { del Nordeste - UNNE } \\
\text { Virtual }\end{array}$ & $\operatorname{sim}^{40}$ & $\operatorname{sim}$ & http://virtual.unne.edu.ar \\
\hline $\begin{array}{l}\text { Universidad Nacional } \\
\text { do Litoral - UNL } \\
\text { Virtual }\end{array}$ & $\operatorname{sim}^{41}$ & não & http://www.unlvirtual.edu.ar/ \\
\hline $\begin{array}{l}\text { Universidad Nacional } \\
\text { do Tres de Febrero - } \\
\text { UNTREF Virtual }\end{array}$ & não & não & http://www.untrefvirtual.edu.ar/ \\
\hline $\begin{array}{l}\text { Universidad Nacional } \\
\text { do Rio Negro - UNRN } \\
\text { Virtual }\end{array}$ & não & $\operatorname{sim}^{42}$ & $\begin{array}{l}\text { http://www.unrn.edu.ar/sitio/index.php/educ } \\
\text { acion-a-distancia }\end{array}$ \\
\hline $\begin{array}{l}\text { Universidad Nacional } \\
\text { do Rio Cuarto }\end{array}$ & não & não & http://www.unrc.edu.ar/servicios/EaD.htm \\
\hline $\begin{array}{l}\text { Universidad Nacional } \\
\text { do Mar del Plata - } \\
\text { Uabierta }\end{array}$ & não & não & http://www.mdp.edu.ar/uabierta/ \\
\hline $\begin{array}{l}\text { Universidad Nacional } \\
\text { do Lanús - UNLA }\end{array}$ & não & $\operatorname{sim}$ & $\begin{array}{l}\text { http://www.unla.edu.ar/index.php/oferta- } \\
\text { academica }\end{array}$ \\
\hline $\begin{array}{l}\text { Universidad Nacional } \\
\text { de Cuyo - UNCU } \\
\text { (Mendoza) }\end{array}$ & não & $\operatorname{sim}^{43}$ & http://www.uncuvirtual.uncu.edu.ar/ \\
\hline
\end{tabular}

${ }^{38}$ Professorado em Belas Artes. Ao contrário do Brasil, licenciaturas são os nomes dos cursos de bacharelado, pois licenciam para a profissão. Os cursos de formação de professores se chamam "professorado", pois formam "maestros", como são chamados os professores do Ensino básico.

${ }^{39}$ Bacharelado em Artes. O Curso se chama "Licenciatura en Artes y Tecnologías", ao contrário do Brasil, licenciaturas são os nomes dos cursos de bacharelado, pois licenciam para a profissão. Os cursos de formação de professores se chamam "professorado", pois formam "maestros", como são chamados os professores do Ensino básico.

${ }^{40}$ Bacharelado em Artes. O Curso se chama "Licenciatura en Artes Visuales", ao contrário do Brasil, licenciaturas são os nomes dos cursos de bacharelado, pois licenciam para a profissão. Os cursos de formação de professores se chamam "professorado", pois formam "maestros", como são chamados os professores do Ensino básico.

${ }^{41}$ Bacharelado em artes, chamado de "Ciclo de Licenciatura en Artes Visuales". Pertence ao departamento de Arquitectura, Diseño y Urbanismo. Ao contrário do Brasil, licenciaturas são os nomes dos cursos de bacharelado, pois licenciam para a profissão. Os cursos de formação de professores se chamam "professorado", pois formam "maestros", como são chamados os professores do Ensino básico.

${ }_{42}$ Licenciatura em Artes Visuales, Licenciatura em Diseño Visual, Licenciatura em Arte Dramática.

${ }^{43}$ Profesorado de Grado Universitario en Artes Visuales. 


\begin{tabular}{|c|c|c|c|}
\hline $\begin{array}{l}\text { Universidad Nacional } \\
\text { de San Martín - } \\
\text { UnSan }\end{array}$ & não & $\operatorname{sim}^{44}$ & http://www.unsam.edu.ar/campusvirtual/ \\
\hline $\begin{array}{l}\text { Universidad Nacional } \\
\text { de Cordoba }\end{array}$ & não & não & http://www.unc.edu.ar/academicas/PROED \\
\hline $\begin{array}{l}\text { Universidad Nacional } \\
\text { do Sul }\end{array}$ & não & não & http://www.continuar.uns.edu.ar/ \\
\hline $\begin{array}{l}\text { Universidad Nacional } \\
\text { do Centro da } \\
\text { Provincia de Bs. As. }\end{array}$ & não & não & $\begin{array}{l}\text { http://www.rec.unicen.edu.ar/wiki/doku.php? } \\
\text { id=educacionadistancia:start }\end{array}$ \\
\hline $\begin{array}{l}\text { Universidad Nacional } \\
\text { do Santiago del } \\
\text { Estero }\end{array}$ & não & não & http://www.unse.edu.ar/ \\
\hline $\begin{array}{l}\text { FLACSO Virtual - } \\
\text { http://virtual.flacso.or } \\
\text { g.ar }\end{array}$ & não & não & http://virtual.flacso.org.ar/ \\
\hline $\begin{array}{l}\text { Instituto Universitario } \\
\text { da Policía Federal } \\
\text { Argentina }\end{array}$ & não & não & $\begin{array}{l}\text { http://www.universidad- } \\
\text { policial.edu.ar/distancia/index.htm }\end{array}$ \\
\hline $\begin{array}{l}\text { Instituto de } \\
\text { Educación Superior } \\
\text { do Ejército }\end{array}$ & não & não & http://www.iese.edu.ar/distancia/distancia.htm \\
\hline
\end{tabular}

Privadas:

CURSOS DE ARTES

VISUAIS

\begin{tabular}{|c|c|c|c|}
\hline Instituição & Distância & Presencial & Endereço Internet \\
\hline $\begin{array}{l}\text { Universidad } \\
\text { Maimones Online }\end{array}$ & não & não & $\begin{array}{l}\text { http://www.maimonides.edu/online/area virt } \\
\text { ual/area.html }\end{array}$ \\
\hline $\begin{array}{l}\text { Universidad Virtual } \\
\text { Juan Agustín Mazza }\end{array}$ & não & não & http://www.umazavirtual.edu.ar/ \\
\hline $\begin{array}{l}\text { Universidad Gerencial } \\
\text { do Siglo XXI }\end{array}$ & não & não & http://www.21.edu.ar/modalidades/distancia/ \\
\hline $\begin{array}{l}\text { Universidad do } \\
\text { Salvador }\end{array}$ & não & $\operatorname{sim}$ & http://www.salvador.edu.ar/vrid/EaD/EaD \\
\hline $\begin{array}{l}\text { Universidad de } \\
\text { Belgrano }\end{array}$ & não & não & http://www.ub.edu.ar/distancia \\
\hline $\begin{array}{l}\text { Universidad Blas } \\
\text { Pascal }\end{array}$ & não & não & http://www.ubp.edu.ar/ \\
\hline Universidad FASTA & não & não & http://www.ufasta.edu.ar/Edist/ \\
\hline $\begin{array}{l}\text { Escuela de Negocios } \\
\text { na Argentina }\end{array}$ & não & não & $\begin{array}{l}\text { http://www.ean.edu.ar/cursos elearning/e- } \\
\text { learning.asp }\end{array}$ \\
\hline $\begin{array}{l}\text { Instituto de Ciencias } \\
\text { da Salud Barceló } \\
\text { Fundación }\end{array}$ & não & não & http://www.fundacion-barcelo.com.ar/ \\
\hline $\begin{array}{l}\text { Universidad Popular } \\
\text { do Buen Aire }\end{array}$ & não & não & http://ww1.upba.info/ \\
\hline $\begin{array}{l}\text { Centro de } \\
\text { Aprendizaje a } \\
\text { Distancia }\end{array}$ & não & não & http://www.cenaed.com.ar/ \\
\hline Universidad Favaloro & não & não & $\begin{array}{l}\text { http://www.favaloro.edu.ar/cursos-de- } \\
\text { posgrado-a-distancia.html }\end{array}$ \\
\hline
\end{tabular}

${ }^{44}$ Bacharelado em Artes. O Curso se chama "Licenciatura en Artes", ao contrário do Brasil, licenciaturas são os nomes dos cursos de bacharelado, pois licenciam para a profissão. Os cursos de formação de professores se chamam "professorado", pois formam "maestros", como são chamados os professores do Ensino básico. 


\begin{tabular}{|c|c|c|c|}
\hline $\begin{array}{l}\text { Universidad Abierta } \\
\text { Interamericana }\end{array}$ & não & não & http://www.iese.edu.ar/distancia/distancia.htm \\
\hline Universidad ISALUD & não & não & http://www.isalud.org/htm/site/cursos vigentes.asp \\
\hline $\begin{array}{l}\text { Universidad do } \\
\text { Cuenca del Plata }\end{array}$ & não & não & http://www.educacionucp.edu.ar/html/ \\
\hline $\begin{array}{l}\text { Instituto Universitário } \\
\text { CEMIC }\end{array}$ & não & não & $\begin{array}{l}\text { http://www.cemic.edu.ar/instituto universitario/iu } \\
\text { c cursosposgrado cursos distancia.asp }\end{array}$ \\
\hline
\end{tabular}




\subsection{Modelos Pedagógicos em EaD}

Os números da EaD Brasil são bastante expressivos e significativos. Dados apresentados pela Revista Educação (UOL, 2012) mostram que:

No Brasil atualmente, mais professores para a Educação infantil e para o fundamental I são formados por meio de Educação Distância (EaD) do que por Educação presencial.

Dos 118.376 estudantes que concluíram essas habilitações em 2009, 65.354 (55\%) foram graduações obtidas por EaD, contra 52.842 (45\%) egressos da Educação presencial, de acordo com números do Instituto Nacional de Estudos e Pesquisas Educacionais Anísio Teixeira (Inep).

Esse resultado é inédito e confirma uma tendência já evidenciada na série histórica iniciada em 2005.

Daquele ano até 2009, a quantidade de concluintes pelo modelo presencial decresceu, ano a ano, com queda de quase $50 \%$ no período (de 103.626 para 52.842). Ao mesmo tempo, a quantidade de formados por EAD cresceu, aproximadamente, 464\% (de 11.576 para 65.354 ), ou seja, em termos e tendências a EaD (UOL, 2012).

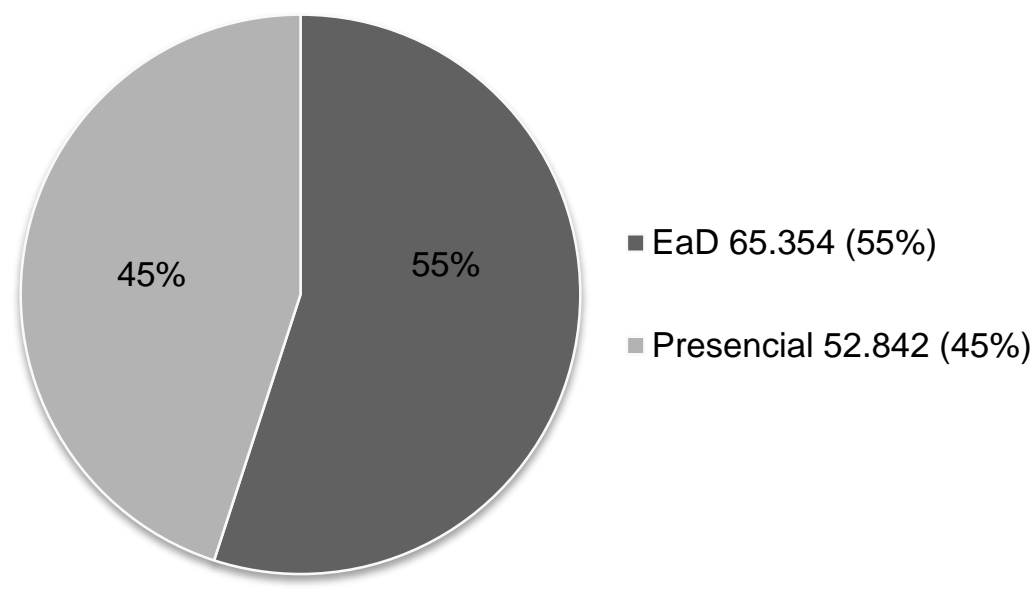

Figura 12 - Gráfico ilustrativo com dados do INEP, do percentual de professores formado por EaD em 2009 (UOL, 2012).

Segundo a Associação Brasileira de Educação a Distância - ABED (2010), quase 310 mil alunos fazem cursos a distância no país. As principais modalidades oferecidas são: pós-graduação; graduação; Educação de jovens e adultos (antigo supletivo); e técnico. O Ministério da Educação - MEC autoriza e regula os dois primeiros; as secretarias são responsáveis pelos demais.

Várias teorias embasam os modelos pedagógicos usados em EaD. Já em 1995 Leindner e Jarvenpaa, estudiosos do tema, mencionam várias escolas pedagógicas 
que sustentam as propostas educacionais por $\mathrm{EaD}$ e suas principais características, numa síntese teórica.

Tabela 16 - Escolas pedagógicas, tradução adaptada de Leindner e Jarvenpaa (1995).

\begin{tabular}{|c|c|c|c|c|}
\hline Modelo & Definição & Objetivo & Premissas & Instrutor/Prof. \\
\hline Objetivismo & $\begin{array}{l}\text { Aprendizado é a } \\
\text { absorção do } \\
\text { conhecimento, sem } \\
\text { nenhuma ênfase na } \\
\text { crítica. }\end{array}$ & $\begin{array}{l}\text { Transferência do } \\
\text { conhecimento do } \\
\text { professor para o } \\
\text { aluno. } \\
\text { Memorização do } \\
\text { conhecimento }\end{array}$ & $\begin{array}{l}\text { Professor detém } \\
\text { todo o } \\
\text { conhecimento. } \\
\text { Estudantes } \\
\text { aprendem melhor } \\
\text { estudando de forma } \\
\text { intensiva e isolada. }\end{array}$ & $\begin{array}{l}\text { Controla o material e } \\
\text { a velocidade de } \\
\text { aprendizado. Provê } \\
\text { estímulo. }\end{array}$ \\
\hline Construtivismo & $\begin{array}{l}\text { Aprendizado é o } \\
\text { processo de } \\
\text { construção de } \\
\text { conhecimento por } \\
\text { um indivíduo. }\end{array}$ & $\begin{array}{l}\text { Formação de } \\
\text { conceitos abstratos } \\
\text { para representar a } \\
\text { realidade. } \\
\text { Dar significado a } \\
\text { eventos e } \\
\text { informações. }\end{array}$ & $\begin{array}{l}\text { Indivíduos aprendem } \\
\text { melhor quando } \\
\text { descobrem sozinhos } \\
\text { e quando controlam } \\
\text { a velocidade do } \\
\text { aprendizado. }\end{array}$ & $\begin{array}{l}\text { Aprendizado } \\
\text { centrado nas } \\
\text { atividades dos } \\
\text { alunos. } \\
\text { Instrutor mais ajuda } \\
\text { do que direciona. }\end{array}$ \\
\hline Colaborativismo & $\begin{array}{l}\text { Aprendizado emerge } \\
\text { através de } \\
\text { entendimento } \\
\text { partilhado por mais } \\
\text { de um aluno. }\end{array}$ & $\begin{array}{l}\text { Promove habilidades } \\
\text { grupais, } \\
\text { comunicação, } \\
\text { participação, } \\
\text { capacidade de ouvir. } \\
\text { Promove } \\
\text { socialização. }\end{array}$ & $\begin{array}{l}\text { Envolvimento é } \\
\text { crítico no } \\
\text { aprendizado. } \\
\text { Reconhece que } \\
\text { alunos tem algum } \\
\text { conhecimento } \\
\text { anterior sobre o } \\
\text { assunto. }\end{array}$ & $\begin{array}{l}\text { Orientado para a } \\
\text { comunicação. } \\
\text { Instrutor atua como } \\
\text { questionador e líder } \\
\text { da discussão }\end{array}$ \\
\hline Cognitivo & $\begin{array}{l}\text { Aprendizado é o } \\
\text { processamento e } \\
\text { transferência de } \\
\text { novos conhecimentos } \\
\text { para a memória de } \\
\text { longo termo. }\end{array}$ & $\begin{array}{l}\text { Melhora as } \\
\text { habilidades } \\
\text { cognitivas dos } \\
\text { estudantes. } \\
\text { Melhorar } \\
\text { memorização e } \\
\text { retenção do } \\
\text { conhecimento. }\end{array}$ & $\begin{array}{l}\text { Limitado pela } \\
\text { atenção seletiva. } \\
\text { Conhecimento } \\
\text { anterior afeta nível de } \\
\text { apoio necessário. }\end{array}$ & $\begin{array}{l}\text { Estímulo pode afetar } \\
\text { a atenção. } \\
\text { Instrutor necessita } \\
\text { retorno do } \\
\text { aprendizado dos } \\
\text { estudantes. }\end{array}$ \\
\hline Sócioculturalismo & $\begin{array}{l}\text { Aprendizado é } \\
\text { subjetivo e } \\
\text { individualista. }\end{array}$ & $\begin{array}{l}\text { Emancipação do } \\
\text { aprendizado. } \\
\text { Orientado para a } \\
\text { ação, consciência } \\
\text { social com a visão } \\
\text { mais de mudar do } \\
\text { que de aceitar ou } \\
\text { entender a } \\
\text { sociedade. }\end{array}$ & $\begin{array}{l}\text { Aprendizado ocorre } \\
\text { melhor em ambientes } \\
\text { familiares ao aluno. }\end{array}$ & $\begin{array}{l}\text { Instrutor é sempre } \\
\text { considerado } \\
\text { representante de } \\
\text { uma cultura. } \\
\text { A instrução é sempre } \\
\text { no contexto social e } \\
\text { cultural do grupo. }\end{array}$ \\
\hline
\end{tabular}

\section{Rodrigues \& Barcia (2013) nos lembram de que}

A adoção de uma teoria em particular ou a criação de um conjunto de atividades que considere várias correntes têm interferência direta na seleção dos conteúdos, no planejamento de atividades e interação entre alunos com professores e colegas, na flexibilidade necessária para considerar o contexto do aluno e no controle do ritmo do aprendizado (RODRIGUES \& BARCIA, 2013). 
Ou seja, a escolha de um modelo de EaD embute, mesmo que não nos demos conta, ideologias e modos de ação e trabalho, inerentes ao modelo escolhido. No entanto, Mattar (2012, p. 16) afirma que o que vivemos nos dias atuais, com a EaD, é o conectivismo, que define como "um desenvolvimento do construtivismo, para o atual cenário do uso da tecnologia na Educação, funcionando assim como uma filosofia para uma EaD alternativa ao fordismo". Essa alternativa também se torna uma escolha e, com ela, também traz características específicas, que devem ser ponderadas. Se é crítica frequente à $\mathrm{EaD}$ fordista que sua estrutura não atende mais às necessidades da contemporaneidade, pois o conceito de autonomia, base dos modelos de EaD fordista e conteudista, é questionado (SIEMENS, 2005), também há críticas quanto à "novidade" do chamado cognitivismo (VERHAGEN, 2006; KERR, 2007; KOP \& HILL, 2008; BELL, 2011), como teoria de aprendizagem.

Moore e Kearsley (2000) sintetizam a história da evolução da EaD, e propõem uma subdivisão em três gerações, sendo que não há necessariamente a substituição de uma alternativa pela outra. $O$ que acontece é que as novas alternativas vão se incorporando e se ajustando às anteriores, criando assim novos modelos.

Tabela 17 - As gerações de Ensino a Distância (MOORE \& KEARSLEY, 2000)

\begin{tabular}{|c|c|c|}
\hline Geração & Início & Características \\
\hline $1^{\text {a }}$. ou textual & Até 1970 & $\begin{array}{l}\text { Estudo por correspondência, no qual o principal meio de } \\
\text { comunicação eram materiais impressos, geralmente um guia } \\
\text { de estudos, com tarefas e outros exercícios, enviado pelo } \\
\text { correio. }\end{array}$ \\
\hline $2^{\text {a }}$. ou analógica & 1970 & $\begin{array}{l}\text { Surgem as primeiras universidades abertas com design e } \\
\text { implementação sistematizadas, no formato de cursos à } \\
\text { distância, utilizando, além do material impresso, transmissões } \\
\text { por televisão aberta, rádio e fitas de áudio e vídeo, com } \\
\text { interação por telefone, satélite e TV a cabo. }\end{array}$ \\
\hline $3^{\text {a }}$. ou digital & 1990 & $\begin{array}{l}\text { Essa geração é baseada em redes de conferência por } \\
\text { computador e estações de trabalho multimídia. }\end{array}$ \\
\hline
\end{tabular}

Anderson \& Dron (2011) nos mostram que, para além dos modelos de EaD anteriores, também há variáveis das pedagogias, esclarecendo as três gerações da pedagogia EaD: behaviorismo-construtivismo, sócioconstrutivismo e conectivismo. 
Tabela 18 - Três gerações da Pedagogia EaD (ANDERSON \& DRON, 2011 apud MATTAR, 2012).

\begin{tabular}{|c|c|}
\hline Geração & Características \\
\hline $\begin{array}{l}\text { behaviorista- } \\
\text { construtivista }\end{array}$ & $\begin{array}{l}\text { Representada pelas teorias de Edward Watson, John Thorndike e } \\
\text { Buruhus F. Skinner. São as ideias que impulsionam o } \\
\text { desenvolvimento do design instrucional e do Instructional System } \\
\text { Design (ISD) e foram bastante usadas em treinamentos, em que os } \\
\text { objetivos de aprendizagem são, em geral, claramente mensuráveis e } \\
\text { demonstráveis comportamentalmente. [...] Da tradição behaviorista } \\
\text { emergiu a teoria cognitivista [...] cujos modelos se baseavam nas } \\
\text { funções e nas operações do cérebro e do modo pelo qual os } \\
\text { modelos computacionais eram utilizados para descrever e testar a } \\
\text { aprendizagem e o pensamento. [...] O foco é a aprendizagem } \\
\text { individual, com liberdade para o aluno seguir seu ritmo e com a } \\
\text { presença da docência reduzida à produção de conteúdo e avaliação } \\
\text { (MATTAR, 2012, p. 18). } \\
\text { O lócus de controle nos modelos behavioristas-cognitivistas é o } \\
\text { professor ou o designer instrucional. É importante notar que esses } \\
\text { modelos adquiriram proeminência em EaD quando havia limitadas } \\
\text { tecnologias disponíveis que permitissem a comunicação muitos-para- } \\
\text { muitos. [...] O foco é a aprendizagem individual, com liberdade para o } \\
\text { aluno seguir seu ritmo e com a presença da docência praticamente } \\
\text { reduzida à produção de conteúdo e avaliação. Esse modelo pode ser } \\
\text { ampliado em larga escala com custos baixos, o que seria } \\
\text { demonstrado pelo sucesso das mega universidades à distância } \\
\text { (MATTAR(1), 2012). }\end{array}$ \\
\hline sócioconstrutivista & $\begin{array}{l}\text { Baseada em Jean Piaget, Lev Vygotsky e John Dewey. [...] } \\
\text { desenvolveu-se em conjunção com as tecnologias de comunicação } \\
\text { de duas mãos, que possibilitaram, em vez de transmitir informações, } \\
\text { propiciar oportunidades para interações entre alunos e professores } \\
\text { (MATTAR, 2012, p. 19). } \\
\text { As pedagogias construtivistas de EaD moveram a aprendizagem a } \\
\text { distância para além do tipo estreito de transmissão de conhecimento } \\
\text { que podia ser encapsulado facilmente em mídia, pela utilização de } \\
\text { aprendizagem síncrona e assíncrona, baseada em comunicações } \\
\text { humanas (ANDERSON \& DRON, } 2011 \text { apud MATTAR, 2012, p. 19). }\end{array}$ \\
\hline conectivista & $\begin{array}{l}\text { Pedagogia da era das redes, em que há grande quantidade } \\
\text { disponível de informações, sendo então o papel do aprendiz não de } \\
\text { memorizar ou mesmo entender tudo, mas de ter a capacidade de } \\
\text { encontrar e aplicar o conhecimento onde e quando necessário. O } \\
\text { conectivismo assume que muito do processo mental e resolução de } \\
\text { problemas pode e deve ser descarregado em máquinas. [...] A } \\
\text { presença cognitiva é enriquecida pelas interações periféricas e } \\
\text { emergentes das redes, em que ex-alunos, profissionais e outros } \\
\text { professores são capazes de observar, comentar e contribuir com o } \\
\text { aprendizado conectivista (MATTAR, 2012, p. 21). }\end{array}$ \\
\hline
\end{tabular}

Uma questão se instala nessa proposição desta pesquisa: Seria a EaD transdisciplinar, baseada nos recursos da web 2.0 o caminho para a pedagogia EaD de 4⿳亠丷. Geração? Ou seja, a EaD feita de modo transdisciplinar?

A chamada pedagogia de redes (PICONEZ, 2012) já tem recursos para isso disponíveis. É preciso a efetivação de propostas de formação que faça uso 
desses recursos tendo essa compreensão de possibilidades, abrangências e desdobramentos, além de ideologias de formação de professores com visões diferentes das atuais propostas.

A organização do currículo em disciplinas, sequenciais, isoladas, o que é realidade frequente, parece não fazer mais sentido. A organização de uma proposta curricular em forma de nuvem de conceitos, ou Nuvem de Tags ${ }^{45}$ poderia proporcionar uma mudança de percepção de necessidades na formação inicial, hierarquizando visualmente os níveis de conhecimento, proporcionando acesso à qualquer tipo de conteúdo em formato digital de forma dinâmica. As nuvens de tags são móveis e alternam o tamanho das tags de acordo com critérios pré-estabelecidos, como importância, pertinência, relação com 0 anteriormente apresentado ou simplesmente por frequência de acesso.

Seria possível, por exemplo, reunir todas as habilidades e competências ${ }^{46}$ mapeadas no estudo dos projetos pedagógicos, e trata-las de modo transdisciplinar, proporcionando navegação trans-temática, de acordo com a evolução/necessidade/especificidade/desdobramento da aprendizagem, de modo individualizado e respeitando os ritmos de cada aluno, numa abordagem realmente trans-conectivista, onde a transdisciplinaridade se dá pelo conectivismo, proporcionando o desenvolvimento individual e coletivo da aprendizagem.

\footnotetext{
${ }^{45}$ Nuvem de tags - ou lista hierarquizada visualmente - é uma forma de apresentar os conteúdo em um espaço hipertextual, como um ambiente web, site, blog ou similares. 'Tag' significa é 'rótulo', 'legenda'. Pense na tag como uma categoria. O uso das tags na web foi difundido por sites como Technorati, del.icio.us e Flickr e o aproveitamento inteligente das novas possibilidades de classificação em interfaces inovadoras significou um alento aos internautas ávidos por melhor sinalização para navegação no mar de conteúdo da rede. Uma nuvem de tags em geral reúne um conjunto de tags utilizadas em um determinado website disposto em ordem alfabética, e o volume de conteúdos que o site apresenta em cada tag é mostrado proporcionalmente pelo tamanho da fonte. Dessa forma, em uma mesma interface é possível localizar uma determinada tag tanto pela ordem alfabética como pela frequência da incidência de conteúdos marcados com a mesma tag no referido site. As tags disponibilizadas na nuvem são links que levam a coleções de itens relacionados às palavras da tag. Ë uma ótima ferramenta para localização de termos e assuntos em ambientes web based (BRASIL, 2012).

${ }^{46}$ Lembrando que o discurso de habilidades e competências é consequência do eficientismo, de uma formação conteudista (que tem, por exemplo, o Sistema $S$ como exemplo claro de organização), que tem como principal defensor, Perrenoud.
} 
Professores conhecedores do "Conteúdo de Conhecimento Tecnológico e Pedagógico ${ }^{47 "}$ capazes de transitar pelos conteúdos já disponíveis na Internet de modo crítico, desenvolto, consciente de seus percursos e processos, que saiba diferenciar e qualificar esses conteúdos, apontando caminhos para que possa vir a orientar os alunos em suas navegações e construções de conhecimentos, bem como auto alimentar a formação, continuadamente. A verificação do atendimento do desenvolvimento das habilidades e competências vem a ser feita pelo que chamo, inicialmente, de transnavegação, ou transaprendizagem, onde o que se busca de novo só é possível ser despertado interesse se o passo anterior for devidamente consolidado como aprendizado.

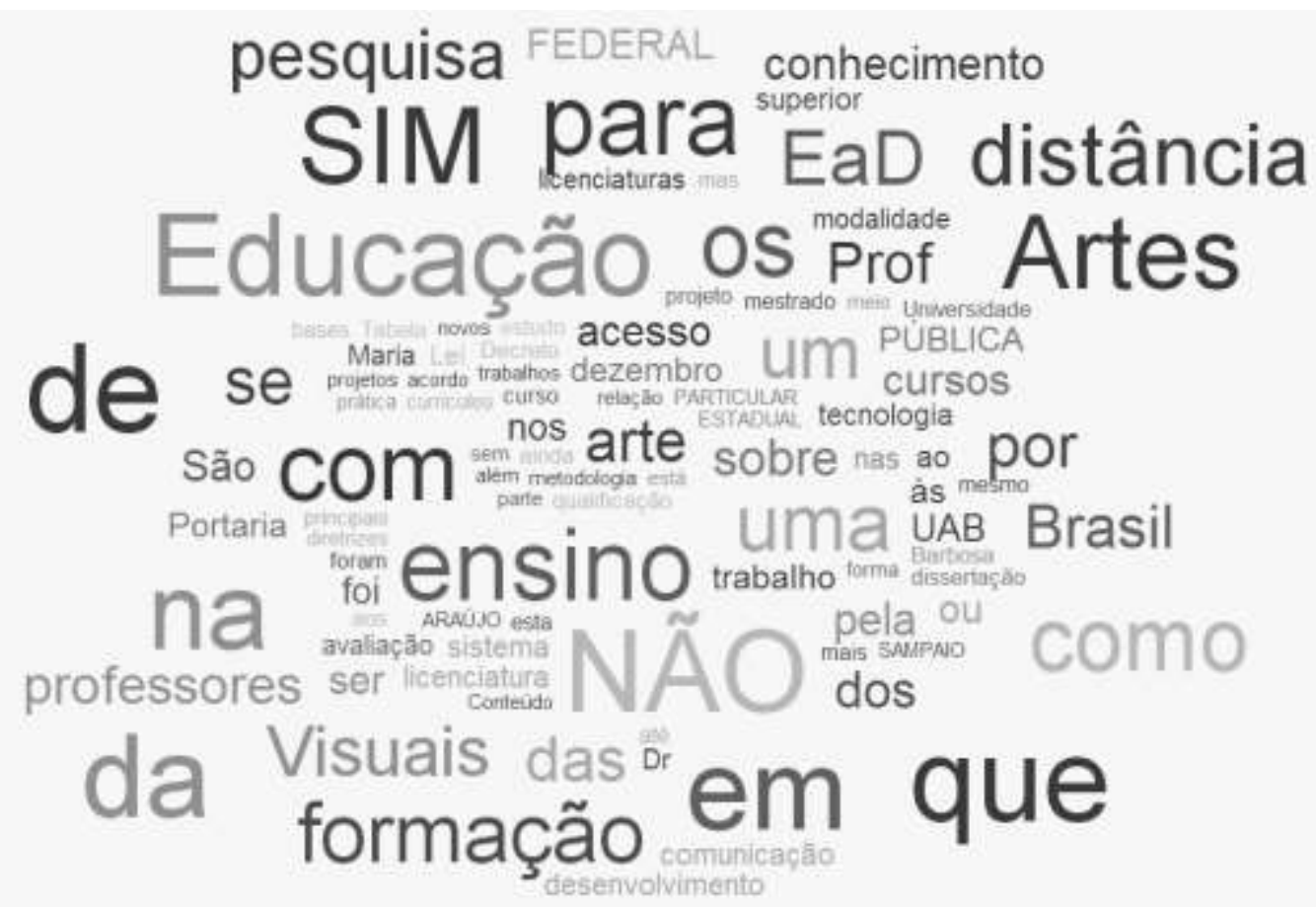

Figura 13 - Exemplo de nuvem de Tags construída com os principais termos relacionados à esta pesquisa ${ }^{48}$.

Os LMS/AVA dão suporte a isso tudo, embora já não sejam nem mais necessários nesse formato de processo de formação. Além de suas funções de gestão e gerenciamento institucional dos processos, os LMS também dão suporte às ferramentas interativas como as disponíveis gratuitamente no Google Art

\footnotetext{
${ }^{47}$ Tradução da sigla TPACK.

${ }^{48}$ Todas as palavras são links que levam ao aprofundamento de conceitos, URL, textos e qualquer outro tipo de material em formato digital. Feita no Word lt Out.
} 
Project $^{49}$, às Ferramentas Open Frameworks como o software Kinect ${ }^{50}$ que permitem interação direta com conteúdos e possibilidades criativas quase infinitas; o Cacoo (criação interativa de gráficos e mapas mentais e conceituais); e uma infinidade de possibilidades, que se multiplicam à cada dia na Internet.

Essas ferramentas ampliam a compreensão da Educação em arte para além da leitura de textos somente. E proporcionam prática artística de ação e criação interativa, em tempo real, ou não; individual ou coletiva; possibilitando, inclusive, transposições espaço-temporais, simulação de presença, Realidade Virtual, sensoriamento etc. Para isso acontecer não é preciso escrever livros novos (os conteudistas), mas sim professores (quiçá tutores, mas num entendimento bem específico do que seja tutoria), não como os atuais, concordando com Mattar (2012) que sempre nos lembra de que

[...] um professor de EaD que não é um mero distribuidor de avisos motivacionais ou respostas pré-formatadas para $F A Q$ - essa função nossos $A V A^{51}$ já estão suficientemente avançados para desempenhar (MATTAR, 2012).

\footnotetext{
${ }^{49}$ Google Art Project é uma espécie de "Street View" (Outra das ferramentas gratuitas do Google) para museus e galerias. São mais de cento e cinquenta espaços totalmente digitalizados, de quarenta países que, no total, somam mais de trinta mil peças de arte em alta resolução. $\mathrm{Na}$ resenha do Olhar Digital é descrito como "Mais do que as obras em alta resolução, o projeto permite que o visitante virtual faça um passeio dentro dos museus, sala por sala. Assim, é possível conhecer exatamente onde cada peça está localizada. Mas, tão bacana quanto visitar virtualmente essas salas, é saber como essas imagens são produzidas!' Disponível em http://www.googleartproject.com

${ }^{50}$ Disponível gratuitamente no site http://www.openframeworks.cc/.

51 AVA é a sigla para Ambientes Virtuais de Aprendizagem, que é como os LMS (learning management system) são chamados por alguns pesquisadores. A tradução de LMS, em português, seria Sistema de Gestão de Aprendizagem. São softwares e/ou sites web que dispõe de funcionalidades de publicação e oferecem interface de administração (back-office) que permite a um administrador de site criar ou organizar as diferentes conteúdos. Falaremos mais dos AVA/LMS a seguir.
} 


\title{
CAPÍTULO III - EDUCAÇÃO A DISTÂNCIA EM ARTES VISUAIS: ANÁLISES, REFLEXÕES, RELAÇÕES E POSSÍVEIS CAMINHOS
}

\begin{abstract}
[...] "embora as políticas públicas anunciem a necessidade da inovação e distribuam equipamentos informáticos como expressão desta vontade, a estreita passagem do anterior para o novo é, ainda, responsabilidade dos professores".
\end{abstract}

Kátia Alonso (2008, p. 756).

Abro o terceiro capítulo com esta epígrafe, de autoria de Kátia Alonso (2008, p. 756), como forma de demarcar qual a visão que dá sustentação às reflexões aqui postas: a preocupação com a qualidade de formação de professores de arte. $\mathrm{O}$ professor é o responsável por formar as novas mentes, que virão a desenvolver a tão aclamada inovação. Segundo Ana Mae Barbosa, em orientação à essa pesquisa,

\footnotetext{
"Inovação" é a criatividade pós-moderna. O "novo" é a revisão do que existe, em prol de suas próprias necessidades. O discurso do início do século, oficial, é a criatividade como ponto central da arte/Educação. De 1920 a 1936 foi o período riquíssimo de criatividade e isso se reflete uma extensa produção cultural. Extensa e significativa (BARBOSA, 2012).
}

Já vimos que, desde a popularização das Tecnologias Digitais de Informação e Comunicação, aliadas às necessidades, cada dia maiores de formação e qualificação profissional, as iniciativas de formação superior de professores via Educação a Distância, embora não sejam exatamente uma novidade, vem ganhando força e muitos novos adeptos.

No evento da Fundação Telefonica, acontecido em 12 de novembro de 2012, em Madrid, com transmissão direta via web direta, Ana María Llopiz (2012) falou de um ponto interessantíssimo que chamou de "La Ley de Internet: 90 / 9 / 1". Em resumo simples, ela disse que a cada 100 conteúdos disponíveis na rede, 90\% das pessoas somente replicam, $9 \%$ interage com esses conteúdos e somente $1 \%$ produz conteúdo novo. 
- replicam - interagem e replicam - conteúdos novos

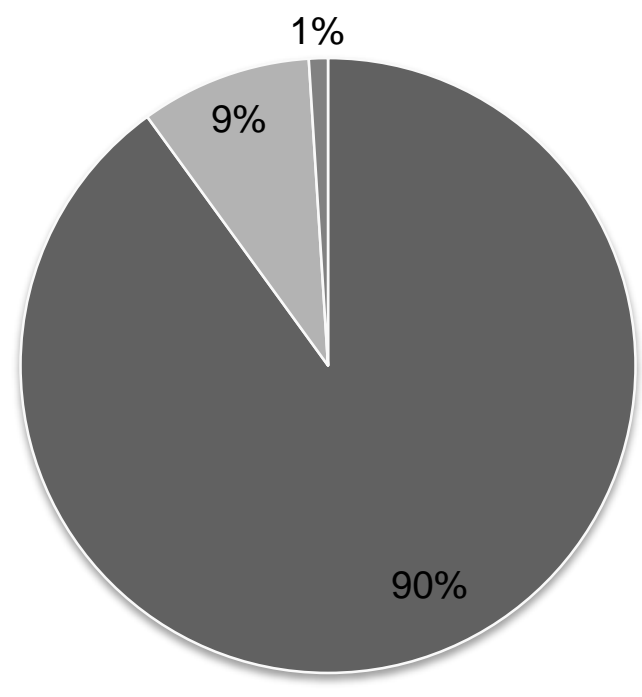

Figura 14 - Gráfico da Lei de Internet, de Ana María Llopiz

Isso é alarmante, levando-se em conta as potencialidades da rede e, principalmente, o volume de informação disponível. Nunca antes se teve tanta facilidade em publicar/disseminar conteúdos e a maioria prefere, simplesmente, repassar conteúdos de terceiros, quase sem reflexão, do que aproveitar as oportunidades tecnológicas para assumir o protagonismo da autoria?

A "inovação", tão falada e mesmo tida como o "caminho" do "futuro da Internet" estaria no conteúdo, mas no conteúdo ORIGINAL de quem realmente PRODUZ conteúdo.

Como área de conhecimento que é, o Ensino de Arte não fica "de fora" desse movimento de popularização e facilitação de acesso à formação e ao conhecimento que as diversas modalidades de Educação a Distância proporcionam, cabendo, também, aos professores, a reflexão acerca dessas possibilidades de ação criadora, criatividade e no que Carlos Seabra (2013) chama de protagonismo autoral. 
Surgem, então, as proposições de formação distância (básica, complementar e continuada) dos profissionais da área, nos fazendo rever e, neste caso em especial, questionar quais os critérios de a eficiência e eficácia vem sendo utilizados para avaliar as iniciativas nesta modalidade de Ensino para a formação de profissionais na área de Artes Visuais que, ressalte-se, irão atuar junto a um público que já nasceu sob a égide tecnológica e é considerado "nativo digital" ${ }^{2}$. Para tanto, parte-se de algumas questões: estarão, estes professores, aptos a exercer uma prática reflexiva em seu trabalho docente? Que professores de arte estamos formando nas Licenciaturas em Artes Visuais por EaD?

Para buscar entender o modo como a EaD em Artes Visuais vem se processando no Brasil, foi necessário localizar e analisar alguns dos programas oferecidos atualmente. Mesmo que em pouca quantidade, como afirma Medeiros (2010):

O potencial da Educação à distância, tão alardeado nos últimos anos, ainda não reverberou suficientemente nas artes, dado que atualmente só existem 21 cursos à distância credenciados na área de artes em todo o Brasil (MEDEIROS, 2010).

Esses programas vêm trazendo propostas de formação que refletem ideais, ideias e politicas educacionais e as práticas de formação utilizadas nessas formações, também distintas, refletem essas situações.

Numa abordagem educacional da arte on-line podemos perceber que, mesmo com todas as possibilidades, características e viabilizações técnicas interativas, que apresentamos e defendemos aqui como positivas para o uso em Educação on-line, não se pode esquecer de que a arte de um povo é um de seus Patrimônios Culturais e que, mesmo com as possibilidades, interessantes e inimagináveis antes do surgimento das tecnologias digitais de comunicação e informação, os indivíduos exercem sua poética e sua criatividade nestes espaços e refletem, em suas ações e interações, sua cultura de origem, projetando, assim, dentro do todo-global, o único-local, se desprendendo, ás vezes, do local, mas

52 Segundo o site <http://www.nativosdigitais.com/> "Nativos Digitais são todos aqueles que nasceram com a tecnologia e são fluentes na linguagem digital dos computadores enquanto que Imigrantes Digitais são todos aqueles que falam a linguagem digital, mas que revelam dificuldades em compreender e expressar-se digitalmente". 
não completamente, e adicionando ao global traços de sua origem e cultura, de seu patrimônio.

As possibilidades de Ensino aprendizagem por $\mathrm{EaD}$ já experimentadas em diversas áreas de conhecimento são tanto possíveis quanto desejáveis em arte. Diferente da "tecnofobia", propagada como senso comum, de algumas áreas da arte-Educação, como constatado, em 2003, em pesquisa de mestrado

Os resultados apresentados pelas pesquisas de campo deste trabalho de investigação indicam que os profissionais entrevistados, em especial os da área artística, apresentam níveis de "tecnofobia" não superiores aos dos públicos não acadêmicos, porém, suas atitudes são conservadoras em relação às tecnologias digitais, levando-os a manterem certo grau de afastamento. O motivo desse distanciamento quando se fala em Realidade Virtual (RV) é maior ainda, pois a RV, antes mesmo de não ser aceita, não é conhecida (SAMPAIO-RALHA, 2003).

Desde essa pesquisa diversos trabalhos, experiências e, principalmente, resultados, mostram, claramente, a eficiência e eficácia educacional da proposição e uso das tecnologias digitais de comunicação e informação e da $\mathrm{EaD}$ nesta área de conhecimento.

Sob a perspectiva sóciointeracionista de Vygotsky (1989) mesmo que a ação seja intencionalmente independente, o artista traz, a sua essência, os traços culturais de sua formação. Isso porque o artista é, antes de tudo, uma pessoa e as pessoas apresentam, em sua formação, os traços de suas culturas e tradições e são as interações e mediações socioculturais que resultam as significações e ressignificações que venham a construir. Ao mesmo tempo em que proporcionam as edições e reedições, em processos intermináveis, as tecnologias digitais de comunicação e informação também proporcionam "acesso".

Entendendo o uso do termo "acesso" como possibilidade de "dar ao conhecimento" as tecnologias digitais de comunicação e informação se tornam, a cada dia mais, vetores de difusão cultural, de acesso imediato e sua característica 
de "editabilidade" 53 acaba por dar voz às minorias que não tinham acesso aos mídias tradicionais para ter expressão, se fazer ouvir e dar-se a conhecer.

A desterritorialização do lócus da cultura proporcionada pelas tecnologias digitais de comunicação e informação e vista pelos críticos da tecnologia como negativa, por desencantar e expatriar pessoas, culturas e manifestações artísticas, argumento frequente dos anti-tecnológicos, também proporciona a diminuição de distâncias físicas entre povos e suas culturas, proporcionando, também, interações criativas que, em análise simples já se percebem extremamente ricas em possibilidades poéticas e educacionais.

A interação globalizada é, ao contrário do que acontece nos mídias convencionais, que impõem uma única visão, editada e formatada dentro de uma visão de mundo e cultura, essencialmente uma via de mão dupla onde trocas são, além de possíveis, desejáveis! Do mesmo modo que sofremos influência de outras culturas, deixamos traços da nossa nos processos interativos e colaborativos.

André Lemos (1999), da UFBA, em seus estudos sobre Arte e Cibercultura, destaca que

[...] a arte exprime sempre o imaginário de sua época; [...] as novas possibilidades tecnológicas começam a interessar os artistas contemporâneos (fotografia, cinema, televisão e vídeo) [...] na década de 70. [...] A transformação espaço-temporal contemporânea, impulsionada pelo advento das novas tecnologias e pela crise dos meta-discursos da modernidade, vai concretizar aquilo que o sociólogo francês Léo Scheer identificou como 'civilização do virtual.

Mesmo usando o termo "virtual", o entendimento de Lemos (1999) das potencialidades desse virtual está, nitidamente, relacionado com as tecnologias digitais de comunicação e informação como sinônimo de acesso e manipulação das propriedades da linguagem digital.

53 Neologismo usualmente referido na área de tecnologia, referindo-se a capacidade ou possibilidade de edição de conteúdos, códigos e aplicativos, no sentido de serem ou estarem abertos às contribuições de terceiros, para customização e atendimento de necessidades específicas dos usuários. Uma das mais evidentes características das TIC é a editabilidade. 
Destaque especial pode ser feito à afirmação que faz de que "Toda arte ("tekhnè") exprime um processo de virtualização e de atualização. Toda técnica é a virtualização de uma ação e, ao mesmo tempo, atualização (de uma questão) pelo dispositivo. A arte/técnica, como atividade "poiética", é um dom original do homem". Reafirmando que a Arte está presente em todas as culturas, como atividade inerente à condição humana.

Interessante notar, ainda, que Pierre Levy (1994, apud LEMOS, 1999) afirma que "a Arte é uma 'virtualização da virtualização" e Lemos (1999) adiciona ao raciocínio de Levy a afirmação de que:

[...] encontrando-se no meio dos processos de virtualização da linguagem, da técnica e da ética buscando, ao mesmo tempo, escapar do aqui e do agora (virtualizando) e propor soluções concretas às suas questões (atualizando). A Arte virtualiza as virtualizações, tentando saídas de situações limitadas a um aqui e agora físico e/ou simbólico. Esse processo não é exclusivo da arte eletrônica, fazendo parte de toda forma artística. No contexto da arte eletrônica contemporânea, esse processo atinge uma radicalização sem precedentes, pois a arte continua a ser virtualização de uma virtualização, só que agora sob uma forma puramente digital, utilizando-se de uma tecnologia também virtualizante (digital) (LEMOS, 1999, S/N).

Seu Art. "Arte Eletrônica e Cibercultura" (LEMOS, 1999) merece estar presente em qualquer discussão atual sobre arte, cultura, história e Educação pela riqueza e propriedade com que embasa suas propostas. Sua reflexão acerca da cibercultura substituir a "tecno-cultura" da modernidade é de uma lucidez quase "oracular" sobre a condição da arte na cultura digital afirmando que a "conexão, interação, simultaneidade, participação plural e interativa constituem o espaço híbrido fundamental da ciberarte hoje", mesmos temas e abordagens tratados e incluídos no conceito de wikinomics $^{54}$, de Tapscott (2006). Destacando e

\footnotetext{
${ }^{54}$ Wikinomics é um neologismo criado por Don Tapscott e Anthony D. Williams, que deu origem ao livro Wikinomics: How Mass Collaboration Changes Everything, publicado em 2006 nos EUA e, no ano seguinte, lançado no Brasil. Para cunhar o termo Wikinomics, os autores basearam-se na ferramenta wiki, que, segundo eles, "mais que um programa que permite que múltiplas pessoas editem sites, é uma metáfora para uma nova era de colaboração e participação". O conceito tem como base a ideia da "colaboração de massa" e de como essa possibilidade de trabalho está mudando o mundo empresarial. Ele afirma que "a nova colaboração de massa está mudando a maneira como as empresas e as sociedades utilizam o conhecimento e a capacidade de inovar
} 
lembrando que Lemos faz suas observações antes do ano 2000, é particularmente interessante notar o último parágrafo do seu texto, que diz:

A ciberarte tem no processo de virtualização, digitalização e desmaterialização do mundo a sua força e particularidade. Ela é interativa e atua dentro dos espaços híbridos da cultura contemporânea (o espaço, o tempo e o corpo). Por ser imaterial, a arte eletrônica não se consome com o uso e pode circular ao infinito, escapando da lei entrópica da sociedade de consumo. É nessa circulação frívola de bits que está o coração da arte eletrônica da cibercultura. Mais sexual e intuitiva do que racional e dedutiva, a ciberarte tenta produzir novos espaços de experiências estéticas e interativas, sob a energia do digital (LEMOS, 1999, S/N).

As orientações formuladas pela UNESCO (1991) para a formação de professores no Projeto Principal de Educação para a América Latina e Caribe (1981-2001), embora considerem que a formação de professores seja ponto central na sequência das prioridades de universalização da Educação, é colocada pela UNESCO como

elemento central para o desenvolvimento econômico, devendo ser objeto de consensos nacionais que garantissem o compromisso de toda sociedade e a continuidade das políticas públicas (UNESCO, 1991, p. 01).

O documento lembra que as aprendizagens escolares eram, até a ocasião, pouco significativas, não refletindo os aspectos da cultura contemporânea e as demandas sociais e foi sugerida a promoção de mudanças curriculares que concretizassem propostas baseadas na satisfação das necessidades educativas básicas do indivíduo e da sociedade. Tais propostas

[...] deveriam possibilitar o acesso à informação que permitisse pensar e expressar-se claramente e que fortalecesse capacidades para resolver problemas, analisar criticamente a realidade, vincular-se ativa e solidariamente com os demais, proteger e melhorar o meio-ambiente, o patrimônio cultural e as suas próprias condições de vida (UNESCO, 1991, p. 01).

Porém, ação coletiva não é coletivismo. O pioneiro digital Howard Rheingold (2006, p. 28) ressalta que "coletivismo envolve coerção e controle centralizado,

para criar valor" e que "isso afeta praticamente todos os setores da sociedade e todos os aspectos da gestão". 
ação coletiva envolve auto seleção livremente escolhida e coordenação distribuída". Se já se acreditava que a individualidade criativa reflete, por e em diversos momentos, a herança coletiva dos indivíduos, os processos colaborativos, facilitados pela manipulação das tecnologias digitais de comunicação e informação permitem tecer fios e encadear tramas capazes de proporcionar o desenvolvimento de conhecimentos, habilidades e competências permeadas por visões sócioculturais, políticas e educacionais.

Para atender a estas novas demandas sócioculturais e educacionais pode-se recorrer ao uso dos recursos e ferramentas das tecnologias digitais de comunicação e informação nos processos de Ensino-aprendizagem também para a formação docente.

\subsection{Que professores queremos formar?}

Durante os levantamentos iniciais dessa pesquisa, constatei que, antes de avaliar qualquer das propostas pedagógicas, era preciso estabelecer, para base dessa avaliação, que tipo de professor esta pesquisa considera um "bom professor", para que, assim, fosse possível construir um olhar adequado para a avaliação proposta.

As Diretrizes Curriculares Nacionais dos Cursos de Graduação em Artes Visuais, que foram definidas pela Câmara de Educação Básica do Conselho Nacional de Educação, por meio da Resolução №. 01, de 16 de janeiro de 2009, em seu Art. 2․ dizem que:

\footnotetext{
A organização do curso de que trata esta Resolução e o Parecer indicado no artigo precedente se expressa através de seu projeto pedagógico, abrangendo o perfil do formando, as competências e habilidades, os componentes curriculares, o trabalho de curso, o projeto de iniciação científica, o estágio curricular supervisionado, as atividades complementares, o sistema de avaliação, além do regime acadêmico de oferta e de outros aspectos relevantes.
}

Nos dias atuais é quase consenso que os saberes racionais não são suficientes para enfrentar, sozinhos, a complexidade e a diversidade das situações de 
trabalho. Busca-se, em todas as áreas de atuação, refletir sobre novas formas de exercício das profissões. As ideias de Donald Schön (1992) a respeito do profissional reflexivo se encaixam nesse cenário, propondo a reabilitação da razão prática, a aprendizagem por meio da experiência (DEWEY), a utilização da intuição e da reflexão na ação e sobre a ação. Assim, um dos enfoques dados à formação docente é o da "formação do professor-pesquisador; ou seja, ressaltase a importância da formação do profissional reflexivo; aquele que 'pensa-naação', e cuja atividade profissional parece estar aliada à atividade de pesquisa" (SCHÖN, 1992, p. 41). "Prática reflexiva", "reflexão na ação" e "professor como investigador na ação" são alguns dos termos usados para designar este enfoque, dentre outros.

O fato de um profissional refletir sobre sua ação, diz Schön (1992), pode torná-lo um pesquisador no contexto prático dentro do modelo de racionalidade técnica. Porém, nos programas guiados por esta lógica, o mundo acadêmico é separado do mundo da prática, e as disciplinas em que se 'aprende' os conhecimentos específicos aparecem no início dos cursos de formação, seguidas com as de aplicação do conhecimento. Isso torna implícita a ideia de que o desenvolvimento de competências profissionais deveria vir só após o conhecimento científico básico (SILVA E SCHNETZLER, 2000). Mas este modelo se sustenta num mundo onde temos, como hoje, acesso facílimo à informação, pelas Tecnologias Digitais? Sabemos que somente o conhecimento específico de conteúdos de disciplinas não torna o estudante um profissional apto a exercer sua atividade, neste caso, prática docente em Artes Visuais. Mas, sabemos como formar profissionais de Ensino de Arte por meio dessas mesmas tecnologias?

Como um ponto de partida, Sardelich, Santana \& Melo (2012) destacam que, na formação de professores, é necessário, contemplar "os desafios propostos pelo entendimento do par "teoria-prática" e o conceito de simetria invertida, expressos no Art. 3o, da Resolução CNE/CP №. 01/2002, que institui as Diretrizes Curriculares Nacionais para a Formação de Professores da Educação Básica" (BRASIL, 2002). Ao afirmar que "em linguagem visual o conceito de simetria vincula-se à organização formal e refere-se à igual distribuição dos elementos de 
uma forma dos dois lados de uma linha ou eixo imaginário" (SARDELICH, SANTANA \& MELO, 2012). E questionam: "A partir desse conceito visual poderíamos pensar na organização formal dos espaços virtuais de aprendizagem com a igual participação e poder de decisão entre professores e alunos? De que modo se daria a inversão dessa igual distribuição?' (Idem, 2012). As inquietações propostas em trabalho reflexivo do trio (Idem, ibidem, 2012) sugerem caminhos investigativos:

\begin{abstract}
A Resolução CNE/CP №. 01/2002 indica que o preparo do professor ocorre em lugar similar àquele em que vai atuar e demanda consistência entre o que faz na formação e o que dele se espera como professor. Isso implica a coerência entre a formação oferecida e a prática esperada do futuro professor. [...] O conceito de simetria invertida indicado na Resolução CNE/CP №. 01/2002 [...] nos levaram a questionar sobre como Licenciados que aprenderam gestos, expressões, maneiras, movimentações de corpo, por conviver com seus professores presencialmente durante a sua formação inicial atuam na modalidade a distância que requer outro tipo de gesto e comunicação com os alunos. Também invertemos essa mesma observação e nos questionamos sobre como Licenciandos que aprendem gestos e maneiras de atuar e comunicar mediados pelas Tecnologias da Informação e Comunicação de um Ambiente Virtual de Aprendizagem (AVA) poderão atuar com seus alunos na presencialidade? De que modo professores formados na modalidade presencial estão "formando/se" para "formar" a distância professores que "formarão" na modalidade presencial? [...] Até que ponto propomos aos Licenciandos na modalidade a distância situações de aprendizagem coerentes com a prática que se espera do mesmo como futuro professor? As situações de aprendizagem propostas nesta Licenciatura dão conta de desenvolver as competências indicadas no PPC como perfil profissional? O corpo docente propõe as situações de aprendizagem no AVA a partir das suas teorias ingênuas conformadas em suas experiências como alunos na modalidade presencial? O corpo docente propõe situações de aprendizagem no AVA a partir das próprias experiências de "forma/R/se" nesse ambiente na medida em que necessita resolver situações diferentes das aprendidas na formação inicial? (SARDELICH, SANTANA \& MELO, 2012).
\end{abstract}

João Mattar reforça a ideia de questionar as especificidades da formação dos professores em EaD, questionando as funções dos professores tutores nos atuais cursos pode $\mathrm{EaD}$, afirmando que o ideal, na prática da EaD é

[...] Um tutor é um professor que precisa dominar as ferramentas e plataformas que utiliza, conhecer diversas teorias de aprendizagem e comunicação, ser letrado em linguagens on-line e transitar por diferentes paradigmas educacionais (MATTAR, 2012, p. 175). 
Para Piaget (apud OLIVEIRA, FONSECA e BIAZUS, 2007) o conhecimento se produz na interatividade.

Interatividade é hoje em dia uma palavra de ordem no mundo dos media eletrônicos. Hoje tudo se vende como interativo; da publicidade aos fornos de micro-ondas. Temos agora, ao nosso alcance, redes interativas como Internet, jogos eletrônicos interativos, televisões interativas, cinema interativo... A noção de "interatividade" está diretamente ligada aos novos media digitais. O que compreendemos hoje por interatividade, nada mais é que uma nova forma de interação técnica, de cunho "eletrônico-digital", diferente da interação "analógica" que caracterizou os media tradicionais (LEMOS, 1999, p. 01).

Mas somente 0 uso das tecnologias não implica necessariamente em interatividade, embora sejam ricas em possibilidades. Piaget diz que

[...] na vida social, como na vida individual, o pensamento procede da ação e uma sociedade é essencialmente um sistema de atividades, cujas interações elementares consistem, no sentido próprio, em ações se modificando umas às outras, segundo certas leis de organização ou equilíbrio [...] É da análise dessas interações no comportamento mesmo que procede então a explicação das representações coletivas, ou interações modificando a consciência dos indivíduos (1973, p. 33).

Essas representações coletivas a que se refere Piaget são as bases de qualquer trabalho em rede, ou seja, "o conhecimento humano é essencialmente coletivo, $e$ a vida social constitui um dos fatores essenciais da formação e do crescimento dos conhecimentos [...]" (PIAGET, 1973, p. 17). Assim, reforça-se o questionamento: a universidade está apta a desenvolver formação eficiente e eficaz para os futuros professores por meio de tecnologias? As novas gerações já dominam e têm trânsito "corriqueiramente" como meio de aprendizagem? Estão, os professores dos cursos de licenciatura por EaD, aptos a exercer essa formação, proporcionando interatividade, reflexão, prática artística e desenvolvimento de poéticas no ciberespaço?

Tanto a Epistemologia genética de Piaget quanto o sócioconstrutivismo de Vygotsky, apesar de suas diferenças, são considerados teorias interacionistas. Ambas defendem que é através de interações que os seres humanos se desenvolvem e aprendem. [...] Freire (1982) defende também a importância da interação na Educação (MATTAR, 2012, p. 27). 
Como provocar situações de desequilíbrio, orientando para construção do conhecimento e não somente ao acesso à informação? Como proporcionar, aos futuros professores de Artes Visuais, no Ensino superior e na universidade, uma formação para a pesquisa e à prática reflexiva? Como promover a interatividade e a reflexão por meio de ferramentas que são distribuidoras de informação? Como transformar esta informação, de fácil acesso, em elementos de uma reflexão acerca de sua futura prática? Como proporcionar condições para que esta prática venha a ser também reflexiva?

Bailey (Et. Al. 1998) lembra-nos que a reflexão feita regularmente sobre suas próprias experiências de sala de aula auxilia os professores a identificarem as áreas de sua prática de Ensino que precisam de atenção e, assim, promover a sua formação contínua. Como promover esta reflexão constante em nossos alunos em formação na Licenciatura em Artes Visuais por EaD? Nós mesmos, quando somos os formadores, refletimos sobre nossa prática com uso dessas mesmas tecnologias para fins educacionais? Será que estamos mesmo refletindo e promovendo a reflexão ou apenas repetimos padrões presenciais não reflexivos de Educação e formação, potencializados pela tecnologia, no que diz respeito à "entrega" de conteúdos cristalizados, por meio de modelos fixos, ou "engessados", de "ambientes" que nem mesmo exploram adequadamente as possibilidades comunicacionais e interativas proporcionadas pelas Tecnologias Digitais?

A definição dos contornos do trabalho do professor em EaD depende diretamente do modelo adotado. Modelos mais rígidos acabam limitando de tal maneira o trabalho do professor que ele se transforma em um mero emissor de mensagens motivacionais (com um cronograma já traçado), o que suscita questionar se isso deve ser considerado trabalho docente. Esse tutor-robô não é um professor. De outro lado, modelos mais flexíveis permitem um trabalho docente criativo e construtivo em EaD. [...]. Essa discussão é importante para mostrar que um modelo não é somente um enfeite pedagógico, mas traz em si marcas de suas origens, de seus objetivos e de seus comprometimentos, determinando decisivamente o desenho dos projetos de EaD. Convenço-me cada vez mais de que muitas pessoas que decidem, planejam e elaboram projetos têm apenas um modelo industrial de EaD na cabeça, um modelo de "autonomia" do aluno, e naturalmente não conseguem construir - nem mesmo enxergar - um universo alternativo. [...] Projetos pedagógicos, portanto, não são atividades totalmente neutras, ao contrário, pressupõem paradigmas, matrizes culturais e históricas [...] (MATTAR, 2012, p. 01-02, grifo nosso). 
Os professores e tutores das Licenciaturas em Artes Visuais a distância estão realmente preparados para exercer uma prática reflexiva dentro do Universo Virtual? Como promover a nossa própria reflexão contínua, como professores nessas licenciaturas, motivando em nossos alunos, pela repercussão de nossa prática junto ao trabalho na sua formação, inicial, e em nossa própria formação continuada? Como construímos nossa prática? Ela é reflexo de formação e intencionalidade educacional reflexiva? Sabemos onde queremos chegar?

Segundo André (1995, p. 107):

[...] ao se definir o professor como produtor de conhecimento que é, julga-se necessário refletir com ele como se (re) apropriar de conhecimentos que permitam reconstruir continuamente a sua prática docente (ANDRÉ, 1995, p. 107).

Ou seja, sendo o professor um produtor de conhecimento, nesse universo virtual deveríamos ser, nós mesmos, reflexivos em nossa prática, a ponto de exemplificar, na prática, as teorias de formação centrada no aluno (discurso muito empregado pela Educação superior atual), para proporcionarmos aos nossos alunos de Licenciaturas em Artes Visuais a distância, em sua formação, uma visão consistente sobre a prática reflexiva.

Como desenvolver uma prática reflexiva nessa organização onde "o tutor não tem liberdade nenhuma" (MATTAR, 2012, p. 52)? Para Mattar (2012, p. 52) "tutor não é um ator na EaD fordista, conteudista e behaviorista: é uma marionete, um robô". Como isso acontece com a atual estrutura da UAB, maior iniciativa em EaD no Brasil?

Para tentarmos responder a essas questões é necessário pensamos, antes de metodologias, em Epistemologia da Educação a Distância em Artes Visuais! Refletirmos sobre a própria prática docente no sentido da construção do conhecimento nos suportes digitais e virtuais de Educação, usados pela EaD. A reflexão acerca da prática, procurando, senão explicação, ao menos consciência sobre $\mathrm{o}$ andamento e gerenciamento de tarefas/funções como professores à 
distância é uma prática a ser definitivamente adotada como uma episteme contemporânea de termos (e processos) como mestiçagens, hibridações, ruptura das fronteiras disciplinares em contraposição aos princípios de pureza e eugenia nos campos de saber - conduzidos pelo chamado saber disciplinar - que se deu, sobretudo, a partir de Descartes. Seria possível dentro desse modelo "fordista" de EaD? Estabelecer claramente objetivos e metas de Ensino aprendizagem e as rever ao longo do processo ou continuaremos a agir como meros aplicadores de conteúdos?

É fato que as atribulações da vida cotidiana "atropelam" e, muitas vezes, a consciência da necessidade de reflexão está presente, mas que, na prática, não acontece... E, como querer formar professores de Artes Visuais que estejam aptos a exercer uma prática reflexiva, e assim venham a agir, se os processos responsáveis por essas formações, não exercem prática reflexiva em sua didática? Como efetivar uma prática reflexiva sem, realmente, praticar a reflexão? E, dentro de uma estrutura de formação fordista? Segundo Brown (2001):

[...] é por meio da compreensão de algumas variáveis no gerenciamento de classe - que incluem inúmeros fatores, desde a disposição física dos objetos e móveis na sala de aula e estilos diferentes de ensinar, até o fluxo energético no contexto de aprendizagem - que o professor pode aperfeiçoar suas habilidades como facilitador do aprendizado, pois ele poderia ir além destes aspectos observáveis, abrindo portas para o intangível, para o universo inesgotável da criatividade e da arte, para as partículas invisíveis de energia que alimentam o brilho de uma aula eficaz (BROWN, 2001).

Brown (2001) se refere, especificamente, aos espaços físicos, mas, como exercer o gerenciamento do espaço virtual, a disposição dos recursos e o que ele chama de "fluxo energético", que nos espaços virtuais de prática é chamado de "convivialidade" e "pertença" (SAMPAIO-RALHA, 2007, p. 167-182), sem a autonomia de ser um professor autor, ou, como chamam Mattar \& Valente (2007): "aututor"? Pode parecer até ingênuo e "romântico", num primeiro momento, pensar essas questões, que percebemos como essenciais para 0 desenvolvimento de práticas reflexivas consistentes e eficazes, mas a quantidade exorbitante de formandos que não sabem desenvolver nem mesmo um Trabalho de Conclusão de Curso consistente nos mostra que é uma discussão essencial! 
Desde o anterior Ensino de "mexer no computador", até os dias de hoje, muito foi percorrido, mas é fato que estamos diante do desafio prático de formar professores de arte e ensinar Artes Visuais por meio das Tecnologias Digitais. Fato que não extingue a necessidade de saber "mexer no computador", mas que exige reflexão acerca de como promover a aprendizagem a distância por meio do uso do computador, configurando-se em um campo epistemológico ainda pouco estudado.

A busca de uma Epistemologia da Educação a Distância em Artes Visuais, que contemple a própria "Epistemologia da arte", de que fala Ana Mae (2010, p. 34), é o que vem norteando os rumos tomados por esta investigação. Um olhar para além do foco nas metodologias, frequentemente abordadas nos trabalhos de investigação atuais. As diferentes terminologias, conceituações e características da EaD emergem de bases epistemológicas de como se dá o processo de compreensão de mundo e de relações sujeito-objeto, professor-aprendente etc., e que dão sustentação a toda e qualquer prática educativa. Já passamos da "fase" de questionar a validade e eficiência da EaD como modalidade educativa. Centenas de trabalhos mostram as qualidades (e defeitos!) dessa modalidade. Tomando emprestada a referência à Marcel Duchamp, feita por Medeiros (2010, p. 96) de que "Existe arte boa e arte ruim. Assim como existe sentimento bom e sentimento ruim", ampliando a percepção, é válido afirmar que existe $\mathrm{EaD}$ em Artes Visuais boa e ruim.

O objetivo desta investigação não é o de defesa da modalidade, mas sim o de averiguar a forma de alcançar excelência em EaD em Artes Visuais, sugerida por Ralph Smith, que destaca que

a preocupação com a qualidade deve, na verdade, estar presente em todas as esferas da instituição escolar, [...] ao falar de excelência no Ensino de Arte estamos falando não somente sobre as qualidades e significados de trabalhos dos grandes artistas e das experiências que eles podem nos proporcionar, mas da postura diante da realização artística em geral [...] (2001, p. 98), 
procurando uma consciência crítica sobre as práticas atuais, buscando evitar "cair na tentação" de querer ser definitivo, mas procurando conhecer possibilidades, a fim de evitar um caminho que parece querer "reinventar a roda".

Já estamos vivendo o que apontou Robert Ott, quando afirmou que:

[...] os alunos do futuro continuarão a aprender a partir de reproduções, mas essas imagens serão, sem dúvida, obtidas por computador. [...] Uma simulação da Roma Antiga ou da Londres Vitoriana ou de uma obra específica como Mona Lisa ou Guernica serão realizadas por computador e [...] apresentadas como nos museus [...] fazendo com que os alunos possam perceber que pinturas como essas não são do tamanho que parecem ter na tela de projeção na sala de aula (OTT, 2001, p. 121-122).

Dessa forma, os questionamentos aqui levantados não se encerram neste trabalho. Nem mesmo creio que sejam os únicos e definitivos, no processo. Ao contrário, se constituem em marcos iniciais, pontuadores de reflexões acerca de possíveis caminhos para aprofundamento, sempre abertos ao diálogo e à interlocução, porém com um norte a guiar.

Sendo a EaD uma forma de comunicação pedagógica não contínua, seja ela unidirecional ou bidirecional (HOLMBERG, 1989, p. 20), é necessário destacar que, no meio educacional, a comunicação é, muitas vezes, encarada como um processo de mão única. Nos processos educacionais atuais o emissor parece dominar, e isto acontece não apenas na sala de aula, mas também nas escolas e nos sistemas públicos de Ensino. A escola, até então vista como sinônimo de livros, vê a situação mudar - e isso também é devido à acessibilidade de novas tecnologias de informação e comunicação (VAN VELZEN, 1998, p. 29). Será que os projetos de cursos de Licenciatura em Artes Visuais na modalidade EaD estão realmente assimilando e refletindo estas mudanças?

Com efeito, nos modelos de $\mathrm{EaD}$ (em geral) nota-se uma ênfase excessiva nos processos de Ensino (estrutura organizacional, planejamento, concepção de metodologia, produção de materiais etc.) e pouca ou nenhuma consideração dos processos de aprendizagem (características e necessidades dos estudantes, modos e condições de estudo, níveis de motivação etc.). Pode-se dizer que as práticas propostas e/ou descritas pelos modelos de $\mathrm{EaD}$ referem-se muito mais 
aos "sistemas ensinantes" do que aos "sistemas aprendentes" (CARMO, 1997, p. 30).

A busca do perfil de professor como egresso de formação que esta pesquisa desenvolveu deu-se com base na síntese reflexiva acerca das teorias que propõem o perfil do professor reflexivo. O quadro, a seguir, sintetiza as reflexões acerca de autores que tratam do tema "Professor Reflexivo", estudados nesta pesquisa na busca do perfil "ideal" de formação de professores, considerando as tendências contemporâneas em Educação.

As atuais tendências investigativas sobre formação de professores valorizam o professor-reflexivo (SCHÖN, 1990; ALARCÃO, 1996), onde o professor é compreendido como um ser intelectual em processo contínuo de formação, mas as referências teóricas que embasam a perspectiva aqui apresentada incluem trabalhos sobre a formação de professores prático-reflexivos (DEWEY, 1959; ZEICHNER, 1992 1993; ZEICHNER e LISTON, 1996; PÉREZ GÓMEZ, 2000) e sobre a formação de professores reflexivos por meio da EaD (VALENTE, 2009; SCHERER, 2009; PRADO E ALMENIDA, 2009 e NEVADO et. at., 2009), numa busca de um modelo de formação fundamentado na "racionalidade prática" (SCHÖN, 2000) por reconhece a complexidade do trabalho docente e da realidade escolar.

Esse quadro reflete a síntese teórica dos trabalhos de Moraes (2002), Stenhouse (1998), Schön (1992, 2000) e Zeichner (1993) de como age, pensa, atua e se organiza a prática de um professor reflexivo, e é este perfil de professor, que esta pesquisa considera como um professor "bem formado" e que serviu como base na análise das propostas estudadas por esta pesquisa: um professor ativo, atuante, com competências e habilidades práticas e teóricas que buscará desenvolver, com seus alunos, essas mesmas habilidades e competências de forma a formar cidadãos reflexivos e questionadores da(s) realidade(s) em que vivam.

Dessa forma, na busca da construção da chamada Epistemologia da Educação a Distância em Artes Visuais consideramos que a autonomia e prática reflexiva são 
fatores relevantes na formação de professores de arte, em qualquer modalidade como seja feita essa formação, seja presencial, seja por Educação a Distância. 
Tabela 19 - Professores reflexivos (PITARELLO, SAMPAIO, SUZUKI \& TRAMUJAS, 2010).

\section{O que é a prática reflexiva?}

A prática reflexiva é, sobretudo, um modo humano de educar. Trata-se de uma prática voltada para a ação e para a reflexão a partir da ação, contrária à passividade do aluno;

$O$ aprender pelo fazer enfoca o processo de desenvolvimento e não o produto, o que possibilita a contínua reconstrução da experiência concreta, ativa e produtiva de cada um;

Na prática reflexiva a ação é verificada de maneira científica;

A prática reflexiva exerce uma função crítica,

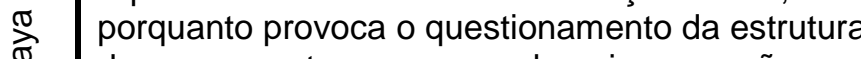
de pressupostos em que se baseiam as ações, permitindo ao sujeito reestruturar suas estratégias e conceber novos problemas;

Auxilia no processo criativo, na capacidade de o aluno inventar novas maneiras de atuação e lida com as situações incertas, únicas e conflituosas com as quais deverá se deparar.

Vê o processo de Ensino-aprendizagem como um processo aberto e experimental, conduzido por hipóteses extraídas da realidade.

\section{Como é um professor prático reflexivo?}

Integra o fazer na aprendizagem, indicando o valor do componente artesanal na constituição do

artista;

Tem a possibilidade de interrogar seu exercício, fazer frente à racionalidade técnica e conquistar autonomia;

Considera a interação com outras pessoas, tão presente no universo de aprendizagem artesanal tradicional, um importante meio de aprendizagem; Propicia o pensamento reflexivo a partir de uma experiência concreta;

Estimula o conhecimento-na-ação;

Possui coragem e vontade de correr riscos e desenvolver um espírito de indagação crítica, desatando os nós que o prendem ao habitual. Examina-se criticamente, o que lhe capacita a fazer escolhas e formular perguntas, a partir das quais se instaura uma busca de suas reais intenções para aprender e exercitar a profissão que escolheu.
Como se forma um professor prático reflexivo?

Devem-se desfazer as históricas dicotomias entre arte e artesanato, arte e indústria, arte e ciência, arte popular e erudita, prática e teoria, razão e sensibilidade, entre outras tantas, às quais se somam repartições tais como arte e Educação, artista e professor, entre outras;

Deve-se reforçar a ideia de mediação na formação docente;

Devem-se criar condições para a Organização qualitativa do praticum;

Deve-se integrar a pesquisa-ação à práxis docente;

Os professores devem ser concebidos como pesquisadores, à medida que a atitude investigativa diferencia o professor que não cria e não inventa modos de ação educativa, limitandose a executar os projetos elaborados por outrem, daquele que autonomamente investiga o seu próprio campo de trabalho, elabora teorias e as põe à prova;

O currículo deve ser compreendido como processo inacabado, o que nos permite pensar na adequação do Ensino e aprendizagem ao ritmo e peculiaridade de cada escola, classe e aluno e deve ser visto como um processo de experimentação da própria prática docente e não algo dogmático a ser seguido cegamente; Deve-se seguir rumo a uma práxis docente social e humana, que se eleve ao nível criador. 


\begin{tabular}{|c|c|c|}
\hline 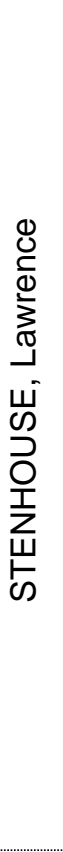 & $\begin{array}{l}\text { Relação entre o currículo, a pesquisa-ação e o } \\
\text { desenvolvimento profissional do professor. } \\
\text { Exploração dos princípios que norteiam a relação } \\
\text { entre Ensino e pesquisa, utilizando a investigação } \\
\text { como recurso didático e de grande valor formativo, } \\
\text { cabendo ao professor assumir uma postura } \\
\text { investigativa do cotidiano e transformar a sala de } \\
\text { aula em objeto de pesquisa. A mudança curricular } \\
\text { satisfatória dependeria do desenvolvimento da } \\
\text { capacidade de autoanálise e de reflexão dos } \\
\text { professores. Na prática reflexiva o professor } \\
\text { assume o papel de aprendiz e o Ensino é baseado } \\
\text { em pesquisa e descoberta. }\end{array}$ & $\begin{array}{l}\text { É um professor indagador, que assume a sua } \\
\text { própria realidade escolar como objeto de pesquisa, } \\
\text { de reflexão, de análise. Um profissional que } \\
\text { analisa a própria prática e efetua ajustes e } \\
\text { transformações no seu trabalho, modificando e } \\
\text { criando o próprio currículo. Mas não basta } \\
\text { investigar a própria prática, é preciso melhorar } \\
\text { tanto suas qualidades internas, como as condições } \\
\text { em que ela ocorre. Essa melhoria das situações } \\
\text { sociais, reais e conflitivas se constitui num dos } \\
\text { pilares da pesquisa-ação. Os professores prático- } \\
\text { reflexivos modificam suas práticas à luz de suas } \\
\text { próprias reflexões, pois a Educação é uma forma } \\
\text { de práxis e não um processo técnico e a } \\
\text { investigação é o único meio de construir um } \\
\text { pensamento independente e não de reprodução } \\
\text { do discurso alheio. Este profissional acredita no } \\
\text { direito do aluno ao saber, na conexão dos } \\
\text { conteúdos escolares com o conhecimento de } \\
\text { mundo e na importância do diálogo como método } \\
\text { pedagógico. }\end{array}$ \\
\hline 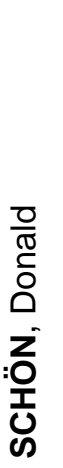 & $\begin{array}{l}\text { Donald A. Schön afirma que a ideia de reflexão na } \\
\text { ação "nada tem de novo"; suas origens podem ser } \\
\text { encontradas em "obras de escritores como Léon } \\
\text { Tolstoi, John Dewey, Alfred Schutz, Lev Vygotsky, } \\
\text { Kurt Lewin, Jean Piaget, Ludwing Wittgenstein e } \\
\text { David Hawkings", todos pertencendo, se bem que } \\
\text { de formas distintas, a certa tradição do } \\
\text { pensamento epistemológico e pedagógico. }\end{array}$ & $\begin{array}{l}\text { Algumas das competências/habilidades que } \\
\text { caracterizam o professor competente/ reflexivo } \\
\text { sugeridas por Donald Schön: } \\
\text { 1. Enfrentar situações novas e diferentes; } \\
\text { 2.Toma as decisões apropriadas; } \\
\text { 3. Intuição na resolução de problemas; } \\
\text { 4. Sensibilidade estética; }\end{array}$ \\
\hline
\end{tabular}

Superação, nos espaços formativos, dos pressupostos da racionalidade técnica, que definiram os conhecimentos necessários para a docência na modernidade (na qual o professor competente é aquele capaz de solucionar problemas através da aplicação sistemática de teorias e de procedimentos científicos),

insuficientes para dar conta da complexidade da docência. Inserção da prática reflexiva, de um modelo de Ensino baseado na pesquisa-ação: investigação reflexiva da prática e do processo de investigação sobre ela, ou seja, a pesquisa que se faz do fazer e para melhorar o fazer do professor. Formação na direção da autonomia dos processos de produção de práticas e de conhecimentos. $O$ professor que tem a pesquisa como rotina é mais autônomo e tem plenas condições de desenvolver um currículo próprio (autonomia do currículo).

Questões levantadas por Donald Schön para análise da prática e formação docente:

1. Que tipos de conhecimento e do saber-fazer permitem aos professores desempenharem o seu trabalho de forma competente?

2. Que tipos de formação são mais viáveis para equipar os professores com as capacidades necessárias ao desempenho de seu trabalho? 
Breve histórico do termo prática reflexiva nos EUA e aponta John Dewey como um dos principais

intelectuais que expôs a distinção entre o ato

humano que é reflexivo e o que é rotina. $\mathrm{O}$ ato de rotina é guiado pelo impulso, tradição e

autoridade, e nos espaços educativos, existem

diferentes definições de realidade, de acordo com

as quais se definem os problemas, metas e os

objetivos. Os professores não reflexivos aceitam

automaticamente o ponto de vista normalmente

dominante numa dada situação, aceitando a

realidade posta. A ação reflexiva implica uma

consideração ativa, persistente e cuidadosa

daquilo em que se acredita ou se pratica, à luz dos

motivos que justificam e das consequências a que

conduz. Essa ação implica mais do que a busca

de soluções lógicas e racionais para os problemas.

Implica intuição, emoção e paixão, portanto, não

há nenhum conjunto de técnicas que possa ser

empacotado e ensinado aos professores. Assim,

define três atitudes necessárias para a ação

reflexiva:

1- Ter abertura de espírito, ouvir diferentes

opiniões e alternativas; admitir a possibilidade de

erro; não banalizar o que é natural e correto

sempre buscando compreender as causas dos

conflitos; questionar-se sobre o que faz na sala de

aula.

2- Ter responsabilidade ponderando

cuidadosamente as consequências de uma ação.

Assim, devem perguntar-se por que estão a fazer

o que fazem de um modo que ultrapasse o

imediatismo e leve-os a pensar de que maneira

está a dar resultado e para quem. A atitude de

responsabilidade implica na reflexão sobre três

tipos de consequências do Ensino: os efeitos do

seu Ensino nos autoconceitos dos seus alunos, no desenvolvimento intelectual e os efeitos nas vidas
O autor aponta as cinco tradições da prática reflexiva dos programas de formação de professores nos EUA (acadêmica, de eficiência social, desenvolvimentista, de reconstrução social e genérica) e explicita como deve ser a prática reflexiva a partir dos estudos e integração destas tradições:

1- O professor deve dirigir sua atenção para o interior, para a sua própria prática, como para o exterior, para os seus estudantes e para as condições sociais nas quais a sua prática se situa. Uma reflexão que desconsidere estes fatores, distorce a auto compreensão do seu trabalho.

\section{2- Possuir uma tendência democrática e} emancipatória, reconhecendo o caráter político das suas ações. Zeichner diz que "a reflexão dos professores não pode ignorar questões como a natureza da escolaridade e do trabalho docente ou as relações entre raça e classe social por um lado e o acesso ao saber escolar e o sucesso escolar por outro", devendo incluir estas considerações no seu pensamento, sem naturalizá-las.

3- Ter o compromisso com a reflexão enquanto prática social. O autor cita o exemplo da

construção de comunidades de aprendizagem, nas quais os professores apoiam e sustentam 0 crescimento uns dos outros, assim percebem sua situação vinculada à dos seus colegas. Este compromisso tem um valor Estratégico para a criação de condições visando a mudança institucional e social.
Partindo destas considerações, explica como desenvolve seu trabalho de formador de professores:

Estimula os alunos a tornarem-se tanto consumidores críticos das investigações de terceiros como pessoas capazes de participarem na sua criação. Para isso, no seu programa, os alunos-mestres fazem análises críticas sob várias perspectivas de práticas, programas educativos e de gestão na sala de aula. Assim, contribui para que compreendam os pressupostos e

compromissos morais subjacentes a vários programas e tomarem decisões autônomas (onde se sintam a vontade para discordarem dos seus tutores) sobre o uso a dar-lhes.

Pontua a importância que dá aos professores enquanto produtores de saber e sublinha duas ações: estudos sobre a ação na sala de aula, feitos pelos alunos-mestres sobre seu próprio trabalho; e esforço concentrado para incluir os trabalhos dos professores do Ensino básico e secundário no material de leitura do curso de formação de professores.

O autor pontua algumas estratégias de Ensino utilizadas nesse processo de formação: estudos etnográficos, lidos e realizados por alunos-

mestres; feitura de jornais; estudos de casos; investigação-ação e atenção às práticas de Ensino multiculturais e curriculares. 


\begin{tabular}{l|l|} 
3- Ter sinceridade, ou seja, abertura de espírito e \\
a responsabilidade devem ser componentes \\
centrais da vida de um professor reflexivo, que tem \\
que ser responsável pela sua própria \\
aprendizagem. \\
O que se propõe é um equilíbrio entre a reflexão e \\
a rotina, entre o ato e o pensamento; buscando \\
sempre saber em que medida, o professor dirige \\
seu Ensino para metas para as quais se trabalha \\
conscientemente, projetando e planejando suas \\
ações de acordo com os fins que tem em vista, o \\
que lhes permite saberem quem são e quando \\
agem.
\end{tabular}

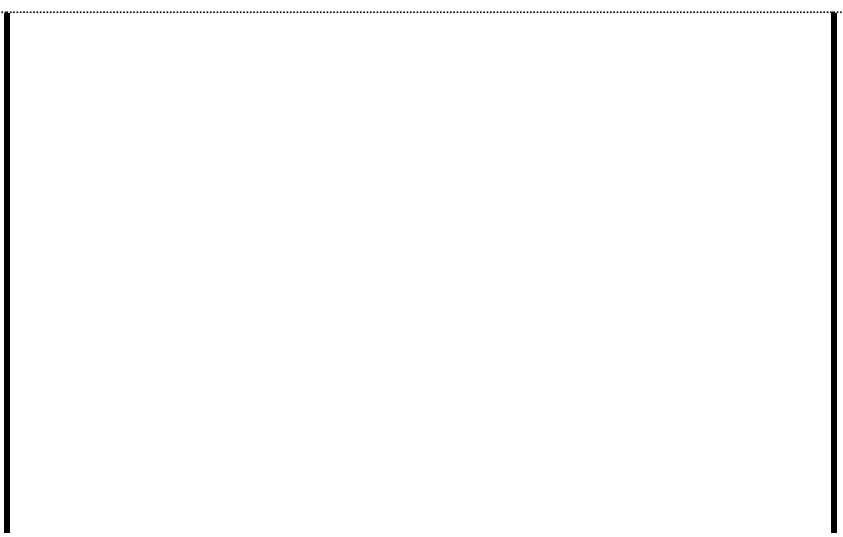




\subsection{As primeiras experiências de EaD em Artes Visuais}

Os primeiros trabalhos a questionarem as possibilidades de Ensino de Arte com uso da tecnologia como suporte datam dos fins dos anos de 1990 e início dos anos 2000. Em diversas propostas de pesquisas as Profas. Dras. Maria Emília Sardelich (UFPB) e Maria Cristina Villanova Biazus (UFRGS), desde 1994 destacam-se como pioneiras ${ }^{55}$ nos questionamentos dos usos das tecnologias digitais de comunicação e informação como ferramentas para o aprendizado da arte, com destaque para as oficinas virtuais, e com investigações sobre interação com interfaces e o uso do ambiente virtual Second Life ${ }^{56}$ na Educação superior em arte de Biazus. Pesquisa também pioneira que trabalha os aspectos educacionais que envolvem aspectos cognitivos e subjetivos, além das potencialidades técnicas, onde objetivo não é replicar aulas expositivas e palestras no Second Life, mas expandir este ambiente virtual 3D através de Webcams e facilidades de vídeo streaming para aumentar a comunicação bem como os processos de colaboração artística on-line.

Em 2003, em minha pesquisa de mestrado ${ }^{57}$ em Artes Visuais, iniciada em 2000 e desenvolvida no Instituto de Artes da Universidade Estadual paulista - UNESP, mesmo acreditando nas possibilidades do uso de mundos virtuais como possibilidades interessantes de solução para os problemas de simulação de presença em EaD (Diferenciada na pesquisa como EDMC - Educação a Distância Mediada por Computador (VIEIRA, 1998), visto que EaD engloba uma gama imensa de possibilidades e, inclusive, o uso de computadores) e para contemplar os aspectos tridimensionais do Ensino de Arte, constatei a inviabilidade de, na época, testar a aplicação prática da proposta de utilização de Realidade Virtual (RV) para Educação à Distância em Arte, tema da dissertação,

\footnotetext{
${ }^{55}$ Ver Ambiente de Realidade Virtual Cooperativo de Aprendizagem - ARCA. Disponível em http://www.pgie.ufrgs.br/projetos/arca. O projeto ARCA busca o desenvolvimento de um ambiente de Ensino aprendizagem que, apoiado pela Internet, possa atuar como instrumento no auxílio à uma prática pedagógica diferenciada.

${ }^{56} \mathrm{O}$ Second Life é um simulador da vida real, em um mundo virtual totalmente 3D, onde os limites de interação com o game vão além da sua criatividade. Nele, além de interagir com jogadores de todo o mundo em tempo real, é possível também criar seus próprios objetos, negócios e até mesmo personalizar completamente seu avatar, tudo em modelagem 3D. 
por verificar o desconhecimento dessa tecnologia pela quase totalidade dos professores entrevistados para o estudo. No mesmo trabalho, os resultados da pesquisa de campo já apontaram para a questão fundamental: "será que estão desenvolvendo EDMC estão capacitadas e habilitadas para isso?". Como argumentar junto às IES que oferecem os cursos de licenciatura nesta modalidade sobre recursos mais ou menos adequados aos objetivos propostos se são desconhecidos os fundamentos desses recursos? Enfim, como fazer EaD sem conhecer EaD?

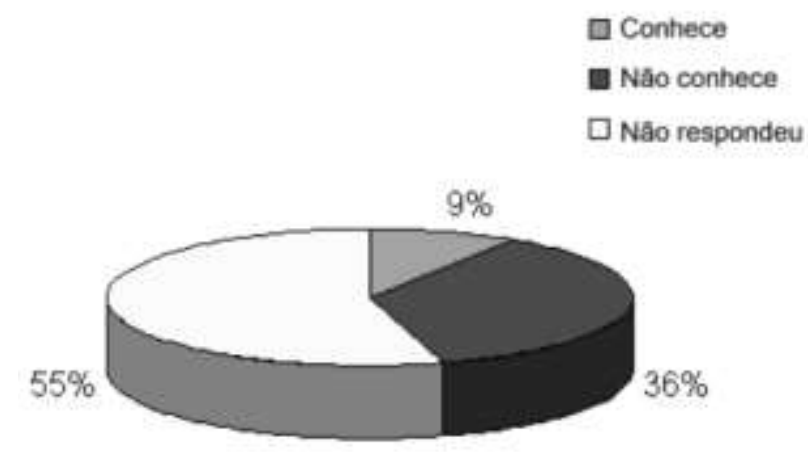

Figura 15 - Gráfico que ilustra o desconhecimento das possibilidades tecnológicas e da EaD em 2003, segundo a pesquisa Uso de Realidade Virtual por VRML para Educação a Distância em Arte. ${ }^{58}$

$\mathrm{Na}$ ocasião da pesquisa não foram, também, encontradas efetivadas nenhuma iniciativa de formação em licenciatura em arte/Educação por EaD em Artes Visuais, inclusive e, no caso da pesquisa em questão, principalmente, a utilização específica de RV (SAMPAIO-RALHA, 2003), porém, uma das primeiras instituições a ser credenciada para oferecer cursos EaD na área de artes, foi a Faculdade Integrada da Grande Fortaleza.

Em 2004 havia credenciado uma complementação pedagógica (SANCHES, 2005). A UNIMONTES tem o credenciamento mais antigo, 1994; e a UFES vem logo em seguida, 2001. Mas os cursos somente iniciaram em 2008, na UFES e em 2009 na UNIMONTES.

${ }^{58}$ SAMPAIO-RALHA, J.L.F. "Uso de Realidade Virtual por VRML para Educação a Distância em Arte". Dissertação de mestrado defendida em 2003 no programa de Pós-Graduação Stricto Senso da Universidade Estadual Paulista UNESP, sob orientação do Prof. Dr. Milton Sogabe. Disponível em http://www.athena.biblioteca.unesp.br/exlibris/bd/bia/33004013063P4/2003/ralha ilfs 
A Portaria n. 559, de 20 de fevereiro de 2006 credenciou a Universidade Metropolitana de Santos para a oferta de cursos superiores à distância no estado de São Paulo, e não a Licenciatura em Artes Visuais dessa instituição. Em agosto de 2006 a UNIMES inicia a oferta da Licenciatura em Pedagogia na modalidade a distância. Em março de 2007 iniciou a oferta da Licenciatura em Artes Visuais, bem como das demais Licenciaturas. A Portaria n. 417, de 30 de abril de 2009, ampliou a abrangência dos cursos a distância da UNIMES para os estados da Bahia, Espírito Santo, Piauí, Maranhão e Minas Gerais. A primeira turma da Licenciatura em Artes Visuais da UNIMES formou-se em 2009.

Tabela 20 - Linha do tempo das licenciaturas em Artes Visuais no Brasil

\begin{tabular}{l|l|c}
\hline & \multicolumn{1}{|c}{ CREDENCIAMENTO } & INÍCIO \\
\hline FGF & Portaria Ministerial №. 2.143 de 16 de julho de 2004. & $02 / 08 / 2004$ \\
\hline UNIMES & $\begin{array}{l}\text { Portaria do Ministério de Educação do Brasil, №. } \\
\text { 559, de 20 de fevereiro de 2006. }\end{array}$ & $17 / 03 / 2006$ \\
\hline UNB & Portaria Ministerial №. 4.055/2003. & $27 / 08 / 2007$ \\
\hline UFAM & Parecer do Conselho Nacional de Educação 2010 & $10 / 12 / 2007$ \\
\hline CLARETIANO & Portaria Ministerial №. 3.635/2004. & $09 / 02 / 2008$ \\
\hline UFG & Portaria Ministerial №. 1.369/2010. & $08 / 03 / 2008$ \\
\hline UCS & Portaria Ministerial №. 792/2004. & $20 / 09 / 2008$ \\
\hline UFRGS & Portaria Ministerial №. 4.068/2005. & $18 / 10 / 2008$ \\
\hline UFES & Portaria Ministerial №. 2.215/2001. & $10 / 11 / 2008$ \\
\hline UNIMONTES & Portaria №. 1.116 de 21 de julho de 1994. & $27 / 03 / 2009$ \\
\hline UNIVASF & Portaria Ministerial №. 1.369/2010. & $03 / 08 / 2009$ \\
\hline UFRPE & Portarias Ministeriais №. 1.369 / 2010 & $02 / 09 / 2009$ \\
\hline UNIASSELVI & Portaria Ministerial №. 4.017/2005. & $16 / 12 / 2009$ \\
\hline UNITAU & Portaria Ministerial №. 280/2009. & $20 / 02 / 2010$ \\
\hline UNAR & Portaria Ministerial №. 403/2010. & $01 / 09 / 2010$ \\
\hline UNICENTRO & Portaria Ministerial №. 646/2008. & $01 / 09 / 2010$ \\
\hline UECE & Portaria MEC №. 1.065, de 08 de maio de 2003. & 2010 \\
\hline UFMA & Portaria Ministerial №. 682/2006. & 2009 \\
\hline UNOPAR & Portaria Ministerial 2.794/04 de 06/09/04 & 2014 \\
\hline & & \\
\hline
\end{tabular}

De março de 2003 a abril 2012 nenhuma outra pesquisa relacionada à EaD em Artes Visuais, em nível de graduação, ou seja, relacionada às licenciaturas em Artes Visuais por EaD pode ser encontrada no Banco de Teses e Dissertações da 
CAPES além desta, acima citada. Somente em 2013 um novo trabalho stricto sensu é registrado no banco de trabalhos.

Fernanda Cunha (2008), em trabalho de doutorado de 2008, denominou como eArte/Educação, e trata do Ensino de Arte englobando o universo digital. Ou Seja, a e-Arte/Educação fala de, e investiga o modo de ensinar arte englobando a produção digital em arte, usando das ferramentas desse tipo de linguagem (digital) para aplicar o que chama de "ações mentais" (e-fazer, e-ler e econtextualizar), ou Sistema Triangular Digital, numa alusão direta a leitura/aplicação da Abordagem Triangular. Cunha (2010) acredita que...

[...] o estímulo aos processos mentais metalinguisticamente está no centro epistemológico do desenvolvimento da capacidade cognitiva (e, portanto, perceptiva) da fluência digital crítica", o que constitui o que chama de "Sistema Triangular Digital" (CUNHA, 2010),

...considerando que, "saber pensar e se expressar metalinguisticamente é ter fluência digital - pensamento digital", afirma, ainda, que o "Sistema Triangular Digital está embasado nas ações mentais que estão imbricadas nos códigos metalinguísticos da cultura digital'. Embora não trate de EaD, nem de formação de professores, é importante destacar o que

[...] os processos sociais e culturais não surgem em consequência de transformações tecnológicas. Tecnologia e sociedade compõem um sistema interativo, em que a tecnologia é a sociedade e a sociedade só pode ser entendida por meio de seus aparatos tecnológicos (CUNHA, 2008, p. 14).

Pontos extremamente importantes na compreensão das relações entre arte e tecnologia, que certamente se relacionam com a EaD.

Já o que Sheila Campelo (2010) chama de "ciberEducação em arte", tendo o projeto Arteduca como referência/exemplo de suas preocupações de pesquisa, trata da EaD em arte para formação continuada, ou seja, pós-graduação. Baseiase na busca de uma metodologia para a arte/Educação na web, e objetiva em acompanhar os desdobramentos dessa pós-formação e acompanhar seus naturais desdobramentos nas práticas de seus egressos. Porém, ainda que de 
excelente qualidade, nem uma, nem outra, dessas propostas de estudos abordam a questão da formação inicial de professores de Artes Visuais nas Licenciaturas por $\mathrm{EaD}$, que se encontra descoberta de proposições efetivamente desenvolvida/pensada para as relações entre suportes e Epistemologia da Educação a Distância em Artes Visuais, no ciberespaço, web-mediada, para formação de professores de arte.

Muitas iniciativas foram surgindo, pontuais, porém de abrangência significativa no que trata, principalmente, de contingente de formandos por esta modalidade, embora ainda sejam relativamente poucos os cursos de artes nesta modalidade segundo o Prof. Dr. Afonso Medeiros, em sua fala no Congresso da Federação de arte/educadores do Brasil de 2010:

[...] nosso país tem atualmente 607 cursos superiores credenciados na área de artes (dados de 2010 do e-Mec), dos quais se presume que cerca de 1/3 (pouco mais de 200) são Licenciaturas. Para efeito de credenciamento e avaliação, o Ministério da Educação considera cada habilitação/especialidade como um curso. Desses 607 cursos/habilitações, 189 são de Música, 185 de Artes Visuais, 97 de Artes, 43 de Cinema e Audiovisual, 34 de Artes Cênicas, 33 de Teatro e 26 de Dança. Portanto, só com esses números, podemos perceber que na área em que atuamos, as discrepâncias são mais visíveis e gritantes. Se Música e Artes Visuais adquiriram capilaridade, Cinema, Teatro e Dança ainda estão muito aquém da quantidade e da distribuição desejável em todo o país.

[...] A média nacional é de um curso de arte para cada grupo de 322.889 habitantes.

[...] O potencial da Educação à distância, tão alardeado nos últimos anos, ainda não reverberou suficientemente nas artes, dado que atualmente só existem 21 cursos à distância credenciados na área de artes em todo o Brasil (MEDEIROS, 2010, p. 92).

\subsubsection{A Universidade Aberta do Brasil - UAB}

Belloni (1999) destaca dois tipos de instituições como os mais consolidados dentre os que fazem EaD.

Instituições Especializadas, que se exclusivamente ao Ensino a Distância. Nesta categoria podemos enquadrar as grandes Universidades europeias, que seguem 0 modelo operacional da UK Open University. As características essenciais desse tipo de instituição são a abrangência (nacional ou internacional), orçamentos 
próprios e independentes, e emissão de seus próprios diplomas, com o mesmo valor formal das instituições que operam no modelo presencial.

Instituições Integradas, que parte de uma instituição formal tradicional e atuam também a distância. Os exemplos mais significativos podem ser encontrados nos EUA, Canadá e Austrália. Apresentam como características, efeitos de "sinergia" benéficos para a modalidade presencial (uso de tecnologia) e a distância (feedback mais rápido dos cursos e a estrutura do presencial).

Os consórcios são outro tipo de organização mencionada por Belloni (1999), que vem se tornando uma nos últimos anos. Agrupam várias instituições, educacionais ou não, com o intuito de otimizar os recursos necessários para a produção e administração de cursos e expandir os mercados de atuação. Embora sejam uma opção que permite gerar ganhos em escala de produção (devido ao maior número de alunos que vem a usar o mesmo material) e em possibilitar o atendimento local aos alunos (por meio dos polos de apoio), esbarram nas questões políticas e prioridades de cada instituição. Quando os consórcios envolvem vários países, tem-se que considerar também os valores políticos, sociais e econômicos e questões culturais.

A UAB pode ser enquadrada no terceiro tipo apresentado. Em sua própria descrição, um programa que "busca ampliar e interiorizar a oferta de cursos e programas de Educação superior, por meio da Educação a Distância" (BRASIL(8), 2012), que tem como prioridade "oferecer formação inicial a professores em efetivo exercício na Educação básica pública, porém ainda sem graduação, além de formação continuada àqueles já graduados." (Idem). O objetivo é

a disseminação e o desenvolvimento de metodologias educacionais de inserção dos temas de áreas como Educação de jovens e adultos, Educação ambiental, Educação patrimonial, Educação para os direitos humanos, Educação das relações étnico-raciais, de gênero e orientação sexual e temas da atualidade no cotidiano das práticas das redes de Ensino pública e privada de Educação básica no Brasil (Idem Ibidem).

Desde 1996, data da promulgação da LDB № 9.394/96 a formação de professores em nível superior vem se adequando com mais intensidade a 
necessidade. Embora a temática não seja exatamente nova, com a Lei de 1996 se intensifica, visto que ela própria determinava a necessidade da formação, o que gerou uma demanda de desenvolvimento e consolidação de políticas públicas direcionadas ao atendimento dessa necessidade.

\begin{abstract}
Para atender a essa demanda, o Ministério da Educação (MEC) tem investido prioritariamente na formação de professores, implantando uma política pública nacional de formação pela Educação a Distância $(E a D)$, que passa a alcançar proporção e escala por meio da criação e implementação do Sistema Universidade Aberta do Brasil (UAB), em 2005 (LAPA \& PRETTO, 2010).
\end{abstract}

O Sistema Universidade Aberta do Brasil (UAB), instituído pelo Decreto 5.800, de 8 de junho de 2006, foi criado em parceria com a Associação Nacional dos

Dirigentes das Instituições Federais de Ensino Superior (ANDIFES) e Empresas Estatais, no âmbito do Fórum das Estatais pela Educação, com foco nas Políticas e a Gestão da Educação Superior (SARDELICH, 2012, p. 72), está estruturado no Plano de Desenvolvimento da Educação - PDE, e faz parte da Rede Nacional de Formação Continuada de Professores, que foi criada em 2004, com o objetivo de colaborar com melhoria da formação dos professores. O programa surge, de acordo com a Secretaria de Educação a Distância do MEC, como uma alternativa primordial para viabilizar a formação universitária de $30 \%$ dos estudantes brasileiros até 2011 (ZUIN, 2006).

Art. 1‥ Fica instituído o Sistema Universidade Aberta do Brasil - UAB, voltado para o desenvolvimento da modalidade de Educação a Distância, com a finalidade de expandir e interiorizar a oferta de cursos e programas de Educação superior no País.

Parágrafo único. São objetivos do Sistema UAB:

I - oferecer, prioritariamente, cursos de licenciatura e de formação inicial e continuada de professores da Educação básica;

II - oferecer cursos superiores para capacitação de dirigentes, gestores e trabalhadores em Educação básica dos Estados, do Distrito Federal e dos Municípios;

III - oferecer cursos superiores nas diferentes áreas do conhecimento;

IV - ampliar o acesso à Educação superior pública;

$\mathrm{V}$ - reduzir as desigualdades de oferta de Ensino superior entre as diferentes regiões do País;

VI - estabelecer amplo sistema nacional de Educação superior a distância; e

VII - fomentar o desenvolvimento institucional para a modalidade de Educação a Distância, bem como a pesquisa em metodologias inovadoras de Ensino superior apoiadas em tecnologias de informação e comunicação (BRASIL, 2006). 
Participam do Sistema UAB as universidades públicas (federais, estaduais e municipais) e os Institutos Federais de Educação, Ciência e Tecnologia. Essas instituições, exclusivamente públicas, são responsáveis pela criação dos projetos pedagógicos dos cursos e por manter sua boa qualidade com base nos Referenciais de Qualidade para Educação Superior a Distância - SEED/MEC.

Para isso, deveriam considerar as particularidades da Educação a Distância, em especial o uso das ferramentas tecnológicas de informação e comunicação e os recursos instalados nos polos de apoio presencial como suporte para 0 cumprimento das exigências nos momentos presenciais da Educação a Distância (UAB-CAPES).

O público prioritário da rede são professores de Educação básica dos sistemas públicos de Educação. As áreas de formação são: alfabetização e linguagem, Educação matemática e científica, Ensino de ciências humanas e sociais, artes e Educação física.

A Lei № 11.502, de julho de 2007, atribui à Coordenação de Aperfeiçoamento de Pessoal de Nível Superior (Capes) a responsabilidade pela formação de professores da Educação básica uma prioridade do Ministério da Educação. O objetivo é assegurar a qualidade da formação dos professores que atuarão ou que já estejam em exercício nas escolas públicas, além de integrar a Educação básica e superior visando à qualidade do Ensino público. A Política Nacional de Formação de Professores tem como objetivo expandir a oferta e melhorar a qualidade nos cursos de formação dos docentes (BRASIL(1), 2012).

A UAB Tem por meta o desenvolvimento da modalidade de Educação a Distância, possibilitando a formação de grande número de pessoas geograficamente dispersas e, muitas vezes, isoladas na zona rural, sem, contudo, deslocá-las de seus municípios (UNIMONTES, 2012).

Prioriza cursos de licenciatura para formação inicial e continuada de professores da Educação básica e é uma ação política do MEC, por meio de sua Secretaria de Educação a Distância - SEED e com o apoio da Coordenação de Aperfeiçoamento de Pessoal de Nível Superior - CAPES e, 
com o objetivo de democratizar as possibilidades de acesso para todos os interessados, o Ministério da Educação (MEC), por meio da Secretaria de Educação a Distância (SEED) e da Capes, tornou público o Edital de Seleção № 01/2006-SEED/MEC/2006/2007, permitindo a participação dos municípios e das universidades públicas interessadas (UNIMONTES, 2012).

Desde o surgimento da proposta os especialistas em Educação vêm questionando a essência de sua estrutura, e não os objetivos dela. João Mattar diz que

Inauguramos tardiamente a Universidade Aberta (que não é nem universidade, nem aberta) assumindo um modelo fordista, com ênfase no conteúdo e rebaixamento do trabalho docente [...] (MATTAR, 2012, p. 07, grifo nosso).

A afirmação de Mattar (2012, p. 07) é consistente, na medida de que a UAB não é realmente uma universidade. É um projeto, fruto de uma política educacional, que criou um consórcio de universidades ${ }^{59}$.

Art. 2ำ A Universidade Aberta do Brasil será configurada a partir do conjunto de ações dos Consórcios entre a União, os Estados e os Municípios, formados nos Estados da Federação, para oferta de Educação superior a distância, envolvendo a participação de Universidades Públicas, nos quais participam, ao menos, uma Universidade Federal. [...] A possibilidade de utilização da modalidade de Educação a Distância (EaD) aponta para impactos positivos quanto ao acesso à Educação superior, especialmente nas Instituições Federais de Ensino Superior - IFES e demais Universidades Públicas Estaduais. Dessa forma, também há a possibilidade de atender a outra demanda educacional urgente: a necessidade de formação e capacitação de mais de um milhão de docentes para a Educação básica, bem como a formação, em serviço, de um grande contingente de servidores públicos. Para isso, há que se fomentar o campo de pesquisas em tecnologias de informação e comunicação (TIC), tendo em vista sua relevância para a consolidação do conjunto diversificado de experiências exitosas em EaD, em variados níveis de Ensino, que vem gradativamente tomando forma no país (BRASIL(1), 2012).

...e, também como afirma Mattar (2012, p. 07) não é aberta pois

Universidade Aberta (UA) mais do que uma instituição é um conceito. Entre as características de uma UA estão: aberta na entrada, sem a

${ }^{59} \mathrm{O}$ resultado desse processo, publicado no Diário Oficial da União, em 20 de maio de 2008 , habilitou às universidades envolvidas a responsabilidade para oferecer os Cursos de Licenciatura em Artes Visuais, Ciências Biológicas, Ciências Sociais, Geografia, História, Letras/Espanhol, Letras/Inglês, Letras/Português e Pedagogia. UFG, UnB, UNIMONTES, UFMA e UFAL, formaram o consórcio que foi responsável pela oferta do Curso de Licenciatura em Artes Visuais, Música e Teatro, que foi aprovado em 2006 e teve seu inicio em 2007. 
rigidez dos processos seletivos tradicionais ou outras formas de discriminação, democratizando o acesso da população; aberta no processo, oferecendo opções e atividades relevantes mais flexíveis quanto às exigências formais de Conselhos ou corporações profissionais; aberta na saída, permitindo aos estudantes concluírem, encerrarem ou suspenderem seus estudos com maior flexibilidade, em atendimento às suas necessidades (Idem, 2012).

Belloni (1999) destaca a distinção entre Educação Aberta e Educação a Distância. Educação Aberta: Critérios de acesso ao sistema educacional e flexibilidade de tempo, espaço e ritmo. Educação a Distância: Separação professor-aluno e uso de meios técnicos para comunicação. $\mathrm{E}$ as duas modalidades podem existir de forma independente ou consorciada

Os processos seletivos da UAB são os mesmos das universidades já constituídas (MATTAR, 2012). Ainda, se observarmos que

Entre os atributos de uma UA estão: base em EAD e TIC de aprendizagem flexível; aprendizagem individualizada ou personalizada; estrutura organizacional própria: simples, pequena e ágil; compromisso com a excelência e eficiência (Idem Ibidem).

A UAB não tem essa estrutura, pois, por estar associada ao consórcio das universidades convencionais, segue suas estruturas e usa seu pessoal (professores e técnicos) na realização dos trabalhos. Exceção feita aos tutores que Mattar (2012), devido ao modelo educacional utilizado pela UAB, "fordista e conteudista", considera que são "professores desvalorizados".

[...] Principais problemas da docência na UAB - Universidade Aberta do Brasil, dentre os quais foram levantados: o fato de o professor, ao exercer a função hoje denominada de tutor, receber uma remuneração ínfima em relação à remuneração de professores que exercem a docência na mesma instituição pública; o fato de receber uma bolsa (e não salário), sem nenhum direito trabalhista; e a transitoriedade e instabilidade de sua atuação, sem vinculação com a instituição [...]. 0 salário é indecente, e o tutor é quase sempre convidado a atuar passivamente, como um monitor, não como um professor. Isso reforça um modelo de EaD conteudista, fordista, industrial e instrucional, que acaba afastando muita gente da EaD, embora não seja o único modelo possível de se fazer Educação a Distância (MATTAR, 2012, p. xxxi-xix) 
Podemos caracterizar a UAB como "uma política de articulação entre o MEC e a Diretoria de Educação a Distância (DED) da CAPES" (SARDELICH, 2012, p. 73).

No final de 2010 foram contabilizadas 89 universidades públicas credenciadas à UAB, com mais de 500 polos de Ensino. Em 2013, o sistema ampliou sua rede de cooperação para alcançar a totalidade das instituições públicas brasileiras de Ensino superior e atender a 800 mil alunos por ano. Não há, até a data de finalização desta pesquisa, divulgação de resultados.

Segundo a CAPES, as universidades e institutos que oferecem cursos gratuitos de graduação e que são credenciadas pelo MEC são:

\section{Região Centro-Oeste}

Distrito Federal: UnB.

Goiás: UFG; UEG.

Mato Grosso: UFMT; IFMT; Unemat.

Mato Grosso do Sul: UFMS; UEMS.

\section{Região Nordeste}

Alagoas: UFAL; IFAL; Uncisal; UNEAL.

Bahia: UFBA; IFBA; UEFS; UESB; UESB; UNEB.

Ceará: UFC; IFCE; UECE.

Maranhão: UFMA; UEMA; IFMA.

Paraíba: UFPB; IFPB; IFPB.

Pernambuco: UFPE; Univasf; UFRPE; IFPE; UPE.

Piauí: UFPI; UESPI.

Rio Grande do Norte: UFRN; Ufersa; IFRN; UERN.

Sergipe: UFS.

\section{Região Norte}


Amazonas: UFAM; IFAM; UEA.

Pará: UFPA; IFPA; UEPA.

Rondônia: UNIR.

Roraima: UFRR.

Tocantins: UFT; UNITINS.

\section{Região Sudeste}

Espírito Santo: UFES; IFES.

Minas Gerais: UFMG; UFV; UFJF; UFLA; UFOP; UFSJ; UFU; UFVJM; Unifal; Unifei; IFTM; UEMG; Unimontes.

Rio de Janeiro: Cederj (UENF, UERJ, UFF, UFRJ, UNIRIO); UFRRJ; Cefet-RJ; FIOCRUZ.

São Paulo: Unifesp; UFSCar; UFABC; Unesp.

\section{Região Sul}

Paraná: UFPR; UTFPR; UEM; UEPG; Unicentro.

Rio Grande do Sul: UFRGS; UFPel; UFSM; FURG; IFSul.

Santa Catarina: UFSC; IFSC; UDESC.

\subsection{Trabalhos sobre o tema EaD em Artes Visuais / licenciaturas}

Tem sido árdua a tarefa de pesquisadores que desejem debater as questões de formação de professores em Artes Visuais nos últimos anos. O acesso às informações institucionais é precário, mesmo para simples análise de programas e projetos pedagógicos, o processo é dificultado por falta de transparência e comunicação. A legislação recomenda que os Projetos Pedagógicos estejam disponíveis nos websites das instituições públicas, mas, na maioria absoluta dos sites pesquisados, na prática, isso não acontece. Nem mesmo a tentativa de contato, via e-mail, é respondida.

Maria Cristina Rosa (2010) diz que 
a Federação dos Arte-Educadores do Brasil - FAEB - foi o instrumento de resistência dos arte/educadores na concretização do modelo de Ensino da Arte na década de 1990. Poucos são os documentos que registram essa participação, porque ainda é pequena a tradição de registrar a história dos arte/educadores no Brasil. Barbosa, a partir das produções de 1978,1982, 1985, 1986, 1990 e 2008 foi pioneira nessa tarefa. Podemos identificar os textos de 1986 e 2008 como o marco desse movimento de escrita histórica, mas com certeza ainda há muito que registrar, pela própria autora e por outros educadores do País que a acompanharam nas últimas décadas (ROSA, 2010).

Isso por que

seminários e congressos no Brasil não são fori de discussão e polêmica enriquecedora, mas tão somente painéis expositivos, onde os pesquisadores silenciam elegantemente quando confrontados com opiniões diversas das suas. Além do mais, no Brasil se confunde debate de ideias com embate pessoal [...] Pesquisadores publicam para um público restrito - basicamente seus colegas - e é raro que seus estudos alcancem um universo mais amplo de leitores e comentadores (MEDEIROS, 2010).

Ainda assim, é quase que somente nesse universo, de pesquisas incipientes, que se encontram trabalhos sobre o tema EaD em Artes Visuais. Esta pesquisa buscou fazer um levantamento dos trabalhos sobre a temática. Em relação ao stricto sensu não foram localizados trabalhos muitos significativos, embora seja importante registrar que, em relação ao uso das inovações tecnológicas no âmbito da produção artística contemporânea exista um grupo de teses de doutorado que aponta para a importância das tecnologias na formação de professores de Artes e, com relação à abordagem no campo da teoria critica as teses de Rosa (2004) e Cunha (2008) se destacam.

O quadro a seguir sintetiza esses dados recolhidos sobre os trabalhos nos últimos dois anos, em especial em relação aos congressos, publicações e demais eventos das áreas de Artes e Ensino de Artes: Esse quadro não pretende ser um documento definitivo. Configura-se como um registro da produção disponível entre 1999 e 2013 no Banco de Teses e Dissertações CAPES, periódicos e anais de eventos aos quais tive acesso. 


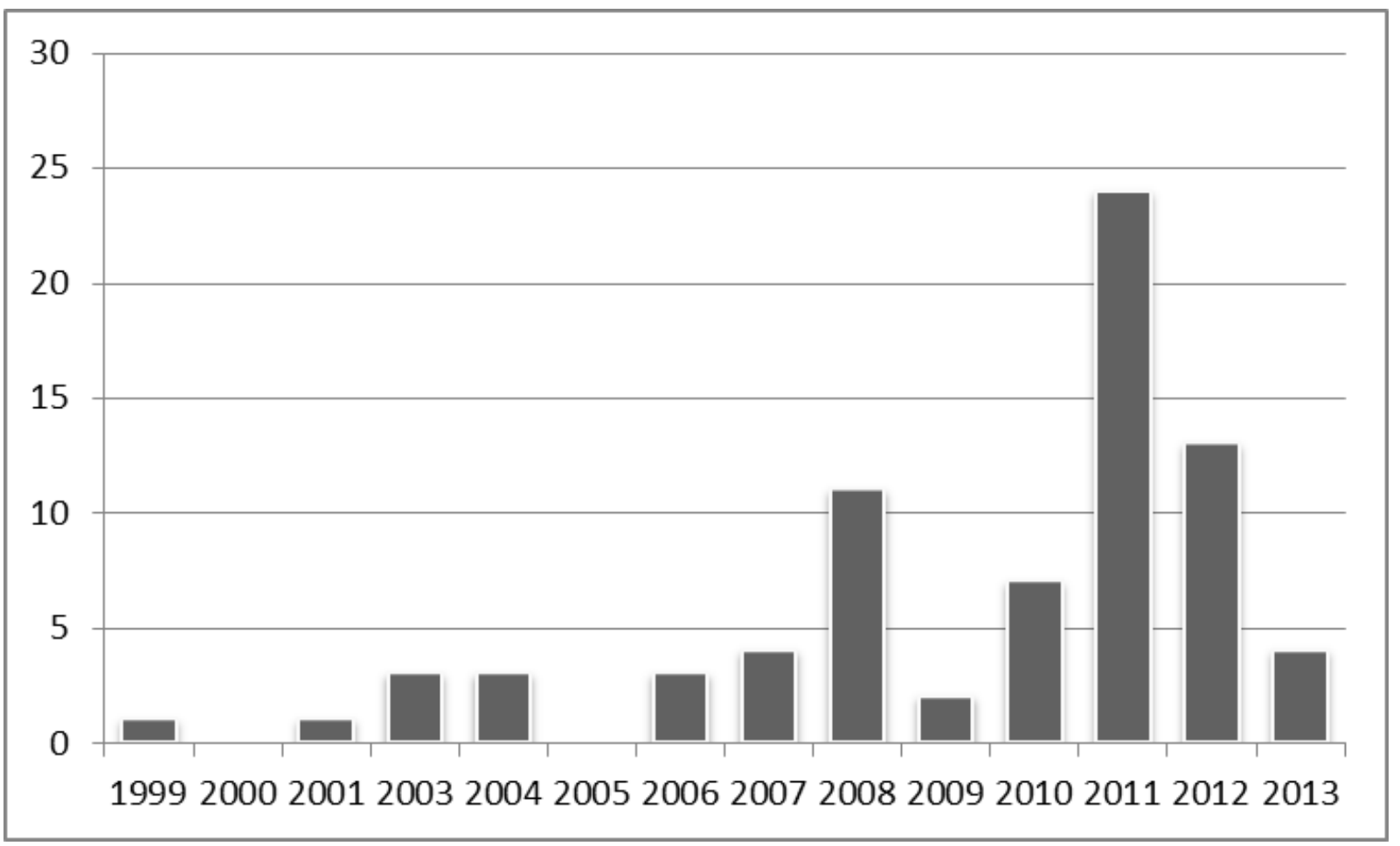

Figura 16 - Trabalhos sobre EaD em Artes Visuais, por ano, entre 1999 e $2013^{60}$.

${ }^{60}$ De 1999 a 2004 os trabalhos são todos desta autora. 
Tabela 21 - Trabalhos de pesquisa sobre o Tema EaD em Artes Visuais (entre 1999 e 2013).

\begin{tabular}{|c|c|c|c|c|}
\hline AUTOR & TíTULO & REFERÊNCIA & $\begin{array}{c}\text { TESE / } \\
\text { DISSERTAÇÃO / } \\
\text { ARTIGO }\end{array}$ & ANO \\
\hline \multicolumn{5}{|l|}{1999} \\
\hline Jurema Luzia de Freitas Sampaio. & $\begin{array}{l}\text { As Novas Tecnologias e o Professor de } \\
\text { Educação Artística. }\end{array}$ & $\begin{array}{l}\text { II Workshop sobre fatores Humanos em } \\
\text { Sistemas Computacionais. IHC99, } \\
\text { Out.1999. }\end{array}$ & ARTIGO & 1999 \\
\hline \multicolumn{5}{|c|}{ (7 } \\
\hline Jurema Luzia de Freitas Sampaio. & Artes, Comunicação e EaD. & Portal EduKbr, em 09 Jul.2001. & ARTIGO & 2001 \\
\hline \multicolumn{5}{|l|}{2003} \\
\hline Jurema Luzia de Freitas Sampaio. & $\begin{array}{l}\text { A utilização de linguagem VRML na } \\
\text { Educação a Distância em arte. }\end{array}$ & $\begin{array}{l}\text { Dissertação de mestrado defendida no } \\
\text { Programa de Pós-Graduação em Artes do } \\
\text { Instituto de Artes da Universidade Estadual } \\
\text { Paulista - UNESP como requisito final para } \\
\text { obtenção do Título de Mestre em Arte. } \\
\text { Área de Concentração: Artes Visuais. } \\
\text { Mar./2003. }\end{array}$ & DISSERTÇÃOO & 2003 \\
\hline Jurema Luzia de Freitas Sampaio. & $\begin{array}{l}\text { Comunidades Virtuais de Aprendizagem } \\
\text { Colaborativa, para Educação à distância em } \\
\text { Arte. }\end{array}$ & $\begin{array}{l}\text { Atas do Seminário Estadual de Arte na } \\
\text { Educação: Repensando a Identidade do } \\
\text { Professor de Arte. Univille/FURB/Uniplac. } \\
\text { Joinville-SC: Univille, } 2003 .\end{array}$ & ARTIGO & 2003 \\
\hline Jurema Luzia de Freitas Sampaio. & $\begin{array}{l}\text { Uso e VRML em e-Learning para Ensino de } \\
\text { Arte: Possibilidades e Condições de uso no } \\
\text { Brasil. }\end{array}$ & $\begin{array}{l}\text { Actas da Conferência lbero-Americana } \\
\text { WWW/Internet 2003. Algarve, Portugal. } 08 \\
\text { e } 09 \text { Nov.2003. }\end{array}$ & ARTIGO & 2003 \\
\hline \multicolumn{5}{|l|}{2004} \\
\hline Jurema Luzia de Freitas Sampaio. & $\begin{array}{l}\text { Uso de VRML em EDMC para Ensino de } \\
\text { Arte: Possibilidades e Condições Atuais. }\end{array}$ & $\begin{array}{l}\text { Revista Técnica IPEP, São Paulo, SP, } \\
\text { v.04, n.02 p.09-19. Jul./Dez. 2004. ISSN } \\
\text { 1676-1758. }\end{array}$ & ARTIGO & 2004 \\
\hline Jurema Luzia de Freitas Sampaio. & $\begin{array}{l}\text { Uso de VRML em e-Learning para Ensino de } \\
\text { Artes Visuais. }\end{array}$ & $\begin{array}{l}\text { III edição do Fórum Mundial de Educação. } \\
28 \text { a } 31 \text { de julho de } 2004 \text {, Porto Alegre/RS. }\end{array}$ & ARTIGO & 2004 \\
\hline Jurema Luzia de Freitas Sampaio. & $\begin{array}{l}\text { Uso de VRML para Educação à Distância em } \\
\text { Arte. }\end{array}$ & $\begin{array}{l}\text { XV ConFAEB - Trajetória e Políticas para o } \\
\text { Ensino de Arte no Brasil. Pôster. 10, } 11 \text { e } \\
12 \text { Nov.2004. Rio de Janeiro - RJ. }\end{array}$ & ARTIGO & 2004 \\
\hline Maria Cristina Rosa & $\begin{array}{l}\text { A Educação de professoras e professores de } \\
\text { arte: construindo uma proposta de Ensino } \\
\text { multicultural a distância. }\end{array}$ & $\begin{array}{l}\text { Universidade Federal de Santa Catarina, } \\
\text { Florianópolis. }\end{array}$ & $\begin{array}{l}\text { TESE DE } \\
\text { DOUTORADO }\end{array}$ & 2004 \\
\hline
\end{tabular}




\begin{tabular}{|c|c|c|c|c|}
\hline \multicolumn{5}{|l|}{2006} \\
\hline Maria Cristina da Rosa. & $\begin{array}{l}\text { A Educação inclusiva de professores de arte } \\
\text { a distância: possibilidades e conflitos. }\end{array}$ & $\begin{array}{l}\text { Revista do Centro de Educação. Edição: } \\
\text { 2006. v. } 31 \text { - n. } 02 \text {. }\end{array}$ & ARTIGO & 2006 \\
\hline Jurema Luzia de Freitas Sampaio. & Espaço Virtual e Educação em Arte. & $\begin{array}{l}\text { Revista Digital Art\&, Brasil, v. 05, n. } 01 . \\
\text { Out.2006. }\end{array}$ & ARTIGO & 2006 \\
\hline Jurema Luzia de Freitas Sampaio. & $\begin{array}{l}\text { Use of VRML in e-Learning for Art } \\
\text { Education: Possibilities and use conditions in } \\
\text { Brazil. }\end{array}$ & $\begin{array}{l}\text { Proceedings of the International InSEA } \\
\text { Congress 2006: Interdisciplinary Dialogues } \\
\text { in Arts Education, } 2006 \text {. }\end{array}$ & ARTIGO & 2006 \\
\hline Anna Rita Ferreira de Araújo. & $\begin{array}{l}\text { Editorial - Projetos pedagógicos: O pró- } \\
\text { licenciatura. }\end{array}$ & $\begin{array}{l}\text { In: Revista Digital Art\& - ISSN 1806-2962 - } \\
\text { Ano IV - Número } 06 \text { - Out. } 2006 .\end{array}$ & EDITORIAL & 2006 \\
\hline \multicolumn{5}{|l|}{2007} \\
\hline Wanderley Alves dos Santos. & $\begin{array}{l}\text { Ensino de Arte na modalidade a Distância: } \\
\text { uma proposta e desafios com as tecnologias } \\
\text { contemporâneas para uma prática de } \\
\text { excelência. }\end{array}$ & Revista Solta a Voz. v. 18. n.0 2. 2007. & ARTIGO & 2007 \\
\hline Maria Emília Sardelich. & Nós-das-redes da UNIMES Virtual. & $\begin{array}{l}\text { Revista Paidéi@ (Santos), v. 1, p. 1-15, } \\
2007 .\end{array}$ & ARTIGO & 2007 \\
\hline Sheila Maria Conde Rocha Campello. & $\begin{array}{l}\text { Licenciatura em Artes Visuais a distância no } \\
\text { Instituto de Artes da Universidade de Brasília }\end{array}$ & $\begin{array}{l}16^{\circ} \text { Encontro Nacional da Associação } \\
\text { Nacional de Pesquisadores de Artes } \\
\text { Plásticas. Dinâmicas Epistemológicas em } \\
\text { Artes Visuais - } 24 \text { a } 28 \text { de setembro de } \\
2007 \text { - Florianópolis }\end{array}$ & ARTIGO & 2007 \\
\hline $\begin{array}{l}\text { Maria Cristina V. Biazus; Fernanda } \\
\text { Spanier Amador e Andreia Machado } \\
\text { Oliveira. }\end{array}$ & $\begin{array}{l}\text { Arte, Educação, Tecnologia: } \\
\text { experimentações num campo } \\
\text { transdisciplinar. }\end{array}$ & $\begin{array}{l}30 \text { a. Reunião Anual da ANPED. Outubro } \\
\text { de } 2007 .\end{array}$ & ARTIGO & 2007 \\
\hline Leda Maria de Barros Guimarães. & $\begin{array}{l}\text { Operações sinergéticas na Educação a } \\
\text { Distância de Artes Visuais. }\end{array}$ & $\begin{array}{l}6^{\circ} \text { Encontro Internacional de Arte e } \\
\text { Tecnologia: interseções entre arte e } \\
\text { pesquisas tecno-científicas. (Resumo) } \\
\text { Brasília: Mai. } 2007 .\end{array}$ & ARTIGO & 2007 \\
\hline Luzirene do Rego Leite & Atelier Virtual & Instituto de Artes; Universidade de Brasília & DISSERTAÇÂO ${ }^{61}$ & 2007 \\
\hline \multicolumn{5}{|l|}{2008} \\
\hline Sheila Maria Conde Rocha Campello. & $\begin{array}{l}\text { Redes sociais na Internet: possibilidades de } \\
\text { aplicação na arte-Educação a Distância. }\end{array}$ & $\begin{array}{l}\text { \#7ART - Encontro Internacional de Arte e } \\
\text { Tecnologia. Out.2008. }\end{array}$ & ARTIGO & 2008 \\
\hline $\begin{array}{l}\text { Leda Maria de Barros Guimarães e } \\
\text { Teresinha Losada. }\end{array}$ & $\begin{array}{l}\text { Novos e velhos tremores: o Ensino de Artes } \\
\text { Visuais na modalidade EaD. }\end{array}$ & $\begin{array}{l}\text { In: MARTINS, Raimundo. Visualidade e } \\
\text { Educação. Grupo de Pesquisa - Educação } \\
\text { e Cultura Visual. PPG-CV/UFG - IdA/UNB }\end{array}$ & $\begin{array}{l}\text { CAPITULO DE } \\
\text { LIVRO. }\end{array}$ & 2008 \\
\hline
\end{tabular}

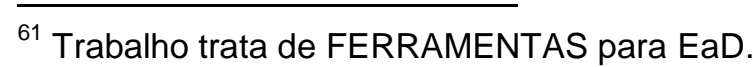




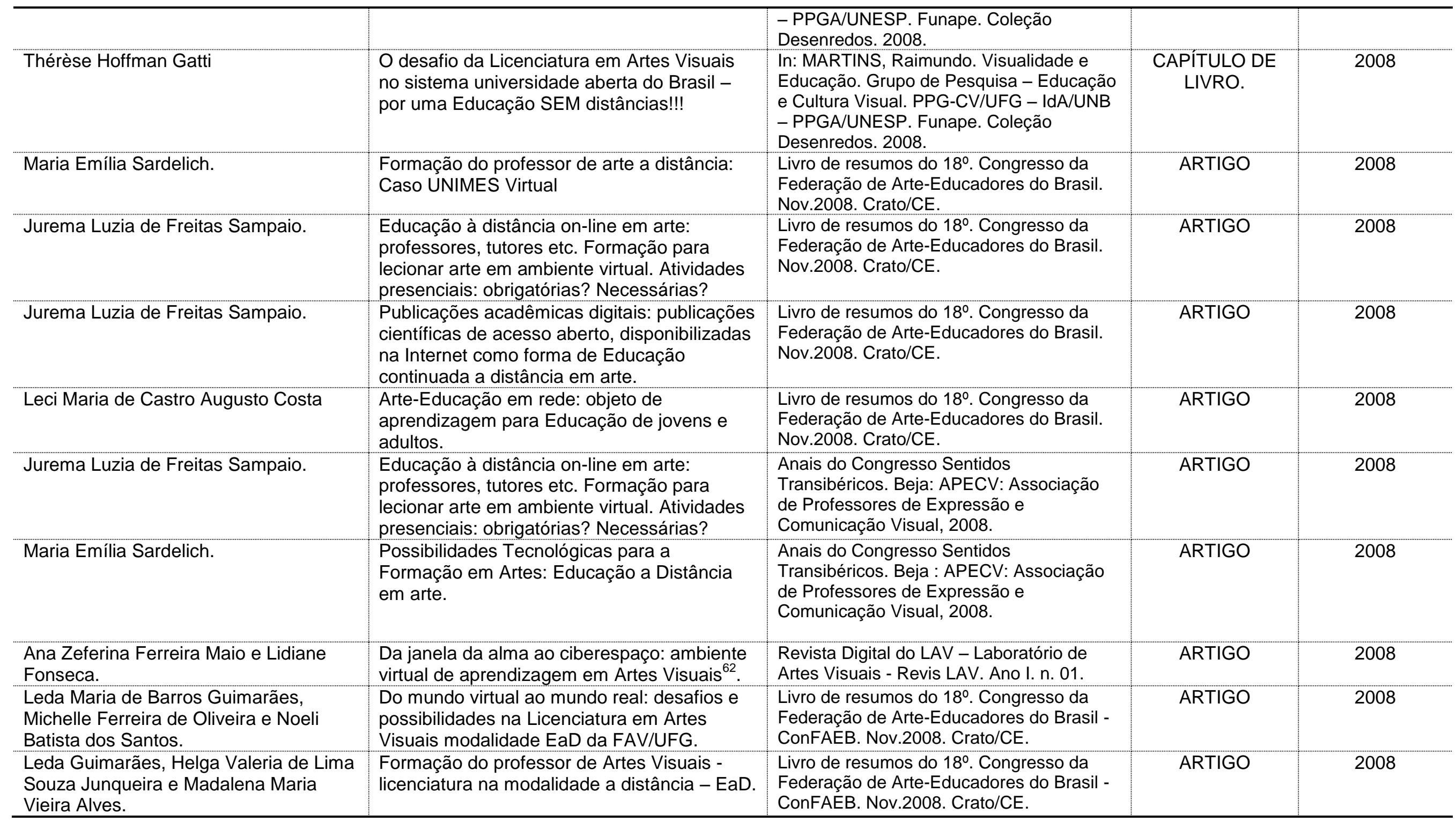

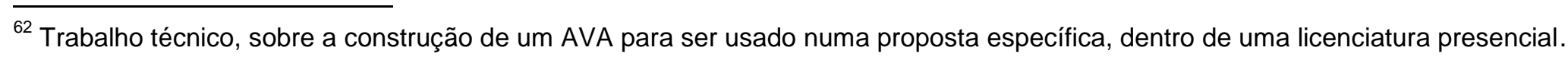




\begin{tabular}{|c|c|c|c|c|}
\hline $\begin{array}{l}\text { Jordana Falcão Tavares, Pablo Petit } \\
\text { Passos Sérvio }\end{array}$ & $\begin{array}{l}\text { O aluno como protagonista do processo de } \\
\text { Ensino-aprendizagem na formação de } \\
\text { professores de Artes Visuais na modalidade } \\
\text { a distância. }\end{array}$ & $\begin{array}{l}\text { Livro de resumos do 18ํ. Congresso da } \\
\text { Federação de Arte-Educadores do Brasil - } \\
\text { ConFAEB. Nov.2008. Crato/CE. }\end{array}$ & ARTIGO & 2008 \\
\hline Fernanda Pereira da Cunha & $\begin{array}{l}\text { Cultura Digital na e-Arte/Educação: } \\
\text { Educação Digital Crítica. }\end{array}$ & ECA USP. & $\begin{array}{l}\text { TESE DE } \\
\text { DOUTORADO }\end{array}$ & 2008 \\
\hline \multicolumn{5}{|l|}{2009} \\
\hline $\begin{array}{l}\text { Lidiane Fonseca Dutra e Ana Zeferina } \\
\text { Ferreira Maio. }\end{array}$ & $\begin{array}{l}\text { O Ensino de Arte diante das tecnologias } \\
\text { contemporâneas. }\end{array}$ & Revista Palíndromo. Mar.2009. & ARTIGO & 2009 \\
\hline Alexandra Cristina Moreira Caetano. & $\begin{array}{l}\text { Objetos de Aprendizagem em Artes } \\
\text { Visuais }^{63} \text {. }\end{array}$ & $\begin{array}{l}\text { IV Congreso de la CiberSociedad } 2009 . \\
\text { Crisis analógica, futuro digital. Grupo de } \\
\text { trabajo A-7: Enseñanza de competencias } \\
\text { digitales a colectivos específicos. }\end{array}$ & ARTIGO & 2009 \\
\hline $\begin{array}{l}\text { Maria Cristina Rosa Fonseca da Silva e } \\
\text { Katiuscia Sosnovsky. }\end{array}$ & $\begin{array}{l}\text { Recortes do Ensino de Artes a Distância no } \\
\text { Brasil: diversidade e inclusão. }\end{array}$ & $\begin{array}{l}\text { Anais do Congress D’Educación de Les } \\
\text { Arts Visuals, 3., 2009, Barcelona. } \\
\text { Barcelona: Universidad de Barcelona, } \\
2009 \text {. }\end{array}$ & ARTIGO & 2009 \\
\hline Maria Cristina Rosa Fonseca da Silva. & $\begin{array}{l}\text { Objetos Pedagógicos de Inclusão: uma ação } \\
\text { política na formação de professores de arte. }\end{array}$ & $\begin{array}{l}\text { In: LAMPERT, Jociele e MACEDO, Silvana } \\
\text { Barbosa. (Org.) Simpósio de Integração } \\
\text { das Artes Visuais: arte e política (1.: } 2009 \text { : } \\
\text { Florianópolis, SC). }\end{array}$ & ARTIGO & 2009 \\
\hline Leda Maria de Barros Guimarães. & $\begin{array}{l}\text { Formação de professores em Artes Visuais } \\
\text { na FAV/UFG - deslocamentos da distância e } \\
\text { deslocamentos da cultura visual. }\end{array}$ & $\begin{array}{l}\text { Revista VIS. Revista do Programa de Pós- } \\
\text { Graduação em Arte da UnB } \\
\text { v. } 8 \text { n.1 Jan./Jul. 2009. Brasília. }\end{array}$ & ARTIGO & 2009 \\
\hline Lilian Ucker & $\begin{array}{l}\text { Diálogos entre vivências e deslocamentos a } \\
\text { partir de experiências de Educação e } \\
\text { distância. }\end{array}$ & $\begin{array}{l}\text { Revista VIS. Revista do Programa de Pós- } \\
\text { Graduação em Arte da UnB } \\
\text { v. } 8 \text { n.1 Jan./Jul. 2009. Brasília. }\end{array}$ & ARTIGO & 2009 \\
\hline $\begin{array}{l}\text { Thérèse Hofmann Gatti \& Rosana de } \\
\text { Castro }\end{array}$ & $\begin{array}{l}\text { Licenciatura em Artes Visuais - UAB/UnB: } \\
\text { uma análise das possibilidades em cultura } \\
\text { visual sob a perspectiva do pensamento } \\
\text { complexo }\end{array}$ & $\begin{array}{l}\text { Revista VIS. Revista do Programa de Pós- } \\
\text { Graduação em Arte da UnB } \\
\text { v. } 8 \text { n.1 Jan./Jul. 2009. Brasília. }\end{array}$ & ARTIGO & 2009 \\
\hline Sainy C. B. Veloso & $\begin{array}{l}\text { Um novo ou um mesmo desafio no Ensino } \\
\text { das Artes Visuais? }\end{array}$ & $\begin{array}{l}\text { Revista VIS. Revista do Programa de Pós- } \\
\text { Graduação em Arte da UnB } \\
\text { v. } 8 \text { n.1 Jan./Jul. } 2009 \text {. Brasília. }\end{array}$ & ARTIGO & 2009 \\
\hline Jurema Luzia de Freitas Sampaio. & $\begin{array}{l}\text { E-ducaç@o: Comunidades virtuais ou } \\
\text { monarquias disfarçadas de novidade? }\end{array}$ & $\begin{array}{l}\text { Congresso Interdidática. Brasília. Mai. } \\
2009 .\end{array}$ & PALESTRA & 2009 \\
\hline Daniele Quiroga Neves. & $\begin{array}{l}\text { Ambiente Virtual de Aprendizagem em Artes } \\
\text { Visuais: da janela da alma ao ciberespaço. }\end{array}$ & $\begin{array}{l}\text { Anais do V Colóquio sobre o Ensino de } \\
\text { Arte "Desafios da prática docente". I }\end{array}$ & ARTIGO & 2009 \\
\hline
\end{tabular}

\footnotetext{
${ }^{63}$ Artigo sobre o desenvolvimento de objetos de aprendizagem em artes e sua utilização no Ensino tanto presencial quanto a distância.
} 


\begin{tabular}{|c|c|c|c|c|}
\hline & Ensino de Arte: antigas e novas tecnologias. & $\begin{array}{l}\text { Encontro regional da FAEB Regional/Sul, } \\
2009 \text {. }\end{array}$ & & \\
\hline \multicolumn{5}{|c|}{ 20 } \\
\hline Jurema Luzia de Freitas Sampaio & $\begin{array}{l}\text { O que se ensina e o que se aprende nas } \\
\text { licenciaturas em Artes Visuais a distância? }\end{array}$ & $\begin{array}{l}\text { Anais do } 20^{\circ} \text {. ConFAEB - Congresso da } \\
\text { Federação dos Arte/Educadores do Brasil. } \\
\text { Goiânia: UFG, } 2010 .\end{array}$ & ARTIGO & 2010 \\
\hline $\begin{array}{l}\text { Cibelle Amorim Martins, } \\
\text { José Rogério Santana e } \\
\text { Mônica Barbosa dos Santos. }\end{array}$ & $\begin{array}{l}\text { Reflexões Artísticas e Educacionais acerca } \\
\text { da Ação Docente no Processo de Produção- } \\
\text { Formação em Artes Visuais. }\end{array}$ & $\begin{array}{l}\text { Anais do 3o. Simpósio Hipertexto e } \\
\text { Tecnologias na Educação. Redes Sociais e } \\
\text { Aprendizagem. } 2010 \text {. }\end{array}$ & ARTIGO & 2010 \\
\hline Sheila Maria Conde Rocha Campello. & $\begin{array}{l}\text { CiberEducação em Arte: uma proposta } \\
\text { metodológica para a arte/Educação no } \\
\text { ciberespaço }\end{array}$ & $\begin{array}{l}\text { 90 Encontro Internacional de Arte e } \\
\text { Tecnologia. Brasília, } 2010 .\end{array}$ & ARTIGO & 2010 \\
\hline Ángeles Saura e Maria Emília Sardelich. & $\begin{array}{l}\text { Interterritorialidades en la Web } 2.0 \text {. } \\
\text { Posibilidades para la formación contínua del } \\
\text { maestro de educación artística en el contexto } \\
\text { latinoamericano. }\end{array}$ & $\begin{array}{l}\text { Revista lbero Americana de Educación. } \\
\text { Número 52/3. Mar.2010. }\end{array}$ & ARTIGO & 2010 \\
\hline Marcella Barroso. & $\begin{array}{l}\text { O Ensino de Artes na Educação à distância: } \\
\text { Reflexões, benefícios e limites }{ }^{64} \text {. }\end{array}$ & $\begin{array}{l}\text { Revista InterSaberes. Ano 05. n. 09. p. 42- } \\
\text { 58, Jan./Jun.2010. }\end{array}$ & ARTIGO & 2010 \\
\hline Maria Emília Sardelich. & $\begin{array}{l}\text { A Licenciatura em Artes Visuais a Distância } \\
\text { da UNIMES Virtual: desafio para a formação } \\
\text { do professor. }\end{array}$ & Revista Paidéi@.v. 02. n. 03. Jul.2010. & ARTIGO & 2010 \\
\hline Maria Emília Sardelich e Angeles Saura. & $\begin{array}{l}\text { Interterritorialidades en la Web } 2.0 \text { : } \\
\text { posibilidades para la formación contínua del } \\
\text { maestro de educación artística en el contexto } \\
\text { latinoamericano. }\end{array}$ & $\begin{array}{l}\text { Revista Ibero-americana de Educación, v. } \\
52, \text { p. } 1-15,2010 .\end{array}$ & ARTIGO & 2010 \\
\hline Leda Maria de Barros Guimarães. & $\begin{array}{l}\text { Deslocamentos na Formação de professores } \\
\text { de Artes Visuais na modalidade a distância. }\end{array}$ & $\begin{array}{l}\text { 19² Encontro da Associação Nacional de } \\
\text { Pesquisadores em Artes Plásticas “Entre } \\
\text { Territórios" - } 20 \text { a } 25 \text { Set.2010 - Cachoeira } \\
\text { - Bahia - Brasil. }\end{array}$ & ARTIGO & 2010 \\
\hline Katyúscia Sosnowski. & $\begin{array}{l}\text { Professores e o Ensino de Artes Visuais on- } \\
\text { line: interações multiculturais críticas. }\end{array}$ & $\begin{array}{l}\text { Mestrado em Artes Visuais pelo PPGAV - } \\
\text { UDESC. }\end{array}$ & DISSERTAÇĀO & 2010 \\
\hline Soraya Misty Pereira Hamasaki. & $\begin{array}{l}\text { Relato de uma prática de tutoria no curso de } \\
\text { Artes Visuais - modalidade a distância - na } \\
\text { Universidade Federal do Espírito Santo. }\end{array}$ & $\begin{array}{l}\text { Revista Palíndromo. Ensino de Arte. } \\
\text { Jun./Dez. } 2010 .\end{array}$ & ARTIGO & 2010 \\
\hline Jurema Luzia de Freitas Sampaio. & $\begin{array}{l}\text { O que se ensina e o que se aprende nas } \\
\text { licenciaturas em Artes Visuais a distância? }\end{array}$ & $\begin{array}{l}\text { ConFAEB } 20 \text { Anos, 2010, Goiânia - Goiás. } \\
\text { Anais ConFAEB. } 2010 .\end{array}$ & ARTIGO & 2010 \\
\hline Maria Emília Sardelich. & Desafios para a formação do professor de & ConFAEB 20 Anos, 2010, Goiânia - Goiás. & ARTIGO & 2010 \\
\hline
\end{tabular}

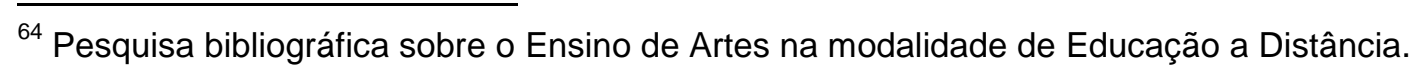




\begin{tabular}{|c|c|c|c|c|}
\hline & $\begin{array}{l}\text { arte a distância: as aprendizagens do corpo } \\
\text { docente da UNIMES Virtual }\end{array}$ & Anais ConFAEB. 2010. & & \\
\hline Myriam Fernandes Pestana Oliveira. & $\begin{array}{l}\text { O curso de Artes Visuais - Licenciatura - } \\
\text { Modalidade a Distância no Espírito Santo: } \\
\text { Desafios e possibilidades. }\end{array}$ & $\begin{array}{l}\text { ConFAEB } 20 \text { Anos, } 2010 \text {, Goiânia - Goiás. } \\
\text { Anais ConFAEB. } 2010 .\end{array}$ & ARTIGO & 2010 \\
\hline $\begin{array}{l}\text { Isabela Avancini, } \\
\text { Vinícius Bispo, } \\
\text { Marianna Schmidt e } \\
\text { Hugo Cristo. }\end{array}$ & $\begin{array}{l}\text { Modelos conceituais e aprendizado: estudo } \\
\text { sobre o contexto do Centro de Artes - UFES. }\end{array}$ & $\begin{array}{l}\text { Simpósio de Aprendizagem em Ambientes } \\
\text { Virtuais - Simpav. 10, } 11 \text { e } 12 \text { de Dez. } \\
\text { 2010. UFES. }\end{array}$ & ARTIGO & 2010 \\
\hline \multicolumn{5}{|l|}{2011} \\
\hline Ana Luiza Ruschel Nunes. & $\begin{array}{l}\text { Diretrizes para a formação inicial de } \\
\text { professores em cursos de licenciatura em } \\
\text { nível superior e o Ensino de Artes Visuais }\end{array}$ & $\begin{array}{l}\text { XXI Congresso Nacional da Federação de } \\
\text { Arte/Educadores do Brasil São Luís - } 2011 \\
\text { ANAIS 2: TEXTOS COMPLETOS. }\end{array}$ & ARTIGO & 2011 \\
\hline Maria Emília Sardelich. & $\begin{array}{l}\text { Hipertexto colaborativo e prática de pesquisa } \\
\text { na formação de professores a distância. }\end{array}$ & $\begin{array}{l}\text { III Seminário de Formação de Professores: } \\
\text { Trabalho Docente, Educação Superior e } \\
\text { Cultura Digital. Uberlândia : Editora UFTM, } \\
\text { 2011. p. 104-104. }\end{array}$ & ARTIGO & 2011 \\
\hline Maria Emília Sardelich. & $\begin{array}{l}\text { Os papéis da equipe docente no processo de } \\
\text { acompanhamento da aprendizagem em } \\
\text { cursos a distância. }\end{array}$ & Revista Paidéi@, v. 2, p. 1-29, 2011. & ARTIGO & 2011 \\
\hline Maria Emília Sardelich. & $\begin{array}{l}\text { A formação do professor de Educação } \\
\text { artística a distância. }\end{array}$ & $\begin{array}{l}\text { Revista EFT: Educação, Formação e } \\
\text { Tecnologias, v. 4, p. 53-65, } 2011 .\end{array}$ & ARTIGO & 2011 \\
\hline $\begin{array}{l}\text { José Maximiano Arruda Ximenes de } \\
\text { Lima. }\end{array}$ & $\begin{array}{l}\text { A abordagem triangular como base teórica na } \\
\text { elaboração de objetos de aprendizagem no } \\
\text { curso de Licenciatura em Artes Visuais do } \\
\text { instituto Federal do Ceará. }\end{array}$ & $\begin{array}{l}\text { XXI Congresso Nacional da Federação de } \\
\text { Arte/Educadores do Brasil São Luís - } 2011 \\
\text { ANAIS 2: TEXTOS COMPLETOS. }\end{array}$ & ARTIGO & 2011 \\
\hline Gisele Costa Ferreira da Silva & $\begin{array}{l}\text { Entre alunicidades desejadas: analisando } \\
\text { subjetividades no Ensino à distância. Estado } \\
\text { da arte: representações de professores de } \\
\text { Artes Visuais sobre o trabalho docente no } \\
\text { Ensino médio }\end{array}$ & $\begin{array}{l}\text { XXI Congresso Nacional da Federação de } \\
\text { Arte/Educadores do Brasil São Luís - } 2011 \\
\text { ANAIS 2: TEXTOS COMPLETOS. }\end{array}$ & ARTIGO & 2011 \\
\hline Meire Assunção Sousa Araujo. & $\begin{array}{l}\text { Mediação pedagógica no Ensino de Arte: } \\
\text { construindo possibilidades de criação virtual } \\
\text { a distância. }\end{array}$ & $\begin{array}{l}\text { XXI Congresso Nacional da Federação de } \\
\text { Arte/Educadores do Brasil São Luís - } 2011 \\
\text { ANAIS 2: TEXTOS COMPLETOS. }\end{array}$ & ARTIGO & 2011 \\
\hline Nayara Joyse Silva Monteles. & $\begin{array}{l}\text { Desafios e possibilidades de aprendizagem } \\
\text { nos cursos de Artes Visuais a Distância da } \\
\text { Universidade Federal do Maranhão. }\end{array}$ & $\begin{array}{l}\text { XXI Congresso Nacional da Federação de } \\
\text { Arte/Educadores do Brasil São Luís - } 2011 \\
\text { ANAIS 2: TEXTOS COMPLETOS. }\end{array}$ & ARTIGO & 2011 \\
\hline $\begin{array}{l}\text { Rosifrance Candeira Machado e } \\
\text { Luciana Aguiar }\end{array}$ & $\begin{array}{l}\text { Pró-Licenciatura em Artes Visuais na } \\
\text { Universidade Federal do Maranhão - desafios } \\
\text { e conquistas nos anos de } 2008 \text { a } 2011 \text {. }\end{array}$ & $\begin{array}{l}\text { XXI Congresso Nacional da Federação de } \\
\text { Arte/Educadores do Brasil São Luís - } 2011 \\
\text { ANAIS 2: TEXTOS COMPLETOS. }\end{array}$ & ARTIGO & 2011 \\
\hline
\end{tabular}




\begin{tabular}{|c|c|c|c|c|}
\hline $\begin{array}{l}\text { Camila Oliveira de Medeiros, João } \\
\text { Helder Alves Silva e José Maximiano } \\
\text { Arruda Ximenes de Lima }\end{array}$ & $\begin{array}{l}\text { AVETCOR - Ambiente Virtual de Ensino da } \\
\text { Teoria da Cor. }\end{array}$ & $\begin{array}{l}\text { XXII Congresso da Federação de Arte- } \\
\text { Educadores do Brasil - ConFAEB. São } \\
\text { Paulo. }\end{array}$ & ARTIGO & 2011 \\
\hline Myriam Fernandes Pestana Oliveira. & $\begin{array}{l}\text { O curso de Artes Visuais - licenciatura - na } \\
\text { modalidade a distância - no Espírito Santo: } \\
\text { desafios e possibilidades. }\end{array}$ & $\begin{array}{l}\text { XXI Congresso Nacional da Federação de } \\
\text { Arte/Educadores do Brasil São Luís - } 2011 \\
\text { ANAIS 2: TEXTOS COMPLETOS. }\end{array}$ & ARTIGO & 2011 \\
\hline Joelma Cellin. & $\begin{array}{l}\text { Formação de professores em Artes Visuais: } \\
\text { um estudo reflexivo na Cidade de Cachoeiro } \\
\text { do Itapemirim. }\end{array}$ & $\begin{array}{l}\text { XXI Congresso Nacional da Federação de } \\
\text { Arte/Educadores do Brasil São Luís - } 2011 \\
\text { ANAIS 2: TEXTOS COMPLETOS. }\end{array}$ & ARTIGO & 2011 \\
\hline Eliane Hilario da Silva Martinoff & A pesquisa em Arte no Ensono a Distância & $\begin{array}{l}\text { XXI Congresso Nacional da Federação de } \\
\text { Arte/Educadores do Brasil São Luís - } 2011 \\
\text { ANAIS 2: TEXTOS COMPLETOS. }\end{array}$ & ARTIGO & 2011 \\
\hline Leda Maria de Barros Guimarães. & $\begin{array}{l}\text { Estágios curriculares na EaD - Como? Onde? } \\
\text { Para quê? Para quem? }\end{array}$ & $\begin{array}{l}\text { XXI Congresso Nacional da Federação de } \\
\text { Arte/Educadores do Brasil São Luís - } 2011 \\
\text { ANAIS 2: TEXTOS COMPLETOS. }\end{array}$ & ARTIGO & 2011 \\
\hline Rosana de Castro & $\begin{array}{l}\text { Ensinar artes a distância: isso é possível? Os } \\
\text { desafios das práticas de ateliê na } \\
\text { Licenciatura em Artes Visuais da UAB/UnB }\end{array}$ & $\begin{array}{l}\text { Congresso da ABED. Brasília - DF - Maio } \\
2011\end{array}$ & ARTIGO & 2011 \\
\hline $\begin{array}{l}\text { Débora Cristina Santos e Silva \& Leda } \\
\text { Maria de Barros Guimarães. }\end{array}$ & $\begin{array}{l}\text { Uma experiência de autoria, mediação } \\
\text { pedagógica e pesquisa em EaD (Educação a } \\
\text { Distância) }\end{array}$ & $\begin{array}{l}\text { Cibertextualidades. Porto. ISSN 1646- } \\
\text { 4435. } 4 \text { (2011) 115-127. }\end{array}$ & ARTIGO & 2011 \\
\hline Maria Emília Sardelich. & $\begin{array}{l}\text { A formação do professor de Educação } \\
\text { artística a distância. }\end{array}$ & $\begin{array}{l}\text { Revista Educação, Formação \& } \\
\text { Tecnologias (Maio, 2011), } 4 \text { (1), 53-65. }\end{array}$ & ARTIGO & 2011 \\
\hline Bárbara Angelo Moura Vieira. & Ensino de Artes Visuais à Distância. & $\begin{array}{l}\text { Universidade, EaD e Software Livre. } \\
\text { Evento On-Line Assíncrono. Promoção } \\
\text { Texto Livre e FALE/UFMG. } 06 \text { de junho de } \\
2011 .\end{array}$ & ARTIGO & 2011 \\
\hline $\begin{array}{l}\text { Fernanda Pereira da Cunha; André } \\
\text { Thiago de Almeida Barz; Carmen } \\
\text { Rizzotto Borba e Michelle Santos Costa. }\end{array}$ & $\begin{array}{l}\text { e-Arte/Educação Crítica: Interterritorialidade } \\
\text { entre Design, Artes Visuais e Musica. }\end{array}$ & $\begin{array}{l}\text { Congresso Nacional de Ambientes } \\
\text { Hipermídia para Aprendizagem. } \\
\text { Pelotas/RS. Set.2011. }\end{array}$ & ARTIGO & 2011 \\
\hline Rosana de Castro. & $\begin{array}{l}\text { Ensinar artes a distância? Isso é possível? } \\
\text { Os desafios das práticas de ateliê na } \\
\text { Licenciatura em Artes Visuais da UAB/UnB. }\end{array}$ & $\begin{array}{l}\text { 17o. Congresso Internacional ABED. } \\
\text { Ago./Set. 2011. Manaus/AM. }\end{array}$ & ARTIGO & 2011 \\
\hline $\begin{array}{l}\text { Tânia Cristina Costa Ribeiro e Luciana } \\
\text { Silva Aguiar Mendes Barros. }\end{array}$ & $\begin{array}{l}\text { A pesquisa na Educação a Distância do } \\
\text { curso de Artes Visuais: desafios e } \\
\text { possibilidades. }\end{array}$ & $\begin{array}{l}\text { ESUD } 2011 \text { - VIII Congresso Brasileiro de } \\
\text { Ensino Superior a Distância Ouro Preto, } 03 \\
\text { - } 05 \text { Out. UNIREDE. }\end{array}$ & ARTIGO & 2011 \\
\hline $\begin{array}{l}\text { Cecilia Noriko Ito Saito e Lêda Maria de } \\
\text { Barros Guimarães. }\end{array}$ & $\begin{array}{l}\text { Redes em expansão: Desafios EAD- } \\
\text { FAV/UFG e o Projeto Rede de Conexões e } \\
\text { Pesquisas: um campo experimental nas }\end{array}$ & $\begin{array}{l}\text { ABCiber. V Simpósio. Florianópolis. } \\
\text { Nov./2011. }\end{array}$ & ARTIGO & 2011 \\
\hline
\end{tabular}




\begin{tabular}{|c|c|c|c|c|}
\hline & Artes Visuais. & & & \\
\hline Betânia Libanio Dantas de Araújo. & $\begin{array}{l}\text { O Ensino da Arte: discussões sobre a } \\
\text { aprendizagem presencial e virtual. }\end{array}$ & $\begin{array}{l}\text { Educação a Distância. Revista Científica do } \\
\text { Centro Universitário Claretiano. v. 01. N.01. } \\
2011 .\end{array}$ & ARTIGO & 2011 \\
\hline $\begin{array}{l}\text { Cláudia Mariza Mattos Brandão, Daniela } \\
\text { Pereira dos Santos. }\end{array}$ & $\begin{array}{l}\text { A formação docente em Artes Visuais } \\
\text { mediada pelas novas tecnologias: anotações } \\
\text { de um projeto em desenvolvimento. }\end{array}$ & $\begin{array}{l}\text { Anais do } 6^{\circ} \text { Encontro de Pesquisa em Arte. } \\
\text { Montenegro. Ed. da Fundarte. }\end{array}$ & ARTIGO & 2011 \\
\hline Andrea Hofstaetter. & $\begin{array}{l}\text { Criação de objeto de aprendizagem para } \\
\text { Artes Visuais }\end{array}$ & $\begin{array}{l}\text { Anais do } 60 \text { Encontro de Pesquisa em Arte. } \\
\text { Montenegro. Ed. da Fundarte. }\end{array}$ & ARTIGO & 2011 \\
\hline \multicolumn{5}{|l|}{2012} \\
\hline Rubens de Souza & $\begin{array}{l}\text { Ensino de Artes Visuais em EaD: paradigmas } \\
\text { curriculares. }\end{array}$ & $\begin{array}{l}\text { UNISANTA Humanitas - p. } 55 \text { - 77; v. } 2 \text { a. } \\
1 .\end{array}$ & ARTIGO & 2012 \\
\hline $\begin{array}{l}\text { José Maximiano Arruda Ximenes de } \\
\text { Lima e João Helder Alves e Silva. }\end{array}$ & $\begin{array}{l}\text { Em busca de critérios no processo de } \\
\text { avaliação dos objetos de aprendizagem nos } \\
\text { cursos de Artes Visuais na modalidade de } \\
\text { Ensino a Distância. }\end{array}$ & $\begin{array}{l}\text { XXII Congresso da Federação de Arte-- } \\
\text { Educadores do Brasil - ConFAEB. São } \\
\text { Paulo. }\end{array}$ & ARTIGO & 2012 \\
\hline Jurema Luzia de Freitas Sampaio & $\begin{array}{l}\text { Novos desdobramentos da pesquisa } \mathrm{O} \text { que } \\
\text { se ensina e o que se aprende nas } \\
\text { licenciaturas em Artes Visuais a distância? }\end{array}$ & $\begin{array}{l}\text { XXII Congresso da Federação de Arte- } \\
\text { Educadores do Brasil - ConFAEB. São } \\
\text { Paulo. }\end{array}$ & ARTIGO & 2012 \\
\hline Jurema Luzia de Freitas Sampaio & $\begin{array}{l}\text { EaD em Artes Visuais, abordagem } \\
\text { triangulas, transdisciplinaridade e a TPACK } \\
\text { - Conhecimento Tecnológico Pedagógico } \\
\text { do Conteúdo - um início de diálogo. }\end{array}$ & $\begin{array}{l}\text { XXII Congresso da Federação de Arte- } \\
\text { Educadores do Brasil - ConFAEB. São } \\
\text { Paulo. }\end{array}$ & e-PÔSTER & 2012 \\
\hline Veronica Devens Costa & $\begin{array}{l}\text { Artes Visuais na EaD: práticas e } \\
\text { possibilidades. }\end{array}$ & $\begin{array}{l}\text { XXII Congresso da Federação de Arte- } \\
\text { Educadores do Brasil - ConFAEB. São } \\
\text { Paulo. }\end{array}$ & ARTIGO & 2012 \\
\hline $\begin{array}{l}\text { Antonia Luz de Freitas Lima, } \\
\text { Carmelinda Maria Ferreira, Climeny } \\
\text { Angélia Ericson D'Oliveira, Wanessa } \\
\text { Ferreira Cardoso, Kelly Bianca Clifford } \\
\text { Valença }\end{array}$ & $\begin{array}{l}\text { Formação docente em Artes Visuais no } \\
\text { Ensino a Distância: histórias e implicações } \\
\text { de um caminho sinuoso }\end{array}$ & $\begin{array}{l}\text { XXII Congresso da Federação de Arte- } \\
\text { Educadores do Brasil - ConFAEB. São } \\
\text { Paulo. }\end{array}$ & ARTIGO & 2012 \\
\hline Luciana Silva Aguiar Mendes Barros & $\begin{array}{l}\text { Formação de professores na cibercultura: } \\
\text { um estudo das licenciaturas em Artes } \\
\text { Visuais na modalidade a distância. }\end{array}$ & $\begin{array}{l}\text { XXII Congresso da Federação de Arte- } \\
\text { Educadores do Brasil - ConFAEB. São } \\
\text { Paulo. }\end{array}$ & ARTIGO & 2012 \\
\hline João Helder Alves e Silva & $\begin{array}{l}\text { Em busca de critérios no processo de } \\
\text { avaliação dos objetos de aprendizagem nos } \\
\text { cursos de Artes Visuais na modalidade de } \\
\text { Ensino a Distância. }\end{array}$ & $\begin{array}{l}\text { XXII Congresso da Federação de Arte- } \\
\text { Educadores do Brasil - ConFAEB. São } \\
\text { Paulo. }\end{array}$ & ARTIGO & 2012 \\
\hline $\begin{array}{l}\text { Ana Paula da Silva, Kátia Miyahira, } \\
\text { Vivian Pires Marceniuk }\end{array}$ & $\begin{array}{l}\text { Mediação compartilhada: a experiência do } \\
\text { fazer artístico em ambientes virtuais de }\end{array}$ & $\begin{array}{l}\text { XXIl Congresso da Federação de Arte- } \\
\text { Educadores do Brasil - ConFAEB. São }\end{array}$ & ARTIGO & 2012 \\
\hline
\end{tabular}




\begin{tabular}{|c|c|c|c|c|}
\hline & aprendizagem. & Paulo. & & \\
\hline Maria Emília Sardelich & $\begin{array}{l}\text { Forma/R/Se a distância: aprendendo a ser } \\
\text { professor de Artes Visuais em ambientes } \\
\text { virtuais de aprendizagem. }\end{array}$ & $\begin{array}{l}\text { XXIl Congresso da Federação de Arte- } \\
\text { Educadores do Brasil - ConFAEB. São } \\
\text { Paulo. }\end{array}$ & ARTIGO & 2012 \\
\hline Jurema Luzia de Freitas Sampaio & $\begin{array}{l}\text { Educação à Distância On-line em Arte: } \\
\text { Professores, tutores, etc.: Formação para } \\
\text { Lecionar arte em ambiente virtual. } \\
\text { Atividades presenciais: Obrigatórias? } \\
\text { Necessárias? Tecnologias digitais e uso } \\
\text { pedagógico em arte. }\end{array}$ & $\begin{array}{l}\text { Anais do I Congresso Brasileiro de } \\
\text { Recursos Digitais na Educação. São } \\
\text { Paulo: CE@D - UPM, } 2012 .\end{array}$ & ARTIGO & 2012 \\
\hline Jurema Luzia de Freitas Sampaio & $\begin{array}{l}\text { O que se ensina e o que se aprende nas } \\
\text { licenciaturas em Artes Visuais a distância? }\end{array}$ & $\begin{array}{l}\text { Anais do I Congresso Brasileiro de } \\
\text { Recursos Digitais na Educação. São Paulo: } \\
\text { CE@D - UPM, } 2012 .\end{array}$ & ARTIGO & 2012 \\
\hline Jurema Luzia de Freitas Sampaio & $\begin{array}{l}\text { O que se ensina e o que se aprende nas } \\
\text { licenciaturas em Artes Visuais a distância? }\end{array}$ & $\begin{array}{l}\text { Revista Divers@! (Matinhos), v. 05, p. 08- } \\
30,2012 .\end{array}$ & ARTIGO & 2012 \\
\hline $\begin{array}{l}\text { Joelma Abreu Silva e Silvana Batista } \\
\text { Sales Pereira }\end{array}$ & $\begin{array}{l}\text { Análise da webconferência como objeto de } \\
\text { aprendizagem no curso de Licenciatura em } \\
\text { Artes Visuais - EaD - UFES. }\end{array}$ & $\begin{array}{l}\text { SIED - Simpósio Internacional de } \\
\text { Educação a Distância. EnPED - Encontro } \\
\text { de pesquisadores em Educação a } \\
\text { Distância. Universidade Federal de São } \\
\text { Carlos. Set.2012. }\end{array}$ & ARTIGO & 2012 \\
\hline \multicolumn{5}{|c|}{ (1) } \\
\hline Jurema Luzia de Freitas Sampaio & $\begin{array}{l}\text { Primeiros resultados da pesquisa "O que se } \\
\text { ensina e o que se aprende nas licenciaturas } \\
\text { em Artes Visuais a distância?" }\end{array}$ & $\begin{array}{l}\text { IV Seminário de Educação Brasileira. PNE } \\
\text { em foco: Políticas de responsabilização, } \\
\text { regime de colaboração e Sistema Nacional } \\
\text { de Educação. 1ed.Campinas: CEDES } \\
\text { UNICAMP, } 2013 \text {, v. } 1 \text {, p. } 310-323 \text {. }\end{array}$ & $\begin{array}{l}\text { CAPITULO DE } \\
\text { LIVRO }\end{array}$ & 2013 \\
\hline Jurema Luzia de Freitas Sampaio & $\begin{array}{l}\text { Educação a Distância on-line em arte: } \\
\text { professores, tutores etc.: formação para } \\
\text { lecionar arte em ambiente virtual. Atividades } \\
\text { presenciais: obrigatórias ou necessárias? }\end{array}$ & Revista Trilha Digital, v. 01, p. 24-37, 2013. & ARTIGO & 2013 \\
\hline Jurema Luzia de Freitas Sampaio & $\begin{array}{l}\text { O que se ensina e o que se aprende nas } \\
\text { Licenciaturas em Artes Visuais a distância? }\end{array}$ & $\begin{array}{l}\text { Revista Digital Art\& (São Paulo. On-line), v. } \\
01,2013 .\end{array}$ & ARTIGO & 2013 \\
\hline Vera Lucia de Oliveira Simões. & $\begin{array}{l}\text { A formação do professor de arte na } \\
\text { modalidade Educação a } \\
\text { Distância/EAD/UAB/UFES }\end{array}$ & $\begin{array}{l}\text { Programa de pós-graduação em Educação } \\
\text { da Universidade Federal do Espírito Santo } \\
\text { - UFES. }\end{array}$ & DISSERTAÇÃO & 2013 \\
\hline
\end{tabular}




\subsection{Recursos e ferramentas para EaD em Artes Visuais}

Pensando em sistematizar e organizar os diversos recursos e ferramentas digitais para Educação on-line, surgiram os Ambientes Digitais de Aprendizagem, que permitem integrar múltiplas mídias, linguagens e recursos, apresentar informações de maneira organizada, desenvolver interações entre pessoas e objetos de aprendizagem, elaborar e socializar produções tendo em vista atingir objetivos estabelecidos no planejamento. Percebe-se ainda a conjugação de várias mídias, no atendimento às demandas sociais, e a sua utilização nos mais variados segmentos da sociedade.

A avaliação da aprendizagem se mostra sob novos e particulares aspectos sob a ótica do uso educacional das tecnologias digitais de comunicação e informação e, principalmente, dos Ambientes Digitais de Aprendizagem. Dentro dessa visão, de otimização de resultados, estes podem ser avaliados também de forma diferente, efetivamente formativa e continuada (GOMEZ, 2000), numa verdadeira abordagem construtivista da Educação (HOFFMANN, 1991).

Os atuais alunos já são, em sua maioria, oriundos da chamada Geração Web ${ }^{65}$, para quem o uso e o pensamento por taggin ${ }^{66}$, conceito que a folksonomia ${ }^{67}$ já reconhece como uma possível e nova função de busca orgânica e com base comunitária e os professores, inclusive os de arte, devem estar preparados para esta realidade.

A Educação on-line demanda, portanto, a construção de novos conceitos e práticas pedagógicas que respondam às necessidades de alunos e professores que atuam nessa modalidade de Ensino. Como diz João Mattar (2012, p. 13) "estamos necessariamente forçados a abandonar a segurança e rigidez do fordismo para experimentar novos modelos em EaD".

\footnotetext{
${ }^{65}$ Web Generation é um conceito apresentado e desenvolvido por Don Tapscot em "Growing Up Digital: The Rise of the Net Generation". New York: McGraw-Hill, 1997.

${ }^{66}$ Tags são ferramentas de classificação usadas em conteúdos na internet, como fotos, vídeos, podcasts, e-mails, inserções em blogs etc. Uma tag é, para um conteúdo, como um voto, um aval, uma indicação de classificação.

${ }^{67}$ Folksonomia é a maneira como colocamos ordem nas coisas.
} 
Schlünzen (2005) defende que o uso de recursos tecnológicos em ambientes educacionais possibilita criar um ambiente construcionista, contextualizado e de significado aos alunos [...] e Valente (2005) lembra que a utilização de recursos tecnológicos no processo educativo, possibilita a exploração de diferentes aplicações do conhecimento e que contribui para sua construção.

A organização da EaD no Brasil, com base no modelo "fordista" (MATTAR, 2012), como já dito, dá suporte à adoção e uso frequente dos LMS/AVA como suporte dos processos de Ensino aprendizagem da totalidade dos projetos em funcionamento atualmente no Brasil. Gratuitos ou pagos, os LMS/AVA se tornaram a base da EaD no nosso país. Isso é reflexo das políticas públicas educacionais, em especial as de formação de professores. Falaremos dessas políticas mais adiante, porém a ideia de "salas de aula", implícita no uso dos LMS/AVA como suporte para os projetos pedagógicos vem ao encontro dessa formação massiva, onde se privilegiam os conteúdos, em detrimento das relações e processos...

Mas o que são os LMS/AVA?

\subsubsection{LMS (Learning Manager System) ou AVA (Ambiente Virtual de Aprendizagem)}

Chamados de LMS (Learning Management System) e, em português, por muitos autores, de AVA (Ambientes Virtuais de Aprendizagem), são

[...] sistemas computacionais disponíveis na Internet, que funcionam como suporte tecnológico das atividades em uma proposta, ou projeto educacional, mediados pelas tecnologias de informação e comunicação (ALMEIDA, 2003).

Em 2008 houve, inclusive, a criação do Ambiente Virtual de Aprendizagem em Artes Visuais (AVA-AV).

O Ambiente Virtual de Aprendizagem em Artes Visuais (AVA-AV) originou-se a partir do projeto de iniciação científica "Ambiente virtual de 
aprendizagem sobre percepção visual", financiado pelo CNPq desde 2007, através do Programa de Bolsas de Iniciação Científica (PROBICFURG). O AVA-AV tem como objetivo estruturar, em termos pedagógicos e tecnológicos, ambientes de aprendizagem específicos para áreas que utilizam linguagem gráfico-visual. Destina-se a atender um público graduado em Artes Visuais e áreas correlatas, que buscam atualização de conhecimento, bem como estudantes em processos de conclusão de curso, e profissionais que procuram material de apoio para pesquisas nas especificidades anteriormente citadas. O AVA-AV é constituído de três módulos de aprendizagem, a saber: percepção visual, processos de criação e Educação estética. [...] O processo de aprendizagem no AVA-AV apoia-se nos pressupostos da aprendizagem baseada em problemas (ABP), no potencial das tecnologias da informação e comunicação (TIC), que buscam facilitar a gestão do conhecimento na comunidade virtual através da aprendizagem colaborativa à distância e nos conteúdos de cada módulo de aprendizagem. [...] As atividades pedagógicas do AVA-AV ressaltam o aprendizado colaborativo, com base em processos cooperativos, visando diminuir as incertezas do aprendiz, mediante a resolução de problemas (MAIO \& DUTRA, 2008, p. 03- 09).

A opção pelo uso do termo "digitais", ao invés de "virtuais", como usam muitos autores/pesquisadores da área, é feita nesta proposta, de forma a pontuar, mais claramente, o recorte que é feito quando se fala em Educação on-line. O termo "virtual", em muitos trabalhos, de diferentes autores, tem a conotação de "vir a ser" (JAPIASSU e MARCONDES, 1993) e, para ainda outros autores, inclusive eu mesma, em trabalhos anteriores, consideram a própria virtualidade se configura como um conceito em oposição ao conceito de materialidade (SAMPAIO-RALHA, 1999). Já o termo "digital” se refere à 'linguagem binária', possibilidade real de convergência de linguagens e de suporte de conteúdos.

Nos ambientes digitais de aprendizagem as atividades se desenvolvem no tempo, ritmo de trabalho e espaço em que cada participante se localiza, de acordo com uma intencionalidade explícita e um planejamento prévio denominado design instrucional, também chamado de design educacional, que deve ser claro e abrangente, porém flexível, para que possa ser revisto e reelaborado continuamente no andamento da atividade (ALMEIDA, 2003).

Os ambientes digitais de aprendizagem podem ser empregados de diversas maneiras, como Almeida (2003) destaca,

[...] como suporte para sistemas de Educação à distância realizados exclusivamente on-line; para apoio às atividades presenciais de sala de aula, permitindo expandir as interações da aula para além do espaço- 
tempo do encontro face-a-face ou para suporte às atividades de formação semipresencial nas quais o ambiente digital poderá ser utilizado tanto nas ações presenciais como nas atividades à distância.

Esses ambientes têm a vantagem de permitir que a gestão da informação seja feita de maneira objetiva e segundo critérios pré-estabelecidos de organização definidos de acordo com as características de cada software e possuem bancos de informações representadas em diferentes mídias e interligadas por meio de conexões e links, internos ou externos ao sistema. Como ferramentas, têm suas limitações e vantagens, seu uso é que deve ser pensado e refletir a organização e proposição educacional que sustente o projeto pedagógico a ser trabalhado.

A possibilidade de criar locais de aprendizagem mais lúdicos e ricos nesse percurso, em várias dimensões, provoca nos alunos uma interação mais intensa e prazerosa com seus colegas, com o professor, com o conteúdo e principalmente com os objetos e o próprio ambiente (MATTAR, 2012, p. 47).

O gerenciamento desses ambientes permite diferentes ações e atuação no acompanhamento da aprendizagem,

- Gestão de estratégias de comunicação e mobilização dos participantes;

- gestão da participação dos alunos por meio do registro das produções, interações e caminhos percorridos;

- Gestão do apoio e orientação dos formadores aos alunos e a

- Gestão da avaliação (ALMEIDA, 2003).

A maioria dos programas, no entanto, vem subutilizando os recursos dos LMS/AVA, usando-os somente como repositórios de conteúdo. Novamente reflexo da abordagem "fordista" (MATTAR, 2012) da EaD, que privilegia conteúdos, e posso afirmar, texto, como centro do processo.

Os recursos dos ambientes digitais de aprendizagem, basicamente, os mesmos existentes na web e internet (correio, fórum, bate-papo, conferência, banco de documentos etc.) e, dessa forma, também já é possível agregar ferramentas de colaboração, ou peering, como é chamado, lembra ainda não seja frequente. $O$ Takin/TGlobaf ${ }^{8}$ é um dos melhores exemplos de como a Geração Net age,

68 "Taking/TGlobal.org é uma comunidade on-line que conecta jovens para encontrar inspiração, acesso às informações, envolvimento e desenvolverem ações em suas comunidades, locais e globais. É a mais popular comunidade on-line para jovens interessados em "fazer diferença" com 
usando as tecnologias digitais de comunicação e informação para 'transformar' o que acreditam que necessite ser modificado, das relações sociais, aos processo denominados de ativismo digital, ou ciberativismo ${ }^{69}$. Quando cumprirem sua próxima autodeclarada "missão" - reformar a Educação - estarão nossos professores preparados para enfrentar seu maior questionamento: Porque os conteúdos educacionais não são cativantes?

\subsubsection{Outros recursos}

Em qualquer tipo ou modalidade de atividade on-line, pode-se, ainda, fazer uso de diversos outros meios e recursos como apoio às atividades ou complementação de aprendizado.

Os recursos mais frequentemente usados são "hipertextos veiculados em $C D$ ROM, distribuição de material impresso via correios, vídeos digitais e teleconferências" e cada um destes recursos "contém características estruturais específicas e níveis de diálogos possíveis de acordo com a própria mídia, os quais interferem no nível da distância transacional' (ALMEIDA, 2003).

O termo usado para designar esta abordagem é blended learning ${ }^{70}$ (também chamado de e-Learning híbrido) é a mais forte tendência da atualidade nas propostas consistentes em $\mathrm{EaD}$. Tanto em e-Learning quanto em $\mathrm{EaD}$ e tem sido empregado para indicar a capacidade de um sistema integrar diferentes tecnologias e metodologias de aprendizagem com o intuito de atender às necessidades e possibilidades propostas e às condições dos alunos (tanto de perfil/inclusão tecnológicos, quanto sociais e econômicas) sempre com a intenção primordial de potencializar a aprendizagem e o alcance dos objetivos.

centenas e milhares de visitantes por mês". Definição retirada de do portal http://www.takingitglobal.org/, tradução própria.

69 Ciberativismo, ou ciberativismo, é uma forma de ativismo realizado através de meios eletrônicos, como a informática e a internet. Na visão dos que o praticam, o ciberativismo é uma alternativa aos meios de comunicação de massa tradicionais, permitindo-lhes "driblar" o monopólio da opinião pública por estes meios, ter mais liberdade e causar mais impacto, ou é apenas uma forma de expressar suas opiniões (WIKIPEDIA, 2012)

${ }^{70} \mathrm{O}$ termo "blended" em inglês significa mistura, ou seja, uma combinação com o objetivo de atingir melhores resultados. 
Stela Piconez (2013, p. 09) faz a seguinte proposição para avaliação de classificação dos sistemas de aprendizado eletrônicos.

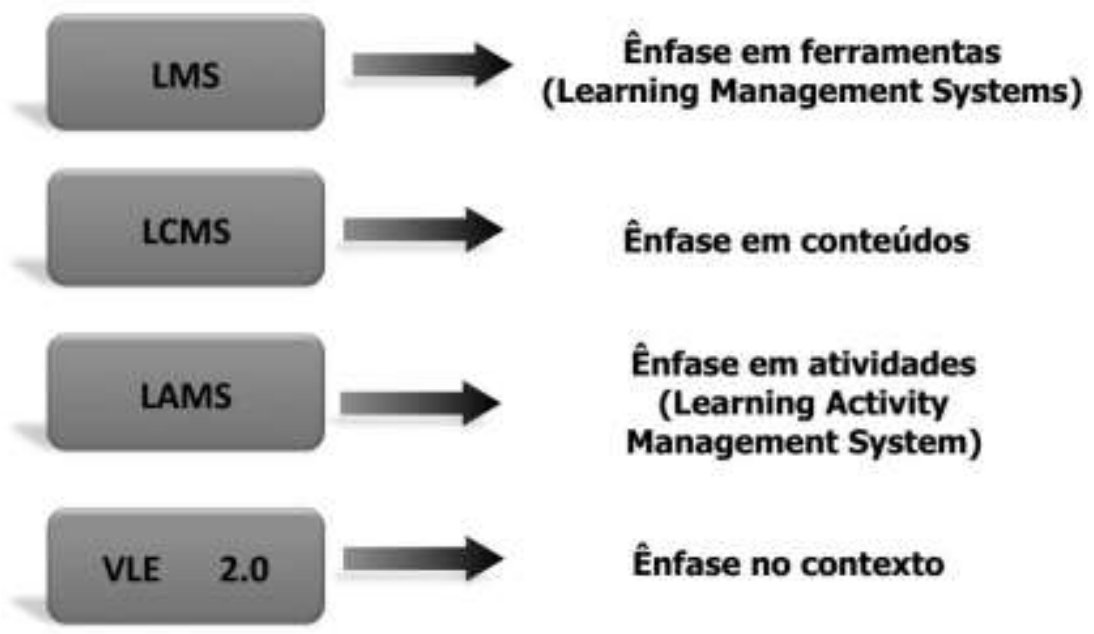

Figura 17 - Classificação dos sistemas educacionais eletrônicos segundo Piconez (2013, p. 09)

Os Virtual Learning Environment - VLE são plataformas de aprendizagem, sistemas de Ensino e-learning baseados na web fornecendo acesso virtual equivalente a aulas, conteúdos de classes, testes, trabalhos de casa, notas, avaliações, e outros recursos externos, tais como links de sites acadêmicos ou museus. São, também espaços sociais onde os alunos e professores podem interagir por meio de discussões temáticas ou chats. Normalmente usa ferramentas da Web 2.0 para a interação de duas vias, e inclui um sistema de gerenciamento de conteúdo. São os sistemas mais indicados para blended learning.

Estudos realizados por Linda Harasim $^{71}$ (1990 e 1995) nos esclarecem que a Educação on-line propõe um novo paradigma que transcende o Ensino presencial e o próprio Ensino à distância já conhecido antes da popularização das tecnologias digitais de comunicação e informação, combinando os benefícios de ambos.

\footnotetext{
${ }^{71}$ Ver em Learning networks: a field guide to teaching and learning on-line e On-Line education: an environment for collaboration and intellectual amplification.
} 
As ferramentas permitem acompanhar, identificar dificuldades, orientar, propor questões que desestabilizem certezas inadequadas e encaminhar situações que possam ajudar o desenvolvimento de suas produções, em processos participativos de avaliação. Os alunos têm a possibilidade de entender claramente: o que já sabem, o que precisam aprender e como vêm se desenvolvendo dentro desse processo educativo. Desta forma, não é possível simplesmente adaptar modelos presenciais para as propostas em EaD. É necessário o desenvolvimento de propostas que englobem e utilizem as particularidades das ferramentas, no sentido de otimizar resultados de aprendizado.

Ferramentas como View of Delf, 'A 3d Flight over Vermeer's Delft in 1660' (um vôo em 3D pela Delft de Vermeer em 1660), que subdivide-se em várias subpropostas, como a 'Walking with Vermeer', nos quais os desenhos originais do artista, digitalizados, são usados como base para a "entrada" nas imagens virtuais 3D, proporcionando ambientação e conhecimento de obras e contextos em experiências únicas e somente possíveis com os adventos tecnológicos. Ou como - LivroClip ${ }^{72}$ que tornam conteúdos elementos de construção interativa sequer Têm uso cogitados. Desconhecimento? Desinformação? Desinteresse? São muitas as questões.

Os museus e exposições virtuais acrescentam no Ensino de Artes mais uma forma de conhecimento. Outro caminho de acesso principalmente para aqueles professores e alunos distanciados dos grandes centros. Utilizar a Internet e seu arsenal de imagens para a Educação é colocar nas mãos dos professores novos elementos para qualificar a prática pedagógica (ROSA, 2006, p. 06).

Projetos como o Digital Michelangelo (de 1999) multiplicam-se na Internet. Este, em que pesquisadores das Universidades de Stanford e Washington passaram o ano acadêmico de 1998/99 na Itália "escaneando" as esculturas e a arquitetura de Michelangelo, como parte do projeto a equipe escaneou, também 1.163 fragmentos da "Forma Urbis Romae", pretende ainda a criação de um mapa gigante, em mármore, da Roma antiga.

\footnotetext{
${ }^{72}$ Ver mais em Ferramentas como o LivroClip - <http://www.livroclip.com.br>.
} 
O objetivo de produzir um conjunto de modelos em 3D, no computador, para cada estátua, detalhe arquitetônico e fragmento que fizeram do mapa em mármore que escanearam e tornar estes modelos disponíveis na pode proporcionar novas formas de acesso a conhecimentos como proporção, dimensões e outros temas das Artes Visuais.
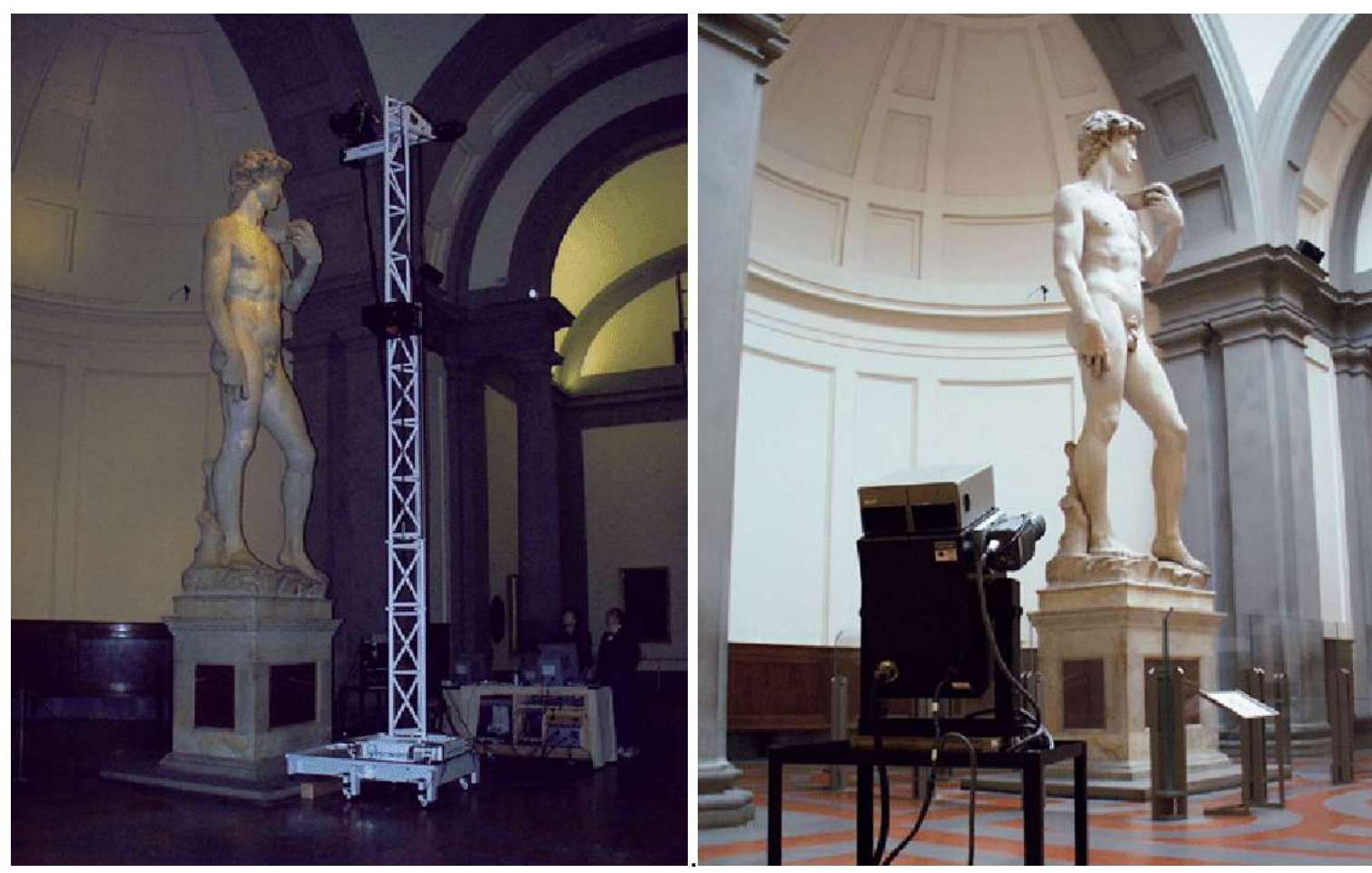

Figura 18 - Escaneamento da Estátua de David.

O Villa Savoye - Le Corbusier (1931), por sua vez, projeto em que, por tecnologia 3D baseada em VRML é possível visitar toda a Villa, proporciona uma experiência em Realidade Virtual única que, segundo Santaella (2003, p. 240), é uma tecnologia "capaz de transmitir informações (imagens, sons, forças, odores) aos órgãos sensórios de um interator, de maneira que o espaço virtual por ele percebido seja um espaço virtual simulado e não um espaço real', interagindo com o ambiente em tempo real. Recurso fantástico para estudar arquitetura, contextualizar obras em ambientes, e épocas variadas.

Villa Savoye é um ambiente colaborativo, construído pela Politécnica de Milão, que dá suporte às navegações tridimensionais através de uma complexa 
colaboração de equipe e professores conectados a um mundo virtual. Baseada em experiências prévias de outros projetos 3D para museus.

A universidade também implementou a construção virtual da 'Cidade Ideal' de Leonardo da Vinci, retirada de várias partes de seus manuscritos. A curadoria deste projeto foi feita pelo Museu Nacional de Ciência Leonardo da Vinci, de Milão, Itália, enquanto um time de modeladores e programadores usavam uma ferramenta de trabalho chamada WebTalk-Il para distribuir a aplicação. Uma ferramenta de estudo? Um recurso? Uma releitura, ou uma co-criação com Da Vinci, ignorando o lapso de tempo?

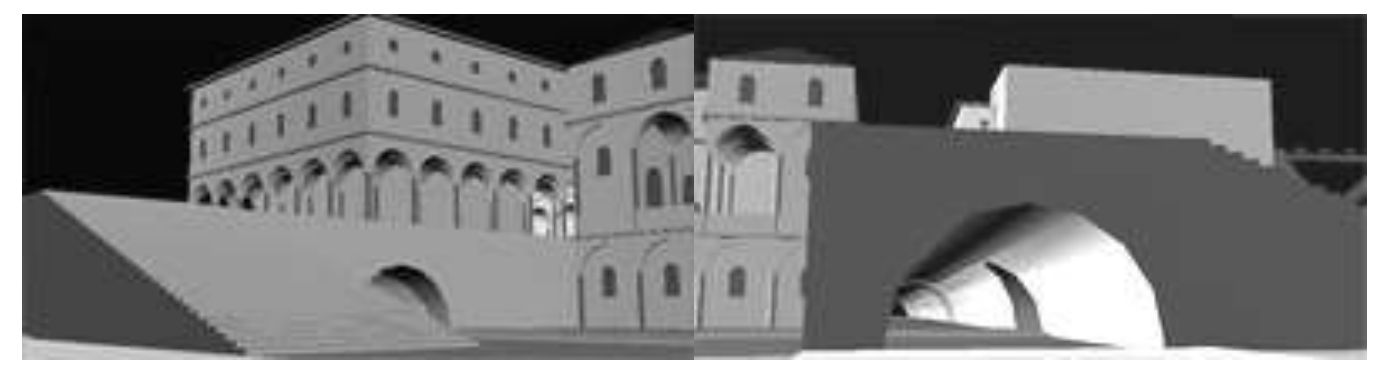

Figura 19 - Imagens do ambiente "Cidade Ideal",73.

Recursos como fractais e estereogramas (SAMPAIO-RALHA, 2003), games, cinema 3D, muitos construídos em código Aberto (Open Source) e disponibilizados como os softwares livres (SL), podem ser trabalhados em modo interativo, dinâmico, ágil. Podem compor propostas, programas, projetos, inter, multi e transdisciplinares, em Artes Visuais, nas licenciaturas. Nas práticas presenciais podem ser exploradas ainda as experiências e/ou relações das poéticas dessa estética digital, ou estética das mídias, com as demais estéticas, "[...] a estética das mídias, longe de produzir objetos ou formas estáticas, está muito mais preocupada com a forma de comunicação que se desenvolve nas manifestações artísticas que se dão em rede e em processo" (ARANTES, 2005, p. 168), proporcionando desdobramentos também inter, multi e transdisciplinares.

Formulada a partir dos estudos culturais na Inglaterra e América do Norte na segunda metade do século XX, a Educação para a cultura visual vem se configurando hoje no Brasil como uma estratégia pedagógica diante da complexidade das sociedades contemporâneas. É um campo de investigação transdisciplinar e transmetodológico, ou seja,

\footnotetext{
${ }^{73}$ Disponível em: <http://webtalk.elet.polimi.it>.
} 
é necessário o concurso e colaboração de diferentes disciplinas e estratégias metodológicas que reforçam a ideia de interdisciplinaridade. Pressupõe uma mudança na finalidade da Educação escolar, pois pondera seu papel de único agente transmissor de conhecimentos nas sociedades contemporâneas, desde que considera a inserção dos sujeitos no meio cultural e os trânsitos e trocas nos vários contextos. Em consequência a escola passa a ser vista não como um sistema reprodutor de saberes, mas como um espaço de preparação dos indivíduos para fazer um uso crítico e democrático das informações que hoje todos os cidadãos têm a disposição. A escola precisa se sintonizar com a sociedade para a qual ela prepara seus estudantes (BARBOSA \& COUTINHO, 2011, p. 49).

Com as tecnologias digitais, "paradigma da representação, a ideia do belo, a contemplação da imagem ou de um objeto é trocada pela ideia de um processo a ser vivido" (DOMINGUES, 2002, p. 63).

\begin{abstract}
O intercâmbio entre os bits transfigura a realidade em símbolos, de tal modo que as pessoas praticamente não têm outra opção a não ser se adaptar à linguagem binária. A expressão "eu ainda não me conectei", utilizada por aqueles que ainda não acessaram seus e-mails, ou então que não entraram nas suas respectivas comunidades do Orkut, desvenda a condição ontológica que predomina atualmente, pois uma existência sem a presença eletrônica torna-se uma não-existência viva (TÜRCKE, 2002, p. 942, apud ZUIN, 2006).
\end{abstract}

Todos esses recursos requerem professores preparados e conhecedores das potencialidades da virtualidade para serem aproveitados em suas amplitudes. João Mattar (2012, p. 57) ainda afirma que é importante que o "professor que exercerá a função docente participe desde o início do processo de produção do conteúdo, ou seja, na elaboração das orientações para o conteudista e na sua contratação" ${ }^{\prime 74}$. Ana Mae Barbosa (2005, p. 110) aponta algumas preocupações ao questionar: "Como ver a arte produzida pelas tecnologias contemporâneas? A arte no ciberespaço estimula mais o intelecto? Qual o alcance da sensorialidade virtual?". E Fernanda Cunha nos instiga ainda mais, ao afirmar que

\begin{abstract}
Ver não é o termo mais adequado à arte digital, mas vivenciar, ou de forma metassensorial perceber-interpretando o conhecimento sensório com o cognitivo, pois obras de arte digital se apresentam inclusive como jogos (games), é preciso aceitar o convite interativo, não sendo suficiente apenas apreciação/observação visual (CUNHA, 2008, p. 225).
\end{abstract}

\footnotetext{
${ }^{74}$ A UFSCar, apesar de seguir o modelo UAB na organização geral dos cursos (Atuei como tutora no curso de Pedagogia, na disciplina Linguagens: Artes II, sob responsabilidade da Profa. Dra. Lúcia M. S. dos Santos Lombardi, no segundo semestre de 2013), segue essa recomendação, o que traz resultados significativos para a interação entre tutores e professores/conteudistas.
} 
Os atuais estudantes de arte, ou seja, professores em formação, estão sendo formados para esse tipo de contato com a obra de arte? E para atuar, ele mesmo, como mediador nesses processos?

Para isso acontecer, é necessário que os professores estejam em constante capacitação e reciclagem de capacitação, com ênfase em conhecer as mais recentes possibilidades. Em linhas gerais, o que a TPACK, já citada, chama de "conhecimento que estão na interseção das áreas" (Tecnologia, Pedagogia e Conteúdos de disciplinas). Tudo bastante diferente do modelo pedagógico fordista implementado pela maioria dos programas vigentes de Formação de Professores de Artes Visuais por EaD. Se no fordismo "o professor não produz o material que deve utilizar em suas atividades de Ensino, no neo e pós-fordismo o professor é o autor elou organizador do material que utiliza como docente" (MATTAR, 2012) e, para isso, precisa ter conhecimentos das possibilidades e modos de como esses recursos e materiais podem ser desenvolvidos e/ou utilizados.

\subsection{Instituições de Ensino superior credenciadas para EaD em Artes Visuais $^{75}$}

No levantamento junto ao Ministério da Educação - MEC sobre as Instituições de Ensino Superior brasileiras credenciadas para a oferta de cursos de Licenciatura em Artes Visuais por EaD encontramos dezenove instituições credenciadas. Dessas, tivemos acesso as seguintes informações.

Tabela 22 - Instituições credenciadas pelo MEC para oferta de EaD em Artes Visuais ${ }^{76}$.

\begin{tabular}{l|l|l:l}
\hline & \multicolumn{1}{|c|}{ Instituição } & \multicolumn{1}{|c}{ Administração } & Coordenador(a) do curso \\
\hline 01 & CLARETIANO & PARTICULAR $^{77}$ & Prof. Esp. Newton Gomes Ferreira \\
\hline 02 & FGF & PARTICULAR $^{\mathbf{7 8}}$ & Prof. Esp. Nertan Dias Silva Maia \\
\hline
\end{tabular}

\footnotetext{
${ }^{75}$ As instituições UAB com Ensino de Artes Visuais - Licenciaturas foram pesquisadas entre 15 de fevereiro de 2010 e 29 de dezembro de 2013, em http://uab.capes.gov.br/index.php?option=com wrapper\&view=wrapper\&ltemid=12. As demais instituições foram pesquisadas no Portal do MEC, no Sistema de Consulta de Instituições Credenciadas para Educação a Distância e Polos de Apoio Presencial (http://siEaD.mec.gov.br/novosiEaD/web/emec/\#tab=0) entre dezembro 2011 e abril de 2013 e 0 detalhamento das informações foi obtido nos respectivos sites institucionais, conforme os documentos dos anexos.

${ }_{77}^{76}$ Dados compilados em pesquisas junto ao sistema e-MEC entre 2010 e 2013.

77 Licenciatura em Artes - Educação Artística.

${ }^{78}$ Licenciatura em Arte e Educação. Complementação Pedagógica em arte para licenciados.
} 


\begin{tabular}{|c|c|c|c|}
\hline 03 & UCS & PARTICULAR $^{79}$ & Prof ${ }^{a}$. Dra ${ }^{\mathrm{a}}$. Maria Helena Wagner Rossi \\
\hline 04 & UECE & PÚBLICA ESTADUAL ${ }^{80}$ & Prof ${ }^{a} M^{e}$. Lucila P. da Silva Basile \\
\hline 05 & UFAM & PÚBLICA FEDERAL ${ }^{81}$ & Prof. Evandro de Morais Ramos \\
\hline 06 & UFES & PÚBLICA FEDERAL ${ }^{82}$ & Prof ${ }^{a}$. Dra . Maria Gorete D. Gonçalves \\
\hline 07 & UFG & PÚBLICA FEDERAL ${ }^{83}$ & $\begin{array}{l}\text { UAB/PARFOR - Prof }{ }^{a} \text { Noeli B. Santos } \\
\text { Pró-Licenciatura - Prof }{ }^{\text {. }} \text { Lílian Ucker }\end{array}$ \\
\hline 08 & UFMA & PÚBLICA FEDERAL ${ }^{84}$ & Prof ${ }^{a}$. Dra . Izabel Mota Costa \\
\hline 09 & UFRGS & PÚBLICA FEDERAL ${ }^{85}$ & Prof ${ }^{a}$. Dra . Umbelina M. Duarte Barreto \\
\hline 10 & UFRPE & PÚBLICA FEDERAL ${ }^{86}$ & Prof ${ }^{a}$ Bianca Carneiro Ribeiro \\
\hline 11 & UNAR & PARTICULAR $^{87}$ & Prof ${ }^{a}$ Débora Martins de Souza \\
\hline 12 & UNB & PÚBLICA FEDERAL $^{88}$ & Prof . Dra ${ }^{\mathrm{a}}$. Therese Hofmann \\
\hline 13 & UNIASSELVI & PARTICULAR $^{89}$ & ------ \\
\hline 14 & UNICENTRO & PÚBLICA ESTADUAL ${ }^{90}$ & Prof ${ }^{a} \mathrm{M}^{\mathrm{e}}$. Clovis Marcio Cunha \\
\hline 15 & UNIMES & PARTICULAR ${ }^{91}$ & Profa . Dra . Maria Emília Sardelich \\
\hline 16 & UNIMONTES & AUTARQUIA ESTADUAL ${ }^{92}$ & Prof ${ }^{\mathrm{a}}$. Me. Maria Elvira C. R. Christoff \\
\hline 17 & UNITAU & AUTARQUIA MUNICIPAL ${ }^{93}$ & Prof ${ }^{a}$. Vania de Moraes \\
\hline 18 & UNIVASF & PÚBLICA FEDERAL ${ }^{94}$ & Profa ${ }^{\mathrm{e}}{ }^{e}$. Flávia M. B. P. Vasconcelos \\
\hline 19 & UNOPAR & PARTICULAR $^{95}$ & Prof. Edson Aparecido Silva \\
\hline
\end{tabular}

${ }^{79}$ Pró-licenciatura, graduação em Artes Visuais. Licenciatura em Artes Visuais - Pró-licenciatura.

${ }^{80}$ Licenciatura plena em artes plásticas - Sistema UAB.

${ }^{81}$ Licenciatura em artes plásticas.

${ }^{82}$ Pró-licenciatura, graduação em Artes Visuais.

${ }^{83}$ Pró-licenciatura, graduação em Artes Visuais.

${ }^{84}$ Pró-licenciatura, graduação em Artes Visuais.

${ }^{85}$ Esse curso está sendo oferecido na forma de projeto especial, com entrada única ocorrida no segundo semestre de 2008, com projeto parceiro com a UCS. O Curso visa possibilitar a formação em nível superior de professores em exercício nas redes públicas de Ensino nos anos/séries finais do Ensino Fundamental e/ou no Ensino Médio sem licenciatura e que estejam exercendo a docência em Artes (Educação Artística) especificamente na área de conhecimento de Artes Visuais.

${ }^{86} \mathrm{O}$ curso de Licenciatura em Artes Visuais Digitas propõe uma formação Pedagógica aliada a conceitos e técnicas de Artes Visuais com o auxílio do computador. Desta maneira, espera-se que o profissional, formado pela Universidade Federal Rural de Pernambuco, possa ser dotado de conhecimentos teórico-formais, poético-técnicos suficientes para atuar em Artes Visuais, no campo da digitalidade.

${ }^{87}$ Licenciatura em Artes Visuais.

${ }^{88}$ Licenciatura em Artes Visuais.

89 Licenciatura em Artes Visuais.

${ }^{90}$ Curso de Licenciatura em Arte-Educação, integrando as quatro linguagens artísticas (visuais, música, dança e cênicas).

${ }^{91}$ Licenciatura em Graduação Plena em Artes Visuais.

${ }^{92}$ Pró-licenciatura, graduação em Artes Visuais. Licenciatura em Artes Visuais (UAB).

${ }^{93}$ Curso de Graduação Plena - Licenciatura em Artes Visuais.

${ }^{94}$ Complementação Pedagógica em Artes Visuais.

${ }^{95}$ Licenciatura em Artes Visuais. Inicia as atividades no primeiro semestre de 2014. 


\section{Tipos de IES}

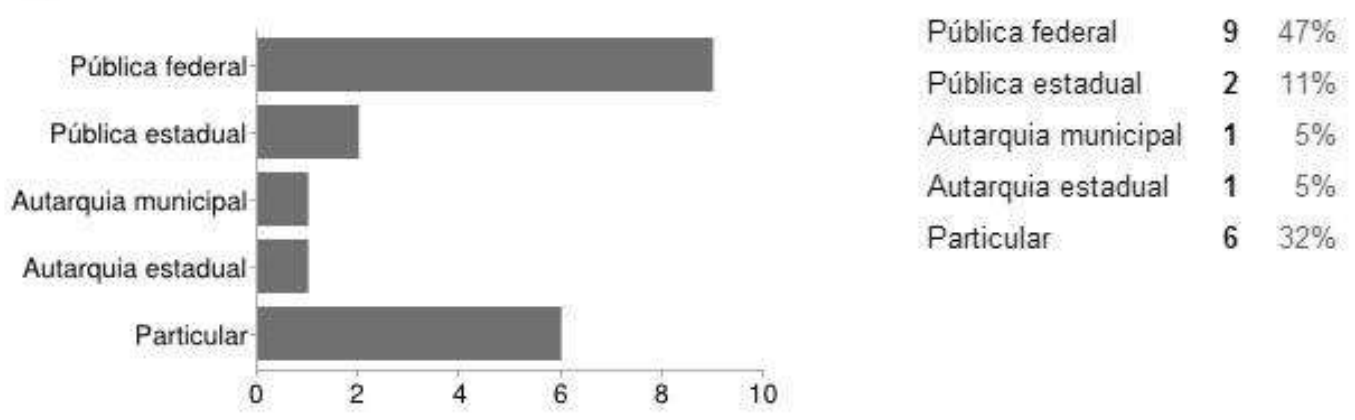

Figura 20 - Distribuição dos cursos por tipo de instituição. 
3.5.1 Detalhamento Institucional ${ }^{96}$

Tabela 23 - Detalhamento da situação legal e condições de trabalho das Instituições credenciadas pelo MEC para oferta de EaD.

\begin{tabular}{|c|c|c|c|c|c|c|c|c|c|}
\hline & Instituição & $\begin{array}{l}\text { Endereço } \\
\text { sede / UF }\end{array}$ & Data do curso/portaria & $\begin{array}{c}\text { 1a. Turma } \\
\text { formada }\end{array}$ & $\begin{array}{l}\text { Duração } \\
\text { do curso }\end{array}$ & $\begin{array}{c}\text { Número de } \\
\text { horas }\end{array}$ & $\begin{array}{c}\text { Plataforma / } \\
\text { LMS-AVA }\end{array}$ & $\begin{array}{c}\text { Encontros } \\
\text { presenciais }\end{array}$ & Polos \\
\hline 01 & $\begin{array}{l}\text { Claretiano } \\
\text { CENTRo Univesastatuo } \\
\text { CLARETIANO }^{97}\end{array}$ & Batatais - $\mathrm{SP}^{98}$ & $\begin{array}{l}\text { Portaria Ministerial №. } \\
\text { 3.635/2004. } \\
\text { Em processo de } \\
\text { recredenciamento } \\
\text { Supervisão Concluída com } \\
\text { arquivamento do processo. } \\
\text { Portaria MEC №. } 333 \text { de } \\
\text { 17/08/2011, publicada no } \\
\text { Diário Oficial da União de } \\
\text { 18/08/2011. } \\
\text { Institucional: Autorizado } \\
\text { Resolução } \\
\text { CONSUP/CEUCLAR n }{ }^{\circ} .03 \\
\text { de 31/05/2007. }\end{array}$ & 2010 & 3 anos & 2.800 horas & $\begin{array}{c}\text { Própria } \\
\text { institucional. }\end{array}$ & $\begin{array}{l}\text { Encontros } \\
\text { presenciais para } \\
\text { todos os polos, } \\
\text { aos sábados no } \\
\text { período diurno, } \\
\text { uma vez por mês } \\
\text { para cada turma. }\end{array}$ & $\begin{array}{l}\text { SP: Batatais, Campinas, Rio } \\
\text { Claro, São José dos Campos, } \\
\text { São Paulo; } \\
\text { MG: Belo Horizonte; } \\
\text { RR: Boa Vista; } \\
\text { DF: Taguatinga; } \\
\text { PR: Curitiba, } \\
\text { RO: São } \\
\text { Miguel do Guaporé. }\end{array}$ \\
\hline 02 & Fin & $\begin{array}{l}\text { Fortaleza - } \\
\mathrm{CE}^{99}\end{array}$ & $\begin{array}{l}\text { Portaria Ministerial №. } 2.143 \\
\text { de } 16 \text { de julho de } 2004 \text { e } \\
\text { Portaria } 643 \text { de } 16 \text { de março } \\
\text { de } 2006 \text {. } \\
\text { Em processo de } \\
\text { recredenciamento. Ainda } \\
\text { não submetida à } \\
\text { Supervisão. }\end{array}$ & --- & $\begin{array}{l}\text { Formação } \\
\text { Pedagógica. } \\
\text { Modular em } \\
\text { tempo } \\
\text { máximo de } \\
20 \text { meses. }\end{array}$ & $\begin{array}{l}\text { O programa terá a } \\
\text { carga horária de } \\
768 \text { horas. }\end{array}$ & ACTOR II & $\begin{array}{l}\text { Cada Módulo } \\
\text { corresponde a } 28 \\
\text { dias via internet } \\
\text { na Sala de Aula } \\
\text { Virtual e a um } \\
\text { encontro } \\
\text { presencial no polo } \\
\text { de presença. }\end{array}$ & $\begin{array}{l}\text { CE: Fortaleza, Crateús; } \\
\text { DF: Brasília, Taguatinga; } \\
\text { PR: Maringá; } \\
\text { MG: Porteirinha. }\end{array}$ \\
\hline
\end{tabular}

${ }^{96}$ As informações contidas nesta tabela foram obtidas no e-MEC e nos websites das instituições entre julho de 2010 e dezembro de 2013.

${ }^{97}$ A pesquisadora trabalhou por dois anos neste programa de licenciatura, tendo desenvolvido material didático para a disciplina 'Processos Escultóricos'.

${ }_{98}$ Centro Universitário Claretiano. Rua Dom Bosco, 466. Batatais/SP. CEP: 14.300-000.

${ }^{99}$ Faculdade Integrada da Grande Fortaleza. Avenida Porto Velho, 401 - João XXIII. Fortaleza/CE. CEP 60510-040. 


\begin{tabular}{|c|c|c|c|c|c|c|c|c|c|}
\hline 03 & 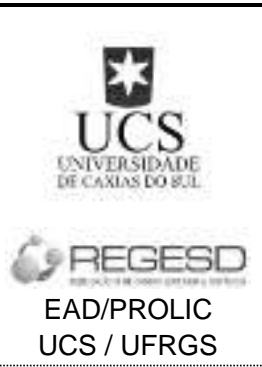 & $\begin{array}{l}\text { Caxias do Sul } \\
- \text { RS }^{100}\end{array}$ & $\begin{array}{l}\text { Portaria Ministerial №. } \\
792 / 2004 . \\
\text { Resolução CONSUNI №. } \\
\text { 03, de 31.03.08. } \\
\text { Em processo de } \\
\text { recredenciamento. Ainda } \\
\text { não submetida à } \\
\text { Supervisão. }\end{array}$ & 2010 & 4 anos & $\begin{array}{c}2.670 \text { horas } \\
\text { Atividades } \\
\text { Complementares, } \\
200 . \\
\text { Total: } 2.870+ \\
\text { ENADE }\end{array}$ & $\begin{array}{c}\text { Moodle } \\
\text { (Customizado) }\end{array}$ & $\begin{array}{l}\text { Avaliações } \\
\text { presenciais. }\end{array}$ & $\begin{array}{l}\text { RS: Caxias do Sul, Terra de } \\
\text { Areia e Porto Alegre (Convênio } \\
\text { UFRGS). }\end{array}$ \\
\hline 04 & UECE & $\begin{array}{l}\text { Fortaleza - } \\
\mathrm{CE}^{101}\end{array}$ & $\begin{array}{l}\text { Portaria MEC №. } 1.065 \text {, de } \\
08 \text { de maio de } 2003 \text {. } \\
\text { Em processo de } \\
\text { recredenciamento. Ainda } \\
\text { não submetida à } \\
\text { Supervisão. }\end{array}$ & 2013 & 4 anos & 2848 & $\begin{array}{c}\text { Moodle } \\
\text { (Customizado) }\end{array}$ & ---- & CE: Orós. \\
\hline 05 & $\begin{array}{c}\text { UFAM } \\
\text { UFAM }\end{array}$ & $\begin{array}{l}\text { Manaus - } \\
\mathrm{AM}^{102}\end{array}$ & $\begin{array}{l}\text { Parecer do Conselho } \\
\text { Nacional de Educação } \\
\text { (DOU-26/11/2010), } \\
\text { amparado pela Resolução } \\
\text { №. 010/2004/CONSUNI, } \\
\text { que aprova as ações de } \\
\text { EaD no âmbito da UFAM, e } \\
\text { pelo Regimento aprovado } \\
\text { pela Resolução } \\
\text { 010/2007/CONSAD. }\end{array}$ & 2010 & 4 anos & 3000 & $\begin{array}{c}\text { Moodle } \\
\text { (Customizado) }\end{array}$ & --- & $\begin{array}{l}\text { UAB I - Coari, Lábrea, } \\
\text { Manacapuru e Maués. } \\
\text { UAB II - Mandaquiri, Santa } \\
\text { Isabel do Rio Negro e Tefé. }\end{array}$ \\
\hline 07 & $\begin{array}{l}\text { UFES } \\
\text { UFES }\end{array}$ & Vitória - ES ${ }^{103}$ & $\begin{array}{l}\text { Portaria Ministerial №. } \\
2.215 / 2001 . \\
\text { Em processo de } \\
\text { recredenciamento. Ainda } \\
\text { não submetida à } \\
\text { Supervisão. }\end{array}$ & 2011 & $\begin{array}{l}3 \text { anos e } \\
\text { meio a } 6 \\
\text { anos }\end{array}$ & 3.110 horas & $\begin{array}{c}\text { Moodle } \\
\text { (Customizado) }\end{array}$ & ---- & $\begin{array}{l}\text { ES: Alegre, Afonso Claudio, } \\
\text { Aracruz, Bom Jesus do Norte, } \\
\text { Cachoeiro de Itapemirim, } \\
\text { Colatina, Conceição da Barra, } \\
\text { Domingos Martins, Ecoporanga, } \\
\text { Itapemirim, lúna, Linhares, } \\
\text { Mantenópolis, Nova Venécia, } \\
\text { Pinheiros, Piúma, Santa } \\
\text { Leopoldina, Santa Teresa, São }\end{array}$ \\
\hline
\end{tabular}

${ }^{100}$ Universidade de Caxias do Sul. Rua Francisco Getúlio Vargas, 1130. Caxias do Sul/RS. CEP 95070-560.

${ }^{101}$ Universidade Estadual do Ceará. Secretaria de Educação a Distância. Avenida Paranjana, 1700. Campus do Itaperi, Fortaleza/CE, CEP 60.714.903.

102 Universidade Federal do Amazonas. Avenida General Rodrigo Octávio, 3000. Campus Universitário, Setor Sul, Bloco N. Coroado, Manaus/AM. CEP 69077-000.

${ }^{103}$ Universidade Federal do Espírito Santo. Avenida Fernando Ferrari, 514. Campus Universitário. Goiabeiras, Vitória/ES. CEP $29075-910$. 


\begin{tabular}{|c|c|c|c|c|c|c|c|c|c|}
\hline & & & & & & & & & $\begin{array}{l}\text { Mateus, Vargem Alta, Venda } \\
\text { Nova do Imigrante, Vila Velha. }\end{array}$ \\
\hline \multirow[t]{3}{*}{08} & 대마 & $\begin{array}{l}\text { Goiânia - } \\
\text { GO }^{104}\end{array}$ & $\begin{array}{l}\text { Portaria Ministerial №. } \\
\text { 1.369/2010, №. } 1.043 / 2010 \text {, } \\
\text { №. } 858 / 2009 \text { e №. } \\
1.050 / 2008 \text {. } \\
\text { Cred. }-07 / 12 / 2015 \text {. Ainda } \\
\text { não submetida à Sup.. }\end{array}$ & $\begin{array}{l}\text { UAB 1 } \\
\text { (Out/2007 - } \\
\text { Dez/2011 - } \\
\text { colação de } \\
\text { grau em } 30 \\
\text { de abril de } \\
\text { 2012). }\end{array}$ & $\begin{array}{l}4 \text { anos } \\
\text { UAB } 1 \\
\text { (Out/2007 - } \\
\text { Dez/2011) } \\
\text { UAB 2 } \\
\text { (Dez/2009 - } \\
\text { Dez/2013) }\end{array}$ & 3.180 horas & $\begin{array}{c}\text { Moodle } \\
\text { (Customizado) }\end{array}$ & ---- & $\begin{array}{l}\text { UAB 1 } \\
\text { GO: Alexânia, Alto Paraíso, } \\
\text { Aparecida de Goiânia, Catalão, } \\
\text { Cezarina, Formosa, Goianésia, } \\
\text { Uruana. } \\
\text { UAB } 2 \\
\text { Anápolis, Cidade de Goiás, } \\
\text { Inhumas, Iporá, Mineiros, } \\
\text { Morrinhos, Rio Verde, São } \\
\text { Miguel do Araguaia. }\end{array}$ \\
\hline & 들 $\underset{U F G}{ } F d V_{2}$ & Goiânia - GO & $\begin{array}{l}\text { Portaria Ministerial №. } \\
\text { 1.369/2010, №. 1.043/2010, } \\
\text { №. } 858 / 2009 \text { e №. 1.050/2008. } \\
\text { Cred. 07/12/2015. }\end{array}$ & --- & $\begin{array}{l}4 \text { anos } \\
\text { PRÓ- } \\
\text { LICENCIATURA } \\
\text { Dez/2008- } \\
\text { Dez } 2012\end{array}$ & 3.180 horas & $\begin{array}{c}\text { Moodle } \\
\text { (Customizado) }\end{array}$ & 4 por semestre & $\begin{array}{l}\text { Pro-Licenciatura } \\
\text { GO: Goiânia, Cidade de Goiás, } \\
\text { Firminópolis, Ceres, Catalão e } \\
\text { Jataí. }\end{array}$ \\
\hline & 대마 & Goiânia - GO & $\begin{array}{l}\text { Portaria Ministerial №. } \\
1.369 / 2010 \text {, } \\
\text { №. } 1.043 / 2010 \text {, } \\
\text { №. } 858 / 2009 \text { e } \\
\text { №. } 1.050 / 2008 \text {. } \\
\text { Credenciado - } 07 / 12 / 2015 \text {. } \\
\text { Ainda não submetida à } \\
\text { Supervisão. }\end{array}$ & $\begin{array}{l}\text { Início - } \\
\text { Out/2011 - } \\
\text { Término- } \\
\text { Dez } 2015\end{array}$ & $\begin{array}{l}4 \text { anOS } \\
\text { PROGRAMA } \\
\text { PARFOR } \\
\text { Início em } \\
\text { outubro de } \\
2011 . \\
\text { Término - } \\
\text { Dez } 2015 .\end{array}$ & 3.180 horas & $\begin{array}{c}\text { Moodle } \\
\text { (Customizado) }\end{array}$ & --- & $\begin{array}{l}\text { PARFOR } \\
\text { GO: Alexânia, Anápolis, } \\
\text { Aparecida de Goiânia, Formosa, } \\
\text { Goianésia, São Simão e } \\
\text { Uruana. }\end{array}$ \\
\hline 09 & UFMA & $\begin{array}{l}\text { São Luís - MA } \\
\text { PARFOR }\end{array}$ & $\begin{array}{l}\text { Portaria Ministerial №. } \\
682 / 2006 . \\
\text { Em processo de } \\
\text { recredenciamento. } \\
\text { Ainda não submetida à } \\
\text { Supervisão }\end{array}$ & 2013 & $\begin{array}{l}4 \text { anos (8 } \\
\text { semestres) }\end{array}$ & 2.650 horas & $\begin{array}{c}\text { Moodle } \\
\text { (Customizado) }\end{array}$ & --- & $\begin{array}{l}\text { MA: São Luiz, Imperatriz e } \\
\text { Pinheiro. }\end{array}$ \\
\hline
\end{tabular}

\footnotetext{
${ }^{104}$ Universidade Federal de Goiás. Campus II. Caixa Postal 131. Samambaia, Goiânia/GO. CEP 74001-970
} 


\begin{tabular}{|c|c|c|c|c|c|c|c|c|c|}
\hline 10 & $\begin{array}{c}\frac{\$ S}{S C S C S} \\
\text { UFRGS }\end{array}$ & $\begin{array}{l}\text { Porto Alegre - } \\
\text { RS }^{105}\end{array}$ & $\begin{array}{l}\text { Portaria Ministerial №. } \\
4.068 / 2005 . \\
\text { Em processo de } \\
\text { recredenciamento. } \\
\text { Ainda não submetida à } \\
\text { Supervisão. }\end{array}$ & $\begin{array}{l}\text { Primeira } \\
\text { turma iniciou } \\
\text { em } 2008 . \\
\text { Conclusão } \\
\text { prevista } \\
\text { para 2012/1 }\end{array}$ & $\begin{array}{l}2008-180 \\
\text { créditos. } \\
2012-194 \\
\text { créditos, } \\
\text { sendo } 180 \\
\text { obrigatórios } \\
\text { e } 14 \text { comp. } \\
\text { - total } 194 \\
\text { créditos. }\end{array}$ & $\begin{array}{c}2008 \\
2.610 \text { horas } \\
2012-2.700 \\
\text { horas }\end{array}$ & $\begin{array}{c}\text { Moodle } \\
\text { (Customizado) }\end{array}$ & --- & $\begin{array}{l}\text { RS: Gramado ( } 30 \text { vagas) } \\
\text { Porto Alegre ( } 60 \text { vagas) } \\
\text { Santo Antônio da Patrulha ( } 30 \\
\text { vagas) } \\
\text { São Leopoldo (30 vagas) }\end{array}$ \\
\hline 11 & UFRPE & Recife - PE ${ }^{106}$ & $\begin{array}{l}\text { Portarias Ministeriais №. } \\
1.369 / 2010, \text { №. } \\
1.043 / 2010, \text { №. } 858 / 2009 \text {, } \\
\text { №. } 1.050 / 2008 \text { e №. } \\
\text { 3.726/2005. } \\
\text { Credenciado - 07/12/2015. } \\
\text { Ainda não submetida à } \\
\text { Supervisão. }\end{array}$ & 2013 & $\begin{array}{l}4 \text { anos ( } 8 \\
\text { semestres) }\end{array}$ & 2.985 horas & $\begin{array}{c}\text { Moodle } \\
\text { (Customizado) }\end{array}$ & ---- & $\begin{array}{l}\text { Recife, Jaboatão dos } \\
\text { Guararapes, Carpina e Gravatá. }\end{array}$ \\
\hline 13 & $\begin{array}{l}\text { Unwitate de trasia } \text { - Ure } \\
\text { UNB/UAB }\end{array}$ & Brasília - DF ${ }^{108}$ & $\begin{array}{l}\text { Portaria Ministerial №. } \\
4.055 / 2003 \text {. } \\
\text { Em processo de } \\
\text { recredenciamento. } \\
\text { Supervisão em análise. }\end{array}$ & $\begin{array}{l}\text { UAB 1- } \\
\text { Ingresso } \\
2007 . \\
\text { Formatura } \\
2011 .\end{array}$ & $\begin{array}{l}4 \text { anos }(8 \\
\text { semestres) }\end{array}$ & 3.180 horas & $\begin{array}{c}\text { Moodle } \\
\text { (Customizado) }\end{array}$ & $\begin{array}{l}\text { Dois encontros } \\
\text { presenciais por } \\
\text { semestre. Tutores } \\
\text { presenciais nos } \\
\text { polos para } \\
\text { suporte. }\end{array}$ & $\begin{array}{l}\text { AC: Acrelândia, Tarauacá, } \\
\text { Brasiléia, Sena Madureira, Rio } \\
\text { Branco, Cruzeiro do Sul, Xapuri } \\
\text { e Feijó; } \\
\text { TO: Palmas; } \\
\text { GO: Posse; } \\
\text { SP: Barretos e Itapetininga. }\end{array}$ \\
\hline
\end{tabular}

${ }^{105}$ Universidade Federal do Rio Grande do Sul. Avenida Paulo Gama, 110. Bairro Farroupilha, Porto Alegre/RS. CEP 90040-060.

${ }^{106}$ Universidade Federal Rural de Pernambuco. Coordenação de Educação a Distância. Rua Dom Manoel de Medeiros, S/N. Recife/PE. CEP 52171-900.

107 Centro Universitário de Araras Dr. Edmundo Ulson. Avenida Ernani Lacerda de Oliveira, 100. Parque Santa Cândida, Araras/SP. CEP 13.603-112.

108 Universidade de Brasília. Campus Universitário Darcy Ribeiro. Decanato de Ensino e Graduação/Universidade Aberta do Brasil (DEG/UAB). Instituto de Artes

Visuais. Asa Norte - Brasília/DF. CEP 70904-970. 


\begin{tabular}{|c|c|c|c|c|c|c|c|c|c|}
\hline 14 & UNIASSELVI & $\begin{array}{l}\text { Blumenau - } \\
\text { SC }^{109}\end{array}$ & $\begin{array}{l}\text { Portaria Ministerial №. } \\
\text { 4.017/2005. Publicada no } \\
\text { D.O.U. de 23/11/2005. } \\
\text { Em processo de } \\
\text { recredenciamento. } \\
\text { Supervisão Concluída com } \\
\text { arquivamento do processo. } \\
\text { Institucional: Resolução №.. } \\
\text { 07A/2007. }\end{array}$ & $\begin{array}{l}\text { Iniciou a } \\
\text { primeira } \\
\text { turma em } \\
2008 .\end{array}$ & $\begin{array}{l}3 \text { anos }(6 \\
\text { módulos) }\end{array}$ & 3.160 horas & $\begin{array}{c}\text { Moodle } \\
\text { (Customizado) }\end{array}$ & $\begin{array}{l}\text { Quatro encontros } \\
\text { presenciais por } \\
\text { período (uma vez } \\
\text { por semana). }\end{array}$ & $\begin{array}{l}\text { AM: Manaus; } \\
\text { BA: Alagoinhas, Feira de } \\
\text { Santana, Itabuna, Jacobina, } \\
\text { Paulo Afonso, Salvador, Teixeira } \\
\text { de Freitas; } \\
\text { ES: Serra; } \\
\text { GO: Itumbiara, Porangatu, } \\
\text { Posse; } \\
\text { MA: São Luís; } \\
\text { MS: Campo Grande, Maracaju; } \\
\text { MT: Colider; } \\
\text { PA: Belém, Cametá, Marabá; } \\
\text { PR: Curitiba, Maringá; } \\
\text { RR: Ji-Paraná; } \\
\text { RO: Rolim de Moura; } \\
\text { RS: Bento Gonsalves, } \\
\text { Camaquã, Capão da Canoa, } \\
\text { Erval Seco, Passo Fundo, Porto } \\
\text { Alegre, São Paulo das Missões; } \\
\text { SC: Camboriú, Blumenau, } \\
\text { Brusque, Capivari de Baixo, } \\
\text { Criciúma, Florianópolis, } \\
\text { Guaramirim, Herval D'Oeste, } \\
\text { Imbituba, Indaial, Itapiranga, } \\
\text { Ituporanga, Joinville, Lages, } \\
\text { Palhoça, Xaxim; } \\
\text { SP: Mairinque. }\end{array}$ \\
\hline 15 & UNICENTRO & $\begin{array}{l}\text { Guarapuava - } \\
\text { PR }^{110}\end{array}$ & $\begin{array}{l}\text { Portaria Ministerial №. } \\
\text { 646/2008. Credenciado - } \\
\text { 27/05/2013. Ainda não } \\
\text { submetida à Supervisão. }\end{array}$ & $\begin{array}{l}\text { Iniciou em } \\
\text { novembro } \\
\text { de } 2010 \text {. }\end{array}$ & $\begin{array}{l}4 \text { anos ( } 8 \\
\text { semestres) }\end{array}$ & 3.422 horas & $\begin{array}{c}\text { Moodle } \\
\text { (Customizado) }\end{array}$ & ---- & $\begin{array}{l}\text { Goioerê, Nova Tebas, Palmeira, } \\
\text { Pinhão e Prudentópolis. }\end{array}$ \\
\hline
\end{tabular}

${ }_{109}$ Centro Universitário Leonardo da Vinci. Rua Dr. Pedro Zimmerman, 385. Salto do Norte, Blumenau/SC. CEP 89065-000.

${ }^{110}$ Universidade Estadual do Centro Oeste. Rua Padre Salvador, 875 (antiga Rua Pres. Zacarias). Guarapuava/PR. CEP 85015-430. 


\begin{tabular}{|c|c|c|c|c|c|c|c|c|c|}
\hline 16 & & Santos - SP ${ }^{112}$ & $\begin{array}{l}\text { Portaria do Ministério de } \\
\text { Educação do Brasil, №. } 559 \text {, } \\
\text { de } 20 \text { de fevereiro de } 2006 \text {. } \\
\text { Resolução CEPE/CONSUN } \\
\text { №. } 011 / 06\end{array}$ & 2009 & $\begin{array}{l}3 \text { anos, } \\
\text { máximo de } 6 \\
\text { anos. } \\
\text { Regime } \\
\text { semestral. }\end{array}$ & 3.080 horas & $\begin{array}{c}\text { Moodle } \\
\text { (Customizado) }\end{array}$ & $\begin{array}{l}\text { Semanais, nos } \\
\text { polos. }\end{array}$ & \\
\hline 17 & 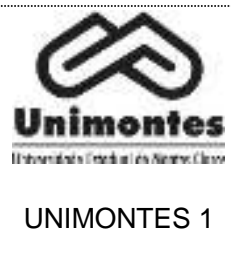 & $\begin{array}{l}\text { Montes Claros } \\
\text { - MG }{ }^{13} \\
\text { UAB } \\
\text { PRÓ- } \\
\text { LICENCIATURA }\end{array}$ & $\begin{array}{l}\text { Portaria №. } 1.116 \text { de } 21 \text { de } \\
\text { julho de } 1994 \text {, do Ministro } \\
\text { de Estado da Educação e } \\
\text { do Desporto. } \\
\text { Credenciamento para EaD - } \\
\text { Portaria MEC } 1065 / 06, \\
\text { publicada D.O.U do dia } \\
\text { 25/05/06. }\end{array}$ & 2013 & $\begin{array}{c}4 \text { anos (8 } \\
\text { semestres) }\end{array}$ & 3.920 horas & $\begin{array}{c}\text { Moodle } \\
\text { (Customizado) }\end{array}$ & $\begin{array}{l}20 \% \text { (vinte por } \\
\text { cento) da carga } \\
\text { horária total do } \\
\text { curso e serão } \\
\text { realizados em } \\
\text { cada Polo de } \\
\text { Apoio Presencial. }\end{array}$ & $\begin{array}{l}\text { Almenara, Mantena, Buritizeiro, } \\
\text { Cristália, Carlos Chagas, } \\
\text { Januária, Janaúba, Pompéu, } \\
\text { São João da Ponte, Pedra Azul, } \\
\text { Itamarandiba, Francisco Sá e } \\
\text { Urucuia. }\end{array}$ \\
\hline 18 & UNITAU & $\begin{array}{l}\text { Taubaté - } \\
\text { SP }^{115}\end{array}$ & $\begin{array}{l}\text { Portaria Ministerial №. } \\
\text { 280/2009. Credenciado - } \\
\text { 26/03/2014. Ainda não } \\
\text { submetida à Supervisão. } \\
\text { Processo Número ARQ- } \\
\text { 078/09. Deliberação } \\
\text { CONSEP №. 134/2009. } \\
\text { Aprova o Currículo do Curso } \\
\text { de Graduação Plena - } \\
\text { Licenciatura em Artes } \\
\text { Visuais, na modalidade a } \\
\text { distância, do programa: } \\
\text { Segunda } \\
\text { Licenciatura. } \\
\text { Processo №. EAD- } \\
\text { 021/2009. }\end{array}$ & --- & 03 anos & $\begin{array}{l}3.280 \text { horas e } \\
1.600 \text { horas ( } 2^{\mathrm{a}} \text {. } \\
\text { Graduação) }\end{array}$ & $\begin{array}{c}\text { Moodle } \\
\text { (Customizado) }\end{array}$ & $\begin{array}{l}\text { Somente } \\
\text { avaliações. }\end{array}$ & $\begin{array}{l}\text { SP: Taubaté, São José dos } \\
\text { Campos e Ubatuba. }\end{array}$ \\
\hline
\end{tabular}

$\overline{111}$ A pesquisadora lecionou por dois anos nesse programa: ARTES - Licenciatura em Graduação Plena em Artes Visuais. Vinculado à faculdade de Educação e Ciências Humanas.

112 Universidade Metropolitana de Santos. Avenida Conselheiro Nébias, 536. Encruzilhada, Santos/SP. CEP 11045-002.

113 Universidade Estadual de Montes Claros. Campus Universitário "Prof. Darcy Ribeiro". Vila Mauricéia, Montes Claros/SP. CEP 39401-089.

$114 \mathrm{O}$ curso de Artes Visuais, 1‥ ou $2^{\mathrm{a}}$. Licenciaturas, é oferecido somente no polo de Taubaté. O curso de Segunda Licenciatura terá duração de um ano se corresponder à mesma Área da Primeira; de um ano e meio para os candidatos que queiram cursar a Segunda Licenciatura em área diferente da primeira e duração de dois anos se o candidato tiver cursado Normal Superior Especial ou Pedagogia Cidadã (duração de 1.600h).

${ }^{115}$ Universidade de Taubaté. Avenida Marechal Deodoro, 605. Jardim Sta. Clara, Taubaté/SP. CEP 12080-000. 


\begin{tabular}{|c|c|c|c|c|c|c|c|c|c|}
\hline 19 & UNIVASF & $\begin{array}{l}\text { Petrolina - } \\
\text { PE }^{116}\end{array}$ & $\begin{array}{l}\text { Portaria Ministerial №. } \\
1.369 / 2010, \text { №. } 1.043 / 2010 \\
\text { e №. 858/2009. } \\
\text { Credenciada - 07/12/2015. } \\
\text { Ainda não submetida à } \\
\text { Supervisão. }\end{array}$ & --- & $\begin{array}{c}4 \text { anos (8 } \\
\text { semestres) }\end{array}$ & $\begin{array}{c}2.820 \text { horas } \\
\text { (mínima) } \\
\text { Formação } \\
\text { pedagógica }-690 \\
\text { h/a. }\end{array}$ & $\begin{array}{c}\text { Moodle } \\
\text { (Customizado) }\end{array}$ & --- & $\begin{array}{l}\text { Petrolina, Juazeiro, Salgueiro, } \\
\text { Ouricuri, Pintadas. }\end{array}$ \\
\hline 20 & $\begin{array}{l}\text { UNOPAR } \\
\text { VIRTUAL } \\
\text { UNOPAR }\end{array}$ & $\begin{array}{l}\text { Londrina - } \\
\text { PR }^{117} \text {. }\end{array}$ & $\begin{array}{l}\text { Portaria Ministerial } 2.794 / 04 \\
\text { de 06/09/04, 10/09/04. } \\
\text { Protocolo e-Mec } \\
\text { 200803857, em processo de } \\
\text { reconhecimento. }\end{array}$ & $\begin{array}{l}\text { Inicia as } \\
\text { atividades } \\
\text { no primeiro } \\
\text { semestre de } \\
2014 \text {. }\end{array}$ & $\begin{array}{l}\text { Mínima } 7 \\
\text { semestres } \\
\text { Máxima } 10 \\
\text { semestres }\end{array}$ & 2.800 horas & & $\begin{array}{l}\text { Quarta-feira das } \\
19 \mathrm{~h} 20 \text { as } 22 \mathrm{~h} 05 \\
\text { no polo de apoio } \\
\text { presencial de } \\
\text { escolha dos } \\
\text { alunos. }\end{array}$ & $\begin{array}{l}\text { AC: Brasiléia, Cruzeiro do Sul, } \\
\text { Feijó, Rio Branco e Tarauacá. } \\
\text { AL: Arapiraca, Maceió, Murici, } \\
\text { Olho d'Água das Flores e } \\
\text { Palmeira dos Índios. } \\
\text { AM: Coari, Itacoatiara, Manaus } \\
\text { e Parintins. } \\
\text { AP: Macapá. } \\
\text { Ba: Alagoinhas e Baixa Grande. }\end{array}$ \\
\hline
\end{tabular}

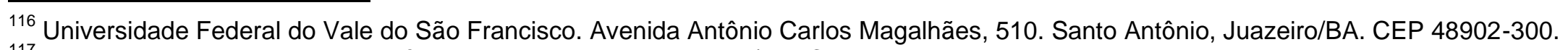

117 Universidade do Norte do Paraná. Avenida Paris, 675. Londrina/PR. CEP 86041-140. 


\subsubsection{Os LMS (Learning Manager System) ou AVA (Ambiente Virtual de} Aprendizagem) das Instituições pesquisadas

A preferência das instituições brasileiras que fazem EaD em Artes Visuais pelo LMS (Learning Management System) ou AVA (Ambiente Virtual de Aprendizagem) Moodle é clara. Ele é um LMS totalmente gratuito e customizável. Dos cursos existentes somente dois programas usam LMS/AVA próprio institucional, ou seja, um sistema desenvolvido pela própria instituição. Todos os demais cursos usam o Moodle como ambiente de suporte.

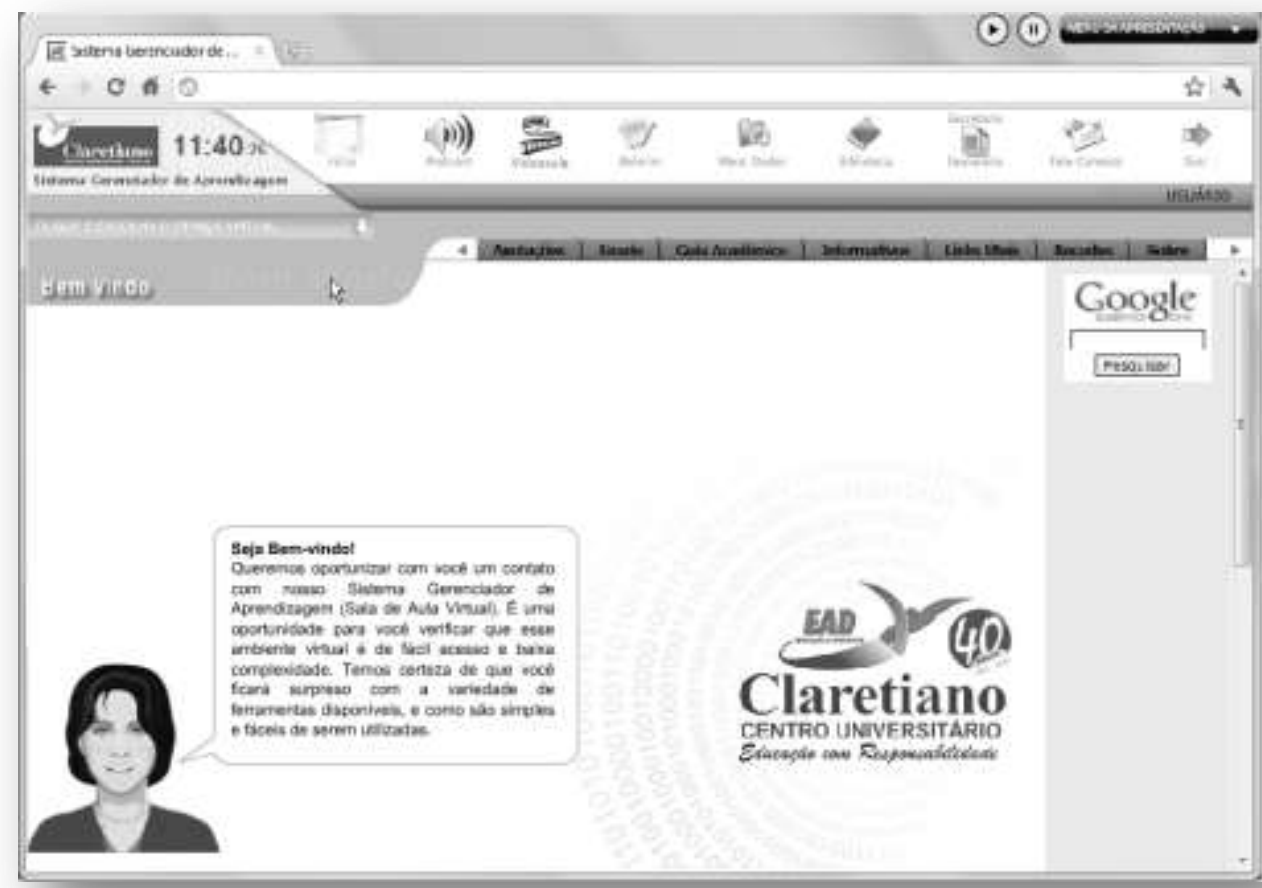

Figura 21 - Imagem do LMS/AVA da IES Claretiano <http://www.claretiano.edu.br/sav> 


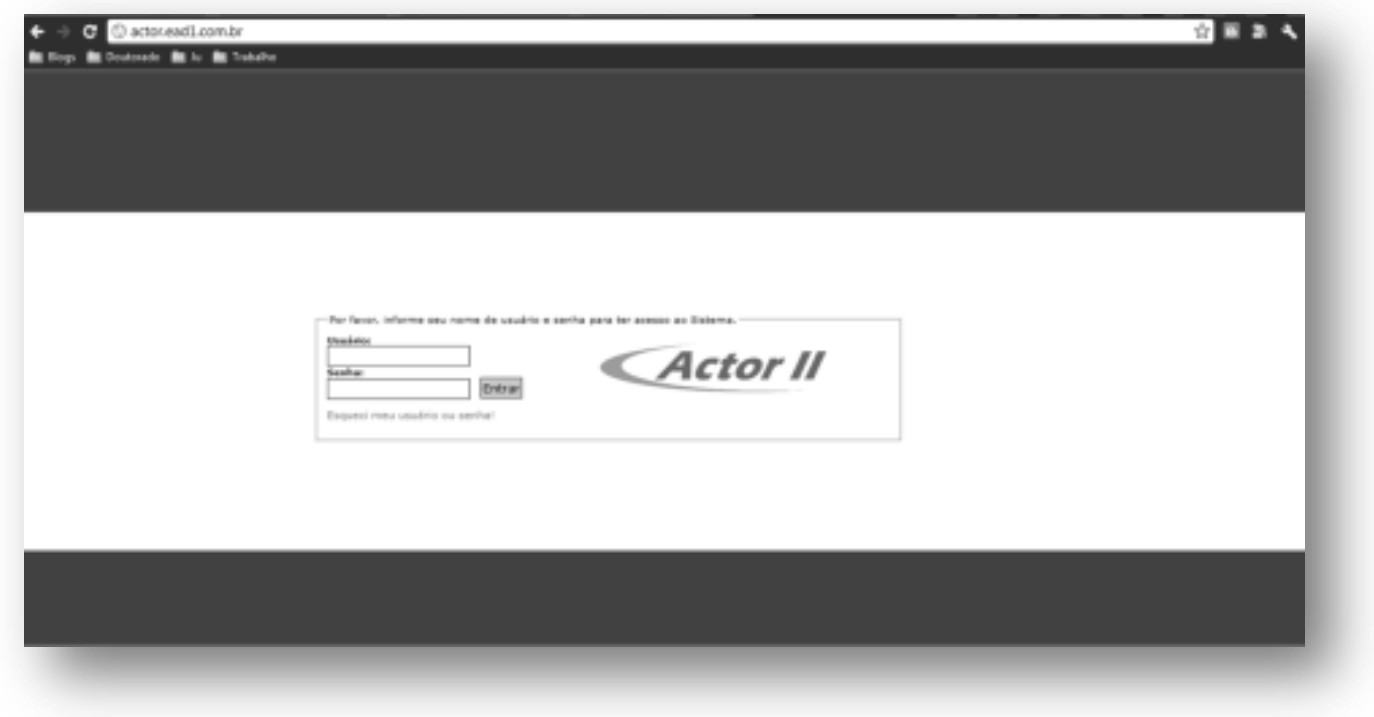

Figura 22 - Imagem do LMS/AVA da IES UGF $<$ http://arteeducacaofgf.blogspot.com.br $>$

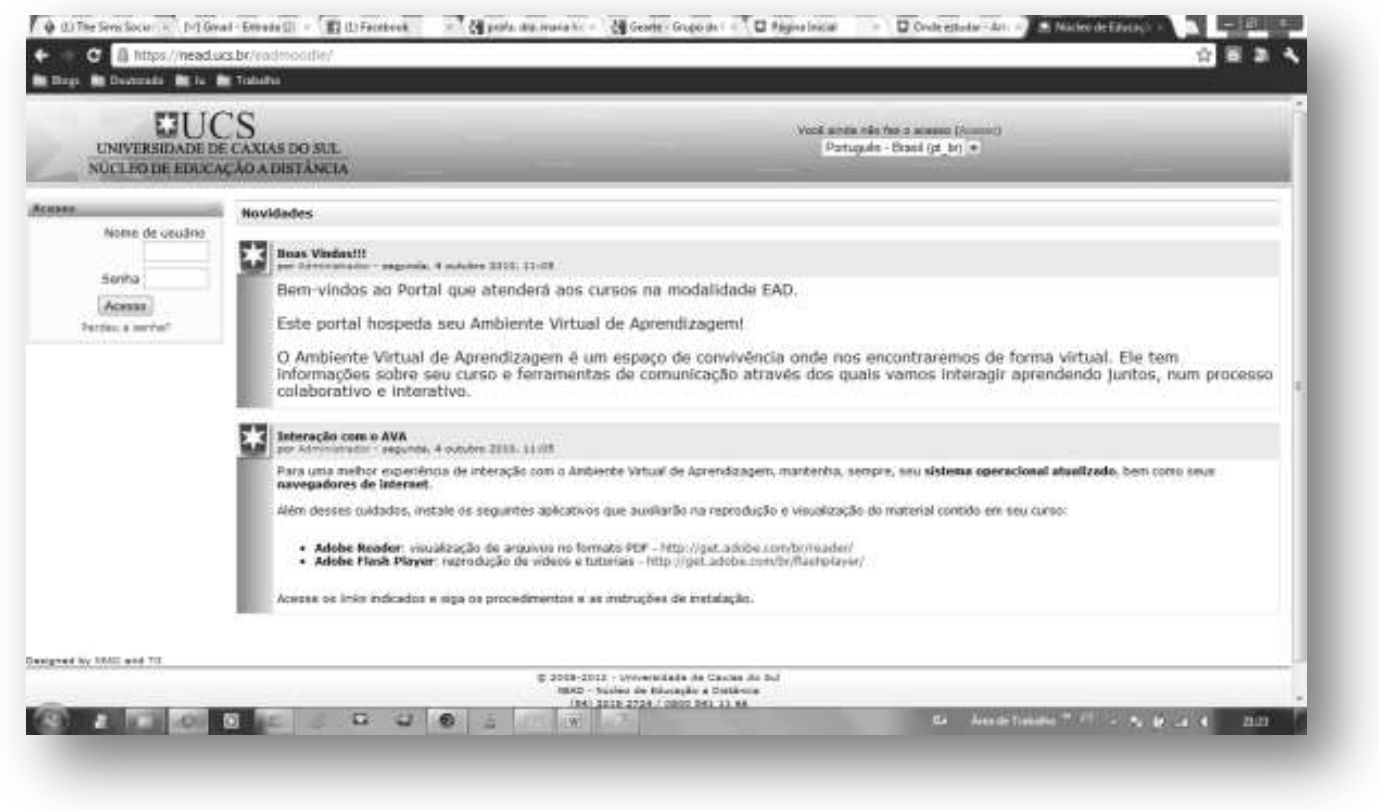

Figura 23 - Imagem do LMS/AVA da IES UCS $<$ https://nEaD.ucs.br/EaDmoodle $>$ 


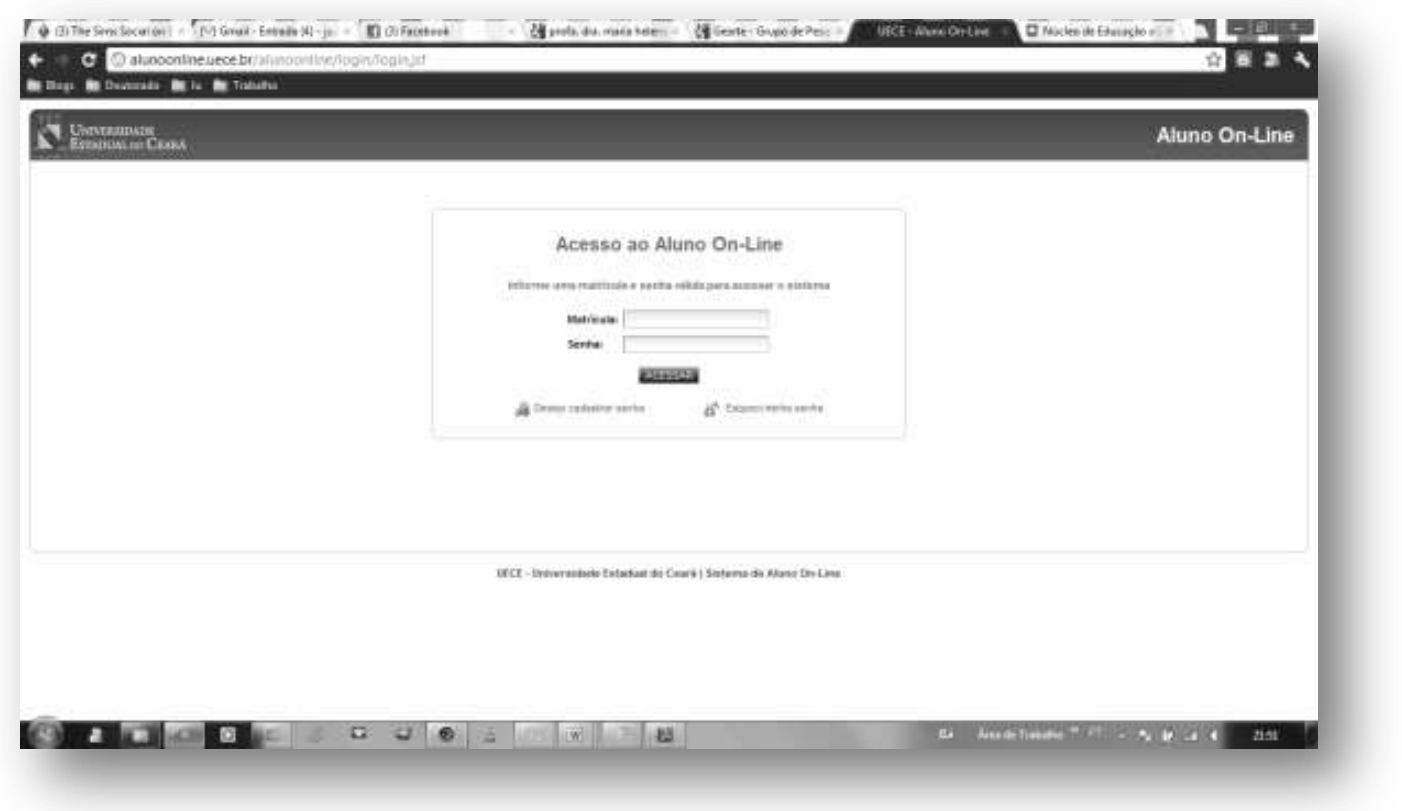

Figura 24 - Imagem do LMS/AVA da IES UECE (Antigo) $<$ http://alunoon-line.uece.br/alunoon-line/login/login.jsf>

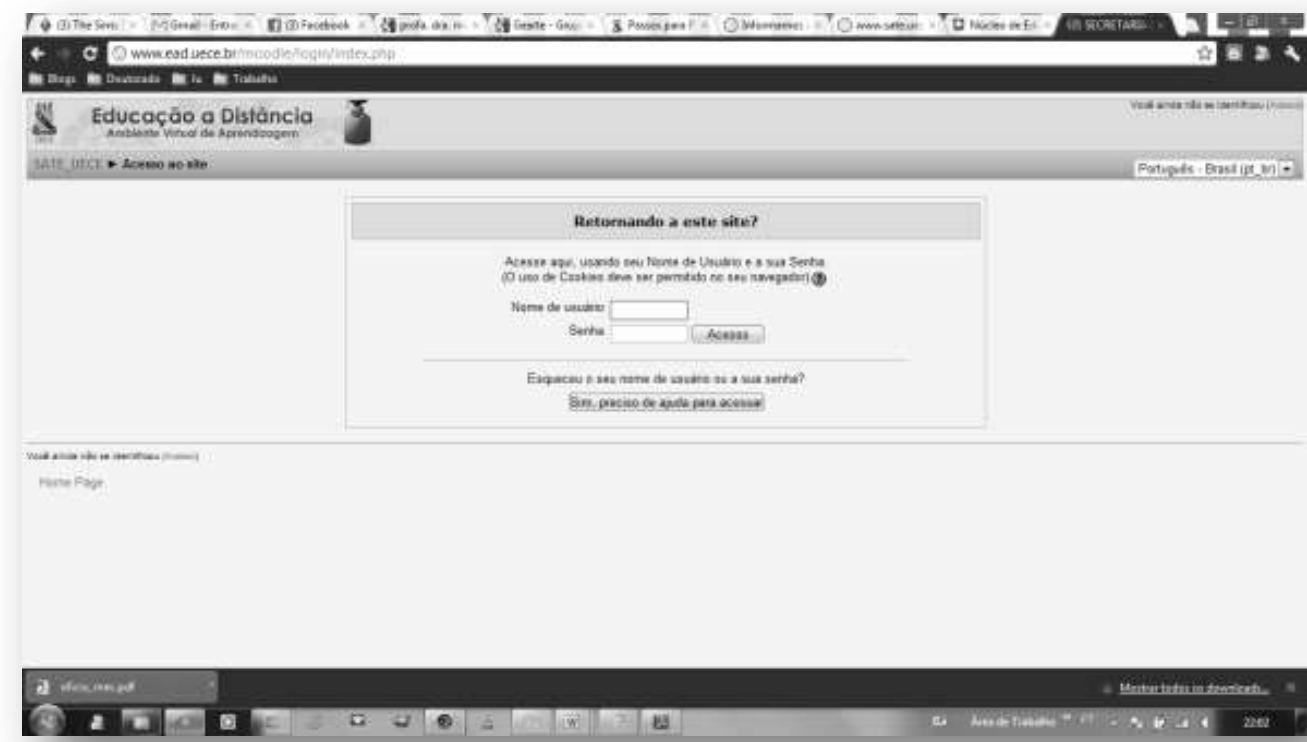

Figura 25 - Imagem do LMS/AVA da IES UECE (Novo) $<$ https://www.EaD.uece.br> 


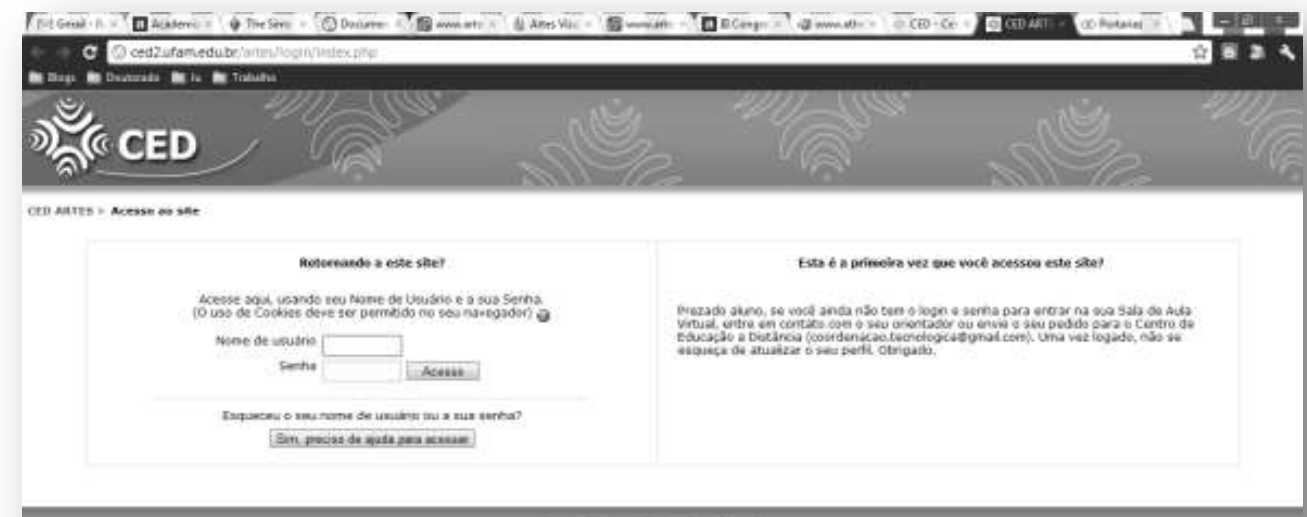

Figura 26 - Imagem do LMS/AVA da IES UFAM $<$ http://ced2.ufam.edu.br/artes/login/index.php>

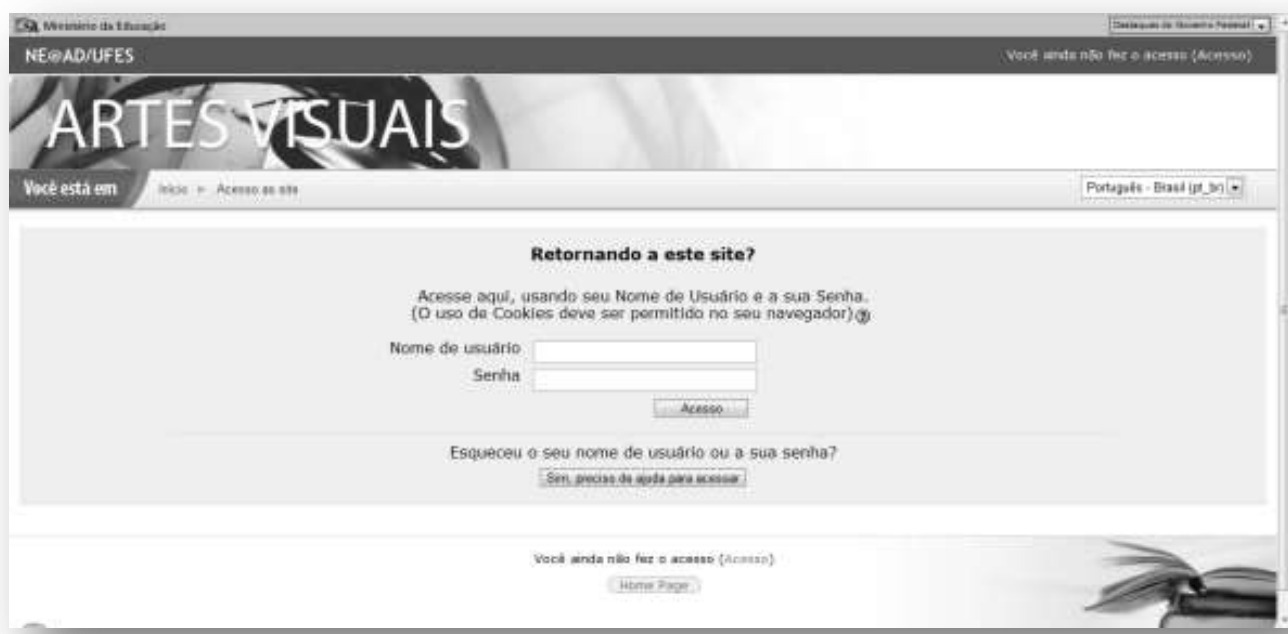

Figura 27 - Imagem do LMS/AVA da IES UFES $<$ http://www.artesvisuais.neaad.ufes.br/login/index.php $>$ 


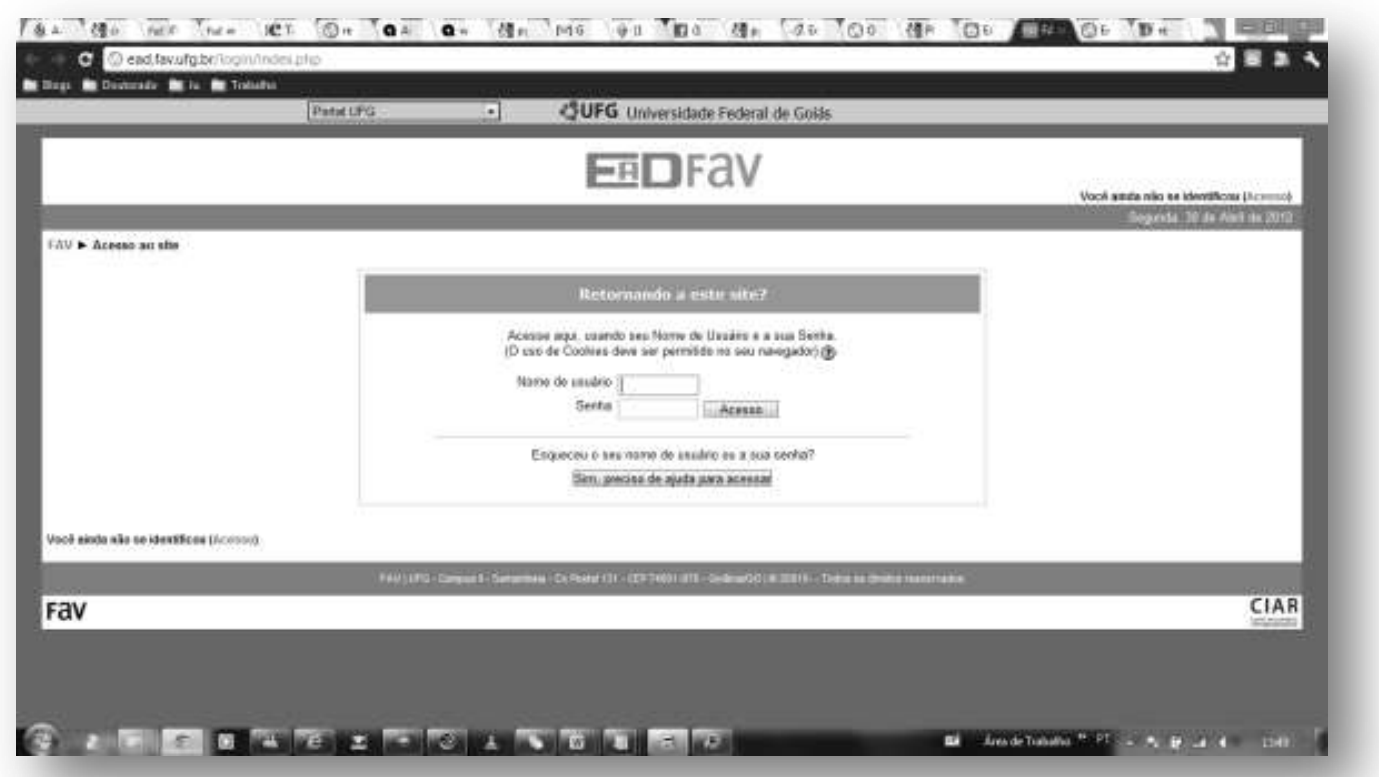

Figura 28 - Imagem do LMS/AVA da IES UFG

$<$ http://EaD.fav.ufg.br/login/index.php>

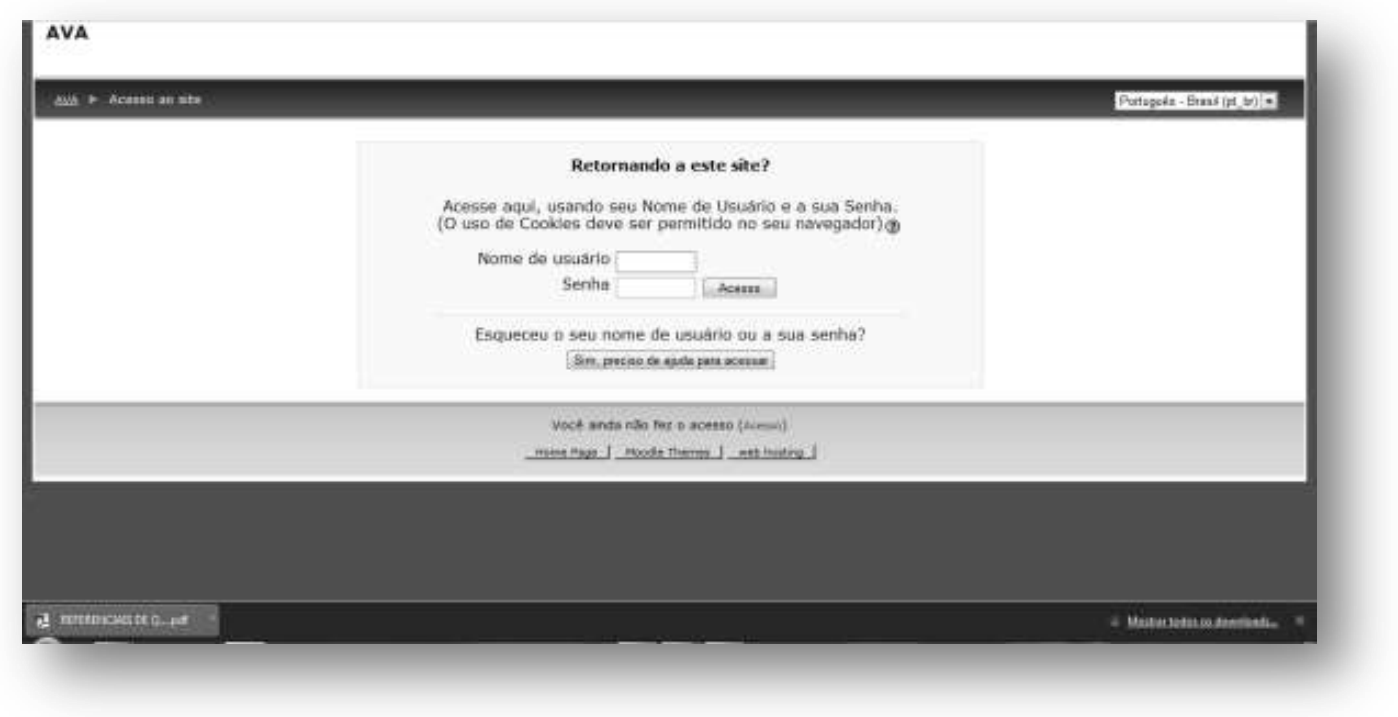

Figura 29 - Imagem do LMS/AVA da IES UFMA <http://www.nEaD.ufma.br/paginas/ava.php> 


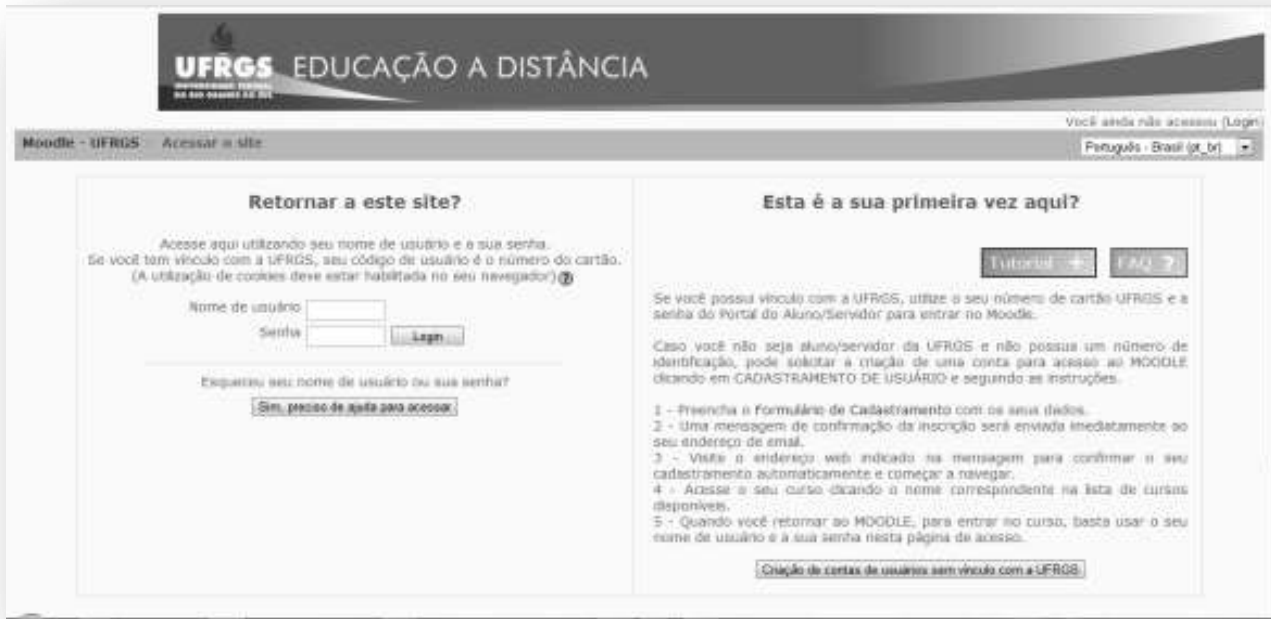

Figura 30 - Imagem do LMS/AVA da IES UFRGS <https://moodleinstitucional.ufrgs.br/login/index.php>

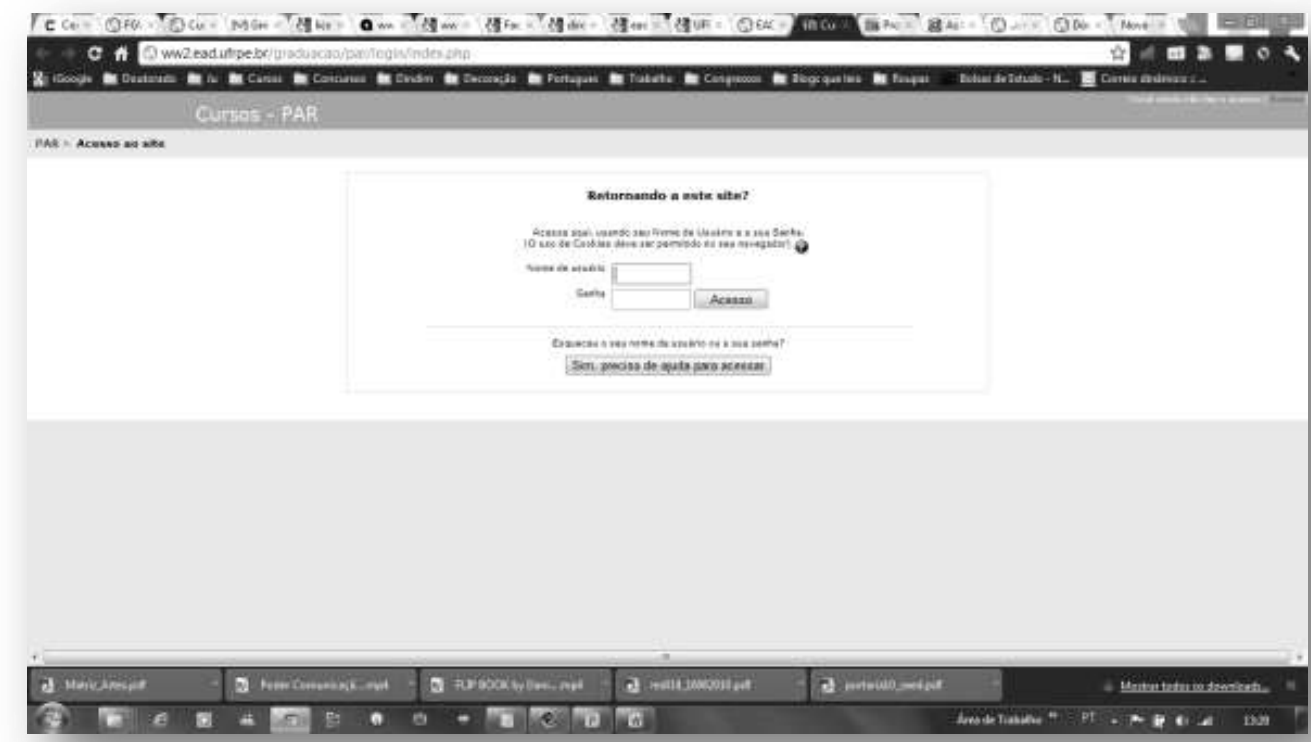

Figura 31 - Imagem do LMS/AVA da IES UFRPE $<$ http://ww2.EaD.ufrpe.br/graduacao/par/login/index.php> 


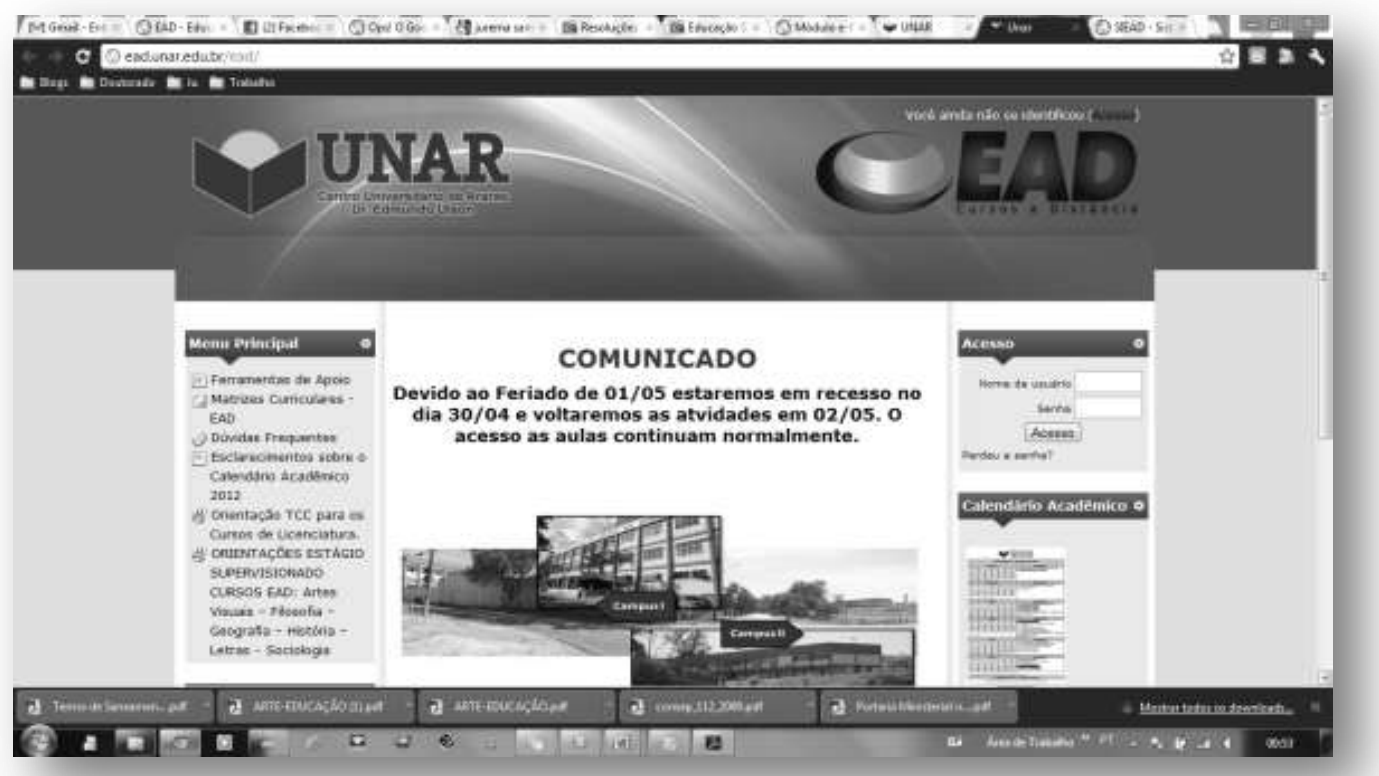

Figura 32 - Imagem do LMS/AVA da IES UNAR $<$ http://ead.unar.edu.br/EaD/>

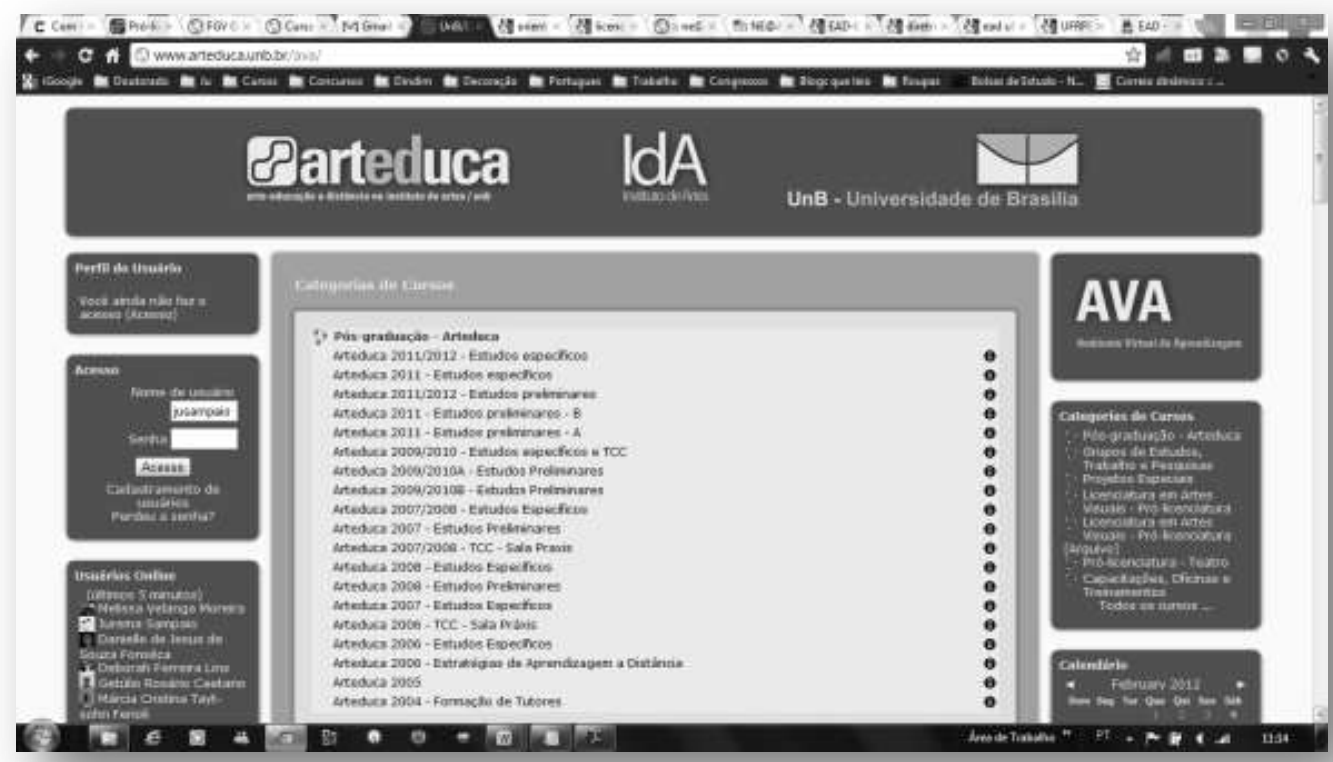

Figura 33 - Imagem do LMS/AVA da IES UNB - Pro-Licenciatura $<$ http://www.arteduca.unb.br/ava> 


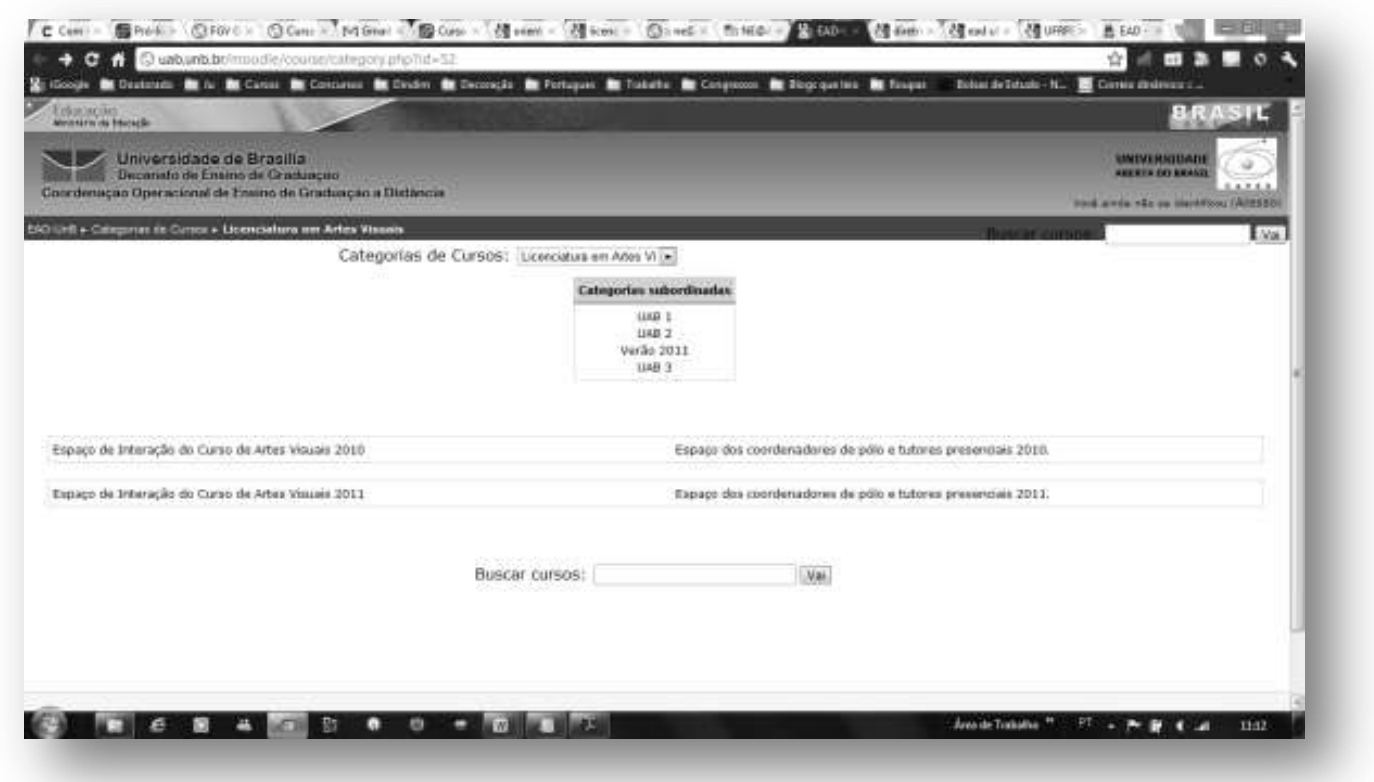

Figura 34 - Imagem do LMS/AVA da IES UNB - UAB $<$ http://uab.unb.br/moodle/course/category.php?id=52>

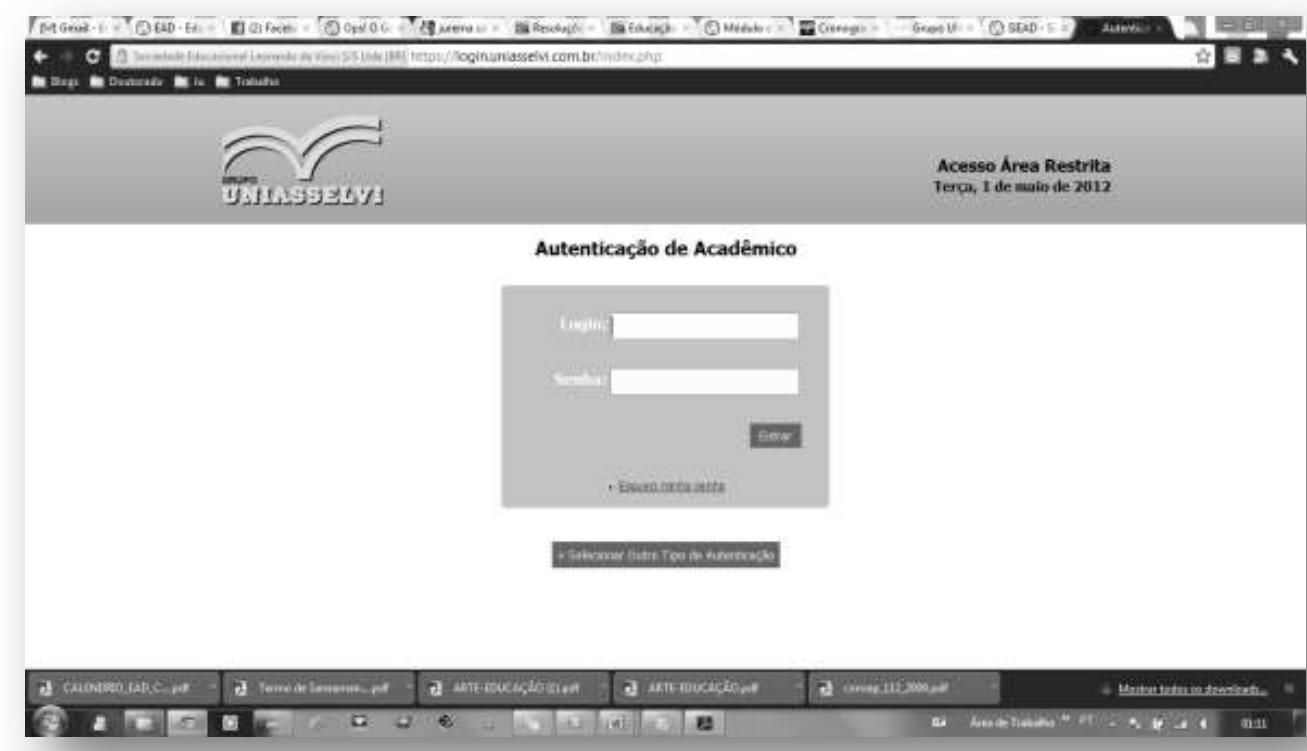

Figura 35 - Imagem do LMS/AVA da IES UNIASSELVI $<$ https://login.uniasselvi.com.br/index.php $>$ 


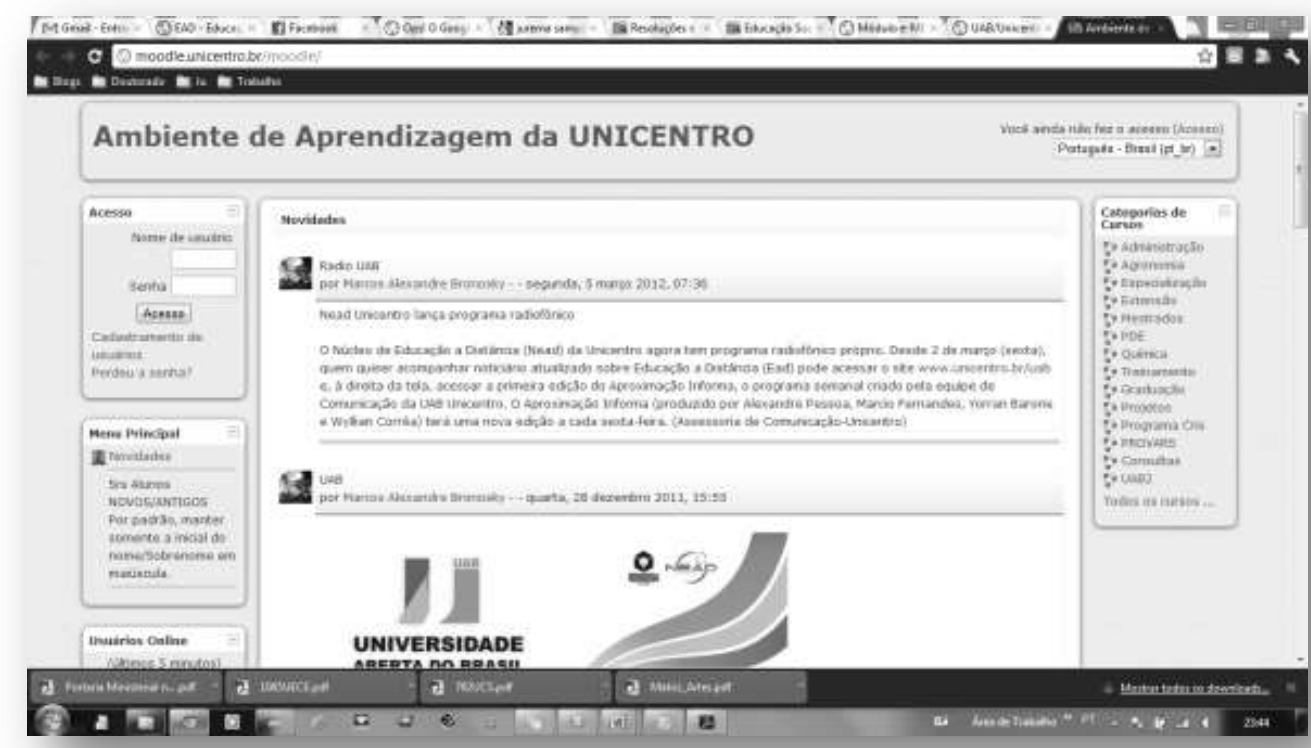

Figura 36 - Imagem do LMS/AVA da IES UNICENTRO $<$ http://moodle.unicentro.br/moodle $>$

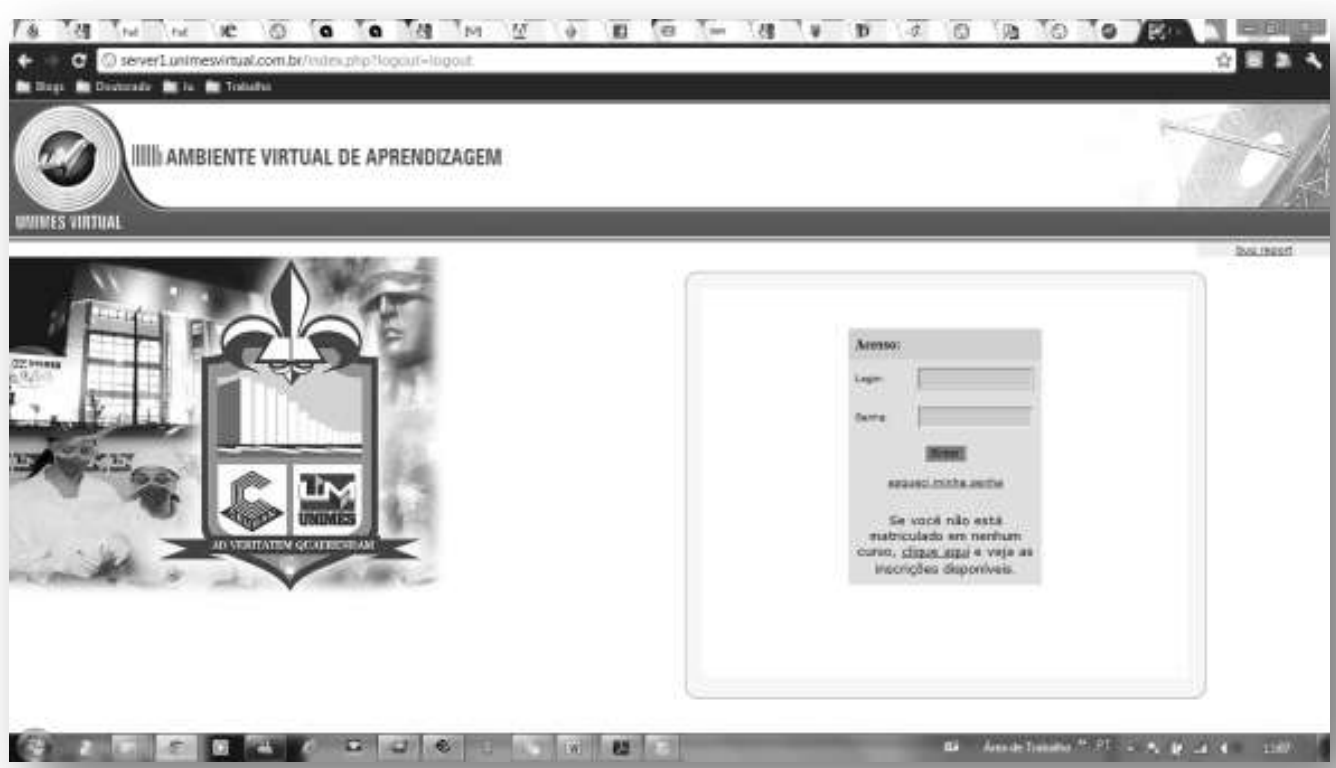

Figura 37 - Imagem do LMS/AVA da IES UNIMES $<$ http://server1.unimesvirtual.com.br/index.php?logout=logout $>$ 


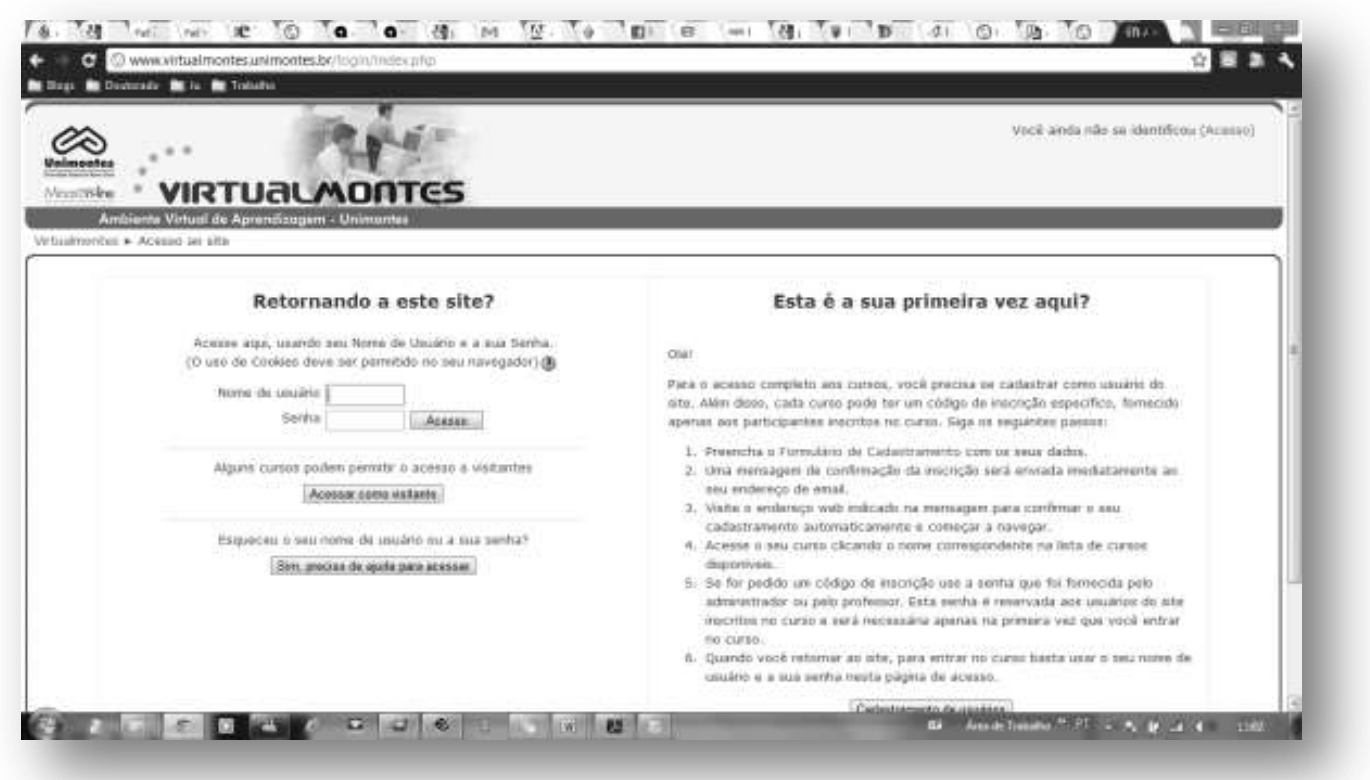

Figura 38 - Imagem do LMS/AVA da IES UNIMONTES $<$ http://www.virtualmontes.unimontes.br $>$

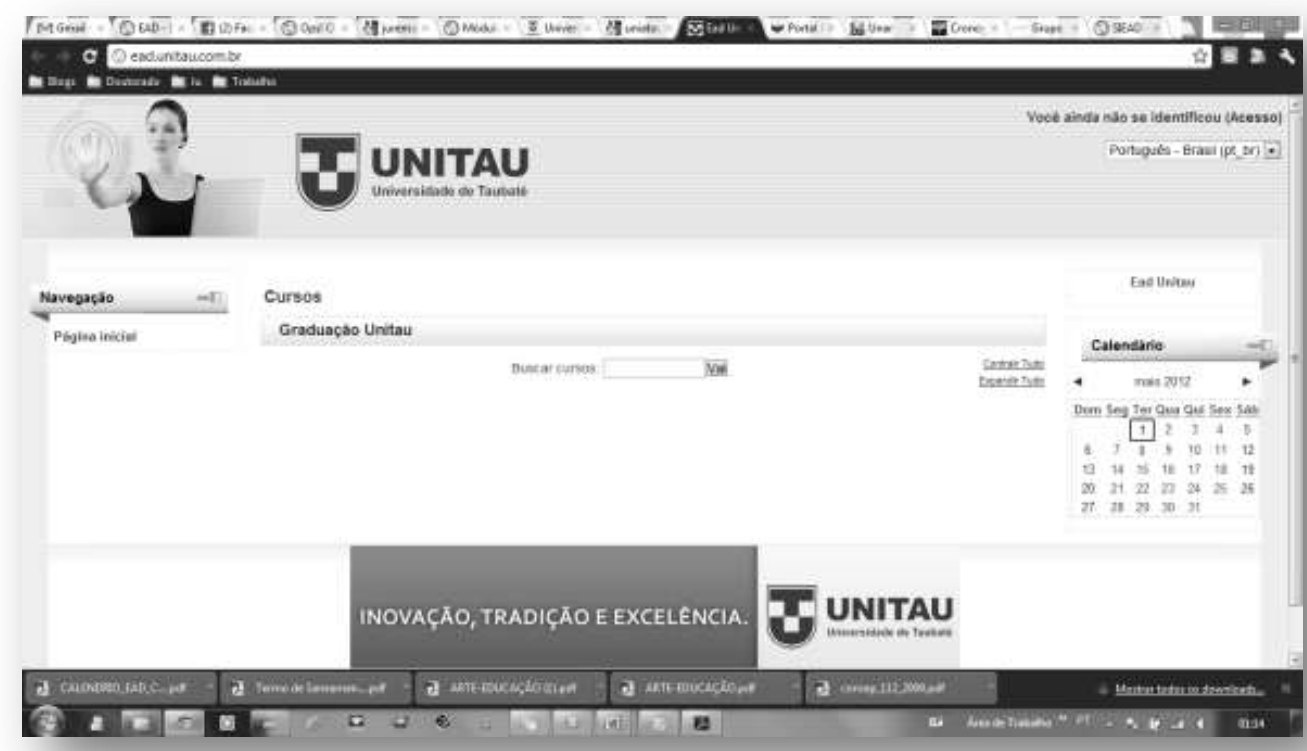

Figura 39 - Imagem do LMS/AVA da IES UNITAU <http://ead.unitau.com.br> 


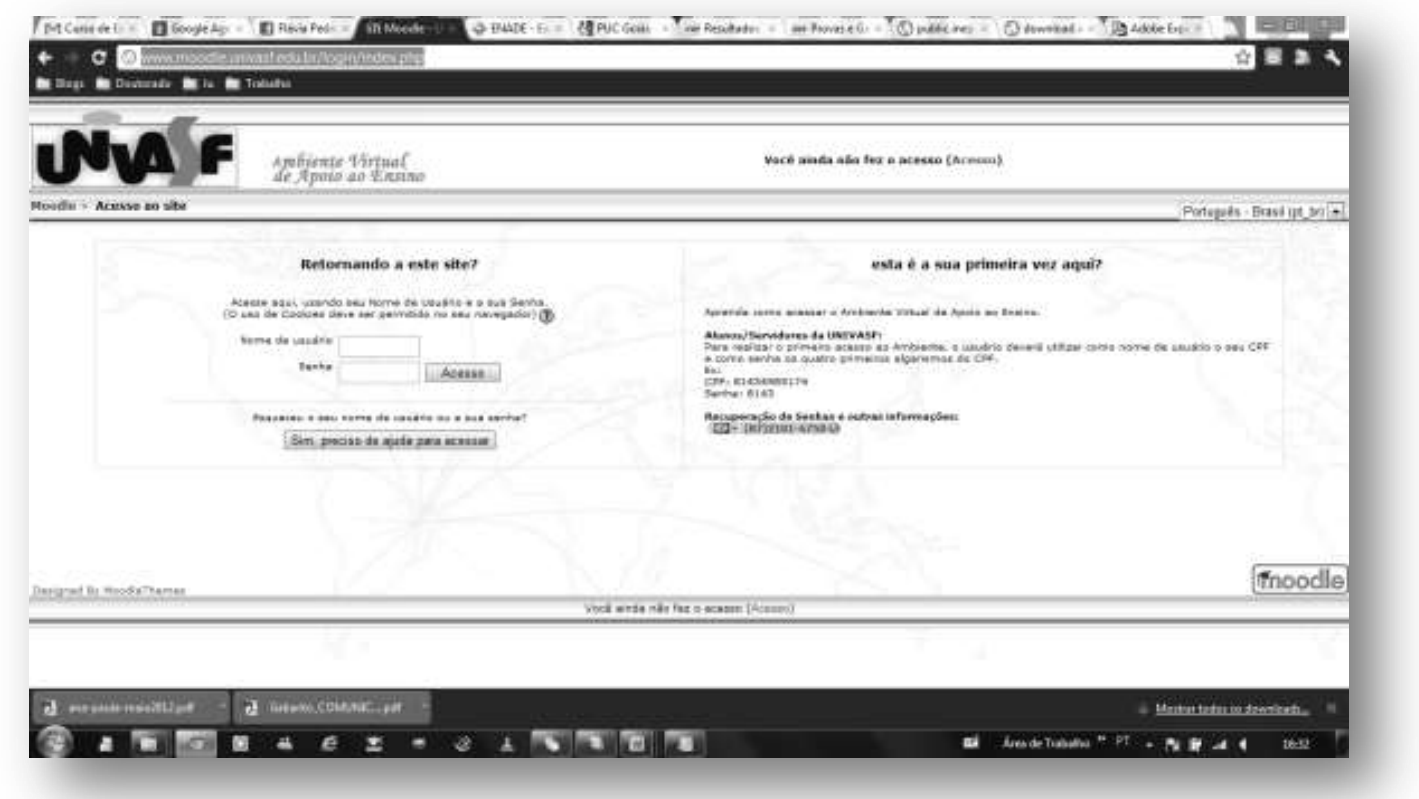

Figura 40 - Imagem do LMS/AVA da IES UNIVASF $<$ http://www.moodle.univasf.edu.br>

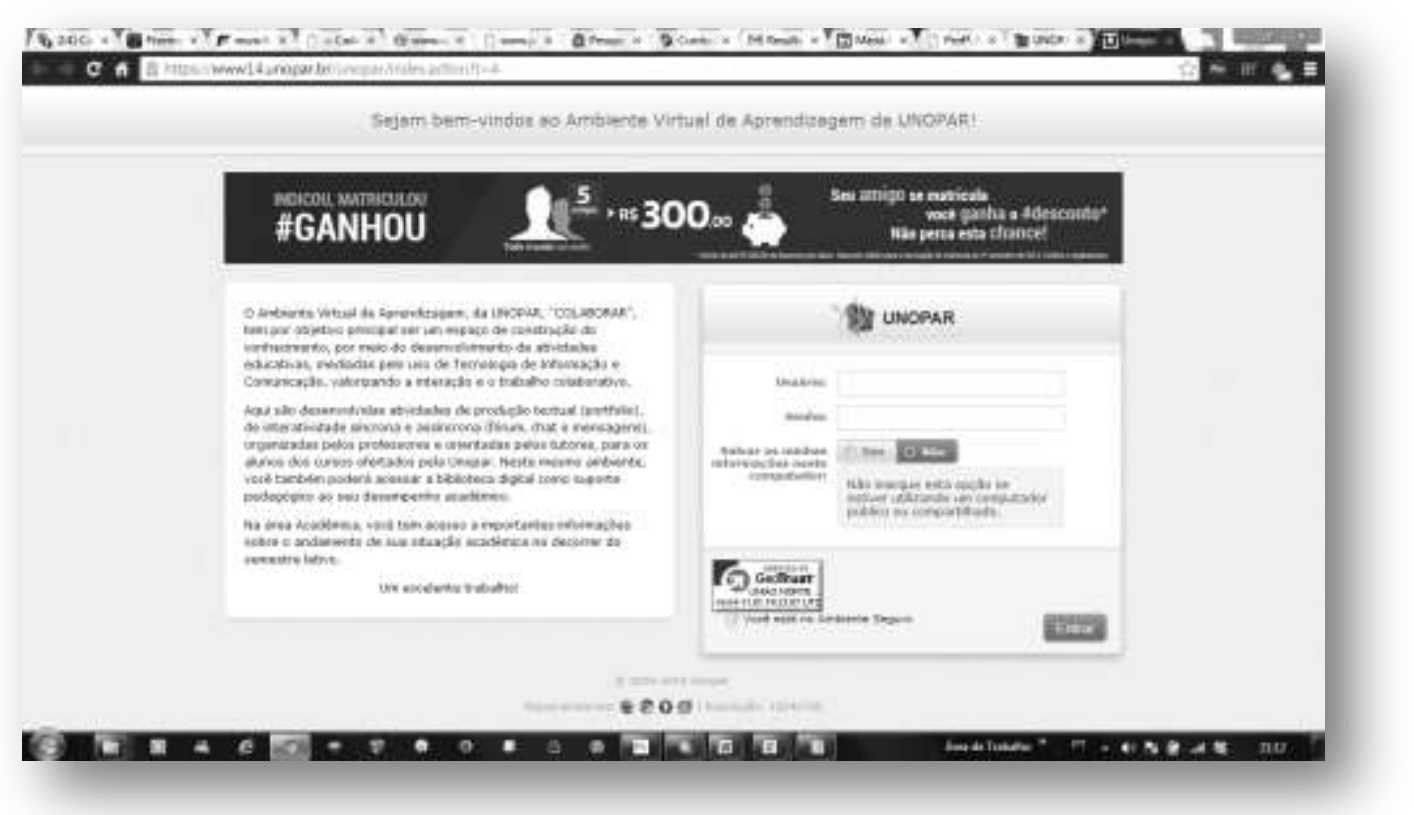

Figura 41- Imagem do LMS/AVA da IES UNOPAR <http://www.unoparead.com.br>

Como podemos ver no quadro abaixo, há grande variedade de LMS/AVA disponíveis no mercado. 
Tabela 24 - LMS/AVA classificados quanto às suas especificidades

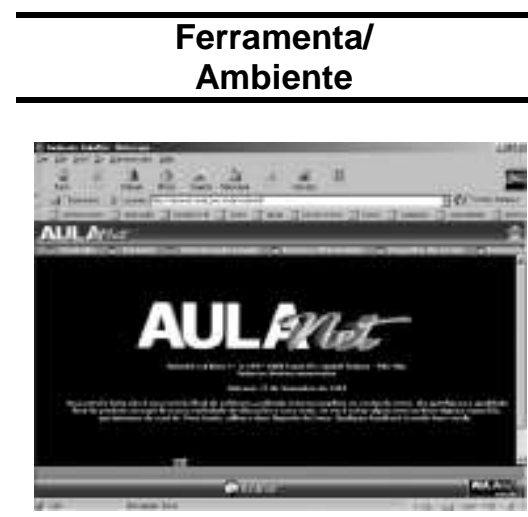

Figura 42 - AulaNet

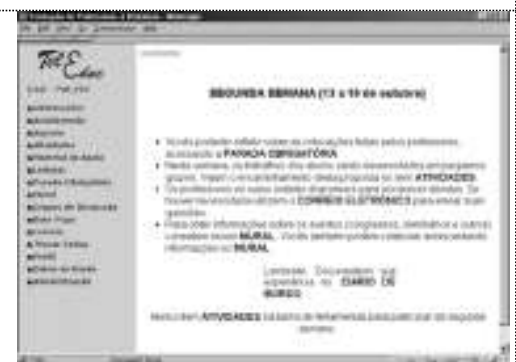

Figura 43 - TelEduc

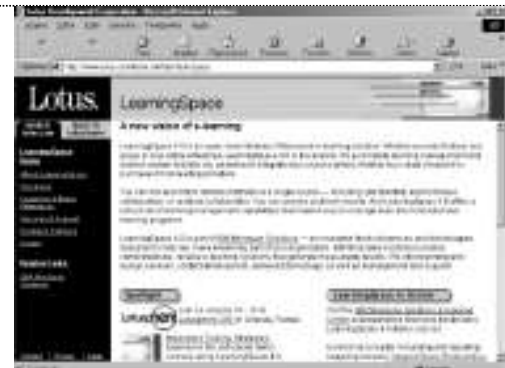

Figura 44 - Learning Space
Desenvolvido pelo

Laboratório de Engenharia de Software - LES - do Departamento de Informática da PUC-Rio. Tem como foco a administração, criação, manutenção e assistência de cursos á distância. $O$ uso do AulaNet enfatiza a cooperação entre os alunos e entre aluno e professor. Suporta grande variedade de tecnologias disponíveis na WWW.

http://www.aulanet.com.br

Ambiente de Ensino a Distância pelo qual se pode realizar cursos através da Internet. Está sendo desenvolvido pelo Núcleo de Informática Aplicada à Educação (Nied) e pelo Instituto de Computação (IC) da Universidade Estadual de Campinas (Unicamp). http://hera.nied.unicamp.br/ teleduc

Desenvolvido pela Lotus permite a criação de cursos de aprendizado a distância com base no ambiente de groupware do Lotus Notes / Domino. Oferece ferramentas que permitem múltiplos níveis de interação entre membros de equipes, alunos e professores.
- Exige poucos conhecimentos de tecnologias web. $\mathrm{O}$ autor do curso não precisa ser um especialista;

- Propicia grande capacidade de interatividade, auxiliando numa maior participação do aluno no processo de aprendizado;

- Tem recursos a criação de cursos correspondentes aos de uma aula convencional somados a outros normalmente disponíveis no ambiente Web; - Possibilita a reutilização de conteúdos já existentes, como por exemplo, a importação de arquivos.

- Possui um esquema de autenticação de acesso aos cursos.

- É um software livre; você pode redistribuí-lo e/ou modificá-lo sob os termos da GNU - General Public License. - Permite aos formadores disponibilizar materiais nas diversas ferramentas do ambiente, bem como configurar opções em algumas.

- Permite gerenciar as pessoas que participam do curso.

- Permite acompanhar a frequência de acesso dos usuários ao curso e às suas ferramentas.

- Os recursos estão distribuídos de acordo com o perfil de seus usuários: alunos e formadores.

- Ambiente para publicação de material multimídia com facilidades para upload de trabalhos de alunos.

\section{- Suporta Vídeo streaming}

(Real Vídeo).

- Suporte para testes.

- Ambientes interativos (apoio ao trabalho de grupo).

- Interessante para aprendizado colaborativo, com

${ }^{118}$ Todos estes ambientes foram desenvolvidos para ser utilizado na Web, o que faz com que trabalhem, basicamente, em linguagem HTML, dando, portanto, suporte à linguagem tridimensional VRML. 


\begin{tabular}{|c|c|c|}
\hline & $\begin{array}{l}\text { http://www.lotus.com/home. } \\
\underline{\text { nsf/tabs/learnspace }}\end{array}$ & $\begin{array}{l}\text { recursos completos de mídia e } \\
\text { gerenciamento de } \\
\text { conhecimento. } \\
\text { - Interface com a Internet para } \\
\text { uso e acesso facilitado. }\end{array}$ \\
\hline 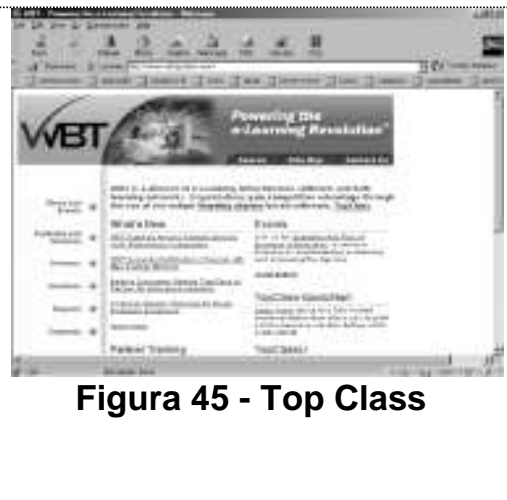 & $\begin{array}{l}\text { Produzido pela WBT } \\
\text { Systems, (Treinamento } \\
\text { Baseado na Web - Web- } \\
\text { Based Training). A WBT } \\
\text { System, investiu } 10 \text { anos } \\
\text { em pesquisas sobre o uso } \\
\text { de tecnologia na Educação } \\
\text { e treinamento, com foco } \\
\text { especial na área de } \\
\text { Educação distribuída e a } \\
\text { distância. } \\
\text { http://www.wbtsystems.com }\end{array}$ & $\begin{array}{l}\text { - É um ambiente de } \\
\text { aprendizagem integrado; } \\
\text { - Proporciona gerenciamento } \\
\text { do conteúdo; } \\
\text { - Permite gerenciamento de } \\
\text { classe (turmas). }\end{array}$ \\
\hline 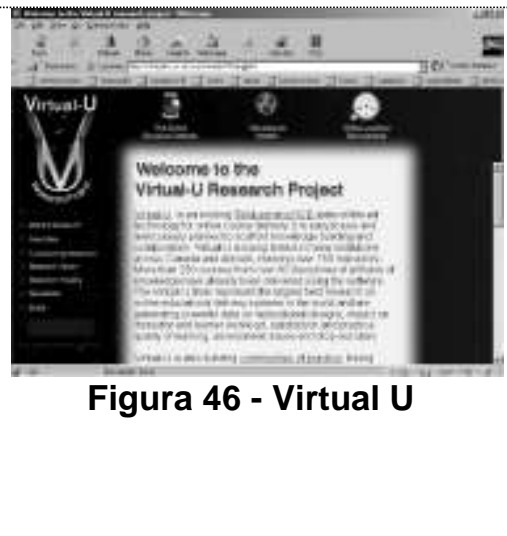 & $\begin{array}{l}\text { Desenvolvido pela Simon } \\
\text { Fraser University, como } \\
\text { parte de projetos de } \\
\text { Educação à distância do } \\
\text { governo canadense, } \\
\text { permite a integração de } \\
\text { ferramentas e templates } \\
\text { para a criação, } \\
\text { manutenção e utilização de } \\
\text { cursos on-line. } \\
\underline{\text { http://virtual- }} \\
\underline{\text { u.cs.sfu.ca/vuweb.new/ }} \\
\underline{\text { new.html }}\end{array}$ & $\begin{array}{l}\text { - E uma ferramenta } \\
\text { estruturada, integrada na Web } \\
\text { para o aprendizado. } \\
\text { - É um ambiente padrão de } \\
\text { suporte para quem necessite } \\
\text { desenvolver cursos baseados } \\
\text { na Web. } \\
\text { - Ferramenta para professores } \\
\text { e alunos que permite acessar e } \\
\text { organizar material de cursos } \\
\text { sem utilização de linguagem } \\
\text { HTML, ou outros protocolos. }\end{array}$ \\
\hline $\begin{array}{c}\text { Figura } 48 \text { - QuadroNegro } \\
\text { (Blackboard) }\end{array}$ & $\begin{array}{l}\text { Desenvolvido pela empresa } \\
\text { de mesmo nome oferece } \\
\text { uma suíte de recursos, } \\
\text { produtos e serviços que } \\
\text { propiciam uma } \\
\text { infraestrutura adequada a } \\
\text { EaD. Integra professores e } \\
\text { alunos de forma simples e } \\
\text { eficiente. Um dos pioneiros } \\
\text { em ambientes para EaD. } \\
\text { http://www.blackboard.com/ }\end{array}$ & $\begin{array}{l}\text { - Monitoramento de frequência } \\
\text { de alunos (entradas e saídas } \\
\text { do sistema). } \\
\text { - Oferece autonomia ao } \\
\text { professor para criar a editar } \\
\text { seus próprios conteúdos } \\
\text { apenas com conhecimentos } \\
\text { básicos em informática. } \\
\text { - Possibilita ainda acesso a } \\
\text { novas ferramentas que } \\
\text { permitirão uma maior } \\
\text { interatividade nas aulas. }\end{array}$ \\
\hline
\end{tabular}


Acredito que a opção pelo Moodle seja a gratuidade de uso desse sistema, os projetos não esclarecem se a opção se deve a isso ou à falta de conhecimento de outras possibilidades. Em nenhum dos trabalhos pesquisados, apresentados em eventos científicos sobre as experiências em EaD em Licenciaturas em Artes Visuais esse aspecto é tratado, justificando a escolha do LMS/AVA.

\subsection{Síntese analítica dos projetos pedagógicos}

Uma síntese analítica dos projetos pedagógicos de seis programas de Licenciatura em Artes Visuais por EaD é feita nesta pesquisa, como forma de embasar as reflexões. Entrei em contato com os coordenadores de curso das instituições, e tive acesso aos dados de seis dos vinte e um programas, das dezenove instituições credenciadas. Dessas instituições, em duas das particulares eu trabalhei, marcadas com X na tabela, como professora tutora nos cursos de Licenciatura em Artes Visuais por EaD.

Tabela 25 - Instituições com oferta de licenciaturas em artes por EaD: acesso ao material.

\begin{tabular}{l|c}
\hline \multicolumn{1}{c|}{ Instituição } & PPP $^{199}$ \\
\hline UCS-UFRGS & \\
\hline UFES & \\
UNB & $\mathrm{X}$ \\
\hline UNIMES & $\mathrm{X}$ \\
\hline CLARETIANO &
\end{tabular}

$\mathrm{Na}$ UNIMES, em Santos/SP, lecionei as disciplinas: Arte Popular, Folclore e Cultura Brasileira; Metodologia e Prática do Ensino da Arte Educação I e Metodologia da Pesquisa Científica. Gravei videoaulas para as duas primeiras e escrevi materiais (livros virtuais) para as três disciplinas.

No Claretiano trabalhei entre setembro de 2009 e dezembro de 2010, nos polos de Campinas e Rio Claro. Lecionei, como tutora virtual, as disciplinas Percepção e Expressão Tridimensional; Percepção e Expressão Bidimensional II: pintura; Percepção e Expressão Bidimensional II: desenho; História da Arte II; para 463 alunos. Atuei como tutora presencial em duas turmas, e professora responsável

\footnotetext{
${ }^{119}$ Projeto Político Pedagógico.

${ }^{120}$ As duas instituições trabalham juntas, UCS/UFRGS pelo consórcio http://www.regesd.tche.br.
} 
pelas disciplinas História e cultura afro-brasileira, africana e indígena I e II; e Museologia/Curadoria/Ação Educativa. Fui responsável por três turmas como tutora presencial, duas em Campinas e uma em Rio Claro. Tendo, ainda, escrito o material da disciplina Processos Escultóricos. Desenvolvi: Plano de Ensino, Mapa Conceitual e o Glossário, mais Caderno de Atividades e Interatividades (CAI), Caderno de Prática (CP) e Caderno de Referência de Conteúdo (CRC), além de 20 questões autoavaliativas. Para uma disciplina de 60hs/aula era estabelecida a quantidade mínima de 289.500 caracteres sem espaço, distribuídas em

Tabela 26 - Orientação de produção de conteúdo de disciplina - Claretiano.

\begin{tabular}{l|l}
\hline \multicolumn{1}{c|}{ Itens } & $\begin{array}{c}\text { Quantidade de caracteres } \\
\text { sem espaço }\end{array}$ \\
\hline Plano de Ensino (antigo Guia de Disciplina) & 10.500 \\
\hline CRC (unidades) & 240.000 \\
\hline CAI & 5.000 \\
\hline CP & 5.000 \\
\hline Roteiro de Videoaula & 20.000 \\
\hline 20 Questões auto avaliativas & 9.000 \\
\hline
\end{tabular}

Essa síntese buscou localizar nos projetos pedagógicos referencial para refletir acerca das questões que, embora pareçam simples, buscam entender como está sendo feita a formação de professores nas licenciaturas em Artes Visuais. Algumas inquietações serviram de disparadores da visão que dá sustentação à análise. Como são compostos os programas? Quais as bases teóricas que dão suporte às visões de formação de professores?

O LTSC - Learning Technology Standards Comitte (1999), trabalha na organização de parâmetros internacionais para programas que utilizem ComputerAided Instruction (CAI). Strong e Harmon (1997), ao analisarem três cursos a distância, apontam a necessidade de formar "consumidores" exigentes para cursos a distância propondo um Guia do Consumidor para Programas On-line. Os critérios desse guia são os mais usados no mercado para analisar programas de EaD. O guia considera várias questões sobre diversos aspectos do programa a ser analisado: 
Tabela 27 - Tradução de Strong e Harmon (1997, apud RODRIGUES, R.S. \& BARCIA, 2013)

\begin{tabular}{l|l}
\hline Verificar & \multicolumn{1}{c}{ Questões } \\
\hline Sobre a & A instituição e o programa são tem certificação reconhecida pelos órgãos \\
Instituição & adequados? \\
& Quais são os critérios de admissão? \\
& Quais os índices de evasão do programa? \\
& Quais recursos da instituição estarão disponíveis aos alunos? \\
Que serviços de suporte aos alunos serão oferecidos?
\end{tabular}

Os critérios apresentados no guia se direcionam à orientação dos 'consumidores' na escolha de um programa educacional a ser cursado e, claramente, embutem uma visão da Educação como 'mercadoria' e, assim, refletem esse pensamento, ao orientar a avaliação do 'produto' e dos 'serviços' como consumidores.

Neste trabalho de pesquisa o interesse se concentra na qualidade de formação e, dessa forma, a análise se volta para a verificação de como a organização do programa contribui na construção do perfil profissional de egresso dos cursos analisados. Assim, embora considere que os critérios de avaliação propostos por Strong e Harmon (1997) sejam uma ferramenta interessante e útil de avaliação, eles não se aplicam diretamente às análises aqui pretendidas.

Segundo o Institute for Distance Education da Maryland University - IDE (1997), os cursos oferecidos por meio de Educação a Distância partilham com os cursos presenciais os seguintes componentes: apresentação do conteúdo; interação com professores, alunos e suporte; aplicações práticas e avaliação. 
Tabela 28 - Questões comuns a todos os Modelos de Cursos. Adaptação do IDE (1997, apud RODRIGUES, R.S. \& BARCIA, 2013).

\begin{tabular}{|c|c|}
\hline $\begin{array}{l}\text { Suporte } \\
\text { Logístico }\end{array}$ & $\begin{array}{l}\text { Distribuição de materiais; } \\
\text { Estrutura de avaliação de aprendizagem que assegure a identificação e } \\
\text { segurança dos testes; } \\
\text { Ressarcimento aos professores e equipe de suporte de custos com } \\
\text { comunicação ou deslocamento para atendimento aos alunos. }\end{array}$ \\
\hline $\begin{array}{c}\text { Suporte aos } \\
\text { Alunos }\end{array}$ & $\begin{array}{l}\text { Orientação acadêmica; } \\
\text { Atendimento individualizado; } \\
\text { Acesso à bibliotecas, laboratórios e equipamentos de informática. }\end{array}$ \\
\hline $\begin{array}{l}\text { Suporte aos } \\
\text { Professores }\end{array}$ & $\begin{array}{l}\text { Treinamento da tecnologia e metodologia do curso } \\
\text { Reconhecimento financeiro e/ou acadêmico do trabalho em EAD; } \\
\text { Assessoria de especialistas na produção de materiais e acesso ás } \\
\text { ferramentas apropriadas; } \\
\text { Seleção e contratação de bons professores. }\end{array}$ \\
\hline $\begin{array}{l}\text { Avaliação de } \\
\text { processo }\end{array}$ & $\begin{array}{l}\text { a) avaliação adequada dos professores; } \\
\text { b) a estrutura de suporte técnico e administrativa deve ser avaliada pelos } \\
\text { alunos e professores. A avaliação deve fazer distinção entre o } \\
\text { desempenho dos professores e os demais sistemas de suporte; } \\
\text { c) avaliação dos treinamento e suporte dos professores. }\end{array}$ \\
\hline Laboratório & $\begin{array}{l}\text { a) desenvolvimento de kits para uso individual; } \\
\text { b) demonstração de experimentos por videoconferência; } \\
\text { c) gravação e edição dos experimentos, usando gráficos e colocando } \\
\text { questões; } \\
\text { d) utilizar simulações por computador disponíveis no mercado ou } \\
\text { especialmente elaboradas; } \\
\text { e) encontros presenciais intensivos em locais com equipamento } \\
\text { adequado. }\end{array}$ \\
\hline
\end{tabular}

Mason (1998, apud RODRIGUES, R.S. \& BARCIA, 2013) faz outra categorização de modelos de cursos. Para ele o ponto mais relevante é a verificação das possibilidades de "interferência do aluno na seleção do conteúdo e nas discussões".

Tabela 29 - Modelos de cursos segundo a possibilidade de interferência do aluno. Tradução de Models of On-line Courses, Mason (1998, apud RODRIGUES, R.S. \& BARCIA, 2013).

\begin{tabular}{|c|c|}
\hline $\begin{array}{l}\text { Conteúdo + } \\
\text { Suporte }\end{array}$ & $\begin{array}{l}\text { A base é a separação entre a equipe que planeja e produz o curso e as equipes } \\
\text { que interagem com os alunos (outros professores ou tutores). Mesmo que os } \\
\text { alunos possam direcionar as atividades e discussões para questões que são de } \\
\text { seu interesse pessoal e/ou profissional. } \\
\text { A estrutura básica do curso, normalmente produzido em larga escala, deve ser } \\
\text { seguida pelo aluno. A possibilidade de contextualização se dá essencialmente } \\
\text { através de interação com os professores assistentes ou tutores. Em relação ao } \\
\text { curso como um todo, o tempo dos alunos em discussões on-line não representa } \\
\text { mais do que } 20 \% \text { do total de dedicação. }\end{array}$ \\
\hline $\begin{array}{l}\text { Wrap } \\
\text { Around }\end{array}$ & $\begin{array}{l}\text { Esta categoria consiste em criar uma parte de curso (guias de estudo, } \\
\text { atividades, discussões) que é construída sobre uma base de materiais já } \\
\text { existentes (livros, CD-ROM, tutoriais). Este modelo tende a incentivar que os } \\
\text { alunos façam mais pesquisas, gerando mais liberdade e responsabilidade. O } \\
\text { papel do professor ou tutor é mais intenso, porque uma parcela menor do curso }\end{array}$ \\
\hline
\end{tabular}


é pré-determinada, de modo que ajustes são feitos a cada vez que o curso é implementado.

Atividades síncronas, trabalhos em grupo e a incorporação de novas referências é possível neste modelo. O tempo dedicado à discussões, em relação ao total do curso, gira em torno de $50 \%$.

Este modelo é oposto ao primeiro. A base do curso são atividades

Integrado colaborativas, pesquisa intensiva e projetos em pequenos grupos. O conteúdo é fluido e dinâmico e determinado, em grande parte, pelas atividades individuais ou do grupo. De certa forma, desaparece a distinção entre conteúdo e suporte.

\section{Todos esses estudos reforçam a ideia de que}

A complexidade do cenário que se apresenta para as instituições que trabalham (ou pretendem trabalhar) com EaD é muito grande. [...] E a complexidade das decisões e as estruturas necessárias para viabilizar os projetos requer o conhecimento das possibilidades e limites da estratégia escolhida. [...] A necessidade de estudos sistemáticos e a análise de várias aplicações da metodologia e uso de tecnologias em Educação a Distância faz-se necessária para o conhecimento do potencial de uma modalidade educacional [...] (RODRIGUES, R.S. \& BARCIA, 2013, p. 15).

Em 2003, junto com Anna Rita Araújo, apresentamos no ConFAEB um mapeamento inicial das 'competências e habilidades' declaradas como esperadas dos formandos de arte/Educação de 14 cursos de formação ${ }^{121}$, todos presenciais. O contexto desse estudo mostrou que

Nas bases contemporâneas de formação e prática da arte-Educação, vemos que a criatividade, a sensibilidade, a percepção do mundo e a reflexão são capacidades que norteiam os caminhos e as abordagens metodológicas da maioria dos programas, fazendo do Ensino e aprendizado em artes um estudo do cotidiano sob a ótica da arte e da visão que cada um faz desta. A Arte-Educação, nesta concepção, passa a ter um caráter social de agente de transformação do processo de Ensino assumindo uma visão includente da arte e sua dinâmica como naturalmente transdisciplinar (SAMPAIO-RALHA \& ARAÚJO, 2003, p. 01).

\footnotetext{
${ }^{121}$ Recolhidos nos programas de cursos das universidades: Universidade Estadual de Campinas UNICAMP; Universidade de São Paulo - USP; Universidade Estadual Paulista - UNESP; Universidade Federal do Rio de Janeiro - UFRJ; Fundação Armando Álvares Penteado; Universidade de Franca - UNIFRAN; Faculdade Santa Marcelina - UFMS; Universidade Federal do Amapá - UNIFAP; Universidade Regional de Blumenau - FURB; Universidade Federal do Maranhão; Universidade Federal do Mato Grosso do Sul; Universidade Federal de Sergipe - UFS; Universidade Nacional de Brasília - UNB; Universidade Federal da Paraíba - UFPB; Universidade Federal do Espírito Santo; Universidade Federal da Bahia - UFBA e Universidade do Estado da Bahia - UNEB.
} 
Essas expectativas de formação se relacionavam ao perfil de egresso esperado, de acordo com os Projetos Político Pedagógicos - PPP das instituições estudadas na época.

É quase consenso geral que sejam consideradas funções do arte/educador:

- Produzir e difundir conhecimentos, bens e valores culturais;

- Integrar a cultura cotidiana às disciplinas acadêmicas;

- Proporcionar momentos de Arte e Cultura;

- Estimular a criatividade, a sensibilidade e a percepção de mundo;

- Conhecer sobre desenvolvimento e aprendizagem para estimular as estruturas cerebrais através da Arte;

- Desenvolver o espírito crítico construtivo;

- Elevar a autoestima, sua e do outro;

- Manipular diversos tipos de materiais com domínio de linguagens e códigos.

- Conhecer formas de interação e inserção no ambiente social criando situações para autonomia e resolução de problemas;

- Desenvolver habilidades de participação;

- Promover a inter-relação entre as diversas áreas do conhecimento;

- Trabalhar com projetos e ações interdisciplinares articulando temas transversais;

- Ter conhecimentos didáticos sobre trabalho multidisciplinar e ambientes multisseriados;

- Gerar cidadão aptos e culturalmente atuantes.

Se tomarmos um viés exclusivamente social, então, espera-se que o arte/educador ainda elabore aulas de arte a partir dos recursos existentes no contexto sócio-econômico-cultural em que se irá atuar; que saiba compreender a arte como um fato histórico e social; analise criticamente conteúdos, procedimentos de Ensino e avaliação; que consiga deduzir objetivos concretos do Ensino de Arte, determinando abordagens metodológicas adequadas e, ainda, que mantenha produção artística própria, expressando-se através da arte, articulando a percepção, a imaginação, a emoção e a reflexão.

Isso tudo acrescentado a uma "natural(?)" função de agente de superação de barreiras na interdisciplinaridade, transdisciplinaridade e parcerias, para proporcionar uma Educação integral, com a abordagem de "Arte para todos" (SAMPAIO-RALHA \& ARAÚJO, 2003, p. 03-04).

Nos estudos da época, já consideramos que, além de demasiado variadas e amplas, as expectativas de formação geravam uma multiplicidade igual ou superior de possibilidades de disciplinas para atender a essas formações, o que fazia com que os programas de formação de professores de arte:

As competências exigidas na Educação, amplamente abordadas e discutidas, já refletem preocupações com relação à compreensão do papel social da escola e a dimensão cultural, social e política da Educação; ao conhecimento de processos de investigação que possibilitem o aperfeiçoamento da prática e domínio do conhecimento pedagógico; ao domínio dos conteúdos e seus significados em diferentes contextos e de articulação interdisciplinar e ao gerenciamento do próprio 
desenvolvimento profissional. No entanto, as competências artísticas parecem fundir-se num misto de arte-produção (técnicas) e arteEducação, sem uma definição entre elas. Por mais teorias que já se tenha, a prática comprova (infelizmente) que a aplicação de técnicas de modo "criativo" parece resumir as competências de toda a área (SAMPAIO-RALHA \& ARAÚJO, 2003, p. 05).

Lembrando, ainda, que

a própria noção de competência como nuclear na formação de professores tem sido contestada por movimentos de educadores do Brasil, como a Associação Nacional pela Formação dos Profissionais da Educação, sinalizando que representa uma concepção fragmentada e instrumental de formação, como também uma concepção individualista na sua essência e imediatista em relação ao mercado de trabalho (SARDELICH, 2012, p. 66).

Em análise quantitativa dos projetos pedagógicos dos cursos na modalidade EaD, nas 19 instituições credenciadas, pude verificar que acontecem vinte e um programas de formação sendo encontramos acesso aos seguintes dados.

Tabela 30 - Instituições credenciadas pelo MEC para oferta de EaD e o acesso aos dados da proposta.

\begin{tabular}{|c|c|c|}
\hline & Instituição & Administração \\
\hline 01 & CLARETIANO & Programa próprio \\
\hline 02 & FGF & Programa próprio $^{122}$ \\
\hline 03 & UCS & Pró-licenciatura \\
\hline 04 & UECE & UAB \\
\hline 05 & UFAM & UAB \\
\hline 06 & UFES & UAB \\
\hline 07 & UFG & UAB / Pró-licenciatura / PARFOR \\
\hline 08 & UFMA & Pró-Licenciatura \\
\hline 09 & UFRGS & Pró-licenciatura \\
\hline 10 & UFRPE & UAB \\
\hline 11 & UNAR & Programa próprio \\
\hline 12 & UNB & UAB \\
\hline 13 & UNIASSELVI & Programa próprio \\
\hline 14 & UNICENTRO & $\mathrm{UAB}$ \\
\hline 15 & UNIMES & Programa próprio \\
\hline 16 & UNIMONTES & Pró-licenciatura / UAB \\
\hline 17 & UNITAU & AUTARQUIA MUNICIPAL \\
\hline 18 & UNIVASF & UAB \\
\hline 19 & UNOPAR & Programa próprio \\
\hline
\end{tabular}

${ }^{122}$ Complementação Pedagógica em arte para licenciados. 


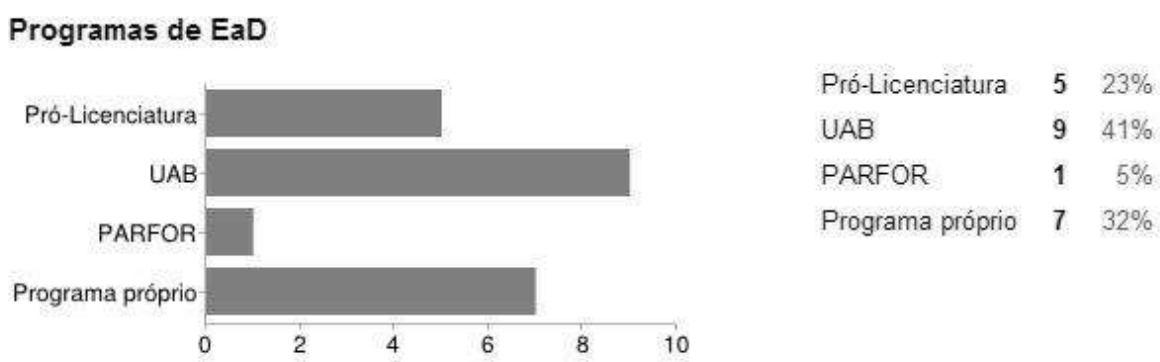

Figura 49 - Programas de Licenciatura em Artes Visuais de acordo com o tipo.

Acreditando que a base artística dos cursos de licenciatura devem contribuir para a prática profissional do licenciando, defendo que

\begin{abstract}
As competências artísticas que se deve desenvolver ao longo do aprendizado artístico organizam-se em quatro eixos estruturantes, sendo adquiridas de forma progressiva, num aprofundamento constante dos conceitos e conteúdos, dando origem a diferentes percursos, de acordo com a especificidade de cada uma delas, vindo a constituir um todo, que chamamos de base artística (SAMPAIO-RALHA \& ARAÚJO, 2003, p. 05).
\end{abstract}

Observando os programas e sistematizando as informações contidas nos projetos pedagógicos dos cursos, em uma tabela, temos o quadro a seguir como resultado.

Observa-se, nas proposições atuais, uma preocupação com a busca de estratégias e atividades que atendam adequadamente aos objetivos declarados, mesmo que os cursos ainda sejam, em maioria, estruturados dentro da visão fordista (MATTAR, 2012) de EaD, com a estrutura de conteudistas, professores e tutores.

Essa estrutura é parte do projeto da UAB e reflete os objetivos da própria criação do projeto, porém é importante ressaltar que esta estrutura não é a única possível para implementação de projetos em EaD. 
Não foram encontrados nos projetos estudados referências à web semântica ${ }^{123}$, e aos recursos da Web $3.0^{124}$ de interação e interatividade.

${ }^{123}$ A Web semântica é uma extensão da Web atualmente conhecida e popularmente usada. Permite que computadores e humanos trabalharem em cooperação, interligando significados de palavras e, assim, conseguindo atribuir um significado (sentido) aos conteúdos publicados na Internet de modo que seja perceptível tanto pelo humano como pelo computador. O conceito de web semântica surgiu em 2001, quando Tim Berners-Lee, James Hendler e Ora Lassila publicaram um artigo na revista Scientific American, intitulado: "Web Semântica: um novo formato de conteúdo para a Web que tem significado para computadores vai iniciar uma revolução de novas possibilidades".

${ }_{124} \mathrm{O}$ termo Web 3.0 foi empregado pela primeira vez pelo jornalista John Markoff, num artigo do The New York Times e logo incorporado e rejeitado com igual ardor pela comunidade virtual. A principal reação vem da blogosfera. A Web 3.0 será, num período de cinco a dez anos, a terceira geração da Internet, segundo os especialistas em inovação em tecnologia. A primeira geração, Web 1.0, foi a implantação e popularização da rede em si; a Web 2.0 é a que a maioria das pessoas no mundo vive hoje, centrada nos mecanismos de busca como Google e nos sites de colaboração do internauta, como Wikipedia, YouTube e as redes sociais, como o Facebook e Twitter. A Web 3.0 conceitua-se como a organização e o uso de maneira mais inteligente de todo o conhecimento já disponível, e tem interesse principal na construção de sentidos para a informação já disponível, proporcionando atuação criativa e criadora mais efetiva. 
Tabela 31 - Síntese dos programas dos cursos de Licenciatura em Artes Visuais por EaD

\begin{tabular}{|c|c|c|c|c|c|}
\hline Programa & Objetivos do curso & $\begin{array}{c}\text { (a) justificativa / } \\
\text { argumentação de opção } \\
\text { pela modalidade de } \\
\text { Ensino (EaD) }\end{array}$ & $\begin{array}{l}\text { (b) bases teóricas que } \\
\text { sustentam a proposta }\end{array}$ & $\begin{array}{l}\text { (c) critérios de avaliação } \\
\text { e/ou autoavaliação }\end{array}$ & $\begin{array}{l}\text { (d) perfis de egresso } \\
\text { esperados por estas } \\
\text { propostas de formação }\end{array}$ \\
\hline $\begin{array}{l}\text { UCS / } \\
\text { UFRGS }\end{array}$ & $\begin{array}{l}\text { O Curso de Licenciatura em } \\
\text { Artes Visuais, modalidade à } \\
\text { distância, tem como objetivo a } \\
\text { formação do professor de } \\
\text { Artes Visuais articulando o } \\
\text { conhecimento artístico à teoria } \\
\text { pedagógica e prática docente } \\
\text { ao longo do curso, } \\
\text { aprofundando o conhecimento } \\
\text { específico da área numa } \\
\text { orientação interdisciplinar. } \\
\text { Está voltado para a } \\
\text { construção de uma escola } \\
\text { capaz de promover a } \\
\text { formação integral dos alunos, } \\
\text { educando-os para o exercício } \\
\text { consciente da cidadania, } \\
\text { apresentando uma discussão } \\
\text { pertinente a questões } \\
\text { inerentes ao jovem e ao } \\
\text { adolescente ao tratar os } \\
\text { conteúdos de forma } \\
\text { contextualizada. }\end{array}$ & $\begin{array}{l}\text { O conjunto de ações } \\
\text { apresentadas busca fortalecer } \\
\text { a proposta defendida pelo } \\
\text { MEC, de articulação dos } \\
\text { diferentes segmentos } \\
\text { responsáveis pelas melhorias } \\
\text { na qualidade da Educação } \\
\text { Básica. Conforme } \\
\text { informações do MEC, cerca } \\
\text { de } 184 \text { mil docentes dos } \\
\text { anos/séries finais do Ensino } \\
\text { Fundamental da rede pública } \\
\text { em todo o País são ocupadas } \\
\text { por profissionais sem a } \\
\text { formação legal exigida para a } \\
\text { função [...] esse número é a } \\
\text { soma dos números de } \\
\text { professores em diferentes } \\
\text { níveis de escolaridade: médio } \\
\text { com ou sem magistério e } \\
\text { superior sem licenciatura, o } \\
\text { que equivale a } 26,21 \% \text { do } \\
\text { total das funções docentes no } \\
\text { Brasil. } \\
\text { [...] a oferta de um curso de } \\
\text { Licenciatura de Artes Visuais } \\
\text { na modalidade a distância } \\
\text { está plenamente justificada, } \\
\text { tanto socialmente como } \\
\text { economicamente. }\end{array}$ & $\begin{array}{l}\text { Cada polo presencial conta } \\
\text { com acervo bibliográfico, em } \\
\text { uma relação de um exemplar } \\
\text { para cada } 10 \text { alunos, } \\
\text { buscando-se atingir três títulos } \\
\text { para cada disciplina. Além } \\
\text { deste acervo básico as } \\
\text { bibliotecas de todas as IES } \\
\text { parceiras estarão disponíveis } \\
\text { para os alunos matriculados } \\
\text { no curso. Também estarão } \\
\text { disponíveis para os alunos o } \\
\text { material produzido pela TV } \\
\text { Escola, bem como todos os } \\
\text { materiais didáticos a serem } \\
\text { produzidos pela Rede. A } \\
\text { intenção destes bancos de } \\
\text { materiais e referências } \\
\text { bibliográficas é propiciar aos } \\
\text { alunos/professores o acesso a } \\
\text { eles, permitindo a melhoria da } \\
\text { qualidade de suas atividades } \\
\text { didáticas em sala de aula. } \\
\text { Bibliografia anexa. }\end{array}$ & $\begin{array}{l}\text { O sistema de avaliação } \\
\text { contempla diferentes formas e } \\
\text { instrumentos de avaliação } \\
\text { formativa e somativa, inclusive } \\
\text { valorizando a prática como } \\
\text { educador do professor-aluno. }\end{array}$ & $\begin{array}{l}\text { O perfil do profissional que se } \\
\text { deseja formar é o de um } \\
\text { professor com um sólido e } \\
\text { atualizado conhecimento da } \\
\text { área de Artes Visuais capaz } \\
\text { de contribuir para a } \\
\text { construção de uma escola de } \\
\text { qualidade, preparado para } \\
\text { propor e implementar as } \\
\text { ações necessárias à sua } \\
\text { transformação. }\end{array}$ \\
\hline UFES & $\begin{array}{l}\text { Objetivo geral } \\
\text { - Formar, de modo consistente } \\
\text { e contextualizado, professores } \\
\text { para atuarem como arte- } \\
\text { educadores no sistema de } \\
\text { Ensino, nas séries finais do } \\
\text { Ensino Fundamental e/ou no } \\
\text { Ensino Médio. }\end{array}$ & $\begin{array}{l}\text { A EAD constitui-se, para nós, } \\
\text { em um importante e eficaz } \\
\text { instrumento de } \\
\text { democratização do acesso à } \\
\text { Educação e uma opção de } \\
\text { qualidade para atender } \\
\text { àqueles que lutam por uma } \\
\text { habilitação em nível superior, }\end{array}$ & $\begin{array}{l}\text { A arte como formação } \\
\text { humanística. } \\
\text { Atividade artística: o homem } \\
\text { e seu meio. } \\
\text { A necessidade da arte para } \\
\text { a Educação. } \\
\text { Educação estética. }\end{array}$ & $\begin{array}{l}\text { A avaliação, no contexto do } \\
\text { Curso de Licenciatura em } \\
\text { Artes Visuais, modalidade } \\
\text { EAD, é entendida na } \\
\text { perspectiva de NEDER } \\
\text { (1996), como uma atividade } \\
\text { político-pedagógica, que tem } \\
\text { por função básica subsidiar }\end{array}$ & $\begin{array}{l}\text { Um curso de Licenciatura em } \\
\text { Artes Visuais deve ter um } \\
\text { programa flexível de forma a } \\
\text { qualificar os seus graduados } \\
\text { para o exercício da atividade } \\
\text { docente em nível de Ensino } \\
\text { Fundamental e Médio, assim } \\
\text { como para a Pós-graduação, }\end{array}$ \\
\hline
\end{tabular}


Objetivos específicos

- Possibilitar aos alunos de arte, uma formação teóricoprática sólida sobre o Ensino da Arte, especificamente nas linguagens pertinentes às Artes Visuais;

- Inserir os alunos nos princípios éticos, estéticos e políticos que envolvem sua atuação no sistema público de Ensino Fundamental e/ou Médio;

- Contribuir para a

compreensão do processo educativo escolar em suas múltiplas interações com as práticas culturais e sua mediação com as questões pedagógicas, históricas, sociais, econômicas e políticas;

- Compreender o fundamento das teorias do conhecimento que sustentam as propostas metodológicas do processo de Ensino-aprendizagem nas Artes Visuais;

- Possibilitar aos alunos condições para o desenvolvimento, no âmbito do projeto pedagógico, da capacidade de organização dos conteúdos estéticos na grade curricular de modo a subsidiar, de forma integrada e contextualizada, a criança o adolescente no processo de construção da sua identidade psicossocial, para sua plena inclusão social

[...] Objetivando democratizar o acesso à Universidade, este projeto propõe a criação de essa população considerável Bibliografia do curso anexa.

e historicamente desassistida.

O Curso de Artes Visuais-

Licenciatura modalidade EaD

é parte do Programa de

Interiorização da UFES, na

modalidade aberta e a

distância. A modalidade

aberta e a distância oferece

uma oportunidade especial

para examinar a ação

pedagógica dos cursos em

termos de sua eficiência.

eficácia, efetividade

sócioeducacional e de seus

impactos específicos no

aprendiz. tomadas de decisão. Nesse

sentido, o processo de

avaliação desse projeto

pressupõe não só análises e

reflexões relativas às

dimensões estruturais e

organizacionais do projeto,

numa abordagem didático-

pedagógica, como também as

dimensões relativas aos

aspectos políticos do

processo de formação de

professores para as séries

finais do Ensino Fundamenta

e do Ensino Médio.

Dentre os aspectos de maior significação para o processo de tomada de decisões relativas ao Curso, destacam-

se: avaliação da proposta

curricular; a avaliação da

aprendizagem; a avaliação do material didático; a avaliação da orientação e coordenação acadêmica; a avaliação do

sistema comunicacional da EaD.

Neste projeto é dado

destaque para a avaliação de aprendizagem, uma vez que

os outros aspectos serão

trabalhados através de

atividades operacionais,

especificamente por meio do

PIP - Projeto Integrado de

Pesquisa, do ne@ad, que

pretende avaliar e

acompanhar os cursos de

licenciatura oferecidos na

modalidade EAD pela UFES

(ver documento em anexo). ou para oportunidades de trabalho fora do ambiente acadêmico. Dentro dessas perspectivas, os programas de Licenciaturas em Artes Visuais devem permitir aos licenciandos uma formação visando, prioritariamente a carreira acadêmica, o que necessita, além de uma sólida base de conteúdos do Ensino da Arte, de uma formação mais flexível contemplando

áreas de aplicação e sua interação com as práticas culturais.

Nesse contexto o Curso de Licenciatura em Artes Visuais deve garantir que seus

egressos tenham:

- uma sólida formação de conteúdos de Arte e de seu

Ensino;

- uma formação que lhes prepare para enfrentar os desafios das rápidas

transformações da sociedade,

do mercado de trabalho e das condições de exercício

profissional;

Por outro lado, desejam-se as seguintes características para

o Licenciado em Artes

Visuais:

- visão de seu papel social de educador e capacidade de se inserir em diversas realidades com sensibilidade para

interpretar as ações dos educandos;

- visão da contribuição que a

aprendizagem das Artes

Visuais pode oferecer à

formação dos indivíduos para 


\begin{tabular}{|c|c|c|c|c|c|}
\hline & $\begin{array}{l}\text { um curso de graduação } \\
\text { inovador e de qualidade, na } \\
\text { área de Artes, na Licenciatura } \\
\text { em Artes Visuais a Distância. }\end{array}$ & & & & $\begin{array}{l}\text { o exercício de sua cidadania; } \\
\text { - visão de que o conhecimento } \\
\text { estético pode e deve ser } \\
\text { acessível a todos, e } \\
\text { consciência de seu papel na } \\
\text { superação dos preconceitos } \\
\text { traduzidos pela angústia, } \\
\text { inércia ou rejeição, que, } \\
\text { muitas vezes, ainda estão } \\
\text { presentes no Ensino } \\
\text { aprendizagem } \\
\text { da disciplina nas escolas de } \\
\text { Ensino Fundamental e Médio. }\end{array}$ \\
\hline UNB & $\begin{array}{l}\text { São objetivos dos cursos: } \\
\text { - qualificar e diplomar dos } \\
\text { alunos; } \\
\text { - melhorar a qualidade de } \\
\text { Ensino da Arte nas escolas e } \\
\text { a ampliação das } \\
\text { possibilidades de aprendizado } \\
\text { por seus alunos; } \\
\text { - proporcionar a construção do } \\
\text { conhecimento de forma } \\
\text { colaborativa que venha a } \\
\text { reforçar a arte local e do } \\
\text { Brasil, apresentando suas } \\
\text { estruturas e complexidades, } \\
\text { ao longo dos cursos; } \\
\text { - proporcionar aprendizagem } \\
\text { das diversas dimensões da } \\
\text { formação do artista, } \\
\text { tais como: a teoria e história } \\
\text { da arte e a análise e prática } \\
\text { da arte contemporânea, em } \\
\text { toda a sua dimensão local da } \\
\text { cultura brasileira; } \\
\text { - desenvolver uma visão } \\
\text { crítica do mundo artístico e de } \\
\text { seus meios de produção, } \\
\text { atualizando, também, o seu } \\
\text { conhecimento dos em relação } \\
\text { à história do Ensino da Arte } \\
\text { no Brasil, suas influências e } \\
\text { tendências metodológicas; }\end{array}$ & $\begin{array}{l}\text { Com o objetivo de colaborar } \\
\text { com mudanças efetivas na } \\
\text { Educação brasileira é que a } \\
\text { Universidade de Brasília } \\
\text { apresenta o programa de } \\
\text { Licenciatura em Artes Visuais. } \\
\text { [...] A área de humanidades, } \\
\text { onde a arte se insere, também } \\
\text { quer valorizar a escola } \\
\text { investindo na qualificação do } \\
\text { docente, pois, dele depende a } \\
\text { reestruturação do sistema } \\
\text { educacional brasileiro. A } \\
\text { reestruturação está } \\
\text { condicionada a uma sólida } \\
\text { preparação daqueles que } \\
\text { serão os responsáveis pela } \\
\text { formação e transformação da } \\
\text { própria sociedade. Nesse } \\
\text { sentido, a licenciatura adquire } \\
\text { uma primordial relevância e } \\
\text { seu planejamento deve } \\
\text { considerar o papel } \\
\text { fundamental que os } \\
\text { educadores ocupam na } \\
\text { construção de novos modelos } \\
\text { sociais. É primordial que a } \\
\text { formação dos futuros } \\
\text { professores inclua a } \\
\text { capacitação e a preparação } \\
\text { para os desafios da mudança }\end{array}$ & $\begin{array}{l}\text { Núcleo de Fundamentação, } \\
\text { Núcleo de Aprofundamento e } \\
\text { Formação Específica e Núcleo } \\
\text { de Conclusão do Curso. O } \\
\text { Núcleo de Fundamentação e } \\
\text { o de Conclusão do Curso } \\
\text { integram núcleos de estudos } \\
\text { comuns às três áreas de } \\
\text { conhecimento Artes Visuais, } \\
\text { Música e Teatro. O Núcleo de } \\
\text { Aprofundamento e Formação } \\
\text { em Específica refere-se a } \\
\text { estudos específicos de cada } \\
\text { uma dessas áreas. [...]Tendo } \\
\text { presente que o currículo do } \\
\text { curso deve incorporar a } \\
\text { compreensão de que o próprio } \\
\text { currículo e o próprio } \\
\text { conhecimento devem ser } \\
\text { vistos como construções e } \\
\text { produtos de relações sociais } \\
\text { particulares e históricas e } \\
\text { ainda, que deve ser orientado } \\
\text { numa perspectiva crítica em } \\
\text { que ação-reflexão-ação se } \\
\text { coloquem como atitude que } \\
\text { possibilite ultrapassar o } \\
\text { conhecimento de senso } \\
\text { comum, três conceitos são } \\
\text { escolhidos para servir não só } \\
\text { de elo entre as diferentes }\end{array}$ & $\begin{array}{l}\text { Nortear as atividades } \\
\text { avaliativas da aprendizagem, } \\
\text { segundo uma concepção que } \\
\text { resgate e revalorize a } \\
\text { avaliação como informação e } \\
\text { tomada de consciência de } \\
\text { problemas e dificuldades, com } \\
\text { o fim de resolvê-los, para } \\
\text { estimular e orientar a } \\
\text { autoavaliação. [...] A equipe } \\
\text { de acompanhamento e } \\
\text { coordenação procederá a um } \\
\text { processo de monitoramento } \\
\text { sistemático e permanente dos } \\
\text { cursos, de forma a atender às } \\
\text { referências indicadas no } \\
\text { próprio Programa da UAB. [...] } \\
\text { A avaliação da aprendizagem, } \\
\text { relacionando seus objetivos, } \\
\text { procedimentos e } \\
\text { instrumentos, bem como os } \\
\text { critérios de aprovação e os } \\
\text { requisitos para diplomação } \\
\text { terão por objetivo verificar o } \\
\text { desenvolvimento, pelo aluno, } \\
\text { das competências previstas } \\
\text { em cada disciplina e a } \\
\text { capacidade de mobilizar } \\
\text { conhecimentos e aplicá-los } \\
\text { para colocar situações- } \\
\text { problemas, delinear hipóteses }\end{array}$ & $\begin{array}{l}\text { Esses princípios que devem } \\
\text { sustentar a formação e o perfil } \\
\text { do profissional de Licenciatura } \\
\text { em Artes Visuais expressos } \\
\text { por meio de duas dimensões: } \\
\text { - dimensão Epistemológica: } \\
\text { que diz respeito à escolha e } \\
\text { aos recortes teórico- } \\
\text { metodológicos das áreas e } \\
\text { disciplinas ligadas as ciências } \\
\text { que integram o currículo das } \\
\text { series iniciais; } \\
\text { - dimensão profissionalizante: } \\
\text { que, implicando a primeira, diz } \\
\text { respeito aos suportes teórico- } \\
\text { práticos que possibilitam uma } \\
\text { compreensão do fazer do } \\
\text { professor de Artes Visuais em } \\
\text { todas as suas relações } \\
\text { sociopolíticas e culturais e nas } \\
\text { perspectivas da moral e da } \\
\text { ética. }\end{array}$ \\
\hline
\end{tabular}


- preparar o aluno para ser pesquisador de arte e não somente transmissor de

conhecimentos;

- possibilitar a experimentação e o aprimoramento de práticas de Ensino aprendizagem na área de arte;

- estabelecer vínculos entre o conteúdo da arte e os conteúdos das diversas áreas do conhecimento, tais como: ciência da computação, história, química, biologia, matemática, sociologia, psicologia, Educação, entre outras;

- tratar o conhecimento de

forma contextualizada, tendo em conta a realidade social cultural de sua região;

- produzir materiais de apoio à prática docente e aprender a utilizar equipamentos e meios de informação e comunicação para a preparação de suas aulas.

- proporcionar condições de acesso aos alunos portadores de necessidades especiais, por meio da proposição de estratégias e do uso de recursos didáticos que atendam às especificidades do caso, conforme demanda levantada durante o período de inscrição.

Objetivos educacionais: - Conciliar a extensão da informação curricular e a variedade de fontes de acesso na web com o aprofundamento da sua de paradigmas e para 0 desenvolvimento de

habilidades interdisciplinares $e$ que estimulem a permanência do aluno até a conclusão com sucesso do curso em que esteja inserido. [...] A valorização e qualificação do professor e a ampliação de seus olhares e saberes é fundamental no desenvolvimento de profissionais críticos autônomos e capazes de construir caminhos e ações pedagógicas significativas. A qualificação deve incluir o conhecimento da importância do desenvolvimento de políticas públicas para transformação do país. Ao ressaltar a relevância em basear o processo de

formação dos professores nesse eixo epistemológico, esperamos contribuir para a concretização de uma reconfiguração

do cenário educacional no qual a arte poderá desempenhar um papel primordial na articulação de projetos interdisciplinares

fundamentados em propostas curriculares atuais.

[...] O programa do curso foi elaborado de modo a fazer com que os alunos aprendam e construam os seus

conhecimentos e habilidades de forma interdisciplinar $e$ colaborativa, fundamentados em estudos teóricos práticos. É também áreas e os diferentes núcleos de conhecimento, mas

também de fio condutor para a base metodológica do curso: historicidade, construção e diversidade. [...] a

aprendizagem colaborativa é compreendida como um

processo onde os indivíduos trabalham em grupos estruturados on-line,

produzem conhecimento pelo intercâmbio mútuo de

experiências, informações, por meio da execução de tarefas educativas. $A$ aprendizagem colaborativa on-line é a

associação entre o trabalho individual e o coletivo, com a formação de pequenos grupos de 5 a 10 participantes, que podem ser parte de um grupo maior de 50 a 150 ou mais estudantes. [...] Nessa modalidade de Ensino os Tutores ocupam um papel importante, atuam como um elo entre os estudantes e a instituição. Cumprem o papel de facilitadores da

aprendizagem, esclarecendo dúvidas, reforçando a aprendizagem, coletando informações sobre os estudantes para a equipe e principalmente na motivação. Os tutores serão escolhidos por processo seletivo que deverá seguir os requisitos para ocupação da função. [...] Para a execução deste projeto, adotar-se á

concepção construtivista, a partir das teorias de Jean etc. As atividades produzidas serão acompanhadas e

avaliadas pelos tutores com apoio da equipe de

professores. [...] A UnB usa o seu sistema habitual de menções ou notas e critérios de aprovação. [...] A

realização das atividades a distância servirá também como registro de frequência. Para aprovação em uma disciplina, é necessário que o aluno tenha realizado ao menos $75 \%$ das atividades previstas. Para diplomação, o aluno deve ter obtido desempenho satisfatório em todas as disciplinas (de acordo com as regras da UnB como explicitado

anteriormente) e ter seu relatório final de estágio aprovado. 


\begin{tabular}{|c|c|c|c|c|c|}
\hline & $\begin{array}{l}\text { compreensão em espaços } \\
\text { menos rígidos e menos } \\
\text { engessados; } \\
\text { - Selecionar as informações } \\
\text { mais significativas e integrá- } \\
\text { las à vida do estudante; } \\
\text { - Incentivar a cooperação para } \\
\text { vencer os desafios do hoje e } \\
\text { do amanhã; } \\
\text { - Incentivar a autonomia e } \\
\text { autoria como metas a serem } \\
\text { alcançadas; } \\
\text { - Proporcionar Grupos } \\
\text { cooperativos como estratégia } \\
\text { didática; } \\
\text { - Adotar perspectiva } \\
\text { construcionista, com ênfase } \\
\text { na produtividade do aluno, no } \\
\text { aproveitamento de seu } \\
\text { conhecimento anterior e na } \\
\text { troca de experiências como } \\
\text { elemento dinamizador da } \\
\text { aprendizagem; } \\
\text { - Promover a interação entre } \\
\text { as pessoas, em ambiente } \\
\text { virtual; } \\
\text { - Propiciar a troca de } \\
\text { experiências entre os } \\
\text { integrantes do curso. }\end{array}$ & $\begin{array}{l}\text { estruturado para que eles } \\
\text { considerem a relevância de } \\
\text { suas experiências prévias, } \\
\text { para tornarem-se aptos a } \\
\text { fazer frente aos desafios que } \\
\text { as escolas, principalmente as } \\
\text { da rede pública no Brasil, } \\
\text { trazem, também em função de } \\
\text { seus aspectos culturais e } \\
\text { regionais. }\end{array}$ & $\begin{array}{l}\text { Piaget e Vygotsky. [...] A } \\
\text { mediação pedagógica tem um } \\
\text { papel primordial no processo } \\
\text { de Ensino-aprendizagem } \\
\text { apoiado em recursos } \\
\text { tecnológicos. A Educação a } \\
\text { Distância se torna mais } \\
\text { eficiente quando aliada às } \\
\text { teorias pedagógicas, como o } \\
\text { construtivismo, onde o } \\
\text { conhecimento não é } \\
\text { repassado, mas sim } \\
\text { construído a partir das } \\
\text { experiências individuais } \\
\text { trocadas pelo aluno com o } \\
\text { grupo. }\end{array}$ & & \\
\hline UNIMES & $\begin{array}{l}\text { Os objetivos fixados } \\
\text { consideram: Legislação, } \\
\text { Diretrizes Curriculares para os } \\
\text { cursos de licenciatura e os } \\
\text { Parâmetros Curriculares para } \\
\text { Arte, relacionados ao Ensino } \\
\text { Fundamental e Médio } \\
\text { aplicados ao curso; } \\
\text { Cenário artístico, cultural, } \\
\text { econômico, social e político; } \\
\text { Missão da universidade e } \\
\text { função do curso dentro do } \\
\text { plano de desenvolvimento } \\
\text { institucional; } \\
\text { Características dos recursos }\end{array}$ & $\begin{array}{l}\text { A Educação a Distância } \\
\text { avançou em termos } \\
\text { quantitativos e qualitativos, no } \\
\text { Brasil e no mundo, } \\
\text { alcançando um status de alta } \\
\text { credibilidade e eficácia em } \\
\text { vários contextos, e nos } \\
\text { norteou na construção deste } \\
\text { projeto que tem como } \\
\text { compromisso uma } \\
\text { fundamentação teórica e } \\
\text { prática sólida que atenda às } \\
\text { necessidades dos alunos, } \\
\text { futuros professores, e que } \\
\text { proporcione os melhores }\end{array}$ & $\begin{array}{l}\text { O currículo do curso está } \\
\text { voltado para a formação de } \\
\text { docentes, com visão de } \\
\text { interdisciplinaridade, } \\
\text { complementaridade e } \\
\text { multidisciplinaridade. Tem } \\
\text { como ponto de destaque a } \\
\text { formação dos licenciados } \\
\text { com espírito reflexivo, crítico } \\
\text { e investigativo, o que facilita } \\
\text { a visão sobre a importância } \\
\text { do desenvolvimento de } \\
\text { projetos e ações } \\
\text { educacionais como forma de } \\
\text { construir a integração }\end{array}$ & $\begin{array}{l}\text { [...]a avaliação é contínua. O } \\
\text { aluno acompanha a avaliação } \\
\text { das atividades, mediante o } \\
\text { recurso Notas, disponível no } \\
\text { AVO. O aluno é avaliado } \\
\text { considerando-se: } \\
\text { - a participação nas atividades } \\
\text { realizadas; } \\
\text { - o cumprimento das } \\
\text { atividades em tempo e forma; } \\
\text { - a pertinência das aulas } \\
\text { planejadas; } \\
\text { - a elaboração do Relatório do } \\
\text { módulo de ECS, em tempo e } \\
\text { forma; }\end{array}$ & $\begin{array}{l}\text { Espera-se ter o perfil do arte- } \\
\text { educador que, ao final do } \\
\text { curso, deverá demonstrar } \\
\text { capacidade de: } \\
\text { I. realização de produções } \\
\text { artísticas individuais ou } \\
\text { coletivas, em consonância } \\
\text { com a reflexão e pesquisa } \\
\text { sobre esses práticas; } \\
\text { II. investigação e } \\
\text { compreensão das práticas } \\
\text { artísticas de Artes Visuais, } \\
\text { pela análise, reflexão e } \\
\text { compreensão de seus vários } \\
\text { processos, com seus }\end{array}$ \\
\hline
\end{tabular}


humanos: supervisor, docentes, tutores e corpo técnico-administrativo engajados no projeto do curso;

Infraestrutura física e tecnológica e recursos materiais alocados.

\section{Objetivos Gerais}

Considerando que a ação educacional é uma prática social mediadora da prática social mais ampla

estabelece-se:

I. Formar o profissional de arte-Educação contemplando suas dimensões profissionais e pessoais, capaz de tomar decisões sobre suas ações pedagógicas de fazer opções, de refletir na ação e sobre ela; II. Sensibilizar o aluno sobre a importância da construção dos percursos pessoais e da transformação contínua do processo de Ensino e de aprendizagem das Artes Visuais para 0 acompanhamento das mudanças do mundo;

III. Formar profissionais estudiosos e investigadores do processo de Ensino e de aprendizagem das Artes Visuais, ao longo de sua atividade docente ou não docente;

IV. Qualificar para exercer atividades:

a) na docência do Ensino

Fundamental regular, do

Ensino Médio e de jovens e resultados à sociedade. [...] $\mathrm{A}$ partir dessa perspectiva,

reconhece-se a importância

da presença da arte como

conteúdo do Ensino

Fundamental e Médio, com a

inserção em atividades

interdisciplinares. O diálogo

acadêmico proposto numa

perspectiva cultural instiga a

relação com outros

conhecimentos, valorizando

tanto a atuação de

professores pesquisadores,

quanto à de alunos

pesquisadores.

Essa valorização da ação do

sujeito em relação à

apreensão do conhecimento

torna-se ainda mais premente

por tratar-se de Ensino

Fundamental e Médio, cujas

etapas do desenvolvimento

global do aluno requerem,

também, prepará-lo para a

vida adulta, com incentivo a

sua autonomia, iniciativa e

tomada de responsabilidades pessoais.

Para que esses perfis de professores e alunos

pesquisadores possam ser

concretizados, o

Ensino/aprendizagem da arte

deve ocorrer de forma

questionadora, com destaque

à reflexão e 0

desenvolvimento do "olhar",

numa práxis contextualizada

histórica e culturalmente,

recolocando questões

pertinentes à experiência

estética e sua inserção na

sociedade hodierna. teoria/prática, de aplicação - a apresentação dos

de conhecimentos na

realidade escolar.

Deve ocorrer a transposição

didática do que o aluno

aprendeu para que ele

possa teorizar a partir das

observações feitas junto à

comunidade. Nesta linha,

algumas ações devem,

necessariamente, ser

estimuladas, como por

exemplo, a realização da

prática do estágio

supervisionado, participação

em projetos educacionais,

com ênfase no Ensino de

Artes.

Bibliografia do curso anexa.

documentos comprobatórios

do estágio realizado, que são

o formulário de dados do

estagiário e da instituição

cedente e o Formulário das

Atividades de Estágio,

devidamente assinados pelos

profissionais da instituição

cedente, pelo tutor do seu

polo de origem. Essa

documentação é

encaminhada ao professor

orientador por correio

tradicional, pois esses

documentos são arquivados

no prontuário acadêmico.

O Trabalho de Conclusão de

Curso (TCC) é um requisito

parcial e obrigatório para a

conclusão do curso de

Licenciatura, na modalidade a

distância. diferentes instrumentos e

manifestações sociais

culturais e históricas.

III. compreensão, análise e

reflexão sobre os critérios

culturalmente constituídos e

embasados em

conhecimentos afins, de

caráter filosófico, histórico,

sociológico, antropológico,

semiótico, científico e

tecnológico, dentre outros

IV. contextualização dos

aspectos históricos e

socioculturais da arte,

analisando e refletindo sobre

as diversas manifestações de

arte, em suas relações

espaciais e temporais e em

suas múltiplas funções, nos

diferentes grupos sociais $e$

étnicos, interagindo com o

patrimônio nacional e

internacional em sua

dimensão sóciohistórica.

V. compreensão de vários

domínios do conhecimento de

arte-Educação e dos

conteúdos disciplinares

específicos e respectivas

metodologias, numa

perspectiva de formação com

técnica e auto

aperfeiçoamento

VI. implementação de projetos educativos em Artes Visuais

consoantes com a diversidade

cultural contemporânea e que

contemplem as diversas

esferas do social: artística,

estética, ética, científica,

tecnológica e cultural;

VII. mobilização de

conhecimentos, capacidades 
adultos;

b) no planejamento,

organização e avaliação de

projetos educacionais em

Artes Visuais ligados aos

sistemas de Ensino, escolas e

outros espaços;

c) na produção e difusão de

conhecimento no campo

educacional das Artes Visuais.

V. Garantir a

indissociabilidade entre

Ensino, pesquisa e extensão

através de um trabalho

conjunto da teoria, da prática

dos estágios, da pesquisa, e

da prestação de serviços para

a comunidade;

VI. Eleger a situação

educacional em Artes Visuais

como base para definir os

saberes relativos aos

diferentes campos das

ciências e das artes que farão

parte da formação do

licenciado em Artes Visuais

que se pretende: autônomo,

crítico e com identidade

própria.

VII. Levar o aluno a conhece e refletir com profundidade,

sobre os fundamentos

estéticos, históricos,

filosóficos, sociais, políticos,

culturais e psicológicos da

arte Educação;

VIII. Formar o docente e o

pesquisador abrangendo,

concomitantemente, para sua

formação os conteúdos e a

metodologia que conduzam

ao sucesso de seu trabalho;

IX. Preparar o arte-educador

para que ele seja capaz de
O Ensino da Arte tem passado

por profundas mudanças em

busca de novos caminhos.

Essa reflexão sobre a prática

educativa desejada para a

arte em contexto escolar

sofreu influência,

especialmente nos últimos

dez anos, da difusão de ideias

baseadas na "Proposta

Triangular" de Ana Mae

Barbosa; na afirmação da

presença dos setores

educativos em Museus e

instituições culturais; na

valorização da pesquisa em

arte Educação e seu

incremento em cursos de

graduação e pós-graduação

(lato e stricto senso)

ampliando o número de

publicações na área, pela

determinação de Parâmetros

Educacionais para a Arte, e,

principalmente, pela busca de

educadores que,

descontentes com as

condições de trabalho em que

se encontram, procuram na

arte formas de tornar os

conteúdos escolares e a

própria experiência estética,

mais significativos para os

alunos e para si próprios.

Esses professores, que fazem

uma opção pela arte, tornam-

se aprendizes nos caminhos e

descaminhos da relação

Ensino/aprendizagem. É a

esses profissionais que nos

remetemos com o objetivo de

fornecer subsídios para

ampliar propostas educativas, e tecnologias para intervir

efetivamente em situações

educacionais concretas,

relacionando a arte ao corpo

de conhecimentos que

compõem o processo

educacional;

VIII. articulação no

processo de reflexão da arte

na escola, de recursos

humanos, metodológicos,

técnicos e operativos,

mediante práticas

participativas;

IX. desenvolvimento de competências e atitudes investigativas para a arte

Educação, implicando mapear

contextos e problemas,

argumentar e captar

contradições em situações;

$X$. desenvolvimento de

sensibilidade ético-

profissional, implicando

responsabilidade social e

atuação por uma sociedade

justa e solidária. 


\begin{tabular}{|c|c|c|c|c|c|}
\hline & $\begin{array}{l}\text { fazer a reflexão sobre sua } \\
\text { ação e construir sua própria } \\
\text { forma pessoal de conhecer. } \\
\text { Objetivos Específicos } \\
\text { Para atingir os objetivos } \\
\text { gerais, apresentam-se os } \\
\text { seguintes princípios e fins no } \\
\text { curso de graduação - } \\
\text { Licenciatura em Artes Visuais: } \\
\text { Aplicação de métodos } \\
\text { artísticos e científicos; } \\
\text { Elaboração e reelaboraração } \\
\text { do conhecimento artístico e } \\
\text { científico, levando a } \\
\text { comunidade acadêmica a } \\
\text { aumentar seu nível de } \\
\text { competência; } \\
\text { Criação e recriação com } \\
\text { equilíbrio de novos } \\
\text { conhecimentos e tecnologias, } \\
\text { pelo processo de investigação } \\
\text { dos procedimentos da arte e } \\
\text { de seu Ensino; } \\
\text { Formulação de processos } \\
\text { históricos, estéticos e técnicos } \\
\text { relacionados ao } \\
\text { desenvolvimento da arte na } \\
\text { Educação; } \\
\text { Provisão, para a sociedade de } \\
\text { arte-educadores pela } \\
\text { formação e instrução de } \\
\text { qualidade. }\end{array}$ & $\begin{array}{l}\text { Ensino da Arte e a } \\
\text { identificação de possibilidades } \\
\text { de interdisciplinaridade com } \\
\text { outros conteúdos do Ensino } \\
\text { escolar. }\end{array}$ & & & \\
\hline CLARETIANO & $\begin{array}{l}\text { O objetivo do Claretiano é ser } \\
\text { uma Instituição de geração de } \\
\text { conhecimentos em um } \\
\text { ambiente dinâmico e criativo, } \\
\text { tendo como meta central o } \\
\text { compromisso com a busca da } \\
\text { verdade e com os problemas } \\
\text { e as aspirações da } \\
\text { comunidade, sem perder de } \\
\text { vista os padrões de qualidade. } \\
\text { É nesse sentido que são }\end{array}$ & $\begin{array}{l}\text { A EaD apresenta várias } \\
\text { vantagens, entre as quais } \\
\text { destacamos: } \\
\text { a) Flexibilidade: } \\
\text { - Amplia as possibilidades de } \\
\text { escolha de local e horário de } \\
\text { estudo. } \\
\text { - Permite maior adaptação ao } \\
\text { ritmo de aprendizagem do } \\
\text { participante. } \\
\text { b) Desenvolvimento de }\end{array}$ & $\begin{array}{l}\text { Não declarada no projeto. } \\
\text { No texto de apresentação do } \\
\text { Coordenador ele cita } \\
\text { (SARTORI, ROESLER, } \\
\text { 2005, p. 64) para justificar o } \\
\text { MDM (Material Didático } \\
\text { Mediacional). No Claretiano, } \\
\text { o MDM não funciona como } \\
\text { mero apoio didático, mas } \\
\text { sim como instrumento } \\
\text { necessário para que a }\end{array}$ & $\begin{array}{l}\text { - avaliação continuada } \\
\text { (atividades e interatividades) } \\
\text { A participação nas } \\
\text { interatividades e a realização } \\
\text { das atividades são } \\
\text { fundamentais para a } \\
\text { integração e interação, pois } \\
\text { melhoram os resultados da } \\
\text { aprendizagem e compõem a } \\
\text { avaliação. }\end{array}$ & $\begin{array}{l}\text { Um professor reflexivo- } \\
\text { investigador, comprometido } \\
\text { com a área da Educação e } \\
\text { com a ética democrática, } \\
\text { trabalhando para a promoção } \\
\text { da dignidade humana, da } \\
\text { justiça, do respeito mútuo, da } \\
\text { participação, da } \\
\text { responsabilidade, do diálogo e } \\
\text { da solidariedade, atuando } \\
\text { como profissional e como }\end{array}$ \\
\hline
\end{tabular}


estabelecidos os seguintes princípios básicos:

a) Buscar a verdade e pesquisar o conhecimento. b) Ampliar as oportunidades de acesso a Educação de qualidade.

c) Difundir a cultura e o saber técnico-científico.

d) Educar para a liberdade responsável, para os valores cristãos e para o exercício da cidadania.

e) Capacitar para o exercício profissional e o serviço ao próximo.

f) Valorizar o conhecimento que transforma a realidade (aprender a fazer); que promove a integração humana (aprender a conviver); que dá sentido pleno a vida (aprender a ser); e que abre o entendimento para a busca do novo (aprender a aprender).

\section{competências:}

- Promove a autonomia de aprendizagem e organização do trabalho intelectual.

c) Incentivo à pesquisa:

- Favorece a troca de

informações e de experiências com os melhores profissionais da área e com os demais participantes.

d) Amplitude:

- Possibilita atender a um

grande número de pessoas, situadas em diferentes

localidades, simultaneamente, sem frequentes

deslocamentos de casa ou

trabalho.

- Atende a necessidades

específicas.

- Possibilita a personalização de cursos, de acordo com a

necessidade da organização, com rapidez e qualidade.

Esta é uma modalidade que permite a aprendizagem, individual e em grupo, com a mediação de recursos didáticos organizados, veiculados em diferentes tecnologias de informação e comunicação, com apoio de um Sistema Gerenciador de Aprendizagem - SGA. aprendizagem a distância aconteça efetivamente e de maneira cooperativa.

Juntamente com a tutoria e com o SGA-SAV e apoiado por uma secretaria ágil $e$ eficiente, o MDM constitui o elemento fundamental da

Educação a Distância, a

partir do qual se constrói o conhecimento de forma

cooperativa e colaborativa, desde que elaborado com a consciência de que o texto instrucional, ao expor seu conteúdo, não cale a palavra do aluno, mas inaugure "um espaço de interlocução no qual o saber discente

possibilita a renovação do próprio texto, a construção do conhecimento e o aprofundamento da

experiência. Ele adquire

sabedoria e não há nada que um estudante queira mais do que o conselho de um professor amigo".

Cita Herbert Read (1943, p.

6) "Todo processo de

conhecimento é

aprendizagens humanos

acontece sobre dois fatores: as vivências (o que é

sentido) e as simbolizações (o que é pensado)" para justificar a afirmação "Ensino da Arte não apenas como

uma linguagem, mas

também como uma

Educação para os sentidos". Cita Albert Einstein (s.d.) "a

imaginação é mais
[...] A participação nas interatividades e a realização das atividades são

fundamentais para a

integração e interação, pois melhoram os resultados da aprendizagem e compõem a avaliação (p. 08). cidadão, conhecedor de suas realidades econômica,

cultural, política e social para atuar como agente

transformador do contexto em que está inserida a prática educativa; orientador e

mediador de um processo

Ensino-aprendizagem

democrático, que lide de

forma justa com a diversidade existente entre seus alunos,

envolvido com a escola e com a comunidade (cidadania). Um docente que saiba planejar, organizar, implementar e desenvolver a práxis pedagógica, bom como projetos e experiências educativas, utilizando-se das tecnologias de informação e comunicação e também das estratégias como suportes educacionais para que torne 0 conhecimento acessível aos educandos. Em educador que saiba avaliar, criticamente, sua própria atuação e o contexto em que atua, que saiba desencadear um trabalho em equipe e que seja atualizado e autônomo para buscar o aprimoramento de sua formação continuada. 


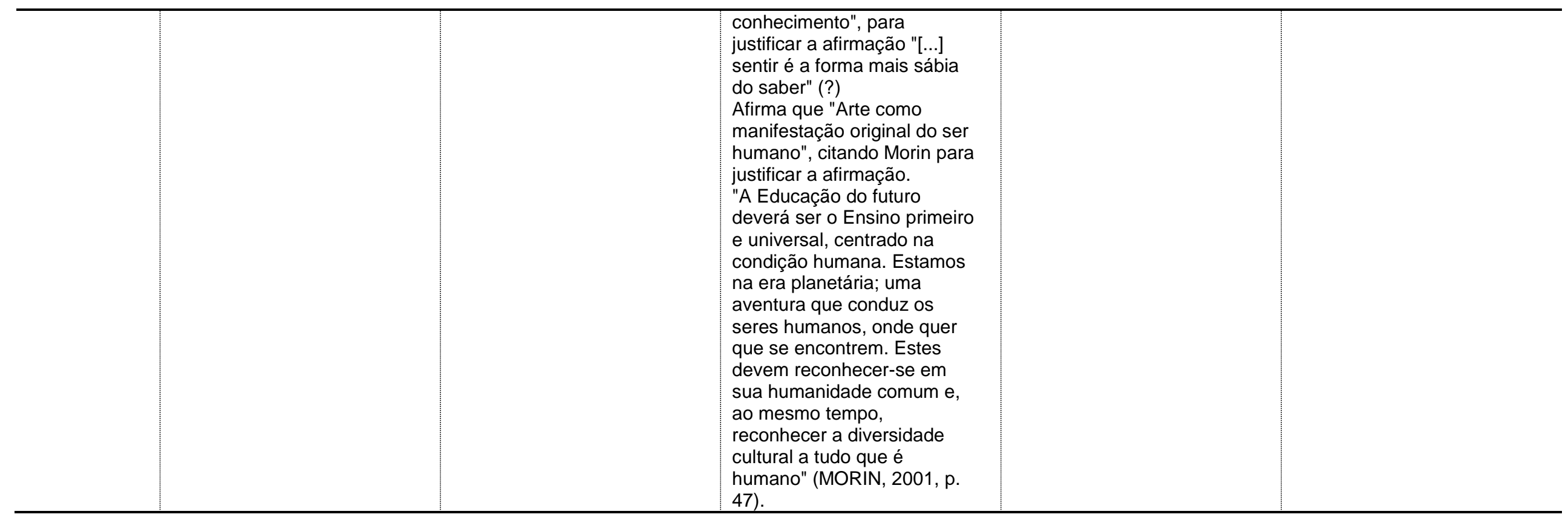




\title{
3.7 Pesquisa de Campo: Entrevistas
}

Como parte da pesquisa, foi desenvolvido um questionário, aplicado de forma online, com suporte do sistema de pesquisas gratuito do Google Docs, onde foram questionados alunos e professores de cursos de Licenciatura em Artes Visuais por EaD sobre suas experiências.

Essa pesquisa de campo visou subsidiar as reflexões acerca do que vem sendo feito nos atuais programas de Ensino, e teve a seguinte estrutura de percursos, de acordo com cada perfil ${ }^{125}$. As bases de estruturação das questões dessa pesquisa foram os pressupostos de Sims (1997, apud MATTAR, 2012, p. 30-31).

\begin{abstract}
Estilos de aprendizagem: implementar estratégia e recursos que possibilitem a aplicação de diferentes preferências de aprendizagem por parte do aprendiz;

Completar o curso: apenas se determinadas atividades forem realizadas corretamente pelo usuário. Os conteúdos não precisam ser idênticos, ou seja, o curso pode ter uma diversidade de caminhos pelos quais 0 aprendiz possa navegar. Sims propõem um design construído com uma sequência baseada em narrativa, de maneira que a finalização seja em si mesma uma indicação de sucesso e maestria. Avaliações estão assim incorporadas à narrativa e às atividades do curso;

Atividade cognitiva: que mantenha o usuário ativamente engajado, o que pode incluir testes de hipóteses, construções de soluções, ajustes de variáveis e introdução ou modificação de conteúdos no ambiente. Uma estratégia útil para rever aplicações interativas com essa métrica seria, a cada display, perguntar: "o que o aprendiz está fazendo aqui?".

Papéis: os usuários podem ser encarados como atores imersos num ambiente, trabalhando e com um script e que podem ensaiar, improvisar com os colegas e trocar de papel a qualquer momento, inclusive com professores e designers;

Efeitos Audiovisuais: avaliados em relação à sua função em cada momento do curso, de maneira que auxilie (e não prejudique) o envolvimento do aluno com a narrativa;

Feedback: adequado e individualizado, como atividades de auto avaliação críticas e reflexivas;

Design para o aprendizado: integrando todos esses elementos com o conteúdo, a interface e a estratégia do curso (SIMS 1997, apud MATTAR, 2012, p. 30-31).
\end{abstract}

O instrumento foi construído de forma a proporcionar diferentes percursos, de acordo com o perfil do(a) entrevistado(a).

\footnotetext{
${ }^{125}$ Uma cópia do questionário se encontra nos anexos desta pesquisa.
} 


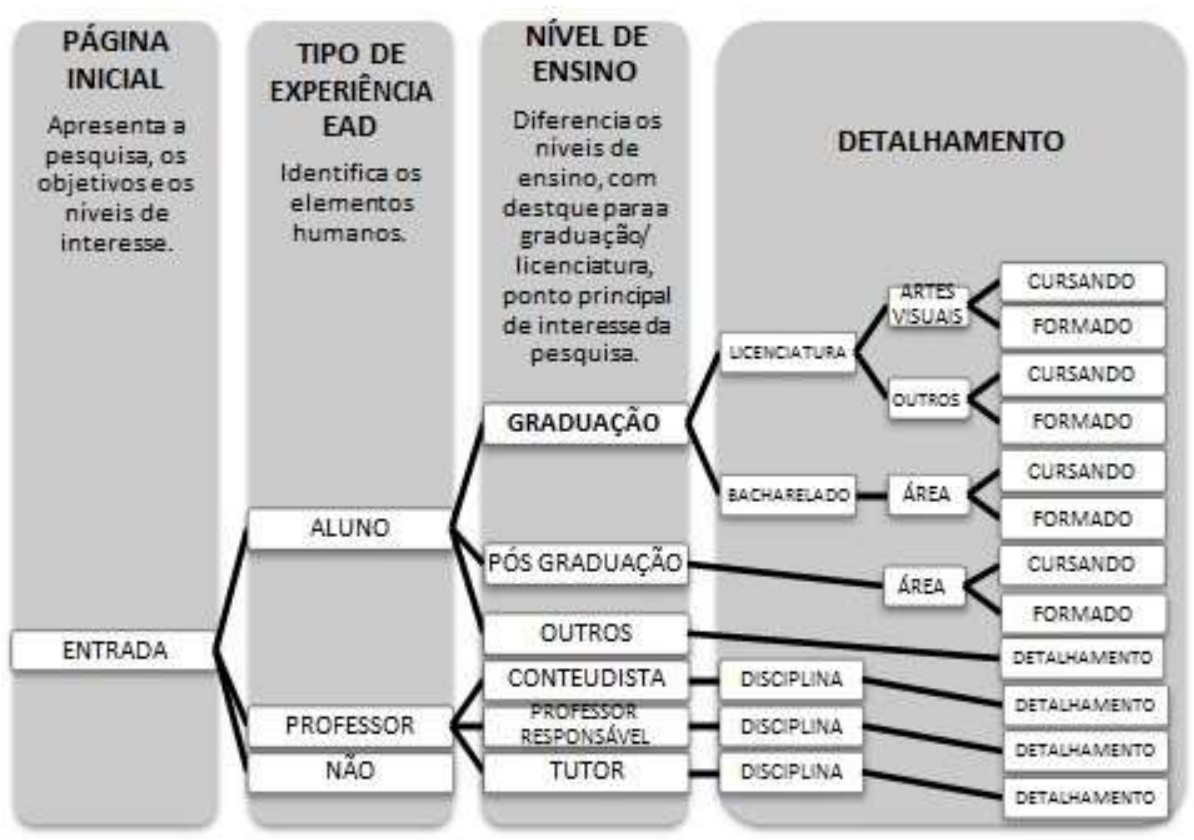

Figura 50 - Estrutura do questionário da pesquisa de campo.

Os resultados obtidos nas entrevistas feitas com o questionário web são, então, são apresentados e avaliados dentro desses perfis pré-definidos da pesquisa: aluno e professor.

O questionário, na versão definitiva, esteve disponível na internet para as entrevistas entre 23 de novembro de 2013 e 08 de janeiro de 2014. Foi feito um teste anterior (cujos resultados não estão contabilizados nessa pesquisa) de janeiro a junho de 2013, esse teste serviu para ajustar as questões do instrumento.

Foram convidados a participar da pesquisa, primordialmente, alunos de graduação de licenciaturas por $\mathrm{EaD}$ em Artes Visuais, por meio de mensagem enviada por e-mail aos coordenadores de cursos, pedindo que repassassem 0 convite a os alunos.

Também foram feitos convites abertos, nos grupos temáticos da área de Ensino de Arte: Comunidade Yahoo da Federação dos Arte Educadores do Brasil - 
FAEB; Comunidade Yahoo e Facebook da Revista Digital Art\&. Esses convites geraram participação espontânea de colaboradores.

O texto/convite enviado por e-mail pode ser visto no quadro abaixo.

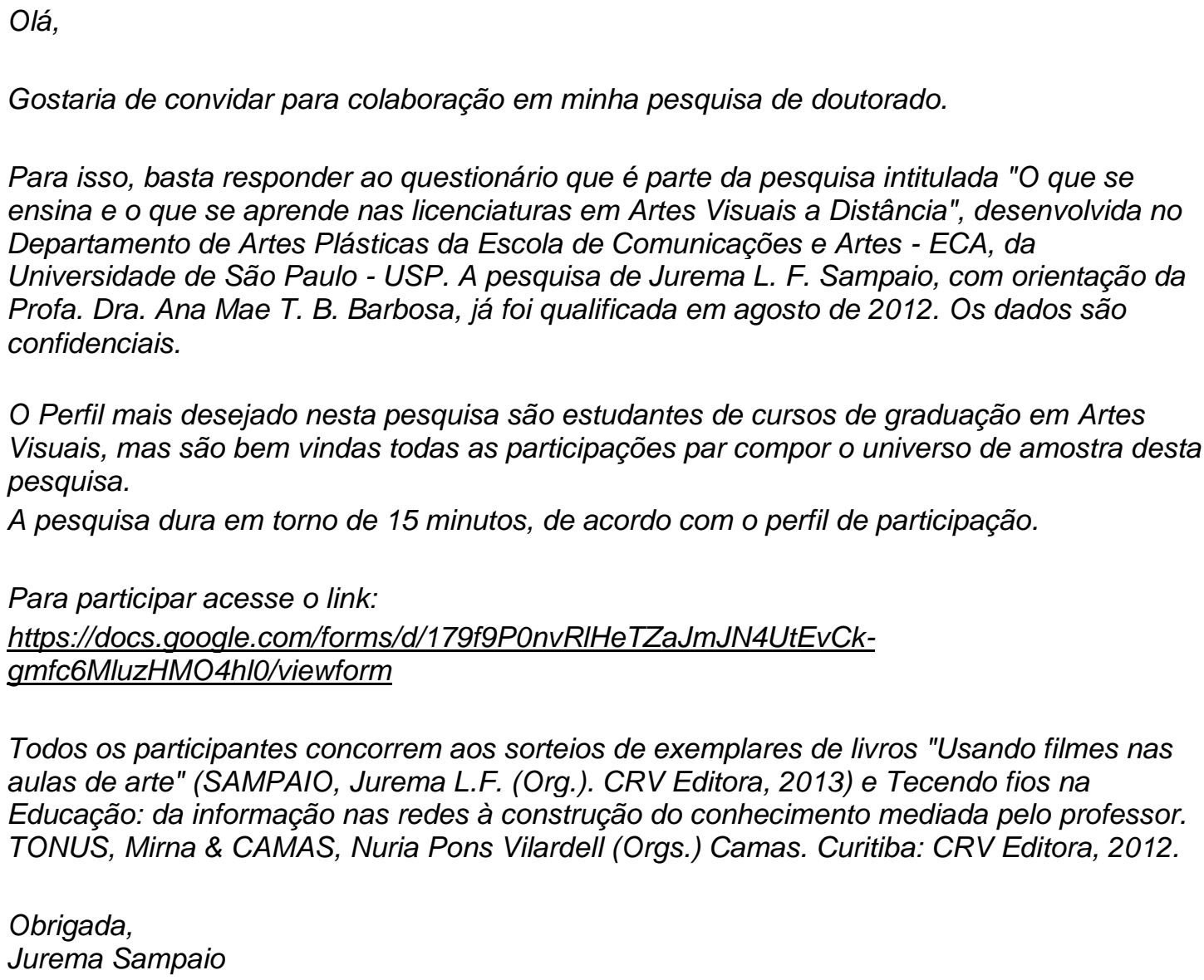

Todos os participantes concorrem aos sorteios de exemplares de livros "Usando filmes nas aulas de arte" (SAMPAIO, Jurema L.F. (Org.). CRV Editora, 2013) e Tecendo fios na Educação: da informação nas redes à construção do conhecimento mediada pelo professor. TONUS, Mirna \& CAMAS, Nuria Pons Vilardell (Orgs.) Camas. Curitiba: CRV Editora, 2012.

Obrigada,

Jurema Sampaio

Figura 51 - Texto da mensagem/convite para responder ao questionário

Responderam positivamente aos convites 94 pessoas.

Essas pessoas responderam a totalidades de questões apresentadas de acordo com seu perfil. Respostas e participações parciais foram descartadas dessa análise. Acredito que o número de participantes é bastante expressivo, se considerado que o questionário é composto de mais de cem perguntas (no perfil mais longo, de aluno de graduação em Artes Visuais), o que demandou tempo e dedicação, por parte do entrevistado para terminar de responder. 
Como estímulo e agradecimento pela participação, os participantes que concluíram a pesquisa, respondendo todas as questões, passaram a concorrer ao sorteio de dois livros, como esclarece o convite. O sorteio será feito após a defesa da tese.

Das 94 pessoas que participaram da pesquisa, 07 relataram nunca ter tido experiências com EaD, 12 relataram experiências como professor/tutor (um como professor responsável, um como conteudista e tutor e 10 como tutor somente) em EaD e 74 relataram experiências como aluno em EaD. É esse grupo o de interesse central desta pesquisa.

Dos participantes que relataram experiências como aluno, temos:

- 01 alunos de curso livre

- 01 aluno de complementação pedagógica

- 01 aluno de curso de arte e novas tecnologias

- 01 aluno de curso de línguas

- 01 aluno de curso de extensão

- 15 alunos de pós-graduação (sem experiência em graduação)

- 54 alunos de graduação (três declararam ter feito graduação e pósgraduação por EaD, porém, foram contados em graduação, pois disseram que, como primeira experiência, foi a graduação, embora não tenham declarado qual curso fizeram), 25 atualmente cursando licenciatura por EaD em Artes Visuais; 23 formados em licenciaturas por EaD em Artes Visuais; um participante declarou como curso, pedagogia, mas não informou se já está formado, ou ainda cursando).

Nossa amostra de análise, portanto, se configura em um universo de 74 participantes, sendo 48 alunos e ex-alunos de licenciaturas por EaD em Artes Visuais: 25 cursando $^{126}$ e 23 formados $^{127}$.

${ }^{126}$ Nas instituições UFRPE, UFRGS, UFG, UNIMES, UFG, UERGS e Centro Universitário Claretiano.

${ }^{127}$ Pelas instituições UFRGS, UNIMES, UFG, UERGS, Centro Universitário Claretiano. 
Após preencherem questões pessoais, como nome e perfil pessoal foi perguntado para todos os participantes como foi sua primeira experiência com EaD. De todos os participantes, $81 \%$ teve seu primeiro contato com EaD na condição de Aluno, $12 \%$ como professor/tutor e 7 \% relataram outras formas de contato, como conteudista, professor responsável etc.

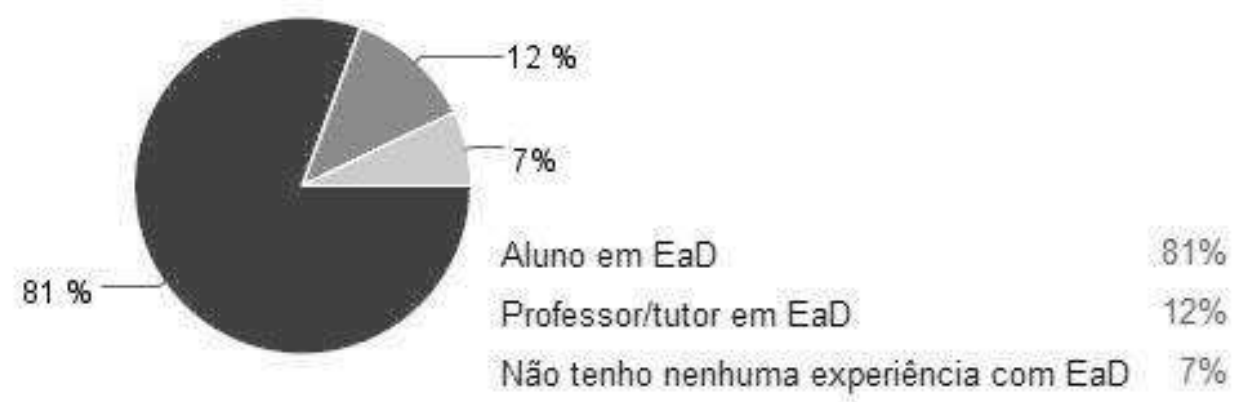

Figura 52 - Em relação à PRIMEIRA experiência com Educação a Distância

Aos que responderam que seu primeiro contato com EaD foi como aluno, foi perguntado em que nível de formação foi esse contato. A graduação foi a primeira opção de $71 \%$ dos entrevistados, seguida da pós-graduação, com $18 \%$ das opções. Outros formatos de cursos, como extensão, livre etc. foram relatados por $11 \%$ dos entrevistados.

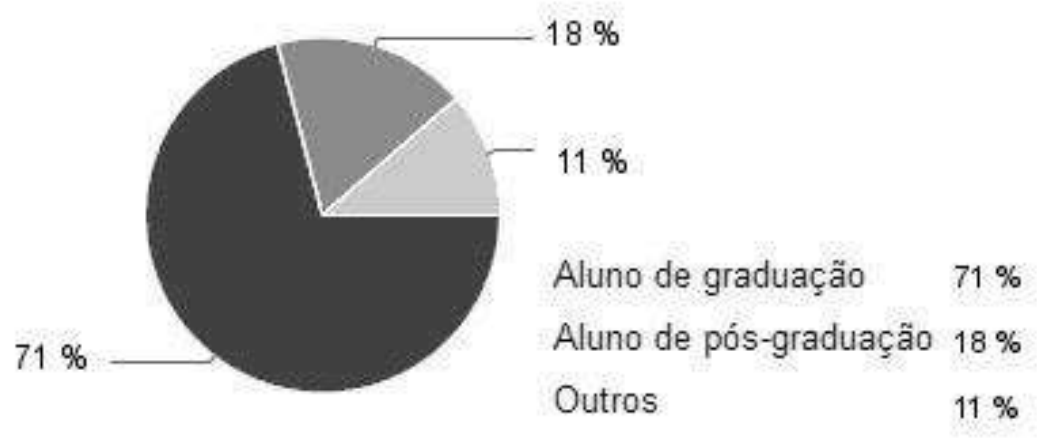

Figura 53 - Alunos em EaD, primeira experiência

Aos que responderam que o primeiro contato com EaD foi como professor, foi perguntado como aconteceu essa experiência. 
O percentual foi igual, $8 \%$, para as funções conteudista, professor responsável e a soma de todos os outros tipos relatados (opção "outros" do formulário de entrevista, em que os entrevistados escreviam o que desejassem). A imensa maioria $(75 \%)$ dos que tiveram a primeira experiência em EaD como professores atuou como tutor em cursos.

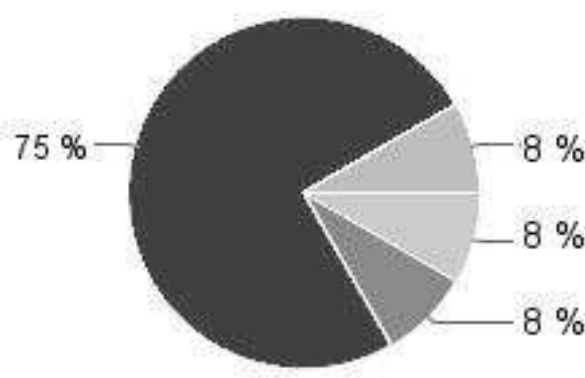

Conteudista

Professor responsável $8 \%$

Tutor

Outros
$8 \%$

$75 \%$

$8 \%$

Figura 54 - Primeira experiência com EaD como professor/tutor.

No campo de comentários, livre e opcional, alguns escritos chamam a atenção:

- O meu contato com a tutoria, com o AVA, me fez mudar o meu objeto de estudo para o Doutorado que iria iniciar.

- Com o desafio de trabalhar com a disciplina tridimensional a distancia uma vez que ensinar a disciplina no presencial já nos traz um desafio para desmistificar a questão do "dom divino" do saber fazer escultura nos diversos materiais.

- Na estrutura de oferta de nosso curso, o professor responsável foi também o conteudista, e o mediador em todo a estrutura de oferta.

- A minha experiência na $E a D$, além de tutora a Distância foi também como professora conteudista e professora formadora ou responsável. Experiência muito boa e significativa, conhecendo, aprendi a gostar e respeitar esta modalidade de Ensino.

- A primeira experiência obviamente carregada de novidades, pairava a desconfiança de que esse modelo de Ensino a Distância não vingaria.

- Veio à tona a metáfora da aranha "que fica à espera" do aluno se manifestar na plataforma do curso/disciplina e fazer suas obrigações.

- O calendário, com seus prazos determinados, era e ainda é um dos principais cuidados e alerta para que, tanto professor quanto aluno mantenham-se obedientes com os prazos. Pois a "máquina" está programada para essa obediência.

- Outro aspecto importante e trabalhoso é a forma de diálogos, sobretudo para o professor que, com esse modelo de Educação, passa a atender cada aluno de forma exclusiva, personalizada, individual. ${ }^{128}$

${ }^{128}$ Comentários pinçados das entrevistas com professores tutores que participaram da pesquisa, grifo nosso. 
A experiência de cada relato traz uma gama de questões. Uns relatam experiências positivas, outros, bem negativas. Estas, selecionadas, chamaram a atenção pelo inusitado, em especial a "metáfora da aranha", que é de um reducionismo em relação à função do tutor, que reforça a ideia combatida por Mattar (2012, p. xxxi-xix), do tutor com um papel passivo, com uma subfunção, quase dispensável.

Aos professores que informaram ter desenvolvido material para cursos EaD foi perguntado que tipo de recursos usou no material desenvolvido por ele(a). Vídeo aulas, apostilas, textos e indicação de sites foram os únicos recursos usados pelos conteudistas em materiais desenvolvidos. Quando questionados sobre os motivos dessas escolhas, não houve respostas, mesmo havendo espaço/campo para comentários, nenhum dos conteudistas comentou nada sobre suas escolhas. Assim, não é possível saber se seguiam alguma metodologia institucional de trabalho, ou se a escolha foi deles próprios. É importante comentar que, quando desenvolvi material para uma IES, as orientações eram bastante restritivas quanto aos recursos possíveis. No primeiro retorno que tive dos avaliadores, atividades que eu havia proposto, como palavras cruzadas, jogos etc. foram todas cortadas, pedindo que eu me restringisse ao "modelo" de dois fóruns, duas atividades para serem feitas fora da web, mais prova presencial, restringindo o conteúdo ao chamado "caderno de conteúdos", uma apostila a ser enviada aos alunos, gravada num CD ROM. 


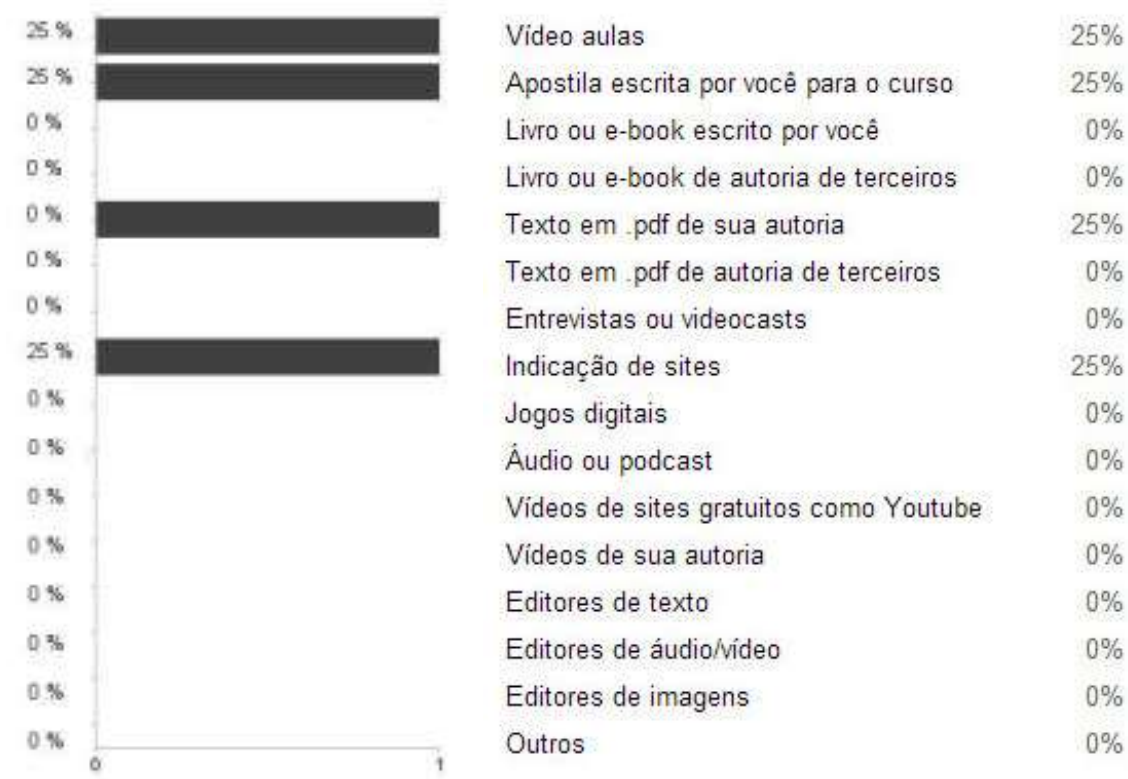

Figura 55- Recursos usados no(s) material(is) da(s) disciplina(s) desenvolvida(s) por conteudistas

Pode ter sido o caso de esses professores terem recebido orientações rígidas de desenvolvimento de conteúdos e, assim, não terem tido liberdade de escolha de recursos, mas é importante o registro, pois, ao serem questionados sobre as características do curso que haviam feito ou estava fazendo, os alunos e exalunos de licenciaturas em Artes Visuais entrevistados disseram que o material dos cursos era predominantemente composto de textos. Dos alunos e ex-alunos de licenciaturas em Artes Visuais entrevistados 78\% afirma a predominância do texto como recursos, seguido de $6 \%$ para filmes e vídeos, $3 \%$ para imagens e nenhum recursos de áudio foi informado. Os demais recursos da lista apresentada $^{129}$ somaram, juntos, $13 \%$ das percepções dos alunos.

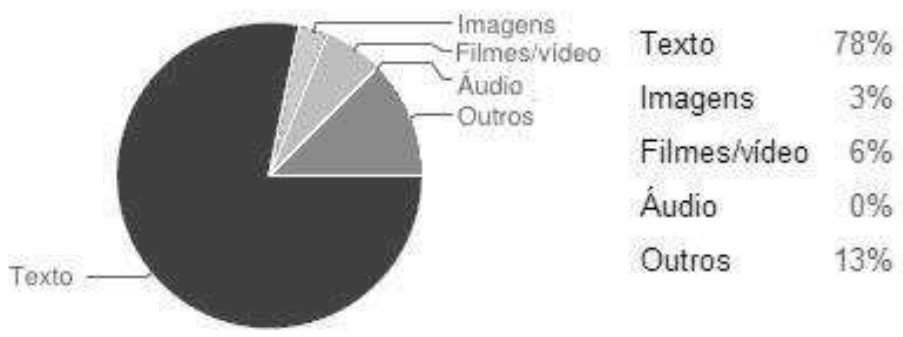

Figura 56 - Declaração dos alunos sobre formato/recursos dos conteúdos do cursos que fizeram ou fazem.

\footnotetext{
${ }^{129}$ Nos anexos podem ser vistas todas as questões apresentadas na pesquisa.
} 
Sobre os cursos de Licenciatura em Artes Visuais por EaD, os participantes das entrevistas declararam que $50 \%$ foram ou são alunos de programas da UAB; $16 \%$ do Pró-licenciatura; $20 \%$ de Programas Próprios de instituições particulares de Ensino e $14 \%$ de outros programas.

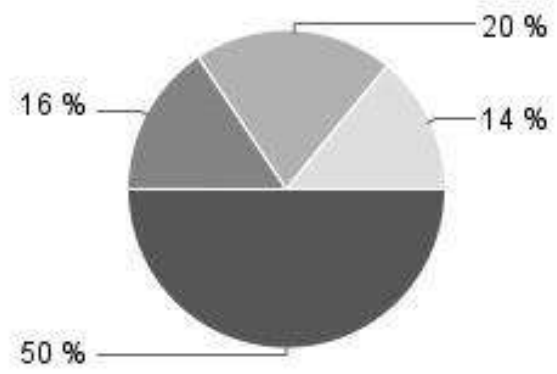

Figura 57 - Cursos de Licenciatura em Artes Visuais por EaD

Sobre os recursos usados no curso, os alunos declararam:

\section{Vídeo aulas gravadas}

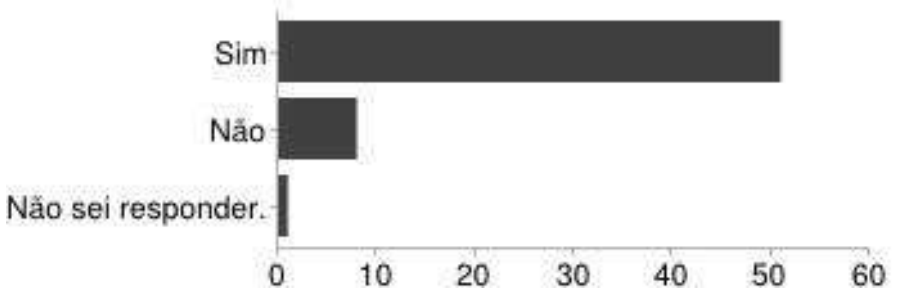

$\begin{array}{lrr}\text { Sim } & 51 & 85 \% \\ \text { Não } & 8 & 13 \% \\ \text { Não sei responder. } & 1 & 2 \%\end{array}$

\section{Vídeo aulas ao vivo}

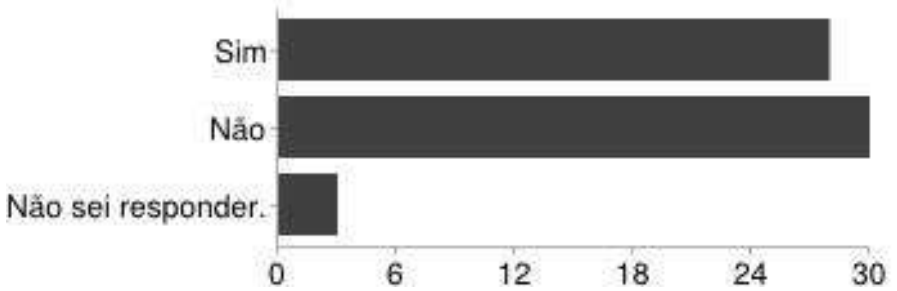

$\begin{array}{lrr}\text { Sim } & 28 & 46 \% \\ \text { Não } & 30 & 49 \% \\ \text { Não sei responder. } & 3 & 5 \%\end{array}$


Apostila escrita para o curso

Nầo sei responder.

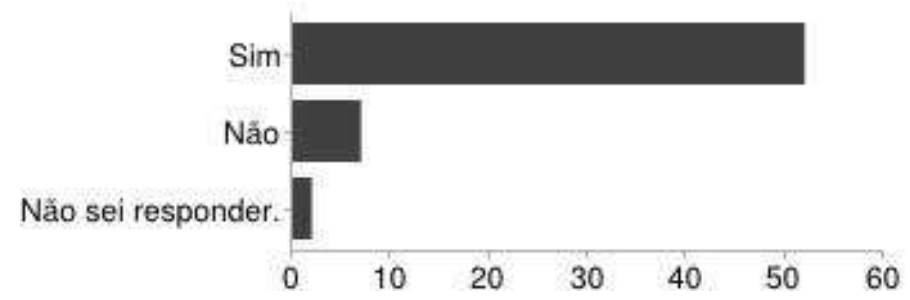

$\begin{array}{lrr}\text { Sim } & 52 & 85 \% \\ \text { Não } & 7 & 11 \% \\ \text { Não sei responder. } & 2 & 3 \%\end{array}$

Textos em .pdf escritos para o curso
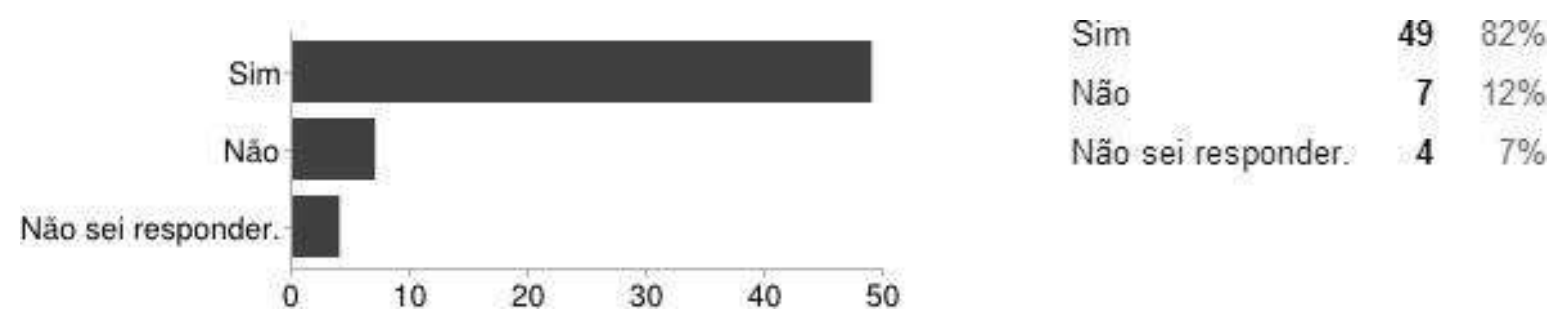

Textos em .pdf retirados da Internet
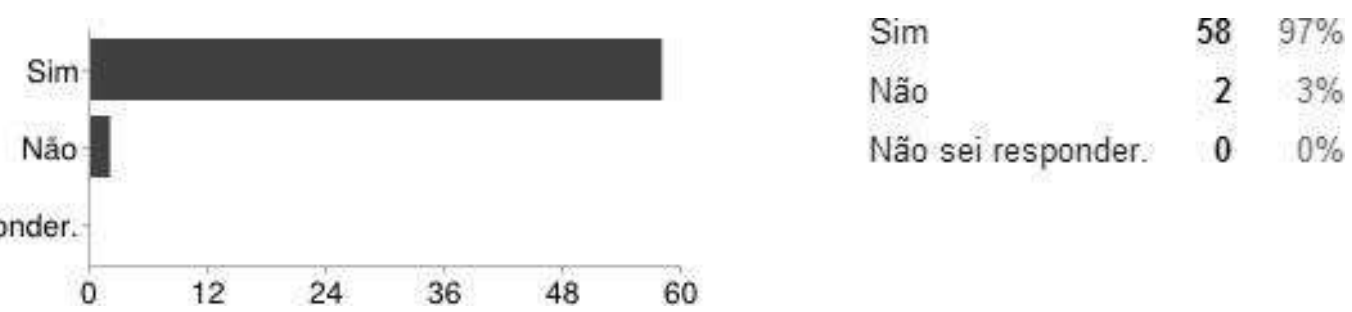

Nầo sei responder

$\begin{array}{llllll}0 & 12 & 24 & 36 & 48 & 60\end{array}$

Vídeos de sites gratuitos como YouTube (ou similar).
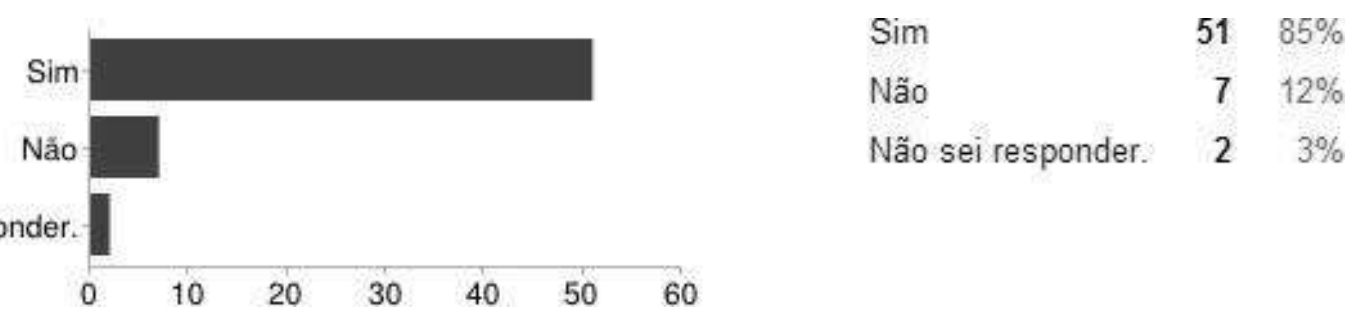

Nằo sei responder

Vídeos feitos para o curso pela instituição (documentários, edições de filmes, animações etc.)

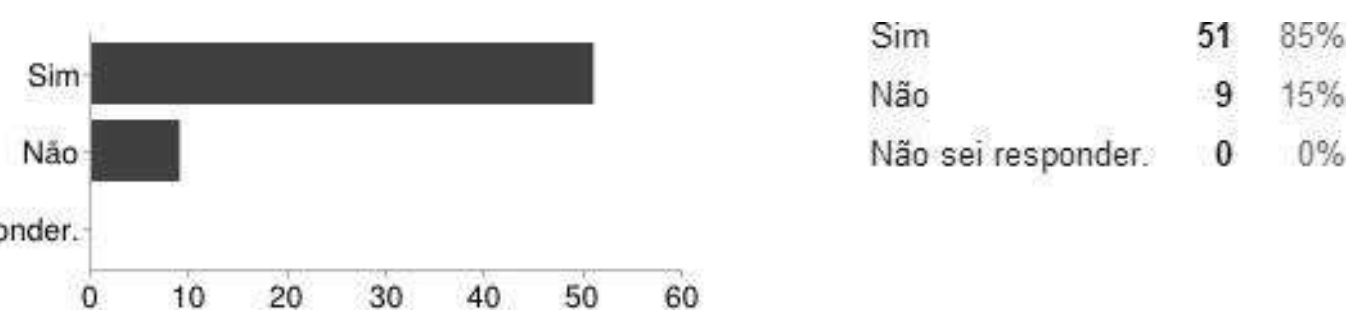


Atividades dentro do ambiente do curso com autocorreção.

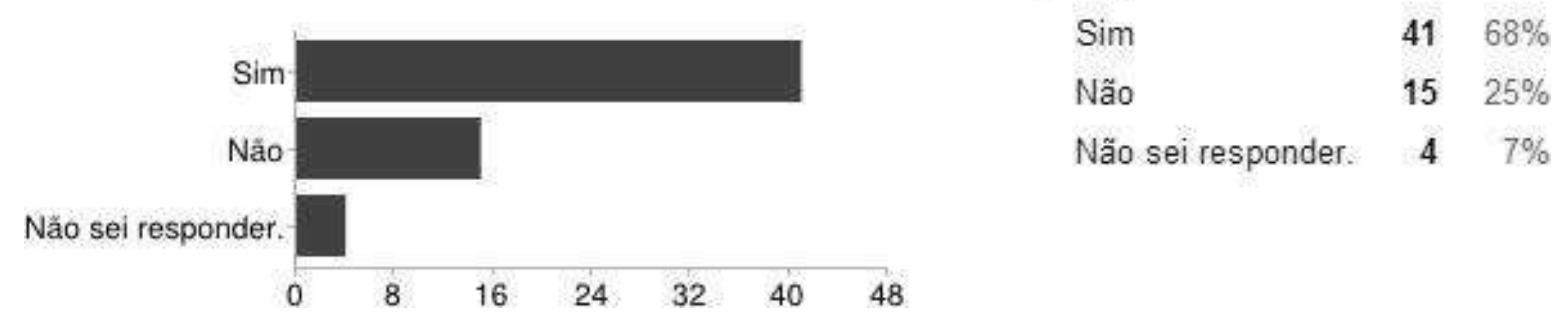

Atividades dentro do ambiente do curso com correção pelo professor/tutor.

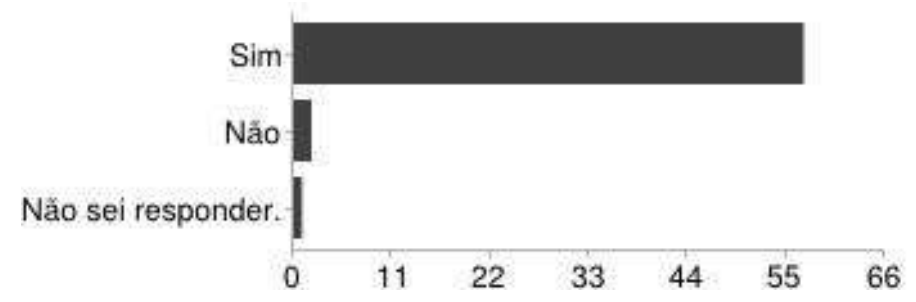

$\begin{array}{lrr}\text { Sim } & 57 & 95 \% \\ \text { Não } & 2 & 3 \% \\ \text { Não sei responder. } & 1 & 2 \%\end{array}$

Jogos digitais.
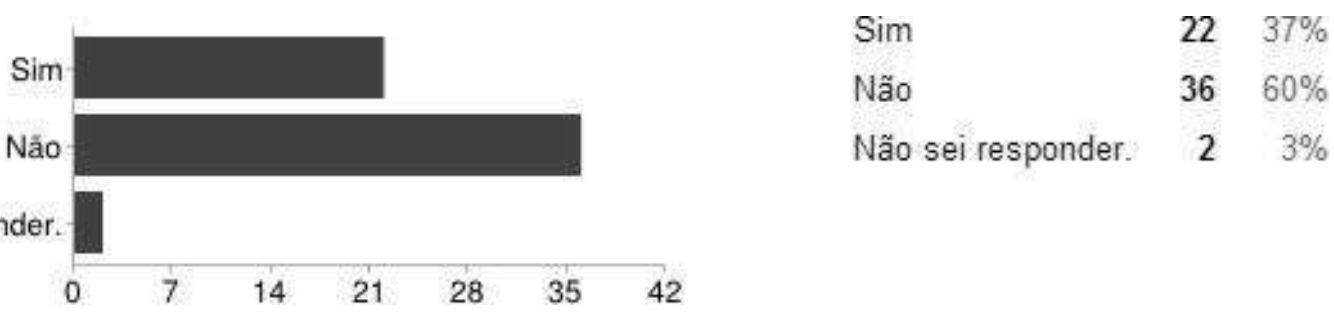

Năo sei responder

\section{Redes Sociais.}

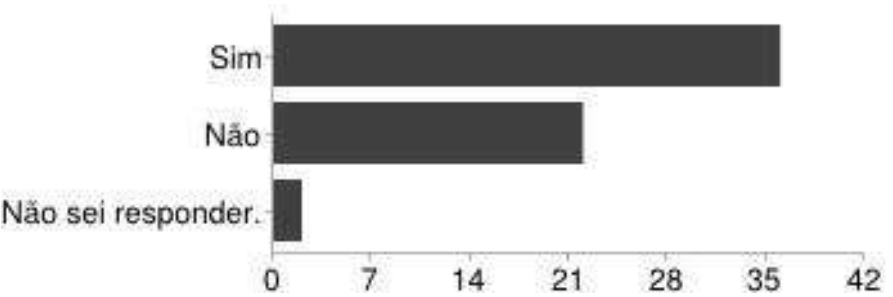

$\begin{array}{lrr}\text { Sim } & 36 & 60 \% \\ \text { Não } & 22 & 37 \% \\ \text { Não sei responder. } & 2 & 3 \%\end{array}$

Atividades de pesquisa.

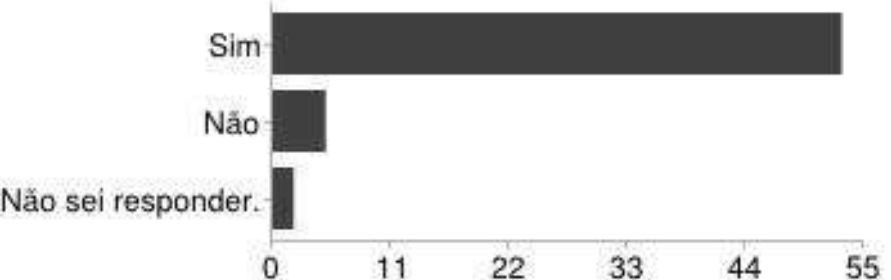

$\begin{array}{lrr}\text { Sim } & 53 & 88 \% \\ \text { Não } & 5 & 8 \% \\ \text { Não sei responder. } & 2 & 3 \%\end{array}$


Atendimento presencial.
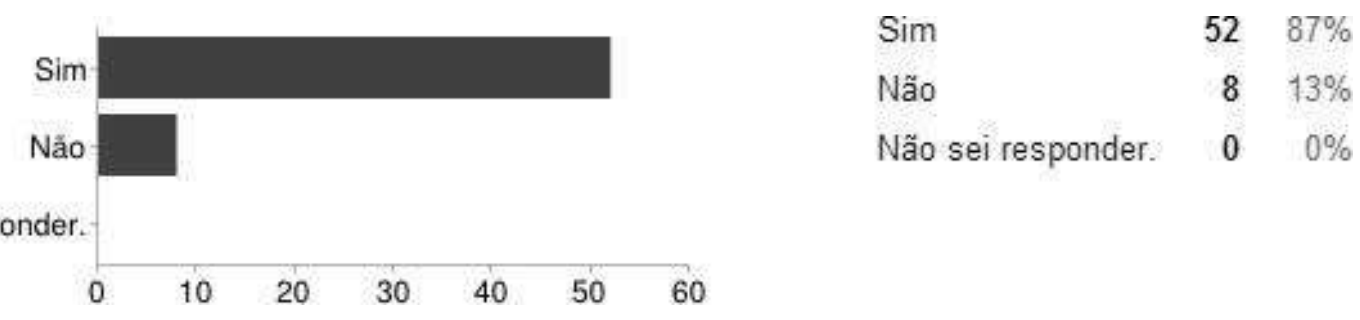

Nằo sei responder

\section{Atendimento online 24 horas}

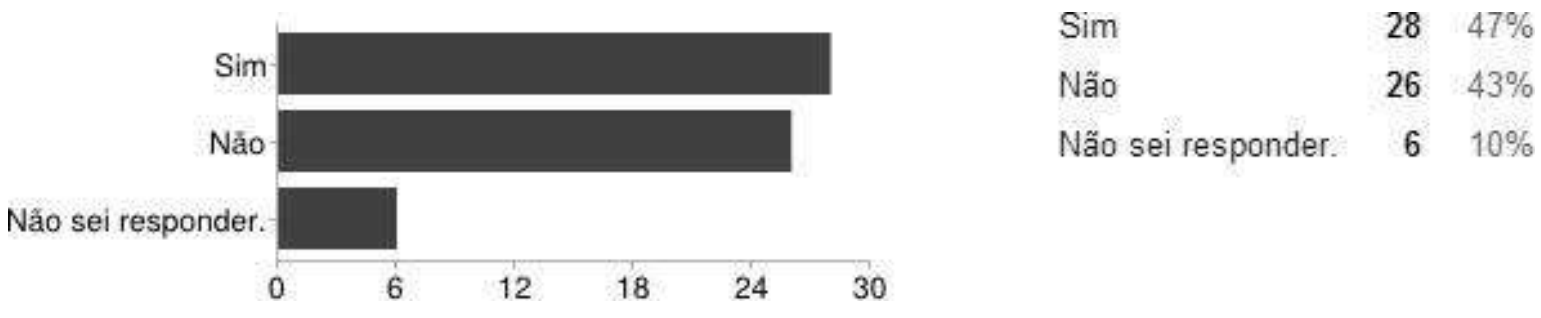

No campo destinado à complementação, foi pedido aos alunos que relatassem recursos usados no curso que não constavam na lista de opções. Foram relatados, pontualmente, o uso de Chat, telefone, algo chamado de 'livro das disciplinas', que não foi esclarecido o que era; softwares como o CMap Tools e editores de imagens (não relatou como foi o uso), imagens e textos simultaneamente, biblioteca online, fóruns, visitas a museus, visitas (passeio) virtual, atividades tendo como suporte serviços oferecidos de sites gratuitos como nuvem de tags, pintura interativa em 2D, CD com recursos auxiliares cedidos pelos professores como autoajuda, secretaria online, web conferência e podcats, seminários e encontros regionais e nacionais, cursos de extensão, ambiente de aprendizagem TelEduc, pesquisa de campo e aulas presenciais com recursos diversos e testes de questões de múltipla escolha.

Curioso notar como não é feita a diferenciação do que é recurso virtual e não virtual, nem a diferença entre recurso e estratégia. Mais ainda, a classificação de 'curso de extensão' como recurso. É desanimador encontrar dados como os que mostram que $68 \%$ dos participantes desta pesquisa declararam realizar atividades com autocorreção nos ambientes digitais. Atividades que, em geral, se realizam por imposição de um modelo anacrônico, ligado diretamente a uma concepção de 
transmissão e reprodução de conteúdos; que menospreza as possibilidades das tecnologias para o empoderamento das pessoas e a produção do conhecimento.

Em seguida, foi perguntado qual o recurso predominante usado no curso. $O$ resultado foi que $78 \%$ dos entrevistados apontaram o texto como o recuso mais usado no curso, seguido de imagens (3\%), filmes/vídeo (6\%), áudio (0\%) e outros $(13 \%)$.

É interessante notar que nenhum dos entrevistados marcou a opção de áudio como recurso dos mais usados, embora um participante tenha, anteriormente, declarado o uso de podcast no seu curso. Ou o uso foi muito pequeno, ou insignificante, para o participante.

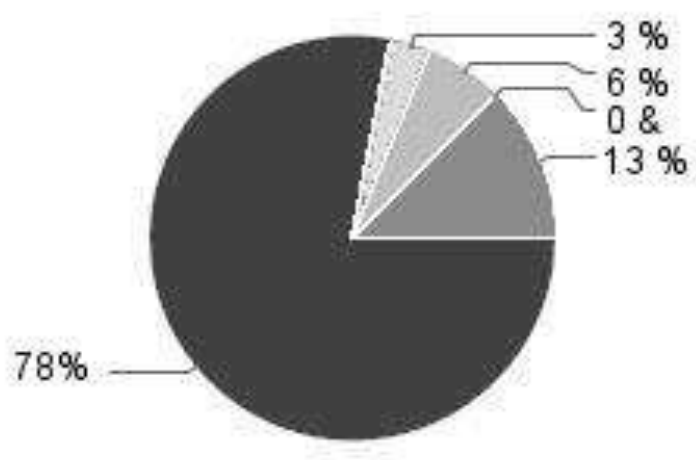

Figura 58 - Predominância de texto em relação aos demais recursos

Com relação ao perfil dos alunos de EaD, é interessante destacar que $50 \%$ deles é, atualmente, aluno de algum curso de Licenciatura em Artes Visuais, assim, sua percepção/experiência é bastante recente e significativa para esta análise.

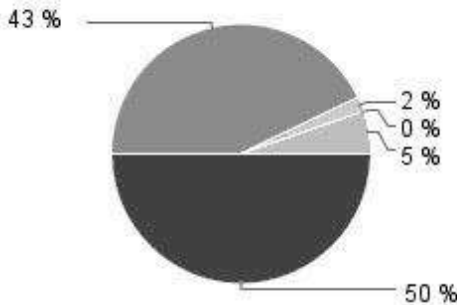

Aluno de licenciatura a distância em artes visuais (cursando)

Aluno ou ex-aluno de licenciatura a distância em outra linguagem artística (teatro, dança ou música) $0 \%$ Outros

Figura 59 - Alunos EaD - Licenciatura em Artes Visuais 
Para $68 \%$ dos entrevistados este foi/é seu primeiro curso superior, contra $32 \%$ que já possuía diploma de outro curso superior.

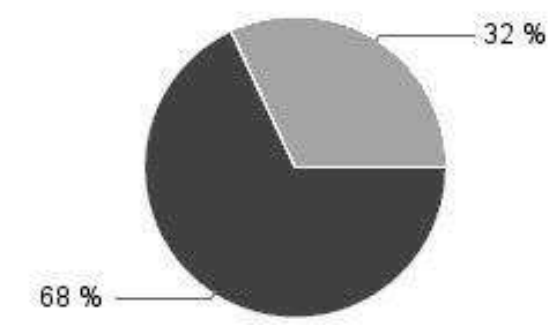

Primeiro curso superior

Já possuia diploma de outro curso superior $32 \%$

Figura 60 - Percentual de alunos que cursa Ensino superior pela primeira vez.

A maioria reside em cidades grandes (mais de 500 mil habitantes, pela classificação do IBGE); é casada ou vive com companheiro(a) (73\%), tem dois filhos em média (34 \%) e não é o principal responsável financeiro de sua família (56\%), contribuindo com até metade dos recursos financeiros da família (47\%).

Os gráficos ilustram mais detalhadamente o perfil.

\section{Estado Civil}

Solteiro(a) - 17\%

Casado(a) ou vivendo com companheiro(a) - 73\%

Separado(a)/Divorciado(a) - 9\%

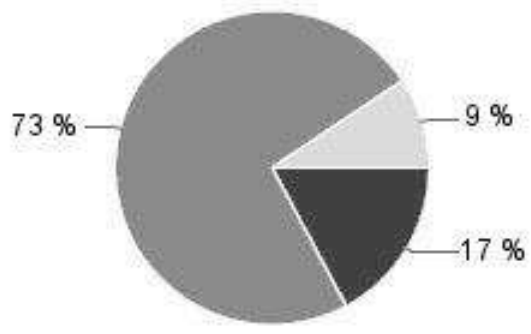

Figura 61 - Estado civil 


\section{Número de Filhos}

Não tenho filhos - 31\%

1 filho $-16 \%$

2 filhos $-34 \%$

3 filhos - $16 \%$

Outros $^{130}-3 \%$

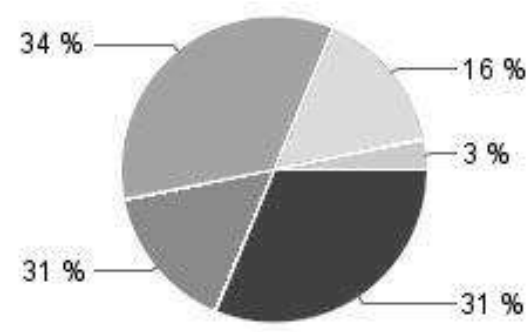

Figura 62 - Número de filhos

Você é o maior responsável pelos recursos financeiros da família?

$\operatorname{Sim}-44 \%$

Não - 56\%

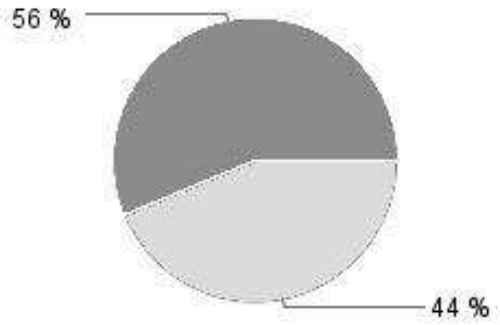

Figura 63 - Principal responsável financeiro pela família

Se NÃO for o maior responsável pelos recursos financeiros da família, qual a sua contribuição?

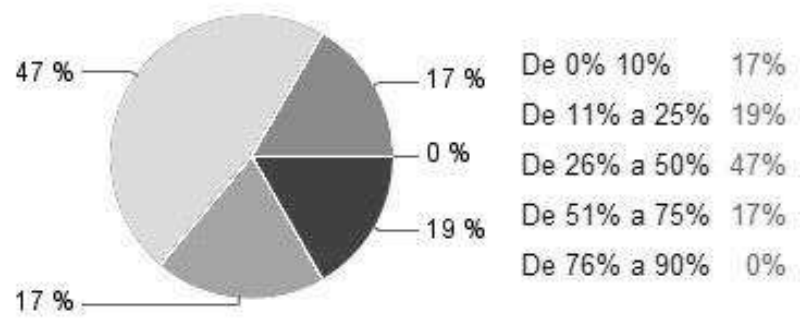

Figura 64 - Percentual de colaboração da renda familiar

${ }^{130}$ Alguns entrevistados declararam ter enteados. 
Em relação aos formados, a data mais antiga de formação declarada, 2007 foi apontada por somente $4 \%$ dos entrevistados, sendo 2009 e 2012 os anos de maior concentração de formados, com $36 \%$ deles em cada uma. Mesmo assim, datas bastante recentes, o que faz com que a opinião deles também seja considerada pertinentes em relação ás práticas que viveram nos cursos.

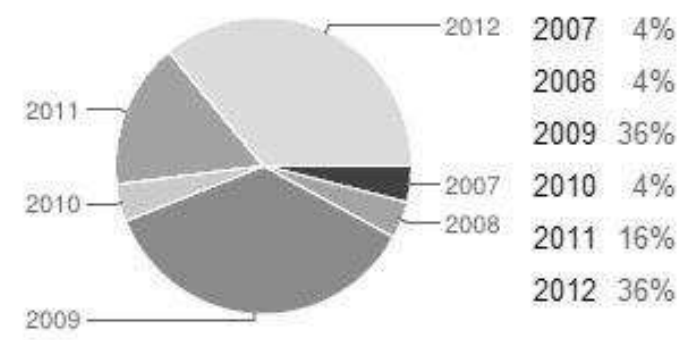

Figura 65 - Datas de formatura e percentuais de formados

Quando questionados sobre os motivos para escolher $\mathrm{EaD}$, e não um curso presencial, as respostas são variadas, mas, a maioria, gira em torno de flexibilidade de tempo, dificuldade de acesso ao curso convencional (seja por não ter a opção na cidade onde a pessoa reside, seja por questões de falta de horário disponível para os deslocamentos necessários). Alguns exemplos de depoimentos:

- Por já possuir uma graduação presencial e querer investir em outra num tempo e espaço mais flexível.

- Eu tenho 53 anos e professora há 29 anos e não tinha graduação.

- Enquanto pedagoga, já atuava como professora de artes em um município próximo, que tinha grande déficit de professores desta área.

- Por já ser professora da rede estadual e trabalhar com Arte e não saber nada a cerca da disciplina, fiquei sabendo que haveria esse curso à distância então realizei as provas e vi-me diante de um desafio maior que esperava.

- Na minha cidade não tinha curso presencial de Artes Visuais. Optei pelo curso a distância, pela flexibilidade dos horários para realizar as atividades.

- Devido o meu pouco tempo disponível é que optei pela $\mathrm{EaD}$, pois nessa modalidade é o aluno quem programa seu tempo a hora e o lugar para estudar.

- Pela oportunidade de estudo e a dificuldade que eu tinha de locomoção até as escolas presenciais.

- Pela flexibilidade do tempo entre trabalho e estudo.

- Porque no momento facilitaria minha vida, em função de trabalhar o dia inteiro e em algumas noites ter outros cursos. 
- Possibilidade de conciliar família $x$ casa $x$ trabalho com facilidade de horário.

- Por não querer e não poder frequentar aulas regulares em outra cidade.

- Optei por um curso em EaD, por se tratar de uma graduação em Artes Visuais, visto que no período que eu residia em Minas Gerais, na cidade de Pouso Alegre não existia uma graduação em Artes Visuais presencial.

- Na região não existia curso de Graduação em Arte.

- Pela dificuldade de deslocamento presencial e pela oportunidade de cursar numa Universidade Federal.

- Pela disposição do tempo em sala de aula.

- Acredito nesta modalidade de Ensino, flexibilidade com relação aos horários (atividades/trabalhos).

- Por atender minhas necessidades/objetivos.

- Eu optei pela EaD, porque moro no interior e foi uma oportunidade de estudar em uma Universidade Federal.

- Flexibilidade nos estudos (horários), valor e confiabilidade na instituição de Ensino.

- Minha opção se deu pelas circunstâncias de ser moradora de uma cidade do interior na qual a unidade universitária existente não oferece cursos na área de artes.

- Porque na minha cidade não tinha o curso que queria fazer.

- Este curso não tem na minha cidade e também por entender que a distância (virtual) é uma ótima oportunidade para se fazer um curso.

- Facilidade de programar o horário de estudos.

- Devido trabalhar muitas horas por dia fica inviável viajar para tão longe para estudar, ou até mesmo ficar muito tempo fora.

É interessante perceber que é claro, para os alunos, que EaD tem características específicas, mas nenhum disse, ou sugeriu, que seja mais fácil que a Educação presencial. A flexibilidade em relação à organização do tempo se mostra a mais evidente razão de opção pela modalidade.

Quando questionados se, com base na experiência vivida, fariam, futuramente, um novo curso por EaD a maioria $(20 \%)$ declara que pretende fazer cursos só por EaD. 


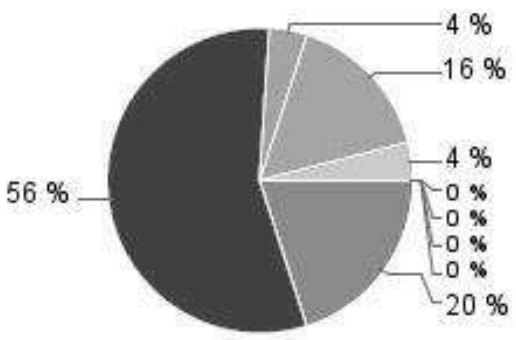

$100 \%$ - Só pretendo fazer cursos a distância.

$80 \%$ a $99 \%$ - Sempre que eu puder escolher, vou preferir cursos à distância.

$60 \%$ a $79 \%$ - Só farei outro curso a distância se não houver outra forma de fazer.

$50 \%$ a $69 \%$-Dependendo do curso, posso optar pela modalidade a distância ou presencial. $16 \%$

$40 \%$ a $59 \%$ - Tanto faz ser presencial ou a distância, o que me interessa é o curso. $\quad 4 \%$

$30 \%$ a $49 \%$ - Minha preferência é por cursos presenciais.

$20 \%$ a $39 \%$ - Não estou certo se voltaria a fazer um curso a distância.

Menos de $10 \%$ - Fortemente inclinado a não fazer nenhum outro curso por $\mathrm{EaD} \quad 0 \%$

1. $0 \%$ - Nunca mais farei um curso a distância.

Figura 66 - Sobre voltar a fazer cursos por EaD

Aos alunos já formados também foram feitas questões específicas sobre a pósformação. Por exemplo, se estão atualmente exercendo a atividade em que se formaram, se demoraram muito tempo entre se formar e se enquadrar na nova função e se a conclusão do curso afetou a vida profissional e, em caso positivo, como isso aconteceu. Nos gráficos podemos acompanhar mais detalhadamente esse perfil de formados e sua trajetória profissional.

Questão: A conclusão do curso afetou sua vida profissional?

Respostas:

Em nada, fiz o curso por gosto pessoal - 5\%

Médio, fiz o curso para progredir na carreira - 10\%

Muito, fiz o curso para me qualificar mais na minha área - 38\%

Bastante, fiz o curso para ser professor - $24 \%$

Totalmente, fiz o curso para mudar de área de trabalho - $24 \%$

Não sei responder - $0 \%$ 


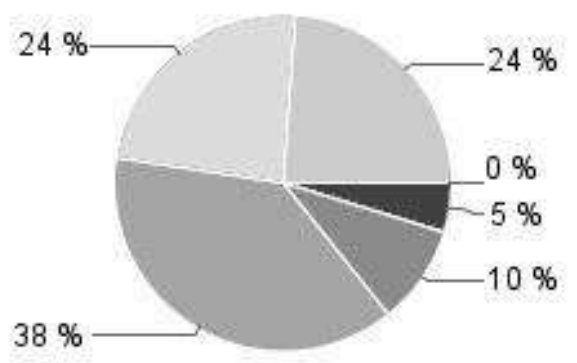

Figura 67 - Conclusão do curso e vida profissional

Questão: Você está exercendo atividade profissional atualmente?

Respostas:

Sim, na área de minha formação acadêmica - 72\%

Sim, fora da área de minha formação acadêmica - 20\%

Não, não trabalho - $8 \%$

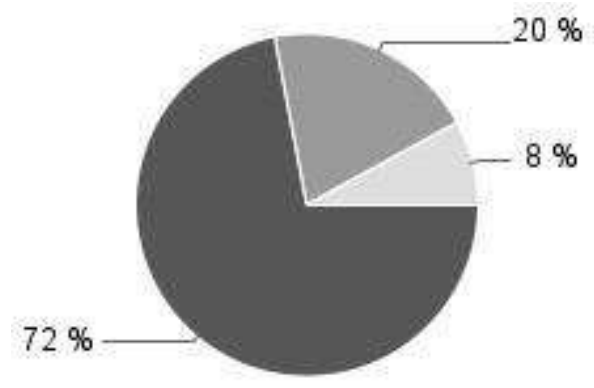

Figura 68 - Percentual de formados que exerce atividade profissional na área de formação

Questão: Caso esteja exercendo atividade profissional fora de sua área de formação, qual o principal motivo?

Respostas:

Mercado de trabalho saturado - $18 \%$

Melhor oportunidade em outra área - 27\%

Motivos particulares - $18 \%$

Outros - $36 \%$ 
Curiosamente a opção 'outros', com espaço para escrever o motivo, apresentou uma maioria significativa de marcações. No entanto, ao declararem o motivo, este era, geralmente, particular, como, por exemplo, "só fiz o curso por gosto pessoal", opção que, quando foi oferecida em relação ao curso ter afetado, ou não, a vida profissional, atingiu o menor índice de respostas.

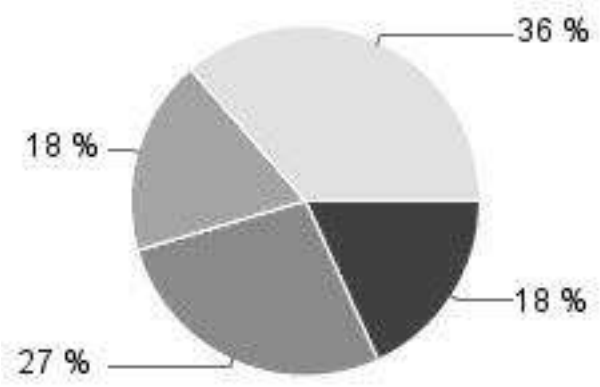

Figura 69 - Motivos por estar atuando fora da área de formação

Questão: Quanto tempo se passou entre a formatura e o início de sua atividade profissional?

Respostas:

Menos de 01 ano - $72 \%$

De 01 a 02 anos - 8\%

De 02 a 03 anos - 12\%

Mais de 03 anos - $8 \%$

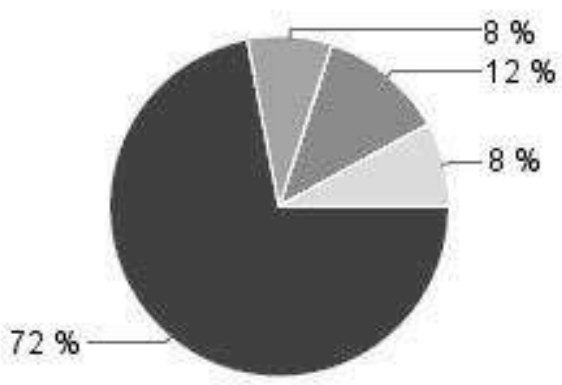

Figura 70 - Tempo médio entre a formatura e início em atividade profissional na área em que se formou

Essa questão foi somente apresentada aos entrevistados que afirmaram que estão exercendo atividade profissional na área de formação acadêmica. Ou seja, 
em menos de um ano os formados se colocaram no mercado, dentro da área de formação, o que significa, passaram a atuar como professores de arte.

Em seguida foram apresentadas questões para que avaliassem os encontros presenciais dos cursos concluídos. Foram feitas as questões sobre a frequência dos encontros presenciais, o que acontecia neles, as expectativas e avaliação que fariam dos encontros, e, se pudessem escolher, o que mudariam e foi pedida a opinião sobre 'para que devam servir os momentos presenciais'. Os resultados mostram que a maioria dos cursos tem encontros semanais ou mensais (35\% para cada opção), onde acontecem atividades práticas (oficinas, 24 \% e ateliês 15 \%). Nos gráficos podemos ver o detalhamentos dos encontros.

Questão: Qual era a frequência dos encontros presenciais de seu curso?

Respostas:

Duas vezes por semana - $4 \%$

Semanal - 35\%

Quinzenal - 8\%

Mensal - 35\%

Semestral - 0\%

Somente no início e no fim do curso - 0\%

Outros - $19 \%$

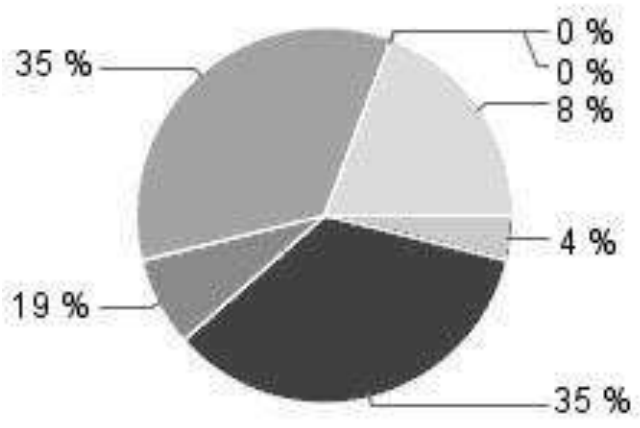

Figura 71 - Frequência de encontros presenciais 
Questão: O que acontecia, com mais frequência, nos encontros presenciais no seu curso?

Respostas:

Somente as avaliações - $18 \%$

Oficinas Práticas - 24\%

Palestras - 14\%

Atividades Culturais - $17 \%$

Encontros Sociais (Almoços, jantares, coffee break etc.) - 8\%

Ateliês - $15 \%$

Outros - 5\%

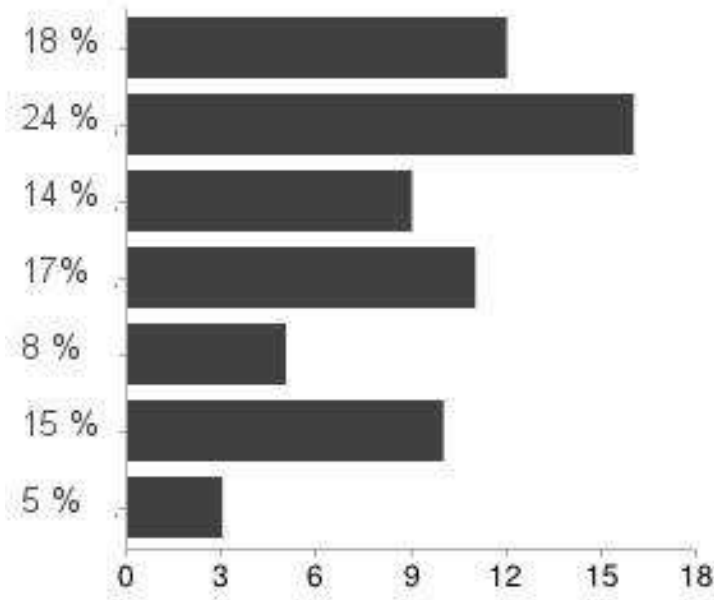

Figura 72 - Atividades em encontros presenciais

Nos campos disponíveis para comentários (bastante utilizados) os entrevistados fizeram observações importantes de serem registradas. Enquanto uns afirmam que os encontros promoviam a prática artística em ateliês, visitas culturais a museus e galerias, e mesmo a promoção de encontros sociais, outros reclamam explicitamente, da falta de atividades práticas, de relações intrapessoais etc. Enfim, não há como generalizar a análise, mas sim destacar a multiplicidade de possibilidades de composição dos encontros presenciais. A questão que desperta interesse nesse item, que não foi levantada por nenhum dos participantes, é sobre a prática artística ser prioritariamente organizada para acontecer de forma presencial. Não são relatadas práticas artísticas virtuais por nenhum dos participantes. 
Quando questionados, em seguida, sobre como acreditam que deva ser um encontro presencial "ideal", ou seja, para que "serve" o encontro presencial em sua formação, a maioria das respostas aponta para a ideia de convivialidade, ao responder que os encontros presenciais

- Servem para troca de experiências. Além do convívio social com turma e tutores.

- Ampliação dos conhecimentos com atividades lúdicas. Quanto mais utilizar o lúdico melhor para assimilar o que ficou vago no estudo em casa. Oficinas Práticas.

- Conhecer e ter a presença física do tutor/professor.

- Maior interação com os/as colegas.

- [...] socializar o conhecimento adquirido entre si e com a comunidade.

- E além de palestras ao vivo, mais encontros de cultura, viagens para estudos, por exemplo.

- Servem para esclarecer as dúvidas, confraternizar e fortalecer o aprendizado.

- [...] momentos de se conhecer, trocar experiências, realizar atividades artísticas e de ateliês, visitar museus e bienais, obter orientações.

Ao afirmarem que os encontros presenciais devem ser compostos de

- Aulas práticas e trocas de experiências.

- [...] ateliês e oficinas experimentais.

- Apresentação da disciplina e sua ementa; seminários e demais culminâncias previstas em ementa; ateliês e oficinas experimentais; debates sobre conteúdos teóricos; estudos e atividades em grupo.

Os alunos reforçam a ideia predominante na maioria dos programas brasileiros de que a prática artística só pode ocorrer presencialmente, demonstrando desconhecimento de práticas artísticas virtuais. Uma das participantes, na descrição de como seria o encontro presencial ideal, em sua visão, diz

[...] acredito que o que faltou no curso de Artes Visuais que eu fiz, foi a parte prática, embora houvesse boa vontade dos professores em no propor algo prático para fazermos em termos de pintura, modelagem e desenho, aos meus olhos isso ficou MUITO defasado, porque não tivemos nenhum tipo de oficina, nenhuma orientação técnica em termos práticos quanto ao fazer artístico. Nossa sorte, no caso da minha turma é que já tínhamos uma bagagem técnica por conta do Conservatório de Música de Pouso Alegre que ofereça curso de desenho e Design de Interiores em nível técnico. Agora eu penso e se não tivéssemos??? Em termos de currículo eu até achei muito bom o curso enquanto instrumentalização do professor que pensa, reflete e produz projetos para aulas de Arte, mas professor produtor de Arte realmente ficou em 
falta esse aspecto. No meu caso eu tenho procurado cursos livres na parte prática de cerâmica, pintura e etc., para sanar essa deficiência.

Claramente a aluna relaciona prática artística e presencialidade e, em nenhum momento de sua participação, menciona a possibilidade de práticas artísticas virtuais.

Os resultados da pesquisa junto aos alunos que estão cursando atualmente licenciatura a distância em Artes Visuais, com relação aos motivos da escolha de $\mathrm{EaD}$, são bem semelhantes aos motivos apontados pelos formados.

- Escolhi a EaD por ter uma flexibilidade no horário e não precisar me deslocar como acontece nos cursos presenciais.

- Flexibilidade de horários e didática do Ensino.

- Minha opção pelo curso de Licenciatura em Artes Visuais na modalidade a distancia, foi pelo correria e o pouco tempo que muito vez nos impede de esta presente todos os dias em uma sala de aula, mas como estamos em um tempo voltado para a tecnologia, isso contribuiu muito para a eficiência do Ensino a distancia.

- A princípio porque em minha cidade, assim como nas localidades vizinhas há oferta do curso.

- Mais facilidade em conciliar com outros papel que desempenho, como: mãe, esposa, dona de casa e ainda trabalho fora.

- Pela facilidade de adequação de horário, me permitindo uma organização própria do tempo.

- O tempo que não possuo mais para frequentar a universidade porque já passei dos 40 , fica complicado.

- Não necessitar de deslocamento físico, flexibilidade de horários.

- Devido as possibilidades e oportunidades que o mesmo oferece, como uma formação em que o aluno tem uma flexibilidade de horários de estudo.

- Falta de tempo e vontade em estudar de forma presencial.

- Pela facilidade de não estar em sala de aula diariamente, para aperfeiçoar-me e conhecer novas formas de Ensino-aprendizagem.

- Devido a não ter esse curso próximo da minha cidade.

- Falta de tempo.

- Pela flexibilidade de tempo e horário.

- Por trabalhar e facilita o acesso.

- Pela oportunidade de acesso a um curso de Artes Visuais no local onde moro.

- Hoje tenho 52 anos, um curso presencial se torna complicado, depois trabalho o dia todo a noite estou muito cansado e EaD me proporcional, esta oportunidade de fazer um curso de qualidade, eu mesmo administrando meu tempo.

- Posso fazer minhas atividades no horário propicio e não preciso sair de casa todos os dias para estar em uma faculdade.

- Por ser prático e com horário bastante flexível para os estudos.

- Optei pelas dificuldades encontradas aqui na minha região, sou exmorador da área rural, e vim para cidade na expectativa de estuda, chegando aqui os horários do trabalho não coincidia com os das faculdades. Os cursos eram oferecidos durante o dia e eu não poderia 
fazer pois tinha que trabalhar para me manter. Sou professora de matemática, 8 horas/dia.

- Pouco tempo.

- Por proporcionar o estudar em casa, tenho duas crianças pequenas e não seria possível me ausentar por muito tempo.

- Pela oportunidade e por ser pela UFG. O meu sonho de ser aluna dessa instituição e é uma modalidade que tem facilitado as minhas condições, aproveitando o tempo em casa, no trabalho. Enfim, uma forma que ajuda o estudante a EAD.

De sonhos pessoais de "ser aluna dessa instituição" até a afirmação equivocada de "falta de tempo", que deixa perceber um entendimento de que a EaD é mais "fácil" que a Educação presencial, a maioria apresenta a organização do tempo de acordo com suas necessidades e prioridades como maior razão para a escolha. Uma pessoa entrevistada afirmou que sua escolha se deve à "Flexibilidade de horários e didática do Ensino", porém não detalhou o que entende por didática de Ensino.

O perfil do atual aluno de EaD em Artes Visuais pode ser observado nos gráficos a seguir.

Questão: Qual a duração do seu curso?

Respostas:

$$
\begin{aligned}
& 3 \text { anos - } 0 \% \\
& 4 \text { anos - } 96 \% \\
& \text { Outros - } 4 \%
\end{aligned}
$$

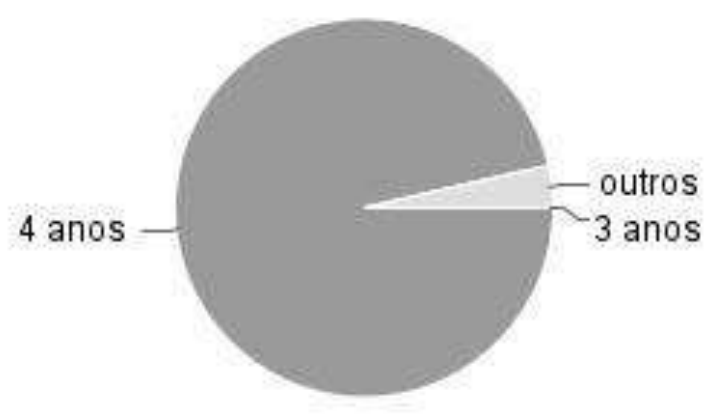

Figura 73 - Duração dos cursos

Pelos relatos dos alunos, as licenciaturas que os entrevistados frequentam duram, todas, quatro anos. Não há nenhuma de três anos e o item 'outros' corresponde 
aos cursos modulares, que têm duração flexível, à medida que sejam cursados os módulos. Porém, o curso do Claretiano, por exemplo, tem duração de três anos, e os participantes dele declararam que dura quatro anos. Equívoco que não foi esclarecido no campo de comentários por nenhum deles.

Sobre a previsão de conclusão, a questão feita foi "Qual o ano previsto para a conclusão de seu curso?" Dos participantes, $21 \%$ concluiria o curso ainda em 2013 (a pesquisa realizou as entrevistas, como já dito, entre 23 de novembro de 2013 e 08 de janeiro de 2014); 43\% dos entrevistados concluirão o curso em 2014 e $36 \%$ em 2015.

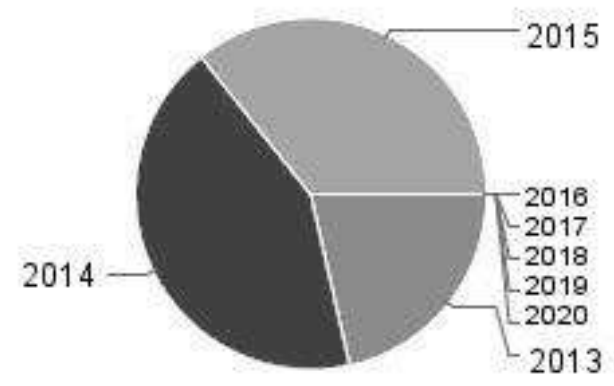

Figura 74 - Previsão de conclusão do curso

É o primeiro curso superior de $71 \%$ dos participantes, contra $29 \%$ de participantes que já possuem diploma de nível superior.

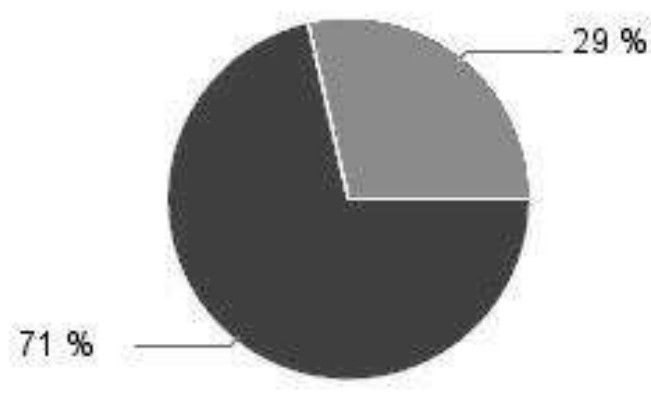

Figura 75 - Percentual de alunos em primeira graduação

Sobre os encontros presenciais dos cursos de Licenciatura em Artes Visuais que estão participando, os alunos dizem que a maioria dos encontros acontecem 
semestralmente (36 \%), seguido de mensais, com 28 \% e a opção 'outros' foi marcada por $24 \%$ dos entrevistados, que não detalharam essa opção. Somente um entrevistado, que marcou a opção 'outros', disse que a frequência "Varia de acordo com o calendário, podendo ser mensal ou trimestral".

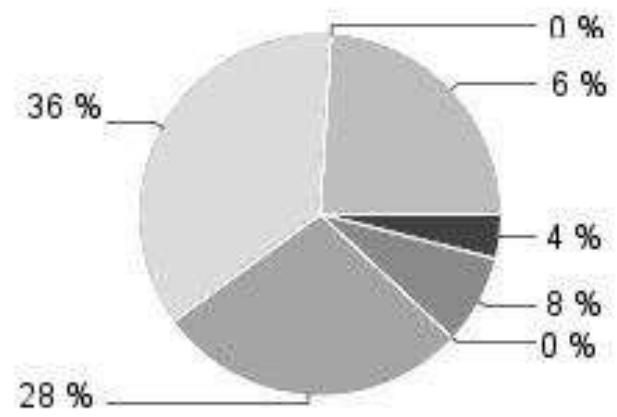

Figura 76 - Frequência de encontros presenciais

Os participantes também relatam uma mudança significativa no perfil dos encontros presenciais dos atuais cursos. Se antes aconteciam predominantemente avaliações e práticas de ateliês, os relatos dos atuais alunos mostram que houve uma mudança significativa. Não que as avaliações e ateliês tenham deixado de acontecer, mas os encontros passaram a oferecer uma gama mais equilibrada de atividades.

Questão: O que acontece nos encontros presenciais?

Respostas:

Somente as avaliações - $9 \%$

Oficinas Práticas - 18\%

Palestras - 15\%

Encontros Sociais (Almoços, jantares, coffee break etc.) - 11\%

Ateliês - 17\%

Atividades Culturais - 11\%

Atividades Artísticas - 15\%

Outros - 4\% 


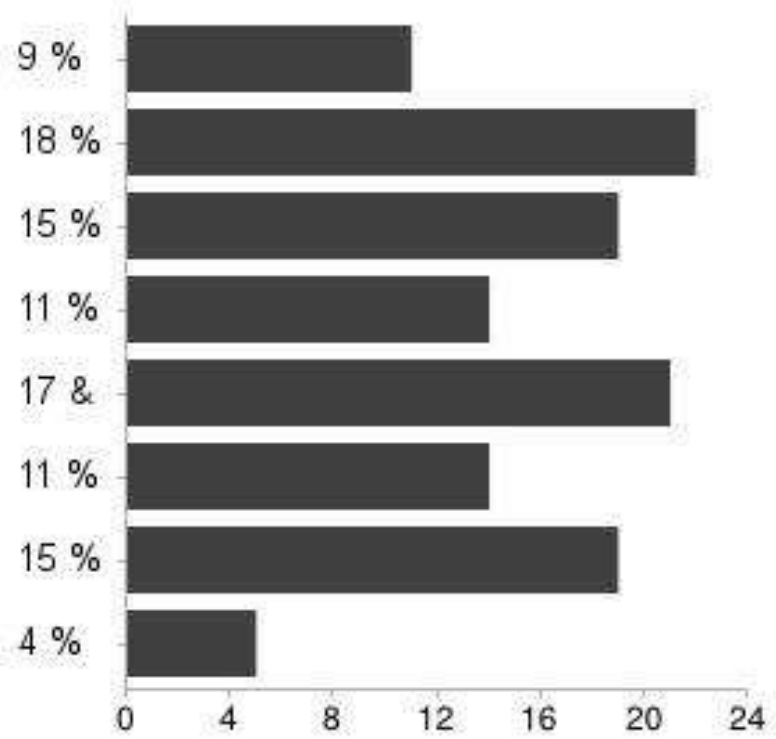

Figura 77 - 0 que acontece nos encontros presenciais

\begin{abstract}
Nos relatos do campo 'Como os encontros acontecem', onde os participantes deveriam relatar um encontro padrão, percebe-se, ainda, a presença das oficinas e ateliês como predominantes.
\end{abstract}

- São apresentados os professores formadores e posteriormente vamos para os ateliês [...] quando realizamos as atividades práticas.

- [...] há palestras com professores convidados de outras Universidades.

- Nos intervalos ocorrem os coffee break, a noite o jantar. Sempre acontece um "assalto cultural" realizados pelos alunos das Artes Cênicas. $O$ encerramento das atividades é feito com a exposição dos trabalhos realizados durante o encontro.

- Tem duração de três dias cada presencial [...] onde aprendemos técnicas de arte e muita coisa na área de Educação.

- [...] ateliês, aulas teórica, e as vezes avaliações.

- Geralmente acontecem aulas das matérias estudadas no semestre, com apresentação do material de didático, esclarecimento de duvidas, geralmente um café da manhã, avaliações, entrega de atividades etc. Tudo e muito bem organizado afim de que o aprendizado aconteça.

- [...] Aulas Oficinas Avaliações.

- Os nossos presenciais são para apresentar as disciplinas e as proposições dos professores formadores, atividade de Ateliês, avaliações.

- [...] oportunidade de conversar pessoalmente com o professor (geralmente não o conhecemos) e apresentar outras formas da produção, geralmente uma produção artística e/ou pedagógica.

- Explicações gerais sobre as disciplinas, plano de curso e atividades que acontecerão durante o semestre.

- Atividades práticas de ateliê como pintura, desenho, gravura, escultura, artes da fibra, fotografia e vídeo, com instalações provisórias de equipamentos no polo de apoio para o desenvolvimento destas. 
- Apresentações de vídeos, slides e filmes que dialogam e explicam as disciplinas com a presença e explicação dos tutores.

- Avaliações escritas, orais ou práticas, individualmente ou em grupo.

- Trabalhos em grupo com leitura de textos, vídeos e outros, com apresentação dos alunos.

- [...] aulas práticas usamos o ateliê.

- No último presencial do semestre acontecem seminários que são apresentados pelos alunos com o tema proposto nas disciplinas.

- [...] receber o material didático do curso.

- [...] os encontros servem de apoio à algumas disciplinas, com esclarecimento de dúvidas e informações gerais sobre a disciplina, às vezes, uma avaliação.

- Na maioria das vezes, oficinas práticas e ateliês com atividades artísticas.

- São Ateliês de arte, exposições, aulas práticas.

- Orientações, palestras, oficinas práticas, seminários, apresentações de atividades pelos alunos com o auxílio dos professores (as), visitas a museus, galerias, jantares, coffee break e uma ótima interação com todos os envolvidos, ótimo.

- [...] as atividades nos encontros presencias são ateliês com oficinas práticas, para melhor conhecermos o que vai ser trabalhado no semestre.

- [...] oficina praticas de gravura, tear, desenhos bidimensional e tridimensional, intervenções artísticas...

- [...] No polo presencial em salas ambiente. São ministradas palestras relacionadas aos temas propostos.

- Práticas no ateliê.

- [...] atividade de ateliê e montagem de estalagem.

- [...] no fim do curso muitos seminários (essa troca foi muito aproveitável - muitos diálogos), nossas práticas artísticas sempre vem acompanhada de um seminário para podermos explanar todo processo.

Nenhum dos entrevistados fala, em nenhum momento, sobre práticas artísticas virtuais, relacionando as práticas quase sempre à presencialidade dos encontros. Porém, quando convidados a falar sobre como acreditam que seria um encontro presencial 'ideal' poucos dos entrevistados mencionaram práticas artísticas. Uma observação, de uma pessoa, chama a atenção:

Não somente eu, mas grande parte dos cursistas (em torno de $99 \%$ ) da minha turma pensam que todos os instantes dos presenciais deveriam ser aproveitados em experiências do fazer artístico. Essas experiências feitas para serem somente postadas no ambiente não possibilitam as trocas da manipulação do suporte, do material e da ideia. Até ocorrem muito bem, mas de forma isolada para cada aluno. O que eu entendo como experiências do fazer é algo em torno de atividades de ateliês e ações poético-pedagógicas.

Embora afirme que $99 \%$ dos cursistas concordam com ela, a pessoa não apresentou nenhuma pesquisa concreta, e faz uma afirmação categórica com "todos os instantes dos presenciais deveriam ser aproveitados em experiências 
do fazer artístico" e uma crítica ao método do curso, desvalorizando as atividades práticas individuais afirmando que somente 0 ateliê presencial proporcionaria 0 que chama de "ações poético-pedagógicas", num claro desconhecimento das possibilidades de ação/atuação de práticas artísticas em espaços virtuais.

\section{Os principais pontos apontados como necessários num encontro presencial foram:}

- Para interação do grupo, resolver problemas pendentes, conhecer e aproximar dos professores.

- Para conhecermos os alunos de outros polos, professores os quais temos contato mais a distância e no presencial faz muita diferença, onde tiramos as dúvidas, falamos das dificuldades ou seja, trocamos as nossas experiências e socializamos.

- [...] é o momento de trocas e avaliações e autoavaliações dos alunos.

- Realização de atividades práticas e outras com mais recursos que os disponibilizados pelo AVA;

- Comunicação entre professores, tutores e alunos;

- Comunicação entre os alunos.

- [...] compartilhar conhecimentos com todos ali presentes.

- Além da socialização que tem um ponto essencial neste curso, com a troca de experiências. Na minha opinião além de ser um momento de interação [...]

- Em minha opinião, para apresentação de seminários pelos alunos, e interação entre os alunos e tutores.

- Troca de experiências, mais oficinas, ateliês, debates sobre como utilizar o que estamos aprendendo em sala de aula.

- [...] conhecemos a turma e os professores, debatemos e tiramos nossas dúvidas que não foram sanadas durante a semana via internet.

- É o momento de descontração e aprendizado juntos, olho no olho.

- Também é o momento da troca de experiências e fortalecimento de ideias e concepções.

- A percepção de estar junto é importante para a permanência no curso.

- [...] conhecer os professores e colegas, trocar experiências.

- Tirar dúvidas e interagir.

- [...] fortalecem os laços afetivos aluno-aluno e aluno-tutor.

- Acredito que seja um momento para complementar a didática, esclarecimento de duvidas, avaliações, momentos de socialização com a turma, professores, funcionários e com a universidade, esclarecer a proposta da disciplina, enfim, momentos de socializações, esclarecimentos e avaliações.

- [...] Para aproximar as pessoas, a tela do computador e muito fria, não tem os momentos olho no olho. Os encontros presencias precisam acontecer no início do semestre para que alunos, tutores e professores conversem sobre o que será proposto.

- Para tirar dúvidas e promover integração entre os colegas.

Ou seja, a maioria dos entrevistados acredita que a presencialidade é responsável pela sensação de pertencimento à um grupo, colaboração e pela 
interação, desconhecendo, ou não percebendo o espaço virtual como espaço de interação. Algumas questões surgem, em decorrência dessas afirmações. Por que isso acontece? A convivialidade virtual não acontece nos cursos? Não há práticas de colaboratividade? Essas questões não são trabalhadas durante o curso nos espaços virtuais? Questões sem resposta, por enquanto, por não terem sido nem comentadas pelos participantes, mas importantes para 0 desenvolvimento da EaD.

Quando perguntados sobre como acreditam que o curso venha a influenciar, ou não, sua vida profissional, os resultados são:

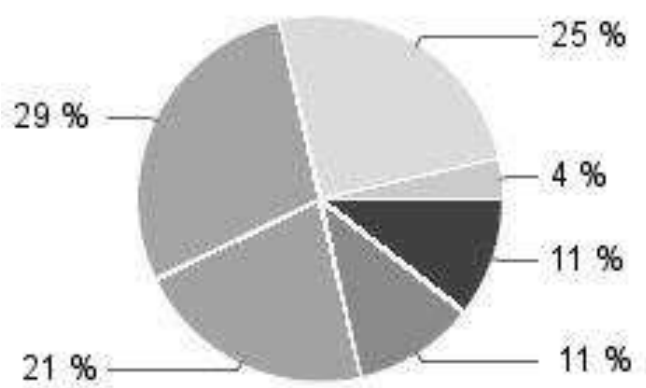

Figura 78 - Conclusão do curso e vida profissional

A maioria (29\%) acredita que a conclusão do curso vai influenciar bastante sua vida profissional pois está cursando a licenciatura para ser professor sendo que $25 \%$ dos entrevistados declarou que está fazendo o curso para mudar de área de trabalho. Somente $11 \%$ dos entrevistados declarou que faz o curso sem interesses profissionais, porém os mesmos $11 \%$ disse que está fazendo o curso para progredir na carreira e $21 \%$ declarou que faz o curso para se qualificar mais na área. Não souberam responder a questão $4 \%$ dos entrevistados.

Quanto ao perfil tecnológico dos alunos, foram feitas questões com a ideia de entender o tipo de usuário que configura o aluno de cursos de Licenciatura em Artes Visuais. 


\section{Acesso a Internet}

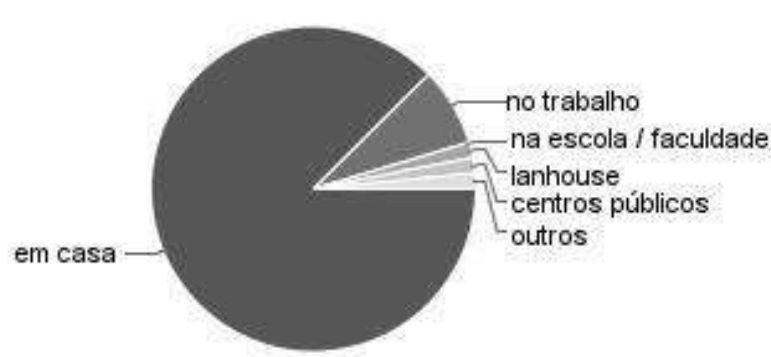

Em casa

$88 \%$

No trabalho

$\mathrm{Na}$ escola/faculdade

Centros públicos de acesso $2 \%$

Outros

Figura 79 - Tipo de acesso à Internet

\section{Há quanto tempo você usa a Internet?}

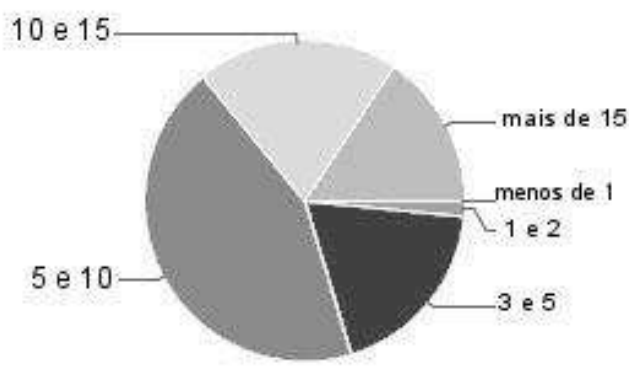
Menos de um ano $0 \%$
Entre 1 e 2 anos $2 \%$
Entre 3 e 5 anos $19 \%$
Entre 5 e 10 anos $44 \%$
Entre 10 e 15 anos $20 \%$
Mais de 15 anos $16 \%$

Figura 80 - Tempo como usuário de Internet

\section{Quantas vezes você acessa a internet em uma semana?}

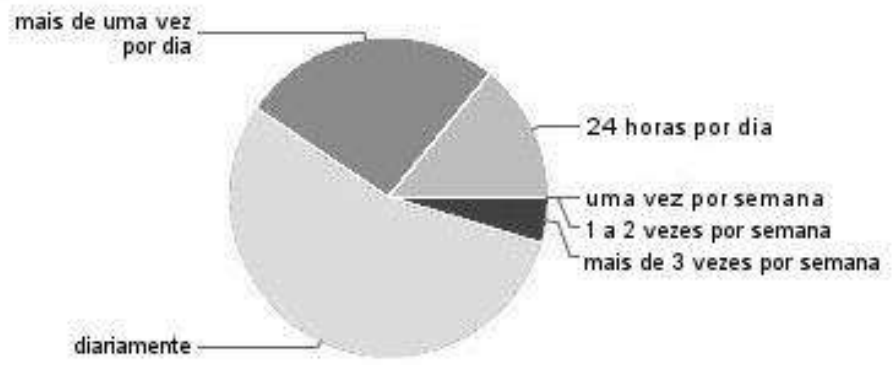

$\begin{array}{lr}\text { Uma vez por semana } & 0 \% \\ \text { De } 1 \text { a } 2 \text { vezes por semana } & 0 \% \\ \text { Mais de } 3 \text { vezes por semana } & 5 \% \\ \text { Diariamente } & 55 \% \\ \text { Mais de uma vez por dia } & 27 \% \\ \text { Conectado } 24 \text { horas por dia } & 14 \%\end{array}$

Figura 81 - Frequência semanal de acesso

\section{Quanto tempo você gastar na Internet por acesso?}

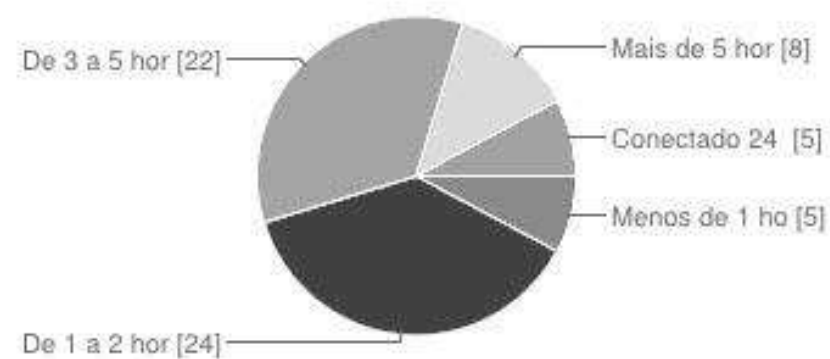

Menos de 1 hora por acesso $8 \%$

De 1 a 2 horas por acesso $38 \%$

De 3 a 5 horas por acesso $34 \%$

Mais de 5 horas por acesso $13 \%$

Conectado 24 horas por dia $8 \%$

Figura 82 - Tempo gasto nos acessos 
Qual é o seu principal motivo de acesso a internet?

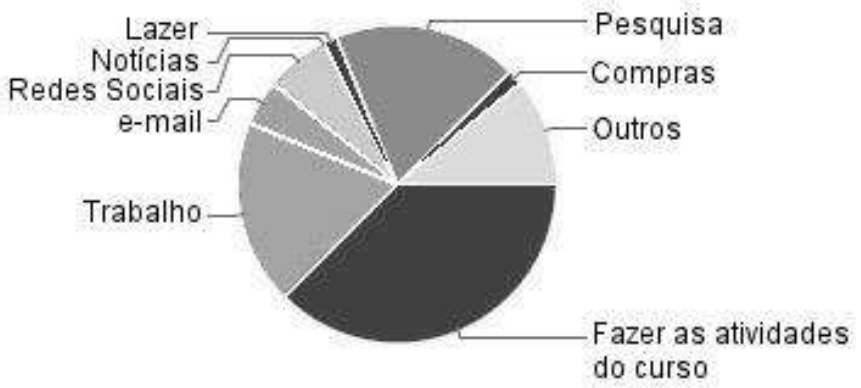

$\begin{array}{lr}\text { Fazer as atividades do curso } 38 \% \\ \text { Trabalho } & 19 \% \\ \text { Ler e-mails pessoais } & 5 \% \\ \text { Redes Sociais } & 6 \% \\ \text { Ler notícias } & 0 \% \\ \text { Lazer e entretenimento } & 2 \% \\ \text { Pesquisa } & 19 \% \\ \text { Fazer compras } & 2 \% \\ \text { Outros } & 11 \%\end{array}$

Figura 83 - Principal motivo de acesso à Internet

Com relação aos navegadores mais usados pelos alunos, o Chrome é o mais conhecido, com $66 \%$ da preferência, enquanto o Enigma é o menos conhecido deles.

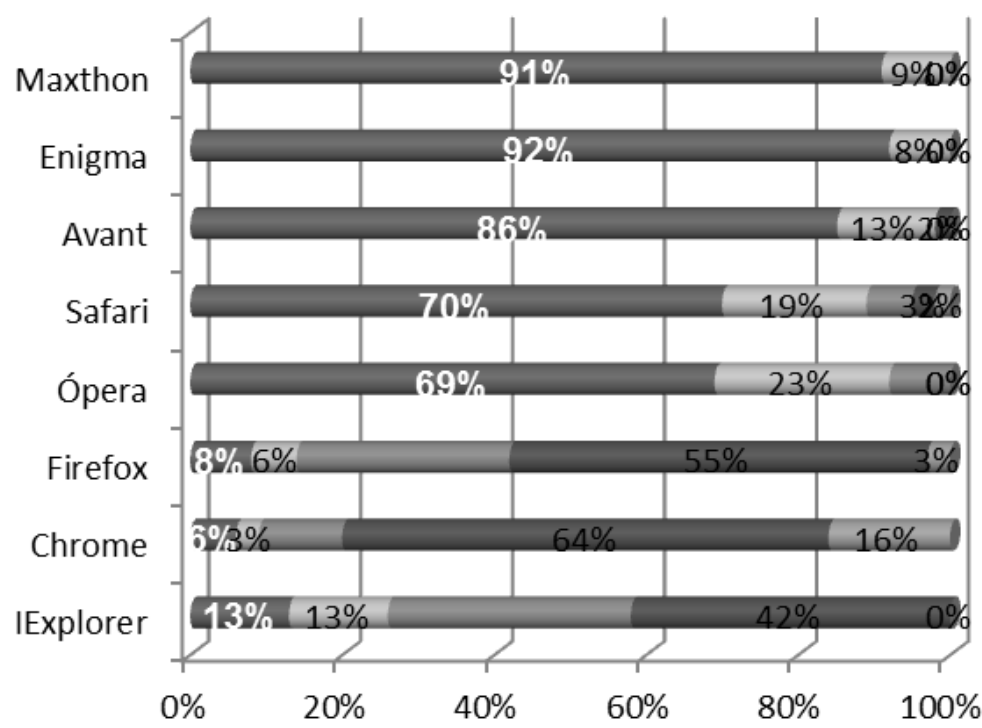

- Não conheço

- Conheço mas nunca usei

- Conheço e já usei uma vez

- Conheço e uso sempre

- É o único que eu uso

Figura 84 - Uso de navegadores web

Em relação ao uso de redes sociais, o perfil dos alunos mostra que o trânsito pela web é em nível muito superficial, usando com alguma frequência apenas as redes sociais mais 'famosas' e as redes Classmate, Flixter e WeHeartlt ${ }^{131}$ são desconhecidas de $89 \%$ dos alunos.

${ }^{131}$ Rede social de curadoria e compartilhamento de conteúdo visual. 


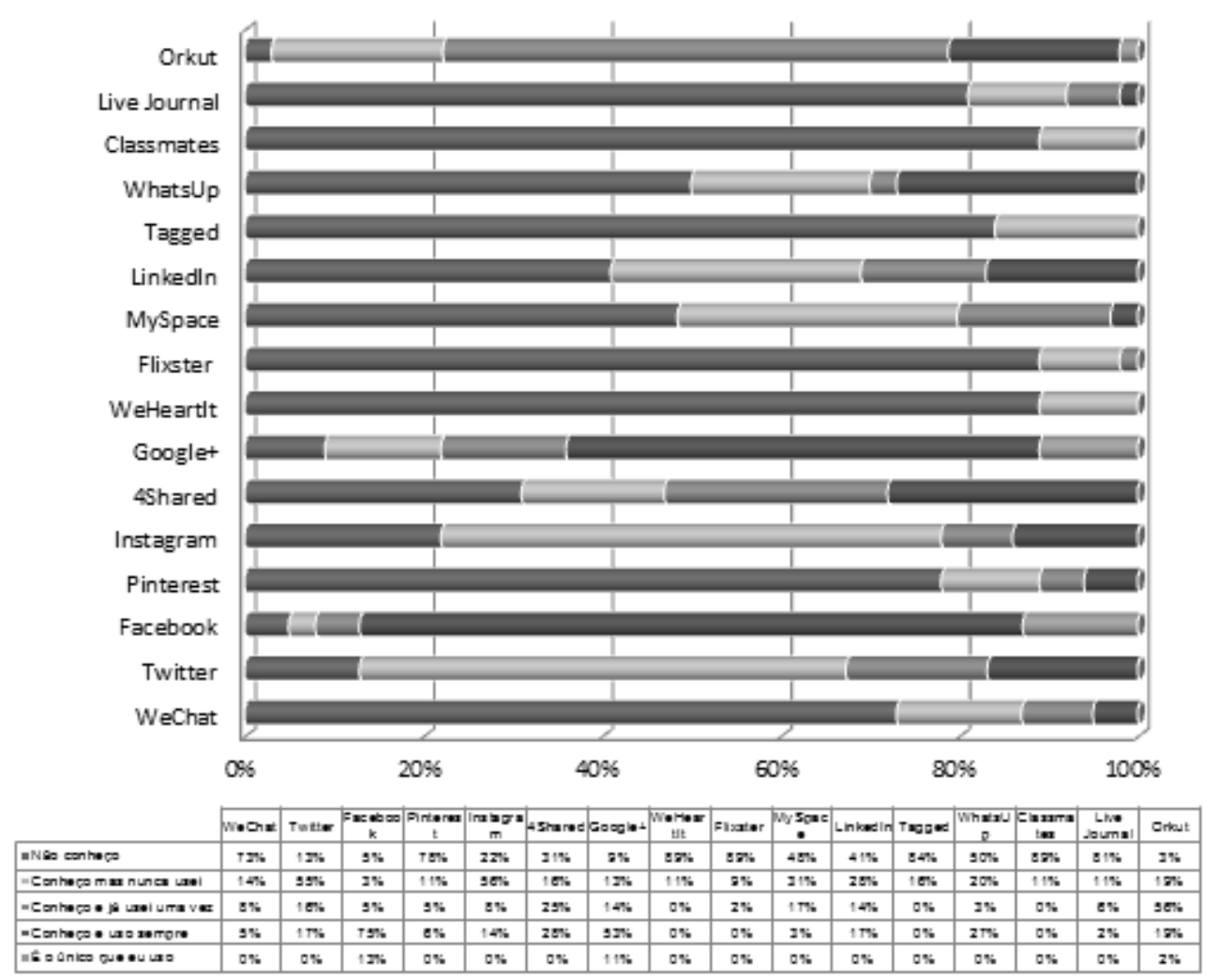

Figura 85 - Uso de redes sociais pelos alunos

Quando questionados sobre LMS (Learning Management System), foram apresentadas cinco opções para serem analisadas. Blackboard foi o menos conhecido (77\%) e o mais conhecido e usado é o Moodle, o que vem ao encontro da informação já apresentada de que dos programas EaD em Artes Visuais em atividade somente duas instituições usam LSM próprios, institucionais.

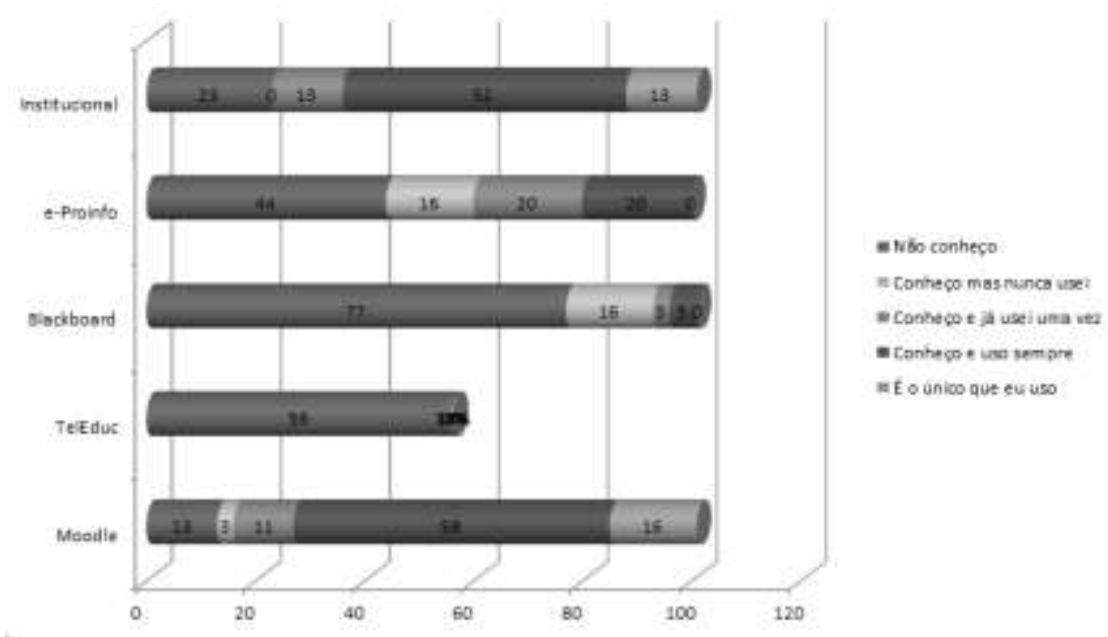

Figura 86 - Nível de conhecimento de LMS 
No fim, foi pedido que, caso conhecessem algum LMS que não estava listado, acrescentassem no campo destinado aos comentários. Curiosamente foram adicionados neste campo: Udemy ${ }^{132}$, que não é um LMS, mas uma rede social educacional de cursos gratuitos; Ensine OnLine, que é o site de uma empresa que implementa cursos com uso do Moodle; o site institucional "ead.fav.ufg" e a palavra "Prisma", que não é o nome de nenhum LMS e, somente como foi citada, não dá clareza do que a pessoa queria dizer. No entanto, as citações deixa margem para a interpretação de que não sabem o que seja um LMS.

Sobre o uso de buscadores, ou sites de pesquisa, foram apresentados os mais usados atualmente, de acordo com os sites de tecnologia. A maioria absoluta usa o Google como site de pesquisa e, quando perguntado se havia algum que não estava na lista mas que a pessoa usava, nenhum foi citado.

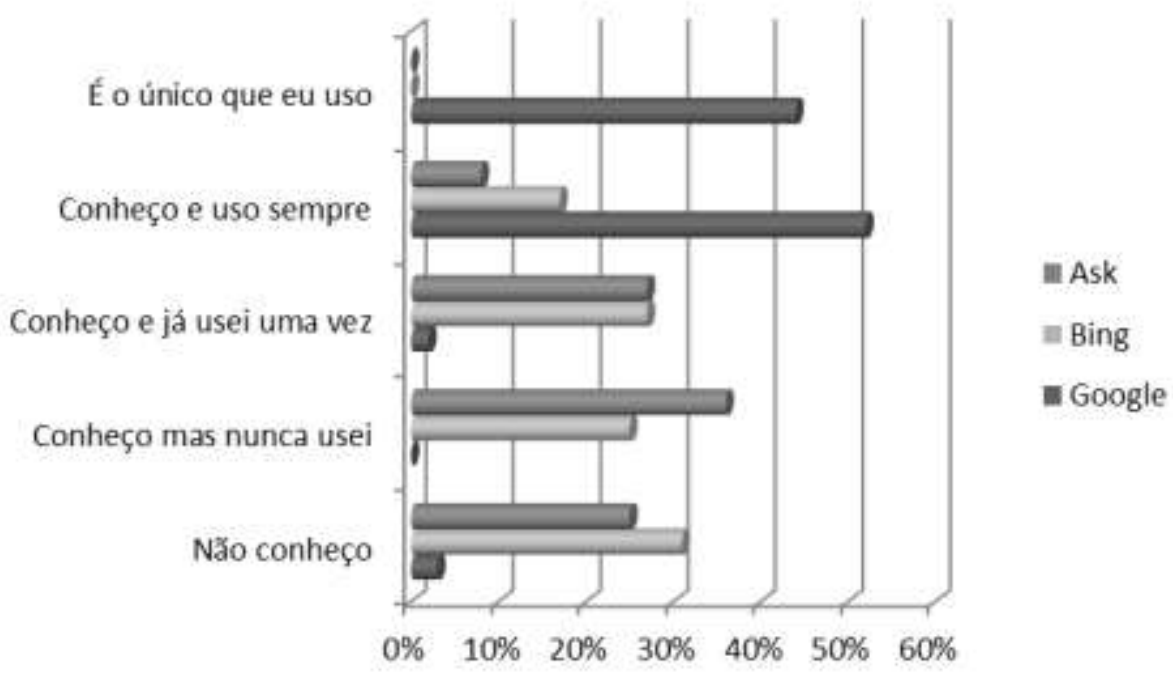

Figura 87 - Uso de buscadores

Situação das mais curiosas acontece com a pergunta sobre uso de comunicadores em rede. Primeiro vamos lembrar que as entrevistas ocorreram entre novembro de 2013 e janeiro de 2014. Em seguida, o resultado: 34\% declararam usar mais o Skype, e 50\% declararam que o comunicador que mais usa é o MSN. Só que o MSN foi descontinuado no Brasil em maio de 2013. Esse

${ }^{132}$ Ver em detalhes em https://www.udemy.com/ 
resultado é realmente surpreendente. O que as pessoas teriam entendido da questão para que respondessem que usam "com frequência" um comunicador que não existe há mais de seis meses? O que será que é compreendido como uso frequente? Essa foi uma das maiores surpresas da pesquisa.

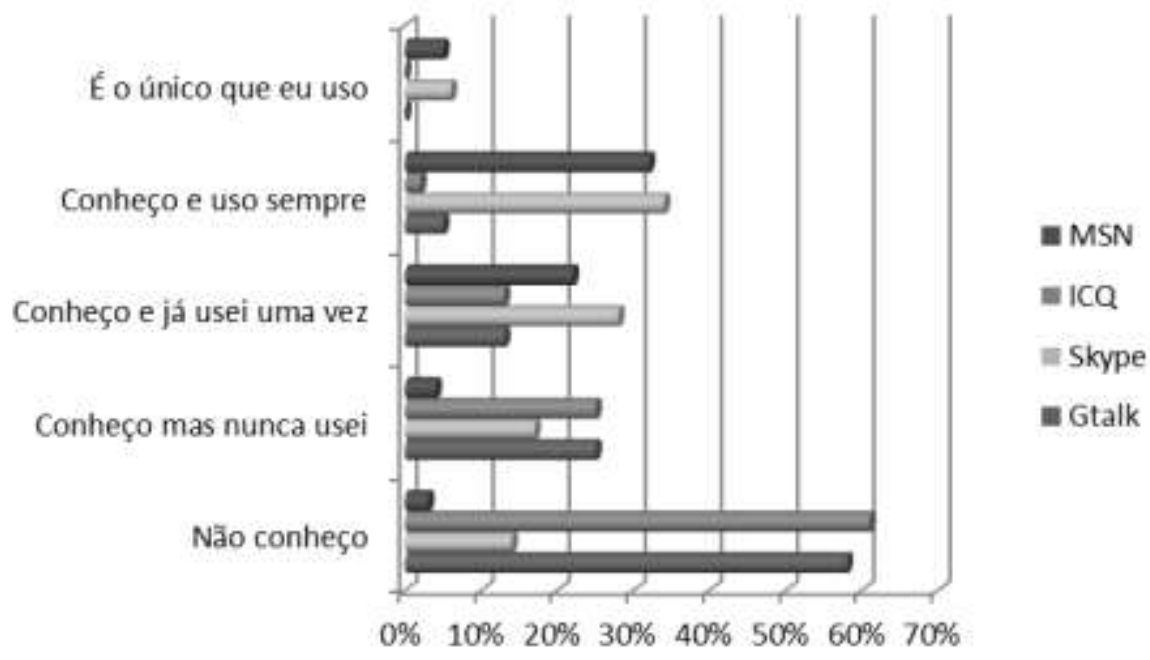

Figura 88 - Uso de comunicadores em rede

O detalhamento de uso dos recursos disponíveis na internet nos dá uma maior percepção do nível tecnológico dos alunos entrevistados.

Quando perguntados se participam de Listas de Discussão na Internet, $56 \%$ diz que não, contra $44 \%$ que diz que sim, participa. Porém quando é pedido para dizer de qual(is) lista(s) participa, somente dois participantes citam listas corretamente. O restante cita sites de redes sociais, sites temáticos, sites de pesquisa, numa clara demonstração de que não sabem o que são Listas de Discussão.

Situação semelhante acontece com a questão sobre uso de fóruns. $50 \%$ diz que participa de fóruns, quando pedido que listasse os fóruns que participa, foram listados sites de redes sociais, sites temáticos, os fóruns do curso que participam (a questão era clara: "Você participa de fóruns na Internet?" e não se relacionava com o curso, pois estava na área da pesquisa relacionada com o perfil tecnológico dos alunos), o que deixa perceber, ou desconhecimento do que seja 
um Fórum de Internet, ou uma tentativa de parecer mais "conectado" do que na realidade seja.

Na questão sobre Blogs 94\% declaram ler com frequência Blogs. Quando pedido para listarem os blogs que leem houve certa confusão, sendo listados, misturados, sites, portais e blogs. Quando questionados se escrevem ou participam de algum grupo que mantenha um Blog, somente $38 \%$ respondem afirmativamente e, na área de detalhamento, onde deveriam citar os blogs em que participam, somente são citados realmente blogs, o que faz compreender que os que usam a ferramenta sabem o que ela é e para que servem.

Quanto aos protocolos da web de transferência de arquivo como FTP e Usenet, de uso avançado, que mostra um perfil de usuário realmente desenvolto na internet, somente 11\% declarou usar/conhecer FTP e $2 \%$ declarou usar/conhecer Usenet. O que se conclui é que, na maioria das vezes, as pessoas superdimensionam seus conhecimentos de tecnologia, acreditando que realmente têm um bom nível de conhecimento, quando, na verdade, não conseguem dimensionar isso adequadamente, pois, se não conhecem um recurso/ferramenta, como poderiam dizer se o usam bem ou mal?

Esse tipo de informação é importantíssima em EaD na medida em que o perfil de usuário deveria ser testado e não arguido, sob o risco de ser mal dimensionado se for somente autodeclarado.

O perfil socioeconômico dos alunos também foi levantado nas entrevistas, e pode ser conferido nos dados da pesquisa, nos anexos eletrônicos, porém, para o interesse desta pesquisa é suficiente constatar que somente $5 \%$ declarou não possuir TV; 63\% possuem aparelho de DVD; 19\% não tem celular, 41\% não tem smartphone, 11\% não tem máquina fotográfica digital (dado curioso, pois diverge do numero de celulares e smartphones e, nos dias atuais, quase não são mais vistos aparelhos sem câmeras); somente 6\% tem BlueRay; 58\% usam desktops; $42 \%$ usam notebooks; $45 \%$ têm tablets, o que mostra certa convivência tranquila 
com itens de tecnologia no dia a dia, mas não intimidade com as categorizações como sites, grupos de discussão etc.

É importante destacar, por fim, que, dentro da visão de ampliação de formação de professores, que faz parte das políticas públicas educacionais brasileiras, como vimos, a implementação, desenvolvimento e ampliação da $\mathrm{EaD}$ vem se mostrando ser uma boa estratégia e conta com ferramentas eficazes, confirmando a necessidade das licenciaturas em Artes Visuais serem, inclusive, ampliadas. Porém, as entrevistas também mostram que há, ainda, necessidade de ampliar o uso efetivo de tecnologias, no sentido de proporcionar apropriação e empoderamento. 


\section{CONSIDERAÇÕES FINAIS}

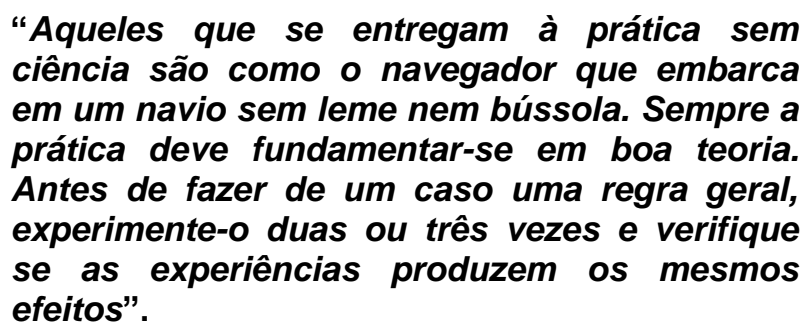

Leonardo da Vinci

Vejo a Formação de Professores de Arte, independente do suporte onde seja feita, como o caminho para que os profissionais do Ensino de Arte venham a se tornar profissionais conscientes, reflexivos, ativos e atuantes, não somente em relação ao domínio de conteúdos e práticas em arte, embora sejam pontos importantíssimos, mas sim, e principalmente, a formação é a oportunidade de que os professores de arte se transformem em seres políticos. Compreendendo a ação política na sua amplitude, não restrita às visões segmentadas e/ou partidárias, mas na ideia ampla de que política é "tudo aquilo que diz respeito aos cidadãos e ao governo da cidade, aos negócios públicos" (JAPIASSU e MARCONDES, 2002, p. 152) ${ }^{133}$ e não somente "a arte de conquistar, manter e exercer o poder, o governo", no sentido maquiavélico (MAQUIAVEL, 1513, apud BOBBIO et al. 2002) ${ }^{134}$.

Considerando que todo currículo embute uma ideologia, seja ela qual for, por trás de sua organização, e mesmo que a abordagem de haver um currículo já é, em si, ideológica, é certo que as diversas formas de fazer EaD também estão cheias de vieses ideológico, tão distintos quantos sejam os atores envolvidos no processo, e que também não é a solução de todos os problemas da Educação, mas, também é certo que EaD não pode ser entendida somente, como uma sucessão, ou substituição da Educação presencial, pois, sua função é, além de aumentar o acesso ao conhecimento, a de concretamente realizar-se como uma prática significativa e consequente em relação aos princípios do projeto pedagógico

133 JAPIASSU, H. e MARCONDES, D. Dicionário Básico de Filosofia. Rio de Janeiro: Zahar, 2001. ${ }^{134}$ MAQUIAVEL, N. O Príncipe, 1513, apud BOBBIO, Norberto et al. Dicionário de Política. 12 ed. Brasília: UnB, 2002. 2V. 
contemporâneo de "busca da autonomia, o respeito à liberdade e à razão" (LOBO NETO, 2000).

Tentando ser ou parecer "moderno" ${ }^{135}$, o programa nacional de formação por EaD da UAB, mesmo usando, em alguns casos, recursos tecnologicamente sofisticados, se sustenta em suportes, teorias e ideologias "congelados" na modernidade industrial, sem se colocar efetivamente diante das situações de Ensino-aprendizagem proporcionadas pela contemporaneidade. É desanimadora a constatação de que o formato de texto é, não só a base do material didático, como também o ponto de partida da maioria das atividades realizadas pelos Licenciados nos ambientes digitais de aprendizagem.

$\mathrm{Na}$ universidade pública o quadro não é muito diferente das instituições particulares, como pudemos constatar ao longo dos quatro anos desta pesquisa, e dos mais de quinze anos de estudos e prática, do meu percurso profissional e acadêmico. O modelo em que os conteudistas são contratados para produzirem "livros" que são, muitas vezes, impressos e entregues aos alunos é simplista, e alguns desses livros contam com material retirado da própria internet, usado, muitas vezes, sem autorização dos autores originais ${ }^{136}$, o que mostra ainda a questão seríssima de formação para a pesquisa ética, além de respeito aos direitos autorais. É muito angustiante que não tenham sido feitas referência, pelos participantes entrevistados, às práticas artísticas do ambiente digital, ou, quando o fazem, eles afirmem que essas experiências não possibilitam as trocas sobre manipulação do suporte, do material e da ideia. Não houve como checar se as afirmações são verdadeiras, ou fruto de percepção equivocada dos alunos, mas o fato dessa percepção ter-se constituído dessa forma denota algumas possíveis falhas, caso as propostas tenham sido efetivadas, visto que não se configuraram como experiência significativa aos alunos.

Especialistas em EaD em Artes Visuais, que estejam aptos a propor e desenvolver ações e atividades que realmente usufruam das possibilidades

\footnotetext{
${ }^{135}$ No sentido popular do termo, equivalente a "atual".

${ }^{136}$ Eu mesma já tive, por duas vezes, material de minha autoria reproduzido sem autorização em material produzido por duas IES públicas.
} 
interativas dos mídias digitais, precisam que as instituições compreendam melhor a natureza do conhecimento artístico, que este não "cabe" em metodologias rígidas e científicas, mesmo que essas metodologias possam funcionar muito bem em outras áreas do conhecimento. O conhecimento em arte tem especificidades que devem ser consideradas na EaD em arte.

Se, por um lado, a pesquisa mostra algumas das deficiências dos atuais cursos, pelos dados colhidos, que são um recorte pontual, sim, mas que espelham uma realidade, por outro lado, foi bastante significativo e animador constatar o quanto os cursos, a formação impacta na vida profissional e o pouco tempo para a inclusão no mercado de trabalho. Isso reafirma minha ideia de que a formação é o "caminho" para a "mudança" que tanto desejamos, despertando a curiosidade de, futuramente, acompanhar a prática profissional desses alunos, já formados, nas escolas em que atuam. E esse é apenas um dos aspectos de desdobramento que esta pesquisa pode proporcionar, para novas pesquisas e novos estudos sobre 0 tema.

Desde o fim do mestrado venho desenvolvendo a ideia de que as proposições neorrenascentistas (SHNEIDERMAN, 2006) apoiadas pela visão transdisciplinar da Educação se configuram em um caminho interessante para traçar a Epistemologia da Educação a Distância em Artes Visuais, pela compreensão dos necessários desdobramentos da contemporaneidade em níveis de conhecimentos. Essas ideias se juntam na forma de uma proposição de Ensinoaprendizagem que envolva conceitos fundamentais de Educação, Educação a Distância, recursos de tecnologia, arte, arte/Educação, teorias de comunicação e informação, web, redes etc. e todo o "arsenal" de recursos contemporâneos, onde tantos e tão variados conceitos e conhecimentos se inter-relacionam, em variados momentos, por quase todo o tempo, somados ao todo de percepções do "ator" desse processo de aprendizagem e sua bagagem individual, ideológica e sociocultural. 
O que se mostrou como "evolução natural ${ }^{137 "}$ dos estudos da pesquisa inicial do mestrado, que vem se configurando nessa pesquisa de doutorado, foi o interesse pelos desdobramentos no uso prático dessas possibilidades tecnológicas e suas consequências, encaminhando o processo de pesquisa para a área epistemológica, a fim de buscar novas reflexões, que venham sustentar proposições e caminhos a serem vivenciados nas práticas educativas experienciadas e sustentadas, através e por meio desses suportes. Dessa forma, esse estudo e sistematização das reflexões ocorridas no período entre a finalização do mestrado e o presente trabalho, de pesquisas de doutoramento, com um recorte teórico pontual, e embasado nas proposições e teorias transdisciplinares, pelo viés da Educação, desdobrando-se em projeção para uso e práticas em EaD em Artes Visuais, busca refletir acerca de uma Epistemologia da Educação a Distância em Artes Visuais para a formação inicial de professores que se baseie em Ambientes Virtuais de Aprendizagem, mas que ocorra, se não totalmente, prioritariamente por EaD. Essa reflexão passa pela possível interação entre a EaD e a Transdisciplinaridade, concordando com Egreja, Machado e Silva (2009, p. 11) quando afirmam que

[...] A interação entre a Educação a Distância e a transdisciplinaridade possibilita pensar no desenvolvimento de uma aprendizagem construída por princípios intuitivos, imaginários, cooperativos, incluindo o resgate do amor, prazer, respeito nas relações, mas, principalmente, da ideia de consideração da vida. O processo educativo, por meio da atitude transdisciplinar, poderá ir além das disciplinas por estar entre e através dela. O rigor na argumentação, a abertura ao desconhecido e a tolerância às diferenças farão parte dessa verticalização em que o ser humano poderá retomar os aspectos qualitativos do conhecimento (EGREJA, MACHADO \& SILVA, 2009, p. 11).

\footnotetext{
${ }^{137}$ Nenhuma referência ao evolucionismo darwinista, apenas uma frase da linguagem vulgar para sinalizar que o caminho transcorreu de forma pouco planejada e quase espontânea devido aos estudos anteriores.
} 


\section{REFERÊNCIAS}

ABED. Associação Brasileira de Educação a Distância. (Org.) Censo EaD BR. Relatório analítico da aprendizagem a distância no Brasil. São Paulo: Pearson Education do Brasil, 2010.

ALFARO, S.F. Financiación de la Educación Superior en América Latina. Tese de doutoramento. Faculdade de Ciências Econômicas e Empresariais. Universidad de Santiago de Compostella. 2007.

ALARCÃO, I. Ser professor reflexivo. In: ALARCÂO, I. (et. Al.) - Formação reflexiva de professores: estratégias de supervisão. Porto: Porto Editora, 1996.

ALMEIDA, F.J. "Aprendizagem colaborativa: 0 professor e 0 aluno ressignificados". In: ALMEIDA, F.J. (Coord.) Projeto Nave. Educação a Distância. Formação de professores em ambientes virtuais e colaborativos de aprendizagem. São Paulo: s.n. 2001.

ALMEIDA, M.H.B. "Educação a Distância na internet: Abordagens e contribuições dos ambientes digitais de aprendizagem". In: Educação e Pesquisa. v.29 n.2. São Paulo July/Dec., 2003.

ALONSO, K.M. Tecnologias da informacao e comunicacao e a formacao de professores: sobre redes e escolas. In: Educacao e Sociedade v. 29, n.104. Especial. p. 747-768, out. 2008. Disponível em: <http://www.cedes.unicamp.br>. Acesso em: 11 Dec.2013.

AMSTRONG, A. \& CASEMENT, C. A criança e a máquina: como os computadores colocam a Educação de nossos filhos em risco. Trad. de Ronaldo Cataldo Costa. Porto Alegre: ARTMED, 2001.

ANDERSON, T. \& DRON, J. Three generations of distance education pedagogy. In: IRRODL International Review of research in open and distance learning. Disponível em: <http://www.irrodl.org/index.php/irrodl/article/view/890>. Acesso em: 10 Jan.2013.

ANDRÉ, M.E. Etnografia da prática escolar. Campinas: Cornacchia Livraria e Editora, 1995.

ARANTES, P. Arte e mídia: perspectivas da estética digital. São Paulo: SENAC, 2005.

ARAÚJO, A.R.F de. "Os cursos superiores de formação de professores de Artes Visuais no Brasil: percursos históricos e desigualdades geográficas". In: Anais da 32 ${ }^{\mathrm{a}}$. Reunião Anual da ANPED. Caxambu, 04 a 07 de outubro de 2009. GT 24. Educação e Arte. Disponível em: $<$ http://www.anped.org.br/reunioes/32ra/arquivos/trabalhos/GT24-5360--Int.pdf > .

Acesso em: 30 Abr.2012. 
. "Políticas educacionais para o Ensino de Artes". p. 15-17. Disponível

em: $<$ http://issuu.com/design.ead/docs/1 politicas educacionais para o Ensino de artes>. Acesso em: 30 Abr.2012.

ARAÚJJO, I.A. "Formação de professores e Tecnologias da Informação e da Comunicação: professor, você tem medo de que? In: Revista Vertentes. n. 35. v. 1. 27 mar. 2010. Disponível em: <http://www.ufsj.edu.br/portal2repositorio/File/vertentes/Vertentes 35/ivanildo amaro.pdf>. Acesso em 15 Nov.2013.

ARETIO, L.G. Educación a distancia hoy. Madrid: UNED, 1994. APUD IBÁNEZ, R.M. A Educação à Distância: Suas modalidades e economia. Tradução de Ivana de Mello Medeiros e Ana de Lourdes Barbosa Castro. Rio de Janeiro: UCB, 1996. p. 10.

ARGENTINA(1). Ministério de Educación de Argentina. Educación Inicial. Disponível em: <http://www.mapaeducativo.edu.ar/Atlas/inicial>. Acesso em: 15 Nov.2013.

(2). Educación Primaria. Disponível em: $<$ http://www.mapaeducativo.edu.ar/Atlas/primaria $>$. Acesso em: 15 Nov.2013.

(3). Educación Secundaria. Disponível em: <http://www.mapaeducativo.edu.ar/Atlas/secundaria $>$. Acesso em: 15 Nov.2013.

(4). Educación Superior. Disponível em: $<$ http://www.mapaeducativo.edu.ar/Atlas/superior $>$. Acesso em: 15 Nov.2013.

(5). Educación Artistica. Disponível em: $<$ http://portal.educacion.gov.ar/modalidades/educacion-artistical>. Acesso em: 25 Nov.2013.

(6). Más información sobre Educación Superior. Disponível em: $<$ http://www.mapaeducativo.edu.ar/images/stories/men/info superior.html>. Acesso em: 15 Nov.2013.

(7). Universidades e Institutos Universitarios. Disponível em: $<$ http://www.mapaeducativo.edu.ar/Atlas/Universidades-e-Institutos $>$. Acesso em: 15 Nov.2013.

8). Red Nacional Virtual de Institutos Superiores de Formación Docente - RED Infod. Disponível em: <http://red.infd.edu.ar/lared.php>. Acesso em: 25 de Nov. 2013.

(9). Políticas de formação docente na Argentina. Disponível em: $<$ http://portales.educacion.gov.ar/infd/>. Acesso em: 25 Nov.2013. 
(10). Relevamiento Anual 2010. DiNIECE. Ministerio de Educación. Cartografia: Programa Nacional Mapa Educativo 2012.

(11). Ministerio de Educación. Servicio de Educación a Distancia. Disponível em: <http://www.me.gov.ar/curriform/sead.html>. Acesso em: 25 Nov.2013.

(12). Ministerio de Educación. Servicio de Educación a Distancia. Disponível em: <http://www.me.gov.ar/curriform/sead.html>. Acesso em: 25 Nov.2013.

AUDI, R. Diccionario Akal de Filosofía. Trad. Humberto Marraud Y Enrique Alonso. Madrid: Ediciones Akal, 2004.

BAILEY, F. et al. Language Teacher Educators Collaborative conversations. Tesol Quarterly. v. 32, n. 3. Autumn, 1998.

BARBOSA, A.M.T.B. e CUNHA, F.P. (Org.) Abordagem triangular no Ensino das Artes Visuais e culturas visuais. São Paulo: Cortez, 2010.

BARBOSA, A.M.T.B. A imagem no Ensino da Arte: anos 1980 e novos tempos. $7^{\text {a }}$. ed. São Paulo: Perspectiva, 2010.

. A imagem no Ensino da Arte. São Paulo:Perspectiva, 1996. Série Estudos, ${ }^{a}$ ed. Reimpressão.

- "Dilemas da Arte/Educação como mediação cultural em namoro com as tecnologias contemporâneas". In: BARBOSA, A.M.T.B. (Org.). Arte/Educação contemporânea: consonâncias internacionais. São Paulo: Cortez, 2005. \#2. p. 98112.

- (Org.). História da Arte-Educação. A experiência de Brasília. I Simpósio Internacional da Arte-Educação. ECA/USP. São Paulo: Max Limonad, 1989.

2012.

Anotações de reunião de orientação de pesquisa de doutorado. Mai. . Anotações de reunião de orientação de pesquisa de doutorado. Jan. 2014.

BARBOSA, A.M.T.B. \& COUTINHO, R.G. "Ensino da Arte no Brasil: Aspectos históricos e metodológicos". In: Rede São Paulo de Formação Docente. Cursos de Especialização para o quadro do Magistério da SEESP Ensino Fundamental II e Ensino Médio. São Paulo, 2011.

BARANAUSKAS, C.; ROCHA, H.V.; MARTINS, M.C. e D'ABREU, J.V. "Uma taxonomia para Ambientes de Aprendizado Baseados no Computador". In: 
VALENTE, J.A. O computador na sociedade do conhecimento. Campinas: UNICAMP/NIED, 1999.

BELL, F. "Connectivism: its place in theory-informed research and innovation in technology-enabled learning". In: IRRODL International Review of research in open and distance learning. Disponível em: <http://www.irrodl.org/index.php/irrodl/article/view/902/>. Acesso em: 10 Jan.2013.

BELLONI, M.L. Educação a Distância. Campinas: Autores Associados, 1999.

BLIKSTEIN, P. \& ZUFFO, M.K. As sereias do Ensino eletrônico. In: SILVA, M. (Org.). Educação on-line. São Paulo: Loyola, 2003. p. 23-38.

BORDENAVE, J.D. TelEducação ou Educação a Distância: fundamentos e métodos. Editora Vozes: Petrópolis, 1987.

BRANDÃO, C.M.M \& SANTOS, D.P. "A formação docente em Artes Visuais mediada pelas novas tecnologias: anotações de um projeto em desenvolvimento". In: HUMMES, J.M. (Org.) Anais do 6을 Encontro de Pesquisa em Arte. Montenegro Ed. da Fundarte, 2011. p. 85-90.

BRASIL(1). Lei de Diretrizes e Bases da Educação. Brasília, 1999.

(2). Ministério da Educação. Regulamentação da EaD no Brasil. Disponível em: <http://www.mec.gov.br>. Acesso em: 13 Out.2010.

(3). Pró-Licenciatura. S/d. Disponível em: $<$ http://portal.mec.gov.br/index.php?Itemid=708\&id=12349\&option=com content\& view=article $>$. Acesso em: 05 Nov.2013.

(4). Diretrizes Curriculares Nacionais dos Cursos de Graduação em Artes Visuais. Resolução no 1, de 16 de janeiro de 2009. Disponível em: <http://www.mec.gov.br>. Acesso em: 13 Out.2010.

(5). Diretrizes Curriculares Nacionais para a Formação de Professores da Educação Básica. Resolução CNE/CP no 1, de 18 de fevereiro de 2002. Disponível em: <http://portal.mec.gov.br/cne/arquivos/pdf/rcp01 02.pdf>. Acesso em: 13 Out.2010.

(6). Diário Oficial da República Federativa do Brasil. Educação à distância. Decreto no 2.494, de 10 de fevereiro de 1998. Disponível em: <http://www.mec.gov.br/sesu/ftp/decreto/d 2.494.doc>. Acesso em: 03 Dez.2000.

(7). Ministério da Cultura. Nuvem de Tags. Disponível em <http://www.cultura.gov.br/site/o-que-e-nuvem-de-tags >. Acesso em: 13 Out.2010.

(8). Universidade Aberta do Brasil - UAB. Disponível em: $<$ http://uab.capes.gov.br/index.php?option=com content\&view=article\&id=6:0que-e\&catid=6:sobre\&ltemid=18>. Acesso em: 01 de Mai.2012. 
(9). Decreto ํo 5.800, de junho de 2006. Dispõe sobre o Sistema Universidade Aberta do Brasil - UAB. Disponível em: $<$ http://www.planalto.gov.br/ccivil 03/ Ato2004-2006/2006/Decreto/D5800.htm>. Acesso em: 01 Mai.2012.

(10). Sistema Nacional de Formação de Professores. Disponível em: $<$ http://portal.mec.gov.br/index.php?option=com content\&view=article\&id=232\&lte mid=459 $>$. Acesso em: 01 Mai.2012.

(11). Decreto № 2.494, de 10 de fevereiro de 1998. Regulamenta o Art. 80․․ LDB (Lei n.ำ 9.394/96).

(12). Constituição da República Federativa do Brasil.: Texto constitucional promulgado em 5 de outubro de 1988, com alterações adotadas pela Emendas Constitucionais no1/92 a 43/2004 e pelas Emendas Constitucionais de Revisão o 1 a 6/94 - Brasília: Senado Federal. Subsecretaria de Edições Técnicas, 2004.2 Disponível em: $<$ http://www.planalto.gov.br/ccivil 03/constituicao/constituicao.htm>. Acesso em: Acesso em: 01 Mai.2012.

(13). CAPES. Governo Federal institui política nacional de formação de professores. Disponível em: <http://www.capes.gov.br/servicos/sala-deimprensa/36-noticias/2523-governo-federal-institui-politica-nacional-de-formacaode-professores->. Acesso em: 01 mai.2012.

(14). PNE - PLANO NACIONAL DE EDUCAÇÃO. Brasília: 2001.
(15).
MEC.
PARFOR.
Disponível

em:<http://freire.mec.gov.br/index/principal>. Acesso em: 14 Jan.2014.

BROWN, J. Dean Understanding research in second language learning. Cambridge University Press, 1983.

. Douglas Teaching by principles. Pearson Education, 2001.

BUENOS AIRES Ciudad. Adulto 2000. Disponível em: $<$ http://www.buenosaires.edu.ar/areas/educacion/adultos2000/index.php $>$.Acesso em: 26 Nov.2013.

CAETANO, A.C.M. "Objetos de Aprendizagem em Artes Visuais". In: IV Congreso de la CiberSiciedad 2009. Crisis analógica, futuro digital. Grupo de trabajo A-7: Enseñanza de competencias digitales a colectivos específicos. Online. 2009. Disponível em: <http://www.cibersociedad.net/congres2009/es/coms/objetos-deaprendizagem-em-artes-visuais/419/>. Acesso em 15 Nov.2012.

CALLEGARO, T. "Ensino da Arte na internet: contexto e pontuações". In: BARBOSA, A. M. (Org.). Inquietações e mudanças no Ensino da Arte. São Paulo: Cortez, 2007. \#12. p. 139-49. 
CAMPELLO, S.M.C.R. Educação em Arte: uma proposta de formação continuada dos professores de Arte por meio das tecnologias de informação e comunicação. Dissertação de Mestrado. Programa de Pós-Graduação em Artes. Universidade de Brasília. Brasília, 2003.

"O Ensino de Arte no ciberespaço: a proposta metodológica do curso Arteduca". In: BARBOSA, A.M.T.B. \& CUNHA, F.P. (Org.). Abordagem triangular no Ensino das Artes Visuais e culturas visuais. São Paulo: Cortez, 2010. p. 381409.

CARMO, H. Ensino Superior a Distância, v. I e II. Lisboa: Universidade Aberta, 1997.

CASTRO. C.M. "A difícil escalada no rumo da universidade". In: Planejamento e desenvolvimento. Brasília. v. 01. n. 10 p. 12-15, Abr.1974.

CASTRO, M.L.O. "Brasil e Argentina: estudo comparativo das respectivas leis gerais sobre Educação". In: textos para discussão 32. Brasília, junho / 2007. Disponível em: $<$ http://www12.senado.gov.br/senado/institucional/atribuicoes?orgao=49/textos di scussao $>$. Acesso em: 25 Nov.2013.

1998.

. A Educação na Constituição de 1988 e a LDB. Brasília, André Quicé,

CASTELLS, M. A sociedade em rede. A era da informatização: Economia, sociedade e cultura. $2^{\text {a }}$. ed. V.I. São Paulo: Paz e Terra, 1999.

. La Sociedad Red. Madrid: Alianza, 1998. (La era de la información: economia, sociedad y cultura. v. 1).

. The Internet galaxy. Oxford: Oxford University Press, 2001.

CEUNES, UFES. Estruturas de suporte ao Ensino a Distância na UFES. Disponível em: $<$ http://www.ceunes.ufes.br/conteudo.asp?cod=1183 > Acesso em: 01 mai.2012.

CHAVES, E. Ensino à distância: Conceitos Básicos. Disponível em: <http:/www.edutecnet.com.br>. Acesso em: 16 mar.2001.

CIRIGLIANO, M. Dinámica de Grupos Y Educación: Fundamentos Y Tecnicas. Edifícios Administrativos. v.11. OIT, Buenos Aires: Humanitas, 1983. p. 175.

COLI, J. O que é Arte. 2ª reimpressão. São Paulo: Editora Brasiliense, 1977.

CUNHA, F.P. "e-Arte/Educação crítica". In: BARBOSA, A.M.T.B. \& CUNHA, F.P. (Org.) Abordagem triangular no Ensino das Artes Visuais e culturas visuais. São Paulo: Cortez, 2010. p. 259-281. 
Cultura Digital na e-Arte/Educação: Educação Digital Crítica. Tese de doutorado. São Paulo: USP, 2008.

CUNHA, R.M.R.; BRAZ, S.G.; DUTRA, P.O. \& CHAMON, E.M.Q.O. Os recursos tecnológicos como potencializadores da interdisciplinaridade no espaço escolar. In: The 4th International Congress on University-Industry Cooperation - Taubate, SP - Brazil - December 5th through 7th, 2012.

DEMO, P. (1) Tecnologia Educacional v.26 (143) Out./Dez. 1998.

(2) Questões para a telEducação. Petrópolis: Vozes, 1998.

DEFOURNY, V. "Apresentação". In: GATTI, B.A. \& BARRETO, E.S.S. Professores do Brasil: impasses e desafios. Brasília: UNESCO, 2009.

DÍAZ, A.M. "La Ley de Internet". In: Fundação Telefonica. Disponível em: <http://fundacaotelefonica.org.br>. Acesso em: 12 Nov.2012.

DIDONET, V. Plano nacional de Educação. Disponível em: $<$ http://www.artmed.com.br/patioonline/fr conteudo patio.php?codigo $=436 \&$ secao $=54 \&$ pai $=53 \mathrm{P}$. Acesso em: 15 Nov.2005.

DOMINGUES, D. Criação e interatividade na ciberarte. São Paulo: Experimento, 2002.

EGREJA, J.J.C.; MACHADO, M.J \& SILVA, V.A. "A Educação a Distância na perspectiva transdisciplinar: a contribuição das disciplinas de Laboratório de Pesquisa no curso de Pedagogia". In: CINTED-UFRGS Novas Tecnologias na Educação. v. 07. n. 03. Dez.2009.

EID, J.P. Formação de professores de música a distância: um survey com estudantes da UAB/UNB. Dissertação de mestrado. UNB. 2011.

FACUNDO, A. "Tecnologías de información y comunicación y educación superior virtual en Latinoamérica y el Caribe: Evolución, características y perspectivas", Instituto Internacional para la Educación Superior en América Latina y el Caribe, IESALC / UNESCO, Bogotá, oct.2004. p. 0145. Disponível em <http://www.iesalc.unesco.org.ve>. Acesso em 26 nov.2013.

FNDE. Fundo Nacional de Desenvolvimento da Educação. Resolução/CD/FNDE n. 34, de 09 de agosto de 2005. Disponível em: $<$ http://www.fnde.gov.br/fnde/legislacao/resolucoes/item/4185resolu\%C3\%A7\%C3\%A3o-cd-fnde-n\%C2\%BA-34,-de-9-de-agosto-de-2005> Acesso em: 05 nov.2013. 
(2) Portaria no 07, de 22 de fevereiro de 2006. Disponível em: $<$ http://portal.mec.gov.br/seb/arquivos/pdf/Proletr/prolicen rf.pdf> Acesso em: 05 Nov.2013.

FUSARI, M.F.R. e FERRAZ, M.H.C.T. Arte na Educação escolar. São Paulo:Cortez, 1993. 2ª ed., revisada.

FREIRE, P. Pedagogia da esperança: um reencontro com a Pedagogia do Oprimido. Rio de Janeiro: Paz e Terra, 1992. (Original de 1921).

Ação cultural para a liberdade e outros escritos. 8ª . ed., São Paulo: Paz e Terra, 1987.

GATTI, B.A. \& BARRETO, E.S.S. Professores do Brasil: impasses e desafios. Brasília: UNESCO, 2009.

GATTI, B.A. "Formação de professores no Brasil: características e problemas". In: Educação e Sociedade. v. 31 n. 113, Campinas Out./Dec. 2010. p. 1355-1379. Disponível em: <http://dx.doi.org/10.1590/S0101-73302010000400016>. Acesso em: 11 Dec.2013.

. Os Agentes Escolares e o Computador no Ensino. Acesso. São Paulo:Edição Especial, 1993. p. 22-27.

GOMEZ, M.V. Avaliação formativa e continuada baseada na Internet. Disponível em:

$<$ http://www.abed.org.br/antiga/htdocs/paper visem/margarida vitoria gomez.htm >. Acesso em: 13 Out.2000.

HARASIM, L.; HILTZ, S.; TELES, L. \& TUROF, M. Learning networks: a field guide to teaching and learning on-line. Cambridge, Massachusetts:MIT Press, 1995.

HARASIM, L. "On-Line education: an environment for collaboration and intellectual amplification". In: HARASIM, L. On-Line education: perspectives on a new environment. New York: Praeger, 1990. p. 39-64.

HERMANN, R. Wilfer. In: Blog Querido Leitor. Disponível em: <http://queridoleitor5.zip.net/>. Acesso em 12 Abr.2007.

HOFFMANN, J. Avaliação: Mito e Desafio. Uma perspectiva construtivista. Porto Alegre: Mediação, 1991.

HOLMBERG, B. "Status and Trends of Distance Education". $2^{\text {nd }}$ Edition. Sweden:Sector Publishing, 1985. In: Revista Iberoamericana de Educación Superior a Distancia. v. 01. n. 03. Jun.1989. 
IDE. Institute for Distance Education. A conceptual Planning Tool. 1997. University System of Maryland Institute for Distance Education. Disponível em: $<$ http://www.umuc.edu/ide/modlmenu.html>. Acesso em: 20 Mar.2000.

INEP. Instituto Nacional de Pesquisas Educacionais Anísio Teixeira. "Censo da Educação Superior 2011: resumo técnico". Brasília: Instituto Nacional de Estudos e Pesquisas Educacionais Anísio Teixeira, 2013.

- Instituto Nacional de Pesquisas Educacionais Anísio Teixeira. "Censo da Educação Superior 2012: resumo técnico". Brasília: Instituto Nacional de Estudos e Pesquisas Educacionais Anísio Teixeira, 2013.

IRWIN, R. A/r/tografia: uma mestiçagem metonímica. In BARBOSA, A.M.T.B. \& AMARAL, L. Interterritorialidade. Mídias, contextos e Educação. São Paulo: SESCSP/SENAC, 2008.

JAPIASSU, H. \& MARCONDES, D. Dicionário Básico de Filosofia. 2ª . ed., Rio de Janeiro: Jorge Zahrar, 1993.

JONASSEM, D. "Applications and limitations of hypertext technology for distance learning". In: Distance Learning Workshop. San Antonio, Texas: Armstrong Laboratory, 1992. APUD SÁ, P.S.S. Dissertação de Mestrado. Orientação de MOREIRA, D.A. Apresentada ao programa do Instituto de Matemática e de Computação de São Carlos - USP - 2000. p. 33. Disponível em: $<$ http://java.icmc.sc.usp.br/research/master/Paulo Sa/tese.pdf>. Acesso em: 12 Dez.2002.

KEEGAN, D.J. Foundations of distance education. 2ª ed. Londres: Routledge, 1996, p. 11. APUD NUNES, I.B. "Noções de Educação à distância". In: Revista Educação a Distância. Brasília: Instituto Nacional de Educação a Distância. Dez.1993/Abr.1994. n. 04 e 05. p. 07-25. Disponível em: <http://www.intelecto.net/ead/ivonio1.html>. Acesso em: 29 Nov.1999.

KER, B. "A Challenge to connectivism. Transcript of keynote speech". In: On-line Connectivism Conference, University ou Manitboa, Fev.2007. Disponível em: $<$ http://ltc.umanitoba.ca/wiki/index.php?title=Kerr Presentation $>$. Acesso em: 10 Jan.2013.

KOP, R. \& HILL, A. Connectivism: Learning theory of the future or vestige of the past? Oct. 2008. Disponível em: $<$ http://www.irrodl.org/index.php/irrodl/article/view/523/1103>. Acesso em: 10 Jan.2013.

LAPA, A. \& PRETTO, N.L. "Educação a Distância e precarização do trabalho docente". In: Em Aberto. Brasília, Nov.2010. v. 23, n. 84. p. 79-97.

LEIDNER, D.E. \& JAVENPAA, S.L. The use of information techonology to enhance management school education: a theoretical view. MIS Quartely. Sep.1995. p. 265291. 
LEMOS, A. Arte Eletrônica e Cibercultura. 1999. Revista da FAMECOS, n. 06, "Tecnologias do Imaginário", PUC-RS, Porto Alegre, 1997. Disponível em: $<$ http://www.cac.ufpe.br/labvirt/aulas/9801b/ARTE.HTM>. Acesso em: 01 Mar.1999.

Anjos Interativos e retribalização do mundo. Sobre interatividade e interfaces $\quad$ digitais. $1999 . \quad$ Disponível em:<http://www.facom.ufba.br/ciberpesquisa/lemos/interac.html>. Acesso em: 01 Mar.1999.

LÉVY, P. As tecnologias da inteligência: o futuro do pensamento na era da informática. Rio de Janeiro: Editora 34, 1993.

LIMA, M.R. \& LEAL, M.C. "Ciberpedagogia: indicativos para o rompimento com a lógica da transmissão". In: In: Revista Vertentes. n. 35. v. 01. 28 Abr.2010. Disponível em: <http://www.ufsj.edu.br/portal2repositorio/File/vertentes/Vertentes 35/ivanildo amaro.pdf>. Acesso em: 15 Nov.2013.

LLAMAS, J.L.G. Educação à distância: conceituação. Disponível em: <http:// www.cciencia.ufri.br/educnet/EDUAD.HTM> Acesso em: 23 Mai.1999.

LOBO NETO, F.J.S. Educação à distância: regulamentação, condições de êxito e perspectivas. Disponível em: <http://www.intelecto.net/ead textos/lobo1.htm>. Acesso em: 03 Dez.2000.

LOYOLLA, W.P. e PRATES, M. Educação à distância Mediada por Computador (EDMC) - Uma Proposta Pedagógica. Disponível em: <http://www.puccamp.br/ prates/edmc.html>. Acesso em: 01: Mar.1999.

LONGUINI, M.D. e NARDI, R. "Uma pesquisa sobre a prática reflexiva na formação inicial de professores de física". In: ENSAIO - Pesquisa em Educação em Ciências. v. 04, n. 02, Dez.2002.

MACHADO, J. O sujeito na tela: modos de enunciação no cinema e no ciberespaço. São Paulo: Paulus, 2007.

MAIO, A.Z.F. \& DUTRA, L.F. Da janela da alma ao ciberespaço: Ambiente virtual de aprendizagem em Artes Visuais. In: Revista Digital do LAV - Laboratório de Artes Visuais - Revis LAV. Ano I. n. 01. 2008.

MARIOTTI, H. Os operadores cognitivos do pensamento complexo, 2005. Disponível em: <http://www.geocities.com/pluriversu>. Acesso em: 24 Set.2009.

MASON, R. Models of Online Courses. Networked Lifelong Learning: Innovative Approaches to Education and Training Through the Internet. edited by L. Banks, C. Graebner and D. McConnell. University of Sheffield, 1998. ALN Magazine v. 02, Issue

02.

Oct.1998.

Disponível

em: 
$<$ http://www.aln.org.alnweb/magazine/vol2 issue2/Masonfinal.htm>. Acesso em: 08 Jan. 1999.

MATTELART, A. História da sociedade da informação. São Paulo:Loyola, 2001.

MATTAR, J. \& VALENTE, C. Second life e web 2.0 na Educação: o potencial revolucionário das novas tecnologias. São Paulo: Novatec, 2007.

MATTAR, J. Tutoria e integração em Educação a Distância. Série Educação e Tecnologia. São Paulo: Cengage Learning, 2012.

(1). Three generations of distance education pedagogy. In: De Mattar. 23 Mar.2012. Disponível em: <http://joaomattar.com/blog/2012/03/23/threegenerations-of-distance-education-pedagogy/>. Acesso em: 28 Jan. 2014.

MEDEIROS, J.A. "Formação e qualificação dos arte-educadores no Brasil: caminhos e descaminhos". In: Anais do $20^{\circ}$ Congresso da Federação de Arte/Educadores do Brasil, ConFAEB. Goiânia, Nov.2010. p. 86-104. CD ROM.

MEIGUINS, B.S. Uso de Realidade Virtual em Ensino à Distância Mediado por Computador. Dissertação de mestrado. Orientação de BEHRENS, F.H. Instituto de Informática da PUC Campinas. Área de Concentração: Sistemas de Informação. Campinas, 1999. Disponível em: <http://www.puccampinas.edu.br/ceatec/inst/sistel/dissertacoes.htm>. Acesso em: 31 Jul.2002.

MELO, P.A. \& LUZ, R.J.P. A formação docente no Brasil. Florianópolis: 2005.

MOORE, M.G. \& KEARSLEY, G. Distance Education - A System view. CalifórniaUSA: Wadsworth Publishing, 1996.

MORAES, S.M. Aprender a ouvir o som das águas: o projeto poético-pedagógico do professor de arte. (Dissertação de mestrado). Faculdade de Educação da Universidade de São Paulo, 2002.

MORAIS, F. Arte é o que eu e você chamamos arte. Rio de Janeiro: Record, 2002.

MORRIN, E.; NICOLESKU, B. \& LIMA DE FREITAS. Carta da Transdisciplinaridade. Convento de Arrábida, Portugal, 2-6 novembro, 1994. Disponível em: $<$ http://www.universidadedoespirito.org/index.php?option=com content\&view=cate gory\&layout=blog\&id=48\&ltemid=66> $>$. Acesso em: 26 Jun.2010.

MUGRIDGE, I. Collaboration in Distance Education. Oxford:Routledge, 1993.

MUNDIM, K.C. "Ensino a Distância no Brasil: problemas e desafios". In: Desafios da Educação a Distância na formação de professores. Brasília: Ministério de Educação, SEED, 2006. p. 119-126. 
NEGROPONTE, N. A Vida Digital. São Paulo: Companhia das Letras, 1995.

NICOLESCU, B. "A Visão do que há Entre e Além, entrevista a Antónia de Sousa”. In: Diário de Notícias, Caderno Cultura, Lisboa, 03 Fev.1994. p. 02-03.

NOVATEC. Resenha. Disponível em <https://novatec.com.br/livros/gestaoead/>. Acesso em: 14 de Jan.2014.

NUERE, S. E-lerning y educación artística: hacia a la enseñanza virtual de las artes visuales. Revista Arte, Individuo y Sociedad, v. 14, 2002. p. 79-103.

NUNES, I.B. "Pequena Introdução à Educação a Distância". In: Educação a Distância. n. 01. Brasília: INED, Jun.92

. "Noções de Educação à Distância". In: Revista Educação à Distância. n. 04-05, Dez./93-Abr/94 Brasília, Instituto Nacional de Educação a Distância. p. 07-25. Disponível em: <http://www.intelecto.net/ead/ivonio1.html>. Acesso em: 29 Nov.1999.

NUNES FILHO, P. "Processos de Significação hipermídia, ciberespaço e publicações digitais". In: Fórum Mídia 6. Revista do Curso de Comunicação Social - ISPV - ESEV. v. 1, n. 6. 2003. IPV - Instituto Politécnico de Viseu. Disponível em: <http://www.ipv.pt/forumedia/6/default.htm>. Acesso em: 19 Jun.2011.

OLIVEIRA, A.M.; FONSECA, T.M.G. e BIAZUS, M.C.V. O uso da web em produção multimídia na área de Artes Visuais. Revista Informática na Educação: teoria \& prática. Porto Alegre, Jan./Jun. 2007. v. 10. n. 01.

OTT, R. "Ensinando Crítica nos Museus". In: BARBOSA, A. M. (Org.) ArteEducação: Leitura no subsolo. 3․․ Ed. São Paulo:Cortez, 2001. p. 113-141.

PEREIRA, J.E.D. "As licenciaturas e as novas políticas educacionais para a formação docente". In: Educação \& Sociedade. Ano XX. n. 68. Dez.1999. p. 109125.

. "As licenciaturas e as novas políticas educacionais para a formação docente". In: Educ. Soc. v. 20 n. 68 Campinas Dec. 1999. Disponível em: $<$ http://dx.doi.org/10.1590/S0101-73301999000300006>. Acesso em: 19 Jun.2011.

PERRATON, H. "A theory for distance education II". In: SEWART, KEEGAN, \& HOLMBERG (ed.). Distance education: International perspectives. New York:Routledge, 1988. p. 34-45.

PERRENOUD, P. "Formar Professores em contextos em mudança. Prática reflexiva e formação crítica”. In: Revista Brasileira de Educação, Set/Out/Nov/Dez 1999. p. 05-21. Trad. Denice Barbara Catani. 
L'Harmattan, 1994.

. La formation des enseignants entre théorie et pratique. Paris: . Dez Novas Competências para Ensinar. Porto Alegre: Artes Médicas, 2000.

PERRY, W. e RUMBLE, G. A Short Guide to Distance Education. Cambridge:International Extension College, 1987. Disponível em: $<$ http://wbweb5.worldbank.org/disted/Management/Operations/sch-03.html>. Acesso em: 09 Jun.1999.

PIAGET, J. Estudos sociológicos. Rio de Janeiro: Forense, 1973.

PICONEZ, S.B. "Projeto de Lei do Plano Nacional de Educação (PNE 2011/2020)". In: Educação e tecnologia. Post de Blog. 20. Jan.2014. Disponível em: <http://stelapiconez.blogspot.com.br/2014/01/projeto-de-lei-do-plano-nacionalde.html>. Acesso em: 20 Jan.2014.

PIMENTEL, L. G. "Formação de professor@s: Ensino de Arte e Tecnologias Contemporâneas". In: Anais do I Congresso de Educação, Arte e Cultura. Anais. Santa Maria: UFSM, 2007.

. Tecnologias contemporâneas e o Ensino da Arte. In: BARBOSA, A. M. (Org.). Inquietações e mudanças no Ensino da Arte. São Paulo: Cortez, 2007. \#10. p. 113-121.

PITARELLO, A.; SAMPAIO, J.L.F.; SUZUKI, C. \& TRAMUJAS, S. Quadro de síntese conceitual. Trabalho apresentado à disciplina CAP5048-3: Professores de arte: formação e pratica educativa. Prof $^{a}{ }^{a} r^{a}{ }^{a}$ Sumaya Mattar Moraes. ECA/USP, 2010.

PRADO, M. E. B. B e VALENTE, J. A. "A Educação a Distância possibilitando a formação do professor com base no ciclo da prática pedagógica”. In: Moraes, M. C. Educação a Distância: fundamentos e práticas. OEA/MEC, Unicamp, NIED, 2002.

RHEINGOLD, H. apud. TAPSCOT, T \& WILLIAMS, A.D. Wikinomics: Como a colaboração em massa pode mudar seu negócio. Rio de Janeiro: Nova Fronteira, 2006.

RHEINGOLD, $H$. The Virtual Community. Disponível em: $<$ http://www.rheingold.com/vc/book>. Acesso em: 03 Dez.1999.

. La Comunidad Virtual: Una Sociedad sin Fronteras. Gedisa Editorial. Colección Limites de La Ciência. Barcelona, 1994.

ROCHA, E.C.de F. Problematizando a Inclusão Digital. XXIX Congresso Brasileiro de Ciências da Comunicação - UnB, Intercom, 2006. Disponível em: 
<http://www.intercom.org.br/paperS/Nacionais/2006/resumos/R1197-1.pdf> Acesso em: 11 Out.2011.

RODRIGUES, F. "Das utopias à realidade: é possível uma didática específica para a formação inicial do professor de Artes Visuais?” In: BARBOSA, A.M.T.B. \& CUNHA, F.P. (Org.) Abordagem triangular no Ensino das Artes Visuais e culturas visuais. São Paulo: Cortez, 2010.

. Cultura digital na E-arte/Educação: Educação digital crítica. Tese de doutorado. 277p. Universidade de São Paulo, São Paulo, 2008.

RODRIGUES, R.S. \& BARCIA, R.M. Modelos em Educação a Distância. Disponível em: < http://www.nead.ufmt.br/publicacao/.../Modelos de EAD Rosangela09.doc >. Acesso em 15 Nov.2013.

ROSA, M. C. A Educação de professoras e professores de arte: construindo uma proposta de Ensino Multicultural a distância. 187p. Tese de doutorado. Universidade Federal de Santa Catarina, Florianópolis, 2004.

A Educação inclusiva de professores de arte a distância: possibilidades e conflitos. In: Revista do Centro de Educação. Edição: 2006. v. 31. n. 02.

. "Formação de professores de arte e perspectivas de atuação política". In: Anais do II Simpósio da Licenciatura em Artes Visuais da FAP e do II Encontro Regional da Federação de Arte/Educadores da Região Sul. 23 a 27 Ago. 2010. Faculdade de Artes do Paraná. Disponível em: $<$ http://www.fap.pr.gov.br/arquivos/File/extensao/2-ENREFAEB 3-SimposioAV/02MariaCristinadaRosa.pdf>. Acesso em: 01 Fev.2012.

ROWNTREE, D. Aprenda a Estudiar. Barcelona: Herder, 1976.

SAMPAIO, H. Evolução do Ensino Superior brasileiro, 1908 - 1990. NUPES, USP, 1991.

SAMPAIO-RALHA, J.L.F. \& ARAÚJO, A.R.F. "Desenvolvimento de Competências no Ensino de Arte: Soluções ou Provocações?". Anais do XIV ConFAEB - Arte e Educação: Culturas do Aprender e do Ensinar. Goiânia: ConFAEB, 2003.

SAMPAIO-RALHA, J.L.F. Uso de Realidade Virtual por VRML para Educação a Distância em Arte. Dissertação de mestrado defendida em 2003 no programa de Pós-Graduação Stricto Senso da Universidade Estadual Paulista UNESP, sob orientação do Prof. Dr. Milton Sogabe. Disponível em: $<$ http://www.athena.biblioteca.unesp.br/exlibris/bd/bia/33004013063P4/2003/ralha jlfs >. Acesso em: 01 Mai.2013.

"Comunidades Virtuais - O que é, para que serve, porque usar; como usar e como não usar". In: MORAES, Ubirajara Carnevale. (Org.) Tecnologias 
Educacionais e Aprendizagem: Estratégias no uso dos recursos Digitais. 1a. ed. São Paulo: Livro Pronto, 2007. v. 1. p. 167-182.

"Educação à distância em arte: Licenciatura à distância. Professores, tutores etc.: Formação para Lecionar arte em ambiente virtual. Atividades presenciais: Obrigatórias? Necessárias? Tecnologias digitais e uso pedagógico em arte". In: Congresso Ibero-Americano de Educação Artística: SentidosTransibéricos, 2008, Beja. Anais do Congresso Sentidos Transibéricos. Beja: APECV - Associação de Professores de Expressão e Comunicação Visual, 2008. v.1. p.1.

. "O que se ensina e o que se aprende nas licenciaturas em Artes Visuais a distância?" In: Anais do $20^{\circ}$. ConFAEB - Congresso da Federação dos Arte/Educadores do Brasil. Goiânia: UFG, 2010. v.1. p. 2241-2251.

SAMPAIO, J.L.F. Primeiros resultados da pesquisa "O que se ensina e o que se aprende nas licenciaturas em Artes Visuais a distância?". In: ALMEIDA, L.; PINO, I.R.; PINTO, J.M.R. \& GOUVEIA, A.B. (Org.). IV Seminário de Educação Brasileira. PNE em foco: Políticas de responsabilização, regime de colaboração e Sistema Nacional de Educação. 1a. ed. Campinas: CEDES UNICAMP, 2013. v. 01. p. 310-323.

(1). "O que se ensina e o que se aprende nas licenciaturas em Artes Visuais a distância?". In: Divers@! (Matinhos).v. 05. 2012. p. 08-30.

(2). "O que se ensina e o que se aprende nas licenciaturas em Artes Visuais a distância?" In: Anais do I Congresso Brasileiro de Recursos Digitais na Educação. São Paulo: CE@D - UPM, 2012. v.1. CD ROM.

(3). "Educação à Distância On-line em Arte: Professores, tutores, etc.: Formação para Lecionar arte em ambiente virtual. Atividades presenciais: Obrigatórias? Necessárias? Tecnologias digitais e uso pedagógico em arte". In: Congresso Brasileiro de Recursos Digitais na Educação, 2012, São Paulo. Anais do I Congresso Brasileiro de Recursos Digitais na Educação. São Paulo: CE@D UPM, 2012. v. 01. p. CD ROM.

(4). "O que se ensina e o que se aprende nas licenciaturas em Artes Visuais a distância?". In: XXI CONFAEB Congresso da Federação dos Arte/Educadores do Brasil, 2011, São Luís. XXI ConFAEB Anais 2: Textos Completos. São Luís: Editora da UFMA, 2012.

(5). "O que se ensina e o que se aprende nas licenciaturas em Artes Visuais a distância?". In: 20o. ConFAEB - Congresso da Federação dos Arte/Educadores do Brasil, 2010, Goiânia. Anais do 20․ ConFAEB - Congresso da Federação dos Arte/Educadores do Brasil. Goiânia: UFG, 2010. v. 1. p. 2241 2251.

(6). "Você sabe o que é Virtual?" In: Revista de Comunicação da FACOM.-FAAP, 2000. v. 7. p. 22-25. 
(7). "Novas Tecnologias e o Professor de Educação Artística". In: II Whorkshop Sobre Fatores Humanos em Sistemas Computacionais, 1998, Campinas. Atas do II Workshop sobre Fatores Humanos em Sistemas Computacionais. Campinas: Unicamp. p. 37-38.

SAMPAIO, J.L.F. \& DOMINGUEZ, J.A. "Educação a Distância no Brasil: um resgate histórico como base da afirmação de que a democratização do conhecimento com uma EaD de qualidade é possível". In: Tecendo fios na Educação: da informação nas redes à construção do conhecimento mediada pelo professor. 1 ed. Curitiba: Editora CRV, 2012. v.1, p. 95-115.

SANTAELLA, L. Culturas e artes do pós-humano: da cultura das mídias à cibercultura. São Paulo: Paulus, 2003.

SANTOS, M. A natureza do espaço. 2ª . ed. São Paulo: HUCITEC, 1996.

SANTOS, R.P. "Transdisciplinaridade". In: Miniweb. Disponível em: $<$ http://www.miniweb.com.br/educadores/artigos/pdf/transdisciplinaridade.pdf >.

Acesso em: 26 Jun.2010.

SANTOS, W.A. "Ensino de Arte na modalidade à distância: uma proposta e desafios com as tecnologias contemporâneas para uma prática de excelência". In: Revista Solta a voz. V. 18, n. 2, 2007. Disponível em: $<$ http://www.revistas.ufg.br/index.php/sv/article/viewArticle/3416>.

Acesso em: 13 Set.2008.

"Nuevas tecnologías: pintura digital, digitalización y manipulación creativa de la imagen aplicada en la formación del professorado de Educación Artística". In: Revista Solta a Voz. v. 14. p. 19-20. Jul./Dez.2003.

SARAIVA, T. "Educação a Distância no Brasil: lições da história". In: Em Aberto. Brasília, a.16, n.70, p.17, Abr./Jun.1996.

SARDELICH, M.E.; SANTANA, P.; MELO, J.M. "Forma/R/se a distância: aprendendo a ser professor de Artes Visuais em ambientes virtuais de aprendizagem". In: XXII ConFAEB: Arte/Educação - Corpos em Trânsito. 2012 São Paulo. Anais do XXII ConFAEB: Arte/Educação - Corpos em trânsito. São Paulo: UNESP, 2012. v. 01. p. 01-12.

SARDELICH, M.E. "Formação de professores da Educação básica na modalidade a distância: os desafios do século XXI". In: Revista Eletrônica Pesquiseduca. v. 04. n. 07. Jan./jul. 2012. p. 62-84. Disponível em: $<$ http://periodicos.unisantos.br/index.php/pesquiseduca/article/viewFile/161/pdf > .

Acesso em: 15 Nov.2012.

SARRAMONA, J. La enseñanza a distancia, posibilidades y desarrollo actual. Barcelona: CEAC, 1975. APUD TRINDADE, A.R. Fundamentos da Educação a Distância: O panorama conceitual da Educação à distância. Mimeo, 1997. 
SCHLÜNZEN, E.T.M. Escola inclusiva e as novas tecnologias. In: BRASIL, Ministério da Educação. Integração das Tecnologias na Educação. Secretaria de Educação à distância. Brasília: Ministério da Educação, SEED, 2005. p. 80-83.

SCHÖN, D. "Formar professores como profissionais reflexivos". In: NÓVOA, A. (Org.) Os professores e a sua formação. Lisboa: Dom Quixote, 1992. p. 77-91.

. Educando o profissional reflexivo: um novo design para o Ensino e a aprendizagem. Trad. Roberto Cataldo Costa. Porto Alegre: Artes Médicas Sul, 1996 e 2000.

SEABRA, C. Opinião - O que quer, o que pode essa língua. In: A Rede Tecnologia para inclusão social. Disponível em: <http://www.arede.inf.br/edicao-n14-maio-2006/3119-opiniao-o-que-quer-o-que-pode-essa-lingua>. Acesso em: Acesso em: 12 Nov.2013.

SHNEIDERMAN, B. O Laptop de Leonardo: como o novo Renascimento já está mudando a sua vida. Rio de Janeiro: Nova Fronteira, 2006.

SILVA, L.H.A. e SCHNETZLER, R.P. Buscando o caminho do meio: a "sala de espelhos" na construção de parcerias entre professores e formadores de professores de ciência. Ciência e Educação. v. 06. n. 01. 2000. p. 43-53.

SILVA, M. Sala de aula interativa. Rio de Janeiro: Quartet, 2000.

Cibercultura e Educação: a comunicação na sala de aula presencial e online. FAMECOS (on-line), v. 37, p. 69-74, 2008.

SILVA, M.C.R.F.; FRADE, I.N.; RIZZI, M.C.S.L. \& BUJÁN, F. "Observatório da formação de professores de artes: diálogos entre Brasil e Argentina". In: Anais do XXII ConFAEB 2012. Mesa 02. Livro 03. Disponível em: $<$ http://faeb.com.br/livro03/Arquivos/mesas/maria cristina da rosa fonseca da $s$ ilva.pdf >. Acesso em: 15 Nov.2013.

SILVA, M.C.R.F. "Objetos Pedagógicos de Inclusão: uma ação política na formação de professores de arte". In: LAMPERT, J. \& MACÊDO, S.B. (Orgs.) Simpósio de Integração das Artes Visuais: arte e política. Florianópolis, SC. p. 242-257. Disponível em: <http://www.dav.ceart.udesc.br/arquivos/livro dav.pdf >. Acesso em: 01 Mai.2012.

. "Formação de professores de arte e perspectivas de atuação política". In: ANAIS do $2^{\circ}$ Encontro Regional da Federação de Arte Educadores da Região

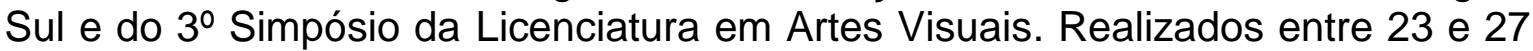
Ago.2010.

SMITH, R. "Excelência no Ensino da Arte". In: BARBOSA, A.M. (Org.) ArteEducação: Leitura no subsolo. 3ạ. ed. São Paulo: Cortez, 2001. p. 97-109. 
STALLIVIER, L. O Sistema de Ensino Superior do Brasil: características, tendências e perspectivas. Acessoria de Relacões Insterinstitucionais e Internacionais, UCS, $2006 . \quad$ Disponível em: $<$ http://www.ucs.br/ucs/tp/Padrao/tplCooperacaoCapa/cooperacao/assessoria/artig os/imprimir/sistema Ensino superior.pdf>. Acesso em: 29 Jan2014.

STENHOUSE, L. La investigación como base de la enseñanza: selección de textos de J. Rudduck y D. Hopkins. Ediciones Morata: Madrid, 1998.

STRONG, R. \& HARMON, G. Online Graduate Dregrees: A Review of Three Internet-based Master's Degree Offerings. The American Journal of Distance Education. v. 11 n. 03. 1997.

TAKAHASHI, T. (Org.) Sociedade da Informação no Brasil: Livro Verde. Brasília: Ministério da Ciência e Tecnologia, 2000. p. 45.

TAPSCOT, T. Wikinomics: Como a colaboração em massa pode mudar seu negócio. Rio de Janeiro: Nova Fronteira, 2006.

TAROUCO, L.M.R. Ensino à Distância no WWW. Disponível em: <http://penta.ufrgs.br/edu/eduwww.html>. Acesso em: 01 Out.1998.

TODOROV, J.C. "A Importância da Educação à Distância". In: Educação à Distância: INED. Brasília. v. 3. n. 04-05. Dez.1993 - Abr.1994. p. 05-06.

TORNAGHI, A. J. C.; PRADO, M. E. B. B.; ALMEIDA, M. E. B. Tecnologias na Educação: ensinando e aprendendo com as TIC: guia do cursista. 2. Ed. Brasília, DF: Secretaria de Educação à distância, 2010.

TÜRCKE, C. Erregte Gesellschaft: philosophie der sensation. München: C.H. Beck, 2002.

UAB - CAPES. Instituições participantes. Disponível em: $<$ http://uab.capes.gov.br/index.php?option=com content\&view=article\&id=13:instit uicoes-participantes\&catid=9:cursos\&ltemid=26>. Acesso em: 19 Mar.2012.

UNIMONTES. CEAD. Disponível em: $<$ http://www.cead.unimontes.br/index.php/uab $>$. Acesso em: Acesso em: 26 de Nov.2012.

UFOP. Universidade Federal de Ouro Preto. Núcleo de Educação aberta e à distância. Evolução do Ensino a Distância. Disponível em: <http://www.nead.ufop.br/EnsinoDistancia.htm>. Acesso em: 20 Out.2001.

UNESCO. Declaración de Quito. Boletín Pryecto Principal de Educación. n. 24, 1991. p. 44-49. 
UNIVERSIDAD Nacional de Mar del Plata - UNMdP. Reseña Histórica. Disponível em: <http://www.mdp.edu.ar/uabierta/info institucional.htm>. Acesso em: 26 de Nov.2013.

UOL. "Formação Docente: A virada na formação". In: Revista Educação. Edição 181. Mai.2012. Capa.

VALENTE, J.A. Pesquisa, comunicação e aprendizagem com o computador. O papel do computador no processo Ensino-aprendizagem. In: BRASIL, Ministério da Educação. Integração das Tecnologias na Educação. Secretaria de Educação à distância. Brasília: Ministério da Educação, SEED, 2005. p. 22-31.

. Notas de aula. Unicamp. Mai.2007.

VAN VELZEN, B.A.M. "Comunicação e Reforma Educacional: Quem Está Ouvindo?" In: Revista Contato. Revista Brasileira de Comunicação, Arte e Educação. Brasília/DF. Ano 01. n. 01. Out./Dez.1998. p. 29-42.

VERHAGEN, P. Connectivism a New Learning Theory? 2006. Disponível em: $<$ http://pt.scribd.com/doc/88324962/Connectivism-a-New-Learning-Theory >.

Acesso em: 10 Jan.2013.

VIANNEY, J.; TORRES, P. \& SILVA, E. A Universidade Virtual no Brasil: os números do Ensino superior a distância no país em 2002. In.: Seminário Internacional sobre universidades virtuais na América latina e caribe. Quito Equador: 13 e 14 Fev.2003.

VIANNEY, J. Universidade Virtual Brasileira. Disponível em: <http://www.rnp.br/tirij/material/Vianney.pdf >. Acesso em: 01 Mai.2012.

VIEIRA, M.B. Uma Proposta de Educação a Distância Mediada por Computador (EDMC) para Cursos de Graduação. Tese de Mestrado. Pontifícia Universidade Católica de Campinas. Programa de Pós-Graduação em Informática. Campinas/SP. Dez.1998.

VYGOTSKY, L.S. A Formação Social da Mente. São Paulo: Martins Fontes, 1989.

WIKIPEDIA, Epistemologia. Disponível em: $<$ http://pt.wikipedia.org/wiki/Epistemologia >. Acesso em: 13 Out.2013.

Ciberativismo digital. Disponível em: <http://pt.wikipedia.org/wiki/Ciberativismo>. Acesso em: Acesso em: 13 Out.2013.

Teorias da aprendizagem. Disponível em: <http://pt.wikipedia.org/wiki/Teorias da aprendizagem >. Acesso em: Acesso em: 13 out.2013.

ZEICHNER, K.M. A Formação Reflexiva de Professores: Ideias e Práticas. Lisboa: Educa, 1993. 
ZUIN, A.A.S. Educação a Distância ou Educação distante? O programa Universidade Aberta do Brasil, o tutor e o professor virtual. Educ. Soc., Campinas, v. 27, n. 96. Especial. p. 935-954, Out.2006. Disponível em: $<$ http://www.cedes.unicamp.br>. Acesso em: 01 Mai.2012. 
ANEXOS 


\section{ANEXO A - QUESTIONÁRIO DA PESQUISA DE PERFIL ALUNOS E EGRESSOS DE CURSOS DE ARTES VISUAIS A DISTÂNCIA}

Todos os dados fornecidos serão usados somente na pesquisa e não serão divulgados.

\section{Dados pessoais / Identificação}

1. Nome:

(Os dados não serão divulgados)

2. Data de nascimento (DD/MM/AAAA)

3. $R G-C P F$

4. Cidade / Estado / Pais de nascimento

5. Cidade / Estado / Pais em que reside atualmente
A. Motivo da mudança?

6. Estado civil:
A. Casado
B. Solteiro
C. Separado/Divorciado

7. Filhos
A. Não tenho filhos
B. 1
C. 2
D. 3
E. Mais de 3 filhos. Quantos?

8. Você é o maior responsável pelos recursos financeiros da família?

9. Se não, qual a sua colaboração?
A. De $0 \% 10 \%$
B. De $10 \%$ a $25 \%$
C. De $25 \%$ a $50 \%$
D. De $50 \%$ a $75 \%$
E. De $75 \%$ a $99 \%$

10. Qual a sua profissão?

11. Se não tivesse esta profissão, no que você gostaria de trabalhar? (Pergunta aberta) Por quê?

12. E-mail / telefone

13. A pesquisadora pode entrar em contato com você para uma entrevista?

Perfil sócio/econômico/Cultural

14. Você mora:
A. Sozinho
B. Com meus pais
C. Com esposa (marido) e filhos
D. Com amigos
E. Hotel/Flat/Pensão 
15. Quantos banheiros há no local em que você mora?
A. 0
B. 1
C. 2
D. 3
E. Mais de três; (Quantos)

16. Quantos quartos há no local em que você mora?
A. 0
B. 1
C. 2
D. 3
E. Mais de três; (Quantos)

17. Assinale quais itens você tem em sua casa e, se existirem, marque as quantidades.

(se não tiver o item, marque o 0 - zero)

A. TV
A. 0
B. 1
C. 2
D. 3
E. Mais de três; (Quantos)

De que tipo?
F. Convencional
G. TV de plasma
H. Outro - Qual?

B. DVD
A. 0
B. 1
C. 2
D. 3
E. Mais de três; (Quantos)

C. Aparelho de som (inclusive MP3 e demais players)
A. 0
B. 1
C. 2
D. 3
E. Mais de três (Quantos)

De que tipo?
F. Convencional (CD/Rádio)
G. TV de plasma
H. Outro - Qual?

D. Máquina fotográfica
A. 0
B. 1
C. 2
D. 3
E. Mais de três; (Quantos)

De que tipo?

F. Convencional 
E. Geladeira
G. Digital profissional
H. Digital amadora
I. Outro - Qual?
A. 0
B. 1
C. 2
D. 3
E. Mais de três; (Quantos)

F. Automóvel
A. 0
B. 1
C. 2
D. 3
E. Mais de três; (Quantos)

G. Geladeira
A. 0
B. 1
C. 2
D. 3
E. Mais de três; (Quantos)

$H$. Telefones (fixo)
A. 0
B. 1
C. 2
D. 3
E. Mais de três; (Quantos)

I. Telefones (celular)
A. 0
B. 1
C. 2
D. 3
E. Mais de três; (Quantos)

De que tipo?

F. Convencional

G. Smarphone

H. IPhone

I. Androide

J. Outro - Qual?

J. Tablet
A. 0
B. 1
C. 2
D. 3
E. Mais de três; (Quantos)

De que tipo?

(questão aberta ou lista de marcas)

K. Computador (inclusive notebooks e netbooks)
A. 1 

B. 2
C. 3
D. Mais de três; (Quantos)

L. Impressora
A. 0
B. 1
C. 2
D. 3
E. Mais de três; (Quantos)

M. De que tipo?
A. Convencional /Doméstica - jato de tinta
B. Laser preto e branca
C. Laser colorida
D. Multifuncional (com Scanner/FAX)
E. Outro-Qual?

\section{Perfil Tecnológico}

18. Acesso a Internet
A. Em casa
B. No trabalho
C. Na escola
D. LanHouse pagas
E. Centros públicos de acesso
F. Outros - Qual?

19. Há quanto tempo você acessa a Internet?
A. Menos de um ano
B. Entre 1 e 2 anos
C. Entre 3 e 5 anos
D. Entre 5 e 10 anos
E. Mais de 10 anos
A. Desde quando?

20. Quantas vezes você a cessa a internet em uma semana?
A. Uma vez por semana
B. De 1 a 2 vezes por semana.
C. Mais de 3 vezes por semana.
D. Diariamente.

21. Quanto tempo você gastar na Internet por dia?
A. Menos de 1 hora diária.
B. De 1 a 2 horas diárias.
C. De 3 a 5 horas diárias.
D. Mais de 5 horas diárias.
E. Conectado 24 horas por dia.

22. Qual o principal motivo de acesso a internet?
A. Fazer o curso.
B. Trabalho.
C. E-mails pessoais.
D. Redes sociais.
E. Lazer e entretenimento. 
F. Pesquisa.

23. Qual(is) desses recursos da Internet você conhece/usa:

(Marque quantas opções desejar em cada item)

A. Navegadores
A. Não uso nenhum.
B. IExplore
C. Chrome
D. Firefox
E. Ópera
F. Outro
1. Qual?

B. Ambientes Virtuais
A. Moodle
B. TelEduc
C. Blackboard
D. Da instituição
E. e-Proinfo
F. Outro
1. Qual?

C. Redes sociais
A. Não uso nenhum.
B. Orkut
C. Twitter
D. Facebook
E. Fourshare
F. Outros (Quais?)

D. Listas de discussão
A. Não uso nenhum.
B. Quais?

E. Fóruns
A. Não uso nenhum.
B. Quais?

F. Buscadores (Yahoo, Google, Bing etc.)
A. Não uso nenhum.
B. Quais?

G. E-Mail

$\mathrm{H}$. Agendas na web (Google etc.)
A. Não uso nenhum.
B. Quais?

I. Blogs
A. Não conheço/acesso nenhum blog.
B. Tenho um blog
1. Do que?
2. Qual o endereço?
C. Sou somente leitor
1. De qual(is) blog(s)?

J. Comunicadores
A. Msn
B. GTalk 
C. Outro

K. Serviços

$$
\text { 1. Qual? }
$$
A. Bancos
B. Compras
C. Reservas de hotéis
D. Compra de ingressos (teatro, cinema, shows etc.)

L. Jornais/Portais de notícias
A. G1
B. $\mathrm{R} 7$
C. Uol
D. Terra
E. Outro

M. FTP
1. Qual?

\section{A. Qual?}

N. Usenet

Histórico de formação

24. Formação média
A. Instituição de Ensino
B. endereço
C. Tipo
A. Técnico (qual?)
B. Magistério
C. Outro

25. Formação superior anterior?
A. Não
B. Sim
A. Qual?
B. Onde?
C. Quando?
D. Concluído?

\section{Curso atual}

26. Nome da Instituição

27. Endereço da Instituição

28. Nome e endereço do polo

29. Nome do curso
A. Licenciatura
B. Bacharelado

30. Linguagem
A. Artes Visuais
B. Dança
C. Teatro
D. Música

31. Vinculado à qual departamento? 
32. Duração do curso
A. 3 anos
B. 4 anos
C. Outro - explique

33. Outros comentários

34. Ano de conclusão
A. Se cursando, qual a previsão de conclusão?
B. Que ano está cursando?

\section{Questões qualitativas em EaD}

35. Porque optou por um curso à distância?

(Pergunta aberta)

36. O que você esperava ao optar por um curso à distância?

(Pergunta aberta)

37. Quanto tempo você leva para ir de sua casa ao polo?

(Pergunta aberta)

38. Qual a frequência dos encontros presenciais?

(Pergunta aberta)

39. Como eles acontecem?

(Pergunta aberta)

40. Para que servem os momentos presenciais, em sua percepção?

(Pergunta aberta)

41. Qual a probabilidade de você fazer outro curso a distância após este?

A. $100 \%$ - Só pretendo fazer cursos a distância.

B. De $80 \%$ a $99 \%$ - Sempre que eu puder escolher, vou preferir cursos à distância.

C. De $60 \%$ a $79 \%$ - Só farei outro curso a distância se não houver outra forma de fazer.

D. De $50 \%$ a $69 \%$ - Dependendo do curso, posso optar pela modalidade a distância ou presencial.

E. De $40 \%$ a $59 \%$ - Tanto faz ser presencial ou a distância, o que me interessa é o curso.

F. De $30 \%$ a $49 \%$ - Minha preferência é por cursos presenciais.

G. De $20 \%$ a $39 \%$ -

H. Menos de $10 \%-$

I. $0 \%$ - Nunca mais farei um curso a distância.

J. Comentários

(Pergunta aberta)

\section{Para alunos que estão cursando}

42. Como você acredita que a conclusão do curso vai afetar sua vida profissional?
A. Em nada, estou fazendo o curso por gosto pessoal.
B. Médio, estou fazendo o curso para progredir na carreira.
C. Muito, estou fazendo o curso para me qualificar mais na minha área.
D. Bastante, estou fazendo o curso para ser professor.
E. Totalmente, estou fazendo o curso para mudar de área de trabalho. 
43. Como você acessa mais o ambiente do curso?
A. Computador pessoal
B. Computador do polo
C. LanHouses
D. Celular
E. Tablet
F. Outros - Qual?

44. Já tinha familiaridade com a modalidade?
A. Sim, já havia feito outros cursos livres a distância.
B. Sim, mas nunca havia estudado em um curso a distância.
C. Não, mas era a única forma de fazer um curso superior.
D. Não, mas estou gostando da experiência.
E. Não, e não gostaria de repetir a experiência.
F. Não, e não vou continuar este curso.

45. Você tem acesso aos professores do curso com facilidade?
A. Sim
B. Não
Comente
(Pergunta aberta)

46. Os professores dão retorno adequado às suas dúvidas?
A. Sim
B. Não
Comente
(Pergunta aberta)

47. Você conhece o currículo e percurso profissional de seus professores?
A. Sim
B. Não
Comente
(Pergunta aberta)

48. Qual a função dos tutores em seu curso?
A. Sim
B. Não
Comente
(Pergunta aberta)

49. Tutores e professores fazem as mesmas atividades?
A. Sim
B. Não
Comente
(Pergunta aberta)

50. Qual o maior ponto positivo do seu curso?
A. Sim
B. Não
Comente
(Pergunta aberta)

51. Qual o ponto mais negativo do seu curso?
A. Sim
B. Não
Comente
(Pergunta aberta) 
52. Qual o seu grau de satisfação com o curso escolhido?
A. Muito satisfeito
B. Satisfeito
C. Indiferente
D. Insatisfeito
E. Outro - Explique:

53. O curso atende às suas expectativas?
A. Sim
B. Não
Comente
(Pergunta aberta)

54. Qual disciplina, das que teve até agora, você teve ou está tendo maior dificuldade?

Por quê?

55. Qual disciplina, das que teve até agora, você teve ou está tendo maior facilidade?

Por quê?

56. O que você gostaria de ter como disciplina/atividade, que ainda não teve, neste curso?

Por quê?

\section{Somente para formados}

57. Você está exercendo atividade profissional atualmente?
A. Sim, na área de minha formação acadêmica.
B. Sim, fora da área de minha formação acadêmica.
C. Não.

58. O principal motivo pelo qual você não exerce atividade profissional na sua área de formação é:
A. Estou exercendo atividade profissional na minha área de formação.
B. Mercado de trabalho saturado
C. Melhor oportunidade em outra área
D. Motivos particulares

59. Quanto tempo houve entre a formatura e o início de sua atividade profissional?
A. Menos de 1 ano
B. De 02 a 03 anos
C. De 02 a 04 anos

60. Em que tipo de organização você exerce sua atividade profissional ?
A. Autônoma
B. Escola própria
C. Escola privada
D. Escola pública
E. A pergunta não se aplica a minha situação atual

61. Como você obteve seu emprego atual?
A. Por concurso público
B. Por efetivação de estágio
C. Por seleção de currículo
D. Por indicação de pessoas influentes 
E. A pergunta não se aplica a minha situação atual

62. Qual é sua faixa salarial?
A. Até 5 salários mínimos
B. De 5 a 10 salários mínimos
C. De 11 a 20 salários mínimos
D. Acima de 20 salários mínimos

63. Qual é em sua visão, a perspectiva profissional na sua área?
A. Ótima
B. Boa
C. Razoável
D. Desanimadora
E. Não tenho condições de avaliar

64. Qual o seu grau de satisfação com o curso escolhido?
A. Muito satisfeito
B. Satisfeito
C. Indiferente
D. Insatisfeito
E. Por quê? Explique:

65. O curso atendeu às suas expectativas?
A. Sim
B. Não
C. Parcialmente
B. Por quê? Explique

66. Qual a disciplina que teve maior dificuldade?

Por quê?

67. Qual a disciplina que teve maior afinidade?

Por quê?

68. O que você gostaria de ter tido, ou ter mais, que não lhe foi oferecido nesse curso?
A. Conteúdo.
B. Encontros/momentos presenciais.
C. Atividades práticas.
D. Oficinas.
E. Ateliês.
F. Acesso aos professores.
G. Outro - Qual?
(Pergunta aberta)

69. Acredita que se o curso fosse presencial isso seria diferente? Por quê?

70. Você acredita que o que foi ensinado no curso tem relação com a realidade do mercado da profissão?

Por quê?

71. O que você percebe, no mercado de trabalho, que é uma necessidade real e que não foi ensinado no seu curso?

(Pergunta aberta)

72. Como acredita que essa defasagem pode ser corrigida? (Pergunta aberta)

73. Você fez estágio?
A. Sim 
B. Não

Comente

(Pergunta aberta)

74. Como foi a experiência?
A. Muito boa
B. Boa
C. Indiferente
D. Ruim
Por quê? Explique:

75. Você teve oportunidade de fazer Iniciação Científica?
A. Não
B. Sim, mas não me interessei.
C. Sim, e eu fiz.

A. Em que área?

76. As disciplinas profissionalizantes contribuíram para o seu desempenho profissional?
A. Muito
B. Razoavelmente
C. Pouco
D. Nada

77. O curso como um todo colaborou para seu desenvolvimento cultural e pessoal?
A. Muito
B. Razoavelmente
C. Pouco
D. Nada
E. Não tenho opinião a respeito

78. Qual o conceito que você atribui aos professores do curso que você concluiu?
A. Ótimo
B. Bom
C. Regular
D. Ruim
E. Péssimo
F. Comentários?
(Pergunta aberta)

79. Qual é o conceito que você atribui ao curso que concluiu?
A. Ótimo
B. Bom
C. Regular
D. Ruim
E. Péssimo

80. Gostaria de fazer algum comentário que não foi questionado?
A. Não
B. Sim

A. Qual?

(Pergunta aberta)

81. Gostaria de enviar uma cópia de seu TCC para divulgação? (Anexar arquivo). 


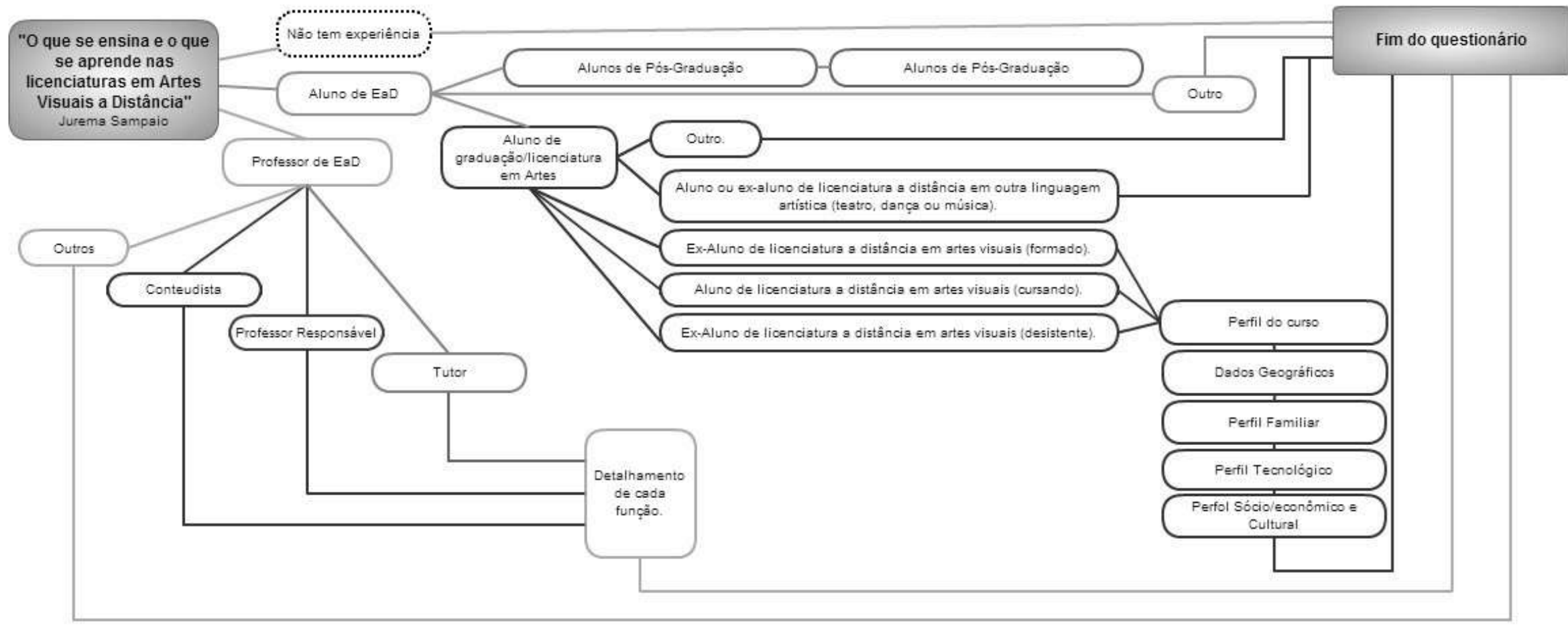




\section{ANEXO B - BIBLIOGRAFIA - UCS/ UFRGS}

ALAVA, S. \& Colaboradores. Ciberespaço e Formações Abertas. Porto Alegre: ARTMED, 2002.

ARANHA, M.L.A. Filosofia da Educação. São Paulo: Moderna, 2001.

ARANHA, M.L.L. \& MARTINS, M.H.P. Filosofando: Introdução à filosofia. $2^{\mathrm{a}} \mathrm{ed}$. São Paulo: Moderna, 1993.

ARANTES, P. @rte e mídia: perspectivas da estética digital. São Paulo: Editora Senac São Paulo, 2005.

ARGAN, G.C. Arte Moderna. São Paulo: Cia das Letras, 1992.

ARNHEIM, R. Arte e percepção visual: uma psicologia da visão criadora. São Paulo: Pioneira, 1980.

AUMONT, J. A imagem. Campinas: Papirus, 1993.

AZEVEDO, E. \& CONCl, A. Computação Gráfica: teoria e prática. 2. Ed. Rio de Janeiro: Elsevier, 2003.

BACHELARD, G. A poética do espaço. São Paulo: Martins Fontes, 1993.

BARBOSA, A.M.T.B., FERRARA, L.D. \& e VERNASCHI, E. (Orgs.) O Ensino de Artes nas universidades. São Paulo: EDUSP, 1993.

BARBOSA, A.M.T.B. (Org.) Arte/Educação contemporânea: consonâncias internacionais. São Paulo: Cortez, 2005. Arte-Educação no Brasil. São Paulo: Perspectiva, 1978. . Dilemas da Arte/Educação como mediação cultural em namoro com as tecnologias contemporâneas. In: BARBOSA, A.M.T.B. (Org.) Arte/Educação contemporânea: consonâncias internacionais. São Paulo: Cortez: 2005. . Tópicos utópicos. Belo Horizonte: C/Arte, 1998.

. A imagem no Ensino da Arte. São Paulo: Perspectiva, 1991.

BARROS, A. A arte da percepção. São Paulo: ANNABLUME, 1999.

BASBAUM, R. Além da pureza visual. Porto Alegre: Zouk, 2007.

BENJAMIN, C. (Org.). A opção brasileira. Rio de Janeiro: Contraponto, 1998. p. 147-176.

BERTRAND, I. \& VALOIS, P. Paradigmas Educacionais. Lisboa: Instituto Piaget, 1994. BOURDIEU, P. Lições da aula. São Paulo: Ética, 1988.

BRASIL. Constituição. Constituição da República Federativa do Brasil., de 05 de outubro de 1988 (com a redação atualizada).

. Lei no 9394 de 20 de dezembro de 1996. Estabelece as Diretrizes e Bases da Educação Nacional. Brasília - 1996.

Brasília, 2001.

Lei oํ 10172, de 09 de janeiro de 2001. Plano Nacional de Educação.

. Ministério da Educação e do Desporto, Parâmetros Curriculares

Nacionais - Arte. 1997/1998.

BEAUD, M. Arte da Tese: como preparar e redigir uma tese de mestrado, uma monografia ou qualquer outro trabalho universitário. Rio de Janeiro: Bertrand, 1997.

BENJAMIN, W. Obras escolhidas: magia e técnica, arte e política. São Paulo:

Editora Brasiliense, 5. ed. 1993.

BIAZUS, M.C.V. Ambientes digitais e processos de criação: gerando a produção

de sentido. Tese (doutorado) - Universidade Federal do Rio Grande do Sul.

Programa de Pós-Graduação em Informática na Educação. Porto Alegre:

UFRGS, 2001. 
BOAL, A. Jogos para o ator e o não ator. Rio de Janeiro: Civilização Brasileira, 2000. BOZAL, V. (Org.) História de las Ideas Estéticas y de las teorías artísticas contemporáneas. Madrid: Visor, 1996. (2 v.)

BRITES, B. \& TESSLER, E. O meio como ponto zero - Metodologia da pesquisa em artes plásticas. Porto Alegre: UFRGS, 2002.

CANTON, K. Retrato da Arte Moderna: uma história no Brasil e no Mundo Ocidental. São Paulo: Martins Fontes, 2002.

COSTA, C.T. Arte no Brasil 1950-2000: Movimentos e Meios. São Paulo: Alameda, 2004.

CHAUÍ, M.S. Convite à Filosofia. São Paulo, SP: Ática, 1994.

CODO, W. \& VASQUEZ-MENEZES, I. (Orgs.) Trabalho docente e sofrimento:

burnout em professores. In: AZEVEDO, J.C. (Org.) Utopia e democracia na

Educação cidadã. UFRGS/ Secretaria Municipal da Educação, 2000. p. 369-382.

Porto Alegre.

COLL, C.; PALACIOS, J. \& MARCHESI, A. Desenvolvimento Psicológico e

Educação: Psicologia da Educação. v. 2. Porto Alegre, Artes Médicas, 1996. \#01 e \#24

COUCHOT, E. A tecnologia na arte da fotografia à realidade virtual. Porto Alegre:

UFRGS, 2003.

COX, M. Desenho da criança. São Paulo: Martins Fontes, 2001.

DANTO, A.C. A transfiguração do lugar-comum. São Paulo: Cosac Naify, 2005.

DE MICHELI, M. As vanguardas artísticas. São Paulo: Martins Fontes, 2004.

DEMPSEY, A. Estilos, Escolas \& Movimentos - Guia Enciclopédico da História da Arte.

São Paulo: Cosac \& Naif, 2003.

DERDYK, E. Formas de pensar o desenho. São Paulo: Ática, 1989. . Linha de Horizonte. São Paulo: Escuta, 2001.

DESCARTES, R. Discurso do método. Trad. J. Guisburg e Bento Prado Júnior. 4ª .

Ed. São Paulo: Nova Cultural, 1987.

DIAMOND, P. \& MULLER, C. O Educador Pós-Moderno. Lisboa: Instituto Piaget, 2004.

DOMINGUES, D. (Org.). Arte e vida no século XXI: tecnologia, ciência e

criatividade. São Paulo: Editora UNESP, 2003.

. (Org.) A Arte no século XXI. São Paulo: UNESP, 1997.

DUCHAMP, M. O ato criador. In: BATTCOCK, G. A nova arte. São Paulo: Perspectiva, 1975.

ESTABEL, L. B.; MORO, E. L.; DIAS, J. \& CARNEIRO, M.L.F. As novas

Tecnologias da Informação e Comunicação e a pesquisa escolar. Anais do VIII

Workshop de Informática na Educação: XXII Congresso da SBC.

. A pesquisa escolar propiciando a integração dos alunos, educadores,

bibliotecários, irradiando o benefício coletivo e a cidadania em um ambiente de aprendizagem mediado pelo computador. In: RENOTE, v. 1, 2004. Disponível em http:cinted.ufrgs.br/renote/mar2004/artigos/03-pesquisa_escolar.pdf

FARIAS, A. Arte Brasileira Hoje. São Paulo: Publifolha, 2002.

FLUSSER, V. A pós-história: vinte instantâneos e um modo de usar. São Paulo: Duas Cidades, 1983.

. Filosofia da caixa preta. São Paulo: Hucitec, 1985.

FOULIN, J-N. \& MOUCHON, S. Psicologia da Educação. Porto Alegre: ArtMed, 2000. \#5.

FRANCO, S.R. (Org.) Informática na Educação. Porto Alegre: UFRGS, 2004.

FRANGE, L.B.P. Por que se esconde a violeta? São Paulo: Annablume, 1995. 
GARCEZ, L. \& OLIVEIRA, J. Explicando a Arte Brasileira. Rio de Janeiro: Ediouro, 2003.

GHIRALDELLI Jr, P. Filosofia e história da Educação brasileira. São Paulo: Manole, 2003.

GOMBRICH, E.H. A História da Arte. Rio de Janeiro: LTC, $16^{a}$ ed., 1999.

. Arte e llusão: um estudo da psicologia da representação pictórica. São

Paulo: Martins Fontes, 1986.

GONÇALVES, M.A.S. Sentir, pensar, agir: corporeidade e Educação. Campinas:

Papirus, 1994.

HERNÁNDEZ, F. Cultura Visual, Mudança Educativa e Projeto de Trabalho. Porto

Alegre: Artmed, 2000.

IAVELBERG, R. Para gostar de aprender arte. Porto Alegre: Artmed, 2003.

KINCHELOE, J.L. A formação do professor como compromisso político. Porto Alegre:

Artmed, 1997.

KRAUSS, R. Caminhos da Escultura Moderna. São Paulo: Martins Fontes, 2001.

1985

. La Originalidad de la Vanguardia y otros mitos modernos. Madrid: Alinaza,

LEITE, D. Reformas Universitárias. Petrópolis: Vozes, 2005.

LICHTENSTEIN, J. (Org.) A Pintura: Textos Essenciais. São Paulo: 34,14 volumes, 2004.

LEÃO, L. (Org.) INTERLAB, Labirintos do pensamento contemporâneo. São Paulo: lluminuras, 2002.

MACHADO, A. A arte do vídeo. São Paulo: Brasiliense, 3. Ed. 1995.

EDUSP, 1999.

Máquina e imaginário: o desafio das poéticas tecnológicas. São Paulo:

. A televisão levada a sério. São Paulo: Senac, 3. Ed. 2003.

MACIEL, K. \& PARENTE, A. Redes Sensoriais, arte, ciência, tecnologia. Rio de Janeiro: Contra Capa, 2003.

MAGDALENA, B.C. \& COSTA, Í. INTERNET em sala de aula: com a palavra, os professores. Porto Alegre: ARTMED, 2003.

MANOVICH, L. The language of new media. Cambridge: The Mit Press, 2001.

MARQUES, M.O. Escrever é preciso - O princípio da Pesquisa. ljuí: Unijuí, 1997.

MARTINS, M.C.; PICOSQUE, G. \& GUERRA, M.T. Didática do Ensino de arte: a língua do mundo: poetizar, fruir e conhecer arte. São Paulo: FTD: 1998.

MARTINS, M.C. Mediação: provocações estéticas. UNESP. São Paulo, v. 1, n. 1. outubro, 2005.

. Avaliação e planejamento: a prática educativa em questão -

instrumentos metodológicos II. São Paulo: Espaço Pedagógico, 1992.

. Aprendiz da Arte: trilhas do sensível olhar-pensante. São Paulo:

Espaço Pedagógico, 1992.

MEYER, M.; BABER, R. \& PFANFFENBERGER, B. Nosso futuro e o computador. $3^{\circ}$ ed., Porto Alegre: Bookman, 2000.

MIDGELY, B. Guia Completa de Escultura, Modelado y Ceramica: Tecnicas y Materiales. Madrid: H. Blume, 1982.

MORAES, S. C. \& SCHOLZE, L. (Orgs.) Caderno temático: multimeios e informática educativa. Porto Alegre: Secretaria Municipal de Educação de Porto Alegre, 2002.

MOREIRA, A.A. O espaço do desenho: a Educação do educador. São Paulo: Loyola, 1984. 
MORIN, E. A Religação dos Saberes. Rio de Janeiro: Bertrand Brasil, 2002. MORO, E.L.; ESTABEL, L.B. \& TAROUCO, L. O professor e os alunos como protagonistas na Educação aberta e a distância mediada por computador. In: Educar em revista, UFPR, 2003.

NEVE, I.C.B. Ler e Escrever: compromisso de todas as áreas. Porto Alegre: Ed. Da Universidade/ UFRGS, 2006.

NOVAES, A. (Org.) O olhar. São Paulo: Companhia das Letras, 1988.

OLIVEIRA, A.C. \& FECHINE, Y. (Eds.) Imagens Técnicas. São Paulo: Hacker, 1998.

OTT, R.W. Ensinando crítica nos museus. In: BARBOSA, A.M. Arte-Educação: leitura no subsolo. São Paulo: Cortez, 1997.

PALLOF, R.M. \& PRATT, K. O aluno Virtual: um guia para trabalhar com estudantes online. Porto Alegre: Artmed, 2004.

. Construindo Comunidades de Aprendizagem no Ciberespaço: estratégias eficientes para salas de aula on-line. Porto Alegre: Artmed, 2002.

PAVIANI, J. Problemas de Filosofia da Educação. 7ª . Ed. Caxias do Sul: EDUCS, 2005. PEÑUELA CANIZAL, E. As fascinantes conquistas da leitura In: BARBOSA, A.M. \& SALLES, H. M. (Orgs.) O Ensino da Arte e sua história. São Paulo: MAC/USP, 1990. p. 64-83.

PIAGET, J. Sobre a pedagogia: textos inéditos. São Paulo: Casa do psicólogo, 1998. p. 181-05; 217-21.

PILLAR, A.D. Desenho e escrita como sistemas de representação. Porto Alegre: Artes Médicas, 1996.

(et al.) Pesquisa em Artes Plásticas. Porto Alegre: UFRGS, 1993.

PILLETTI, C. \& NELSON. Filosofia e História da Educação. São Paulo: Ática, 1988.

PINSKY, J. \& PINSKY, C.B. História da cidadania. São Paulo: Contexto, 2003.

PINSKY, J. (Org.) Pratica da Cidadania. São Paulo: Contexto, 2004.

PLAZA, J. \& TAVARES, M. Processos Criativos com os meios eletrônicos:

Poéticas Digitais. São Paulo: Hucitec, 1998.

PRADO, G. Arte telemática dos intercâmbios pontuais aos ambientes virtuais multiusuário. São Paulo: Itaú Cultural, 2003.

ROMANELLI, O.O. História da Educação no Brasil. Petrópolis, RJ: Vozes, 2006.

ROSE, B. Drawing Now. New York: Metropolitan Museun of Modern Art, 1976.

ROSSI, M.H.W. Imagens que falam: leitura da arte na escola. 3. ed. Porto Alegre:

Editora Mediação, 2006.

A estética no Ensino das Artes Visuais. Educação \& Realidade -

Dossiê Arte e Educação: arte criação e aprendizagem, Porto Alegre, v. 30, n. 2, p.

49-69, jul.-dez. 2005.

RÜDIGER, F. Elementos para a Crítica da Cibercultura: Sujeito, Objeto e

Interação na Era das Novas Tecnologias de Comunicação. São Paulo: Hacker,

2002.

SACKS, O. Ver e não ver. in: Um antropólogo em Marte. SP. Cia das Letras, 2001.

SALLES, C.A. Gesto inacabado: processo de criação artística. São Paulo: Annablume, 1998.

SALLES, M. (Orgs.) O Ensino da Arte e sua história. São Paulo: MAC/USP, 1990. p. 6483.

SANTAELLA, L. Cultura e artes do pós-humano: da cultura das mídias a cibercultura. São Paulo: Paulus, 2003.

SANTAELLA, L. \& WINFRED, N. Imagem. São Paulo: Iluminuras, 1998.

SANTOS, R. As Artes Plásticas no Brasil. Rio De Janeiro: Tecnoprint, 1968. 
SCHNITMAN, D.F. (Org.) Novos paradigmas, Cultura e Subjetividade. Porto Alegre: Artmed, 1996.

SILVEIRA, P. A página violada - da ternura à injúria na construção do livro de artista. Porto Alegre, Editora da UFRGS, 2001.

SMITH. R. Manual prático do artista. Porto: Civilização, 2006.

SOUZA, R.T. Ética como fundamento: uma introdução à ética contemporânea. São Leopoldo: Nova Harmonia, 2004.

STRICKLAND, C. Arte Comentada - da pré-história ao pós-moderno.Rio de Janeiro: Ediouro, 1999.

TREVISAN, A. Como apreciar a arte. Porto Alegre: Mercado Aberto, 1990.

TUCKER, W. A Linguagem da Escultura. São Paulo: Cosac \& Naify, 1999.

VENTURELLI, S. Arte: espaço tempo imagem. Brasília: Ed. Universidade de Brasília, 2004.

VIEIRA, L. Os argonautas da Cidadania: a sociedade civil e a globalização. Rio de Janeiro: Record, 2001.

WICK, R. Pedagogia da Bauhaus. São Paulo: Martins fontes, 1989.

WILSON, B. \& WILSON, M. Uma visão iconoclasta das fontes das imagens nos desenhos de crianças. In: BARBOSA, A.M.T.B. (Org.) Arte-Educação: leitura no subsolo. São Paulo: Cortez, 1997.

WEIL, P. O corpo fala: a linguagem silenciosa da comunicação não verbal. Petrópolis: Vozes, 1986.

WEIBEL, P. El mundo como interfaz: El paseante: la revolucion digital y sus dilemas. Madrid: Ediciones Siruela, n. 27-28, p. 110-121. 1998.

WITTKOWER, R. Escultura. São Paulo: Martins Fontes, 2001.

WÖLFFLIN, H. Conceitos Fundamentais da História da Arte. São Paulo: Martins Fontes, 2000.

WOLLHEIM, R. A Arte e seus Objetos. São Paulo: Martins Fontes, 1994.

ZAMBONI, S. A pesquisa em arte: um paralelo entre arte e ciência. Campinas: Autores Associados, 1998.

ZILIO, C. A querela do Brasil. Rio de Janeiro: Relume Dumará, 1994. 


\section{ANEXO C - Matriz Curricular do Curso de Licenciatura em Artes Visuais modalidade à distância UCS e UFRGS - REGESD}

\begin{tabular}{|c|c|c|c|c|c|}
\hline & Atividade de Ensino & $\underset{*}{\text { TIPO }}$ & $\begin{array}{c}\text { CRÉDIT } \\
\text { OS }\end{array}$ & $\begin{array}{c}\text { CARGA } \\
\text { HORÁRI } \\
\text { A }\end{array}$ & $\begin{array}{c}\text { IES } \\
\text { responsável }\end{array}$ \\
\hline \multirow{6}{*}{ ETAPA I } & Instrumentalização para EAD & 1 & 04 & 60 & UCS/UFRGS \\
\hline & Filosofia da Educação & 1 & 03 & 45 & UCS/UFRGS \\
\hline & Fundamentos da Linguagem Visual & 1 & 04 & 60 & UFRGS \\
\hline & Sistemas de Representação & 1 & 04 & 60 & UFRGS \\
\hline & $\begin{array}{l}\text { Seminário Integrador 1: Ser professor no } \\
\text { contexto atual }\end{array}$ & 2 & 05 & 75 & UCS/UFRGS \\
\hline & TOTAL DA ETAPA & & 20 & 300 & \\
\hline \multirow{8}{*}{ ETAPA II } & $\begin{array}{l}\text { Instrumentalização para Acesso a } \\
\text { Informação }\end{array}$ & 1 & 04 & 60 & UCS/UFRGS \\
\hline & Teoria do conhecimento e Epistemologia & 1 & 03 & 45 & UCS/UFRGS \\
\hline & $\begin{array}{l}\text { História e organização da Educação } \\
\text { Brasileira }\end{array}$ & 1 & 03 & 45 & UCS/UFRGS \\
\hline & Fundamentos da Arte I & 1 & 03 & 45 & UCS \\
\hline & Arte e Processo & 1 & 03 & 45 & UFRGS \\
\hline & Arte e a Tecnologia Digital I & 1 & 03 & 45 & UFRGS \\
\hline & $\begin{array}{l}\text { Seminário Integrador 2: Ser professor de } \\
\text { Artes Visuais }\end{array}$ & 2 & 05 & 75 & UCS/UFRGS \\
\hline & TOTAL DA ETAPA & & 24 & 360 & \\
\hline \multirow{8}{*}{$\begin{array}{l}\text { ETAPA } \\
\text { III }\end{array}$} & Psicologia da Educação & 1 & 04 & 60 & UCS/UFRGS \\
\hline & Sociologia da Educação & 1 & 03 & 45 & UCS/UFRGS \\
\hline & Fundamentos da Arte II & 1 & 03 & 45 & UCS \\
\hline & Percepção e Representação & 1 & 03 & 45 & UFRGS \\
\hline & Processos e Linguagens Tridimensionais & 1 & 03 & 45 & UFRGS \\
\hline & $\begin{array}{l}\text { Desenvolvimento Expressivo Infanto- } \\
\text { juvenil e Processos Educativos }\end{array}$ & 1 & 03 & 45 & UCS \\
\hline & $\begin{array}{l}\text { Seminário Integrador 3: A escola e o } \\
\text { contexto atual }\end{array}$ & 2 & 05 & 75 & UCS/UFRGS \\
\hline & TOTAL DA ETAPA & & 24 & 360 & \\
\hline \multirow{5}{*}{$\begin{array}{l}\text { ETAPA } \\
\text { IV } \\
\text { ETAPA } \\
\text { IV }\end{array}$} & $\begin{array}{l}\text { Gestão da Escola e Planejamento } \\
\text { Educacional }\end{array}$ & 1 & 04 & 60 & UCS/UFRGS \\
\hline & Atelier de Criação Artística I & 1 & 05 & 75 & UFRGS \\
\hline & Leitura de Imagem & 1 & 03 & 45 & UCS \\
\hline & Seminário Arte no Brasil I & 1 & 03 & 45 & UFRGS \\
\hline & Processos de criação artística e reflexão & & & 45 & UFRGS \\
\hline
\end{tabular}




\begin{tabular}{|c|c|c|c|c|c|}
\hline & filosófica & 1 & 03 & & \\
\hline & $\begin{array}{l}\text { Seminário Integrador 4: A especificidade } \\
\text { da formação do artista e do professor de } \\
\text { arte }\end{array}$ & 2 & 05 & 75 & UCS/UFRGS \\
\hline & TOTAL DA ETAPA & & 23 & 345 & \\
\hline \multirow{7}{*}{$\begin{array}{l}\text { ETAPA } \\
V\end{array}$} & Inclusão Social e Cidadania & 1 & 02 & 30 & UCS/UFRGS \\
\hline & $\begin{array}{l}\text { Planejamento Educacional em Artes } \\
\text { Visuais }\end{array}$ & 2 & 08 & 120 & UCS \\
\hline & $\begin{array}{l}\text { Pensamento Estético e Processos } \\
\text { Educativos }\end{array}$ & 1 & 03 & 45 & UCS \\
\hline & Arte e Tecnologia Digital II & 1 & 03 & 45 & UFRGS \\
\hline & Seminário de Arte no Brasil II & 1 & 03 & 45 & UFRGS \\
\hline & $\begin{array}{l}\text { Seminário integrador 5: A Arte e o Ensino } \\
\text { da Arte no Brasil }\end{array}$ & 1 & 05 & 75 & UCS/UFRGS \\
\hline & TOTAL DA ETAPA & & 24 & 360 & \\
\hline \multirow{6}{*}{$\begin{array}{l}\text { ETAPA } \\
\text { VI }\end{array}$} & Estágio de Docência Supervisionado I & 3 & 07 & 105 & UCS/UFRGS \\
\hline & Laboratório de Linguagem Tridimensional & 1 & 03 & 45 & UCS \\
\hline & Seminário de Tópicos Especiais I & 3 & 03 & 45 & UCS \\
\hline & Oficina de Materiais Expressivos & 1 & 03 & 45 & UFRGS \\
\hline & $\begin{array}{l}\text { Seminário integrador 6: O Artista e o } \\
\text { Professor de Arte }\end{array}$ & 1 & 05 & 75 & UCS/UFRGS \\
\hline & TOTAL DA ETAPA & & 21 & 315 & \\
\hline \multirow{6}{*}{$\begin{array}{l}\text { ETAPA } \\
\text { VII }\end{array}$} & Estágio de Docência Supervisionado II & 3 & 07 & 105 & UCS/UFRGS \\
\hline & Seminário de Tópicos Especiais II & 3 & 03 & 45 & UFRGS \\
\hline & Metodologia da Pesquisa em Arte & 1 & 03 & 45 & UFRGS \\
\hline & Atelier de criação artística II & 1 & 03 & 45 & UFRGS \\
\hline & $\begin{array}{l}\text { Seminário integrador 7: Tópicos especiais } \\
\text { no Ensino de Artes Visuais }\end{array}$ & 1 & 05 & 75 & UCS/UFRGS \\
\hline & TOTAL DA ETAPA & & 21 & 315 & \\
\hline \multirow{7}{*}{$\begin{array}{l}\text { ETAPA } \\
\text { VIII }\end{array}$} & Monografia/ TCC & 4 & 06 & 90 & UCS/UFRGS \\
\hline & Multimeios Educativos & 1 & 03 & 45 & UCS \\
\hline & $\begin{array}{l}\text { Seminário de Tópicos Especiais III: } \\
\text { ambientes virtuais de aprendizagem }\end{array}$ & 1 & 03 & 45 & UFRGS \\
\hline & $\begin{array}{l}\text { Seminário integrador 8: Produção de } \\
\text { objetos de aprendizagem }\end{array}$ & 1 & 05 & 75 & UCS/UFRGS \\
\hline & TOTAL DA ETAPA & & 17 & 255 & \\
\hline & TOTAL & & 174 & 2610 & \\
\hline & Atividades Complementares & & & 200 & \\
\hline
\end{tabular}




\section{ANEXO D - BIBLIOGRAFIA - UFES}

ABTCP. História da indústria de celulose e papel no Brasil.

ACKERMAN, D. Uma história natural dos sentidos. $2^{\underline{a}}$ ed. Rio de Janeiro: Bertran Brasil, 1996.

ADES, D. O Dadá e o Surrealismo. Barcelona: Labor, 1976.

1997. Arte na América Latina - a era Moderna, São Paulo: Cosac \& Naify,

AGRA, L. História da Arte do Século XX: ideias e movimentos. São Paulo: Anhembi Morumbi, 2004.

ALDRICH, V.C. Filosofia da arte. Rio de Janeiro, Zahar, 1978.

ALEXANDRIAN, S. O Surrealismo. São Paulo: Verbo/EDUSP, 1976.

ALMEIDA, P.M. De Anita ao Museu. São Paulo: Perspectiva, 1976.

ALVES, R. Conversas com quem gosta de ensinar. São Paulo: Cortêz, 1985.

AMARAL, A. Projeto construtivo na arte. Rio de Janeiro/São Paulo, Pinacoteca ECA/IEB/MAN/MAC, 1972.

AMARAL, A.A. Arte e Meio Artístico: Entre a Feijoada e o X-Burguer. São Paulo: Nobel, 1982.

Arte para que? A preocupação social na arte brasileira: 1930-1970.

São Paulo: Nobel, 1984.

Artes Plásticas na Semana de 22. São Paulo: Nobel, 1976.

Arte no Brasil. São Paulo: Abril Cultural, s/d.

ANDRADE, L.A. Barracão de barro cerâmica. Uberaba: Vitória, 1995.

ARANTES, O.B.F. "Depois das vanguardas". In: Arte em revista. São Paulo, (7): 4-20 agosto/1973.

ARCARI, A. A fotografia, as formas, os objetos, o homem. Lisboa: Martins Fontes, 1980.

ARCHER, M. Arte Contemporânea - Uma História Concisa, São Paulo: Martins Fontes, 2001.

ARGAN, G.C. \& FAGIOLO, M. Guia de história da arte. Lisboa: Estampa, 1992.

ARGAN, G.C. Arte Moderna. São Paulo: Companhia das Letras, 1992.

. Arte e crítica de arte. 2 ed. Lisboa: Estampa, 1993.

ARHEIM, R. Arte e Percepção Visual. Trad. de Ivone Terezinha de Faria. São Paulo: Pioneira, 1980.

ARETIO, L.G. El Aprendizaje a distancia de las personas adultas. In: Educación a distancia hoy. Madrid: UNED, 1994. p. 124-132.

La acción Orientador/Tutorial em la enseñanza a distancia. In: Educación a distancia hoy. Madrid: UNED, 1994. p 295-339.

ASUNCION, J. O papel: métodos e técnicas de fabrico. Portugal: Estampa, 2002.

Arte Brasileira Contemporânea. Coleção Gilberto Chateaubriand. Galeria Bonino, Rio de Janeiro, 1977.

Arte Brasileira no Século XV: Caminhos e Tendências. Galerias Arte Global, 1976. 15a․ a 20a. Bienal Internacional de São Paulo (1979, 1981, 1983, 1985, 1987, 1989).

AUMONT, J. A Imagem. Campinas: Ed. Papirus, 1993.

A’VILA, A. O lúdico e as Projeções do Mundo Barroco. São Paulo: Perspectiva, 1978.

AZZI, F. Vídeo-Arte e Experimentalismo: o surgimento de uma estética nos anos 60 e 70. São Paulo: PUC/SP, dissertação de mestrado, 1995. 
BACHELAR, G. A Poética do Espaço. São Paulo: Martins Fontes, 2000.

BADIOU, A. Pequeno Manual de Inestética. São Paulo: Estação Liberdade, 2002.

BAITELLO JUNIOR, N. Dadá-Berlim: Des/Montagem. São Paulo: Annablume, 1993.

BAKHTIN, M. Marxismo e filosofia da linguagem: problemas fundamentais do método sociológico na ciência da linguagem. 7. ed. São Paulo: Hucitec, 1995.

BANCO SUDAMERES S.A. P.M. BARDI. Arte da Cerâmica no Brasil. 1980.

BANFI, A. Filosofia da Arte. Tradução de Christianismo Monteiro Oiticica, Rio de Janeiro, Civilização Brasileira, 1970.

BARBOSA, A.M.T.B. Teoria e prática da Educação artística. São Paulo: Cultrix, 1975.

Arte e Educação no Brasil. São Paulo: Perspectiva, 1978.

O Ensino das Artes nas Universidades. São Paulo: Edusp, 1993. 119p.

Tópicos Utópicos. Belo Horizonte: Com Arte, 1998.

BARTHES, R. A Câmara Clara. Rio de Janeiro. Ed. Nova Fronteira, 1984.

. Crítica e Verdade. São Paulo: Perspectiva, 1970.

O Óbvio e o Obtuso. Rio de Janeiro: Nova Fronteira, 1990.

Elementos de Semiologia. São Paulo: Cultrix, 1975.

Elementos de Semiologia. São Paulo: Cultrix, 1971.

BARRAL, I. \& ALTET, X. A Alta Idade Média. Da Antiguidade Tardia ao ano mil. Colônia: Taschen, 2002.

BARROS, D.L.P. Teoria do Discurso: fundamentos semióticos. São Paulo: Atual, 1988.

"Texto e imagem". In: Linguagens, Revista da Regional Sul Associação Brasileira de Semiótica, n.1, out. de 1986, p. 29-38.

"Problemas de expressão: figuras de conteúdo e figuras de expressão”. In: Significação, Revista Brasileira de Semiótica, n.6, 1987, p. 5-12.

Teoria Semiótica do Texto. 4. ed. São Paulo: Ática, 1999.

Caminhos da Semiótica literária. Tradução do grupo Casa. Bauru:

EDUSC, 2003.

BASBAUM, R. (Org.) Arte Contemporânea Brasileira: texturas, dicções, ficções, estratégias. Rio de Janeiro: Rios Ambiciosos, 2001.

BAYER, R. História da estética. Lisboa: Estampa, 1979.

BAZIN, G. História da história da arte. De Vasari a nossos dias. São Paulo: Martins Fontes, 1991.

. História da Arte. Lisboa: Martins Fontes, 1980.

BENEVOLO, L. História da Arquitetura Moderna. São Paulo: Perspectiva.

BENJAMIN. W. "Pequena História da Fotografia". In: Obras escolhidas - Magia e Técnicas, Arte e Política. São Paulo: Brasiliense, 1985. p. 91-107.

"A obra de Arte na Era de sua Reprodutibilidade Técnica". In: Magia e técnica, arte e política. Trad. Sergio Paulo Rouanet. São Paulo: Brasiliense, 1985. p. 165-196.

BERENSON, B. Estética e História. São Paulo, Perspectiva, 1972.

BERGSON, H. Matéria e Memória. São Paulo: Martins Fonte, 1990.

BERBEL, N.A.N. Metodologia do Ensino superior: realidade e significado. Campinas: Papirus, 1994.

BERNARDINI, A. O Futurismo Italiano. São Paulo: Perspectiva, 1980.

BETTI, C. \& SALE, T. Drawing: a contemporary approach. University of North Texas. New York : Harcourt College Publishers, 1980. 
BLIKSTEIN, I. Kaspas Hauser ou a Fabricação da Realidade. São Paulo: Cultrix, 1985.

O Signo. São Paulo: Ática, Série Princípios, 1985.

BONTCE, J. Técnicas y Secretos de la Pintura L.E.D.A. Las Ediciones de Arte, Barcelona, 1963.

BORDENAVE, J.V. \& PEREIRA, A.M. Estratégias de Ensino-aprendizagem. Petrópolis: Vozes, 1977.

BORGES, M.E.L. História \& Fotografia. Autêntica, 2003.

BOSI, A. Reflexões sobre a Arte. São Paulo, Ática, 1985.

BOURDIEU, P. As contradições da herança. In: LINS, Daniel (org.). Cultura e subjetividade. São Paulo: Papirus, 1997. p. 07-18.

BOUSQUET, M. Curso de cerâmica. Eldrac, 2000.

BRAHIC, M. A tecelagem. Portugal: Estampa, 1997.

BRANDÃO, C.R. (et al.) Pesquisa participante. São Paulo : Brasiliense, 1985.

BRIONY, F.; BATCHELOR, D. \& WOOD, P. Realismo, Racionalismo, Surrealismo. A arte no entreguerras. São Paulo: Cosac e\& Naify, 1998.

BRITO, R. \& LIMA, S (Org.) Experiência Crítica. Rio de Janeiro: Cosac Naify, 2005.

Neoconcretismo. Rio de Janeiro: FUNARTE/INAP, 1985.

(et. al.) O moderno e o contemporâneo. Rio de Janeiro: Funarte, 1980.

Neoconcretismo: vértice e ruptura do projeto construtivo brasileiro. Rio

de Janeiro: Funarte/Inap, 1985.

BUBMANN, K. (et ali) (Ed.). Contemporary sculpteure: projects in Münster 1997. Münster: Hatje, 1997.

BUENO, M. L. Artes Plásticas no século XX. 2ª ed. Campinas: Unicamp, 2001.

BUORO, A.B. Olhos que pintam. São Paulo: Educ/Cortez, 2002.

. O Olhar em construção. São Paulo: Cortez, 2000. 4를. Ed.

BUSSELLE, M. Tudo sobre fotografia. São Paulo: Círculo do Livro, 1977.

CABANNE, P. Duchamp. Engenheiro do tempo perdido. Coleção Debates São Paulo: Perspectiva, 1998.

CAIXA ECONÔMICA FEDERAL. Fernando Monteiro. Rio de Janeiro: Spala. S/d CALABRESE, O. A Linguagem da Arte. Lisboa: Presença, 1986.

CANABRAVA, I. As imagens do povo e o espaço vazio da arte/Educação: um estudo sobre Antônio Poteiro. Brasília: Senado Federal, 1984.

CANCLINI, N.G. A produção simbólica. Rio de Janeiro: Civilização Brasileira, 1979.

. Culturas Híbridas. São Paulo: Edusp, 1977.

CANGUILHEM, G. O normal e o patológico. Rio de Janeiro: Forence Universitária, 1996.

CARUSO, N. Cerámica viva: manual práctico de la técnica de elaboración cerámica. Trad. Elena Torres. Barcelona: Ediciones Omega. s/d.

CARVALHO, J.A. O Colégio e as Residências dos Jesuítas no Espírito Santo. Rio de

Janeiro: Expressão e Cultura, 1982.

CARVALHO, M.C.M. (Org.). Paradigmas Filosóficos da Atualidade. Campinas: Papirus, 1989. p. 145-166.

CAVALCANTI, L. (Org.) Quando o Brasil era Moderno - Artes Plásticas no Rio de Janeiro 1905-1960. Rio de Janeiro: Aeroplano, 2001. 
CHEN, L.T. Relationships between children's drawing and social contexts: a cross-cultural study. InSea News, Bloomington: Unesco, v.5, n. 1, 1998. p. 04-07. CHAMPIGNEULLE, B. Rodin. London: Thames and Hudson, 1988.

CHIARELLI, T. A fotografia contaminada. São Paulo: Centro Cultural São Paulo, 1994.

Arte internacional Brasileira. São Paulo : Lemos, 1999.

CHIPP, H.B. (Org.) Teorias da arte moderna. São Paulo: Martins Fontes, 1988.

Teorias da Arte Moderna. São Paulo: Martins Fontes, 1996.

CHITI, J.F. Curso Prático de Cerâmica Tomo I. Buenos Aires: Ediciones del Telles Condorhuasi. s/d.

CLARK, K. Cerâmica Torneada. Buenos Aires.

COCCHIARALE, F. \& GEIGER, A.B. Abstracionismo geométrico e informal. Rio de Janeiro: Funarte, 1987.

CODO, W. \& LANE, S. Psicologia Social: o homem em movimento. 4⿳亠丷a ed. São Paulo: Brasiliense, 1986.

COELHO, L.R. As Relações entre Canção, Imagem e Narrativa nos Videoclipes. Intercom, 2003.

COELHO NETTO, T.J. Semiótica, Informação, Comunicação. São Paulo: Perspectiva, 1983.

COERR, E. Sadako e os mil pássaros de papel. EDITORA Z, 2004

COLNAGO, A. \& BRANDÃO, J. Tintas, materiais de arte. Vitória: Edufes / Lei Rubem Braga, 2004.

COMPANHIA Melhoramentos de São Paulo. Segredos da tecelagem. São Paulo: Melhoramentos, 1997.

COPPLESTONE, T. \& MYERS, B.S. (Org.) O Mundo da Arte. São Paulo: Expressão e Cultura.

COSENTINO, P. Enciclopedia de tecnicas de ceramica. Acanto.

COSTA, C. A imagem da mulher: um estudo de arte brasileira. Rio de Janeiro: Senac Rio, 2002.

COSTELLA, A. Introdução à Gravura. São Paulo: Mantiqueira, 1984.

COX, M. Desenho da criança. São Paulo: Martins Fontes.

COUSSRDIĖRE, A. \& SICARD, O. La photographie à l'école - sa pratique et son utilization pédagogique. Paris: Retz, 1988.

CYR, D. Fotografia recreativa para niños. Barcelona: Daimon, 1977.

DA SILVA, O. Poty, O artista grárfico. Curitiba: Fund. Cult. Curitiba, 1980.

. A Arte maior da Gravura. São Paulo: Spade, 1976.

DA-RIN, S. Espelho partido. Tradição e Transformação do documentário. Rio de Janeiro: Editora Azougue, 2004.

DEBORD, G. A sociedade do espetáculo. Rio de Janeiro: Contraponto, 1997. Panegírico. Rio de Janeiro: Conrad Do Brasil, 2002.

DELEUZE, G. \& GUATTARI, F. O Que é a Filosofia? Rio de Janeiro: Editora 34, 1992.

DELEUZE, G. A Imagem-Tempo. Rio de Janeiro: Brasiliense, 2005.

DENVIR, B. O Fauvismo e o Expressionismo. Barcelona: Labor, 1976.

. O Impressionismo. Barcelona: Labor, 1976.

DEMO, P. Introdução à metodologia da ciência. 2ª ed. São Paulo: Atlas, 1995.

DEMPSEY, A. Estilos, escolas e movimentos. São Paulo: Cosac \& Naify, 2003.DENCKER, A.F.M. \& DA VIA, S.C. Pesquisa empírica em ciências humanas com ênfase em comunicação. São Paulo: Futura, 2001. 
DERDYK, E. Formas de pensar o desenho: desenvolvimento do grafismo infantil. São Paulo: Scipione, 1989.

DERFLER Jr; F.J. \& FREED; L. Como Funcionam as Redes. São Paulo: Quark, 1993.

DEWEY, J. El Arte como Experiência. México: Fundo de Cultura Economica, 1959.

Experiência e Educação. São Paulo: Cia Editora Nacional, 1976.

DI IORIO, M. Cerâmica. Uberlândia: Graf. Da UFU, 1991.

DIDI-HUBERMAN, G. O que vemos, o que nos olha. São Paulo: Editora 34, 1998.

DIEGUES, J.L.R. Las funciones de la imagen en la ensenanza. Barcelona: Gustavo Gilli, 1978.

DONDIS, D A. Sintaxe da linguagem visual. Tradução por Jefferson Luiz Camargo. São Paulo: Martins Fontes, 1991.

DERDYK, E. Formas de pensar o Desenho - Desenvolvimento do grafismo infantil, São Paulo: Scipione, 1989.

. O Desenho da figura humana. São Paulo: Scipione, 1990.

DOMINGUES, D. A Arte no Século XX - A Humanização das Tecnologias, São Paulo: UNESP, 1997.

DUBY, G. (Org). A Idade Média. São Paulo: Paz e Terra, 1997.

DUBOIS, P. Cinema, Vídeo, Godard. São Paulo: Cosac Naify, 2004.

DURAND, J.C. A Academia Imperial de Belas-Artes do Rio de Janeiro e o Regime de pensionato. In: Arte, privilégio e distinção. São Paulo: Perspectiva/ Edusp, 1989. p. 03-16.

. Imigração de Artesãos e Artistas Europeus. Academias e Liceus no Ensino de Artes e Ofícios entre 1890 e 1930. In: Arte, privilégio e distinção. São Paulo: Perspectiva/Edusp, 1989. p. 55-73.

EAGLETON, T. A ideologia da estética. Rio de Janeiro: Jorge Zahar, 1993.

ECO, H. As formas do conteúdo. São Paulo: Perspectiva, 1974.

. Arte e beleza na estética medieval. Rio de Janeiro: Globo, 1989.

Obra Aberta. São Paulo: Perspectiva, 1971. Semiótica e Filosofia da Linguagem. São Paulo: Ática, 1991.

EDDINGS, J. Como Funciona a Internet. Quark; São Paulo; 1994.

EDMAM, I. John Dewey. Rio de Janeiro: Fundo de Cultura, [19--]. p. 170-197.

ESPAÇO CULTURAL DOS CORREIOS. Mariana Canepa. Rio de Janeiro. Junho/julho 2000.

ESPAÇO BANDES. Soraya Burlamaqui. A Cerâmica na arte contemporânea brasileira. Rio de Janeiro. Dez. 1993.

EISENSTEIN, S. A forma do filme. Rio de Janeiro: Jorge Zahar Editora, 1990.

. O sentido do filme. Rio de Janeiro: Jorge Zahar Editora, 2002.

FAUSTO NETO, A. (Org.). O Indivíduo e as mídias. Rio de Janeiro: Diadorim, 1996.

FAGUNDES, A. Manual prático de introdução a cerâmica. Caminho, 1997.

FABBRINI, R.N. A Arte depois das Vanguardas. São Paulo: FAPESP, 2002.

FAURE, E. A Arte Antiga. São Paulo: Martins Fontes, 1990.

FABRIS, A. (Org.). Fotografia, uso e funções no Século XIX. São Paulo: Edusp, 1991.

FERRARA, L.D. São Paulo: Perspectiva, 1981.

FERREIRA, H.P. \& TÁVORA, M.L.L. (Org.) Gravura Brasileira Hoje. Depoimentos.

Rio de Janeiro. SESC/ARRJ, 1995. 
FERNÁNDEZ ARENAS, J. Teoría y metodología de la historia del arte. Barcelona: Anthropos, 1986.

FERRAZ, M.H.C.T. Arte-Educação: vivência, experiência ou livro didático? São Paulo: Cia das Letras, 1987.

FERREZ, G. A fotografia no Brasil. (1840-1900). Rio de Janeiro: Funarte, 1985.

FIORIN, J.L. "A noção de texto na semiótica". In: Organon 9, Universidade Federal do Rio Grande do Sul, 1996.

. Elementos de análise do discurso. 6. ed. São Paulo: Contexto, 1997.

Astúcias da enunciação: as categorias de pessoa, espaço e tempo. 2.

ed. São Paulo: Ática, 1999.

FISCHER, E. A necessidade da arte. Rio de Janeiro: Zahar, 1983.

FISCHER, E. A necessidade da arte. 9ª ed. Rio de Janeiro: Zahar, 1983.

FLOCH, J.M. "Imagens, signos, figuras - a abordagem semiótica da imagem". In: Cruzeiro Semiótico: Revista semestral da Associação Portuguesa de Semiótica, n.3, Porto: jul. 1985. p. 75-81.

- Petites mythologies de l'oeil et de l'esprit: Pour une sémiotique

plastique, Paris-Amsterdam: Edition Hades-Benjamins, 1985. . Identités visuelles. Paris: PUF, 1995. 213p.

"Alguns conceitos fundamentais em semiótica geral". Trad. A. D. Pilar.

FLUSSER, V. Filosofia da caixa preta. São Paulo: Hucitec, 1984.

FOCILLON, H. Vida das Formas. Rio de Janeiro: Zahar, 1983.

FOCILLON, H. Arte do Ocidente. A Idade Média românica e gótica. Lisboa.

FOUCAULT, M. As palavras e as coisas. Lisboa: Edições 70, 1977. . Isto não é um cachimbo. Rio de Janeiro: Paz e Terra, 1988.

FRANCIS, F.; HARRIS, J.; HARRISON, C. \& WOOD, P. Modernismo em Disputa - a arte desde os anos quarenta. São Paulo: Cosac \& Nafy Edições, 1988.

FRY, M. A Arte na Era da Máquina. São Paulo: Perspectiva, 1976.

FREIRE, C. Poéticas do Processo, arte conceitual no museu. São Paulo: Iluminuras, 1999.

FUSCO, R. História da Arte Contemporânea. Lisboa: Presença, 1988.

FUSCO, R. Historia y estructura: teoria de la historiografia arquitectónica. Madrid: Alberto Corazón, 1974.

História da arte contemporânea. Lisboa: Presença, 1988.

FUSCO, R. História da arte contemporânea. Lisboa: Presença, 1988.

FUSARI, M.F.R. Educador e o desenho animado. Rio de Janeiro: Loyola, 2002.

GABBAI, M.B.B. Cerâmica: Arte da Terra. São Paulo: Callis, 1987.

GAUDIO, A. Os Etruscos. São Paulo: Mundo Musical, 1973.

GIL, A.C. Metodologia do Ensino superior. São Paulo: Atlas, 1990.

GULLAR, F. (Org.) Arte Brasileira Hoje. Rio de Janeiro: Paz e Terra, 1973. Vanguarda e Subdesenvolvimento. Rio de Janeiro: Civil, Brasileira,

1969.

GOMBRICH, E.H. A história da arte. 15. Ed. Trad. Álvaro Cabral. Rio de Janeiro: Guanabara Koogan, 1993.

GOMBRICH, E.H. A História da Arte. Rio de Janeiro: Zahar, 1983.

GOMBRICH, E.H. Norma e forma. Estudos sobre a arte da renascença. São Paulo: Martins Fontes, 1990. . L'art et l'llusion. Paris, Gallimard, 1971. 
GOMES, F.L.S. Videoconferência: Sistemas e Aplicações. Visual Books: Florianópolis, 2003.

GREENBERG, C.; FERREIRA, G. \& COTRIM, C. (Org.) Clement Greenberg e o Debate Crítico. Rio de Janeiro: Jorge Zahar Editor, 1997.

GROPIUS, W. Bauhaus. Nova arquitetura. São Paulo: Perspectiva, 1977.

GULLAR, F. Vanguarda e subdesenvolvimento. 2. ed. Rio de Janeiro: Civilização Brasileira, 1978.

GRINBERG, N.T. Humanoídes: Transmutação da forma e da matéria. Dissertação de Mestrado. São Paulo: ECA/USP, 1994. . Lugar com arco. Tese de doutorado. São Paulo: ECA/USP,1999.

GRAUER, K. (ed). Community In: Sea News, Vancuver: Unesco, v.2, n. 2, August, 1995.

GREIG, P. A Criança e seu desenho. Artmed, 2004.

GUEDES, S. A arte Educação contra a violência. Revista Poema Pedagógico, Petrópolis: Reproarte, n. 5, 1996. p. 77-88.

GOULART, I.B. Psicologia da Educação. Petrópolis: Vozes, 1987. p.65-91.

GERNSHEIM, H. História Gráfica de la Fotografía. Barcelona: Omega, 1967.

GREIMAS, A.J. "Éléments d'une grammaire narrative". In:

sens:essais sémiotiques. Paris: Éditions du Seuil, 1970. p. 157-183.

. Semiótica e Ciências Sociais. Tradução por Álvaro Lorencini e Sandra

Nitrini. São Paulo: Cultrix, 1981.

"Semiótica Figurativa e Semiótica Plástica". Tradução por J. Assis da

Silva. In: Significação: Revista Brasileira de Semiótica, n. 4, Araraquara-SP, jun. 1984. p. 18-46.

2002.

. Da imperfeição. Trad. de Ana Cláudia de Oliveira. São Paulo: Hacker,

GREIMAS, A.J. \& COURTÈS, J. Dicionário de Semiótica. Trad. de Alceu Dias Lima e outros. São Paulo: Cultrix, 1979.

Semiótica: Diccionario razonado de la teoría del lenguage. Versão

espanhola de Enrique Ballón Aguirre. Madrid:Gredos, 1991.

. "Masculino, feminino, social". Trad. de A. C. de Oliveira. In: Nexos. São

Paulo: Universidade Anhembi-Morumbi, ano II, no 3, agosto, 1998.

"O olhar comprometido". Tradução de A. C. de Oliveira e M. da Vinci

de Moraes. In: Galáxia: Revista transdisciplinar de comunicação, semiótica, cultura/Programa Pós-Graduado em Comunicação e Semiótica da PUC-SP, n. 2, São Paulo, 2001. p. 19-56.

. Presenças do outro: ensaios de sociossemiótica. Tradução por Mary

Amazonas Leite de Barros. São Paulo: Perspectiva, 2002.

HAUSER, A. História Social da Literatura e da Arte. São Paulo: Mestre Jou, 1992.

HAYES, C. Guia completo de Pintura y Dibujo. Técnicas y Materiales. Madri: H.Blume Ediciones, 1978.

HERSKOVITCH, A. Xilogravura - Arte e Técnica. Rio Grande do Sul: Tchê, 1986.

HEDGECOE, J. Curso de Fotografia. Círculo do Livro. São Paulo, 1979.

HADJINICOLAOU, N. História da arte e movimentos sociais. Lisboa: Edições 70/Martins Fontes, 1978.

HAUSER, A. A arte e a sociedade. Lisboa: Presença, 1984.

Teorias da arte. 2. ed. Lisboa: Presença, 1978.

HUSSERL, E. Investigações lógicas. São Paulo: Abril Cultural, 1975.

ITRI, M.P. Internet 2: A próxima Geração. São Paulo: Market Books, 1999. 
IRIS, Revista. Foto. Editora Iris Ltda. Imagens da Segunda Geração. São Paulo, MAC/USP, 1987.

JAKOBSON, R. Linguística e Comunicação. São Paulo: Cultrix, 1985. JACKSON, P. Origami \& artesanato em papel. EDELBRA, 1996.

JANSON, H. História da Arte. Lisboa: Fundação C. Gulbenkian, 1989.

JANSON, H.W. \& JANSON, A.F. Iniciação à História da Arte. São Paulo: Martins Fontes, 1996.

KRAUSS, R. Caminhos da Escultura Moderna. São Paulo: Martins Fontes, 2001. KRISTEVA, J. História da Linguagem. Lisboa: Edições 70, 1974.

KLEE, P. Sobre a arte moderna e outros ensaios. Rio de Janeiro: Zahar, 2001.

KLINTOWITZ, J. O Ofício da Arte: a pintura. São Paulo: Sesc, 1987.

KOSSOVITCH, L.; LAUDANA, M. \& RESENDE, R. Gravura Brasileira. São Paulo: Cosac \& Naif / Itaú Cultural, 2000.

KOSSOY, B. Fotografia e História. São Paulo: Ed. Ática, 1989. . Realidades e Ficções na Trama Fotográfica. São Paulo: Ateliê, 1999.

KUBRUSLY. C.A. O que é fotografia. Primeiros passos, 82. São Paulo: Brasiliense, 1991.

LAMBERT, R. A Arte do Século XX. Introdução à História da Arte da Universidade de Cambridge. São Paulo: Zahar, 1984.

LAKATOS, E.M. Sociologia Geral. 6ª ed. São Paulo: Atlas, 1996. p. 104-122.

LANE, T. M. O processo grupal. In: CODO, W. \& LANE, S. Psicologia Social: o homem em movimento. 4⿳亠丷a ed. São Paulo: Brasiliense, 1986. p. 78-98.

LANGFORD, M. Fotografia Básica. Lisboa: Dinalivro, 1979.

. Tratado de Fotografia. Lisboa: Dinalivro, 1981.

Fotografia. Porto: Civilização, 1993.

LEROI - GOURHAN, A. Evolução e técnicas: 1 - O homem e a matéria. Trad. port. de Fernanda P. Bastos Lisboa: Edições 70, 19984.

LEITE, J.R.T. A Gravura Brasileira Contemporânea. São Paulo: Expressão e Cultura, 1966.

LIMA, I. A Fotografia é a sua linguagem. Rio de Janeiro, Ed. Espaço e Tempo, 1988.

LIMA, L.O. Estórias da Educação no Brasil: de Pombal a Passarinho. Brasília: Brasília, 1974. p. 07-30.

LIMA, T.L. Ver a Música, Ouvir a Imagem: a arte do videoclipe. . A Arte do Vídeo. São Paulo: Brasiliense, 1995.

A Televisão Levada a Sério. São Paulo: SENAC, 2000.

LUCIE-SMITH, E. Moviments in art since 1945. London: Thames and Hudson, 1985.

LUCKESI, C.C. (et al.) Fazer Universidade: uma proposta metodológica. São Paulo: Cortez, 1989.

Avaliação da aprendizagem escolar: estudos e proposições. São

Paulo: Cortez, 1996.

LACOSTE, J. A filosofia da Arte. Rio de Janeiro: Zahar, 1986.

LANGER, S. Filosofia em Nova Chave. Tradução Moysés Baumstein, São Paulo, Perspectiva, 1971.

. Los Problemas del Arte. Buenos Aires: Infinito, 1966.

LYOTARD, J.F. O Pós-moderno. Rio de Janeiro: José Olympio, 1986.

MARTINS, F.C.B. Introdução ao conhecimento da gravura em metal. Rio de Janeiro: PUC, 1982. 
MAYER, R. Manual del Artista. Materiales y técnicas. Buenos Aires: Liberia Hachette.

MARTINS, M.C.; PICOSQUE, G. \& GUERRA, M.T. A Língua do Mundo. Didática do Ensino de arte. São Paulo: FTD, 1998.

MACHADO, L.G. O Barroco Mineiro. São Paulo: Perspectiva, 1978.

MACHADO, A. Máquina e Imaginário. São Paulo: Edusp, 1993.

Pré-cinemas/pós-cinemas. Campinas: Papirus, 1996.

(Org.). Made in Brasil: três décadas do vídeo brasileiro. São Paulo:

Itaú-Cultural, 2003.

. A ilusão especular São Paulo, Brasiliense, 1984.

MARIN, A.J. Educação, Arte e Criatividade. São Paulo: Pioneira,1976.

MASSIRONI, M. Ver pelo desenho. Edições 70, 1996.

MARX, K. \& ENGELS, F. Sobre literatura e arte. 4. ed. Lisboa: Estampa, 1977.

MEREDIEU, F. O desenho infantil. Cultrix, 2000.

METZ, C. A análise das Imagens. Petrópolis: Vozes, 1973.

MELLO, M.B. O Encontro da arte com a Educação. Revista Poema Pedagógico Petrópolis: Reproarte, n. 4, ano 1996. p. 95-100.

MENEZES, C.S. (et al.) Informática Educativa I. ne@ad; Vitória; 2003.

MICHELI, M. Las vanguardias artísticas del siglo XX. Madrid: Alianzza, 1985.

MOREIRA LEITE, M. (Org.) Desafios da Imagem. Campinas: Papirus, 1998.

MONFORTE, L.G. Fotografia Pensante. São Paulo: Ed. Senac, 1997.

MOURA, C.E.M. (Org.) Retratos quase inocentes. São Paulo: Nobel, 1983.

MUSEU de Arte Moderna de São Paulo lole de Freitas. São Paulo: MAM, 1997.

Panorâmica da arte brasileira. São Paulo : MAM, 1997.

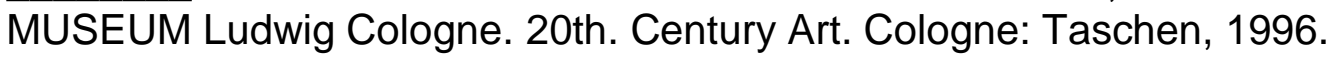

MUSA, J.L. \& PEREIRA, R.G. Interpretação da luz - o controle de tons na fotografia preto e branco São Paulo: Olhar Impresso, 1994.

MORAIS, F. Artes Plásticas: a crise da hora atual. Rio de Janeiro: Paz e Terra, 1975.

Cenas da vida brasileira - 1930-1954. Recife: Prefeitura do Recife.

Fundação Roberto Marinho. Grupo Oton,1980.

Núcleo Bernardelli: arte brasileira nos anos 30 e 40. Rio de Janeiro,

Pinakotheke, 1982.

MACKINTOSCH, A. O Simbolismo e o Art-Nouveau. Barcelona: Labor, 1975.

MADSEN, S.T. Art-Nouveau. Porto: Editora Inova, 1967.

NAUGLE, M. Guia llustrado do TCP/IP. Berkeley; São Paulo; 2001.

NAVES, R. A Forma Difícil. São Paulo: Ática, 1997.

NADEAU, N. História do Surrealismo. São Paulo: Perspectiva, 1985.

NASCH, J. O Cubismo, o Futurismo e o Construtivismo. Barcelona: Labor, 1976.

NÉRICI, I.G. Didática do Ensino superior. São Paulo: IBRASA, 1993.

NORTON, F.H. Cerâmica fina tecnologia Y aplicaciones - Omega, 1975.

NUNES, B. Introdução à Filosofia da Arte. São Paulo, Buriti, 1966.

NOVAES, A. (Org.) O Olhar. São Paulo: Companhia das Letras, 1988.

OLIVEIRA, R.D. Pesquisa social e ação educativa: conhecer a realidade para poder transformá-la. In: BRANDÃO, C.R. (et al.) Pesquisa participante. São Paul : Brasiliense, 1985. p. 17-41.

OSTROWER, F. Criatividade e Processos de Criação. Petrópolis: Vozes. 1978.

OSBORNE, H. Estética e teoria da arte: uma introdução histórica. 4. ed. São Paulo: Cultrix, 1983. 
OLIVEIRA, A.C. \& LANDOWSKY, E. (Eds.) Do inteligível ao sensível: em torno da obra de Algirdas Julien Greimas. São Paulo: EDUC, 1995. p.199-225. . \& FECHINE, Y. (Org.) Semiótica da Arte. São Paulo: Hacker Editores, 1998. “As semioses pictóricas”. In: Face, v. 4, no 2, São Paulo, jul/dez. 1995. "A semiótica na gravitação dos sentidos". In Nexos, $n^{\circ} 3$, Revista de Estudos de Comunicação e Educação. São Paulo: Universidade AnhembiMorumbi, ano II, agosto, 1998.

PANOFSKY, E. Estudos de iconologia: temas humanísticos na arte do renascimento. Lisboa: Estampa, 1986.

Significado nas Artes Visuais. 2 ed. São Paulo: Perspectiva, 1979.

Edições 70, 1993.

A perspectiva como forma simbólica. Trad. Elisabete Nunes. Lisboa:

PARENTE, A. Imagem Máquina. Rio de Janeiro: Editora 34, 1993.

PERSICHETTI, S. Imagens da fotografia brasileira. São Paulo: Estação da Liberdade/Senac, 2000.

PORCHER, L. La photographie et ses usages pedagogiques. Paris: Armand Colin/Bourrelier, 1974.

PLAZA, J. \& TAVARES, M. Processos criativos com os meios eletrônicos: Poéticas digitais. São Paulo: Hucitec, 1989.

PEREIRA, Luís Humberto M. M. Arte, fotografia em um tempo angustiado In: BARBOSA, A.M.T.B. (et alli). Ensino das Artes nas Universidades. São Paulo: Edusp, 1997. p. 91-96.

PEDROSA, M. Forma e Percepção Estética. Org. Otília Arantes. São Paulo: EDUSP, 1997.

Perspectiva, 1976.

PEIRCE, C.S. Semiótica e Filosofia. São Paulo, Cultrix, 1972.

PIGNATARI, D. Informação. Linguagem. Comunicação. São Paulo: Perspectiva, 1977.

PINTO, G.C. Coisa de criança/ Desenho por que não? Agalma, 2003.

PIJOAN, J. (Et Al.) História da Arte. São Paulo: Salvat, 1978.

PIPPARD, L. R. A Arte Pop. São Paulo: Verbo/EDUSP, 1976.

PIAGET, J. A Educação Artística e a Psicologia da Criança. Revista Brasileira de Estudos Pedagógicos, (S.L), v. 49, n. 109, p.211-213. 1968.

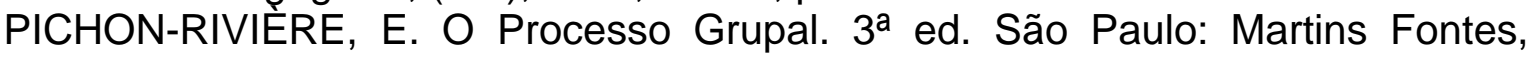
1988.

PONTUAL, R. Arte Brasileira Contemporânea. Rio de Janeiro: JB, 1976.

. Entre dois Séculos - Arte Brasileira do século XX na coleção Gilberto

Chateaubriand. Rio de Janeiro: JB, 1987.

"O índio nosso de cada dia". Texto do catálogo de Glauco Rodrigues, I

Bienal Latino-Americana Mitos e Magia, São Paulo, novembro/dezembro/1978.

PRADO Jr. C. O que é Filosofia. São Paulo, Brasiliense, 1985.

RAMIE, G. Cerâmica de Picasso. EUROPA-AMERICA, 1997

RAMALLO, G. Saber ver a arte românica. São Paulo: Martins Fontes, 1992.

RAMALHO, J. Fotografia digital. Campus, 2004.

RAMÍREZ, J. \& GAGO, L. Guía práctica del profesor-Orientador/Tutor en educación primaria y secundaria. Madrid: Narcea, 1993. 
REALE, M. Paradigmas da Cultura Contemporânea. São Paulo: Saraiva, 1996. p.1- 22.

READ, H. Filosofia da Arte Moderna. S.L.P., Ulisseia, s/d. . O Sentido da Arte. São Paulo, Ibrasa, 1978.

. História da Pintura Moderna. Rio de Janeiro: Zahar, 1980.

As Origens da Forma na Arte. $2^{\underline{a}}$ ed. São Paulo: Zahar, 1981.

Arte e Alienação. São Paulo: Zahar, 1983.

Educacion por el Arte. 2a ed. Buenos Aires: Paidós, 1959.

O Significado da Arte. São Paulo: Ulisséia, 1968.

Modern Sculpture. London: Thames and Hudson, 1988.

REBOUÇAS, M. O discurso modernista da pintura São Paulo: PUC/SP/CPS, 2003.

REYNAUD, A.T.J. Escrevendo com Imagens: Parabolic People de Sandra Kogut. Disponível em: <www.unirio.br/cead/morpheuS/Numero01-2000/anajardim.htm>. Acesso em: 24 Nov.2002.

RIBEIRO, J. Desenho de infância. Editora do Brasil, 2005.

RICHTER, H. Dada; art and anti-art. London: Oxford, 1978.

ROLNIK, S. Uma insólita viagem à subjetividade In: LINS, D. Cultura e subjetividade. São Paulo: Papirus, 1997. p. 35-48.

ROCHA, R. Libro del papel. São Paulo: Melhoramentos, 1992.

RODULFO, R. Desenhos fora do papel: da caricia a leitura-escrita na criança.

ROSEMBERG, H. A tradição do novo. São Paulo: Perspectiva, 1974.

RODRÍGUEZ, M. L. Orientación educativa. Barcelona: CEAC, 1988.

RODIN, A. A Arte. Conversas com Paul Gsell. Rio de Janeiro: Nova Fronteira, 1990.

RUDEL, J. A técnica do desenho. Trad. E. Jorge. Rio de Janeiro: Zahar, 1979.

SALLES, C.A. Gesto Inacabado: processo de criação artística. São Paulo: Fapesp/Annablume, 1989.

. Crítica genética: Uma (nova) Introdução. São Paulo: Educ. 2000.

SANTAELLA, L. A teoria Geral dos Signos. Semiose e Autogeração. São Paulo: Ática, 1995.

SCHISLER, M.W.L. Revelação em branco e preto - a imagem com qualidade. São Paulo: Martins Fontes, 1995.

SONTAG, S. Ensaios sobre a Fotografia. México, Artes Y Libros Ed. 1978.

SAUSSURRE, F. As palavras sob as palavras. A questão da origem. São Paulo: Abril Cultural, 1975.

SILVEIRA, J.E.B.R. Abordagem Metodológica do Objetivo Artístico: consideração sobre alguns princípios teóricos. Bauru: Jolovi, 1979.

SILVA, R.R. \& COSTA, H. Fotografia moderna no Brasil. São Paulo: Cosac \& Naif, 2004

SANTOS, A. \& SANTOS, M.I. Fotografia nos processos artísticos contemporâneos. UFRGS, 2004.

SOARES, T. Videoclipe, o Elogio da Desarmonia: hibridismo, transtemporalidade e neobarroco em espaços de negociação. Intercom, 2004.

SESC - SÃO PAULO, Jacob Klintowitz. A Ressacralização da arte. São Paulo. Março/abril 1999.

SENAC. Oficina: cerâmica. São Paulo: SENAC, 2002. WOLSWAGEN DO BRASIL S.A. Artísticas da Cerâmica brasileira. São Paulo: Raízes, 1985.

SALVAT, J. (Dir.). Historia del Arte. Barcelona: Salvat, 1985. 
SANT'ANNA, A.R. Desconstruir Duchamp - arte na hora da revisão, Rio de Janeiro: Vieira \& Lent, 2003.

SCARINCI, C. A Gravura no Rio Grande do Sul: 1900-1980. Porto Alegre, Mercado Aberto, 1982.

STANGOS, N. (Org.). Conceitos da Arte Moderna. Rio de Janeiro: Zahar, 1991.

STRICKLAND, C. Arte Comentada - Da pré-história ao pós-moderno, Rio de Janeiro: Ediouro, 2002.

SANTAELLA, L. O que é Semiótica. São Paulo: Brasiliense, 1983.

SALLES, C.A. Gesto Inacabado. São Paulo: Anna Blume, 1998.

STANGOS, N. Conceitos da Arte Moderna. São Paulo: Jorge Zahar, 1994.

SYLVESTER, D. Entrevistas com Francis Bacon. Cosac \& Naify, 1995.

SOBRADO, L. Intervención psicopedagógica y orientación educativa. Barcelona, 1990.

SILVA, M. Sala de Aula Interativa. Quartet; Rio de Janeiro; 2002.

TARELLA, A. Como reconhecer a arte romana. São Paulo: Martins Fontes, 1985.

TOMAN, R. (Ed.). O românico. Colônia: Taschen, 2000.

TASSINARI, A. O espaço moderno. São Paulo: Cosac \& Naify, 2001.

TOMAZZI, N. (Coord.). Iniciação à Sociologia. São Paulo: Atual, 1993. p. 67-70.

THIOLLENT, M. Crítica Metodológica: investigação social e enquete operária. São Paulo: Polis, 1982. p. 79-225. . Metodologia da Pesquisa-ação. 7ª ed. São Paulo: Cortez, 1996.

TRIVIÑOS, A.N.S. Introdução à Pesquisa em ciências Sociais: a pesquisa qualitativa em Educação. São Paulo: Atlas, 1987.

TRIGO, T. \& LEPISCOPO, M. Historia da fotografia: 1840-1960. CD ROOM. SENAC São Paulo, 1998.

TOBIAS, J.A. Iniciação à Filosofia. São Paulo: Editora do Brasil, 1974.

UPJOHN, E. (et. al) História Mundial da Arte. Lisboa: Livraria Bertrand, 1965.

VEIGA NETO, A. (Org.). Crítica pós-estruturalista e Educação. Porto Alegre: Sulina, 1995.

VINCENS, F. Arte abstrata e arte figurativa. Rio de Janeiro: Salvat Editora, 1979.

VER, A.C.O. \& LANDOWSKI, E. In: Documentos de estudo do Centro de Pesquisas Sociossemióticas. São Paulo: CPS Editorial, 2001.

WALTER, J.A. A Arte desde o Pop. Barcelona: Labor, 1977.

WILSON, S. A Arte Pop. Barcelona: Labor, 1975.

WOODFORD, S. A arte de ver a arte: Introdução à História da Arte da Universidade de Cambridge. Tradução por Álvaro Cabral. Rio de Janeiro: Zahar, 1983.

WITTKOWER, R. Escultura. Trad. Jefferson Luiz Camargo. São Paulo: Martins Fontes, 1989.

WOOD. P. Arte Conceitual. Rio de Janeiro: Cosac \& Naify, 2002.

WONG, W. Fundamientos del deseño bi y tridimensional. S/l, s/ed., s/d.

. Princípios de forma e desenho. São Paulo: Martins Fontes, 2001.

WOLFF, J. A produção social da arte. Rio de Janeiro: Zahar, 1982.

WOLFFLIN, H. Conceitos Fundamentais da História da Arte. São Paulo: Martins Fontes, 1984.

A arte clássica. São Paulo: Martins Fontes, 1990.

Conceitos fundamentais da história da arte: o problema da evolução

dos estilos na arte mais recente. 2. ed. São Paulo: Martins Fontes, 1989. 
Renascença e barroco. Estudo sobre a essência do estilo barroco e a sua origem na Itália. São Paulo: Perspectiva, 1989.

YAGUELLO, M. Alice no País da Linguagem. Lisboa: Estampa, 1991.

ZANINI, W. (Org.). História geral da arte no Brasil. São Paulo: Instituto Walther Moreira Salles, 1983.

. Tendências da escultura moderna. São Paulo: Cultrix, 1886. 


\section{ANEXO E - Matriz Curricular do Curso de Licenciatura em Artes Visuais modalidade à distância UFES}

Artes Visuais-Licenciatura/EAD

Grade curricular

\begin{tabular}{|c|c|}
\hline Módulo / disciplinas & $\mathrm{CH}$ \\
\hline \multicolumn{2}{|l|}{ Módulo I } \\
\hline Fundamentos estruturais e pedagógicos da EAD & $30 \mathrm{hs}$ \\
\hline Metodologia da Pesquisa em EAD & $30 \mathrm{hs}$ \\
\hline Linguagem Gráfica & $60 \mathrm{hs}$ \\
\hline Interaçoes Culturais & $60 \mathrm{hs}$ \\
\hline Percepcâo e Composiçăo & $60 \mathrm{hs}$ \\
\hline Propostas Metodológicas do Ensino da Arte 1 & $60 \mathrm{hs}$ \\
\hline Seminário I & $60 \mathrm{hs}$ \\
\hline \multicolumn{2}{|l|}{ Módulo II } \\
\hline Propostas metodológicas do Ensino da arte 2 & $60 \mathrm{hs}$ \\
\hline Aspectos Legais do Ensino da Arte & $60 \mathrm{hs}$ \\
\hline História da Arte I & 60hs \\
\hline Desenhol & 60hs \\
\hline Cor e Laboratório de Tintas e Materiais & 60hs \\
\hline Artes da Fibra & $60 \mathrm{hs}$ \\
\hline Seminário II & $60 \mathrm{hs}$ \\
\hline \multicolumn{2}{|l|}{ Módulo III } \\
\hline Didática do Ensino da Arte & $60 \mathrm{hs}$ \\
\hline Sintaxe visual & 60hs \\
\hline Antropologia Visual & $60 \mathrm{hs}$ \\
\hline História da Arte II & $60 \mathrm{hs}$ \\
\hline Modelagem & $60 \mathrm{hs}$ \\
\hline Desenho II & $60 \mathrm{hs}$ \\
\hline Estágio I & $100 \mathrm{hs}$ \\
\hline Seminário III & $60 \mathrm{hs}$ \\
\hline \multicolumn{2}{|l|}{ Módulo IV } \\
\hline Filosofia da Arte & $60 \mathrm{hs}$ \\
\hline História da Arte III & 60hs \\
\hline Fotografia & $60 \mathrm{hs}$ \\
\hline Processo de criaçăo & $60 \mathrm{hs}$ \\
\hline Teorias da Linguagem visual & 60hs \\
\hline Prática de Ensino I & $100 \mathrm{hs}$ \\
\hline Seminário IV & $60 \mathrm{hs}$ \\
\hline \multicolumn{2}{|l|}{ Módulo V } \\
\hline História da Arte IV & 60hs \\
\hline Pintura & $60 \mathrm{hs}$ \\
\hline Cerámica & $60 \mathrm{hs}$ \\
\hline Video & $60 \mathrm{hs}$ \\
\hline Prática de Ensino II & $150 \mathrm{hs}$ \\
\hline Estágio II & $100 \mathrm{hs}$ \\
\hline Seminário V & $60 \mathrm{hs}$ \\
\hline
\end{tabular}




\section{ANEXO F - BIBLIOGRAFIA - UNB}

ALMEIDA, F.J. Educação e Informática: os Computadores na Escola. São Paulo: Cortez, 1987.

(Org.). Educação a distancia: formação de professores em ambientes virtuais e colaborativos de aprendizagem. Projeto NAVE. São Paulo: PUC, 2001.

ALVES-MAZZOTTI, A.J. \& GEWANDSZNAJDER, F. O método nas ciências naturais e sociais: pesquisa quantitativa e qualitativa. São Paulo: Pioneira, 2002.

AZENHA, M.G. Construtivismo. De Piaget a Emília Ferreiro. São Paulo: Editora Ática, 2000.

BARBOSA, A.M.T.B. John Dewey e o Ensino da Arte no Brasil. São Paulo: Cortez, 2001.

BRANCO, A. \& VALSINER, J. A questão do método na Psicologia do Desenvolvimento: uma perspectiva co-construtivista. In: PAZ, M.G.T. \& TAMAYO, A. (org.) Escola, Saúde e Trabalho: estudos psicológicos. Brasília: Editora UnB. 1999.

CASTORINA, J.A. (et al) Piaget - Vygotsky: novas contribuições para o debate. São Paulo: Editora Ática, 2000.

CHIZZOTTI, A. Pesquisa em ciências humanas e sociais. São Paulo: Cortez, 2003. DIONNE, J \& LAVILLE C. A construção do saber: manual de metodologia da pesquisa em ciências humanas. Belo Horizonte: Editora UFMG, 1999.

FAZENDA, I.C. Integração e Interdisciplinaridade no Ensino brasileiro: efetividade ou ideologia? São Paulo: Loyola, 2002.

. A Interdisciplinaridade: história, teoria e pesquisa. 11르 ed. Campinas:

Papirus, 2003.

FERRAZ, M.H.C.T. \& FUSARI, M.F.R. Arte na Educação escolar. São Paulo: Cortez, 1992.

. Metodologia do Ensino da Arte. São Paulo: Cortez, 1993.

FREIRE, P. Pedagogia do oprimido. Rio de Janeiro: Paz e Terra, 1987.

KENSKI, V.M. Tecnologias e Ensino presencial e a distancia. Campinas: Papirus, 2003. KIPNIS, B. Elementos de Pesquisa em Ciências Sociais. Brasília: Editora Universidade de Brasília, 2004.

KIPNIS, Bernardo. Elementos de Pesquisa em Ciências Sociais. Brasília: Editora Universidade de Brasília, 2004.

. Elementos do processo de pesquisa. Brasília: SESI - Serviço Social da

Indústria, 2003. Modulo utilizado na Formação de Formadores em Educação de Jovens e Adultos, oferecida pelo SESI, a Universidade de Brasília e a UNESCO.

. Elementos de Pesquisa em Ciências Sociais. Brasília: Editora Universidade de Brasília, 2004.

LÜCK, H. Pedagogia Interdisciplinar: Fundamentos teórico-metodológicos. Petrópolis:

Vozes, 2004.

MINAYO, M.C.S. Pesquisa Social: teoria, método e criatividade. Petrópolis, Vozes, 1994.

. Pesquisa Social: teoria, método e criatividade. Petrópolis, Vozes, 1994.

MORAES, M.C. O paradigma educacional emergente. São Paulo: Papirus, 1997.

NICOLESCU, B. (et al.) Educação e Transdisciplinaridade. Brasília: Edições UNESCO, 2000.

Manifesto da Transdisciplinaridade. São Paulo: Triom, 2001.

NOGUEIRA, N.R. Pedagogia dos Projetos: Etapas, papéis e atores. São Paulo: Érica, 2005. 
OLIVEIRA, E.G. Educação a distancia na transição paradigmática. Campinas: Papirus, 2003.

PIMENTEL, L.G. Limites em expansão. Belo Horizonte: C/ARTE, 1999. . Educação como pratica da liberdade. Rio de Janeiro: Paz e Terra, 1980.

SIQUEIRA, A. Práticas Interdisciplinares na Educação Básica: uma revisão bibliográfica - 1970-2000. ETD - Educação Temática Digital. Campinas. v.3, n.1.p.90-97, Dez.2001. VYGOTSKY, L.S. Pensamento e linguagem. São Paulo: Martins Fontes, 2003. . Psicologia da Arte. São Paulo: Martins Fontes, 1998. 


\section{AMEXO G - Matriz Curricular do Curso de Licenciatura em Artes - UnB}

\begin{tabular}{|c|c|c|c|c|c|}
\hline Modulo de Acesso & CAM & Créditos & 1 Semestre & Cat & Cré ditos \\
\hline $\begin{array}{l}\text { 01. Fundamendes do curso - Encontro Presencial } \\
\text { haugurai (TA)[1] }\end{array}$ & 45 & 3 & Ca.tetura e-Produçăo de Tarita (TA) & 90 & 6 \\
\hline \multirow[t]{3}{*}{ 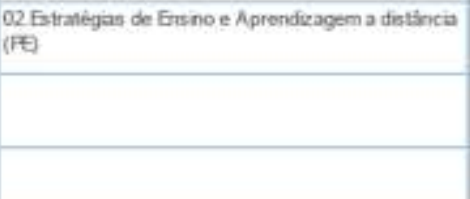 } & 90 & 6. & O4 Tocrias da Edurapjo (TA). & 90 & 6 \\
\hline & & & OS. A Psicologia 6 a construçäe do conhecinvento (TA) & 90 & 6 \\
\hline & & & 06. Antropobga cuhural (TA) & 90 & 6 \\
\hline Total & 135 & 3 & Toed & \$\$स⿴囗十 & 24 \\
\hline rosemestere & CaA & Créditos & $Y$ Semestre & CAH & Créditos \\
\hline Or Ateler de Artes Veucas 1 (TA) & 90 & 6 & 13 Ateber de Artes Vasuas 2 (TA) & 90 & 6 \\
\hline 08 Teora do Ante (TA) & 90 & 6 & 14 Tecrnobgas conterporineas na escola 2 (PE) & 90 & 6 \\
\hline Ga Hetora das Antes Viation (TA) & 90 & 5 & 15. Hsabina das Artes Vouses 2(TA) & 90 & 6 \\
\hline 10. Tecnologias Contemporiness na Escola 1 (TA) & 90 & 6 & 16. Hstoria da Arte-educa, so 1 (TA) & 90 & 6 \\
\hline 11. Hstina de Teatro 1 /OP & 90 & 5 & 17) Hastina do Teabro $2(\mathrm{CP})$ & 90 & 6 \\
\hline 12 Canto $1(O P)$ & 30 & 2 & & & \\
\hline Total & 480 & 32 & Total & $\$ 50$ & 30 \\
\hline 4. Semestre & CAH & Créditos & 5 Semestre & $\mathrm{CHH}$ & Créditos \\
\hline 18. Atefer de Artes Vsurain J (TA) & 90 & 6 & 22. Atefer de Artes Vesuais 4(TA) & 90 & 6 \\
\hline 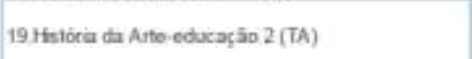 & 90 & 6 & 23 Hestória das Artes Visuas no Brasei 1 (TA) & 90 & 6 \\
\hline 20 Etagio supervisionado 1 [ES] & 90 & 6 & 24 Laborationo de poeticas conterporSheas (TA) & 90 & 6 \\
\hline 21, Tecnologajas contenpordneas na eacola I (PE) & 90 & 6 & 25 Estagio Superviaianado 2 (ES) & 90 & 6 \\
\hline Total & 360 & 24 & Tol & 360 & 24 \\
\hline 60 Semestre & $\mathrm{CA}$ & Creditos & Fisemastre & $\mathrm{CAH}$ & Creditos \\
\hline 26. Laboratóne de Aarte e Tecnobga (TA) & 90 & 6 & 30. Atelar de grodus ào rieedisc pinar (TA) & 90 & 6 \\
\hline $\begin{array}{l}\text { 27. Projeto interdscipinat de ensino e aprendieagen } 1 \\
\text { (PA) }\end{array}$ & 90 & 6 & 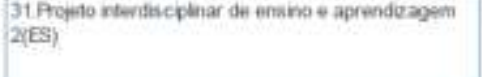 & 270 & 18 \\
\hline 29. Arte es cultura popular (TA) & 90 & 6 & & & \\
\hline 29 Estágo supervisienada 3 (ES) & 90 & 6 & & & \\
\hline Tots & 360 & 24 & Tow & 360 & 24 \\
\hline go Semestre & $\mathrm{CA}$ & Crèditos & Total Geral & $\mathrm{CAH}$ & Créditos \\
\hline 12. Tribatho de Conclusto do Curso (PQ) & 270 & 18 & Desciphnas & $3+00$ & 212 \\
\hline 33. Seminio Presencial de Conchusa do do Curso (TA) & 45 & 3 & 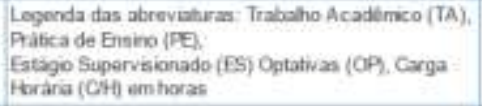 & & \\
\hline Totat & 315 & 21 & & & \\
\hline
\end{tabular}




\section{ANEXO H - BIBLIOGRAFIA - UNIMES}

ALONSO, K.M. A Educação a Distância no Brasil: a busca de identidade. In: PRETI, O. (org.) Educação a Distância: inícios e indícios de um percurso. Cuiabá: NEAD/IE UFMT, 1996.

ALVES, J.R.M. A Educação a Distância no Brasil: síntese histórica e perspectivas. Rio de Janeiro: Instituto de Pesquisas Avançadas em Educação, 1994.

ARETIO, L.G. Educación a distancia hoy. In: LANDIM, Cláudia Maria das Mercês Paes Ferreira. Educação à distância: algumas considerações. Rio de Janeiro: Cláudia Maria das Mercês Paes Ferreira Ladim, 1997.

BABIN, P. \& KOULOUMDJIAN, M.F. Os novos modos de compreender. São Paulo: Edições Paulinas, 1989.

BÉDARD, R. \& PRETI, O. Licenciatura plena em Educação básica: 1aa a ${ }^{a}$ série, através da modalidade de Educação a Distância, breve trajetória e perspectivas. In PRETI, O. Educação a Distância: inícios e indícios de um percurso. Cuiabá: NEAD/IE - UFMT, 1996.

BILLINGS, D.M. A conceptual model of correspondence course completion. In: MOORE, M.G. \& KEARSLEY, G. Distance education: a systems view. Belmont (USA): Wadsworth Publishing Company, 1996.

BORDENAVE. J.D. As novas tecnologias de comunicação e a Educação a Distância. In: PIMENTEL, Nara. O Ensino a Distância na formação de professores. Revista Perspectiva, Florianópolis, UFSC/CED, NUP, n. 24, p. 93-128, 1995.

BRASIL. Educação a Distância. Decreto no 2.494, de 10 de fevereiro de 1998.

FERRETTI, C.J., Modernização tecnológica, qualificação profissional e sistema público de Ensino. Cadernos de Pesquisa, São Paulo, n.80, fev. 1992.

FREIRE, P. Pedagogia do oprimido. 13 ed. Rio de Janeiro : Paz e Terra, 1983.

LAASER, W. (et al.) Manual de criação e elaboração de materiais para Educação a Distância. Brasília: CEAD; Editora Universidade de Brasília, 1997.

LAASER, W. Virtual colloquy on the Internet. Journal of Reserach in Educacional Media, Indian Council for Research in Educational Media, v. 4, n.1, p. 43-49, 1997.

LANDIM, C.M.M.P.F. Educação a Distância: algumas considerações. Rio de Janeiro: Cláudia Maria das Mercês Paes Ferreira Landim, 1997.

LANDSTROM, M.; MAYER, D. \& SHOBE, C. Charles. Indicators to Measure

Performance in Distance Education, a Double-Edged Sword. In: WORLD ICDE

CONFERENCE, 18 th. Proceedings. Pennsylvania: Pennsylvania State University, 1997.

LÉVY, P. O que é o Virtual? Trad. Paulo Neves. São Paulo : Ed. 34, 1996.

Tecnologias da inteligência: o futuro do pensamento na era da informática.

Trad. Carlos Irineu da Costa. Rio de Janeiro: Ed. 34, 1993.

MATTELART, A. Comunicação mundo: história das ideias e das estratégias. Trad.

Guilherme João de Freitas Teixeira. Petrópolis: Vozes, 1994.

MORAN, J.M. Interferências dos meios de comunicação no nosso conhecimento.

Revista Brasileira de Comunicação, São Paulo, v. 17, n. 2, jul./dez. 1994. URL:

NEDER, M.L. Avaliação na Educação a Distância - significações para definição de percursos. In: PRETI, Oreste. Educação a Distância: inícios e indícios de um percurso.

Cuiabá: NEAD/IE - UFMT, 1996.

NEGROPONTE, N. A vida digital. Trad. Sérgio Tellaroli. São Paulo: Companhia das Letras, 1995.

NISKIER, A. Tecnologia educacional: uma visão política. Petrópolis: Vozes, 1993. 
PIMENTEL, N. O Ensino a Distância na formação de professores. Revista Perspectiva, Florianópolis, n. 24, 1995.

PRETTO, A. A escola sem/com futuro. São Paulo: Papirus Editora, 1996. (Coleção Magistério)

PRIETO, D. \& GUTIERREZ, F. A mediação pedagógica - Educação a Distância alternativa. Campinas : Papirus. 1991.

SAMPAIO, T.M.M.S. O não verbal na comunicação pedagógica. Rio de Janeiro: Tempo Brasileiro, 1991.

VIANNEY, J.; SCHAEFER, M.I.; PIMENTEL, N.; RODRIGUES, R.S. \& MORAES, M. Introdução a Educação a Distância. Florianópolis, SINE/Secretaria de Estado do Desenvolvimento Social e da Família/Laboratório de Ensino à Distância/SED, 1998. 


\section{ANEXO I - Matriz Curricular do Curso de Licenciatura em Artes Visuais a distância UNIMES}

\begin{tabular}{|c|c|c|c|c|}
\hline \multicolumn{5}{|c|}{$1^{\circ}$ SEMESTRE } \\
\hline Código & DISCIPLINAS & $\begin{array}{c}\text { C.H. } \\
\text { Semanal }\end{array}$ & $\begin{array}{c}\text { Prática } \\
\text { C.H. Semestral }\end{array}$ & $\begin{array}{c}\text { C.H. } \\
\text { Semestral }\end{array}$ \\
\hline DIDO & Didática & 06 & 20 & 120 \\
\hline PSIO & Psicologia da Educação & 04 & & 80 \\
\hline SOC0 & Sociologia da Educação & 04 & & 80 \\
\hline CETO & Comunicação, Educação e Tecnologias & 04 & & 80 \\
\hline APC1 & Arte e Processos de Criação I & 02 & 10 & 40 \\
\hline & Tot a I & 20 & 30 & 400 \\
\hline \multicolumn{4}{|c|}{ Atividades Complementares de Arte, Estética e Cultura } & 50 \\
\hline
\end{tabular}

\begin{tabular}{|c|c|c|c|c|}
\hline \multicolumn{5}{|c|}{ 2은 SEMESTRE } \\
\hline Código & DISCIPLINAS & $\begin{array}{c}\text { C.H. } \\
\text { Semanal }\end{array}$ & $\begin{array}{c}\text { Prática } \\
\text { C.H. Semestral }\end{array}$ & $\begin{array}{c}\text { C.H. } \\
\text { Semestral }\end{array}$ \\
\hline HECO & História da Educação & 06 & & 120 \\
\hline FIE0 & Filosofia da Educação & 06 & 20 & 120 \\
\hline \multicolumn{5}{|c|}{ Leitura e Produção de Texto } \\
\hline APC2 & Arte e Processos de Criação II & 04 & 10 & 80 \\
\hline & Tot a l & 20 & 40 & 400 \\
\hline \multicolumn{4}{|c|}{ Atividades Complementares de Arte, Estética e Cultura } & 50 \\
\hline
\end{tabular}

\begin{tabular}{|c|c|c|c|c|}
\hline \multicolumn{3}{|c|}{ 30 SEMESTRE } \\
\hline Código & DISCIPLINAS & $\begin{array}{c}\text { C.H. } \\
\text { Semanal }\end{array}$ & $\begin{array}{c}\text { Prática } \\
\text { C.H. } \\
\text { Semestral }\end{array}$ & $\begin{array}{c}\text { C.H. } \\
\text { Semestral }\end{array}$ \\
\hline PEOB & Política e Organização da Educação Básica & 04 & 20 & 80 \\
\hline EHA1 & Estética e História da Arte Mundial I & 04 & & 80 \\
\cline { 1 - 2 } FEB1 & $\begin{array}{r}\text { Fundamentos de Expressão e Linguagem } \\
\text { Bidimensional I }\end{array}$ & 04 & & 80 \\
\hline FEC0 & Fundamentos de Expressão e Comunicação & 04 & & 80 \\
\hline
\end{tabular}




\begin{tabular}{|c|c|c|c|c|}
\hline AFCB & Arte Popular, Folclore e Cultura Brasileira & 04 & & 80 \\
\hline \multicolumn{2}{|c|}{ T o t a I } & 20 & 20 & 400 \\
\hline \multicolumn{2}{|c|}{ Atividades Complementares de Arte, Estética e Cultura } & 50 \\
\hline
\end{tabular}

\begin{tabular}{|c|c|c|c|c|}
\hline \multicolumn{5}{|c|}{ 4온 SEMESTRE } \\
\hline Código & DISCIPLINAS & $\begin{array}{c}\text { C.H. } \\
\text { Semanal }\end{array}$ & $\begin{array}{c}\text { Prática } \\
\text { C.H. } \\
\text { Semestral }\end{array}$ & $\begin{array}{c}\text { C.H. } \\
\text { Semestral }\end{array}$ \\
\hline EHA2 & Estética e História da Arte Mundial II & 04 & & 80 \\
\hline FEB2 & $\begin{array}{l}\text { Fundamentos de Expressão e Linguagem } \\
\text { Bidimensional II }\end{array}$ & 04 & 10 & 80 \\
\hline FTME & $\begin{array}{c}\text { Fundamentos de Teatro e Música na } \\
\text { Educação }\end{array}$ & 04 & 10 & 80 \\
\hline MPCO & Metodologia da Pesquisa Científica & 04 & & 80 \\
\hline MAE1 & $\begin{array}{c}\text { Metodologia e Prática de Ensino da Arte } \\
\text { Educação I }\end{array}$ & 04 & & 80 \\
\hline & Tot a I & 20 & 20 & 400 \\
\hline \multicolumn{4}{|c|}{ Atividades Complementares de Arte, Estética e Cultura } & 50 \\
\hline
\end{tabular}

\begin{tabular}{|c|c|c|c|c|}
\hline \multicolumn{5}{|c|}{ 5 SEMESTRE } \\
\hline Código & DISCIPLINAS & $\begin{array}{c}\text { C.H. } \\
\text { Semanal }\end{array}$ & $\begin{array}{c}\text { Prática } \\
\text { C.H. } \\
\text { Semestral } \\
\end{array}$ & $\begin{array}{c}\text { C.H. } \\
\text { Semestral }\end{array}$ \\
\hline EHAB1 & Estética e História da Arte Brasileira I & 04 & & 80 \\
\hline MAE2 & $\begin{array}{c}\text { Metodologia e Prática de Ensino da Arte } \\
\text { Educação II }\end{array}$ & 04 & & 80 \\
\hline FEB3 & $\begin{array}{c}\text { Fundamentos de Expressão e Linguagem } \\
\text { Bidimensional III }\end{array}$ & 04 & 10 & 80 \\
\hline FET1 & $\begin{array}{c}\text { Fundamentos de Expressão e Linguagem } \\
\text { Tridimensional I }\end{array}$ & 04 & & 80 \\
\hline FEM1 & $\begin{array}{c}\text { Fundamentos de Expressão e Linguagem em } \\
\text { Multimeios I }\end{array}$ & 04 & & 80 \\
\hline & Tot a I & & & 400 \\
\hline \multicolumn{4}{|c|}{ Trabalho de Conclusão de Curso } & 40 \\
\hline \multicolumn{4}{|c|}{ Estágio Curricular Supervisionado } & 200 \\
\hline
\end{tabular}

\begin{tabular}{|c|c|c|c|c|}
\hline \multicolumn{5}{|c|}{ 60 SEMESTRE } \\
\hline Código & DISCIPLINAS & $\begin{array}{c}\text { C.H. } \\
\text { Semanal }\end{array}$ & $\begin{array}{c}\text { Prática } \\
\text { C.H. } \\
\text { Semestral }\end{array}$ & $\begin{array}{c}\text { C.H. } \\
\text { Semestral }\end{array}$ \\
\hline
\end{tabular}




\begin{tabular}{|c|c|c|c|c|}
\hline EHAB2 & Estética e História da Arte Brasileira II & 04 & 80 \\
\hline FEM2 & $\begin{array}{r}\text { Fundamentos da Expressão e Linguagem em } \\
\text { Multimeios II }\end{array}$ & 04 & 100 & 80 \\
\hline FET2 & $\begin{array}{r}\text { Fundamentos de Expressão e Linguagem } \\
\text { Tridimensional II }\end{array}$ & 04 & 20 & 80 \\
\hline FME0 & $\begin{array}{r}\text { Fundamentos de Museologia e Espaços } \\
\text { Expositivos }\end{array}$ & 04 & 80 \\
\hline ELAV & $\begin{array}{r}\text { Expressão, Linguagem e Processos de } \\
\text { Criação em Artes Visuais }\end{array}$ & 04 & 20 & 80 \\
\hline & T o t a I & 50 & 400 \\
\hline & Trabalho de Conclusão de Curso & & \\
\hline
\end{tabular}

\begin{tabular}{|l|c|}
\hline \multicolumn{1}{|c|}{ Duração do Curso } & Horas \\
\hline Disciplinas Pedagógicas & 1000 \\
\hline Disciplinas Específicas & 990 \\
\hline Práticas de Ensino & 410 \\
\hline Atividades Complementares & 200 \\
\hline Estágio Curricular Supervisionado & 400 \\
\hline $\begin{array}{l}\text { Trabalho de Conclusão de Curso - } \\
\text { TCC }\end{array}$ & 80 \\
\hline \multicolumn{1}{|c|}{ Carga Horária Total do Curso } & $\mathbf{3 0 8 0}$ \\
\hline
\end{tabular}




\section{ANEXO J - Matriz Curricular do Curso de Licenciatura em Artes - Educação Artística à distância CLARETIANO}

\begin{tabular}{|c|c|c|}
\hline PERÍODO & DISCIPLINAS & C.H. \\
\hline \multirow{6}{*}{10} & Tecnologia Educacional para EAD & 30 \\
\hline & Educação Patrimonial & 60 \\
\hline & Percepção e Expressão Bidimensional: Desenho & 60 \\
\hline & Estudo dos Elementos Representativos: Desenho & 30 \\
\hline & Gravura & 60 \\
\hline & Processos Escultóricos & 60 \\
\hline \multirow{6}{*}{$2^{\circ}$} & Compreensão dos Elementos e da Linguagem Pictórica & 60 \\
\hline & Estudo de Processos Tridimensionais: Espaço e Forma & 30 \\
\hline & Dança para Educadores & 60 \\
\hline & Teatro para Educadores & 60 \\
\hline & Técnicas Expressivas em Pintura & 30 \\
\hline & Língua Portuguesa & 60 \\
\hline \multirow{6}{*}{$3^{\circ}$} & Iniciação à Pesquisa Científica & 30 \\
\hline & Fundamentos Históricos e Filosóficos da Educação & 60 \\
\hline & Psicologia da Educação & 60 \\
\hline & História da Arte: Da Pré-História ao Barroco & 60 \\
\hline & Estética I & 30 \\
\hline & Folclore & 60 \\
\hline \multirow{7}{*}{40} & Fundamentos da Educação Inclusiva & 30 \\
\hline & Língua Brasileira de Sinais & 30 \\
\hline & Metodologia da Pesquisa Científica & 30 \\
\hline & Didática Geral & 60 \\
\hline & História da Arte: Do Rococó ao Realismo & 60 \\
\hline & Estética II & 30 \\
\hline & Fundamentos e Métodos da Arte-Educação & 60 \\
\hline \multirow{6}{*}{50} & Sociologia da Educação & 60 \\
\hline & Políticas da Educação Básica & 60 \\
\hline & Antropologia Teológica & 30 \\
\hline & História da Arte: Do Impressionismo ao Surrealismo & 60 \\
\hline & Música para Educadores & 60 \\
\hline & História e Cultura Afro-Brasileira, Africana e Indígena I & 30 \\
\hline \multirow{6}{*}{$6^{\circ}$} & História da Arte: Arte Internacional e Arte Brasileira & 60 \\
\hline & Museologia/ Curadoria/ Ação Educativa & 60 \\
\hline & História e Cultura Afro-Brasileira, Africana e Indígena II & 30 \\
\hline & Arte-Educação e Cultura Digital & 60 \\
\hline & Planejamento Visual Gráfico & 60 \\
\hline & Desenho Geométrico & 30 \\
\hline
\end{tabular}


Disciplinas Institucionais

Desde o ano de 2003, constam disciplinas comuns - chamadas Institucionais - no currículo dos cursos de graduação presencial e a distância (2005), disciplinas essas que buscam atender à Missão e aos objetivos do Centro Universitário Claretiano, bem como ao processo de nivelamento de seus alunos.

\begin{tabular}{|c|c|c|}
\hline Disciplinas & $\begin{array}{c}\text { Carga } \\
\text { Horária }\end{array}$ & Ementas \\
\hline $\begin{array}{l}\text { Língua } \\
\text { Portuguesa }\end{array}$ & $60 \mathrm{~h}$ & $\begin{array}{l}\text { Comunicação e linguagem. Texto: conceito, tipologia e } \\
\text { estruturação. Fatores de textualidade: coerência e coesão. } \\
\text { Dissertação, resumo e resenha. Leitura crítica, interpretativa } \\
\text { e analítica. Produção de textos. }\end{array}$ \\
\hline $\begin{array}{l}\text { Tecnologia } \\
\text { Educacional } \\
\text { em Educação } \\
\text { a Distância }\end{array}$ & $30 \mathrm{~h}$ & $\begin{array}{l}\text { Histórico. Tecnologias. Linguagens e formas comunicativas } \\
\text { aplicadas na mediação de atividades de ensino- } \\
\text {-aprendizagem a distância. }\end{array}$ \\
\hline $\begin{array}{l}\text { Iniciação } \\
\text { à Pesquisa } \\
\text { Cientifica }\end{array}$ & $30 \mathrm{~h}$ & $\begin{array}{l}\text { A metodologia da pesquisa científica nos cursos de } \\
\text { graduação. A ciência e a pesquisa científica. Procedimentos } \\
\text { didáticos na vida universitária. Diversos tipos de textos e de } \\
\text { formas de apresentação. }\end{array}$ \\
\hline $\begin{array}{l}\text { Metodologia } \\
\text { da Pesquisa } \\
\text { Científica }\end{array}$ & $30 \mathrm{~h}$ & $\begin{array}{l}\text { Natureza teórico-prática da pesquisa científica e dos tipos } \\
\text { de pesquisa. A construção de um Projeto de Pesquisa. } \\
\text { Trabalhos monográficos. }\end{array}$ \\
\hline $\begin{array}{l}\text { Antropologia } \\
\text { Teológica }\end{array}$ & $30 \mathrm{~h}$ & $\begin{array}{l}\text { Aspectos históricos que envolveram a pessoa e que } \\
\text { influenciaram a concepção social ao mesmo tempo em } \\
\text { que a sociedade influenciava a concepção de pessoa. As } \\
\text { implicações nas diferentes áreas de atuação do ser humano. } \\
\text { A maneira como a sociedade atual concebe o ser humano } \\
\text { e o trata, bem como as implicações decorrentes disto. } \\
\text { Noção de pessoa a partir do Projeto Educacional Claretiano } \\
\text { e as implicações nas diferentes áreas de atuação do ser } \\
\text { humano. }\end{array}$ \\
\hline $\begin{array}{l}\text { Língua } \\
\text { Brasileira de } \\
\text { Sinais }\end{array}$ & $30 \mathrm{~h}$ & $\begin{array}{l}\text { Vocabulário da Língua Brasileira de Sinais - Libras. Libras } \\
\text { em contexto. Gramática da Libras. A importância da Libras } \\
\text { na comunicação e na educação do indivíduo surdo. A história } \\
\text { da educação dos surdos. O indivíduo surdo e suas interações } \\
\text { na escola. Abordagens educacionais. Implementação do } \\
\text { bilinguismo na atualidade. A função do intérprete e do } \\
\text { professor de Libras. }\end{array}$ \\
\hline
\end{tabular}

\begin{tabular}{|l|l|}
\hline Área de Conhecimento & Humanas \\
\hline Modalidade & a distância \\
\hline Carga Horária Total & 2.800 horas \\
\hline Início & $\begin{array}{l}\text { primeiro semestre do ano letivo de } \\
2010\end{array}$ \\
\hline Término & 36 meses após o início do curso \\
\hline Duração & minima de 36 e máxima de 60 meses \\
\hline
\end{tabular}

